za 1850

- 3 -

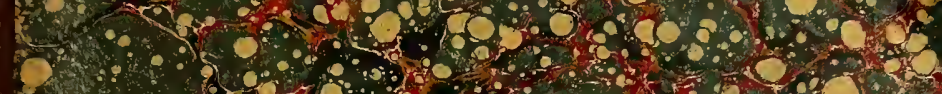

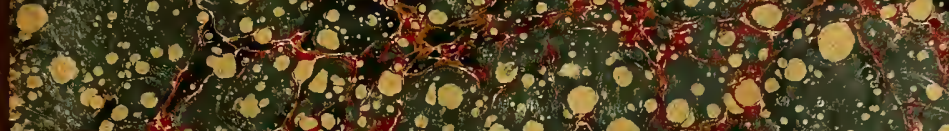

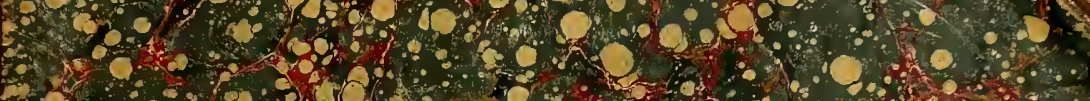

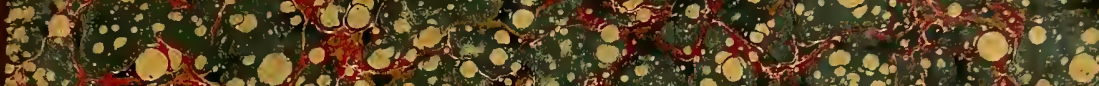

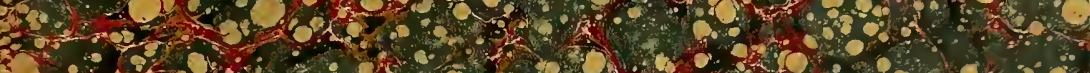

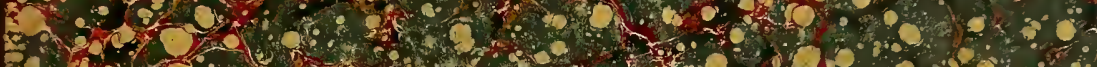

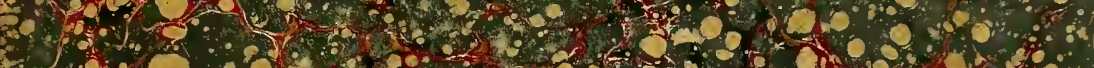

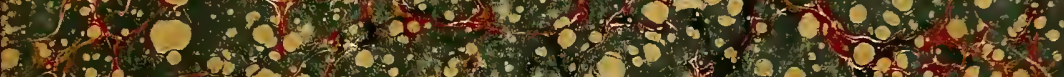

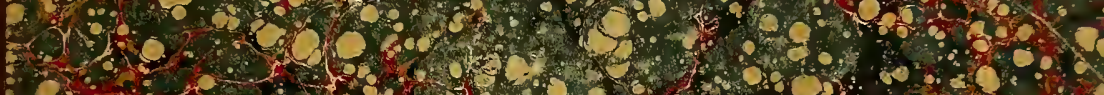

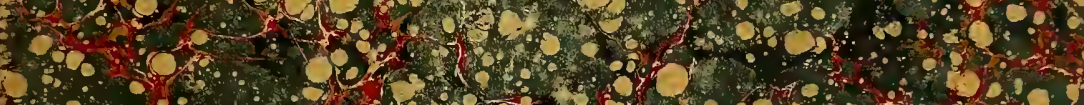

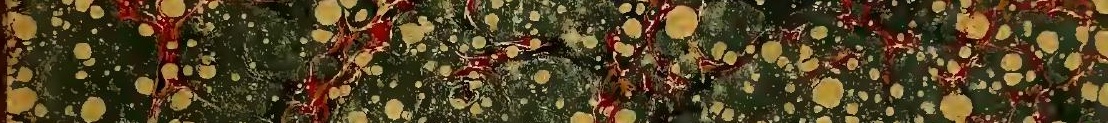

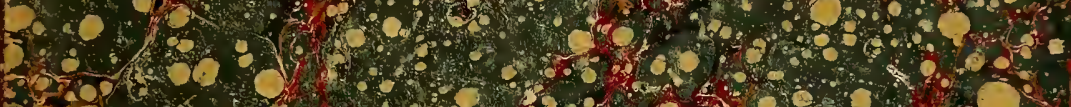

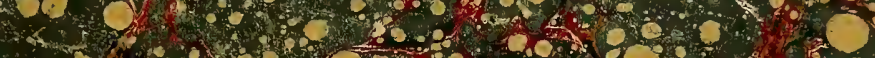

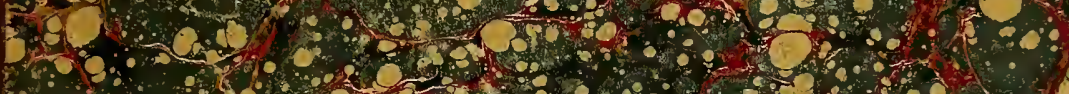

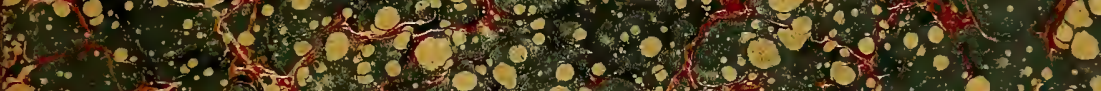

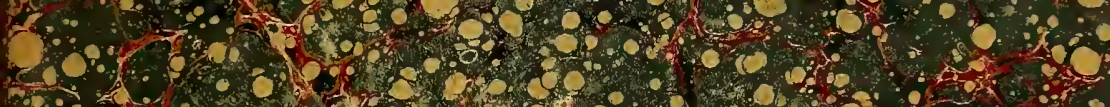

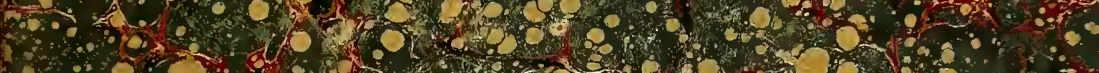

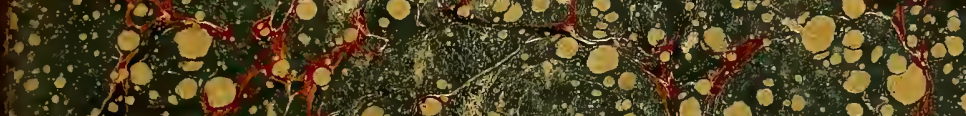

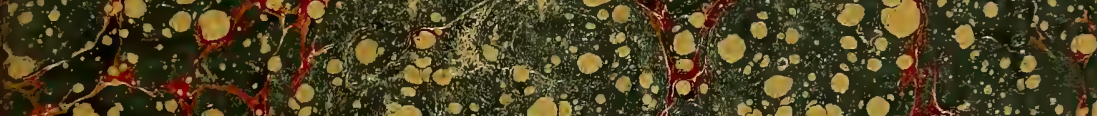

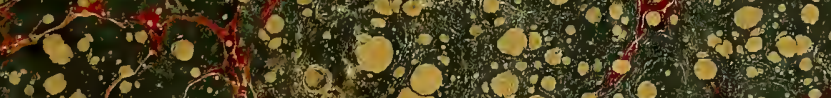

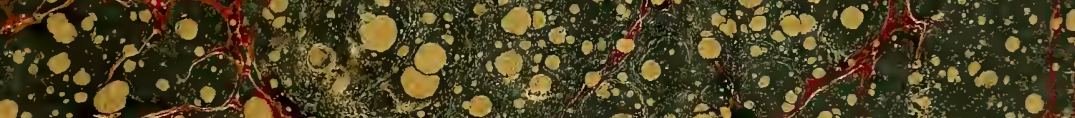

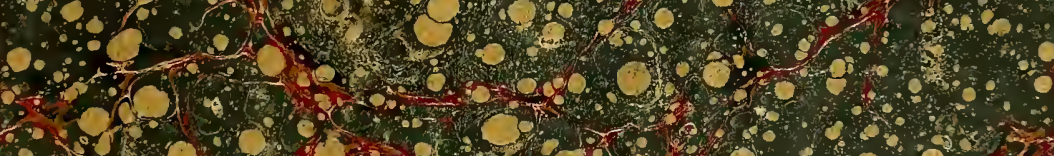

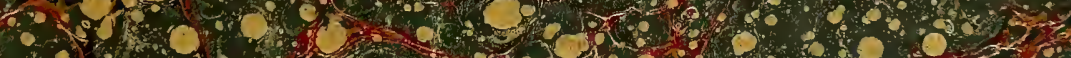

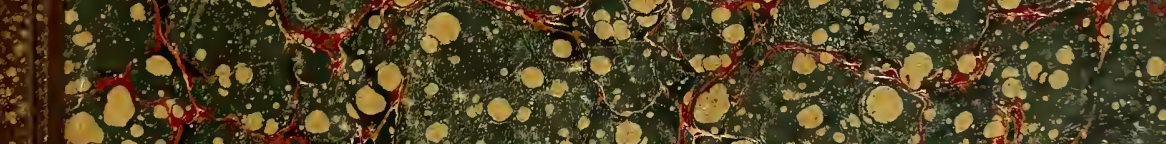

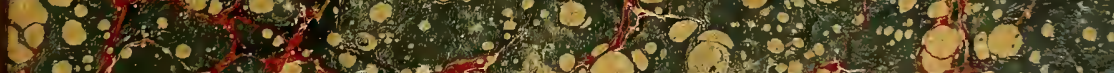

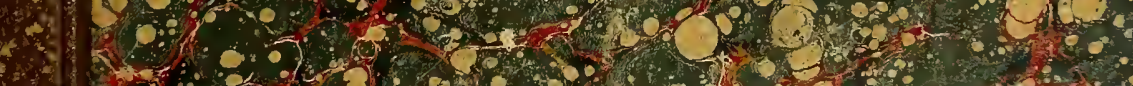

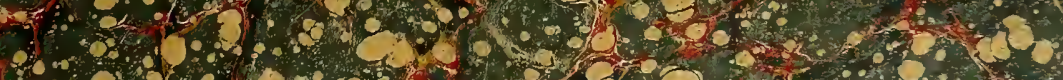

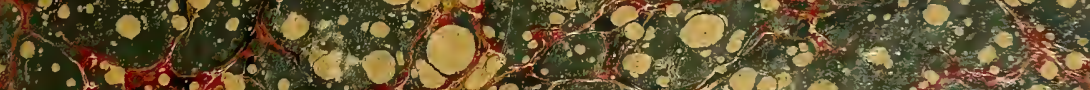

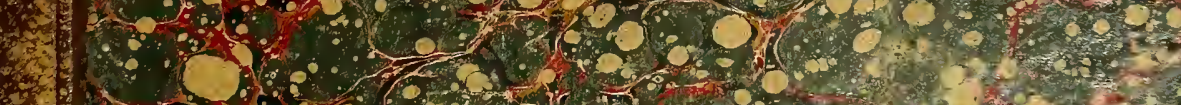

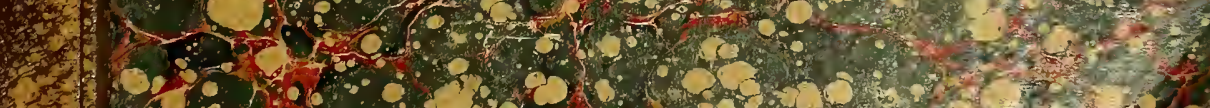

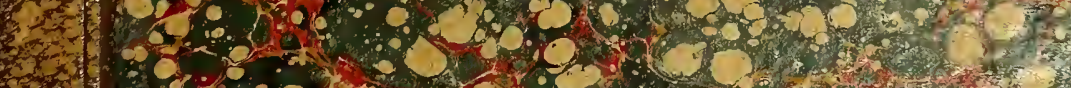

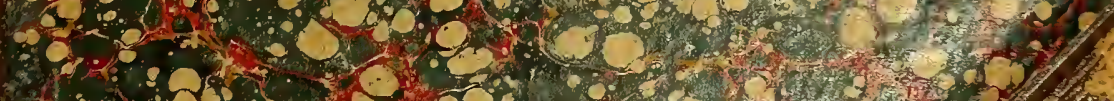

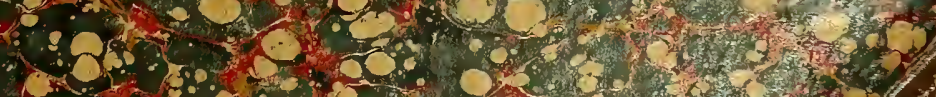

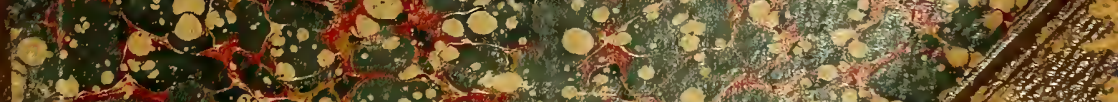

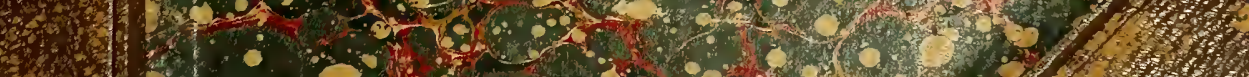
H. 

508.1

. G6
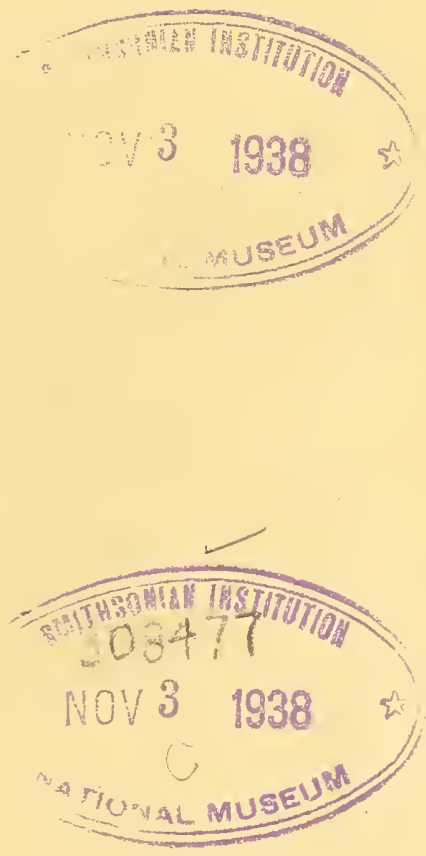












$$
\begin{aligned}
& \text { PL } \\
& 3 \\
& \text { Geo } \\
& \text { SLOA } \\
& \text { SLRA }
\end{aligned}
$$




\section{SUMMER RAMBLES.}

The following is a list of the principal plaees of interest in the vicinity of Middletown, showing the more important mineral. ogieal and botanical localites. It may prove nseful in planning Saturday tramps or evening walks.

Westrield Falls. Five miles N. W. of the college. A romantic caseacle of 50 feets, plunging over a preeipiee of trap.

Lamentation Mountain. On the N. side of the Meriden Pike, six miles W. of the college. A lofty eminence in the trap range, commanding a prospect of the sound on a elear day.

Middlefueld Fatis. Four and a half miles S. W. A beautiful fall of 40 feet, sitnated on the Arrowmamett, in the town of Niddlefield. It is approaehed by a patl leading for a mile along the bank of the ereek, or by a carriage road. Minerals. In the eavities of the trap roek, over which the water falls, are found fine specimens of Datholite, also Olivine, Prehnite and Chlorite.

Cooke's Feldspar Quarry. Oli the Haddami pike, three miles S. E. of the eollege. Minerals. Feldspar, (which is used to make enamel for earthenware,) Albite, Garnet, Beryl, Columbite, Black Tomrmaline, Magnetite, occasional Apatite, Rutile, and Uranite.

White Rocks. Two and a half miles S. E. of the college. A bare ledge of roeks, in the granite hills, commanding a fine view of Middletorn and the surrounding country. Minerals. Here and in the immediate vicinity, Albite, Feldspar, Beryl, Garnet, Columbite, Magnetic Iron, Pyrites, Lepidolite, Blaek, Green and Red Tourmaline. Rare Plants. Liadies'slipper, (Cypripedium acaule), Wake Robins (Trillium erectum and T. eernuum), Bellwort (Uvilaria perfoliata), Wild Sarsaparilla (Aralia nudicaulis), False Spikenard (Smilacins raeemosa), Blood Root (Sangumaria Canadensis). 
Silver Mrne. On the bank of the Connecticut, three miles.S. E. of the college. It was worked by the colony for lead from 1775 to 1778 , with the hope that it conld be obtained in sufficient quantities for military purposes. It is said that the bullets used in the battle of Saratoga were made in a small red house still standing near the mine. The vein which was worked extended northward, toward the river, and was found to be very rich in places. It has since been used by speculators as the basis of a stock com. pany enterprise, and as it furnishes a few good specimens, though no ore in any amount, it paid pretty well. Minerals. Argentiferous Gąlena, Antimonial Sulphuret of Silver, Copper Pyrites, Zinc Blende, Fluor Spar. Quartz in fine drusy crystals. Occasional, Sulphuret of Bismuth, Arsenical Iron Pyrites. Abont a mile sonth of the Silver Mine, on the river side, is a quarry, where is obtained the stone for the Belgian pavement now being laid on Broadway, New York.

Bodrin Pock. On the east bank of the river, nearly opposite the Silver-Mine. This is a sharp point of rock, jutting out into the river at the commencement of the narrows, containing a quite commodious cave. A pleasant row from the city. Minerals. Garnets imbedded in Albite, Beryl, Columbite, Black Tourmaline, Prase. Rare Plants. Near here stands a solitary specimen of the 11. macrophyla, of the southern states. On the rock grows the beautiful Bud-foot Violet (V. pedata).

Cobslt Mrne. As the foot of Great Hill, in the town of Chatham, seren miles S. E. of the college. It inay be reached either by land or by rowing to Middle Haddam, six miles, and walking the remaining two. This mine was opened in 1762, by a company of Germans. Iluch ore was sent to England, Holland and Clina, but as all the parties concerned were foreigners; nothing is known of its character or value. It was 
finally abandoned in 1787, when tradition says that Gonimus. Erkelius, one of the proprietors, sailed for Chins with twenty tons of Cobalt ore. In 1818 mining was recommenced. The person who undertook it knew nothing about his work, and having expended about $\$ 20,000$, he obtained one thousand pounds of ore which he supposed to be Cobalt, but which proved to be nickel, containing only three or four per cent of the desired metal. It was then given up until 1850, when another company began operation and put up the buildings which still stand. After spending $\$ 1 \check{5} 0,000$, they also abandoned it without obtaining half a pound of Cobalt. The shaft which now remains open extends into the side of the mountain about thirty-five feet. At its extremity can be obtained specimens of Cobalt and nickel ore, but it is dangerous to enter.

CIII PSI GLex. One mile south of the college. A pleasant ravine, boasting a fine cascade. A locality of that universal favorite, the Trailing Arbutus (Epigaea :epens.)

ThE Ravise, One-fourth of a mile south of the college. Another locality of the Arbutus.

The Lover's W ALK. A romantic gorge in the midst of the factories at the south end of South Main street. On the dam at its eastern end grows the rare Fly Honeysuckle (Lonicera ciliata.)

tr.

\section{THE COLLEGE ARGUS.}

Wesleyan University, Middletown, Conn. Thunsday, May 27, 1869. 


\section{MUSOA ET MEDICA.}

VerILY, Mr. Editor, there is nothing new under the sun. Will you allow me through your columns to give to the world the following extract, which I conceive to throw much light upon the two great questions of the day. It is translated from an ancient Greek manuscript found at Herculaneum, descriptive of the manners of Ancient Greece. "As we parted with the philosopher A riston, Lasthenia asked after his fly, and whether he sometimes saw it, 'No' replied he 'Agnodice has delivered me from it forever.' When we were alone, I asked Lasthenia to explain this allusion, 'you must have perceived,' replied she "that this old man bears the stamp of singularity. He has told you that during five years he wore himself out with constant application. Whenever he wished to study he laid down on his belly upon the ground surrounded with books, and at these times imagined he saw a fly light upon his nose. Notwithstanding his eonstant endeavor to drive it away, it still returned and thus threw him into despair! The most skillful physicians were consulted, but their learning, and their remedies were unable to remove this daughter of heaven; as one of our poets has called it, from the nose or rather the imagination of Ariston.

At length the celebrated Agnodice had the honor of performing the cure. This Agnodice was a woman of great talents and had so strong a passion for the study of medicine, 
that she disguised herself in a man's clothes to attend the lectures of her father HierophaIus. The ladies of Athens were so enthusiastically fond of this female physician, that on her account they procured the abrogation of the law which prohibited women from the exercise of that profession. This extraordinary woman being consulted by one of Ariston's friends, undertook to relieve him from the importunity of the fly. She no sooner saw her new patient than he asked her what he had upon his nose. 'A fly' replied Agnodice boldly, and having by this artifice gained the confidence of Ariston, she proceeded to inquire, with the grave and sagacious air of a physician, the origin and symptoms of his disorder, the habits of this pertinacious fly, and at what hours it came and went, she then ordered him draughts that were perfectly innocent and having continued these several days, she at last informed him that she was about to extirpate the fly. Upon this she took a knife from her pocket, drew it gently over his nose, and immediately showed him a fly which she had concealed in her hand, 'yes, there it is,' cried Ariston ' $\mathrm{I}$ know it well, it is the very same that has so long tormented me.' Thus did this disciple of $Æ s c u l a p i u s$ cure the philosopher of his phantasm, and so true is it that most of our pains as well as our pleasurcs depend on the imagination."

Your constant reader,

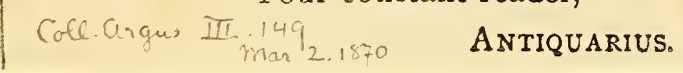




\section{COLLEGE MEN IN CONGRESS.}

UP to 1864 there had been 847 college bred men in Congress. They are distributed as follows. Yale, $3_{3} 8$. Harvard, ri8. Princeton, ro8. Dartmouth, 60. Univ. of N. C, 40. Brown, 35. Univ. of S. C., 32. Union, 30. Bowdoin, 23. Univ. of Va., r8. Dickinson, I7. Columbia, 15. Wm. and Mary, I4. Williams, I3. Univ. of Ky., Ir. Univ. of Pa., Io. Univ. of Vt., 9. Washington (Pa.,) Jefferson and West Point Mil. Acad., 8. Miami, Hamilton and Franklin, 7. Univ of Ga., Amherst, Middlebury and Hampden Sydney, 6. Rutgers and Centre, (Ky.,) 5. St. Johns, (d.,) 4. Univ. of Ala., U. of E. Tenn., Wesleyan, Waterville, Washington, (Va.,) Georgetown, Lafayette, Ohio State Univ., 3. Charlestown, Trinity, Washington, (Md.,) Randolph, Macon, St. Marys, (Md.,) Indiana Asbury, Washington, (Me.,) Mt. Zion, and Kenyon, 2. Univ. of N. Y., Univ. of Mich., Emory, Western Reserve, Oberlin, Wabash and twentytwo others, I. The Universities of Genera, Switzerland., Caen, France., and Glasgow are each represented by one.

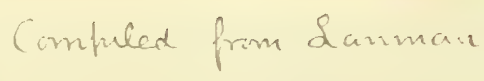






\section{HISTORY OF WESLEYAN UNIVER- SITY.}

G. BROW: COODE, IN COLLEGE REVIEW.

\section{Chapter I.}

ON the 1 ath of September, 1 \&25, the "American Literary, Scientific and Military Acadcmy". at Middletown, Conn., was formally opened to the public. This institution was established by Captain Alden Partridge, the first Superintendent of the U. S. Military Academy at IVest Point, who, becoming dissatisfied with his treatment there, decided to found a smaller school on his own account. llaving obtained the sanction of several prominent citizens of Middletown, he settled upon that as the site of his school, and through the munificence of the citizens suitable buildings were crected at a cost of s+4,000. The institution was a time very prosperous, and cadets were in attendance from almost crery State in the Union. Many cistinguished men received their education here, among whom may be mentioned the late Gor. T. II. Seysour, of Connecticut, and the Hon. Iloratio Seymour, of New York, and many took prominent parts in the late rebellion, especially on the Confederate side. Failing, howcrer, to obtain from the Legislature a college charter it was removed to Northfield, Vt., where it still exists under the name of the Norwich University. The buildings now rererted to the donors, and remained for some time unoccupied.

One day, some of the stockholders being together, a gentleman expressed some surprize at the cnergy and public spirit of the Methodists in Middletown, in the recent erection of a large and commodious church, and laughirgly r-marked that he would not be 
surprised if they should nexi think of establishing a college. To carry out the idea, another sportively added that they had buildings to dispose of which might be had for $\$ 5,000$, provided they would establish a classical school of high order on the premises. This trifing conversation was the immediate cause of the establishing of the Wesleyan University; It was reported to the Rev. LABAN CLARK, who was then in the vigor of his ministry and the Presiding Elder of a district which reached over half of Connecticut.

In common with the other leading men of the Methodist Fipiscopal Church, he had long been impressed with the importance of a grand denominational school, and was nothing disheartened by the sad history of the previous attempt at Abringdon, Md., which had been finally abandoned in 1795 . Ife immediately sent word to the stockholders that he would be one of ten to purchase the property, and would secure the other nine, seren of which he did secure before he had gone once around his district. This led to a serious consideration of the subject, the result of which was that the stockholders determined to gire the property to the M. E Church, if they could be assured that the college would be permanently established. Mr. CLARK, having been entrusted with this offer in due form, presented it to the New York Annual Conference at its session at Troy, N. Y., in I $\$ 29$, and used to tell a good story concerning the introduction of the business. Hc had informed Bishop Rozerts of his intention to present the subject to the Conference, and when the body had been in session sereral days the said, "Now, Brother CLARK, you inay speak to the Conference about the school at Middletown, although I am sorry that so many of the preachers are out of doors." 
Mr. Clark replied, "I will soon have them in, sir, if some one will open those doors." The church doors being opened Brother $\mathrm{C}_{\mathrm{LARK}}$ cried out at the top of his roice, "Thirty thousand collars! Twenty thousand dollars!" and instantly the good brethren gathered in like a flock of sleep, and gave their closest attention to the business in hand. The establishment of a college having been for some time in contemplation, they were readily induced to appoint a committee to confer with a like committee from the New England Conference. The first act of the joint committee was to issue proposals inviting the several towns within a specified region to compete for the location of the college by the offer of subscriptions. Troy, N. Y., Wilbraham, Mass., and Bridgeport, Conn., made liberal proposals; but those from Middletown were now so modified as to leave no room for hesitancy as to which should be preferred. The trustees of the academy, with the consent of the stockholders, offered the entire property to the Conference in fee-simple, with the single condition that it should be sustained as a college or university, besides giving a local subscription of $\$ 18,000$ if $\$ 40,000$ additional endowment should be lobtained. In this way fifteen acres of land, large, commodious and substantial buildings, and the nucleus of a library were placed at once in their lands. The report of the committee in faror of Middletown was adopted at the next session of the Conference, and the name of WesLeyan University agreed upon. Other Conferences came immediately into the measure, and active work was begun August 24 th, 1830, by the election of Rev. WiLBUR FISK, D. D., to the presidency. It was thought by some that no Anerican Methodist was qualified to take charge of such an insti- 
tution, and it was proposed to call from England, Dr. Adan Clarke, the celebrated biblical scholar and author of "Clarke's Commentary," but more practical views prevailed. In the following Cctober a preparatory school was commenced under the care of Rev. W. C. LARRALEe, a graduate of Bowdoin. In I $\delta_{3}$ I a charter was granted by the Legislature securing all the rights and immunities of a university, and on the zist of Eeptember the halls were throin open for the reception of students, the occasion being celebrated by appropriate litcrary ceremonies. The first student who umpacked his trunk in the rooms of the new college, was Osuun C. BAkER, of Concord, N. H., row a bishop; and among his associates in those carly clays ricre the late Abel Stevens, the historian of Methodism; Bishop Clark, Col. T. B. Thorpe, of New York; Du. PAtTen, of Boston Theological Seminary; Dr. KIDDER, of Chicago; Dr. B. F. Tefft; Dr. Curny, of New York; Dr. Wentworth, of Troy; President E. E. WILEY, of Emory and Henry College; JoHn G. SAxE, the poet; Dr. E. O. HAves, of Michigan University, and many others who have since risen to eminence in the church and in literatire.

Dr. Frsk heid his office until his death in $: 839$, and to his untiring labors in its behaif the unirersity owes its prosperity and influence.

His name was suficient to attract a larg number of students at tlic rery beginning, and his energy and skill secured that francial aid which at that time was much less attainable than now.

At the organization of the Unirersity, in acccrdance with the pectliar r:ews of Dr. Fisk, which he shared with Presidents WAYLAND, of Erown University, DuRBI, of Dick: 
inson College, and MARSH, of the University of Vermont, in place of the usual college classes, the pregress of the student and his ability to pass the rigorous examinations required, were the only grounds of classification; the student who could pass the examination for the degree of A. B., receired his diploma without reference to the time spent in college. This system was maintained for some years, but has gradually fallen into disuse, as it has also at Brown University, where it was for a time in successful operation. The regular college classes are now maintained, though a student taking a special course of English studies passing a satisfactory cxamination may receive the degrec of S. B., or students may take a select course without receiving a clegrec. But by far the greater number go regularly through, as in other colleges. During Dr. Fist's administration a manual labor department was established, which, however, met with little encouragement; a commons or boarding hall was also maintained during the first twenty years. The first faculty consisted of the President, two professors and one tutor, and the first class consisted of six members, of whom three now survive, graduated in 1833 .

In I84I, Rer. NAThan Bangs, D. D., was elected President, but resigned in 1842 and : as sticceeded by the Rer. Stephen Orin,

D., L. L. D. Dr. Orin's presidency was a prosperous one for the University, and throagh lis cxertion a licavy incubus of cebt was thrown off and the endowment largely incrased. Although in very poor health, lis infuence was great and still is felt. Ite died in $185 \mathrm{r}$, and his remains repose by the side of those of Dr. Fisk in the beautiful cullege cemetery. 
During this period a law department was established, and for a time continued under the care of Hon. William L. STORRS, Judge of the State Supreme Court; also a department of normal instruction. During Dr. FISk's administration arrangements were also begun for the establishment of a medical department, but the project was postpored and has not been yet resumed.

\section{HISTORY OF WESLEYAN UNIVER-} SITY.

G. BROWN GOODE, IN COLLEGE REVIEW.

\section{Chapter I I.}

In 18 52, Prof. Augustus IV. Siit th, LL. D., who had been a professor in the institution from its very infancy, was elected to the Presidency. It was a novel move to place a layman in this important position, but Prof. Smith was a hard worker and filled the chair with ability. He was subsequently professor in the U. S. Naval Academy, and is well known as an author of mathematical text books. The great event of his administration was the raising of an endowment fund of $\$: 00,000$. IsAAC Rich, of Boston, was the chief contributor to this fund, making at this time the first of his princely donations to the University. President SiIth resigned in ${ } 8_{57}$, and was succeeded by Rev. Joseph Cummngs, D. D., LI. D., President of Genessee College, who has filled the place up to the present time with distinguished ability and great success. Under his administration important changes have been introduced in the course of study, the elective system having been adopted to a certain extent; the endowment fund has been nearly quadrupled; several new buildings hare been erected, and the 
value of the property, orer and above indebtedness, raised to over $\$ 650,000$. It would be a severe blow to the University if the church should call him to a position of more lionor, if not of more responsibility.

The library has been formed around a nucieus of 508 rolumes, which belonged to the "Military Academy." In $\mathbf{r}_{32}$ it numbered 2,750 rolumes, having been enriched by the collection of Thomas Chapman, Esq., of Philadelphia, which was a fine one for the times, and was peculiarly rich in rare editions of standard authors. In 1835 it numbered 5,000 volumes, and in this year was also cnlarged by a collection of classical anci scientific works purchased by 1 r. FISK in Europe; in 1839 it numbered 9,000 ; in $1840,10,000$; in $1845,11,000$; in $1848,12,000$; in 1353 , 13,000 ; in $1864,14,000$; and in $1867,15,000$ rolumes. By the conditions of the gift of the new library building, in 1866 , the Alumni were required to raise the sum of $\$ 25,000$ for a permanent library fund; $\$ 27,000$ was raised, and the income of this has become available within the last three years. The library is now rapidly increasing and contains between I0,000 and 20,000 volumes. The "Odell Aicove" of American History is the commemorative gift of the friends of the late Hon. Moses F. Odell, of Brooklyn. It is intended to be complete in its department, and numbers 3,000 volumes and is rapidly increasing.

The libraly of Rev. John Summerfield, was presented by his brother-in-law, Mr. BLACKSTOCK, and now fills the "Summerfield Alcove."

The Museum of Natural History is to occupy rooms in the new scientific building, and when arranged will compare favorably with any in the country. Besides the extensive collections made in the vicinity by mem- 
bers of the institution, it includes a cabinet of minerals and fossils formerly belonging to the "Literary, Scientific and Military Academy," the Prescott Cabinet of New England shells, minerals and rocks, the Frankfort Cabinet of American and foreign minerals, and the Shurtleff Cabinet which has recently been purchased. This was collected by the late Simeon Shurteeff, M. D., of Simsbury, Conn., and includes a collection of shellsone of the best in New England, containing about 80,000 specimens of 8,000 species, a collection of birds, native and foreign, with a large number from the Pacific railroad survey, a collection of insects, \&c., \&c.

There are many minor collections, some only large enough to serve as nuclei for future acquisitions, also a herbarium of several thousand specimens. The ethnulogical cabinet of the "Missionary Lyceum," and the collections of the "Cuvierian Society" have recently come intu the possession of the University. Mr. Orange Judd has just completed negotiations with Professor WARD, of Rochester, N. Y., for a very complete set of his casts of fussils, at a cost of $\$ 3,500$.

A temporary observatory has been erected, sufficiently commodious for present use, in which has been placed, by the munificence of three citizens of New York, a twelve-inch refracting telescope, made by Alvan Clark, of Cambridge. This ranks third among the telescopes of America, and fourth in the world, and is considered by its maker equal to the best for practical purpose. It is the largest to which the students of any university have free access. The observatory and chemical and philosophical lecture rooms are furnished with necessary apparatus, mostly of London and Paris make.

The University is located on the crown of a 
high hill on which is built the beautiful city of Middletown, and overlooks the city, the Connecticut river, the extensive Portland quarries, and much 'of the surrounding country. The grounds are extensive and well planted with trees, and are soon to be laid out anew by the landscape gardener. The leading buildings stand in a line north and south, facing easterly, leaving a broad campus in front descending to High street, with the President's house in the north-east corner. Beginning at the north we have the old college buiiding or dormitory, erected in 1825 , and which is soon to be remodeled and modernized; next south the old chapel building, erected in 1825 , and now used for recitation rooms; next the memorial chapel, erected in $\mathrm{x} 868$, then the Rich Hall, erected in 1867 , and containing the library, and next the Orange Judd Hall of Natural Science, erected in 1870 . In a rear line stand Observatory Hall, erected in 1825 and remodeled in I868, containing at present the cabinets and natural history recitation rooms, besides a number of student's apartments; the gymnasium, erected in 1865 , and the old laboratory and work shops. All are of "brown stone" except Observatory Hall, which is brick, and the gymnasium which is a frame building.

In front of the main building stands the "Class Maple," around which on Class Day - the great day of the collegiate year-the graduating class gather on the green sward, and having smoked the "pipe of peace," according to the old time-honored custom, sing their parting songs and say their sad farewells.

The Alumni of the University now number 948 , of whom $8 \mathrm{I} 4$ are still living. Of the whole number $4 \mathrm{i} 9$ are ministers, 149 are lawyers, atd 55 physicians; 37 have been 
college presidents, and 82 college professors. Statistics show that the Wesleyan University has furnished a larger proportion of teachers than any similar institution, giving an average of twelve years of teaching for each alumnus, including the youngest; 158 were engaged in the late war, of whom is lost their lives. The beautiful Memorial Chapel commemorates the heroism of these noble men.

Owing partly to the number of preachers among the alumni and students, and partly to the fact that there is an Episcopal theological seminary in the city, the idea is held by some that Wesleyan is a theological school. It is quite needless to state that this belief is without foundation, as there is no such school nearer than Boston. The faculty consists of the president, eight professors, and two lecturers. All of the regular professors, except two, are graduates of the institution. Dr. John Johnston is a graduate of Bowdoin and has been connected with the institution from the days of its infancy. He is well known as an author of text-books on natural science. Prof. J. C. VAn Benschoten received his degree from Madison University and subsequently studied at the University of Berlin.

A new chair of natural science was endowed by Mr. OrANge Judd at the last Commencement, but it has not yet been filled.

The tuition fees are merely nominal, and it is proposed, as soon as possible, to make the institution free to all. Scholarships, entitling the holder to tuition for fifteen and fifty years, may be purchased for $\$ 50$ and $\$ 100$ respectively.

The institution is open to all, irrespective of color; a negro graduated in the regular course with the class of $\mathrm{r} 860$, and a Japanese enters this year; it is even doubted whether women would be refused admission, as there 
is nothing in the laws or charter to prevent their entering.

The governing body of the University, according to the amended charter, which passed the Legislature at its last session, is a Board of Trustees, whose legal title is "The Wesleyan University." The number of Trustees is limited to forty, of whom the Patronizing Annual Conferences of the Methodist Episcopal Church, namely, the New York, New England, New York East, Providence, New Hampshire, Vermont, Maine, East Maine, Troy, Central New York, Black River, Newark and Wyoming have the election of one each. The alumni of three years standing elect five, and the remainder are elected by the Board of Trustees. The Trustees hold their office for five years, and are divided into five classes, one of which goes out each year. The President is ex-officio on the Board.

The Wesleyan University is perhaps the oldest of the Methodist colleges. While perhaps a little discomposed at so often "having her nose put out of joint," and while deprecating the possible financial result of the present policy of the M. E. Church in its educational system, she looks with an affectionate pride upon her forty-two younger sisters, each of whom she hopes yet to see occupying a place in a future number of The College Review. 







\section{OUR MUSEUM.}

The work of classifying and cataloguing the various cabinets is being pushed rapidly forward, and if, as is confidently expected, the new rooms in Judd Hall are finished by the roth prox., the specimens will be in their places on the shelves before Commencement. Heretofore the size and value of our collections have been little appreciated. Specimens have been preserved in at least ten different appartments, many of them in closed cases or otherwise inaccessible to the student, while the Professor in charge has been obliged to organize an exploring expedition whenever specimens were required for the illustration of lectures. Mostly without labels and uncatalogued, a large portion of the collections has been of no practical value whatsoever.

With $187 \mathrm{I}$ begins a new era in the history of our Museum. When systematically arranged in Judd Hall, every specimen will be available, and a well-proportioned growth will for the first time be possible. Though it will fall far short of what is requisite, and though it cannot be mentioned in the same breath with those Museums which are considered indispensable in the Universities of Europe, it will compare favorably with those of most of our sister colleges.

The deficiencies in our collections are apparent to the most casual observer. Take for instance our faunal or local collection. A series of all the animals of New Engiand 
is one of the things indispensable in our Nuseum, and one might suppose, would be casily obtained. Yei in our case it is not so. Of the forty or more mammals, only seventeen are respectably represented, such common species as the raccoon, fox, skunk, woodchuck and chipmunk being wanting. Of the three hundred and fifty birds, the Shurtleff collection gives us a tolerable full series deficient only in the rarest and most common species. Of the sixty reptiles and amphibians we have but twenty-two. About two rundred species of fishes inhabit our waters w ilile only thirty-two species inhabit our alcohol in the museun jars. Of the insects we have. but a tithe, between one and two thousand species, of the spiders and worms almost nune, of the crustaceans, twenty out of cighty. Thanks to Dr. Shurtleff, our collection of shells is quite complete. So much for the local collection. The vacancies in other departments are quite as appalling.

Now the students and friends of the college have it in their power to aid materially in the increase of our collections, and that with rery little trouble to themselves. There are few persons who will not, during the coming summer, meet with raluable specimens. Let them collect what they find, and the result will be very apparent at the end of the season. Mammals, birds, birds nerts and eggs, frogs, snakes, salamanders, turtles, fishes, skeletons and bones of every description, especially skulls, insects, "bugs" spiders worms, crabs, star fish, sea anemones, 
vegetable productions of every kind, fossils, minerals-nothing can come amiss. If specimens of the same are already on hand, the duplicates will be serviceable for study or exchanges. Especial attention is called to the department of Archæology and Ethnology. This is already of promising size and contains many valuable specimens. Anything throwing light upon the history of the Indians of Connecticut is especially desirable. Contributions to the collection of coins are solicited. A careful record is kept of each donation, and the name of the donor attached." to the specimen when practicable. A list of the donations will be occasionally printed in the Argus.

A word as to the preservation of Zoological specimens. When possible they should be brought to the Museum in a fresh state, but if at a distance any but birds, moths, anci butterflies may be put into spirits. Any animal may be easily killed by the use of chloroform or benzine. The locality and date of collection should always be carefully noted.

The following donations have recently been made to the Museum.

DR. J. BARRATT-Collection of native birds -50 species, too specimens.

Dr. G. W. BURKE-Specimen of quartz crystal.

Mrs. S. T. Camp-Specimens of Pinnotheres ostreum.

F. C. Goode-Virginian opossum, crawfish \&c., in alcohol, Knoxville, Tenn. 
M. E. Griffin-Indian hatchet, Middletown.

M. P. Hatfield-Collection of native insects.

P. JEweld, Hartford, Ct.,-Suite of specimens of native sulphur and associated minerals, Girgenti, Sicily.

Miss. S. F. JUDD-Specimens of beetle, (Copris,) Flushing, N. Y.

G. H. McGrew-Specimen of Tourmaline, Middletown.

T. R. MERCEIN-Collection of native insects.

S. Miner-Clay concretion, Middletown.

H. G. Newton-Quartz arrow head, Coginchaug Sivamp, Durham.

C. RAYMoND-Specimen of Sciurus carolineus, Melospiza melodia and Quiscalus versicolor.

J. E. Richards-Myological preparation of human arm, Bellevue Medical College, N. Y.

A. B. SANFORD-Specimen of weasel in winter dress, Redding Ct.

N. J. Squires-Pectoral fins of flying fish.

M. L. TAFT-Specimen of tailless cat, Vermont.

J. VanBenschotex-Specimen of Sialia sialis.

M. W. VAn Denburg--Collection of native insects, bird skins, 3 species 4 specimens.

C. T. Winchester-Piece of rebel ram "Merrimac."

G. Brown Goode.

Zoological Museum Mar. I I, I87r. 




\section{RAMBLING.}

"When we please to walk abroad

For our recreation,

In the fields of our abode,

Full of delectation."

Waltons Complete Angler,

Books and cares are thrown aside this fine April day, and with light hearts and thick boots we are off for a morning ramble. Treebuds are swelling, grassy banks are brightening, and the birds are sounding the first notes of the overture which ushers in the grand spring jubilee. All traces of frost are gone, and the hard turf by the roädside makes easy walking, though the wagon-track itself is still a reci morass. How the spring rains bring out the color of our soil. Herr Frauenhofer with his Spectroscope has overturned the hobby of those astronomers who believed the fiery hue of Mars to be caused by a red sandstone soil like this. A brisk walk of fifteen minutes has brought us to that well known spot, the Students Glen, a delightful little retreat when we first knew it, but now well righ spoiled by the "advance of civilization." A new cemetery on one side and a mill pond on the other, have destroyed that air of seclusion which in former days gave it its chief charm. Iet it is still inviting, with its miniature cascade, its rocky, moss-covered banks, its fern clumps and its thickets.

On yonder slope grows that universal farorite, the Trailing Arbutus. These warm sunbeams must certainly have enticed open some of the early buds. A spasmodic scramble over the stepping stones, at the cost of a pair of wet feet, and then we slowly clamber up the rocky bank. To be sure, here are the little buds modestly opening their fragrant pink petals beneath the carpet of dry leaves. 
Aside from its beauty, this little friend has for us a historic interest. Peeping through the snow, it gave the earliest tidings of Spring to our Pilgrim Fathers at the close of their long and perilous first winter on the Plymouth shore. With joy and thanksgiving they christened it, after their trusty vessel, "The Mayflower," and to this day, its name gives it an additional charm to every true New Englander.

See, we have started from that patch of low ground several beautiful butterflies. For a few moments they flutter about, and then settle again in some sheltered spot. There is one lazily spreading his wings on the dry oak leaves, not six feet away. His color is dark, velvety purple with a broad border of white edged with black and brilliant blue. It must be the Camberwell Beauty, for no other butterfly comes out so early in the season. It is hatched late in the Fall and passes the winter in a semi-torpid state in barns and stone-heaps, where it is frequently found huddled together in great numbers. At the first sign of approaching Spring it ventures forth, and may be seen, even as early as February, flitting through the woods with weatherbeaten wings. It is a native of Europe, and has probably been introduced here. Fifty years ago it was abundant in England, but is now extremely rare, and the capture of a specimen is aniounced in the scientific journals as a remarkable occurrence. There! it has disappeared, though we lave not mored our eyes from the spot where it was resting a moment ago. No, there it is. Now it is gone again. Ah! I see, it had folded its wings over its body, and their under surface is so like a dry leaf in color, markings and form that it nearly escaped our notice. Truly, this 
is a wonderful provision for the safety of an insect, otherwise so conspicuous.

There, by that stone heap, is stretched a young garter snake, his gorgeous golden stripes glistening in the sun. Take him up gently and let us admire him. Do not shudder so when he coils about your wrist; he makes a pretty living bracelet, and you know well that he is perfectly harmless. His eyes vie in brightness with those of any belle of Middletown.

Let us overturn this large stone on which we are resting; underneath, I am sure, is a fine menagerie for our amusement. Just as I hoped. The first object which strikes the eye is a salamander, beautifully banded with dark blue and greenish white; the fasciated salamander so rare in New England. Not the fabled salamander who

" with her touch

Quenched the fire, though glowing ne'r so much."

whose renom was more deadly than aconite or hemlock; whose saliva had "power to remove hair and substitute bald places for luxuriant tresses," and whose skin could transmute quicksilver to gold, but a harmless little being whose whole life is passed in just such places as this. I remember seing one which had been transferred from its woodland home to an aquarium tank, where it lay floating like a log on the surface of the water, the very picture of misery. Here, too, are several centipedes; not venomous, but otherwise perfect miniature editions of their troublesome tropical cousins.

Here is an earthworm, an every day sight, yet none the less amusing and instructive.

Hear honest old Izaak Walton discourse in his quaint, delightful style on worms and their origin. "For worms there be very many 
sorts, which for color and shape alter even as the gronnd out of which they are got; as the dezu-zorm, the lob-worm, the marsh-worm, the tag-tail, the oak-worm, the gilt-tail, \&c., too many to name, even as many sorts, as some think there be of birds in the air. Pliny holds an opinion, that many have their birth or being from dews that in the spring fall upon the leaves of trees; all which kinds of dews being thickened and condensed, are by the sun's generative heat most of them hatch'd and are in three days living creatures, and of several shapes and colors; some being hard and tough, some smooth and soft; some are horned in their head, some in their tail, some liave none; some have hair, some none; some have sixteen feet, some less, some none," \&c., \&c.

"Heresy," cries the theologian, "were not all creatures made directly by the hand of God ?" Softly! honest Izaak Walton was as sound a theologian and, we believe, as sincere a Christian, as you will find in many a day; yet he did not consider it derogatory to the power of Grod to suppose him working by means of fixed laws. The theory of Spontaneous Generation was admitted by the theology of the seventeenth century. Our theology is the same as in A. D. 1653. The plilological discoveries of the past two centuries, and the consequent improvements in Biblical exegesis have affected it but little. Job's exclamation, "I know that my Redeemer liveth, and in my flesh shall I see God," still stands in our burial service as a proof of the resurrection of the body; when we all know that it should be translated "and without my flesh shall I see God." Science proved spontaneous generation an impossibility, and Theology now therefore virtually 




\section{STRAY GLIMPSES AT OLD HARVARD.}

Cambridge is a model university town; in a spot peculiarly favored by nature, art has left little to be desired, and the broad, quiet, elm-arched streets, the tasteful pleasant homes, the very people you meet, bear that air of culture and refinement which is found only near long-established seats of learning. Here, we need hardly say, is Harvard College. Founded in the early days of our colonial listory, it copied the main features of the great English universities, and although the old laws and customs are mostly gone, sufficient traces remain to give to "Old Harvard" and to its student life a peculiar stamp of their own.

A stranger is impressed by the quiet and order which prevail in the class-room, on the campus and in the street. As in the European universities, this results from the large number of students. At an institution so undemocratic as Harvard, in a class numbering two hundred or more, where the student has hardly a speaking acquaintance with half his classmates, "class spirit" and class combinations are things unknown. Individuals, not classes, are held responsible for disorderly acts; indeed, public sentiment in college is strongly against the rowdyism common in some of the neighboring institutions. To this, and to the strict government of President Elliot, may be ascribed the suppression of hazing. The most virulent form of this is now seen in the annual "card-war." It is a common custom of students to post their cards on their study doors; Freshmen, however, are not expected to enjoy the advantages of door-plates, and their attempts in this direction are ruthlessly thwarted by the Sophomores. Last year, inuch to 
the disgust of the latter, the authorities protected Fresliman doors, while the destruction of Sophomore cards was unnoticed. Under the new president, the annual rushes in the gymnasium on "Bloody Monday," and on the campus on Class Day, have been entirely suppressed by threats of suspension, or of delivery into the hands of the law.

Harvard, unlike Yale, and most large colleges, is peculiarly a local institution. Eighty per cent. of its students are from New England, and seventy per cent from Massachusetts. Probably half are Bostonians, and this may account for the spirit of caste which prevails.

The secret society is much less prominent. here than in other colleges. Greek-letter societies were long since abolished, and their place is supplied by semi-secret local organizations, of a social and literary character. Many like the Institute of 1770 , the Everett Athanæum, and the Hasty Pudding Club, are of very long standing, and bear on their records the names of many distinguished men. The Society of the Christian Brethren holds weekly prayer meetings, the only social religious service in college. Amusements are much the same as elsewhere. Theatre going is quite popular. Music is below par, Glee Club and Chapel choir are no better than they should be, and, but for the Freshmen, college songs would be extinct in this their American Alma mater. Base Ball is popular with a few, and all take a learty pride in the University Nine. Boating has deservedly more rotaries, as the spacious boat-house with its fifty practice boats would indicate, but the narrow, shallow, Charles River, meandering through the salt marshes, compares but poorly with our own Connecticut. The Gymnasium is poorly rentilated, and is not generally patronized. The instructor is a broad-slouldered, active mulatto, who also runs a second hand cloth- 
ing store in an adjoining street. He feels the honor of his position. Some years ago mucli comment was excited, by the announcement of the marriage of Frederick Donglass, Jr., to the daughter of Prof. T. M[olyneaux Hewlett, of Harvard University. The range of electives is very great, and so much freedom of choice is allowed, that after the first year the student may devote two thirds of his time to studies bearing directly upon his future profession. Of course this is abused, and men by selecting the easiest branches, make sure of reciting finely (or in Harrard parlance, of "squirting") every time, and thus gain an mufair rank. There are quite substantial motives for this, for the first few scholars in each class are entitled to scholarships of from serenty-five to three hundred dollars per annum. Examinations are very rigid, and play an important part in the determination of class rank.

Evening prayers, and Sophomore and Junior Exhibitions, are things of the past. Morning prayers come at 6.45 A.x. At the sound of the bell, in throng the students, their toilets mayhap not so sumptuous as would be deemed requisite for an evening party. Services are conducted by Dr. Peabody, the college preacher. During the reading of Scriptures the monitors rise in their seats and mark the absentees. Attendance is required only three times a week, each student attending on those mornings which best suit his convenience. Announcements of general interest are made by bulletin and not in chapel. Sabbath morning, if so inclined, students attend divine worship in the Appleton Chapel, a gloomy, cheerless room, whose architectural beauties, few enough in the beginning, are destroyed by the sounding boards and other appliances designed to remedy its acoustic defects. The officiating clergyman is Dr. A. P. Peabody, college preacher and Professor of Morals, 
long the successful editor of the North American Review. Awkward and labored in his delivery, his sermons abound in deep, earnest thought, simply and forcibly expressed. Their theology would pass muster with any Methodist congregation, though the preacher is theoretically a staunch Unitarian of the old school. Regular attendants upon this service are Prof. Longfellow, the Hon. John G. Palfrey, New England's historian, whose residence is close at hand, Prof. Wyman, the anatomist, and many of the Professors.

Prof. Asa Gray, the botanist, and some others cling to the old. Harvard fxith, the congregational.

The library is in Gore Hall, a Yankee Gothic granite structure, built in imitation of Kings College Chapel, Cambridga University. This is not nearly so commodious as our own Rich Hall, and is very inconveniently crammed with books, while four enormous stacks of steam pipes connected with the heating apparatus, add to the cramped appearance of the room. The anunal increase of the library is small, and the management very con. servative.

A noticeable feature is the presence of young lady assistants, who trip about the room apparently understanding and enjoying their business.

Take it for all in all, Harrard is our nearest approach to the grand old universities of Europe. Its liberal and far sighted policy render it certain that when America is ready for a true miversity, Cambridge will be its seat. Cele argen. v 67. 






\section{A P P ENDIX.}

All the names embraced in the tables I, II, III, and IV, following are found in one or more of the lists of "Colleges and Collegiate Institutions in the United States," compiled by JoHs Eıtor, Esq., commissioner of education, David N. Camp, Esq., editor of the American Year Book for 1869, and G. Brown Goode, Esq., editor of the Wesleyan University College Argus, with the exception of seven names in the first table and two names in the third, not contained in either of those lists. The design is, to obtain, if possible, such a classification as shall exhibit the number of regularly chartered colleges in the country; and also the educational institutions heretofore confounded with them, in groups by themselves. With regarci to the colleges and high schools under charge of the clergy of the Roman Catholic church it has been impossible to make this distinction for want of information. Those of these institutions which have college charters are made up in great part of boys below the age and grade of college students. It has been thought best therefore to place them all in a single group.

A recount of the names in the lists above mentioned, made since the report was written, gives as the total number of different names, four hundred and sixty-nine; of which three hundred and six appear to be names of colleges; sixty-six Roman catholic schools; sixty-eight, colleges for females; and twenty-nine, institutes or high schools for males. The following tables contain respectively, the first, three hundred and thirteen names; the second, sixty-six; the third, sixty-eight; and the fourth, thirty-one. 


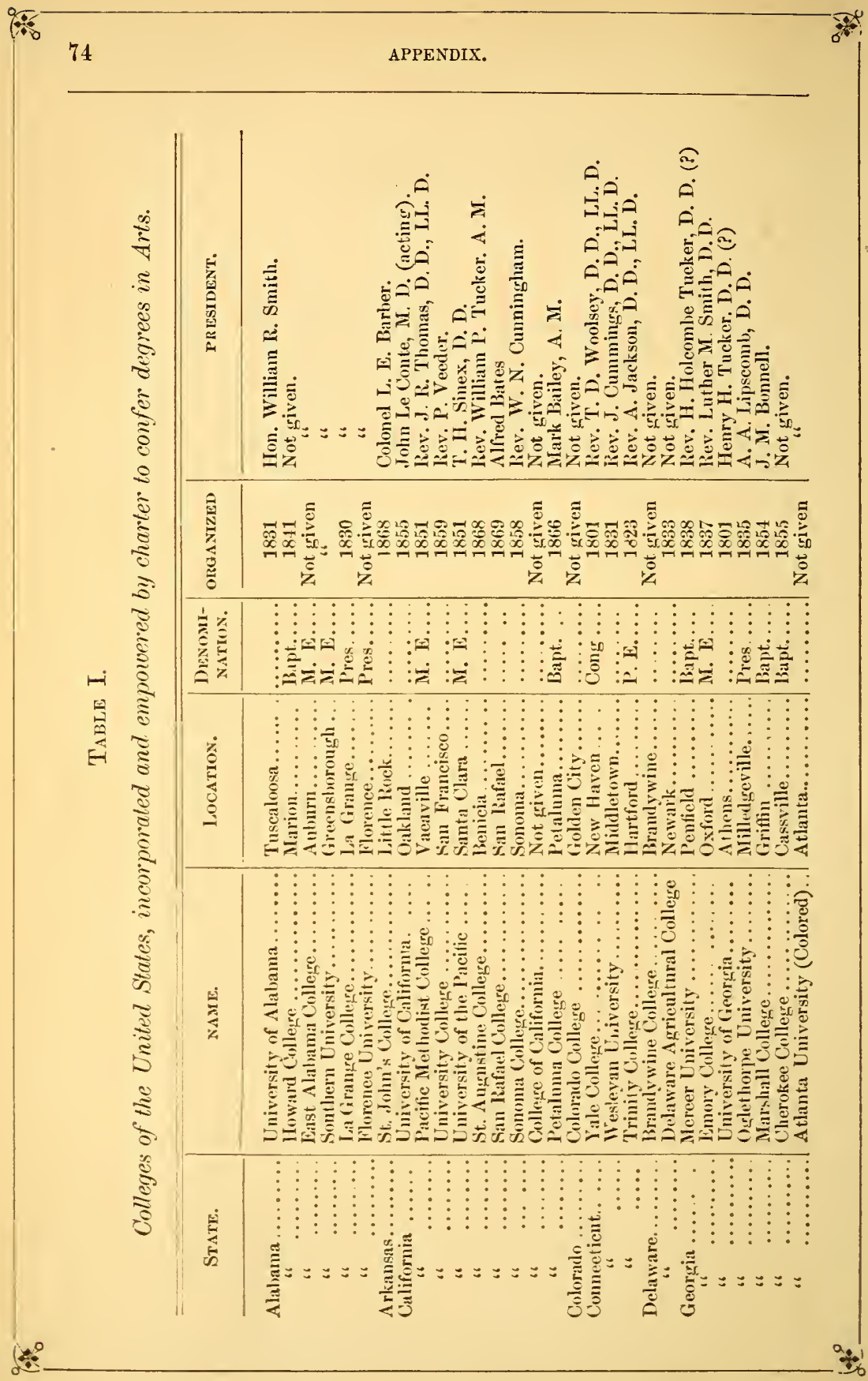




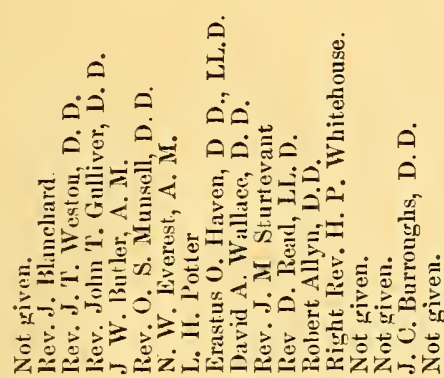

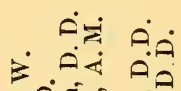
यें

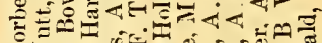

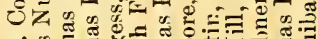

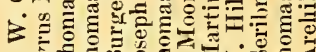

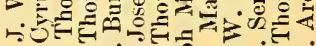
$\therefore<\dot{0}=0$ ن

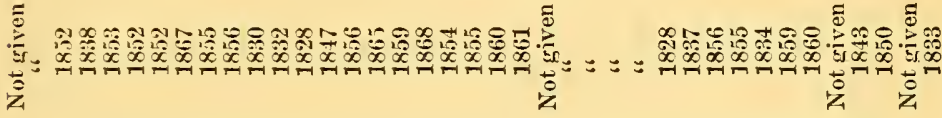

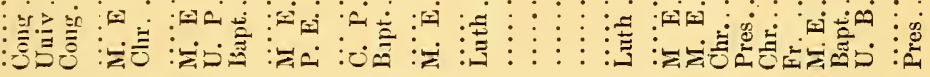

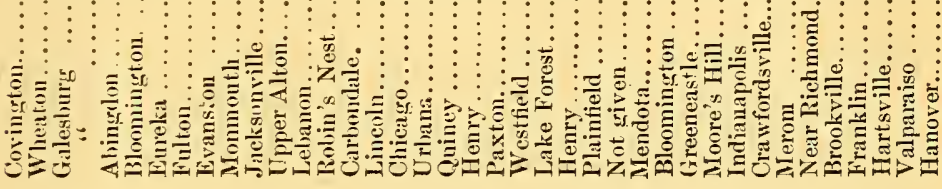

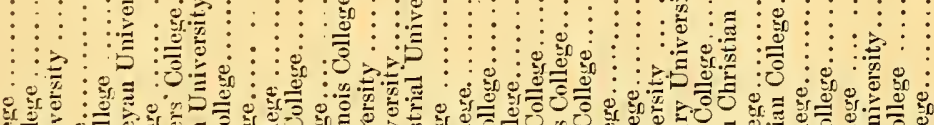

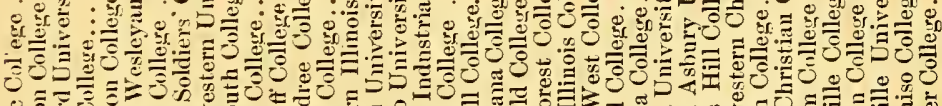

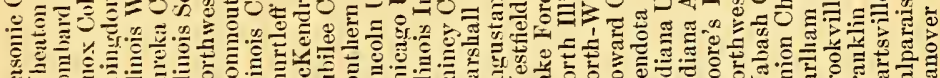

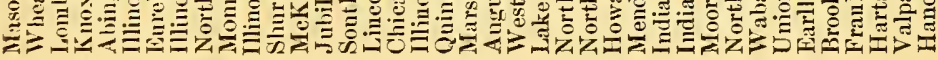

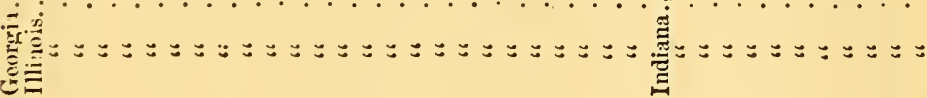
$\because 8$ 


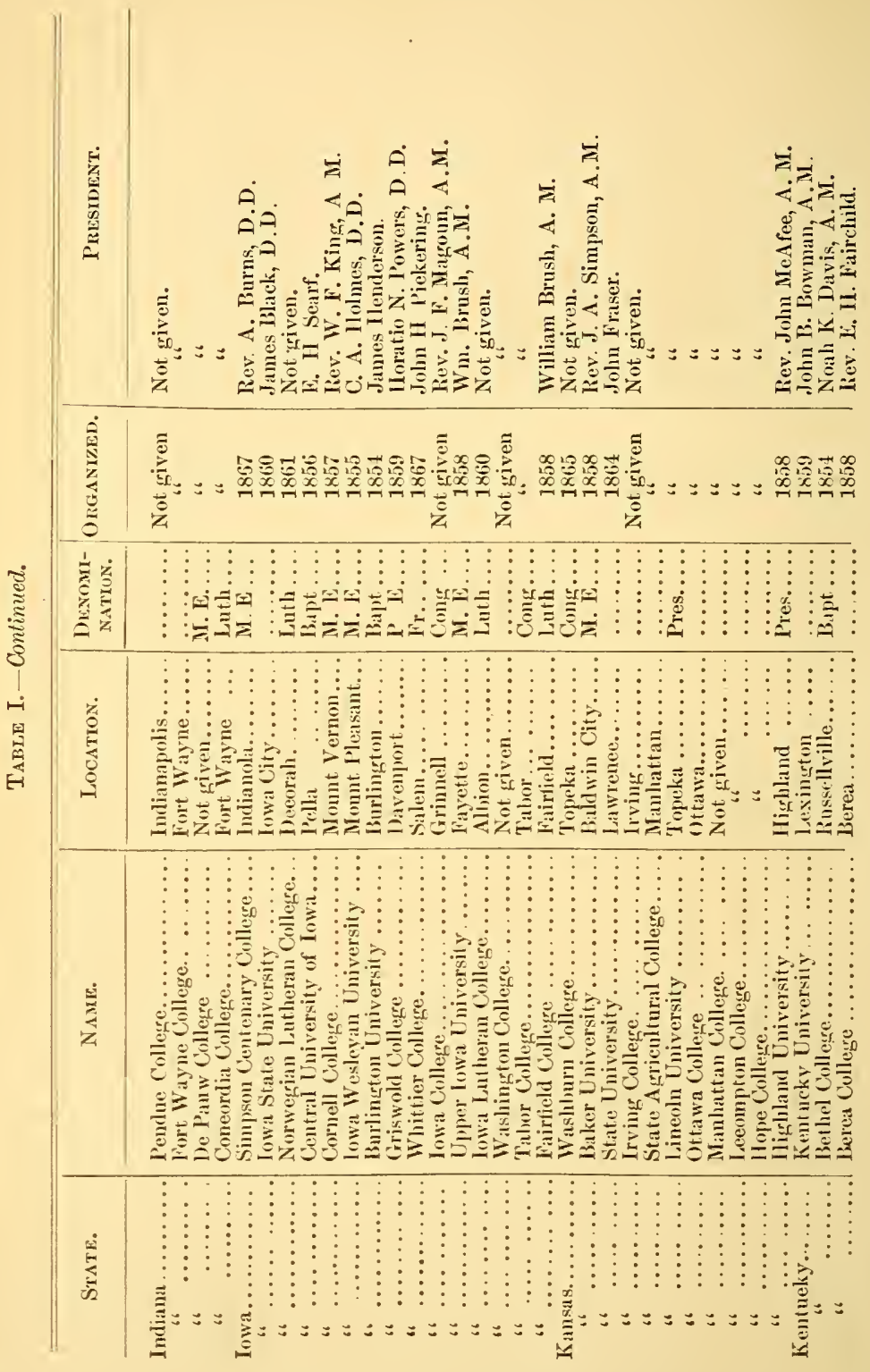




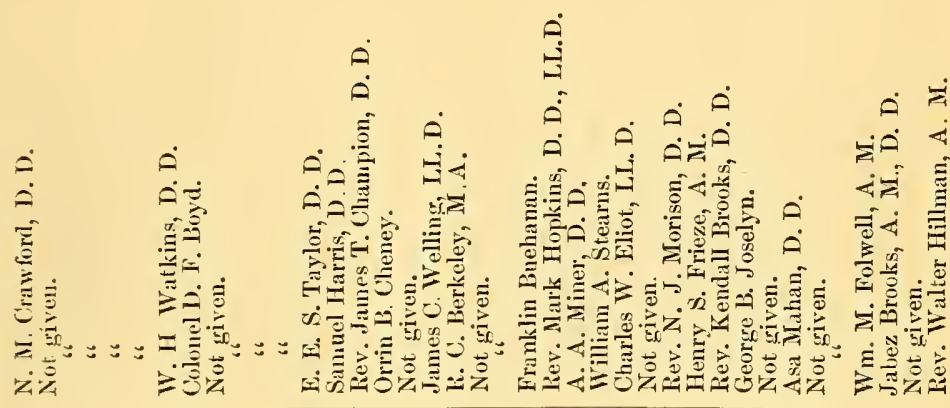

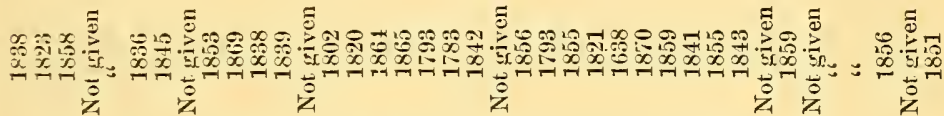

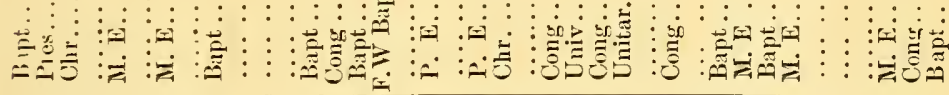

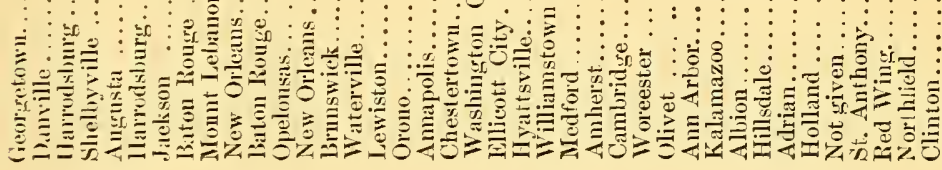

$\frac{0}{0}$

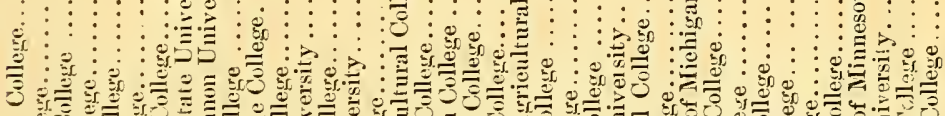

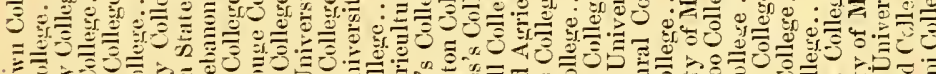

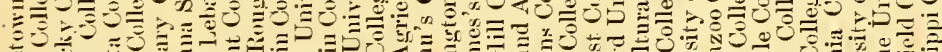

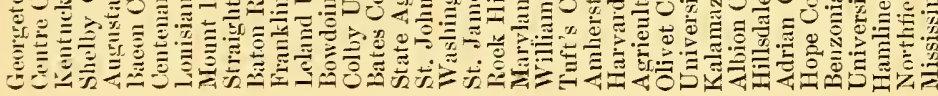

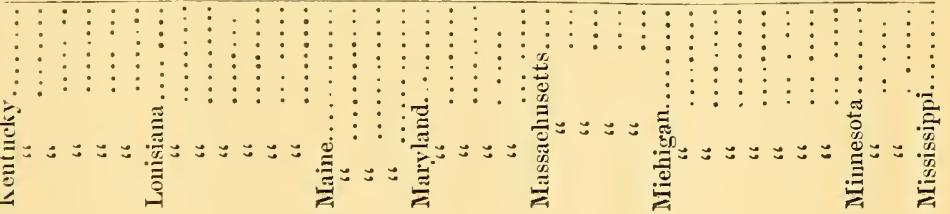




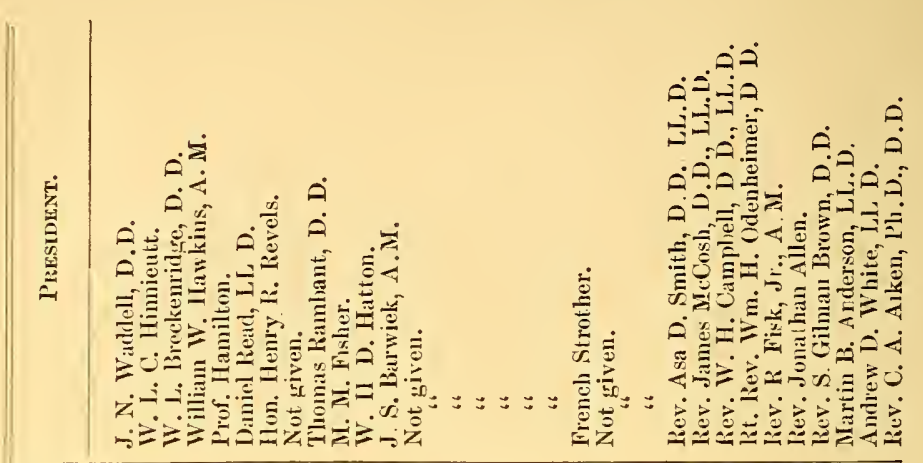

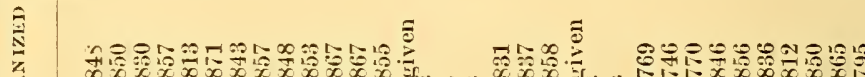

等

(ָ)

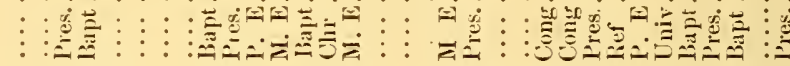



l)

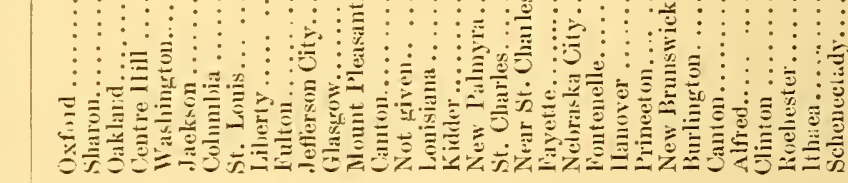

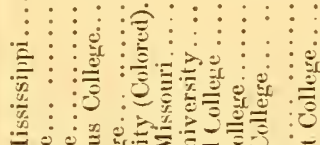

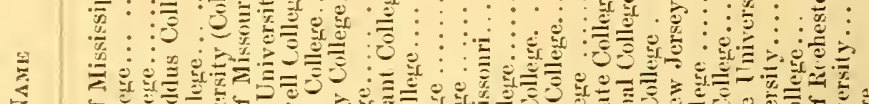

乙 引 - 30.3

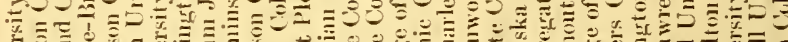

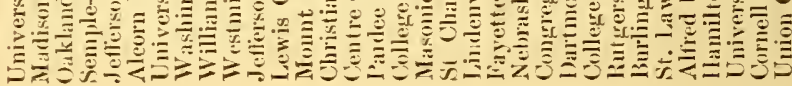

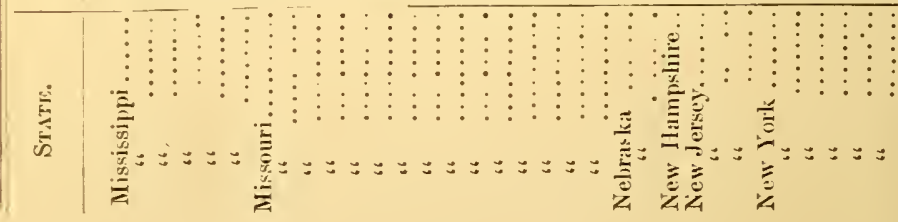



穴

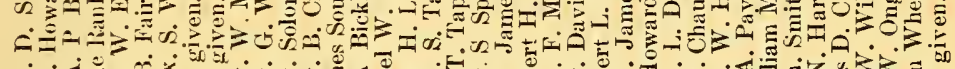

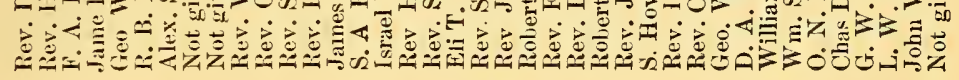

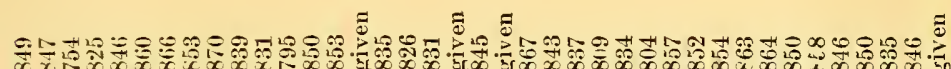

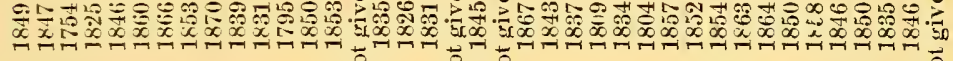
乙

눈

$\therefore=0$ a

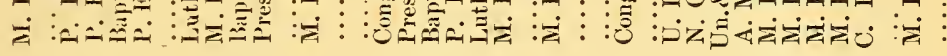

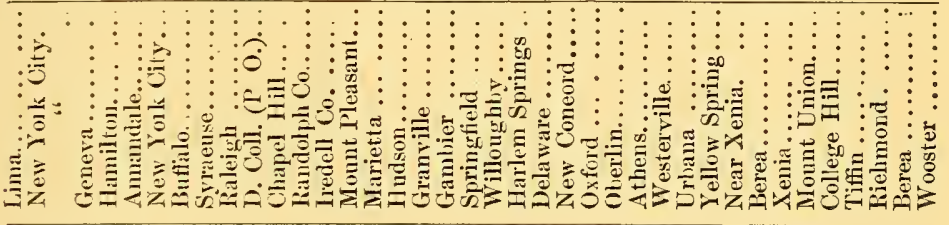

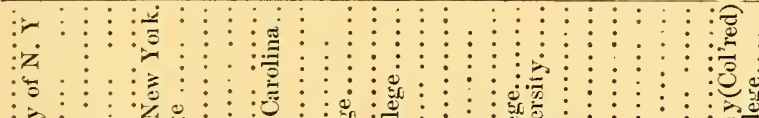

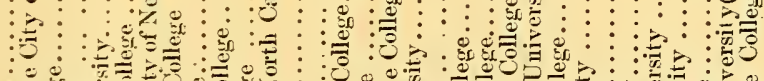

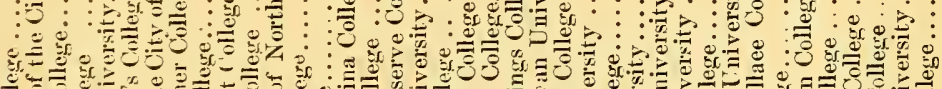

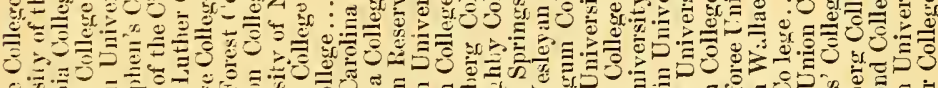

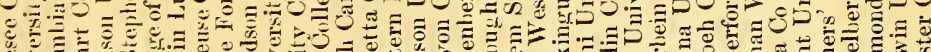

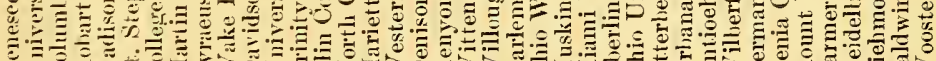

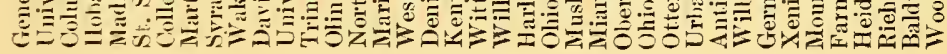

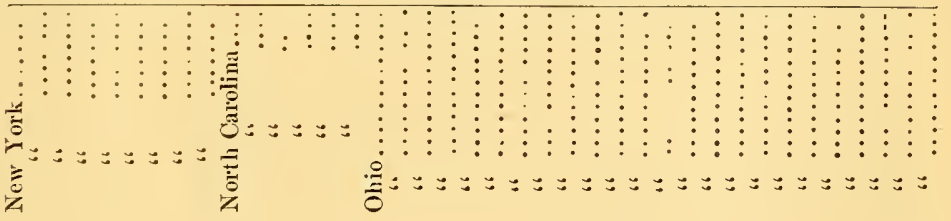




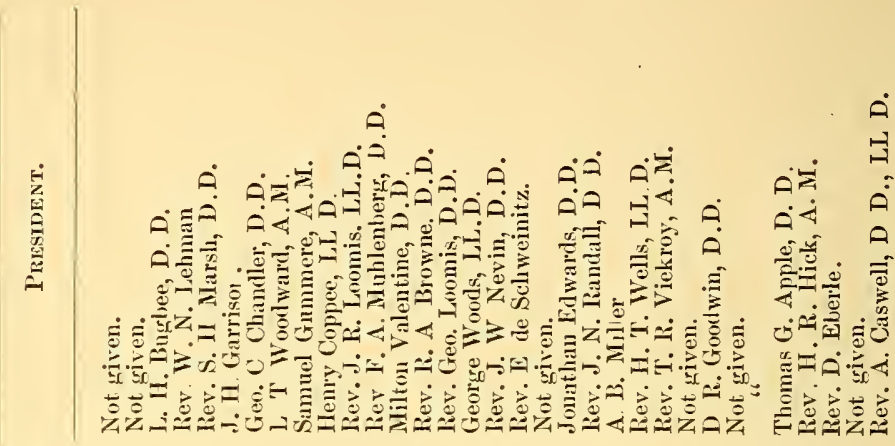

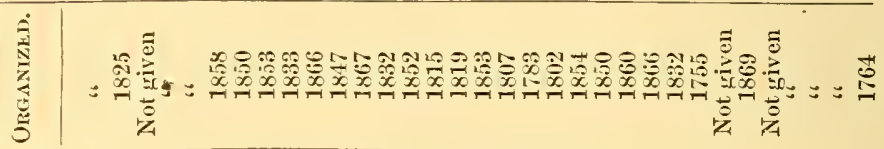

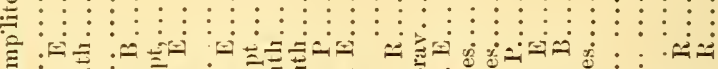

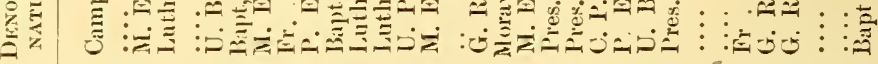

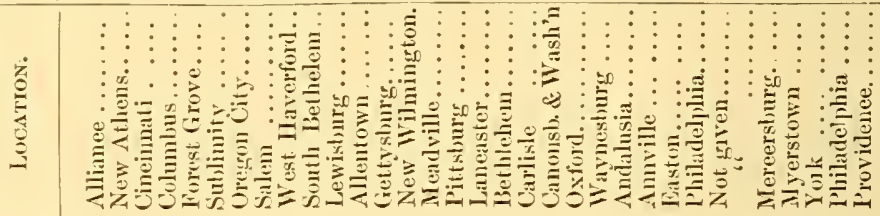

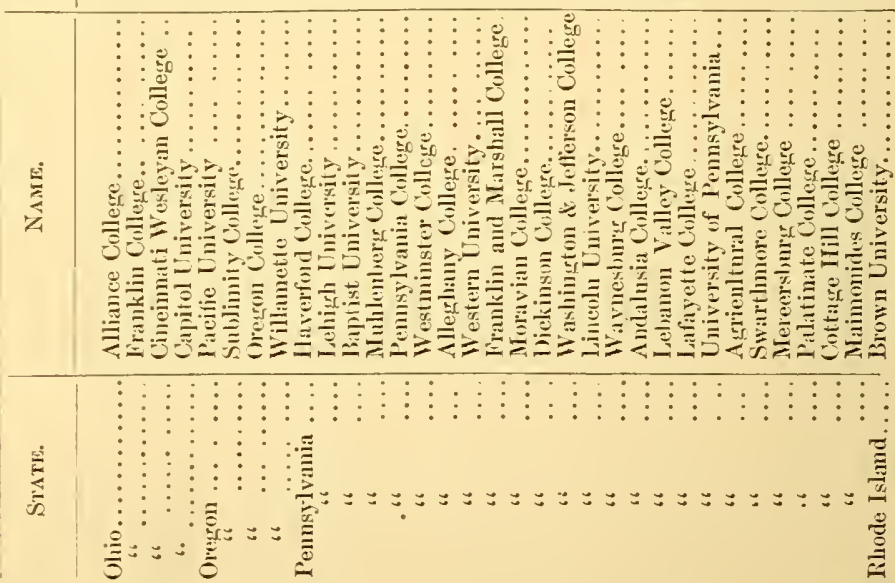


年

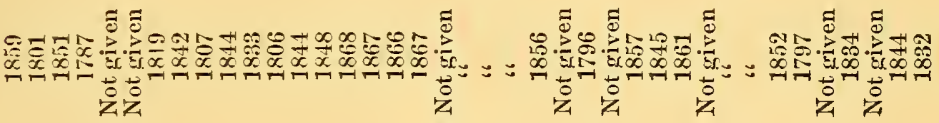

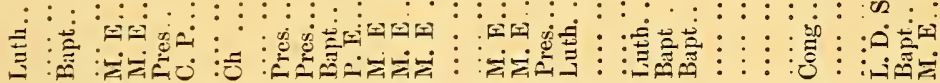

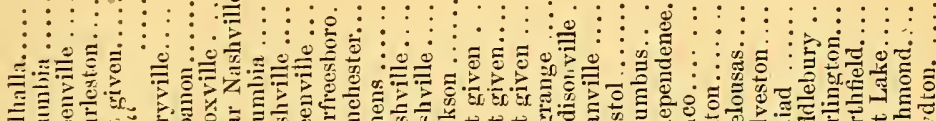

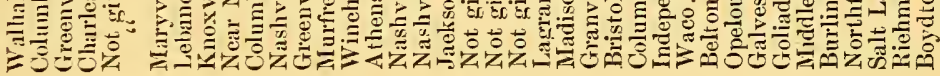

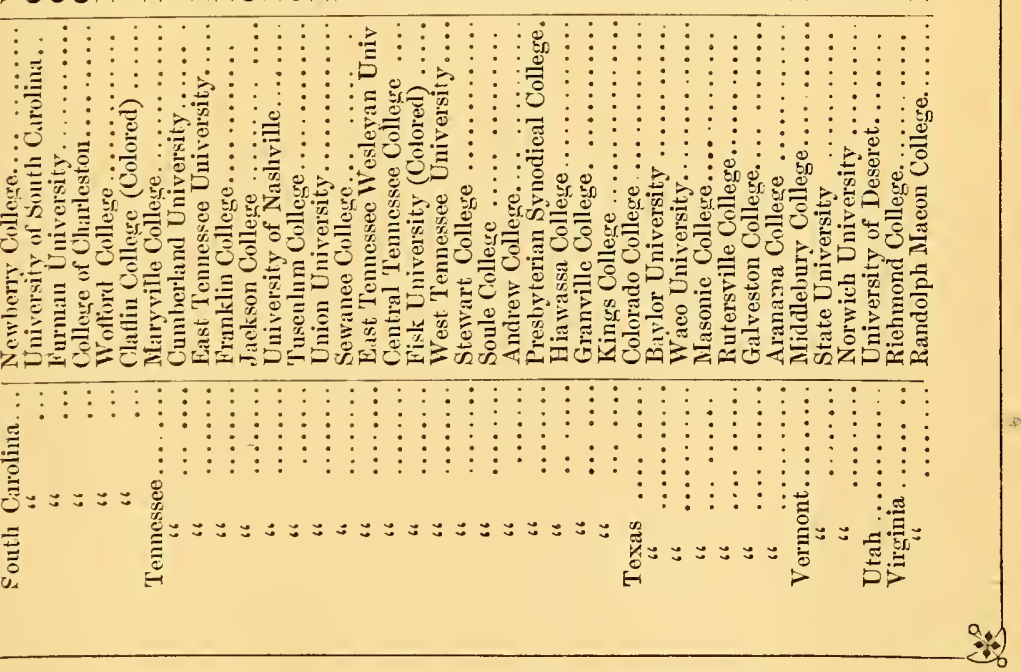




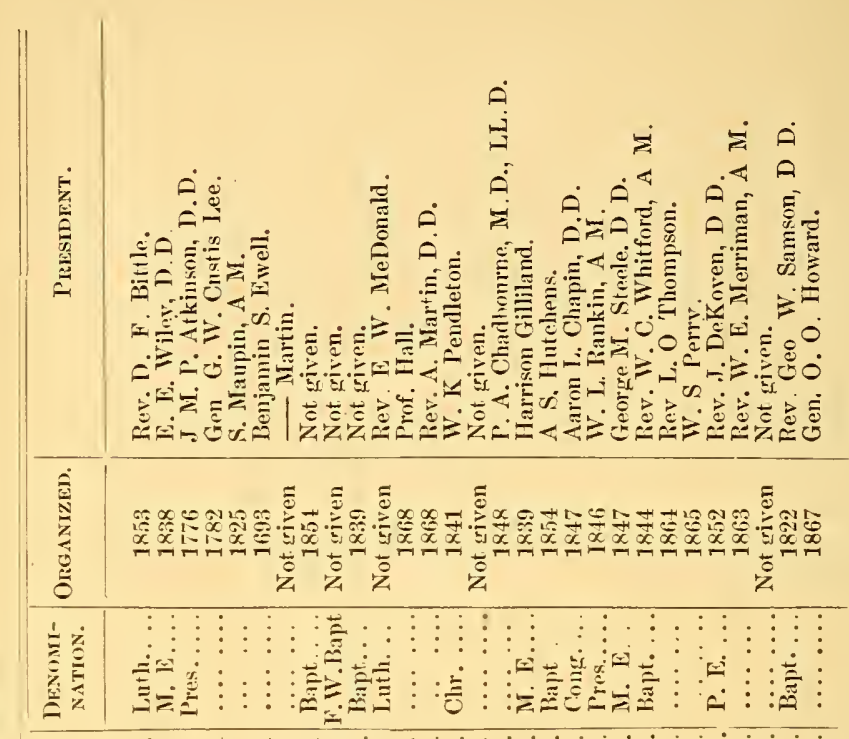

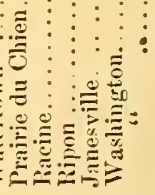

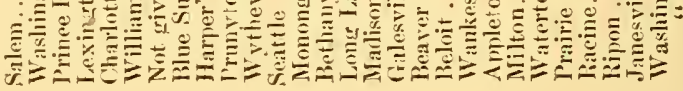
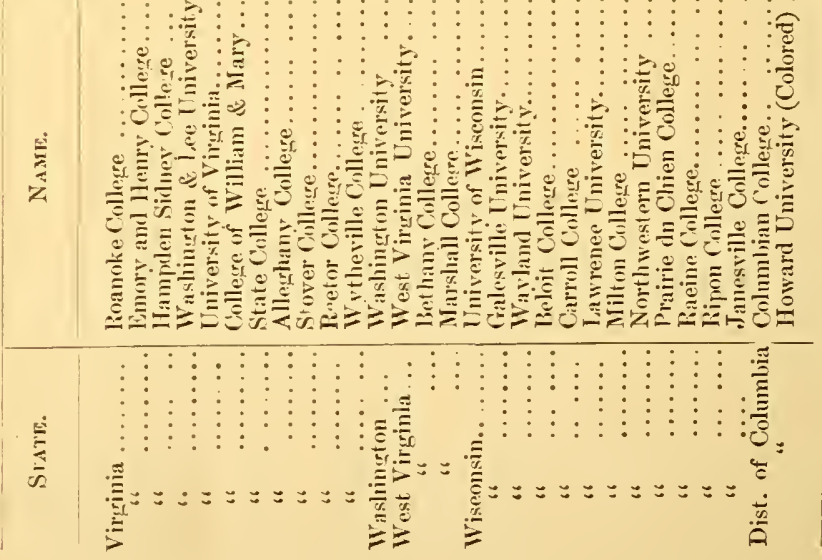


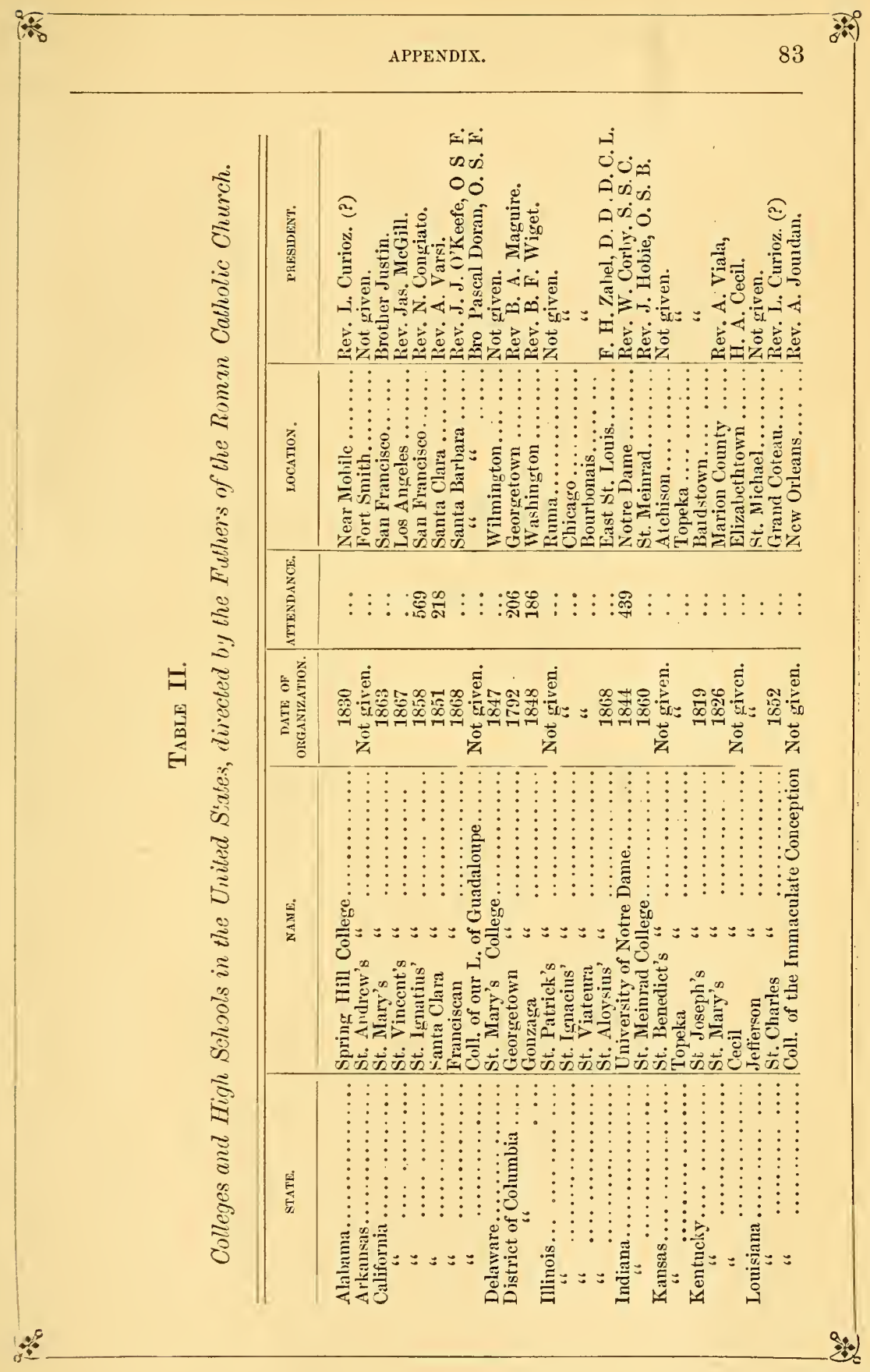




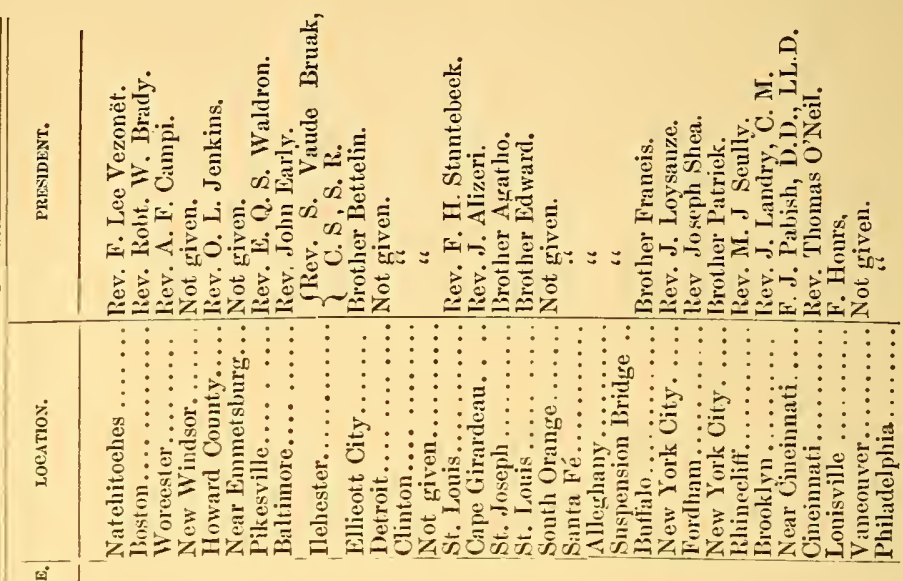

气

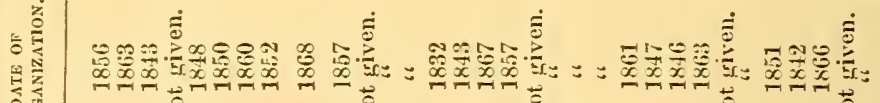

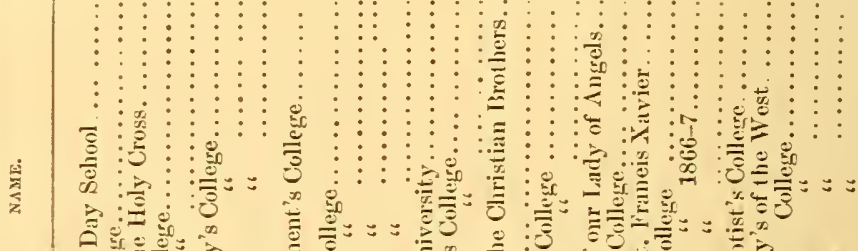

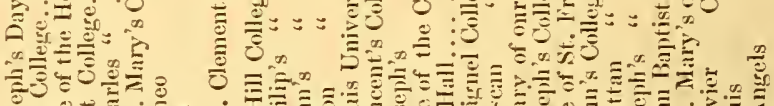

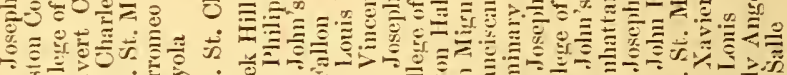

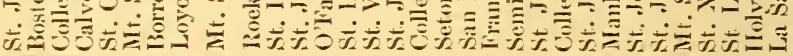

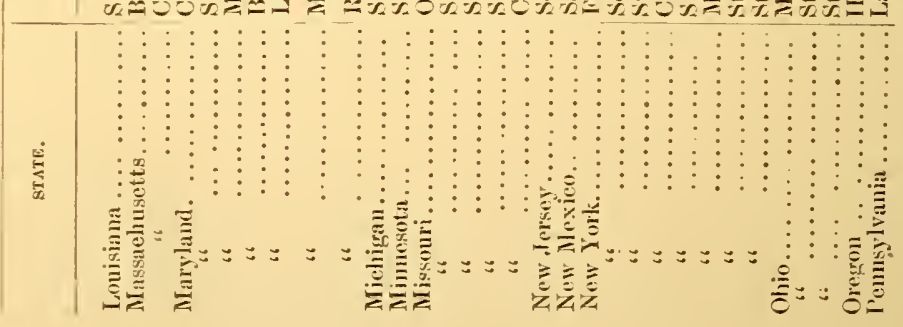




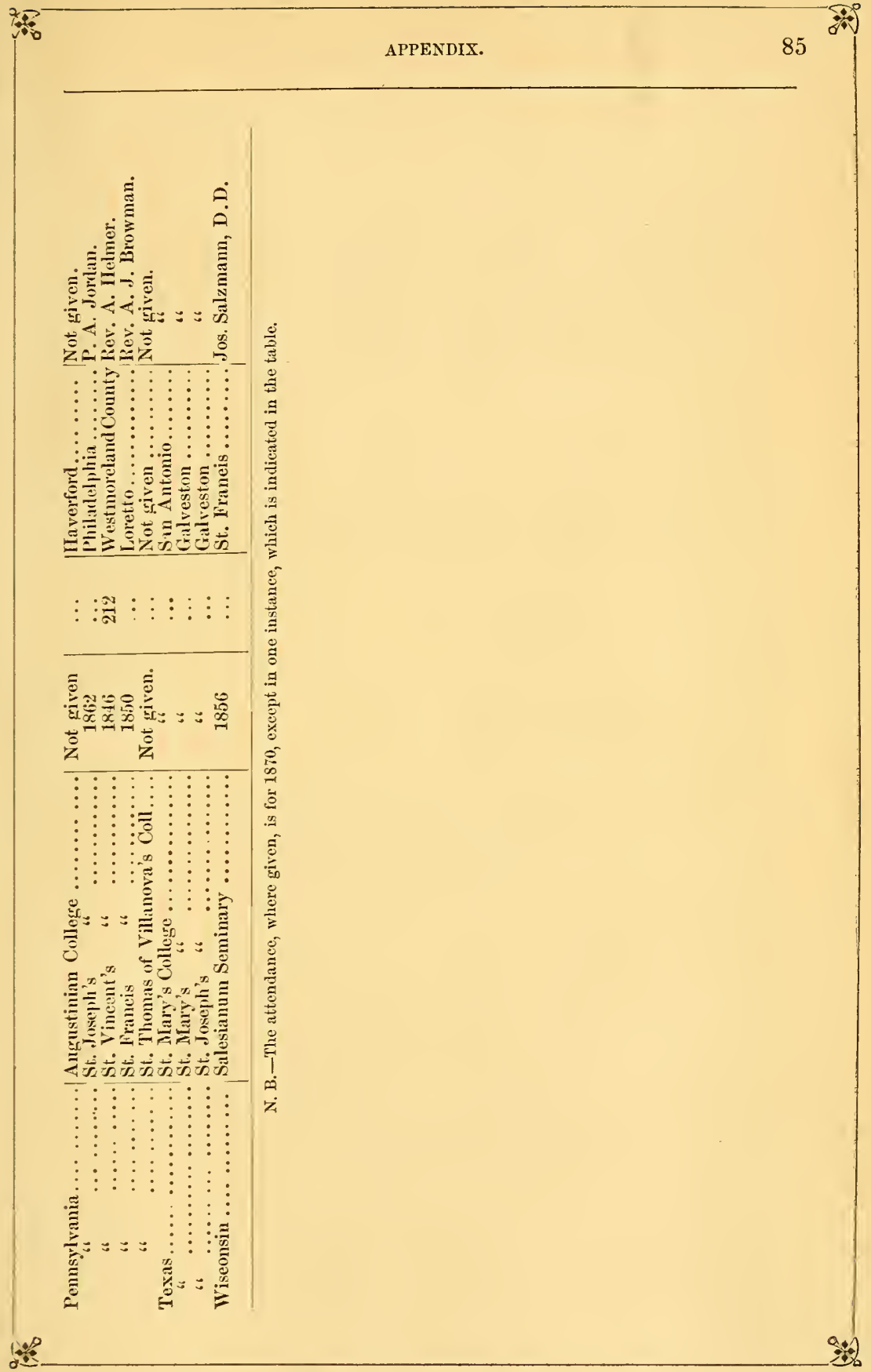




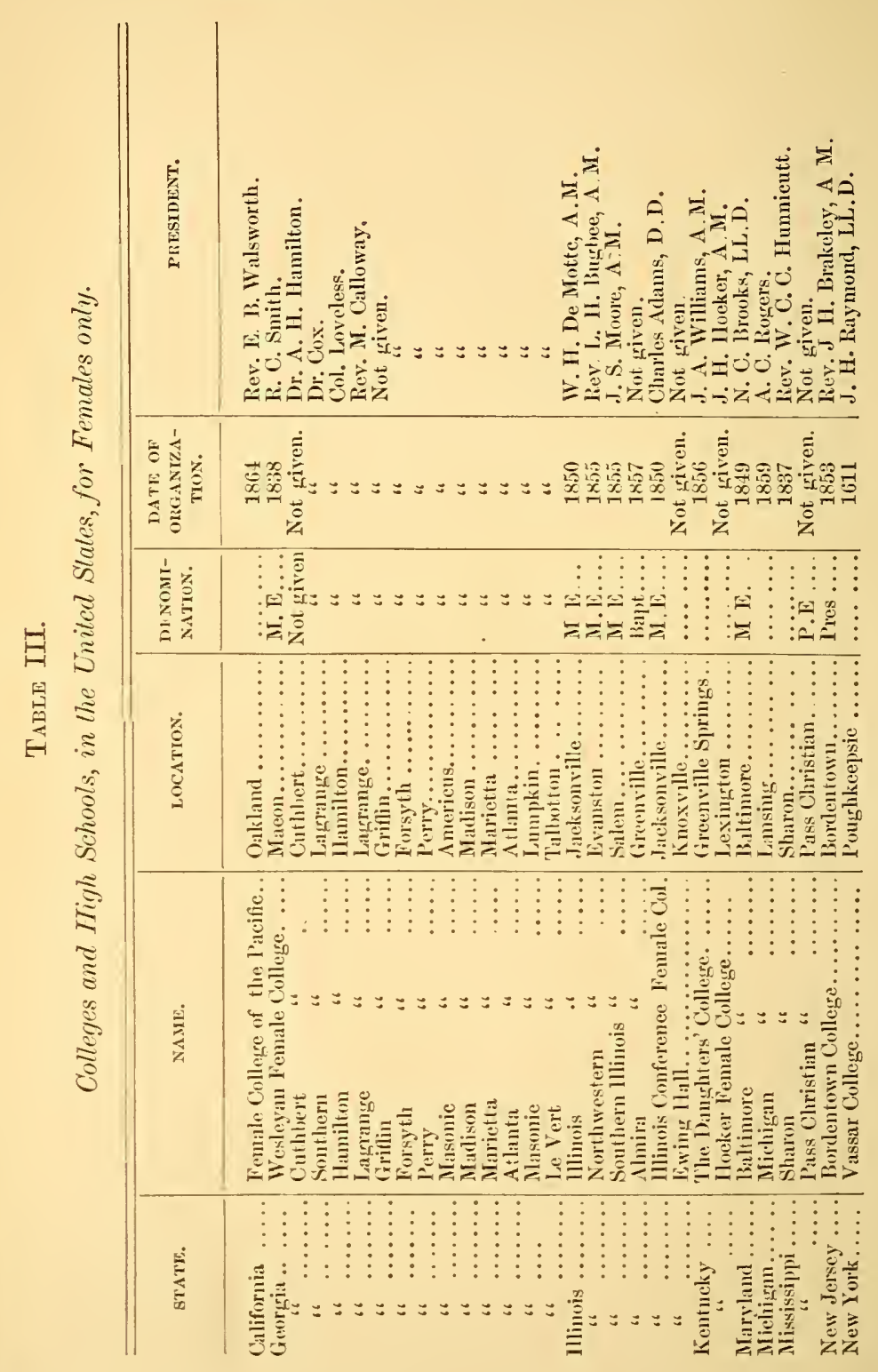




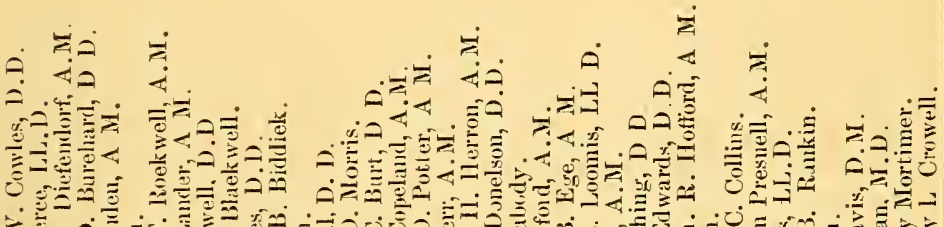

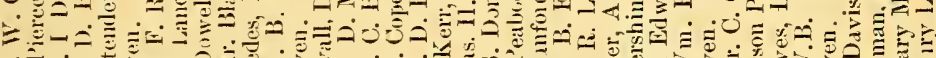
等,

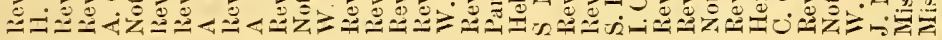

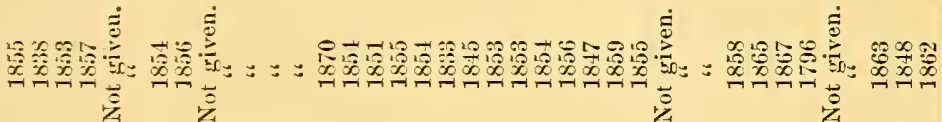

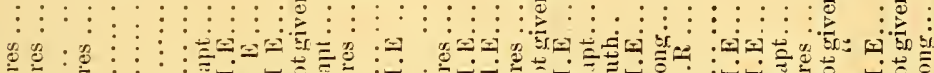

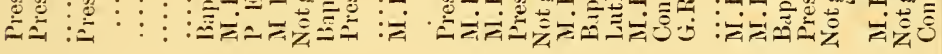

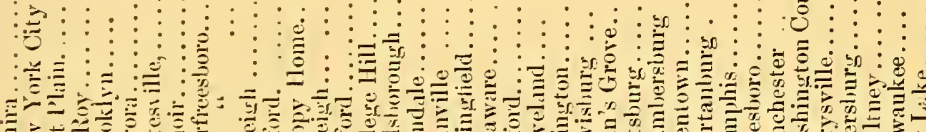

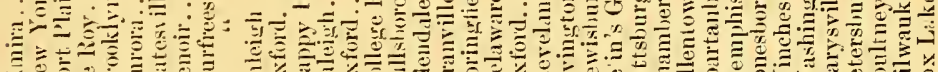

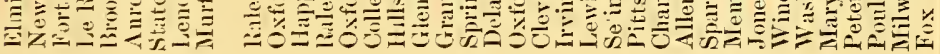

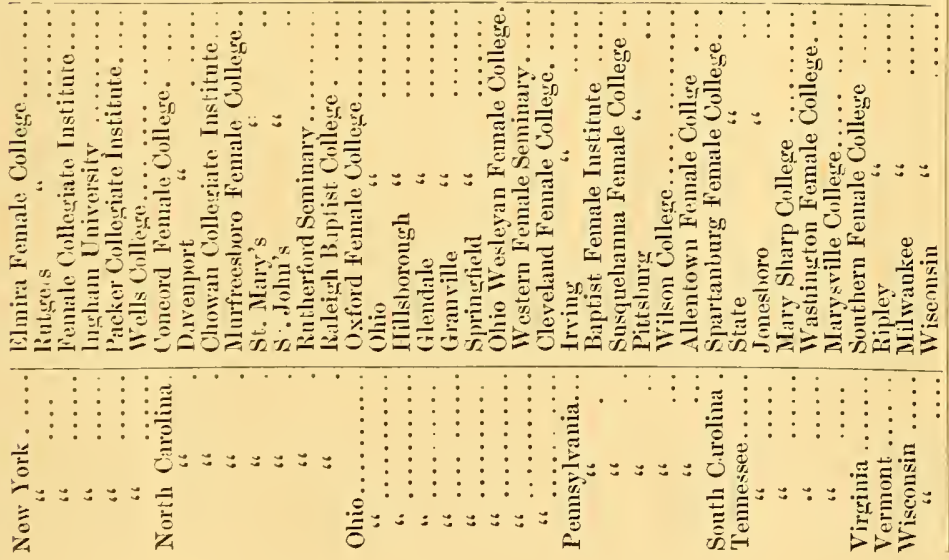




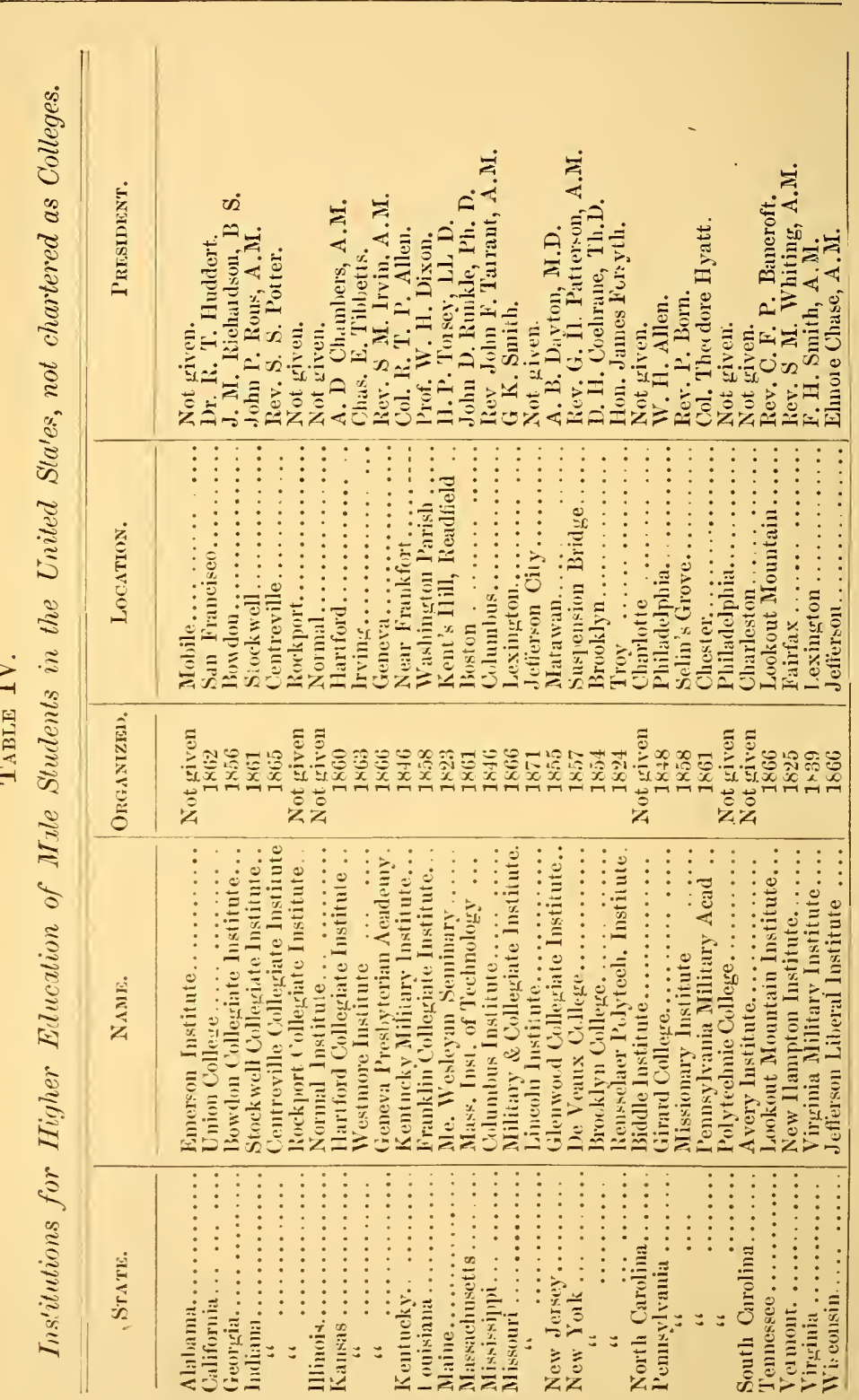




\section{TABLE V.}

Cndergraduates in attendance in one hundred and fifty-three colleges of the Cnited States, mainly in the year 1869-70, showing the number present in each from the New England states, and from Nsw York, New Jersey and Pennsylvania. Where the attendance $i$ siven for other years the dates are designated.

\begin{tabular}{|c|c|c|c|c|c|c|c|c|c|c|c|c|c|}
\hline $\begin{array}{c}\text { Cniversities } \\
\text { and } \\
\text { Colleges of the United States. }\end{array}$ & 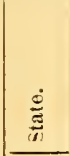 & $\stackrel{\frac{g}{2}}{\frac{g}{2}}$ & 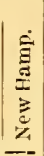 & $\stackrel{\vec{g}}{\stackrel{\Xi}{g}}$ & 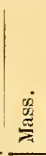 & تح & ప్ & 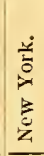 & $\ddot{z}$ & $\stackrel{\Xi}{0}$ & 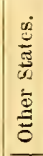 & 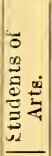 & 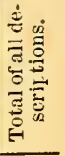 \\
\hline$w$ & Saine & 118 & 2 & .. & 5 & .. & .. & 1 & .. & .. & & 132 & 237 \\
\hline . & " & 43 & & .. & 1 & .. & .. & .. & .. & .. & 1 & 45 & \\
\hline$\ldots$ & " & 60 & 10 & & 3 & 1 & .. & & & .. & 2 & & \\
\hline Dart & " & 9 & 119 & 70 & 30 & 1 & 3 & 16 & .. & 3 & 38 & 289 & \\
\hline e........... & N. H. & .. & 1 & 38 & . & .. & 1 & 11 & .. & .. & 3 & 54 & \\
\hline .......... & Ver... & .. & .. & 40 & i & $\because$ & .. & 3 & & .. & 1 & 45 & 12 \\
\hline$\ldots$ & 6 & .. & 2 & 22 & 7 & $i$ & $\cdots$ & 3 & 1 & & & 36 & \\
\hline ............ & 16 & 16 & 16 & 4 & 372 & 6 & 2 & 51 & 2 & 19 & 75 & 563 & $110^{\circ}$ \\
\hline & Moss. & $\because$ & .. & 5 & 43 & & 4 & 63 & 13 & 3 & 28 & 159 & $=0$ \\
\hline$\therefore$. & 6 & 12 & 6 & 10 & 118 & 2 & 19 & 37 & 3 & 9 & 39 & 255 & 25 \\
\hline if & " & 6 & .. & 6 & 34 & $\overline{1}$ & & 3 & .. & & & 50 & \\
\hline ........ & R. I. . & 4 & 5 & 3 & 33 & 81 & 8 & 6 & 2 & 6 & 11 & 159 & 19 \\
\hline & Cуль. & 8 & 4 & 2 & 42 & 2 & 146 & 129 & 20 & 42 & $1: 3$ & b18 & \\
\hline Frin & " & 2 & .. & .. & 4 & 3 & 25 & 15 & 2 & 6 & 26 & 83 & \\
\hline & 6 & 8 & 6 & 6 & 32 & 2 & 19 & 41 & 14 & 6 & 19 & 153 & 15 \\
\hline ......... & N. Y. & & .. & & - & .. & & 114 & 15 & . & $\because$ & 129 & \\
\hline Euio & 16 & 1 & .. & 1 & .. & .. & 1 & 77 & 1 & 1 & 5 & 87 & \\
\hline 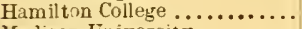 & 6 & $\because$ & $\cdots$ & & & . & . & 138 & & 3 & 19 & 160 & 16 \\
\hline 年 & “ & 1 & . & 7 & 3 & 1 & .. & 59 & 11 & 2 & 16 & 160 & 16 \\
\hline $\mathrm{b}$ & " & .. & .. & . & .. & .. & 1 & 40 & . & 3 & 10 & 54 & \\
\hline & " & & .. & . & . & & & 30 & & 1 & 1 & 32 & \\
\hline ty. & " & 1 & .. & 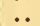 & 1 & 1 & 1 & 26 & $1 \ddot{3}$ & .. & 2 & 45 & 43 \\
\hline & " & .. & .. & 1 & 4 & .. & 1 & 83 & 4 & 3 & 11 & 107 & 11 \\
\hline & " & .. & .. & .. & .. & . & & 169 & 1 & - & . & 170 & 76 \\
\hline & " & 1 & .. & .. & .. & . & 2 & 49 & 3 & 5 & 9 & 69 & \\
\hline & 6 & .. & .. & . & .. & $i$ & 1 & 29 & & 5 & 10 & 4 & 56 \\
\hline fit $x$ & "، & .. & .. & .. & & 3 & .. & 23 & 1 & 1 & 7 & 35 & 36 \\
\hline $0-71 \ldots$ & & .. & . & .. & & .. & .. & 11 & & & & 11 & \\
\hline 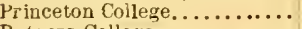 & N. J. & . & 1 & .. & . & . & 2 & 38 & $11: 4$ & 82 & 97 & 324 & \\
\hline & & .. & .. & .. & .. & .. & .. & 40 & 61 & 2 & 2 & 105 & 5 \\
\hline $1870-1$ & Penn & .. & .. & .. & .. & .. & .. & .. & .. & .. & .. & .. & 75 \\
\hline fa & & .. & .. & .. & & . & & 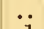 & & 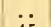 & & & s \\
\hline & " & .. & .. & .. & & & & 1 & 5 & 45 & 33 & 84 & \\
\hline & " & . & .. & .. & & & & . & .. & 7 & 4 & & 1: \\
\hline 2 & " & & .. & . & & & & & .. & 32 & & 32 & 22 \\
\hline & "6 & . & .. & .. & & & & 2 & & 83 & 22 & 167 & 18 \\
\hline h. & " & $\cdots$ & .. & .. & .. & & & .. & .. & & & & 6 \\
\hline 1 & "6 & . & .. & & & & & . & 7 & 53 & 1 & & 12 \\
\hline 8 & " & & .. & .. & . & $\cdots$ & & 2 & 3 & 34 & 12 & 51 & 5 \\
\hline & "6 & & .. & & 1 & & & 4 & .. & 63 & 23 & & 14 \\
\hline frub & " & .. & . & $\cdots$ & .. & * & & .. & & 54 & 3 & 57 & 16 \\
\hline a. & " & & & & .. & & & & & & & & 24 \\
\hline & " & .. & .. & .. & & & & 1 & .. & 123 & 14 & 138 & 15 \\
\hline & "6 & & .. & & & $\cdots$ & & & .. & 11 & & 11 & 35 \\
\hline an & 66 & .. & .. & . & . & .. & . & 1 & $\cdots$ & 73 & 19 & 83 & 16 \\
\hline & & & .. & . & .. & .. & . & $\cdots$ & .. & . & 87 & 87 & 18 \\
\hline ashi & & & & & & & & & .. & & 43 & 43 . & 4 \\
\hline
\end{tabular}


Table V.-Continued.

\begin{tabular}{|c|c|c|c|c|c|c|c|c|c|c|c|c|c|}
\hline $\begin{array}{c}\text { Universities } \\
\text { and } \\
\text { Colleges of the United States. }\end{array}$ & 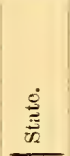 & 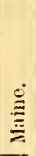 & 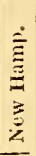 & $\stackrel{\stackrel{\Xi}{\Xi}}{\stackrel{\Xi}{\Xi}}$ & 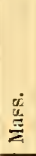 & $\stackrel{\sim}{\sim}$ & อ & $\begin{array}{l}\frac{\cdots}{5} \\
\frac{z}{z} \\
z\end{array}$ & $\stackrel{\dot{z}}{\ddot{z}}$ & ఏ્ & 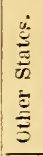 & 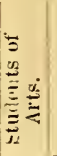 & 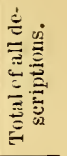 \\
\hline Conmbian College & D. C. & $\cdots$ & .. & .. & .. & & & .. & .. & I & 42 & 43 & 40 \\
\hline nward Uni & & $\cdots$ & $\cdots$ & $\cdots$ & $\cdots$ & $\cdots$ & $\ddot{i}$ & .. & $\because$ & .. & 4 & $\begin{array}{r}700 \\
5\end{array}$ & 414 \\
\hline niversity of Virginia & Va.. & .. & .. & .. & .. & & .. & $\because$ & & .. & 191 & 191 & 465 \\
\hline ashington Coliege. & " & .. & .. & .. & 1 & .. & .. & 5 & 1 & 2 & 332 & $3+1$ & 341 \\
\hline .... & $\because$ & .. & .. & .. & .. & .. & .. & .. & .. & .. & 76 & 76 & 89 \\
\hline unoke College, 1865 & " & .. & .. & .. & .. & .. & .. & .. & .. & .. & $6 \mathbf{1}$ & 61 & 185 \\
\hline nory and Heary Cullege .... & “ & .. & .. & .. & .. & .. & .. & .. & .. & . & 69 & 69 & 165 \\
\hline Richmond College ........... & $" 6$ & $\cdots$ & .. & . & $\cdots$ & $\ddot{0}$ & 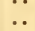 & .. & $\because$ & $\cdots$ & .. & .. & 160 \\
\hline andolph Macon C & 66 & .. & . & .. & . & .. & . & . & .. & . & & & ] 19 \\
\hline B thany Colloge... & IT. Va. & .. & .. & .. & .. & .. & 1 & .. & .. & 10 & 59 & 7i: & 91 \\
\hline Colles & N. C.. & .. & - & .. & .. & .. & .. & .. & .. & .. & 110 & 113 & $1: 5$ \\
\hline Wake Forest $\mathrm{C}$ & 16 & .. & .. & .. & .. & & $\cdots$ & • & .. & .. & 22 & 22 & 116 \\
\hline ersity of & " & .. & . & .. & .. & .. & .. & . & .. & .. & .. & .. & 55 \\
\hline University of S. C & S. C.. & .. & .. & .. & .. & & $\therefore$ & & . & .. & & & 42 \\
\hline Newberry College & & .. & .. & .. & . & $\ddot{0}$ & $\ddot{*}$ & & $\because$ & 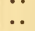 & 18 & $i s$ & su \\
\hline Univ & Ga... & .. & .. & .. & .. & .. & .. & .. & .. & .. & 162 & 162 & $\therefore 44$ \\
\hline Em ry College & 6 & .. & .. & . & .. & .. & $\ldots$ & .. & 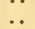 & .. & 110 & 110 & 213 \\
\hline Oglethorpe U & " & .. & .. & .. & .. & .. & .. & . & .. & .. & . & .. & 150 \\
\hline a Univ & " & .. & .. & .. & .. & .. & .. & .. & .. & .. & $\because$ & .. & S9 \\
\hline ... & "6 & .. & .. & .. & .. & .. & .. & & .. & . & 77 & 77 & 82 \\
\hline University & Uiss. . & .. & . & .. & .. & .. & .. & .. & .. & .. & $12 \pm$ & 124 & $: 08$ \\
\hline . & "6 & .. & .. & .. & .. & .. & .. & .. & .. & .. & 20 & 20 & 101 \\
\hline B $\downarrow y$ lor Univarsit & T:xas & .. & .. & .. & .. & .. & .. & & & .. & .. & .. & 111 \\
\hline & Teun. & .. & .. & .. & .. & .. & $\ldots$ & .. & & .. & $y$ & 9 & .60 \\
\hline Cum & " & & .. & .. & .. & & .. & & & $\because$. & 57 & 57 & 401 \\
\hline E. Te & "6 & .. & .. & .. & .. & .. & $\ldots$ & 1 & $\because$. & .. & $3 t$ & 35 & 183 \\
\hline Univ.. & " & .. & .. & .. & .. & .. & .. & .. & .. & .. & 41 & 41 & 157 \\
\hline ge.... & "6 & .. & .. & .. & .. & .. & .. & .. & .. & .. & .. & & 192 \\
\hline .. & " & .. & . & . & . & .. & .. & . & .. & .. & 2 & 2 & 111 \\
\hline ... & Ке... & .. & .. & .. & .. & .. & .. & .. & .. & .. & 192 & 19. & $7 \% 2$ \\
\hline Bethel Colleg & " & .. & .. & .. & .. & .. & .. & .. & .. & .. & 52 & 52 & 1211 \\
\hline & " & & .. & .. & .. & & .. & .. & & & & & 73 \\
\hline & " & .. & .. & .. & .. & .. & .. & & .. & . & 44 & 44 & 120 \\
\hline Wes & ohio & & & & & & & 1 & & 5 & $\because 2$ & is & 115 \\
\hline & & & 2 & 4 & .. & & & 12 & 1 & 4 & 112 & 13. & 1111 \\
\hline Ken & “" & & .. & & & & & 3 & .. & 1 & 6 & in & 70 \\
\hline & 66 & 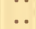 & 1 & 1 & . & & 2 & .. & .. & .. & 53 & $5 i$ & 119 \\
\hline Denis & .6 & & .. & .. & & & 1 & & & $\ddot{i}$ & 47 & 49 & 175 \\
\hline & " & 1 & .. & .. & 2 & - & 1 & 1 & & 1 & $\therefore$ & $1 s$ & $24 t$ \\
\hline & “ & & .. & .. & .. & & .. & 1 & & .. & $1 \leqslant 9$ & 1911 & 417 \\
\hline & " & & .. & . & .. & & .. & & & & & 1 & $16,1)$ \\
\hline & " & & .. & & & & .. & & & & 4 & 4 & it \\
\hline & $"$ & & .. & . & .. & & & & & 2 & 33 & 35 & 178 \\
\hline & "6 & & .. & . & .. & & .. & & .. & .. & & .. & 93 \\
\hline & " & & .. & .. & & & & & & .. & 76 & 76 & 152 \\
\hline & ". & $\cdots$ & .. & $\ldots$ & . & & .. & & $\cdots$ & .. & 11 & 11 & $22 \pi$ \\
\hline & $"$ & & $\ldots$ & .. & .. & & .. & 1 & & 4 & 69 & 74 & 183 \\
\hline , $1869-69$ & "6 & .. & . & .. & .. & .. & .. & .. & .. & 2 & 15 & $1 i$ & $j 61$ \\
\hline & Ind. & .. & 1 & . & .. & & & & 3 & . & 60 & 64 & 209 \\
\hline & 6 & & .. & & .. & & & & & & 11 & 11 & $: 19$ \\
\hline & : : & & .. & .. & .. & & & & & .. & $66^{\circ}$ & 166 & 279 \\
\hline & ". & & & . & . & & & & & & & 2 & 139 \\
\hline ir , $1568-69 .$. & “ & & .. & . & & & & & & & 169 & 169 & $\vdots 21$ \\
\hline Hartsville Enivers & "6 & & .. & .. & .. & & & & & & 4 & 4 & 215 \\
\hline Earlham college.. & 6 & .. & . & $\ldots$ & .. & & . & & $\ldots$ & 1 & 20 & 21 & $\because 12$ \\
\hline & III... & . & 1 & .. & .. & & & & & 2 & $5 t$ & $5 s$ & 3116 \\
\hline College... & & .. & .. & .. & .. & & . & & .. & .. & 48 & 48 & 29 \\
\hline M & "6 & & .. & .. & & & .. & & .. & 8 & 9 & 1117 & 37) \\
\hline & "6 & & $\cdots$ & .. & .. & & . & & & $\cdots$ & 41 & 41 & 210 \\
\hline Il & " & & & & & & & & & & 40 & 4. & 40 \\
\hline North Wers [nir. 15:0-i] & " & & .. & .. & .. & & . & z & & 1 & 64 & $7^{2}$ & 337 \\
\hline Augastana Culleg a and sem... & & & & & & & & & & & & .. & 58 \\
\hline
\end{tabular}


Table V.-Continued.

\begin{tabular}{|c|c|c|c|c|c|c|c|c|c|c|c|c|c|}
\hline $\begin{array}{l}\text { Universities } \\
\text { and } \\
\text { Colleges of the United States. }\end{array}$ & $\underset{⿱ 乛 龰}{0}$ & 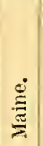 & 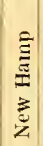 & 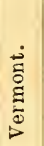 & $\begin{array}{l}\dot{0} \\
\stackrel{\sigma}{\sigma} \\
\frac{\sigma}{2}\end{array}$ & تص & $\stackrel{g}{\mathrm{~g}}$ & 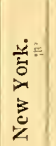 & $\dot{z}$ & 尚 & 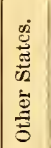 & 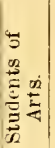 & 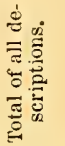 \\
\hline f Chicago......... & Ill.... & . & . & . & $\cdots$ & & & . & & . & & & 346 \\
\hline Hunois Tesleyan Uni & 66 & . & .. & .. & .. & .. & $\ldots$ & .. & 1 & -. & 12 & 13 & 156 \\
\hline Illinois Soldiers' College..... & $\because$ & . & $\cdots$ & $\cdots$ & .. & $\cdots$ & $\cdots$ & - & $\cdots$ & $\cdots$ & $\therefore$ & .. & 187 \\
\hline Eureka College.............. & $\because$ & - & $\cdots$ & . & $\cdots$ & .. & $\cdots$ & $\cdots$ & . & $\cdots$ & 119 & 119 & 172 \\
\hline Illinois Indust. University..... & 66 & - & $\because$ & $\cdots$ & . & $\because$ & .. & .. & .. & $\cdots$ & $\ddot{0}$ & $\because$ & 179 \\
\hline Lombard University.......... & $"$ & . & 1 & $\cdots$ & $\cdots$ & 1 & .. & $\cdots$ & -. & .. & 12 & 14 & 186 \\
\hline Shurtleff College............. & 6 & . & - & - & $\cdots$ & .. & $\cdots$ & 1 & .. & . & 31 & 32 & 125 \\
\hline Quines Coliege, 1868-69 ...... & "6 & . & $\cdots$ & . & $\cdots$ & . & $\cdots$ & .. & $\cdots$ & $\cdots$ & 11 & 11 & 334 \\
\hline Wheaton College, 1S68-69 .... & 66 & $\because$ & . & . & $\cdots$ & . & $\because$ & $\ddot{\circ}$ & $\cdots$ & $\because$ & 20 & $2 \sqrt{3}$ & 239 \\
\hline Eniversity of Mich gan ....... & Misch. & i & . & - & $\cdots$ & . & 1 & 8 & .. & 1 & 161 & 172 & 1112 \\
\hline Hillsdale College ........... & 6 & 1 & . & . & $\cdots$ & . & . & 6 & .. & $\cdots$ & 40 & 47 & 521 \\
\hline Adrian College ............. & 66 & $\cdots$ & $\cdots$ & - & . & . & .. & 1 & .. & .. & 11 & 12 & 103 \\
\hline Oivet College, 18 $70-71 \ldots . .$. & .6 & . & $\cdots$ & . & $\cdots$ & . & - & $\cdots$ & .. & .. & 21 & 21 & 234 \\
\hline Albion Coliege ............. & "6 & $\cdots$ & $\cdots$ & .. & . & $\cdots$ & $\cdots$ & 1 & .. & .. & 15 & 10 & 216 \\
\hline Kalamazoo College, 1870-71... & $\because 6$ & . & . & .. & .. & . & $\because$ & . & & .. & 34 & $\therefore 4$ & 146 \\
\hline Beloit cullege .............. & Wis.. & .. & .. & .. & $\cdots$ & $\cdots$ & 1 & .. & 1 & .. & 75 & 77 & 230 \\
\hline I 2 wrence University ........ & $\because$ & .. & .. & .. & $\cdots$ & - & . & 1 & .. & .. & 20 & 21 & 267 \\
\hline Racine Coliege ............ & 6 & $\ldots$ & . & $\because$ & $\cdots$ & . & - & $\overline{1}$ & .. & 2 & 40 & 43 & 184 \\
\hline Rıpon Cullege ............ & "6 & . & . & 1 & $\cdots$ & . & .. & .. & $\ldots$ & . & 24 & 25 & 330 \\
\hline ersity of Wisconsin..... & 6 & & .. & .. & .. & . & .. & - & .. & . & 38 & 38 & 485 \\
\hline Nortbwestern University .... & " & & . & $\ldots$ & $\because$ & .. & .. & -. & .. & .. & 7 & 7 & 133 \\
\hline Iowa college .............. & Iowa.. & . & 1 & .. & 1 & .. & .. & $\because$ & .. & $\ldots$ & 33 & 35 & 257 \\
\hline Griswold College...$\ldots \ldots \ldots$ & 66 & . & .. & .. & .. & .. & $\cdots$ & 1 & .. & 2 & 11 & 14 & 115 \\
\hline simpson Centenary College... & 16 & - & . & .. & $\cdots$ & . & $\cdots$ & - & .. & . & 14 & 14 & 190 \\
\hline Iowa State Cniversity........ & 6: & - & -. & .. & .. & .. & .. & $\cdots$ & .. & $\because$ & $\ddot{\therefore i}$ & $\because$ & 434 \\
\hline Cornell College...$\ldots \ldots$ & " & - & . & . & .. & .. & .. & $\cdots$ & .. & 1 & 64 & 65 & 352 \\
\hline Iowa Wesleyan Uni.,1868-69. & "6 & . & .. & . & .. & .. & .. & .. & .. & $\cdots$ & 45 & 45 & 278 \\
\hline Whittie: College, 1868-69..... & 16 & . & . & .. & .. & .. & . & $\cdots$ & .. & $\cdots$ & 10 & 10 & 159 \\
\hline Westminster College........ & Mo... & . & .. & .. & .. & . & .. & .. & .. & $\cdots$ & 117 & 117 & 123 \\
\hline Wm. Jewell College......... & $: 6$ & . & . & .. & .. & .. & .. & .. & . & .. & 19 & 19 & 127 \\
\hline Eniversity of Missouri . ...... & 6 & . & .. & .. & .. & .. & .. & .. & .. & -. & 11 & 11 & 243 \\
\hline Wash ington Univ., 1870-71 .. & " & - & . & .. & .. & .. & .. & .. & - & .. & 25 & 25 & 747 \\
\hline Lewis Male ind Female Col.. & 6 & . & . & .. & . & . & .. & .. & .. & $\cdots$ & $\because$ & & 92 \\
\hline Kausas St. Ag. Col., 1868-69.. & Kan.. & . & .. & .. & .. & .. & .. & .. & .. & .. & 15 & 15 & 170 \\
\hline Washburn College.......... & 66 & . & . & .. & .. & .. & .. & .. & .. & .. & 5 & 5 & 45 \\
\hline Pac fic Methodist Col., 1868-9 & Cal. . & . & .. & .. & .. & .. & .. & .. & & . & 26 & 26 & 210 \\
\hline U.uversity of Cali., $1870-71$. & i: & . & .. & .. & .. & .. & .. & .. & .. & .. & $\cdots$ & . & 764 \\
\hline Uaiversity of the Pacific...... & 46 & & . & .. & .. & . & . & . & .. & -. & 9 & 9 & 144 \\
\hline Wailamet Cniv., 1868-69..... & Ore... & - & . & & .. & .. & - & $\cdots$. & & .. & 15 & 15 & 227 \\
\hline University of Aiabama ...... & Ala... & $\cdots$ & $\cdots$ & & $\cdots$ & $\cdots$ & $\cdots$ & $\cdots$ & $\cdots$ & $\cdots$ & 54 & 54 & 54 \\
\hline $\mathrm{H}$ : ward College............ & "6 & $\cdots$ & *. & $\cdots$ & $\cdots$ & $\cdots$ & $\cdots$ & $\cdots$ & $\cdots$ & -. & $\ddot{0}$ & 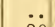 & 184 \\
\hline St. John's College........... & Ark. . & $\cdots$ & $\cdots$ & $\cdots$ & . & $\cdots$ & $\cdots$ & $\cdots$ & - & $\cdots$ & 80 & 80 & 80 \\
\hline Sorthfield College, 1870-71... & Minn. & $\cdots$ & $\cdots$ & $\cdots$ & $\cdots$ & $\cdots$ & $\cdots$ & $\cdots$ & $\cdots$ & $\cdots$ & - & .. & 160 \\
\hline Louisiana State University... & La.... & $\cdots$ & & & $\cdots$ & $\cdots$ & & . & . & & $\cdots$ & . & 217 \\
\hline Total 153 Coll. and Univ. . & $\cdots$ & 293 & 1779 & 221 & 738 & 1117 & 244 & 1370 & 293 & 896 & 549 & $98: 29$ & 459 \\
\hline
\end{tabular}









\title{
ANNUAL REPORT
}

OF THE

\section{PRESIDENT OF COLUMIBIA COLLEGE,}

\author{
MADE TO THE \\ BOARD OF TRUSTEES, \\ JUNE 5, 1871.
}

NEW YORK:

D. VAN NOSTRAND, PUBLISHER, 23 MIurray Street and 27 Warren Street.

$\overline{187} 1$. 









\section{ON TIIE QUESTION}

\section{"DO SNAKES SWALLOW THEIR YOUNG?"}

BY

$$
\text { G. BROWN GOODE. }
$$

[From the Proceedings of the American Association for the Advancement of Science. Portland Neeting, August. 1873.] 



\section{ON THE QUESTION}

\section{"DO SNAKES SWALLOW THEIR YOUNG?"}

BY

G. BROWN GOODE.

[From the Proceedings of the American Association for the Advancement of Science. Portland Meeting, August, 1873.] 



\section{On the Question "Do Swakes Swallow their Young?" By G.}

Brows Goode, of Washington, D. C.

IT has long been a popular belief that the young of certain snakes seek temporary protection from danger by gliding down the open throat of the parent. This has been doubted by many naturalists, and the general disposition has been to class the belief among the popular superstitions. This paper is intended to sum up the evidence, which will show, it is hoped conclusively, that the popular idea is sustained by facts.

Allusions to this habit are found as carly as the sixteenth century. In the "Faerie Queene," Spenser describes Error in these words :-

"But full of fire and greedy hardiment

The youthfull knight could not for ought be staide :

But forth unto the darksom hole he went,

And looked in: His glistring armor made

A litle glooming light, nuch like a shade;

By which he saw the ngly monster plaine,

Halfe like a serpent horribly displaide,

But tls' other halfe did womans shape retaine,

Most lothsom, filthie, foule aud full of vile disdaine.

"And, as she lay upon the durtie ground,

Her huge long taile her den all overspred,

Yet was in knots and many boughtes upwound,

Pointed with mortull sting. Of her there bred

A thousand yong ones which she dayly fed,

Sucking upon her poisnous dugs; each one

Of sundrie shapes, yet all ill-favored:

Soone as that uncouth light upon them shone,

Into her mouth they crept, and suddain all were gone.

"She poured forth out of her hellish sinke

Her fruitful cursed spawne of serpents small,

Deformed monsters, fowle and blacke as inke

Which swarming all about his legs did crall,

And him encombrd sore, but could not hurt at all.

"Her scattred brood, soone as their parent deare

They saw so rudely falling to the ground,

Groning full deadly all with troublous feare

Gathred themselves about her body round,

Weening their wonted entrance to have found

At her wide mouth; but, being there withstood,

They flocked all about ber bleeding wound,

And sucked up their dying mothers blond

Making her death their life, and eke her hurt their good."

L"The Faerie Queene," 1590, Book 1, Canto 1, vv. 14,15, 22 and 25.] 
In Browne's "Vulgar Errors" may be found the following account of the Viper:- "For the young ones will upon any fright for protection run into the belly of the Dam; for then the old one receives them in at her mouth, which way, the fright being past, they will returne againe; which is a peculiar way of refuge, and though it seems strange is avowed by frequent experience and undeniable testimony."*

Gilbert White refers to the prevalent belief in this habit of the viper, and though rather inclined to favor it, he is evidently shaken in his faith by the adverse testimony of the London viper-catchers. $†$

M. Palisot de Beauvois, an eminent French naturalist, published in 1802 some very important observations on the rattlesnake, which will be quoted hereafter.

S. John Dunn Hunter, an early traveller in the United States, says:- "When alarmed, the young rattlesnakes, which are generally eight or ten in number, retreat into the mouth of the parent and reappear on its giving a contractile muscular token that the danger is past." † A few years later a long discussion occurred in the "Gardener's Chronicle" which, however, reached no satisfactory conclusion.

In a note to the eighth edition of "Selborne," Sir William Jardine says:- "The question remains, we believe nearly as it did in White's time. 'The supposed habit is so much at variance with what we know of the general mamners and instincts of animals, that without undoubted proof of its occurrence we are inclined to consider it as a popular delusion."§

In 1865 Mr. Mr. C. Cooke, editor of "Science Gossip," made a strong argument in the affirmative. $\|$

Mr. F. W. Putnam published in the year 1869 \% a very thorough

* "Pseudodoxia Epidemica: or. Enquiries into rery many received Tenents ard commonly presumed Truths. By Thomas Browne, Dr. of Physick." London, 1646, p. 143 .

$\dagger$ †'The Xatural History of Selborne."1789. Series 1. letter xvii; Series 2, letter xxxi.

¥ "Memoirs of a Captivity among the Indians of North America," I.ondon, 1823, p. 170 ; and "North . American Review,"1826. pp. 54, 95-107.

§"Natural llistory of Selborne." London, 1853, p. 58.

"I "Onr Reptiles," London, 1865, p. 58.

T"American Naturalist." rol. ii, p. 173. To this article, which first interested me in the subject. I owe many valuable suggestions. I am also indebted to Prof. Baird. to P'of. Theo. Gill, to Prof. W. N. Rice of Middletown and to Mr. James Simson of lew York. who hare called my attention to facts which would otherwise have es. caped my notice. 
discussion of the question. He speaks of it as still unsettled and, though sympathizing fully with $\mathrm{Mr}$. Cooke, asks for additional proof.

During the past year an animated diseussion has been carried on in the London "Land and Water." Mr. James Simson and others have argued for the aftirmative but Frank Buekland, the editor, elasses the belief among the numerous popular delusions and persistently refuses to believe until he or some other naturalist has personally investigated the subjeet.

The feeling of the majority of naturalists at the present time seems to be well expressed in these words:- "The cumulative testimony of many witnesses would eompel us to receive this supposed habit as an established fact, did not experience warn 11 of the extreme liability of untrained observers to be misled by preconceived opinions. The fact that no competent naturalist has found young vipers in the stomach or œsophagus of the mother raises a strong presumption, on the doetrine of probabilities, of its being a mere delusion. The habit moreover would be eontrary to the ordinary laws of animal instinct whielı lead both parent and offspring to adopt the best available means for the preservation of the raee.*

Theorizing upon this question has proved useless, and it is obvious that it ean only be settled by the statements of persons who have seen the aet. Believing that none would be so likely to supply the desired facts as those whose voeation brings them into daily eontaet with snakes in their native haunts, I wrote a short note to Mr. Orange Judd, Editor of the "Ameriean Agriculturist," whiel le kindly inserted in the issue of that magazine for February, 1873 .

As a result over eighty letters were received, from persons in twenty-four states and provinees, almost every one containing valuable evidence. Many of the writers seem indignant that a faet so well known to them should be questioned. On the depositions of these witnesses, together with those eolleeted by diligent personal inquiry, the ease must rest.

A farmer living in Meehaniesburg, Ohio, writes:-_"In 1835 I saw on the bank of Deer Creek a large water-snake. I proeured a pole for the purpose of killing her. One stroke slightly wounded her and she immediately made for the water; after she had swam

" D" (Yorktown, Virginia) in "Land and Water," xv, p. 78, Feb. 1, 1873. 
about her length she wheeled, placing her under jaw just out of the edge of the water, then opening her month to the fullest extent. Some dozen young snakes, three to four inches long then seemed to run or rather swim down her throat, after which she clumsily turned in scarch of a hiding place. I opened her and found about twenty living young snakes, two or three seven or eight inches long."

A gentleman in Georgetown, S. C., writes :- "I had for several days noticed a very large moccason coiled around the limb of a small tree near the pond. I concluded to capture it and accordingly procured a large rabbit and placed it some way up from the pond to toll her away from the water. She soon came down and disappeared under a large $\log$; when next secn she was near the bait, having traced it along the log on its opposite side. When she had ncarly swallowed the bait we made an advance; quickly disgorging it she gave a shrill whistling noise, and five young snakes ran from under the $\log$ and ran down the throat of the old onc. We cut off her head and found the five young, which made efforts to get away."

A farmer in Rosendale, N. Y., writes :- "I was one day mowing and coming close to a smooth flat rock, I thought I saw as many as a dozen snakes on it. I ran for a fork which was standing within a few yards and when I came back there was only one snakc on the rock. I struck it on the back and scven snakes ran out of the mouth."

A lettcr from Chcsterfield, N. H., says :- "I saw a striped snake on thc hillsidc, and noticed something moring about her head, and counted twenty little snakes, from one and a half to two inches long. I made a move and the old one opened her mouth and they went in out of sight. I stepped back and waited and in a few moments they began to come out. Then I made for the old snake and killed her and forced out several."

A farmer in Newburyport, Mass., writes:- "Riding through a large corn field, in the centre of which was a large shelving rock I observed on the top a curious commotion, but on near approach found nothing. My curiosity was excited, and the next day I repaired to the spot very cautiously, and on the top of the rock saw an enormous striped snake sunning herself, surrounded by a bery of young four to six inches long. After viewing them to my satisfaction I made a demonstration, and to my surprise the 
old snake opened her mouth very wide, the little snakes ran down her throat and then she disappeared in the shelving rock. I repeated the experiment a number of days to the same effect."

The total number of testimonies in my possession is one hundred and twenty. Sixty-seven witnesses saw the young snakes enter the parent's mouth ; twenty-two of these heard the young warned by a whistle or hiss or click or sound of the rattles; five were considerate enough to wait and see them reappear when danger seemed over; one seeing the act repeated on several days.

Three saw young snakes coming out of a large one's mouth, and not having seen them enter were naturally much astonished. Five struck the parent and saw the young rush from its mouth; eighteen saw the young shaken out by dogs or running from the mouth of the dead parent. Thirty-six of those who saw the young enter the parent's mouth, found them living within its body. Only twenty of the sixty-seven allowed the poor, affectionate parent to escape. Thirty-three who did not see the young enter, found them living within the parent's body. 'Testimony of this character concerning the ovo-viviparous species is, however, to say the least, dubious.

It may be objected that these are the testimonies of laymen, of untrained observers, of those who might be influenced in their observations by their prejudices. I reply that the letters are from a class of well-informed farmers, mechanics and business men, intelligent readers of a practical agricultural magazıne. The act of swallowing the young is of such a character as to admit little room for error in the observations, and I find that, as a general rule, opinions on the subject are current only among those who have had it brought to their notice by their own experience or that of their friends. Due weight should be given to the wide distribution of the witnesses, and the remarkable concurrence in their statements.

Let us not, however, trust entirely to the statements of the untrained observer. Says Mr. Cooke:-_Clergymen, naturalists, men of science and repute, in common with those who make no profession of learning, have combined in this belief."* We add the statements of gentlemen, the accuracy of whose observations in other departments of natural history would surely not be doubted. Prof. Sydney I. Smith, of the Sheffield Scientific School, saw a

$$
\text { *"Our Reptiles," p. } 76 .
$$


ribbon-snake (Eutoenia saurita), about two feet long, accompanied by two young ones of three or four inclies; on a hiss from the parent they disappeared down its throat. 'The parent was killed and two ran out of the mouth, while a third was found alive in the body. Dr. Edward Palmer, a well known traveller and collector, assures me that when in Paraguay with the "Waterwitch" expedition, he saw seven young rattlesnakes (Caudisona terrifica) run into their parent's mouth. After it was killed they all ran out. These snakes, parent and brood, are preserved in the U. S. National Museum, Washington.

Rev. Chauncey L. Loomis, M.D., of Middletown, Conn., a keen and enthusiastic observer, saw a black snake (Coluber Alleghaniensis?) open its mouth, allow seven young ones to enter and then glide away.

D. L. Phares, M.D., of Woodville, Miss., writes:- "A few year's ago a gentleman, directing some hands at work on my lawn, heard a low, blowing noise, and on looking saw a large water moccason (Toxicophis piscivorus, I believe) and a large number of young hurrying to her head and disappearing so rapidly that he first thought they ran under her. He soon discovered that they went into her slightly opened mouth, which was held close to the ground till they had all entered. She then attempted to escape, but was cut in two with a hoe. We took from her a large number of young, eight or ten inches long."

I might take from Mr. Cooke's work several statements equally to the point. I quote from the "Zoologist" a note concerning the scaly lizard (Zootoca vivipara), which has all important bearing upon the question. Says the eritor, Mr. Newman:-_"My late lamented friend, William Christy, Jr., found a fine specimen of the common scaly lizard with two young ones; taking an interest in everything relating to natural history, he put them into a small pocket vasculum to bring home, but when he next opened the vasculum the young ones had disappeared, and the belly of the parent was greatly distended; he concluded she had deroured her own offspring. At night the vasculum was laid on a table and the lizard was therefore at rest; in the morning the young ones had reappeared and the mother was as lean as at first."*

Mr. Putnam has kindly put into my hands a note from Thomas Meehan, of Philadelphia, containing strong affirmative testimony 
in the case of the English viper as observed by lim in the Isle of Wight; also a note from Herman Strecker of Reading, Pa., who says :- "Some years ago I came across a garter snake (Eutcenia saurita) with some young ones near her. Soon as she perceired me she hissed and the young ones jumped down her throat, and glided beneath a stone heap. Another time I caught a snake of the same species, but as I thought of immense size, which I took home and put in a cage; on going to look at her some short time afterwards I discorered a great number of young ones (about thirty if I recollect rightly) and whilst I was still looking at the sudden increase, two more crept out of the old one's month, and finally after a little while a third one did likewise."

Prof. C. F. Brackett, of Princeton College, senrls me a note which, besides throwing light upon the question under consideration, gives a rery interesting instance of hereditary instinct: he writes:- "About twenty-fire years ago I saw the following things. A workman who was mowing in my father's liay-field came upon a moist, moss-grown knoll, and his scythe cleft off a portion of the thick'moss and sphagnum and revealed several (at least a dozen, I should say) small soft bodies which he declared to be snakes' eggs. I at that time having no knowledge of such matters was incredulous, and proceeded to tear one of them open, when, to my surprise, there appeared a small, perfectly formed milk adder, which immediately assumed a pugnacious attitude, and brandished its tongue as defiantly as an old snake would have done. Other eggs were torn open with like results. Soon the old snake appeared and after endeavoring, apparently to encourage the young family, thus suddenly initiated into the world, it put its mouth down to the ground, and every one that had been liberated from the egg voluntarily and hastily disappearcd within the abdomen of the old one (mother?). Last of all I put the point of a pitchfork through the old snake and fulfilled the scriptural injunction of bruising its head, when with a pocket knife I opened the abdomen and found the young ones still active."

The snake referred to by Prof. Brackett is apparently the common milk-suake (Ophibolus triangulum).

Col. Nicolas Pike, late U. S. Consul at the Mauritius, assures me that he has seen the garter-snake (Eutconia sirtalis) afford its young family temporary protection in its throat, from which they were soon noticed to emerge.

(182) 
Our last witness is one who appears to have been overlooked throughont this discussion, one whose statement, it would seem, ought of itself to have decided the question loug ago. M. Palisot de Beaurois, an eminent French naturalist, member of the Institute and Councillor of the University of Paris, thns details an observation made near the close of the last centnry :- "When making my first excursion into the Cherokee conntry, * I happened, while botanizing, to see a rattlesnake in my path. I approached as softly as possible, but, just as I was about to strike, imagine my surprise to see it, after sounding its rattle, open a very large mouth and rcceive into it five little serpents, each about the size of a goosequill. Astonisher at this singular spectacle I retired some distance and hid behind a tree. After some minutes, the animal, believing itself out of danger, again opened its mouth and allowed the little ones to escape. I advanced, the little ones retreated to their stronghold, and the mother, carrying her precious treasure, disappeared among the underbrush where I was not able to find her." †

We have the opinion of Dr. Jeffries Wyman, + Prof. Gill and other physiologists, that there is no reason why the young snakes may not live for a time within the parent. It would be very difficult to smother a reptile, eren in such close quarters, and lizards, toads and snakes hare often been rescued, unharmed, after a sojourn in a snake's stomach. It is a well known fact that living tissnes are acted upon rery feebly by the gastric juice. $\$$

The supposition that the serpents swallow their young for food is manifestly absurd, for the act is purely roluntary with the young snakes. If the habit is not protective in its design, it mnst be destructive to a degree that will in time exterminate the spccies which practise it.

An analogous case is found among certain South American fishcs of the genera Geophagus, Arius and Bagrus, the males carrying the eggs in their mouths, depositing them in places of safety and remoring them on the approach of danger.

* The Cherokees were at this time joint.owners of the states of Tennessee, Mrissis. sippi and dlabama, witl the western portions of North Carolina and Georgia.

† Beaurois, "Odserrations sur les Serpens" in D.uulin's "Histoire Natnrelle, Génerale et Particulière des Reptıles" Paris, An. Rep. xi (1803), vol, v, p. 65.

†. Americau Naturalist." rol. ii. p. 137.

§Flint's "Physiology of Jau." New York, 18i1, rol. ii. pp. 275-282.

IW Juan, "Proceedinge of the Boston society of Natural History," vol. vi.p. 328, 1853. "Americau Journal of Science and Aits," vol. xxrii, 1859, p. 11. Günther "Catalogue of the Fishes in the Britioh Museum." vol. v, 1S64, p. 1i3.

(183) 
I have been told of two instances where a large snake was found to contain one of smaller size, which in its turn had within it a number still more diminutive. This may be easily explained by supposing the parent snake, after affording the usual protection to its young brood, to have been swallowed by some hungry reptile of larger size.

The American Indians seem to have had some knowledge of this peculiar habit of the rattlesnake. Among the many legends collected by Maj. J. W. Powell, U. S. Geologist, in his researches among the Pai Utes, is one giving the origin of the echo. An old sorceress was suspected of wrong doing and was pursued by her enemies until in desperation she sought aid from her grandfather, "Takoa," the rattlesnake. His only resource was to open his mouth and allow the old witch to crawl in out of sight and out of danger. She was so well pleased with her safe retreat that she could not be induced to leave it, so the rattlesnake had to crawl out of his skin and leave her within. And there, say the Pai Utes, she remains to this day, and when any one calls she mockingly repeats their words from her hiding place in the cast off snake-skin.

This curious tradition, even if it camnot be counted as evidence, shows in an interesting way the wide prevalence of this belief.

There is much need of other observations, to determine what species of American snakes have this singular habit. Thirty-four of the observations relate to Eutcenia; the habit is probably shared by all the species, but is only well attested for the garter snake (Eutcenia sirtalis) and the ribbon-snake (Eutcenia saurita). Seventeen refer to the water-snake (Tropidonotus sipedon). Nine refer to the banded rattlesnake (Caudisona horrida), two to the copperhead (Ancistrodon contortrix), three to the moccason (Ancistrodon piscivorus) and one to the massasauga (Crotalus tergeminus). Does the habit extend throughout the Crotalida? One instance is given for the blowing-adder (Heterodon platyrhinos) and three for the mountain black snake (Coluber Alleghaniensis). Six relate to the so-called "black snake," but this name is too indefinite. With all deference to Mr. Buckland, I believe the case of the viper (Pelicus berus) to be settled, as well as that of Zootoca. Whether the male snake ever protects the young in this way has not been observed.

It is a noteworthy fact, which may or may not prove an im(184) 
portant one, that the snakes mentioned above are all ovo-viviparous with the exception of Ophibolus. There is nothing to indicate that the habit is shared by the oviparous snakes of the genera Liopeltis, Cyclophis, Storeria, Diadophis, and Pityophis. The case of Bascanion, which is oviparous, is still quite problematical, and it remains to be shown whether the "black snake" of my correspondents is Coluber. Alleghaniensis, or Bascanion constrictor. Mr. Gosse gives facts which make it seem quite probable that the Jamaica boa (Chilabothrus inomatus) may share the habit.*

The breeding habits of North American snakes deserve careful investigation, as they are totally unknown in more than twentyfive of the genera.

* " A Naturalist's Sojourn in .Tamaica," Lonılon. 1851, pp. 315-23, 501. There is reason to believe that some of the Eutenias, like the scaly lizard (Zootoca vipara) are in some instances oriparous, in others ovo-viviparous, and this point should be kept in mind in making observations upon that and other genera.

[Printed at the SALEM PRESs, April, 1874.] 




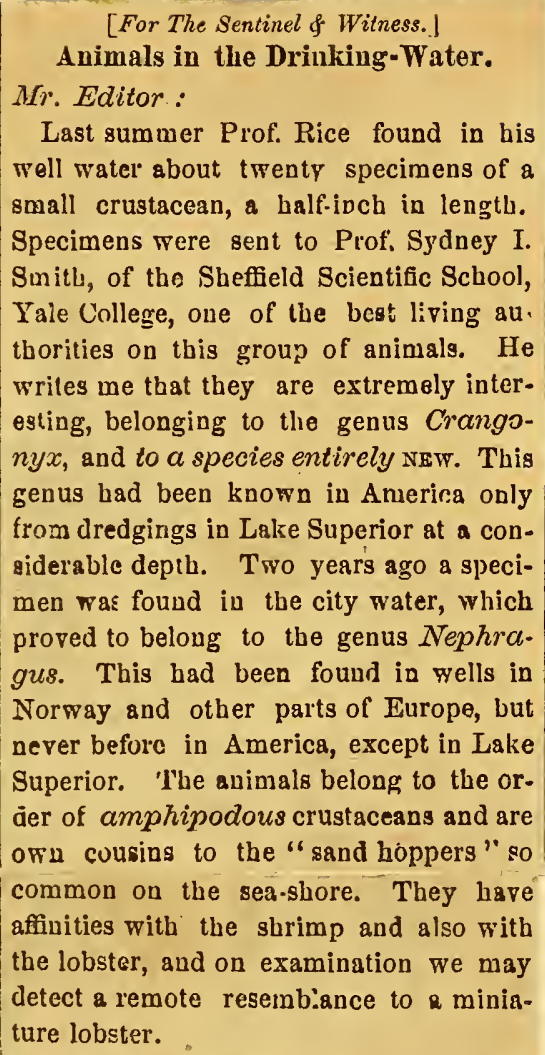

Last summer Prof. Rice found in his well water about twenty specimens of a small crustacean, a half-inch in lengtl. Specimens were sent to Prof, Sydney I Sinith, of the Sheffield Scientific School, Yale College, one of the best living au. thorities on this group of animals. He writes me that they are extremely interesting, belonging to the genus Crango$n y x$, and to a species entirely NEW. This genus bad been known in Anerica only from dredgings in Lake Superior at a considerable deptb. Two years ago a specimen $w$ as found in the city water, which proved to belong to the genus Nephragus. This had been found in wells in Norway and other parts of Europe, but never beforc in America, except in Lake Superior. 'The auimals belong to the oraier of amphipodous crustaceans and are ow a cuusins to the "sand hoppers" so common on the sea-shore. They have affiuities with the shrimp and also with the lobster, and on examination we may detect a remote resembiance to a miniature lobster.

I wish to suggest the great importance of preserving any animals which may be found in our city or well wates. If they cannot be sent at once to the Museum they may be dropped into a small phial of alcohol. G. BRowN GooDE.

College Museum, Sept. 18. 1873. 

CRATGONTX TENUIS, $s p$. nov.

A slender, elongated species, with very low epimera, resembling more n form the species of Diphagus than the typical species of Crangonyx.

Eyes not observable in alcoholic specimens. Secondary flagellum of the antenula rery small, composed of two segments, of which the terminal is very short.

First and second pairs of legs differing but little in the two sexes. First pair stouter than the second, and with the palmary margin of the propodus much more oblique; the palmary margin of the propodus of both pairs, and in both sexes, armed each side with a series of stout, obtuse spines, with a notch and a cilium near the tip.

First three segments of the abdomen longer than the last three of the thorax; fourth, fifth, and sixth together scarcely longer than the third. Caudal stylets all extending to about the same point. First pair with the rami subequal, scarcely half as long as the peduncle. Peduncle in the second pair reaching a little beyond the peduncle of the first pair; the rami very unequal, the outer only half as long as the inner. Posterior pair scarcely as long as the telson; the single terminal segment very sinall, and tipped with four or five setiform spinules. Telson two-thirds as broad as long, tapering very slightly toward the entire and slightly arcuate posterior margin, which is armed with about ten slender spinules.

In the largest male seen, $13^{\mathrm{mm}} .5$ in length, (excluding the antenn $æ$,) the antennulæe are about $5^{\mathrm{mm}}$ long; the flagellum being twice as long as the peduncle, and composed of about twenty-two segments, while the anteunæ are stout, fully $6^{\mathrm{mm}}$ long, and the flagellum as long as the peduncle, and composed of fifteen segments. All the females and most of the males which I have seen are much smaller, being $6^{\mathrm{mm}}$ to $8^{\mathrm{mm}}$ in length, and in these the antennulæ are longer than the antennæ; and the flagellum of the antennulæ is composed of sixteen to nineteen segments, while that of the antennæ has only eight to ten.

The only specimens which $I$ have seen were found in wells at Middle town, Conn., and were sent to me by Mr. G. Brown Goode. 
Do Snakes Sira.... The "ware Yivas a the ann 1,118. Qut 2.18\%3. 
$4 x y$ then is ,

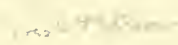

$$
\text { D. 1. } 1573
$$



Ps.ite FIII. Fig. $\overline{2}$. Harris's Point pound, Eastport, Me. Drawn by G. B. Goode. Fix. 3. Herring-Treir, near Eastport, Me. Dranu by G. B. Goode.
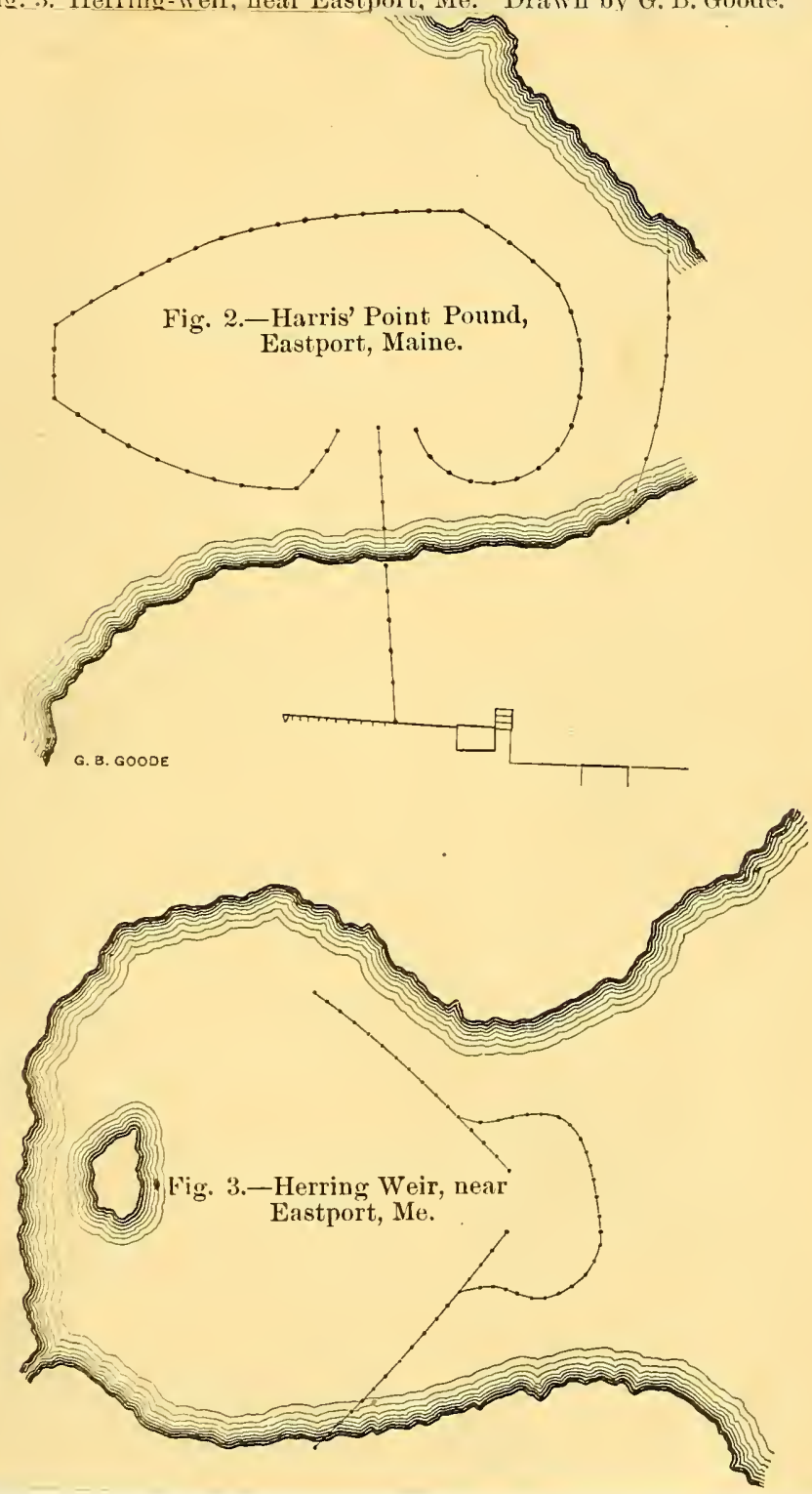

Plate XIII.

Rept U.S Com. Five qTivheres 





\title{
Do Snakes Swallow; their Young?
}

\author{
BI PROF. G. BROWN GOODE.
}

This is what naturalists have been asking each other for nearly a century. In that most fascinating of books, "The Natural History of Selborne," Gilbert White mentions the popular belief, but does not venture to indorse it. $M$. Palisot de Beaurois, a member of the French Institute and a councilor of the University of France, who traveled in the United States early in the present century, claimed to have seen five young rattlesnakes, "each about as thick as a goose quill," run down thcir mother's throat, run ont, and then dowin a second time. John D. Huntcr, in his celeurated "Memoirs of a Captivity among the Indians of North America," gives similar testimony. Sir William Jardine, an eminent English naturalist, wrote in 1853: "We have always looked upon this as a popular delusion, and the supposed habit is so much at variance with what we know of the general manners and instincts of animals, that without undoubted proof we are still inclined to consider it as such." In 1865 Mr. M. C. Cooke, of "Science Gossip," strongly adrocated the affirmative, citing many instances observed by his friends. In $1869 \mathrm{Mr}$. F. W. Putnam, of the "American Naturalist," considered the case unproved, though he inclined to believe with Mr. Cooke. During the past year a lively discussion has been carried on in "Land and Water," Mr. Frank Buckland, nne of the keenest of English naturalists, strenuously opposing the idea. So stood the question, the authorities being about equally divided.

To the American Agriculturist is due the honor, it seems, of finally deciding it. Last February the cditors kindly inserted a paragraph asking for information, and in a few weeks about eighty letters had been received from subscribers in twenty-four different States and provinces. Some of these were not 

to the point, but most of them contained tho statements of those who had personally observed this very curious habit. Many were, very naturally, indignant that a fact so well known should be called in question.

These statements, together with many others collected by diligent personal inquiry, were embodied by the writer in a paper read at the late meeting of the American Association for the Adrancement of Scicnce. The paper elicited some discussion but no opposition. Prof. Gill, of Washington, one of the most skeptical as $w$ ell as one of the ablest of American scientists, expressed himself as convinced by the testimonies of so many witnesses, and so did many others.

Iany of the letters receired deserve to be printed in full; but since want of space forbids, only figures can be given. Our witnesses are 104 in number. 58 saw the young enter their mother's mouth; if heard the mother warn then by a sharp whistle or hiss or click; three $\pi$ rere considerate enough to $\pi$ ait and see the young reappear when danger seemed to be passed; eightcen saw the young shaken out by dogs or running from the mouth of the dead mother; 32 who saw the joung enter killed the mothcr and found then, living, within her; while only 14 of the 58 allowed the poor, affectionate parent to escape ; 29 found the young in the body of the parent, but as they did not see them enter the moutl this testimony is rather dubious.

Among the witnesses are four naturalists of reputation, whose word is as good as gold in other departments of natural history. Eminent physiologists admit that there is rothing impossible in the habit, for living tissues are not easily affected by the gastric juice, and reptiles corlli not easily be smothered, even in the mother's stomach. The habit is known to be shared by the English Scaly Lizard. The males of certain species of South American fishes related to the "Cat-fish" and "Bull-head" carry their eggs in their months and gill openings, 


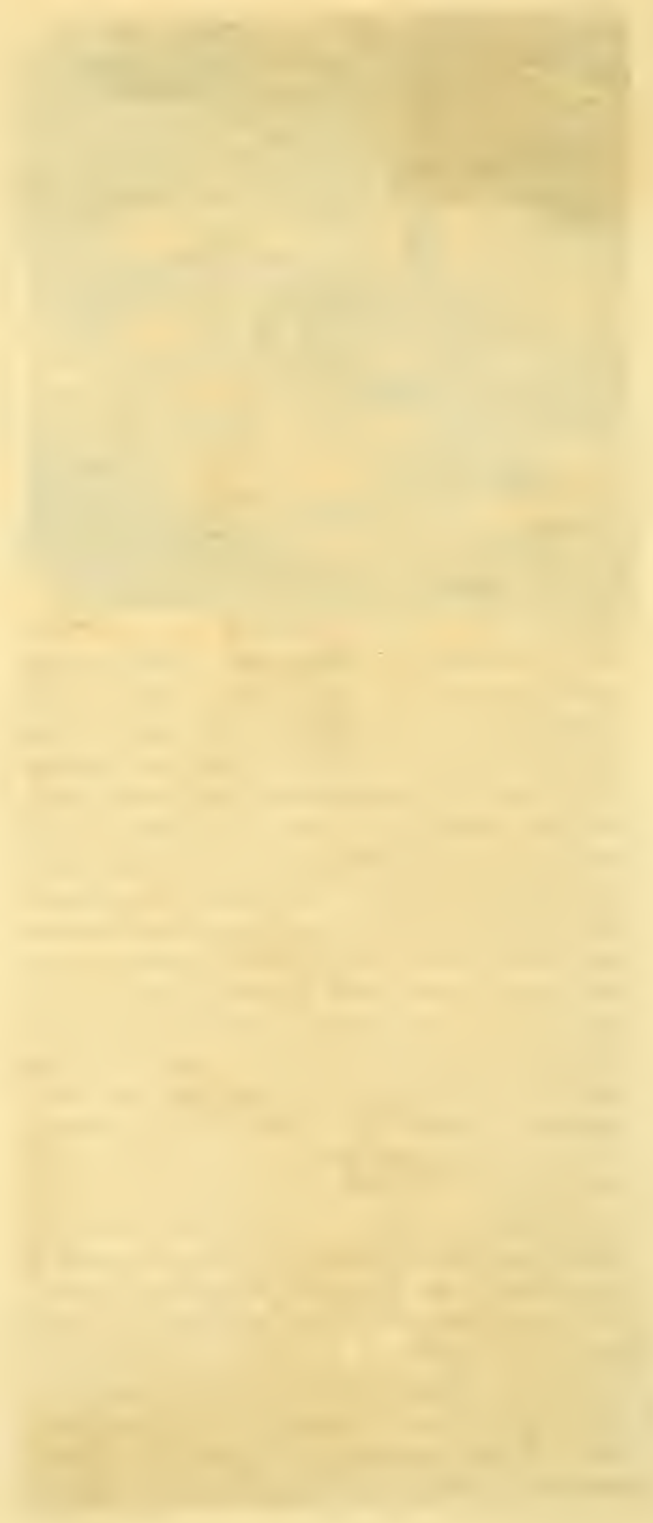


depositing them in places of safety and remoring them at the approach of danger. Equally singular though not similar habits of protecting the joung are found in the well-known Surinam Toar, in the Kangaron and Onossum, and in the Pipe-fist and his cousins.

There is room for many interesting observations, especially to determine what species afford their young this protection. About the Garter-snake (Eutania sirtalis) and the Ribbonsnake (Eutania saurita), the Water-sdder (Tropidonotus sipedon), the Banded Rattlesnake (Caudisona horrida), the Copperhead (Ancistrodon contortrix), the Moccasin (Ancistrodon piscivorus), and the Massasauga (Crotalus tergeminus) there can be little doubt, and the habit probably extends throughout the genera which these species represent. The case of the Hognosed-snake (Heterodon platyrtinos), sometimes called the Blowing or Puffing Adder, needs farther investigation, and so also that of the Black-snakes. It seems more than likely that the Racer or Mountain Black-snake (Coluber Alleghaniensis), which is distinguished by a little ridge or carination in the middle of each scale, does thus protect its young, but it has not been shown that this is the case with the common smooth-scaled Black-snake (Bascanion constrictor). It is very desirable to learn whether, as has been supposed, the habit is peculiar to those snakes which are ovoviviparous-that is, those in which the young are hatched from the egg while still in the body of the parent. As was remarked, there is no proof that the Blacksnake swallows its young, and this is the case with all the egg-laying genera, as the Milksnakes (Ophibolus), Grass-snakes (Liopelitis and Cyclophis), Brown-snakes (Storeria), Ringnecked-snakes (Diadophis), and Bull-snakes (Pityophis), although they are common and easy to observe.

If any reader of the Agriculturist should obeerve a snake with young running down her throat, or should have reason to believe that she had thom in her stomach, it would be a 
capital plan to tie a cord tightly about her neck to prevent their escape, and then carry her to some naturalist or some physician and have a careful dissection made. This would forever settle the question, and might be done without the least difficulty, for all our snakes except the Rattlesnakes, Moccasins, Copperheads, and Massasaugas are perfectly harmless.

Accurate statements are much needed of cases of snakes charming men, quadrupeds, and birds. It would be interesting to know whether the cast-off skin of a snake is always left as the snake wore it, or whether it is sometimes turned inside out.

\section{Museum, Wesleyan University, ?} Middletoron, Ct., Sept. 15.

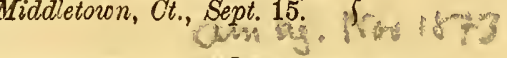




Armorial Bearings. Goope.

Lun Sules, a cherron, or beturear tiree lions ramprant argent.

Head of a keopard red ducally crouned.

Grop.

Ans lsules, a cheorar or between tiree hars randraut. or.

cunt. An otter hassout danding on a ducal corcuction

Gooct or Good

Ans Inles, a clerrm, or, between thee lious nampant or.

cuint a leoprand argent spotted rable wanding on a ducal crrovet or. 
(I) 


\section{SNAKES SHEDDING THEIR SKINS.}

\section{Editor Forest and Stream:-}

I once had the chance to see a snake slied his skin. I think it was in the month of June. I was standing in the field when I observed a striped snake going tlirough some strange contortions, turning first on his back and then on his side, and all this time his head was kept in between two small sprouts about half an inch apart. I thought at first he was insane, or performing for the circus, but in a few moments all was made plain; he was getting the old skin started from around his mouth. At last it gave way, and began to roll over his back, and he soon pulled himself out of it, and left the skin turned completely wrong side out. He then went on his way, acting as though he felt very happy.

Question: Do all snakes shed their skins? and if so, do they shed them more than once in a year? and will snakes freeze and then thaw out and live, as worms, ants, bugs, etc., do? I have found that striped snakes will drown under water in a short time. Now, how is the water adder constituted that he can remain under water? Will some of your correspondents please explain? I found on examina. tion that the snakes shed a covering to their eyes, and I am inclined to the belief that they can see but little, if any, for some days prior to shedding their skins, and lie around inactive.

J. L. HERSEY.

Editor Forest and Stream:-

Mr. Hersey's letter is quite interesting, and I hope it will induce others to send to Forest aNd STREam their observations on the subject. His queries, too, are very suggestive, though they forcibly remind the reader that it is easier to ask questions than to answer them.

Do all snakes shed their skins, and if so do they shed them more than once in a year?

All snakes do shed their skins, the first moult occurring soon after the young snake is born. The moults are repeated at intervals of a month or two during the warm season, but in winter none occur. In captivity the shedding of the skin is not so frequent, and is very laborious and painful, sometimes resulting in death.

The shed skin is usually turned completely inside out, as in the case mentioned by Mr. Hersey. Wother this is: always so is a question on which we need more light. Mr. James Simson, an enthusiastic correspondent of Land and Water, insists that they are frequently left "as the snake wore them." Frank Buckland is equally positive that thi never occurs. I have in my possession the skin of a moun- 


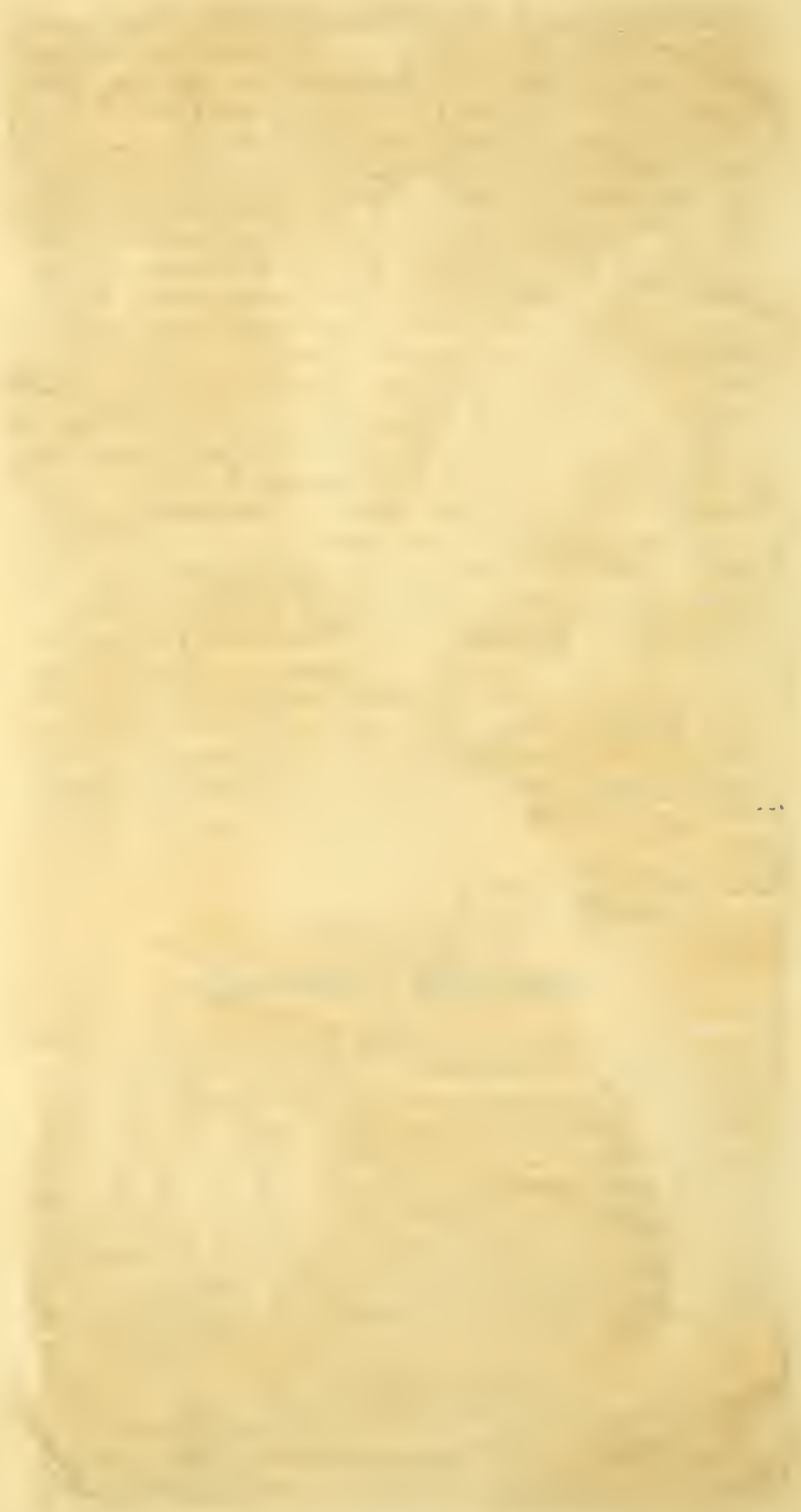


tain black snake (Coluber Alleghaniensis) nearly seven feet long, which is inverted as neatly as a glove finger could be, and wilhout a tear in it; also, an inverted skin of the common black snake, (Bascanion constrictor). I have a skin shed in November by a rattlesnake (Candisona horrida), afterwards a pet of mine, which remains in its natural position. I did not see the operation of moulting, and it is barely possible that the skin may have been turned while fresh and soft, but I do not believe that it was ever completely inverted. I should state that the snake was not in captivity when he shed this skin, but was taken just after the act of moulting.

"Will snakes freeze and then thaw out?"

Spallanzani kept snakes, frogs, and salamanders in a state of torpor in an ice house for three years and a half, and then easily restored them to activity. In our climate snakes retire at the approach of cold weather into their winter retreats in old burrows, hollow trees, or stone heaps, and there they remain, hibernating, until they are revivifled by the warm rays of the spring sun. It would seem as if they would often be exposed to a freezirg temperature. I have found the common toad, in the early spring thaws, nibernating in the soil a foot or two below the surface, where it must have been surrounded throughout the: winter by solid walls of frozen earth. A pet black snake, confined in a well ventilated, unwarmed room, endured weather when the mercury stood at zero in the open air, but succumbed at twenty degrees below. I attribute his death by freezing to the fact that he was not in a state of complete hibcrnation, as he had frequently been handled during the early winter, and thus partially aroused from his stupor. A very interesting series of experiments could be made upon the hibernation of reptiles.

"How is the vater adder constituted that he can remain under" voater?"

Cold blooded animals, such as serpents, consume little food, and, even when in activity, little oxygen, in this re. spect forming a marked contrast with highly vitalized, warm blooded animals. Birds, for instance, in their nervous, restless activity, require incredibly large supplies of food and a miniature blast furnace of oxygen to supply the incessant waste of their tissues. Serpents, on the contrary, pass the greater part of their lives in a state of sluggish repose, much like that of the higher animals in hibernation. Hibernating mammals can be kept under water for an hour at a time without harm, though three or four minutes would be sufficient to kill them if they were in their natural state of activity. The nearly complete suspension of all the functions of life reduces the demand for air, as 
for food, almost to zero. The water snakc, coilcd up under a storie at the bottom of a pond is not in a condition to demand large supplies of oxygen. Still he requires some, and a brief glance at his breathing apparatus will show us where he gets it. Like most other serpents, he has only one lung, the other being present merely as a rudiment. This lung extends a good deal more than half tha length of his body, and the lower part is expanded into a membranous sac, or bag, capablc of containing a considerable quantity of air. This bag stands Mr. Tropidonatus sipedon in good stead in more ways than one. When he dives he 8 wallows his meal in a single mouthful, which is so ungenteelly large that it presses against his windpipe and stops his breathing, so that for the time being he must get lis oxygen from his internal reservoir. Then when he makes a voyage under water he can carry with him a cargo of good fresh air.

I have not compared the lungs of the water and land snakes, but I imagine that very little difference would be detected. Professor Agassiz made a very interesting serics of experiments with a view to determining the relative lung capacities of land and water turtles. He proceeded 'by pumping ail the air from the living turtle, then pumping them full of water, then pumping out and mcasuring the water. He found that the capacity of the lungs of the land turtlc averages twice as much in proportion to the weight of the body as that of the water inhabiting species, although the sea turtles carry a sufficient supply of air in their lungs to enable them to remain under watcr a half hour or more.

It will be found that water animals, as a rule, have their breathing organs much smaller than land animals. This apparent paradox is cxplained by the fact that a large amount of oxygen may be absorbed by the skin from the air diffused through the water.

G. Brown GOODE

Smithsonian Institution, January 3, 1874.

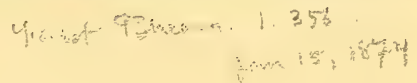



Mr. G. Brown Gooderiof the Smithonian Institution, lias baen In F lorlda during the past winter, ms.king +2 eallestion of beasts, buds, and reptiles for the 700 ogical Gardens in West Philadelphra. Quite R nimber of specimens have alreacy Deen forwarded, and more are now on the way. ToiMe. Goode bemore are now on the way. To Mr. Goode beaffirmative the mooted question of whether snakes swallow their young. The collection of snakes made by Mr: Goode is especially

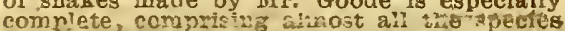
which have been found in Florida. Various kinds of turtles have also been sent. Altogether, Mr. Goode has procured tor the Phila: delphia collection 132 specimens, representing 32 species, distributed as follows: Mammals, 5 species; birds, 1 ; lizards, 4 ; snakes, 16 ; turtles, 5; amphiblans, 1. Some Florida wild hogrs will be shipped, and Mr: Goode is now endeavor. ing to secure some maratees..nA very remarkable jchtbyologicai colleetion has also been made.

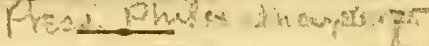




$$
\begin{aligned}
& \text { tresco } \\
& y=\pi \cdot I+292
\end{aligned}
$$





\section{A RARE FISH-THE TARPUM.}

A FISH stall har always had its charms for us, and Mr. A Blackford's slab on Suturday last in Fulton Market was particularly attractive. Now you may wander through a fish market, either like one of Mrs. Barbauld's two little boys in the story book who never saw any thing at all, or like the other good little boy (of course lie was good) who saw everything. A mass of fish are dumped down-on the stand, and if you have a quick eye, if you are the most casual of observers, and even not up itchyologically, you may often discover quite a mine of nondescript wealth. What was in view, however, at Mr. Blackford's did not require peculiar scrutinizing. There extended at full length, full five feet six inches long, was one of the landsomest of fishes we ever saw. He looked as if Tiffany had wanted to make some huge fish out of solid silver, and had burnished a scale liere, and there frosted anotlier scale, so that the work perfectly flashed and sparkled in the sun. "Name it," said Mr. Blackford. "Came from Florida?" We said dogmatically. "No, cauglit off Port Monmouth yesterdar." "Sure of that?" we inquired doubtfully. "Certain." "Then we replied oracularly, pray hand us FOREst aND STrean of June 18th, and you will see that Professor G. Brown Goode, of Middletown University, has precisely descibed that fish, and get a bit of card and write on it TARPUM, or Jew fish, and stick it on the fish and it will save you no end of questions. Now will you be good enough to get us a herring? Not a smoked one." A boy was dispatched to the lower wholesale market and a small sea herring some eight inches long, was soon procured and laid on the big fish. "Now," we commenced, much to the edification of a distinguished audience, a negro boy, a lady buarding house keeper bent on cheap fish, and a market porter, "you will be pleased to observe that your big fish is but an enlarged, a copious edition of this insignificant herring. Just look at those two heads, one scarce an inch and a half in length, the other most a foot and a half long. They bear the most striking family resemblance. Note that prodruding under jaw, how it comes up in a lump before, on both the fishes. Fins the same on both, save that just as Professor Goode says, there is a great prolongation of the last spine of the back fin. Little lerring has not got it, but the great grandfather of all the Cluperdo lias. (Just here looks of astonish- 
ment were visible in the audience, and the tairer portion of it retired apparently overcome). This big spine," we continued, "is fourteen inches long. Here you will see that nature too, yearns after uniformity, for we notice, what we have never seen stated before, that the pectorals too have this same spine, though not so large in r roportion, as the dorsal one."

Just here the audience all went about their business, and we were enabled to get a closer examination of the fish. Such scales! We took two or three of the largest, which measured two and a quarter by two inches sach, each one as beautiful as a shell, and tipped at one side with pure silver. We took his extreme breadth, which was one foot three inches. Down his throat we could have passed our double fist. Asking a fisherman if they were caught frequently, he informed us that he had seen two or three of these fish during his life.

Consulting later Col. De Voe's most excellent book, "The Market Assistant," we saw that tile author states "that to his knowledge this very large and scarce fish has been seen but four times before in New York." The measurement coincided to an inch with the fine specimen we saw. Two tarpons Col. De Voe says he saw in 1865, and another in 1857. Referring to Professor Goode's article we notice that he states that "this fish is found occasionally in the waters of the West Indies, and on the east coast of the United States." The tarpum he declares to be Megalops thr issoidts, and he tells us, as does our other correspondent, S. C. Clarke, Esq., from Smyrna, Fla., (see page 252, May 28) that it is taken in the St. Johns River and brought to Jacksonville. Of cour'se we ate snme of him boiled. Now we are constrained to state that generally the handsomer a fish is the better he tastes, and that sometimes the ughier he is (vide squid) the nicer he is. But Megalops thrissoides, tarpum, tarpon, or Jew fish, is dry fish, with an exaggerated tastelessness common to the herring. Sweet was it, but flavorless. Optimists as to fish, as far as their edible qualities go, we have no doubt, that converted into a mastodonic Yarmouth bloater, Megalops would in small quantity, make a delightful relish for breakfast. 







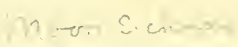
4 . eres: $+4: 1$

1.99. - Sapret tore 





\section{The United States Fish Commission.}

The summer campaign of the United States Fish Commission party, under Prof. Baird, Commissioner of Fisheries, has just begun under very favorable auspiccs. Thc headquarters for the present scason have been established at Noank, New London C'nunty, Connecticut, at the mouth of the Mystic river, a thriving little fishing village of some seven hundred inhabitants. Noank is one of the leading depots for iced fish, shipping large quantitics weekly to New York, and employing thirty or forty simacks, some in "vending" the extensive pounds at Fisher's and Black Islands and at Napeague on the eastern end of Long Island, others in line fishing on the shoals for sea bass and flounders, others in "scrawling" for halibut. So there will probably be no lack of material for the investigations of the commission. The dredging ground also offers many hopeful indications, Fisher's Island sound appearing to be nearly "the divide" between the northern and southern faunas, anu probably hiding beneath its waters the solutions of many important problems in marine plysics and zoology. The U. S. Steamer "Bluelight" has been detailed for the use of the party, and during the winter was repaired and refitted with special reference to the needs of the work, so as to be much more convenient than it was last year. Commander L. A. Beardslce of the Washington navy yard is again in command, and his enthusiastic interest in the work contributes much to its success. The "Bluelight" arrived on Friday, the 10th. and made her first dredging trip on the Monday following; she lies at a wharf in the shipyard of Mr. Robert Palmer, a neat little house near by, at the water's edge, serves as a laboratory for the party carrying on the special fishery investigation, while the dredging party is established in a commodious room at the foot of Main street, formerly used as a town hall. The members of the party are quartered at various privatc houses in the village, as there.is no hotel; several have their families with them. the total number connected with the party being thus quite considerable. The personel of the party as at present established is as follows:

Prof. S. F. Baird, Smithsonian Inst., Washington, Commissioncr; Mr. E. H. Rockwell, Washington, Secretary; Commander L. A. Beardslee, U. S. N., Comd'g "Bluelight"; Prof. Alpheus Hyatt, Custodian, Boston Soc. Nat. Hist.; Prof. A. E. Verrill, Yale Collegc, New Haven; Prof. D. C. Eaton, Yale; Mr. Sidney 1. Smith, also of Yale; Prof. William N. Rice, Wesleyan Union, Middletown; Mr. G. Brown Goode, Smithsonian Inst., Washington; Mr. James H. Blake, Mus. of Comp. Zool. Cambridge, Artist; Dr. H. C. Chapman, Philadelphia Acad. Nat. Sciences; Mr. Bean, Wilkesbarre, Pa.; Messrs. Clarke, Turnbull and Brown, Sheffield Scientific School; Mcssrs. Saltonstall and Rathbon, Boston, Soc. Nat. Hisst. Mr. Carl W. Schurman, Washington; Capt. Ashby, Noank, Conn., Pilot. Capt. H. U. Chester, Noank, Conn.; Capt. William E. Spicer, ank, Conn. 


\title{
THE UITED STATES FISI COMMISSION.
}

\author{
FISH TALES FRON NOANK. \\ Headquarters, U. S. Fish'Com. ? \\ Noank, Conn., July 31, 1874.
}

When at the close of the last season's work, the question of ourlocation for $18 i 4$ was mooted it was generally understood that it would be somewhere on the southein cuast of New England, and not far from the eastern end of Long Island Sound. Watch Hill, Stonington, Block Island, Sag Harbor and New London were discussed and dropper from the docket, and at last Prof. Baird settled upon Noank. That name Noank has puzzled many a lcarned head and after long and unavailing researeh in atlas and railroad guide is for philologieal rcasons usually located somcwhere in Mainc; it improves however, on aequaintanee, especially when we lear'u that it means "crotched tree" and commemorates an ancient landmark under whose leafy boughs the Pequots used to assemble for council or clam-bake. The monuments of their teasts still remain in the shape of shell-heaps, and our party will no doubt some day celchrate one of the original American iestivals by a clam-bake un the spot, giving a flavor to the repast by the study of these ancient lijoekien-moeldingx. An old grudge of the railroad company is probably the cause of the present obscurity of Noank, an obseurity quite undeserved, for the village is pretty, cnterprising and growing. Thirty-five years agu a cargo of iced fish was taken to New York by a Noank smack, the tirst which ever was brought to the city market, and in the tradc thus illauguated, extensive as it now is, Noank bears an important part. The evening train and stonington boat take daily shipments and many of the smacks provided with ice-houses curry their fares directly to Fulton market.

Noank has shipyards, too, of no mean importance. At Mr. Robert Palmer's yard wherc vessels of eight hundred tons are built, the "Dauntless" was remodeled and fitted out for her succcssful ocean race; at the Mystie yards, a unile up the river, she was built. Here too, not loug ago, fifteen guuboats were built for the Spanish govcrnment. Here was built the celebrated clippership, the "Andrew Jacksun," which made the two best voyages from New York to San Francisco, the shortest in eighty-nine days.

The investigations at this station are expected to throw light on many important points in the marine zoology and physics of our coast. In 1871, the firtt year of the work, the party was located at Wood's Hole on the Vineyard Sound, some 120 miles farther east. During the summer many interesting facts were learned 
eoncerning the relations of currents, temperature and depth to the distribution of marine life. Cape Cod has long been known to be a boundary which rather sharply separates two distinet faunas, and which very many species never pass. Three of the faunas recognized by naturalists on the east coast of North America, the Arctic, the Syrtensian including Labrador and Newfoundlaud, and the Acadian, lie nurth of it too, the Virginian and Carolinian are south of it. Now while the line of demareation between the Aeadian, which extends nominally from Nova scotia to Cape Cod, and the Virginian which extends from Cape Cod to Cape Hatteras is mueh sharper than between any others, yet it is merely an approximate or conventional one, unlike the well known "Wallaces Line" in the Malay Archipelago. A larger part of the species in each fauna crosses the boundary, and many of the deep bays in the - vicinity of Wood's Hole were found to contain a great predominanee of life belonging to the Acadian fauna, while the shallow bays showed an equal predominance of southern fauna. In the same way the reconnoissances in Maine show that the Virginian fauna has its colonies far north of the boundary; a very long, shallow cove in Casco Bay was found to abound in southern speeies to the exclusion of others, so that Professur Verrill remarked that it could hardly be distinguished from New Haven Harbor. In the same way small southern colonies were found on the Bay of Fundy and in the Gulf of St. Lawrence. A thorough investigation of these questions is important and it was supposed that a point more distant from Cape Cod would yield many new facts. The rocky reef at Watch Hill seems to be a boundary of minor importance, and our station was chosen partly on aeeount of its proximity thereto. At first blush it may appear to some that such inquiries, however important in themselves, are not properly within the scope of a commissioner appointed "to proseeute investigations with the view of ascertaining whether any and what diminution in the number of the food-fishes of the coast and the lakes of the United States has taken place, and if so, to what causes the same is due, and also whether any and what protective, prohibitory or precautionary measures should be adrpted in the premises," but a moment's thought will convince them that the requirements of the law eannot be carried out by anything less than a complete zoologieal, botanical and physical survey of North American waters. So intrieate and intimate are the relations of the fishes to every form of life with which they are associated, and to the depth, temperature and pressure of the element in which they live, that every fact ascer- 
tainable is necessary to an intelligent understanding of the numerical diminution of any species, its cause and its proper remedy. Even if a given form is not destruetive to another or beneficial to it as food or otherwise, it holds some sucin relations to other forms which are, and we may find under the waters many parallels of Darwin's example in whiel he shows the intimate dependence of bumble-bees upon old maids through the medium of cats, field-mice and clover fields. Then too, the complete survey of the field ean be made at an expense and trouble little greater than the investigation of points which might seem of particular importance.

The Sportsman of July 21 gave some account of the opening of the work which is now going rapidly forward.

A systematic exploration of the bays and sounds has becn eommenced with the aid of pond nets, seins, trawl pots, gill nets and fyke nets; the aid of most of the Noank and New London smacks has been secured and scarcely a day passes without interesting additions to the collections. All specimens arc carefully studied with referenee to habits, food, tine, place and manner of breeding, extcrual and interual parasites, mode of cap. ture economic value relations of size and weight, etc.

Sixty-one species of fishes have been observed, two probably new to the fauna. Among the notable cap. tures have been three Drum-fishes (Pogonius chromis) the largest weighing over one hundred pounds, and threc specimens of the Lump Sueker (Liporis lineatus) taken to-day for the first time south of Capo Cod; others are the Orange File-tish (Coriatacanthus aurantracus), the Hammerhead Shark (Sphyrnazygona), the Broad-winged Sea Rubin (Prionotus lineatus) and the Box-fish (Chilonyeterus geometricus). A large Dusky Shark (Eulumia obscura) was roasted for flavor, being served up as "white sturıeon" but was voted rather tasteless and tough, a similar verdict condemning the Sea Raven (Ilemitripterus acadianus).

Many species are now breeding and experiments in artifieial propagation of somc of them are being made. Several thousand eggs of the Sea Bass (Centropristes atrarius) were fertilized and are now, on the crening of the third day, in promising condition. An interesting experment has been tried by Prof. Baird, to ascertain the effect of sea water upon young shad. On the $23 \mathrm{~d}$ ult. Mr. Fred Mather arrived with 20,000 young fish ? 
from the Holyoke hatching establishment, a portion were immediately transferred to liatehing boxes in the salt water where they died in a few hours, as did others plaeed in a shaded tub of salt water; others still were kept in strongly braekish water, where they lived from thirty to forty hours; some kept in braekish water a few hours and then transferred to fresh water lived about eighty hours. Could the fish have had Mr. IIather's personal care for a longer time they would no doubt have lived longer lives, for the water in the cars was changed only three or four times a day, and partially at that. The experiment is quite satisfactory, however, showing; (1) That a sudden change from fresh to salt water is impraeticable. (2) That they ean be kept for some days in water which is very braekish. I ap prehend little diffieulty in aeeustoming them to salt water by gradual and eareful addition of salt water to the fresi. The experiment has an important bearing on Prof. Baird's .proposed transatlantic shipment of young shad.

The "Bluelight" has been busily employed by the dredging party under eliarge of Prof. Verrill. Over four hundred species of invertebrates have been noticed, some forty of them new to the fauna. To-day in dredging off Wateh Hill we struek a spot where, at eighteen fathoms depth, the temperature was 57 degrees and the bag came up full of northern forms, just sueh a haul as we might have had in Caseo Bay.

The trawl was lowered and brought up at least fifteen hundred pounis of serapings, requiring the whole force to lift it over the rail. Among other things were ninety-seven Clear-nosed Skates, twenty-one flat fishes, two spotted turbots, two four spotted fiounders, one hake, three lump suekers, one eunner, ten skates eggs, and approximately three bushels of sponges seollops and sea urehins.

Captain Beardslee is making a series of experiments with the Miller Casella thermometers whieh have already produeed results of much importanee.

Dur party eontinues to inerease; Prof. Joseph Leidy of Philadelphia and Dr. M. P. Hatfield of Chieago have recently arriver and Prof. Harrison Allen of Philadelphia and Dr. W. G. Farlow of Cambridue have visited us during the past week.

Frater Aquarius.

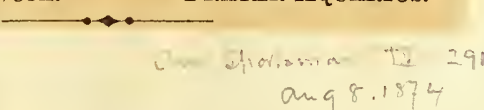




\section{The United States Commission of Fish and Fisheries.}

\section{DREDGING ON THE COAST OF CONNECTICUT.}

As the work of Prof. Baird in his sea-coast investigations is becoming better known its importance is more and more appreciated; the party is this year larger than ever before including twenty actual workers, many of them the highest authorities in their specialties; counting the families of members, seamen and other empluyees the party at Nounk numbers seventy and is still growing. This year for the first time, it has been practicable to divide the party into two sections, one making physical observations, dredging and investigating the bistory of the lower forms, the other undertaking the study of the fishes, their habits and the statistics of the fisheries.

The facilities have never before beell so gord; until last year the work was mostly done on sail boats with eccasional aid from the revenue cutter on the nearest station. In $1871 \mathrm{a}$ steam launch from the Boston Navy Yard was secured for part of the season. In 1873, the Secretary of theNavy placed at the disposal of the Commissinner the steamer "Bluelight" which has since been kept under his orders and has been fitted out especially" for his nceds; by this aid the amount of the Srason's work is at least quadrupled; for the dredging party, independent of wind and tide, can easily make a trip of forty miles, do their work and return the same day. The explorations of St. George's Banks on the coast survey steamer "Bache" are to be continued during the summer.

"The "Bluelight" is a trim little tug-built steamer of eiglity. five tons use during the war as $\AA$ powder brat, and is very strong and sufficiently fast. The; most important part of lier new outfit is it donkey engine of considcrable power by whose aid the heavy instruments are handled, a strong iron davit keeping them clear of the side. Tle engine stands on the forward deck which is shaded by an awning and on which all the work is done: tables are in readiness to be used in assorting the specimens, while near at hand is a little cabin fitted with shelves and racks for bottles, buckets and physical apparatus; this same cabin is fitted with three or four bertlis the use of which is very apparent on the first trip of tlinse who have not aequired their "sca-legs." The main cabin is on the same deck and is more commodious than in many first-class men of war; here twenty persons can easily dine, and since dinner must often be taken on board, this is very convenient. On the hurricane deck is storage room fol the large trawls and dredgres and for the "balsa" or life-raft. On the same deck in front of and around the pilot house is a small balcony from which visitors may witch the husy clowd on the deck below, sure of being out of the way. In the bold may be stored cables and other extras, while a large ice-house preserves the perishable specimens too large to be bottled at once. In "short, the "Bluelight" is a model in its way. The "Challenger" now carrying the British deep sea exploring party on its three years cruise, is of course much larger, being 


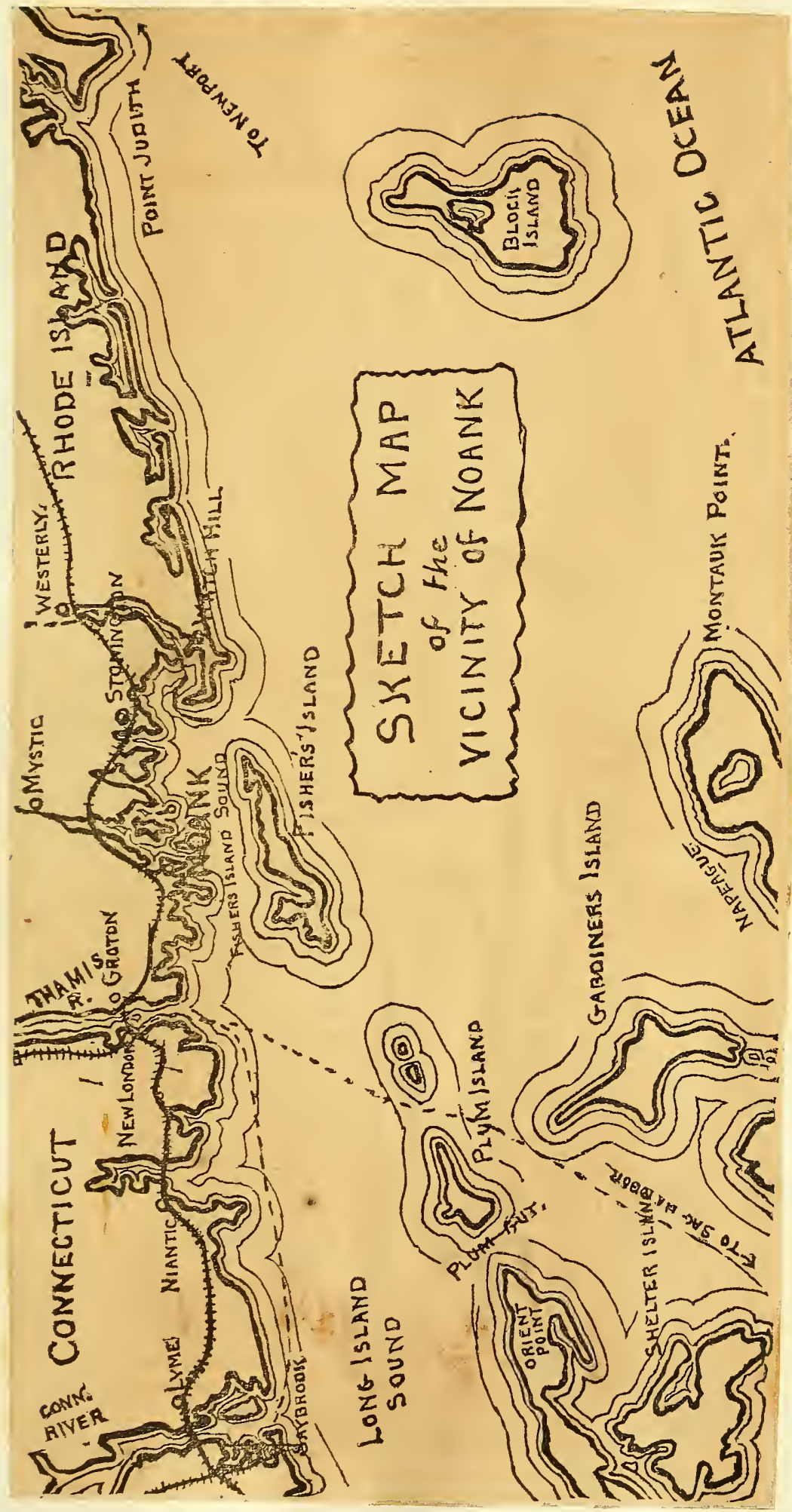


provided with working laboratories with libraries, mleroscope tables, alcoliol, tanks, locker's for speeimens and everything necessary for the study and preservation of material on board. but the exigencies of a survey like ours are better met by a laboratory on land, supplemented as it is by the laboratories and libiaries of the Smithsonian Institution, Yale College and other sclentific institutions.

Every morning after breakfast preparations for the day's work begin. Thick boots of leather or rubber, plue flannel shirts and broad brimmed hats s are promi.

nent features in the make-up of the party. These are considered "first rate chances to wear out all ones old clothes," and when, at the sound of the "Bluelight's" whistle, the motley praecssion starts for the wharf, each member staggering under his load of buckets, bottles and dip-nets, it would hardly be supposed by a casual observer, that in its ranks are several of the lead!ng scientific writers and lecturers of the land, professnes in our ehief literary scientific and medieal eolleges. Here is none of that fastidiousness sometimes seen among naturalists, especially those of the dilettanti order, but each man is ready to lake his pull at a rope, and eager to plunge up to his elbows into the muddy contents of the dredge. Their labor has other than scientific results, for they return in the fall to: their studies with faces and arms bronzed, chests expunded and limbs elastie, with clear eves and elear brains. their blood almost effervescing urider the spell of cool, bracing sea air, twice the men they would otherwise bo.

All are on board, the lines are cast off, we bacl- from our bertl inio the channel, we hear the four bells for "ahead fast" and with a brisk, merry "ching-chug chug-ehug elnug-chu" we stearst alnng past the lorg wharves, margined with smacks, past the busy shipyards, past "The Cedars"where some of the ladies of the party are waving a farewell salute, down by the point and Mystie Light and stand nut through Fisher's Island Sound. An liour brings us to some promising locality designated on the chart perhaps by the symbols "18, s. br. sh." which being interpreted mean, "depth eighteen fatloms, brttom sand with wroken shells." "Stand by to take a sounding!" is the order, and the moment ti,e vessel's way is sufficiently stopped the old quartermaster has had liss lead on the bottom, the tallowed cul) is earefully inspected and the answer comes "eicrlit'n an' a alif fethums, sur, an' a zandy bot'm." The spot is carefully located on the chart, and "over dredge!" is the signal for the instr"ument to be dropped no(re the side, swung off and lowered hy a slow, reversed movement of the donkev. Meantime nne of the party lias lowered a Miller-Casella thermometer on the sounding line and stands watel in hand, nutil it has gained the eqnanimity to tell the true trimperature of the bottom, after which he takes surface temperature and reenids the figures in a book, together witl notes on time of day, time of tide, state of sky, temperature of air, depth nature of bnttom and direction of currents. Tle water-hottle, a lono brass cylinder with ralves, is nsed to dip up some of the bottom water whiel is carefully preserved for the determunation of specifie gravity and the pereentages of salt and air. One man stands with hand on dredge 
rope, for a naturalist feels as keen a delight in the steady tremulous motion of the dredge scraping over a good bottom, as dnes the angler in the tug of the salmon at his slender line; his tlouglitful hrow shows that he is estimating the number of rare ophiurans or pectens it wili soon bring to light; all at once there is a jerk, the safety check-stop snaps asunder, the alert seamen cast loose the line, Mr. Cook pulls the bell and we are steaming towards the dredge, which has caught on a rock: two wlistles, "up dredge!" "up dredge!" echoes the quartermaster and then the donkey snorts and puffs and scatters steam spray and the dredge-line is reeled up, while the seamen coil away the slack. Soon the iron arms and gaping jaws of the dredge come to the surface while all stand on and over the rail, eager for a first glance at the mysterious treasure within the canvas; the davit is swung around, a mass of broken shells and sand is dumped into a large eradle-sieve which hangs over the side; a long hose appears at the engine room door, unrolls as it comes forward and soon a

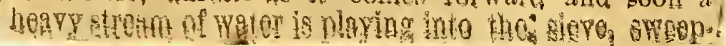

ing out the sand and mud and uncovering countless treasures of animal life. The sleve is now hidden from sight by a knot of heads from which issue exclamations of surpris" and delight. Now it is a superb specimen of 'the beautiful little coral, Astrangia Danae, the most northern of its kind, now it is the sight of the northe: $n$ and snuthern sea-urchins, $A \gamma$ bacia punctulata and Strongylocentrotus Droebactiensis both in the same haul, now it is a half-bushel. or: more of a bright yellow sponge, Cliona sulphurea, which one of the party seems to think wou d set him up for life, "if he culd only keep them alive;" one of the party is in ecstacy over a little spray of crimson sea-wecd Ptilota serrota, "the first time it ever was seen south of Cape Cod," though we used to dredge it by the bag-full on the coast of Maine; another rushes off with one of those curious Jittle black objects known as "mermaids' purses," or "devil's knitting sheaths," ard with a pair of scissors, liberates, from his ovine pison, a lively little skate, Reia eglanteria, an inch in length. And so it goes on; sometimes one hundrcd and thirty species are brought up in a single haul. The living animals are placed in buckets of water, to be studied on our return, then a large table is fitted across the deck, a tarpaulin table-cloth is spread, the remainder of the haul is thrown upon it, and all gather around with a promptness which reminds one of the city newsboys at their annual Thanksgiving dinner. One member, with pencil and note book, takes a catalogue of the species captured; the others, with forceps and fingers, soon transfer the specimens to their bottles and pails. Even the sea men catch the fever, and wander anxiously about with some poor crushid creature in their fists, inquiring : "is this a specinsen?"

Sandy bottom is good for trawling; the trawl net has been lowered and is dragging the ocean floor, while the ship slowly backs along. Dinner is announced and all soon meet in the cabin. A good chowder, "a la Blueliglit," is rolurays the first course, and the party do full 
justice to the menu, even unto the eoflee Notes are compared on the days' work; the eaptain spiees the eon versation with a story of adventure in China Seas or Indian Ocean, and the picture is eomplete if some poor neophytc finds the rolling uneomfortable, and steps out " to see how the trawl is dragging."

Dinnel is over, and the trawl is pulled in: sometimes it is empty, sometimes it brings such a weighty load that the whole force with pulleys and boat hooks can hardly raise it over the rail. Onee it brought up, from seventy fathoms a huge granite boulder, three feet thick, and weighing half a ton; once it brought a barrel of seaeucumbers, Pentacta fromdosi ; once two barrels and more of lobsters, and the last time it was used it eaught two lundred full-grown sliates Rria eglanteria, to say nothing of other fishes, sponges, and pectens. The trawl takes only large things whieh are soon disposed of, and the dredge is put over again; and if it is rocky the "tangles" are allowed to drag The "tangles" are simply great mops of spun-yarn attached to an iron bar to be dragged over the bottom: the fibres of the mops entangle star-fishes, crabs and sea-weeds, and I have secn sercn or eight thousand star-fishes brought up at once. It has been proposed to use this maehine in freeing oyster beds from these their deadly enemies. A few hauls of the dredge will gather more material than can be taken care of before midnight. and by supper-time our ship is snugly made fast to Palmer's wharf.

Prof. Putnim A merican Naturlist, Dr. Holder American Museum of Natural History, Mr. Wyckoff of the Tribuve, Dr. Edmonds, Commissioner of Fisheries, Vt. Col. Eane, Yew Haven, and Commissary Feneral Eatnn, turo simong the recks yisitors.

\section{The Inited States Commission of Fish and Fisheries. \\ NOANK.}

\section{THE "LABORATORY."}

My list letter clescribed a dredging trip in Bloek Island sound. and came to a close with the arrival of the "Bluelight" in Noank harbor. The field work, if we may so call it, of the day being over, a task quite as important rcmains, the assorting and s.udy of the material collected. Let us take a glance at the headquartcrs of the dredging party. A large room, in dimensions some sixty feet by thirty, oecupying the second story of a large building at the foot of Main street and accessible by a flight of outside stairs, has been transformed from a sail-maker's loft to a working laboratory; once this was the public hall of Noank and its walls still bear a reminiscence of former fair or fcstival in the staring, grecn letters of a "Welcome." To the naturalist it is [now a veritable palace, a storehouse of treasures more 
precious thau Aladdin's lamp ever brought into his youthful visions. In front of each window is a tier of tables, between the windows are rows of shelves, filled with jars, bottles, phials, boxes, microscope cases, and books, suggesting to one irreverent mind "a drug store with a literary turn." In one corner is a stock of oars, dip nets, hoes, shovels and picks, grappling irons, towing nets, and the nther appliances for exploring the bays and the shores at low tide. In another corner, amidst a wilderness of old coats and tall boots, we catch a glimpse of a fragmentary looking-glass, a sort of rudimentary organ to the party, a connecting link between the informalities of the summer and the restraints of home life.

A large table in the middle of the room has on it buckets and earthern dishes in which the anima!s are kept alive by constant renewals of fresh sea-water. For the study of the smaller animals a white dish filled with water is more convenient than a large aquarium, for the species can thus be kept separate, and the specimens are always conspicuously visible for examination or draw ing. An aquarium stands near, ready to receive any large specimens which need to be preserved for a longer time.

A flight of steps leads up to the cock-loft, where the visitor beholds an army of lobsters, star-fishes, sea urchins, crabs, sponges and sea weeds, spread upon the floor to dry.

The tables are occupied by busy workers, one at his microscope, another with his note book, others picking over plates tull of dredgings, searching the mud and broken shells for minute forms which had not been picked out in the first culling on board of the steamer; others are transferring the identified specimens to their houses of glass where surrounded by an atmosphere of alcohol, they are to remain until needed for farther study.

At one of the tables sits a learned professor, well known at home and abroad by his studies of fossil cephalopods and his theory of the "Origin of Genera." Sponges of many and beautiful forms fill his bottles and his bowls of sea water. He is studying, too, the lower mollusks, the Bryozoc and the Tunicata. Perhaps he will allow you a peep through his microscope at a curious object which looks like a little "tadpole." Thereby hangs a tale as well as a tail, for this little creature is causing a commotion in scientific circles just now. It is the early or larval stage of one of the "sea peaches," Cynthica carnea, and though one of the lowest of the mollusca, has been ceclared by a Russian naturalist, M. Kowalewsky, to show in its tail traces of a 
segmentation resembling that of the notochord, or em bryonic back bone of vertebrated animals in their early stages. Yet we wait for mere proof before we yield to our feelings, ans l'cfrain from shedding our tears over the possible ancestor of the human race, whose existence is suggested to us by this strange little creature.

At the next table we find an eminent anatomist from Philadelphia, engaged in the study of the Rhizopoda or root-footed animalcules, a group of microscopic animails $c_{\text {f }}$ which the $A m \alpha b a$ is perhaps the best known example; little filmy putches of mucus, they appear, but when highly magnitied inany of them are of exquisite beauty, with delicately and elaborate ly sculptured shells, from which they protrude their "root-feet" (Pseudo-podia) in graceful movements. Some of them are not larger dia meter than 1-2800th of an inch and the largest are barely, visible to the unaided eye. The Professor has already identified them in most of the forms known in Europe, and has in preparation an claborate monograph of the group.

At this window too, is the artist of the expedition. Mr. Blake, whose quick pencil preserves the outlines of the animals as they lie under his microscope or in his watch crystal. It is the intention of Prof. Verrill to figure in his report to the Commissioners, every invertebrate species on the coast which has not been well figured before.

Another table is devoted to crabs and upon it and its predlecessors, during the three vears past, has been done some of the prettiest and most valuable of the work of the party. To its occupant science is indebted for an account of the development of the lobster (Homarus (mericanus) from the egg to the sdult. Just now he is studying the early stages of some of the crabs, and his dishes are tilled with egg loaded parents which he watches with ceaseless care from morning till night. A curious sight is a dish full of the new born young ( 7 nea) a whirlwind of little creatures, witlı enormous com pound eyes and long nose-like rostra.

A tifth table is at present devoted to the Acalephs or "jelly-fisn?s." You are shown specimens, put up in bottles of picric and osmic acid, which are very satis. factory, when it is remembered that of all things, a jelly-fish is the most difficult to preserve, on account of the large proportion of water in its tissues. Yet they seem like poor, discolored caricacures when you see the contents of a wooden bucket under the table which is filled with living specimens of Idyia roseula; this is to my notion the loveliest creature on our coast, shaped 
much like a hen's egg, as transparent as clear glass though with a rosy tinge, its outlines F irely distinguishable as it floats just below the surface; its sides spanned with eight living rainbows whose prismatic changes are indescribably beautiful.

Another bucket has some specimens of the beautiful Staurophora or "cross-bearer" a broad, limpid disk. displaying a white Greek cross which at a distance seems floating unsupported in the water. A group at another table are mounting sea-mosses, dexterously transferring them to paper with their branches as gracefully extended as when afloat in their native element. Prof. Verrill is the presiding genius of the place, each specimen passes under his eye, and the unique ones are taken'to his desk, where midnight always finds him absorbed in his researches, forgetful of hard days work just past and the new one just beginning. The studies made here are only preliminary, the final work being done in the Professor's own laboratory at New Haven, with the aid of the extensive suites of specimens collected in former years.

Frater Aquarius

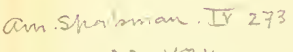

ang 22.1674

\section{THE ORANGE FILE-FISH.}

Ceratacanthus aurantiacus, (Mitchill) Gill.

H'Dq'Rs U. S. Com. of Fish and Fisheries, ? Noank, Conn., Aug. 24, 1874.

The following item was clipped from the New London Telegram of the 25th ult.:

"The fish-laden smack 'Fashion,' which arrived liere to-day from Montauk, included in its cargo an inhabitant of the briny deep, the like of which the fishermen say they never saw or heard of before. This new fish weighs from two to three pounds, has very large eyes, a mouth like that of a monkey, is variegated in colorwhite and blue predominating, - - and in shape resembles the flat-fish. The 'Fashion' is at Bolles \& Benhams' wharf, and has been visited by quite a number of people whose curiosity was excited by stories of the new comer."

Of course this story excited the curiosity of the party at Noank, for, unlike most newspaper announcements of this character, the paragraph did not bear on its face the marks of a canard. Visiting New London we soon found our way to the fish market-a place to which the instincts of a naturalist lead him almost the instant he reaches a seaport town. There, lazily disporting themselves in an open bass car near the wharf, we were shown the strangers, which were, as Professor Baird had predicted, orange file-fishes. I had never before seen the species 
alive, and for an hour or more stood watching their strange movements. The largest was eighteen inches in length and five in height, yet so thin that it weighed only two pounds. The reporter was not far from right in saying that its shape waj like that of a flat-tish; in fact a rnugh idea of it' appearunce may be gained by imagining a flounder having symmetrical sides and swimming in an upright position.

The most noticeable feature about the fish is its mouth, and this is still more striking if the skin and flesh are removed and we get a good view of the skeleton. The bones of the upper jaw are closely uriter and in the lower are completely grown together, instead of being separate as they are in most fishes. This gives the jaws an extremely powerful grip, their action being much like that of a pair of nutcrackers, and they are set with rows of teeth which, though thin, are very sharp and strong. Thus provided the fish browses with ease among the rocks upon its pasturage of barnacles, snails and mussels. A similar union of the bones of the mouth is found in the sunfishes, box-fishes, swell-fishes, porcupine fishes and trunk-fishes, as well as in the file-fishes, and has given the name to the Order in which they are all includedthat of the Plectognathi (plectos, conjoined, and gnathoi, the jaws). If the haud is drawn along the side of the fish it feels a surface like that of coarse sand-paper, and if we examine the sealcs, whicl, instead of overlapping each other as in ordinary fislies, are minute and placed side by side like those of a shark, we find that each is provided with a rougl protuberance or knob. The fishes thus roughly clad are known as "file-fishes" and constitute the Sub-order Scleroderma (skleros, rough, and (lema, skin). The carpenters in the West Indies often usc their skins for polishing wood-work. In front of the dorsal fin we notice a strong, rough spine, about two and one-half inches long, resembling the trigger of a gun. It is arranged to fold into a groove in the top of the back, like a jack-koife blade into its handle, so that it shall offer no resistance when the fish is swimming through the water. A peculiar knack must be used, however, in shutting it down, for it is like a gun-trigger in the mechanism of its hinge as well as in its appearancc. At its base the spine is expanded and divides into two arms, the extremities of which approach each other and embrace the crest of the super-occipital bone, which has upon each sicle a depression to receive the terminal knobs; a long, curved spur, which describes the arc of one-third of a circle, projects backward from the spine, at a point just above the junction of its basal arms, and is received into a curved mortice which extends forward under the super-occipital crest, thus clanping the spine down upon its seat and forming a hinge which allows 


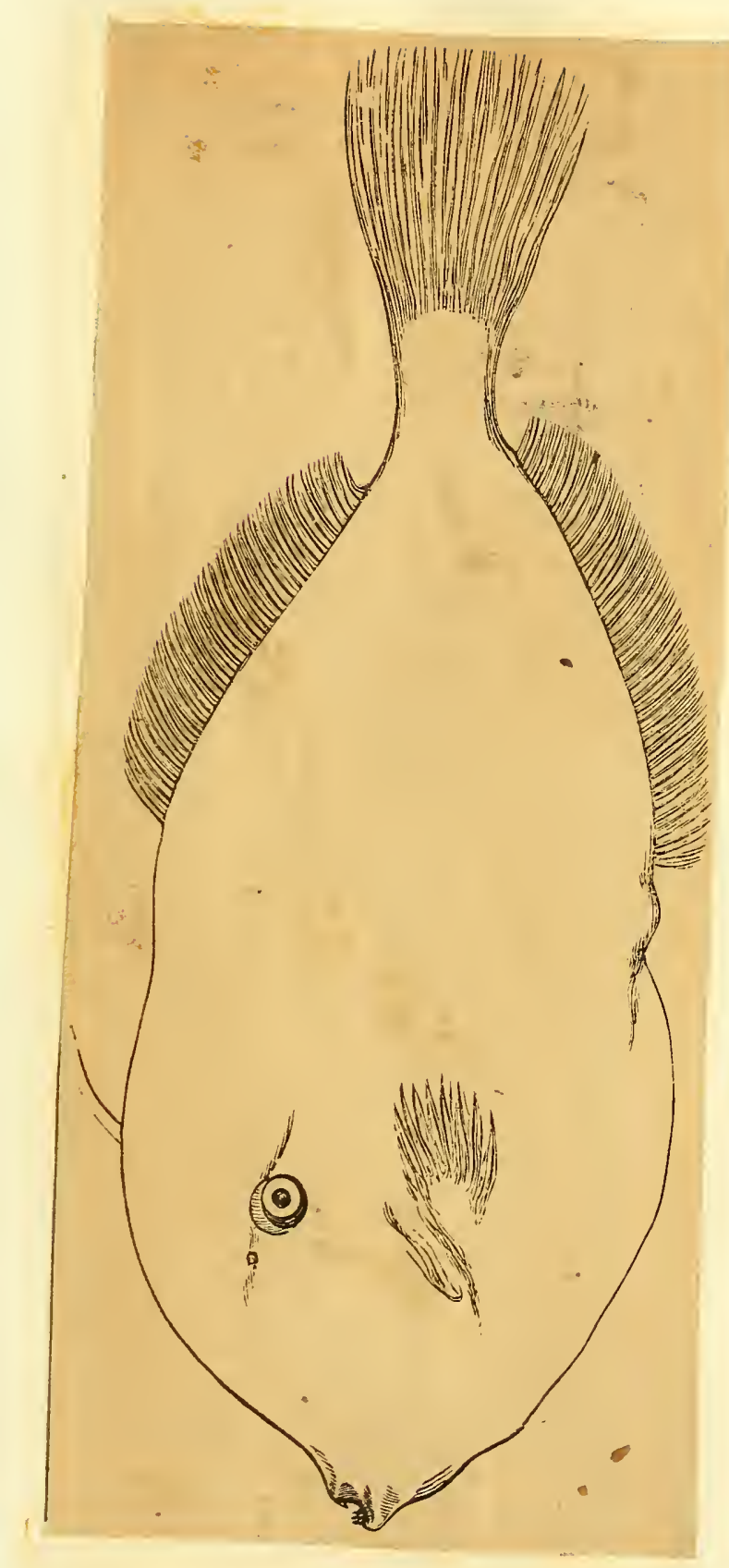


free movement forward and backward but no sideswaying. Close behind the spine is another powerfui saddle-hinge, surmounted by the merest rudiment of a spine which constitutes the "cetch" of the trigger. When it is bent fcrward, as it may be at the wi'l of the fish, its extremity is received into a hollow near the base of the trigger, which is thus set, at an angle of forty or fifty degrees, as immovably as the trigger of a Parker" "rehounder" at half-coclr. hr $r-1 \div$; back the catch, the spine is released and may easily, be pressed back into its sheath. This mechanism of the dorsal spines, so curious and (if I may so speak of what is not of human contrivance) so ingenious, is varied in the different gellt of the family and has given to it the naius Balis. tida. Some of the forms have several spines in the back-fin, but this has only one, and is therefore classed with the "unicorn fishes," or the sub-family Nonacunthince (monos, single, and acantha, a spine). Professor Gill has made for this fis'a a special genus which he calls Ceratacanthus (keres, a horn, and acantha, a spine). Its color is like that of a fresh Messina orange, marbled. with white and dark brown. The throat and cheeks, up to and in front of the eyes, are whitish, with a bcautiful opalescence in which blue predominates. The prcvailng color gives the fish its specific name and completes the title of Ceratucunthus aurantiacus, the "orange filc-fislı," or, better still, the "orange unicornfish."

Our friend, Mrr. A. Ceratacanthus, was first introduced to the scientific world by a gentleman to whom it owes other favors, many and great, MIr. Robert Fulton, who cauglit the first specimen in New York harbor, August 1, 1814. It had for god-father Samucl L. Mitchill, M. D., Professor of Natural History in the University of New York, Representative in Congress, Lc., and was first noticed in a paper entitled "The Fishes of New York, Described and Arranged." read before the "Literary and Philosophical Society of New Fork" on the Sth of December, 1814. Brought to notice by the irrentor of the steamship, christened by the father of American 1chthyology, under the auspices of a learned society whose successor New York cannot at t'ais day show, its record is certainly a creditable one. Its connections, too, are extensive, for no less than forty of the common fishes of the east coast of North Ameri^a claim Professor Mitchill as sponsor and bear his 
name as authol ity for their own. To be sure, his descriptions are but little better than none at all, yet allowance must be made for the difficulties encountered in a fieid of 1 usearch then quite unexplored. I watched the fishes lazily swimming among the sea-bass. Perhaps if Robert Fulton had spent an hour or two in studying the motions of his file-fishes' fins he might have grasped the idea of propelling a boat by a screw under its stern, and saved, steam navigation from the long developmental pe. (CONCLUDED ON PAGE,356.)

(CONTINUED FROM PAGE 353).

riod of side-wheelers. At any rate, he might have found a worse model for a propeller than the file-fish would have been.

I wilk: try to describe its motions as they appeared to me As in all the fishes of this order which I have owserved, the propelling power is exercised chiefly by the dorsal and anal fins, the tail, that powerful sculling oar so inportant to other fishes, being degraded to the rank and function of a rudder. Occasionally, when disturbed, the fish gave a rapid sicie sweep of its tail, yet seemed to depend chiefly on the undulating, Archimedean screw motion of the back-fin anci its counterpart the anal, though perhaps the caudal would be made use of in a long rapid journey. Like the rest of the family, the fish appears to be sluggish and sun-loving in its habits, passing the day lazily float. ing or flapping its broad sides at the surface. A horizontal position was often taken, a sudden and oblique twist of the tail-rudder serving to throw the fish upon its side, in which attitude it would remain slowly propelling itself by a motion of the dorsal and anal, which must be seen to be understood, which I cannot reseribe, though I have seen it also in the flounder. A slight movement of the pectoral fins, situated as they are below and in advance of the centre of gravity, changes the delicate poise of the fish and lowers its head, an oblique motion with the upper edges of the flns turned inward has the contrary effect. Sometimes the fish would assume a strange position, its body upright, head downward, then by a reversed motion of the pectorals it would "back water" until it had raised its tail above the surface as far as the base of its rays; in this attitude it would remain for a short time, wagging its tail with apparent enjoyment. Whetler this act indicates pleasure, as in a dog, or anger, as in a cat, I was not able to learn. But the tail seemed sucli a convenient handle that the temptation to take hold of it was almost irresistible: When swimming near the surface it would of ten turn upon its side with a sudden sweep of 
its tail, and glide along just at the surface, resuming its first attitude as soon as its momentum was gone. Dr. Storer speaks of one taken in the harbor of Portland, Mc., which "appeared, when about a fathom under water, jike a bit of kelp, and was rising toward the surface, when a fisherman, observing its motion, put his hand into the water, and the fish came directly into it and was caught:"

Though the family to which the orange file-fish belongs is a tropical one, this species appears to be contined to the eastern coast of the United States, ranging from Mlaine to Georgia. Professor Baird took several at Wood's Hole, in 1871, and a number were taken, last year, in the pound at Fishcr's Island. The Noank fishermen call it the "cow-fish," but in New London it was so great a novelty as to be witho!nt a name, and the market mell, fisherman fashion, coined for it a new one, which was ingenious if not appropriate-the "sliny night-cap fish." Captain Bolles presented one of the fishes to Professor Baird and its skeleton makes one more in the Bluebeard closet of the Commission.

Friter Aquarius.

\title{
UNITED STATES COHHISSION OF FISH AND FISHERIES.
}

THE EXPERIMEXTS WITH YOUNG SHAD.

\author{
Headquarters U. S. Com. Fish? \\ AND Fisheries.
}

Noank, Conn., Aug. 26.

Having in my two previous letters given some account of the operations of the dredging party, I now propose to perform a like duty by the party engaged in the fishery investigation. This week I send an account of some interesting and important experiments on the effects of transferring newly-hatched sliad from fresh to sea water; no mention has hitherto been made of this investigation as I preferred to wait until the work was completed before attempting to sun up its results. Mr. Milner in whose hands the management of thic investigation had been placed by Professor Baird, was unfortunately called away soon after the experiments were inaugurated; his plans have however, been very efficiently carried out by his assistant Mr. C. D. Griswold, of South Hadley Falls, Mlass, with the aid of Mr. Joln Vealey. From the time of their leaving the cgg. the young fish lave not been left for an ir stant, snme one being always near to regulate the temperature and light or to furnish the necded supply of fresh water. 
I am indebted to Mr. Griswold for the following notes, which by their minute detail, show the care which has been used; as has been stated before, the scheme of work was arranged by MIr. James W. Milner, Deputy Commissioner of Fisheries.

At 5 a. $\mathrm{m}$. on the 15 th inst., 45,000 shad, just out of the eggs, were taken from the hatching boxes at Holyoke, Mass., and placed in five forty-quart tin cans for ransportation.

Noank was reached at 11:30 the same morning; during the transit and for ten hours after their arrival, the tish were supplied with tresh spring water every two hours; one-eightl of the total amount of water in the cans being drawn off and replaced by new. At $9 \mathrm{p} . \mathrm{m}$. the experiment was inaugurated, the fish being placed in ten four gallon stone jars-about four thousand in each. The jars were filled with fresh spring water which was to be gradually replaced by sea water until a c mplete change was made. Four sehemes were simultaneously begun, the details of which will be given in proper order; in these it was the ai :. to keep the temperature uniform with that of the water in the bay. It should be stated that the water in the jars, after the eompletion of the schemes of change, cannot have been pure salt water, but yet so nearly approximated it that there was probably no appreciable difference. The water was changed every third hour, two quarts or oneeighth of the old water being drawn off by a rubber siphon, and replaced by a new supply with which salt water was added in a regular ratio of arithmetical progression which varied in the different schemes. The fresh water was brought from a spring half a mile distant, and this as well as the salt water, had the advantaye of being dipped up, not drawn throtigh a slimy pump. The utmost care was taken to preserve the cleanliness of the jars.

Scheme I.-(Jar No. 1): To ehange the water from fresh spring water to sea water in 45 hours; adding one grll of sea water at each change. Thus at twelve, midnight, two quarts of the old water was withdrawn and replaced by a mixture of fifteen gills of spring water and one of sea water; at 3 a. $\mathrm{m}$., fourteen gills of spring water and two of sea water, and so on. This scheme was completed on the $17 \mathrm{th}$, at $6 \mathrm{p} . \mathrm{m}$. The temperature of the water ranged from $69^{\circ}$ to $71^{\circ}$. On the 18 th at 9 a. m. the young shac showed signs of weakness, and at $6 \mathrm{p}$. m. were all apparently dead, 85 hours after leaving the hatehing boxes, and 24 hours after the water bai hecome entirely salt.

Some were taken at the last moment from the bottom of the jar, where they had fallen, and placed in a two quart glass jar (Jar No. 11), filled with a mixture of half alt and half spring water; here they revived, ard 
lived until $6 \mathrm{p}$. $\mathrm{m}$. on the $22 \mathrm{~d}$, an additional period of 96 hours, making a total of 181 hours.

SCHEME II.-(Jar No. 2): To change from spring water to sea water in 90 hours, adding one-half a gill of sea water at each change. This scheme was completed on the 19th, at $3 \mathrm{p}, \mathrm{m}$. The temperature ranged from $66^{\circ}$ to $70^{\circ}$, except on the $20 \mathrm{th}$, when at $6 \mathrm{p}$. m. it reached $78^{\circ}$, that of the air being $79^{\circ}$; this no doubt, hastened the death of the young shad which showed signs of weakness on the $19 \mathrm{th}$, at 9 p. m., gradually dying from th -t, tim until 9 a. m. on the $22 d$. when all were gone, 172 hours after leaving the hatching boxes, and 66 hours after the water had become entirely salt.

Screjre III.-(Jar No. 3): To change the water in 36 hours from spring water to a mixture of one-third sea watcr and two-thirds fresh water; adding one-half a gill of sea water at every change. This scheme was completed on the 17 th, at 9 a. $\mathrm{m}$. The temperature ranged fron $66^{\circ}$ to $68^{\circ}$ on the 20 th and $23 \mathrm{~d}$ rising with the air as high as $75^{\circ}$, and this excessive heat caus ${ }^{\circ}$ consider. able mortality. On the $23 \mathrm{~d}$ at $6 \mathrm{p}$. m. they showed signs of debility, yet sn the 24 th at $3 \mathrm{p}$. m. fully one-eightl were alive, and some survived until $7 \mathrm{p}$. $\mathrm{m}$. on the 25 th 252 lours after leaving the latching boxes and 174 hours after their water had been changed to the required proportions.

Scheme IV. - (Jar No. 4): To change the watcr in 45 hours to a mixture of spring and sea water in equal parts; adding one-half a gill of sea water every three hours. This scheme was completed on the 1\%th, at $6 \mathrm{p} . \mathrm{m}$. The tish in this jar seemed exceptionally sprightly until they began to settle on the bottom at 9 a. n. on the $22 \mathrm{~d}$; all were dead at 3 a. m. on the $23 \dot{d}$, 190 hours after leaving the hatching boxes and 129 hours after their water was brought to its required proportions.

ScILeme V.-(Jar No, 12): To change the fishes directly from spring water to sea water. This experiment was repcated three times, the fishes dying in from two to three hours.

Scheme VI. - [Jar No. 13]: To keep the fish in water dipped from the surface after a heary rain. The water was very brackish, and its temperature ranged from $69^{\circ}$ to 720 . The fish lived from $8 \mathrm{a} . \mathrm{m}$. on the 16 th to $12 \mathrm{~m}$., on the $21 \mathrm{st}, 124$ hours.

Scheme VII. - [Jar No. 14]: To change from Jar No. 14 to fresh epring water. This change was effected at 5 p. m. on (ae $22 \mathrm{~d}$, and the fish survived until 9 p. n. on the 23 d. 
ScheMe VIII (Jar. No, 15): to keep the young fish in water taken from a fresli water pond. Water for this purpose was taken from a pond of clear water from which the villagers obtain their yearly supply of ice. The fish survived the changc 24 hours.

SCHEME IX. (Jar. No. 5): A temperature test, the jar being filled with spring water, kept constantly at a temperaturc of 65 deg., by the addition of ice water. The fish lived until $3 \mathrm{a} . \mathrm{m}$., on the $23 \mathrm{~d}$. 190 hours from the hatching boxes.

Scheme X (Jar No. 6): Temperature test at, 60 , deg., and ScHeme XI (Jar No 7), temperature test at $55 \mathrm{deg}$. It was found impracticable to keep the temperature at these points, and the average in Nos. 6 and 7 was not below $64 \mathrm{deg}$. In jar No. 6 the fish survived until 9 a. m., on the 23d, 196 hours. Jar No. 7 seems to have on the whole, been the most successful, the grcater part of the fish surviving until $9 \mathrm{p}$. m.. on the $23 \mathrm{~d}$, when they died, all at once, after 208 hours of life.

Scheme XII (Jar No. 8): Temperature test at 50 deg. On the $21 \mathrm{st}$ this jar was placed in the refrigerator, where a temperature of $48 \mathrm{deg}$. for the botiom and $52 \mathrm{deg}$. for the surface was attained, giving an average of $50 \mathrm{deg}$. The young fish died in the course of seven hours.

Scheme XIII (Jars Nos. 9 and 10): Temperature best at 70 deg. This temperature was successfully maintained, The young fish died at $3 \mathrm{p} . \mathrm{m}$. on the $23 \mathrm{~d}$ after living 202 hours.

It will be observed that in some respects the best results were obtained in jar No. 7 , the majority of the fish living 6 hours after they had begun dying in jar No. 3, though some individuals in No. 3 survived much longer than any in No. 7. It may be that the mixture of pond watcr derived from the melted ice hastened death in No. 7, for the experiment of Scheme VIII shows that this water is injurious. The results of Srheme III are probably the best, although only a small proportion of the original number came to the final best. The results of the experiment may bc roughly summarized ag fellows:

1, It has been shown that the young shad cannot be kept alive in cans long enough to make a transatlantic voyage of ten or twelve days. 2. The length of time they can be kept in cans has been satisfactorily determined, being from eight days and ten hours to eight days and sixteen hours; in individuals, extending to ten days and twelve hours. The longes time hitherto made was that by Seth Green, who carried the young fish 
across the eontinent in seven days and ten hours. The motion of the water, caused by the jolting of car or steamboat. is jprnbably rather beneficial than otherwise, and would be 1 iy to prolong the life of the fishes. 3. The impracicability of a sudden change from fresh to salt water has been demonstrated. 4. It has been shown that a partial admixture of salt water is not injurious to the young fish: Scheme III, and Seheme XI. being almost equally successful. 5 . It has been shown that a uniform temperature of from $60^{\circ}$ to $70^{c}$ is the most suitable, a slight deviation beyond those extremes being dangerous. 6. The superiority of spring over pond water has been most satisfactorily demonstrated. 7 . The death of the young shad is undoubtedly due to starvation,--the umbilical sac having been absorberl at the end of five days they were then entirely without food. A microscopic examination of the intestines showed that they were utterly empty. A few of the surplus lot of fishes in the supply can were plaesd in a jar containing a handful of coarse sand and gravel, and, sinking to the bottom, they. seemed busily enmployed among the sand and pebbles. Whether they found any food I do not know, but they were among the last to die, although very little attention was paid them.

The question of the possibility of transporting shad to Europe is one of much importance. The only feasible plans seem to be these: 1 , to discover some means of feeding the young fish in trunsitu; 2 , to start them on the voyage in the eggs, hatching them on the wiy or after their arrival; or, 3 , to capture and transport the young fish after they have been free for some weeks and have by feeding gained the physical stamina to cndure a two weeks' fast. Of the three altermatives, the first seems at present the most practicable: experiment may yet reach some other and better plan.

Friter Ą̨ualius.

\title{
INITED STATES COMMISSION OF FISH ANI FISHERIES.
}

\author{
THE FISII LABORATORY. \\ Headquarters U. S. Com. Fish ? \\ AND Frsheiries.
Nounk, Conn., Sept. 3.
}

At the water's edge, midway between the invertebrate Laboratory and the "Bluelight" wharf stands a small white wooden building, the headquarters of the fisling party. "Iclithyological Hall" sonie eall it; otlicrs, irreverently, "The Sliark's Purlor," but to its oecupants, 
and to Noank in general, it is plainly and simply, "The Fish House." MIust of the work of the party is done in their boats, but here the collections are preserved, dissections are made, and field-notes are " riten up.

At the start it must be confossed the the attractions of the other laboratory, and of the dredging work, are . much the greater to our visitors-both on account of the novelty of the work and the greater variety of living forms brought up in the dredge-net. It is the mis-? fortune of most persons to grow up with the impression that fishes were created only to be eaten: the names of fislies are usually associated with damp, slimy marketstalls, and the hideous clammy masses of flesh so often to be seen there. No one considers a fish "a curiosity," but the strange and lovely creatures drawn up from the unexplored bottom of the sea are new revelations, unexpected visions of beanty. Not a whit less curious fond beautiful are our tinny friends, if you see them as we see them, in their native element; every motion instinct with grace, their color's as delicate as these of a pearl or as brilliantly gorgeous as those of fire-opal. Here in the laboratory are only dead specimens, the ouly traces of their former beauty lingering in the notebuok of the collector and in the portfolio of the artist. Then too, the apparatus used in collection consists merely of modificitions of the nets and lines used by tisheruen fron time immemorial, and as fimiliar to all as the plutugh and the axe. Still a few worls on the work and the laboratury, may be of interest.

In front is a platform-wharf, about twenty feet long, the end of which is ocerpied by a large reel on which the nets and seines are wound at night to dry. On the platform are piled oars, nets, coils of rope, and here may usually be reen several large fisties awailing their fate, - sbarks, sturgeons, skates or rays, brought in lyy the eollecting parties or lyy llse smacks.

In the channel lies the "Cygnet," our little sloop: rigged. working yacht, and near by are moored the seining boats. Close at hand are tied the fluating vivaria, the live car, a little covered boat with numerous holes in its sides and bottom, in which living fisn are towed, and the Green hatching boxes used in the experiments in the artificial propagation of food-fishes.

A force pump supplied from the channel, furnishes fresh sea water to the aquarium, and aids in the frequent cleansings of the estahlishment. Entering the bouse we are saluted by the udor of alcoholic specimens, disagreeable at first, but sweeter than any incenec to the nostrils of the naturalist, 
The room is too small and too crowded with chairs and work-tables to allow extensive cxplorativi, $i \cdot \sigma^{\circ}$ the inspection can he quickly made. One wall is occupicd by shelves a d arge copper tanks standing on $i, \mathrm{~d}^{\mathrm{n}}$ floor under thin the shelves and the rows of glass jais, bottles and phials, receive the smaller specimens; others go into the tanks; the skins and the largest specimens are packed in brine barrels which stand without the door. Another side of the room is occupiod by the refrigerators in which specimens may be kept in good condition for several days. On the table are some of the accessories of field;work, including compound microscope, dissecting instruments, drawing materials, graduated scales, balances, and note-books. Tanks of alcohol, harpoons, boat hooks, grappling irons, nets, and tall wading boots, hung up to dry, may be thrown in adlibitum, to complete the picture.

On the floor is stretcheil a liuge specimen of the Land Shark (Eugomphodus littoralis) just brought in from tte "Middle Ground" by the schooner "Caroline." (The advocates of tine tackle will be interested to learn that this fish, eight feet and ten inches long, weighing probably three liundred pounds, was taken with an ordinary sea-bass look with a two-inch shank. The fishermen, when lie found his houk taken, pulled up anchor and rowed in his sharpie to the smack, holding lis line between his teeth and lending lis captive with the greatest ease.) This is by far the largest of the species ever recorded, the ordinary adult of the speeies, "Johnny Shurks" as the Noankers call them, seldom are seen more than four feet long and fifteen or twenty pounds in weight. Mr. Blake is mounted on a stool near by, rapidly delineating his outlines. Another of the porty is tukil, the measurements of a Tarpum (Megalop)s thry $s$ voides)- a rare species, our fourtis specimen from the coast, taken in Captain Rogers' pound at Squijsset, near Woods' Hole, Massachusetts. 'An exquisitely formed creature it is, every line adapted to quick motion through the water, cach fin sleathed in front by a case of overlipping scales, those of the back and under sile of the tail clinging close to the body by a sucker-like prolongation of their list rays, its lower jaw prolonged far beyond the mouth in a point like the sharp bow of a yacht. The scales, glistening like plates of polished silver, present a smooth, yiclding surface as the fish rushes through th water. Well can we belicve the accounts of the rapidity of the flsh and his enormous leaps out of water as lue pursues the flying schools of menhaden and lerrings. A third is busy over the stove, boiling and cleaning some 
skeletons, while still another stancis over a table near by dissserting out the brain of a thre "not "Mollicut" (jigiflius piscatorius). Enthusiasticit ie s"mmons all to admire the little globule of nervo issue as it lies in its bath of crystal fluid, its complicated system of ner ves branching out to nostrils, eyes, ears, jaws, heart and fins, reminding one of a central station communieating with many distant parts by submarine telegraph cables. The Doctor has injected the arteries with vermilion and their delecate arborescence may be traced through all their wanderings among the tissucs

Two otker occupants of the room arc worthy of passing notice, as they sport their gay eolors in the aquarium; onc the Box-fish (Chilomycterus geometricus), his stomach of aldcrmanic proportions, though it is only filled with water whieh he throws from his mouth a distance of three feet and more if he is lifted out of water; the other a small Fling-tailed File-fish (Alutero cuspicouda), a near relative of the Orange File-fish described in the SPORTSIAN two weeks ago.

Any remarkable speeimens are sent to Washington -packed in ice, to be plotographed and cast in plaster. Professor Bairil's scries of "Photographs of the Fond Fishes of the Uuited States" already ineludes some two hundred and tifty species, many of the pictures of remarkable beauty. Mr. Joseph Palmer, the taxidermist of the United States National Museum, is a master in the art of modeling in plaster; in his hands the eollection of casts is rupidly growing. Thesc are colored from sketches of the living fish, and for public exhibition are far superior to alcoholic specimens or stuffed skins. To the student they are also valuable, showing the unshrunken shapes and undistorted proportions of the uewly caught fish. Fratef Aqútios.

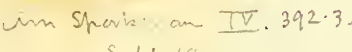









[From the American Journal of Science and Arts, Vol. VIII, Aug., 1874.]

\section{DESCRIPTIONS OF TWO NEW SPECIES OF FISHES FROM THE BERMUDA ISLANDS.}

\section{By G. BROWN GOODE.}

IN a collection of fishes, including some seventy species, made at the Bermudas in the spring of 1872, I find two forms apparently undescribed, descriptions of which are given below. As the marine life of the Bermuda group is essentially West Indian in its character, these species may be regarded as additions to the icthyologica! fauna of the West Indies.

\section{Diapterus Lefroyi, sp. nov.}

This species belongs to the genus Gerres as defined by $\mathrm{Dr}$. Günther. It is distinguished from all other members of the genus and family by its relatively grcatly elongated form. The body is fusiform, compressed, its greatest height, at the thoracic region, being a little less than one-fourth $(\cdot 23)$ of the total length and a little more than onc-fourth ( 27$)$ of the length without caudal $(\cdot 89)$ : in Diapterus aprion, the most elongated of the species hitherto described, the greatest height is but onethird of the length. The height of the body is uniform under the spinous portion of the dorsal, sloping cently and at a nearly uniform angle above and below to the micldle of the caudal peduncle. The height of the body bchind the dorsal $(\cdot 10)$ is less than one-half, that of the least height of the tail $(.06)$ is onefourth of the greatest height of the body.

The scales are large, measuring $\cdot 03$ and $\cdot 04$ in height and 02 and .03 in length: they form about forty-five oblique transverse rows between the head and the caudal, four and one-half longitudinal rows between the back and the lateral line and ten between the lateral line and the belly. 
The length of the head (.22) equals the greatest height of the body and is double the greatest width of the head $(\cdot 11)$ : the height at the pupil $(\cdot 14)$ is double the width of the interorbital space (.07). The length of the snout (.06) equals the length of the operculum $(\cdot 06)$; when the mouth is protruded the length of the snout is doubled ( 12 ) and when retracted the posterior extremity of the intermaxillary process extends to the vertical through the center of the pupil. The nasals are very prominent and the nostrils are nearer to the orbit than to the extremity of the jaw.

The orbit is circular, its diameter $(\cdot 08)$ one-third the length of the head. The origin of the dorsal is slightly behind that of the ventrals, its distance from the snout ( $\cdot 31)$ twice the length of its base (-16). The dorsal spines are graduated nearly in the proportion $(I=\cdot 02 ; \mathrm{II}=\cdot 12 ; \mathrm{III}=\cdot 11 ; \mathrm{IV}=\cdot 10 ; \mathrm{V}=\cdot 09$; $\mathrm{VI}=\cdot 085 ; \mathrm{VII}=\cdot 0725 ; \mathrm{VIII}=\cdot 05 ; \mathrm{IX}=04$ ). The notch between the spinous and soft portions is very deep and the connecting membrane barely perceptible. In the soft dorsal the fifth ray is the longest (.09) and equals the fifth spine, the succeeding rays diminishing regularly to the last, which equals the ultimate spine $(\cdot 04)$; the length of its base $(\cdot 20)$ is greater than that of the spinous dorsal. The anal begins behind the center of the body (.56); the first spine is very short (.01), one-fifth the length ( 05 ) of the second, which is slender; the first ray is the longest (.08), the succeeding rays regularly diminishing in length to the last $(\cdot 03)$. The lobes of the caudal are equal, the outer rays in length (.21) five times the inner ones (.04). The extremity of the pectoral reaches the vertical from the last dorsal spine: its distance from the snout at the axilla $(25)$ is nearly equal to the height of the body. The ventral spine resembles the fifth dorsal spine in shape and size; the length of the longest ray $(\cdot 11)$ slightly exceeds one-third of the distance from the snout to the ventral axilla ( $\cdot 30)$; the axillary appendage consists of four lanceolate scales, the first and longest as long as the last ventral ray.

Color: silvery, with a bluish tint above; axils of the pectorals and extremity of snout brownish.

Radial formula, D. IX, 10. A. II, 8. P. 12. V. I, 5. C. $3,9,9,3$.

The unit of measurement used above is one-hundredth of the total length, which in an average specimen is 7.29 inches (M. O. 185). The species is common in the protected inlets about the islands in company with the "shad" (Diapterus gulti), from which it is distinguished by the name "long-boned shad:" they are in demand for bait and are easily seized in large quantities. I take pleasure in dedicating the species to his Excellency, Maj.-Gen. J. H. Lefroy, F.R.S., Governor of the Ber- 
mudas, who while doing so much for the social and political welfare of the islands, is taking an active part in adding to our knowledge of their natural history.

\section{Engrautis chorostomus, sp. nov.}

This species closely resembles Engraulis surinamensis (Blkr.) Gthr. differing from it, however, in several respects.

The height of the body ( 16$)$ is a little more than two-thirds of the length of the head and is contained six times in the total length and a little more than four times in the length to end of micdle caudal rays $(\cdot 90)$ : the height at the ventrals is less $(\cdot 13)$. The scales are large, in thirty-eight oblique rows between the head and the caudal.

The length of the head ( 22$)$ is less than one-fourth of the total and is double its height at the pupil (11): its greatest width $(\cdot 08)$ is about one-third of its length. The orbit is nearly circular and its diameter $(\cdot 05)$ equals the length of the snout $(\cdot 05)$ and the width of the interorbital area $(\cdot 05)$. The snout projects far beyond the lower jaw, whose extremity just rasses the vertical from the anterior margin of the orbit. The maxillary is dilated above the mandibular joint, rather tapering behind, and extends to the gill opening. The gill-rakers are fine, setiform, not longer than the eye (-05), about 25 on the lower branch of the outer branchial arch.

The origin of the dorsal fin is in front of the middle of the body ( 45 from snout), and directly above the extremities of the ventrals: the length of the first ray (.06) is half that of the second ('12), which nearly equals the length of the base (.11).

The origin of the anal is at the middle of the body ( 51 from snout) and below the posterior dorsal rays: its greatest height $(\cdot 11)$ nearly equals that of the dorsal.

The length of the middle caudal rays (.08) is two-fifths of the outer rays $(\cdot 20)$. The length of the pectorals (-11) equals the length of base of dorsal ( 11$)$, the extremities reaching to the origin of the ventrals. Length of ventrals $(\cdot 09)$ : distance from snout $(\cdot 35)$.

Color: back and sides brownish, belly white; a broad, clearly defined lateral band of silver as wide as the diameter of the orbit $(\cdot 05)$.

Radial formula D. 13-14. A. 23-24. Length 2.68 inches (M. O $\cdot 068)$.

Common in schools in Hamilton Harbor, where it is taken for bait in cast nets. Its enormous mouth has given it the name of "bog-mouth fry."

The types of these descriptions are preserved in the U. S. National Museum in Washington and the University Museum in Middletown, Conn. 


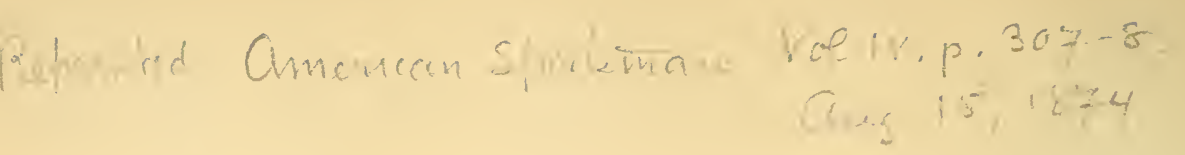






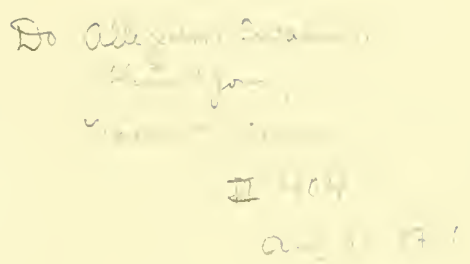







\section{THE PLAGOPTERINAE, and the Ichthyology of Utah.}

BY G. B. $G$.

One of the most interesting of recent contributions to the history of North American fishes is a paper by Professor E. D. Cope "On the Plagopterinae and the Ichthyology of Utah," reprinted from the Proceedings of the American Philosophical Society of Philadelphia. Dr. H. C. Yarrow, U. S. A., and Mr. H. W. Henshaw, the zoologists of Wheeler's survey, have, during the past two years, made extensive collections of the fishes of the Colorado River and its tributaries, and of Utah, and to their labors we owe the materials for this memoir.

The sub-family Plagopterinae which is liere defined for the first time, appears to be confined to the basin of the Colorado River, and to be the only type peculiar to that region. It includes those Cyprinidae which have two strong osseous rays in the dursal fin, the anterior of whic! has a groove in its hinder face, in which the posterior is received, the two furming a compound defensive spine. The ventral rays, except the first and second, are modified in much the same way, the lower part of each being osseous, ditgger-shaped, and posteriorly grooved; their articulated extremities either continuations of their apices or emerging from the grooves below them. The author states that the only other instance of this ossification of the ventral rays is in the fossil family of Saurodontidue extinct since the cretaceous period. The family includes three genera, Med $a$, described by Girard in 1856 , and represented by one species, Meda fulgida, from Arizona, Plagopterus and Lepidomeda, both new; the former represented by Plagopterus argentissimus from the San Louis valley, the lat ter by Lepidomeda vittata and Lepidomeda jarrovis from the Colorado Chiquito River. Twelve species were obtained from Utah Lake, five of them new to scieuce, and from other parts of Utah and Arizona eight more, six of them new. The proportion of undescribed species in the collection, thirteen out of twenty-two, is quite remarkable.

We would venture the criticism that while Professor Cope's method of forming specific names from personal ones, may be in accordance with the strictest classical rules; it is hardly necessary to follow it to such extremes as Minomus jarrovii and Rhinichthlys henshavii: the names $M$. Yarrowi and $R$. Henshawi are more euphonious and more intelligible and better serve the purpose of compliments to the gentlemen who discovered the specimens. 




an account of the method of properly manipulating the adhesire eggs, which will be found in the appendix.

Fortunately the shad, striped bass, and the Salmonidce generally, with perhaps only the exception of the smelt, have smooth or non-adhesire eggs, which permits them to be fertilized and readily manipulated without the inconvenience caused by their sticking together.

It is not my purpose to present here a treatise upon pisciculture in general, as I liare nothing to ard to the works already published on the subject, and which hare been prepared by practical men of great experience. Among the most recent works are those published by Dr. J. H. Slack and Mr. Livingston Stone,* and in them will be found all the best-known methods of treatment, and especially for the trout. I hope, however, to present hereafter some special details in regard to other species that have been developed in conuection with the operations of the United States Fish Commission.

\section{The hatching of striped bass.}

Tothing was known until recently as to the treatment of striped bass; but Mr. M. G. Holton, already referred to in connection with the improved apparatus for hatching the eggs of the Salmonida, while in the employ of Mr. Seth Greell on account of the United States Fish Commission, at Weldon, N. C., took occasion to experiment with the spawn of sereral of these fish. To his surprise he found that it was nonadhesive, precisely like that of the shad, and capable of being treated in the same manner. The eggs were hatched out in four or five days, and with a small percentage of loss. They, however, were considerably smaller than those of the shad, requiring the bottom wire of the boxes to be much finer; twenty-two wires to the inch, at least, being needed.

It is unnecessary for me here to go into detail concerning the special method of treating the eggs oi such fishes as the salmon-trout, the brook-trout, and other species, as these are discussed in detail by Mr. Milner in this volume, and are also considered at length in the various special American treatises.

Haring thus presented a very brief indication of the history of multiplying certain of the food-fishes as practiced in modern times, and having explained the general principles of the method adopted for the purpose, I proceed to discuss more particularly the economical importance and history of the species of fish to which the attention of the commission has so far been more particularly directed, and of some of those which it is proposed to take up hereafter.

* Practical Trout-Culture, by J. H. Slack, M. D. Orange Judd \& Co., New York, 1872. Lomesticated Trout: how to breed and grow them, by Livingston Stone, A. M. Boston, J. R. Osgood \& Co., 1872. 


\section{D-FISHES ESPECIALLY TORTHY OF CULTIVATION.}

\section{1.-The shad.}

Among these fishes, the American shad, Alosa sapidissima may be considered as holding the chief place, occupying in its distribution as it does the entire eastern border of the United States from the Saint John's Rirer in Florida to the Gulf of Saint Lawrence, and even occurring in limited numbers in the raters emptying into the Gulf of Mexico. Its abundance in the early history of the country was such as to excite the unbounded astonishment of those who beheld it for the first time. With scarcely an exception, erery river on the Atlantic coast within the limits mentioned was invaded in the spring by immense sehools, which in their uprard course furnished an ample supply of the best food, first to the aboriginal inhabitants, and then to their European supplanters and their descendants.

At one time it was imagined that the whole body of American shad, haring wintered in the South, started northward with the new sear, seuding ont detachments as they proceeded along the coast, first iuto one river aud then into the next, nntil the last of the immense school made their way into the Saint Lawrence Rirer. This idea, which attached equally to many other species of fish, is now believed to be in great measure at least incorrect: and it is thought more reasonable to suppose that the young fish, hatched in any particular stream, go out into the sea, and remain within a mollerate distance of the coast until the period again recurs for their mptrard migration.* It mas be howerer that a coastwise morement takes place to some extent.

* As a convenieut place for the purpose, I introduce here an important contribntion to the natnral histury of the shad, recentls received from Mr. G. Brown Goode aud Mr. Joseph Sheprird:

"A knowledge of the occnrrence of shad in the waters of the Saint John's appears to have been mans pears before the fishermen unace ans practical use of their information. Shat were not taken in quautity for the local markets until $1 \leq 61$ and 1365 , though I am informed by Colonel Sammis, of Arlington, one of the oldest settler's of Eist Floricla, that he knew of their capture in small numbers as earls as the last Indiau war (1:39) and has since occasionally seen them. At that time the conntry was but sparsely settled, aud there can have been little encouragement, and indeed little need for the usc of seiues, the inhabitants easils supplying their wan ts with the cast-net and the line.

"About $1=59$ or $1=60$ Mr. P. Watchonse, a northern fisherman, introduced gill-nets and took shat in lirge numbers on the bar at the nonth of the Saiut John's; these he shipped to northern markets, aud it is said that he refused to sell a siugle fish in Florida, being angry with his neighbors for laughing at his project of catching shad iu the Saint John's.

"All fishing was interrupted bs the war, but immediatel 5 after its close gill-nets were extensively nsed and the shad wcre fonnd to be very abundant. There can be little donbt that the species has iubabited the Saint Joha's for a great mans years; the conmon idea that they are of recent introduction arises from the fart that through want of proper fishing thes dicl not find their was to the markets till about ten years ago. The Saint Mary's River is still thonght by maur people living on its bauls to be destitute of shad, 


\section{Nothing but impassable dams or natural falls prevented the fish} from making their way to the headwaters of our rivers, and their

thongh there can be little doubt of their occurrence there also. As there is no market near, there is no object in fishing for shad; but an old fisherman assured me that he fonud them abuudant there mans years ago.

"The Saint John's fishermen do not use shad-seines, though small seines are employed along the banks of the river and in creeks to take the smaller species of fish. They do not seem to appreciate the superior advantages of the seinc, and aver that the swiftness of the current prevents its use. This is alssurd since the current of the Conneeticut and other rivers, where seimes are used to advantage, is much greater. As the present system fully supplies, aud often gluts, the market there seems no immediate necessity for a change in the method of fishing.

"The gill-nets in use vary in mesh from three and one-half to four and one-quarter" inches. They are about ten feet wide, and sereral gangs are fastened together so as to stretch nearly across the river, often a milc or more in width. The net is allowed to 'drive' or drift with the current, entangling in its meshes all the full-grown shad which it meets.

"The principal fishing-stations are near Masport, on the bar at the month of the river, at Jullow Blufts, and Trout Creek, respectively twelve and fifteen miles above, at Jacksonville, twenty-fire miles from the mouth, and at Pilatka, a still greater distance up the river. Several nets arc nsed at the head of the river, in Lakes Harney and Ionroe and in Salt Lake, to supply the hotels there. The Pilatka fisherics arc small and snpply the local market. Hore than thirty nets are used in the neighborhood ot Jacksonvile, whence the fish are shipped, packed on ice in barrels, to Central Georgia and Florida, to the interior of Somrh Carolina, and to Alabama. Yellow Blufis is another extensire market, and sends its fish to Savannal and the northern markets. The estimated total number of nets on the river is seventy-five.

"The largest haul of the past season was at Yellow Bluffis, where six hundred were taken from a single net; at Jacksonvile the largest haul was three hundred and twenty.

"The average price at the fisheries during the past season was 21 cents each.

"The hickory-shad (Pomolobus mediocris) nsually makes its appearance in the Saint John's the first or second week in November; and as early as the 20 th the first shad appear. The shad-fishing begins abont the first week in December, and is at its best abont the 1st of January. The season ends about the middle of April. At the time of ny arrival, April 12, the last shad were in the markets. The lerring (Ponolobus pseudo-hurengus) accompanies the shad in great numbers, but is not caught nuch after the 1st of March. Two herrings or two hickory-shad connt in the market for one 'white shad.' The dates given above are only approximate, taken from tho memory of the fishermen and dealers: but as the testimony of the various persons interviowed agrees tolerably well, I believe them to be nearly correct.

"At the time of my visit the shad seemed to be in full spawning condition and were said to be very plentiful in the lakes of Central Florida, where the fishermen believe that most of them deposit their ora. At the time of their first appearance, the ovaries and spermaries are said to he barely distingnishable.

\section{G. BROWN GOODE.}

Accorling to Professor WVyman the young shad, even as early as on the 1st of May, are met with in great numbers retmrning to the ocean and measuring three or four inches in leugth.

:The shart-season on the Saint John's, according to Mr. C. L. Robinson, of Jacksonville, is from the 1st of December to aluont the 8th of April.

"The first fishing done here for shad especially was by Captain Waterhousc, of Connecticut, two years before the war. The first year there were three persons engaged. in the businsss as proprietors, working eight men and four nets. The next year there S. IIis. $74-\mathrm{IV}$ 
diffusion was almost unirersal, so that few portions of the country east of the Alleghany range were destitute of their share.

The fisheries were established on the river banks, and the farmers liv. ing at a distance from the streams were in the habit of coming in their wagons to these stations and hauling the fish to their homes, and there preserving such as were not neerled at the time, for the winter's use. Sometimes the early settlers in new towns, remote from the rivers, before roads ware cut through the forests, having no more conrenient mode of transportation, were in the habit of taking their fish in berlticks lung across the backs of horses, in some well-authenticated cases for as many as thirty miles.

The fisheries were originally prosecuted almost entirely by the use of seines; and although at any one place very few were taken comparèd with the numbers now captured in connection with the great modern contrivances employed for the purpose, yet in riew of their ocenrence in every river and its subrivisions, it is by no means imprcbable that

- was double that number engaged aud some twelve nets, aud so inereased until a year ago; this last winter there were between seveuty and eighty nets and over one huntred men employed from Pilatka down.

"Above Pilatka, partienlarly in the lakes, there were many more employed, say twenty.

"This last winter the business was abont the same as the year before. It is estimated that abont 500,000 were shipred from the Saint John's, mostls to Savannah. From Savannah thes are distribnted to rarious points north.

"In size those caught here are not as larore as those in the Connectient River.

"Onr fishermen nse a uet of $1 \frac{7}{5}$ inches mosh, while in the Connectient they use a $5 \frac{1}{4}$ inch mesh.

"They appear in our river eoming in on their way to our upper lakes and creeks to spawn. When they come in they are fat and go into all parts of the river; but on their retnin, in Jnue and July, they are very poor, and keep low in the deep water and follow tho eliamel.

"Only a small portion of them return. It is thonght the die of exhaustion, and are devomed by alligators aud larger fish. The foung shal go down to salt-water early the sunmer when they are about $1 \frac{1}{3}$ inehes long. The fishermen are of the opinion that the shad have always been abont as numerons as now in the Saint Joln's, but that the applianees for eaptnriug them hare been improved from year to year, aud more persons ellgaged in it.

"The filcts just presented are all frow Mr. Robinson, aud relate to the Saint Johu's River. I nay say in addition, as regarls onr own waters, that there are a few shad taken erery season in the Saint Mary's and Saint Illaby people living on those rivers for their own use; the net used being simply a hoop, 8 or 10 feet in diameter with handle 8 feet long, and held perpendieularly in the water bs oue man wlile another paddles the boat. Then the holder of the net feels the fish against it, he brings it to the surfaee in the sime manuer as a seoop-uet wonld be laudler. Fron two to three and not unfrequently five or six are eanght at one tine in this manner. But I lo not think that slad are as abundant in the abore-mentioned rivers (which are narrow aud dcep) as they are in the (shoal and broad) river Saiut John's

"Tery respeetfully, yours,

"JOSEPH SHEPARD, "Suint Mury's, Ga.

"Hon. Spexcer F. B.rrd, "Cummsssioner, Washington, D. C." 




\section{About Snake's Eggs.}

BY PROF. G. BROWN GOODE.

Mr. J. C. Christian, of Huntington, Ind., writes: "I have several times killed water snakes, which, when opened, contained upwards of twenty good sized young snakes, from six to seven inches long. Last summer, after pulling out a large stump, wc found twenty-seven eggs, which we broke, finding in each a well developed young snake about nine inches long; afterwards we found and killed two snakes near the same place, about four fcet long, and resembling the snakes in the eggs, and I supposed they deposited the eggs. I am satisfied that some snakes bring forth their young alive, while others lay eggs. Now is there any other class of animals which have more than one way of reproducing their young."

Mr. Christian has determined for himself a fact which has long been known to naturalists. Some snakes do lay eggs, while others give birth to living young, jet the difference is not so great as it may at first appear. We all know that every animal, in its earliest stages of development, is enclosed within the walls of an egg. That all life is produced from eggs, "Omne vivum ex ovo", is an adage handed down from the earliest times, and modern investigations have confirmed its truth.

Animals are either viviparous, oviparous, or ovoviviparous. The first class includes all the highest animals, the mammats, or those which suckle their young; and in these the young animal derives its nourishment from the systcm of its parent, until it is strong enough for an independent life. In the other two classes, which ought really to be considered as one, the young animal is walled up at an early period within the outer coverings of the egg, and as it is now entirely separated from the parental system, it is nourished by a supply of nutritious material stored up within the egg, and which we call the yolk. When the young animal is sufficiently grown to care for itself, and the yolk of the egg is all used, it bursts the envelope of the egg, and is born. To this class belong birds, reptiles, batrachians (frogs, toads, etc.), fishes, insects, crustaceans (crabs and lobsters), worms, mollusks, and all the lower animals. Oviparous animals are those which "lay" their cggs to be hatehed by the warmth of the parent's body, as in most birds ; by the warmth or the soil or sun, as in reptiles; or by the warmth of the water, as in fishes. Ovo-viviparous animals, are those which do not lay their eggs, but retain them until the envelopes are broken, so that the young are born alive. The casual observer would be very likely to call these viviparous, but a study of their anatomy shows us that they are very close to the ovipara; in fact, the only difference is this, that the egg is delayed a little longer in the former, so that it is hatched just before it is laid. 
This point established, it is not very hard to comprehend how it is "that some snakes bring forth their young alive, while others lay eggs." I know of a case where one of our common striped snakes (Eutaenia sirtalis) was kept in confinement, and having no satisfactory place in which to lay its eggs, retained them until after they were hatched, thus giving birth to its young alive. The same thing has been known to occur in the common English lizard, (Lacerta agitis), which is also usually oriparous. We find the same thing in other groups of animals; thus many of the sharks and skates of our sea coast, are oviparous, while others bring forth their young alive. The minnows (Cyprinodentid(e) of our brooks, show the same differences of habits, and parallel cases occur among frogs, snails, insects, and worms.

I can not state which of our species of snakes are oviparous or ovo-viviparous, for the very good reason that nobody knows. It is possibie for the readers of the Agriculturist to make some very interesting contributions to science, by telling what they have seen. The breeding habits of most of the reptiles of North America are totally unzinown. We know that the Rattlesnakes, the Copperheads, the Massaugas, the Mocassons, and some of the water snakes are usually ovo-viviparous, and that the Smooth Blacksnake, (Bascanian constrictor), the Milk or House-snakes, (different species of Ophibolus), some of the Bull-snakes, (species of Pityophis), the Grass-snake, (Liopeltis vernalis), and one or two other kinds, are usually oviparous, but of three. fourths of our snakes we know absolutely nothing.

It is probable that the young water snakes which Mr. Christian found inside of the larger ones, had bcen swallowed for temporary protection, and would soon hare crawled out of their parent's mouth, had they not been prevented. The new-born water snake is not so long as six or seven inches.

A jear or tiro ago, the rcaders of the Agriculturist contributed a great mass of eridence, which went far to settle the question, "Do snalses swallow their young?" Every farmer, and every farmer's boy, and frequently the girls, can do something to add to the gencral stock of knowledge, and would be glad to do so if they only knew how. In this article Prof. Goode tells us one thing that they can do-to observe the manner in which snakes reproduce, and other mcthods will be pointed out in due time. To be very useful to science, one needs oniy a good pair of eyes, and a detcrmination to use them. Record only what is seen, but do not see a part, and infer how the rest may be. The books are full of inaccurate observations, made by persons who tell morc than they see. While we expect aid from those who can make obserrations in the field, we, on the other hand, would like to aid them, and if they come across things in regard to animals of all kinds, or plants, that they would like to have explained, they must send us their questions. ED.] 


Mr. G. Brown Goode of the Smithsonian Institution, a gentleman well-known to our readers, has been in Florida, collecting animals for the Zoological Garden, Fairmount Park, Philadelphia. Among the mammals there are 1 wo fine specimens of the southern Fox Squirrel (Sciurus vulpinus), one gray with black head, the other entirely black, in excellent instance of the "melanism" so commen in this species; alsn a Gray or "Cat" Squirrel (Sciurus carolinensis) specifically identical with ibe Gray Squirrel of the Northern States, but smaller and more rufous upon the back. Also two "Salamanders" (Geomys pineti) familiar to Floridians as the animals which nndermine the pine barrens so extensively, throwing up countlcss little hillocks of loose sand; they are pouched rats and clusely resemble the Pocket Gopher (Geomys bursarius) of the western plains, so great a pest to the agriculturist. Eight or nine specimens were obtained, but only two were domesticated sufficiently to bring nonth, the others dying or escaping. A young Wood Hare (Lepus Sylvaticus) is iucluded ard an Earth Mole (Scalops aquaticus, smaller and grayer than moles of the same species at the North.

The on'y birds snipped were ten pairs of Quails (Ortyx virgin ianus) of the Floritis form, wisch are smaller, darker and have heavier bills than the Noitie:n qua:'s. A pair of Carolina Doves Zenuedura carointensis,) sume Parokeets (Conurus carolinensis) a Marsh Een (Rallus e'egans, and a Sparrow-hawk (Falco sparverius, ) were obtained, but all died in captivity before they could be shipped.

A largo Alligator (Alligato mississippiensis, ) over ten feet in lenst'. There g:0 a!so 20 ('hameiesas (Ancius carotinensis) in

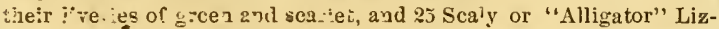

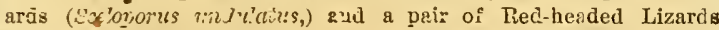
(Piestioilon erytiryocsofaturis) the "Scorpions" so Areadcd by the negioes, in spite o ticei: ingrmiess ratule. Specimeus oi the Wood

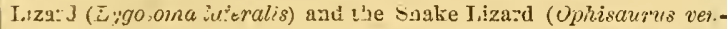
trails) the so.ca"eu "G!ass Saare" or "Joint siske," were secured,

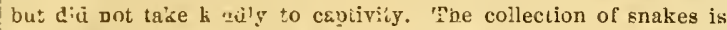
espece'!y comviere, comprising, with a few exceptious, all the species whicin have been ouserveu in Flo::da. Here are all the venonous suakes of live South, a pair of Uiamond Roit!esnakes (Crota-! lus adanurteus) fror the Inü:sn river country, two Grousd Rattlesnake (C,ota'on). (Ancistrodon piscicoms.) and a pain of Harlequins (Etaps futivis) gorgeous in tie varcis of orsnge, black and c:imson. The Garter Snake (Eutcunia suruliis,) the Kias Suake (Cphidotus getutus), the Bead Snake (Cpritibolus cxcrineus,) ise "Calico" Snake (Abastor erythrogranmus) w: th its cielicaie ! '1ls of rose and purple, arc he:e, as well, as a yair of the red "( nicken Srakes" of the Flo idians (Colnuer grtetaius.) There are five sien.ler Black Snakes (Bascanion constrictor, ) snd iwo Bu': Snakes (Pisyophis melanoleucus) the Horn Soake 0: "Patı les:ake's Pilot," who o "eets his visitors with hisses and puffs like a sua'l steam engine. "Water Moccasins," are harm. ?ess water suakes, usuai! y confounded with the poisonous Moccasin, which belongs to tie Ratllesuake innily. One is the Tropidonotui fasciatus, trie of her, w th a copper colored belly, Tropidonotus ery.hrogasier. Several specimens of two species of Spreading Adders (Ifeleralon piaiyrhinos and $H$. atmodes.) Specimens of the Green Snake (Ćyclophis aesturis) and of (Colujer confinis) escaped from their cagas.

Among the turtles there are 19 "Gophers" or Elephant Tortoises (Ferobates carolinus) the peculiar tortoise of Fiorida, so much in favor with the peninsular negro for soups and other culinary compounds. Three large ieather-back Turtics (Plalypeltis ferox) such as Bartram described in his Florida travels published a century aco. Also, two fiue Grecn Turtics (Cheionia mydas) taken in Trout Creek, and thus saved from the Jacksonvi'le epicures, with ninc Yellowbellied Terrapins (Ptychemys concinua) and a specimen of the Alligator Teriapin (Cinosternum pennsylvanicum.)

To sum up: The total number of specimens was 132, representing 32 species, distributed as foilows: Mammals, 5 species; birds, 1 ; lizards, 4; serpents, 16; turtles, 5; amphibians, 1. A number of Florida wild hogs have been elgaged and negotiations are heing carried on for some Manatees (Manatus americanus) ilom the Indian River corniry.

Mir. Goode aiso sends two large tanks containing a collection of the fisbes of the St. John's IRiver, made in benalf of the U. S. Cummissicn of Fish and Fisheries.

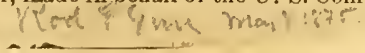




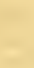




\section{ALBINOISM IN FISHES.}

Museum of Wesleyan UNiversity

EDITOR Forest AND STREAM:-

Middeltown, Conn., May $11 \mathrm{th}, 1875$.

A remarkable specimen of the haddock (Melanogrammus aeglefinus) was shown me last Saturday by my friend Mr. Blackford, of Fulton Market. Your readers are many of them familiar with the appearance of this fish, with its uniform hue of brownish gray, slightly darker upon the back; the heavy black stripe which covers the scales of the lateral line, and the dark blotches behind and above the pectoral fins which mark the spots, we are told, pressed by the lingers of Simon Peter, the disciple fisherman, when he took the tribute money from the fish's mouth. Mr. Blackford's haddock is an albino, the only example in this group of fishes which has ever been brought to my notice. The stripes and blotches are absent, and the tish is uniformly a very light pink, the back slightly darker and approaching a very light salmon color. The ecales have a pearly lustre. The fins are dull white tinged with rose color, except the ventrals, which are a light salmon color. The eyes are normal in color. This fish was taken off Barnegat, N. J., May 1st, by the schooner White Cloud, of New London. Mr. Blackford has had it forwarded to Washington for the use of the National Museum.

Another curious case is that of an albino of the common eel (Anguilla bostoniensis), sent to Professor Baird by Captain Elihu rotter, of Noank, Conn. Its color is a dall yellow of a light shade, approaching white on the belly. According to M. Dareste, albinoism is not uncommon in the European eels, and perhaps white eels may be more abundant with us than is usually supposed. G. Brown Goode. 



Albixo Fisnes. - Two interesting cases of albinism in fishes have recently fallen within my observation. The first was a specimen of the common haddock (Melanogrammus ceglefinus), taken off Barnegat, N. J., May 7th, by the schooner "White Cloud," of Nerr London, and shown to me by my friend, Mr. Blackford, of Fulton Market, New York. This fish, which was thirty-one inches long, was normal in every particular except in color. Its general hue was pinkish-white, with a pearly lustre, instead of the usual brownish-gray. The back and top of the head were slightly darker, approximating a very light salmon color. The black stripe which usually marks the latcral linc and the blackish-brown blotch, behind and above the pectorals - the traditional mark of the thumb of the disciple Peter - were entirely absent. The ins throughout were yellowish white with a tinge of red, except the ventrals which were a shade clarker. The slightest trace of the normal ashy tint of the belly might be discovered just below the origin of the pectorals.

The second instance is a specimen of the common eel (Anguilla Bostoniensis) taken in salt water at Noank, Conn., in December, 1874 , and presented to the U. S. National Museum, by Capt. Elihu Potter. In this the color is a dull, pale yellow above, becoming nearly white beneath.

According to M. Dareste albinism is not uncommon among European eels. It appears, however, to be very exceptional in our waters. I have never seen or heard of an instance besides the case just cited. True albinism is especially uncommon among the members of the family to which the haddock belongs. The ground color of the cod and haddlock varies much with the bottom on which they are taken, but I have never known of a case in which the spots and other markings were obliterated. A familiar instance of the influence of the color of the bottom is found in the rosy "rock-cod" of the coast of Maine, which is usually taken in the neighborhood of ledges covered with the bright red algæ such as Ptilota serrata and Delesseria sinuosa. In a similar manner the "butter-fish" (Enneacentrus ouatalibi) and the "grouper" (Epinephelus fasciatus) are influenced by the white coral-sand bottoms about the Bermuda Islands, but though they assume a very pallid hue, the character of their markings is quite unchanged.-G. Brown Goode, University Museum, Middletown, Conn. 
[In the Fish collection of the Peabody Academy of Science there are examples of both of the above mentioned albinos. The haddock, agreeing with the description given by Prof. Goode, was taken off Newburyport some years ago, and sent to the Museum by Mr. Johnson of that place. The "white" eel was collected under the following pcculiar circumstances: During the severe gale of Nov. 7, 1865, in Mass. Bay, a small Cyclopterus (lump fish) and the eel were washed aboard the schooner "Hero," Capt. Small, who found ther on his deck after the gale and brought them to the Museum on his arrival at Salem the next day.-F. W. P.]

Chloral as a Preserrative.-As it is rery desirable that a substitute for alcohol be found for the purpose of preserving specimens, we copy the following from the New York "Tribune," trusting that trials of the experiment will be reported.

The "Philadelphia American Times" contains an article by Dr. WV. W. Kcen upon the anatomical, pathological, and surgical uses of cliloral, in which he recommends this substance very strongly for the preservation of objects of comparative anatony and natural history. It is used by injection into the blood ressels, or by immersion, and in his opinion it is likely to supersede many of the preparations now in usc. Its special adrantage is that the color of the object is preserred perfectly, and all the parts have a natural cousistency, while there is nothing either poisonous or corrosive to affect the general health of the experimenter or to injure instruments.

For preserving a subject for dissection, half a lb. of chloral will suffice at a cost of a dollar or less. A solution for preserving specimens of natural history of ten or twclve grains to the ounce of water is quite sufficient, is much cheapcr than alcohol, and the bottles instead of being hermetically sealed are closed by glass stoppers, or even ordinary corks. Dr. Keen has thus kept pus from rarious substances, and diseased growths of rarious kinds of other specimens for mouths, and found no change whatever in their character. Chloral is extremely autagonistic to fungi and infusoria. a very weak solution of it killing them instantly.

The deodorizing as well as the antiscptic properties of chloral are cqual in Dr. Kicen's opinion to those of any substance now known. 






\section{AD D E N U M B.}

NOTES ON THE "SALAMANDER" OF FLORIDA (GEOMYS TU7A).

\section{[Communicated to the author by Prof. G. Brown Goode.]}

One of the most interesting mammals of the Southern Atlantic States is the species of Geomys known in Florida and Georgia as the "Salamander." The name of "gopher," by which the various representatives of this genus inhabiting the Upper Mississippi Valley are known, would seem very appropriate for this animal. It appears to be a corruption of the French "gaufre", and to refer to the manner in which the soil is honey-combed by the pouched rats.

Local usage, however, has appropriated this name to a kind of landtortoise, Xerobates carolinus, (Linné) Ag., which is common in Georgia and Florida, and which also excavates a burrow, a habit to which, perhaps, it owes its name. I have never heard an explanation of the name "salamander" in its application to Geomys tuza; but it occurs to me that it may allude to the safety enjoyed by these little animals in their subterranean abodes at the time of the devastating fires which sometimes consume the pine-forests. After such a conflagration has passed over their heads, destroying every other kind of life, thcy are seen at work among the ashes, very good types of the salamander of fable, which passes unharmed over burning coals, and

\section{"with her touch}

Quenches the fire, though blazing ne'er so much."

Although the species was not scientifically described until 1817, it was noticed by several among the earlier writers. William Bartram, an English naturalist, who visited the Southeastern States in 1773, speaks of a large ground-rat, which he observed in the vicinity of Savannah, which was more than twice the size of the common Norway rat, and which in the night threw out earth, forming little mounds or hillocks.*

* Travels through North and Sonth Carolina, Georgia, East and West Florida, the Cherokeo Country, the extensive tervitories of the Museogulges or Creck Confederacy, and the country of the Chractars. * * * - By William Bartram,-Dub]in.-1793. p. 7. [Orig, ed, Philadelphia, 1791.] 


\section{EXPLORATION OF TUE CAÑONS OF THE COLORADO.}

A brief description of the species, under the name of the Hamster of Georgia, was published in the New York Medical Repository in 1802, and afterward in an appendix to the American edition of Bewick's Quadrupeds. On this description was founded the name Mus tuza, cited in the list of American mammals published by Ord in 1815,* a name which antedates that of Rafinesque by about two years, and which has been adopted by Dr. Coues.

Notwithstanding their great abundance, it is extremely difficult to obtain specimens of the salamandcrs. Their acute scnse of smell gives them an early warning of the approach of danger, and they easily make their escape in the maze of tunnels. Should one even be driven into a blind passage, it would find little difficulty in baffling its pursuer, for it can burrow faster than a man can follow with a spade; and, since it obliterates its track by throwing the soil behind, it leaves scarcely more trace of its passage in the loose sand than a fish swimming through the water. It is thought quite impossible to dig them out. Occasionally, they are shot, when they come to the surface to throw out sand; but thcy remain in sight only an instant, and the marksman, to be successful, must have his gum bearing upon the opening at which the animal is cxpccted to appear, with finger on the trigger, and be ready to pull the moment the hoad is sighted.

By the patient use of stccl-traps, while in Florida this spring, I obtaincd a number of specimens, some of which I succeeled in kecping for sevcral wceks, thus having an excellent opportunity of studying their habits.t They may easily be confined in a wooden box, with sides eight or ten inches high, having dry sand two or three inches deep on the bottom. No cover is necessary; I have never seen one look up from the earth, and have rarely known them to attempt to escapc. They require no water, and no food except sweet-potatoes. A single potato of moderate size will feed a salamander for three days.

The senses of sight and hearing seem in them to be very dull. An ohject may be held within a short distance of thcir eyes without attract-

* Guthrie's Geography, 2l American cation, ii, 1s15, p. 292.

†Two of them, which $I$ sent to the Zoological Society of Philadelphia, may bo seen in the garden at Fairmount Park. 
ing their attention; but the moment one is touched, he turns with a jump, smapping fiercely, much to the detriment of fingers which may be near. If two are confined in the same cage, the one does not seem aware of the presence of the other, unless they accidentally come in contact. Their eyes are small, dull, and without expression. Their sense of smell I judge to be very delicate, from the manner in which they approach the hills of potatoes. Their motions are surprisingly quick and energetic; their activity never ceasing from morning to night.

They are very pugnacious, and a rough-and-tumble combat between two vigorous males would seem terrific, if their size could be magnified a fer diameters in the eye of the spectator. Every muscle of their compact, clastic, stout bodies is brought into action, and they plunge and bite with wonderful ferocity. A battle is usually followed by the death of one or both. I have examined them after death, and found the whole anterior part of the body bruised almost to the consistency of paste, the bones of the legs crushed in four or five places. When two come together in the cage, their salutation is a plunge and a bite.

I watched their burrowing with much interest. They dig by grubbing with the nose and a rapid shoveling with the long, curved fore paws, assisted by the pushing of the hind feet, which remove the dirt from beneath the body and propel it back with great power a distance of eight or ten inches. When a small quantity of earth has accumulated in the rear of the miner, around he whirls, with a vigorous flirt of the tail, and joining fore paws before his nose, he transmutes himself into a sort of wheelbarrow, pushing the dirt before him to a convenient distance, and repeating the act until the accumulation is removed, then resuming his mining. Any root or twig which blocks his way is quickly divided by his sharp chisel-teeth. I have never seen a salamander place sand in his cheek-pouches, though I have watched their burrowing hour after hour. It is, of course, impossible to observe them when at work under ground, but I incline to believe that most of the refuse earth from the burrows is transported in the manner just described. The negroes told me that they had seen the salamander appear at the mouth of its hole for an instant and "spit out" the sand which it carried in its pouches, aiding the act by inserting the fore paws into the pockets. I have never met any one who 
could tell exactly what the salamander does at the instant he appeared, his motions being so quick that one cannot be quite sure; the general impression, however, is, that they are unloading their cheek-pouches. This is not at all improbable, for we know that they carry their food in these receptacles, and it seems a very natural way for them to bring their refuse sand to the surface, since they often have to transport it a distance of several feet. Still it is quite desirable to have other and more careful observations; for observers are apt to be deceived by their own eyes, especially in the light of preconceived opinions.

The subterranean labyrinth constructed by this clever army of sappers and miners penetrates the pine-barrens and cultivated fields in every direction. An energetic salamander, with a slight linowledge of engineering, would find little difficulty, I suspect, in making an underground journey through Florida from the Atlantic to the Gulf of Mexico. The direction of the burrows may easily be traced by the loose hillocks of white sand which are thrown up along the line at intervals of three or four feet. These are the "dumps" marle by the burrower in throwing out his refuse accumulations. Each consists of about a peck of loose sand, and, by the casual observer, might easily be mistaken for an ant-hill. No opening is visible, but by digging under the hill a hole is found, the mouth of the adit to the main tunnel, which may be three feet below the surface if made in cold weather, but perhaps not more than six inches if in summer. One of these mounds is thrown up in a very few moments; I have seen thirty raised in a single night on the line of one tunnel; this would represent nearly one hundred feet of tumneling. I have seen one hundred and fifty in one continuous row raised in about two days; this would make between four and five hundred feet of burrow completed in that short time apparently by one little animal, an amount of work which may seem incredible to one who has not watched the restless movements of these animated plows, which are seemingly as well adapted for piercing the sand as birds are for cleaving the air. The burrows are about two and one-half inches in diameter, barely large enough to admit a man's hand, and, as has been stated, are at various depths below the surface. They meander in all directions, except in straight lines; their builders being guided alpparently only by their whims or their oltatedories. They, no doulst, intersecet cach other at many 
points, and one tunnel serves as a passage for a community, though fierce battles must often ensue when two rival claimants meet in a common highway.

The nests are large chambers, one or two feet from the main tunnel, with which they are connected by side-passages, which leave nearly at right angles. Here the miners lay up a supply of provisions, and the chambers are often found to contain a half-bushel of sweet-potatoes cut up into chunks as large as peach-stones, and of convenient size to be carried in the pockets. The salamander is a liberal provider. In this region, cellars are unknown, and sweet-potatoes are stored in heaps at the surface, covered with straw and sand. The salamanders are cunning enough not to throw up sand-heaps in the vicinity of these potato-heaps, but remove the loose earth into their old tunnels. When they once get access to the "tater-hake," they quickly remove its contents, and the owner wakes up the some morning to find lis cache a hollow pretense. In these side-chambers, the salamanders rear their young, building a nest of grass, pine-necdles, and live-oak leaves. I found them breeding in April.

The color of Geomys tuza is quite constant, light reddish-brown above, darker along the back, and lighter yellowish-brown beneath. One specimen was caught for me which showed a decidedly melanistic tendency, being nearly black. The measurements of a very large male are as follows: Nose to eye, $1 \frac{1}{6}$ inches; mose to ear, $1 \frac{5}{6}$; nose to root of tail, $11 \frac{1}{8}$; tail from root to end of vertebræ, 3 ; arm, fore foot to end of claws, 13 ; leg, hind foot from heel to end of claws, 11; muzzle to bottom of cheek-pouch, 3 ; circumference of expanded mouth of pouch, 5 ; distance from tip to tip of the longest toes of the fore feet, when stretched apart at right angles with the body, 7 ; same measurement applied to hind feet, $6 \frac{1}{2}$; girth of body behind shoulders, 5 ; distance from eye to eye, $\frac{3}{4}$; distance from ear to ear, 1 t.

The contents of one of the check-pouches in sand filled an old-fashioned silver tablespoon, heaped full. The contents of the pouch of an ordinary salamander will fill a dessertspoon in the same way.

[SEPARATELY REPRINTED FROM THE REPORT OF MAJ. J. W. POWELL'S EXPLORATION OF THE COLORADO RIVER OF THE WEST AND ITS TRIBUTARIES. EXPLORED

IN 1869, 1870, 1871, AND 1872, UNDER THE DIRECTION OF THE SECRETARY OF THE SMITHSONIAN INSTITUTION. Chap. XIII, PP. 215 ET SEQq.] 


ef 


Department of the Interior:

Ij. S. NATIONAL MUSEUMr.

\section{BULLETIN}

OF THK

\section{UNITED S'TATES NATIONAL MUSEUM.}

\section{No. 5.}

PUBLISHED UNDER THE DIRECTION NF THE SMITHSONIAN INSTITUTION.

WA SH I N G TON:

GOVERNMENT PRINTING OFFICE.

1876. 


\section{A D V ERTISEMENT.}

This work is the fifth of a series of papers intended to illustrate the collections of Natural History and Ethnology belonging to the United States and constituting the National Museum, of which the Smithsonian Institution was placed in charge by the act of Congress of August 10, 1846 .

It has been prepared at the request of the Institution, and printed by authority of the honorable Secretary of the Interior.

JOSEPH HENRY, Secretary Smithsonian Institution.

Smithsunian Institution,

Washington, November, 1875. 


\section{CA T A L OGUE}

OF THE

\section{FISHES OF THE BERMUDAS.}

BASED CHIEPLY UPON THE COLLECTIONS OF THE UNITED

STATES NATIONAL MUSEUM.

By G. BROWN GOODE, M. A.

ASSISTANT CURATOR U. S. NATIONAL MUSEUMI.

WASHINGTON:

GOVERNMENT PRINTING OFFICE.

1876. 



\section{TABLE OF CONTENTS.}

Introductory remarks ............................................

Page.

Topography of the islands ..................................... 8

Fisheries and fish-markets ..................................... 9

The relations of the Bermudian fauna ........................... 11

Popular names .............................................. 15

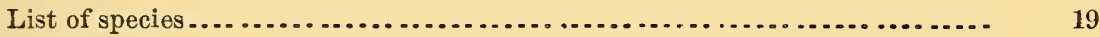

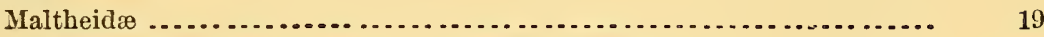

Malthe vespertilio, (Linn.) Cuv. subsp. vespertilio................. 19

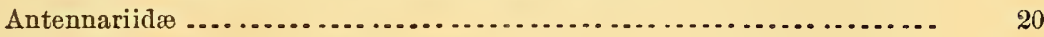

Pterophryne picta, $($ Val. $)$ Goode............................... 20

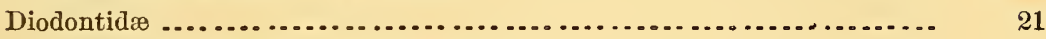

Paradiodon hystrix, (Linn.) Bleeker........................... 21

Chilomycterus reticulatus, (Linn.) Bibron.................... 21

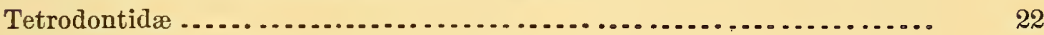

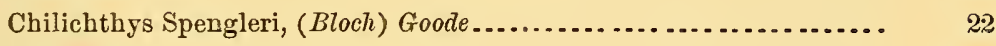

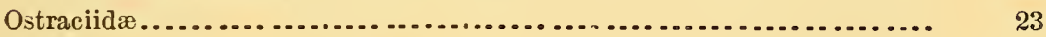

Ostracium triquetrum, Linn.............................. 23

Ostracium quadricorne, Linn................................ 24

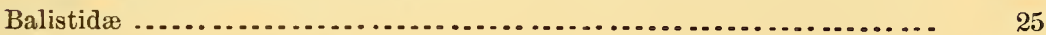

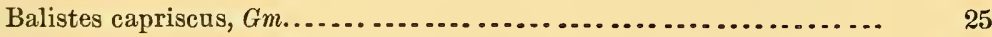

Alutera scripta, (Osb.) Bleeker................................ 26

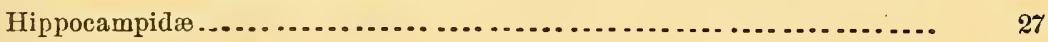

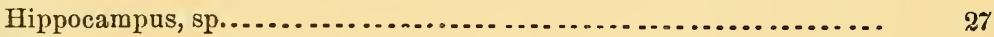

Syngnathidø ............................................. 27

Syngnathus Jonesii, Günther............................... 27

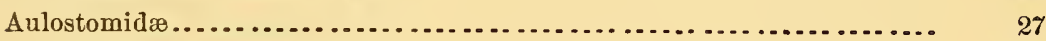

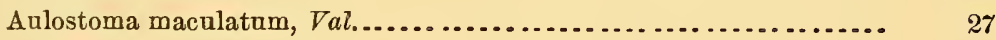

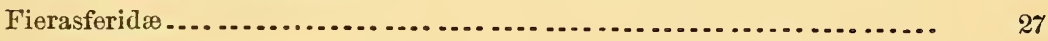

Lefroyia bermudensis, Jones............................... $\quad 27$

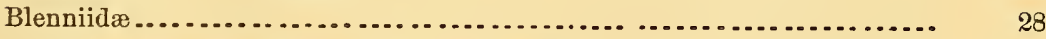

Labrosomus nuchipinnis, $(Q . \&$ G.) Poey........................ 28

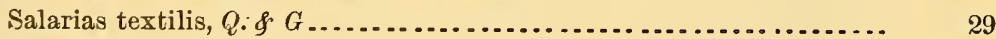

Triglidæ.............................................. 31

Dactylopterus volitans, (Linn.) Cuv.......................... 31

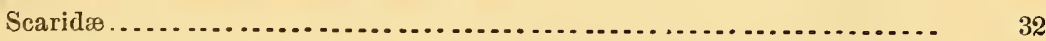

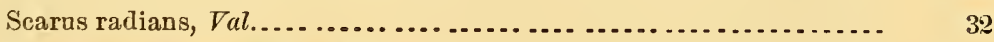

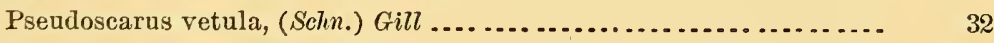

Pseudoscarus coerulens, (Bl.) Günther.......................... 33

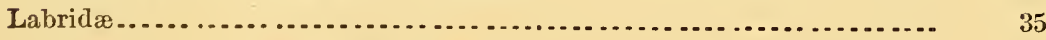

Chcrojulis radiatus, (Linn.) Goode ........................... 35 
List of species-Continued.

Page.

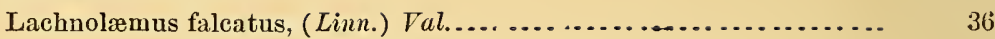

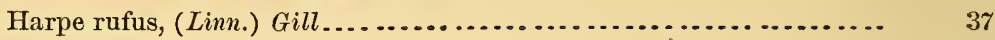

Pomacentridæ ................................................ 38

Glyphidodon saxatilis, (Linn.) Cuv......................... 38

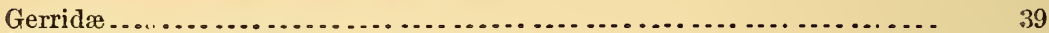

Encinostomus gula, $(C . \& V$.$) Goode......................... \quad 39$

Eucinostomus Lefroyi, Goode .............................. 39

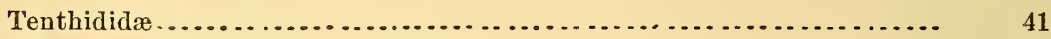

Acanthurus nigricans, (Linn.) Gill........................... 41

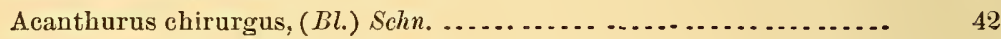

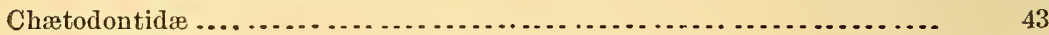

Sarothrodus bimaculatus, $(B l$.$) Poey........................ 43$

Holacanthus ciliaris, (Linn.) Lacép. .......................... 433

Holacanthus tricolor, (Bl.) Lacép........................... 44

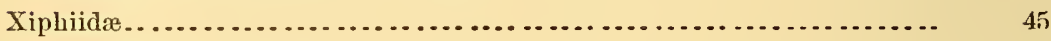

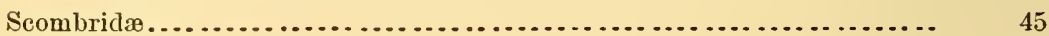

Oreynus alliteratus, (Raf.) Gill............................ 45

Carangidæ .............................................. 46

Decapterus punctatus, (Ag.) Gill ............................ 46

Trachurops crumenophthalmus, (Bl.) Gill..................... 47

Paratractus pisquetus, $\left(C . \& V_{\text {. }}\right.$ Gill....................... 47

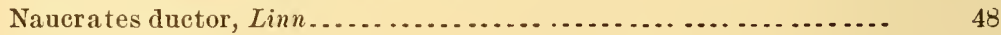

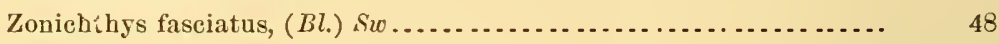

Corgphaenidx ............................................... 48

Coryphæna hippurus, Linn ................................... 48

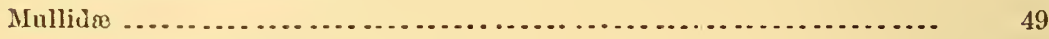

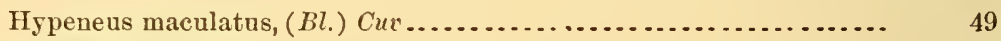

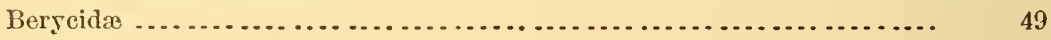

Holocentrum sogo, Block ................................... 49

Scỉænidæ .................................................. 50

Pareques acuminatus, (Schn.) Gill............................ 50

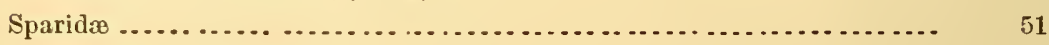

Calamus megacephalus, $(S w$.$) Poey .............................. 51$

Calamus orbitarius, Poey .................................. 51

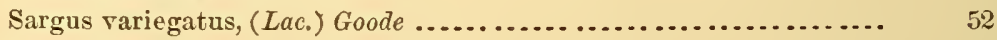

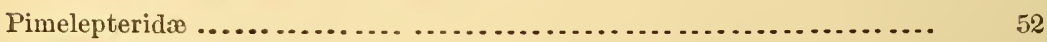

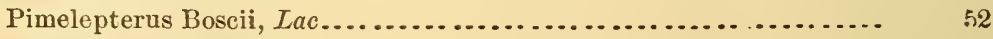

Pristipomatidæ................................................... 53

Hæmylum capeuna, (Licht.) Goode ........................... ' 53

Hæmylam chrysopterum, (Linn.) Cuv ......................... 53

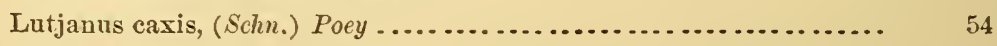

Lutjanus aya, (Bloch.) Gill .................................. 55

Serranidæ................................................... 55

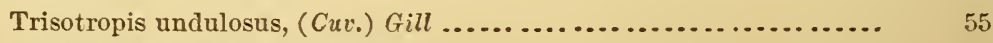

Trisotropis guttatus, $($ Schn.) Gill........................... 56 
List of species-Continued.

Page.

Epinephelus striatus, (Bloch.) Gill......................... 57

Epinephelus guttatus, (Gmel.) Goode ....................... 58

Enneacentrus punctatus, (Linn.) Poey ....................... 59

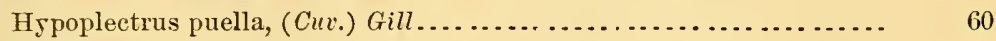

Echeneididæ ........................................ 61

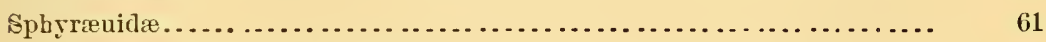

Spbyræua spet, (Haïy) Goode ............................. 61

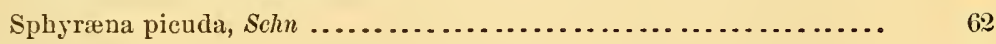

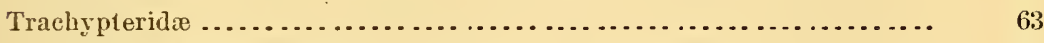

Regalecus gladius, (Walb.) C. \& $\nabla \ldots \ldots \ldots \ldots \ldots \ldots \ldots \ldots \ldots \ldots \ldots . \ldots \ldots \ldots$

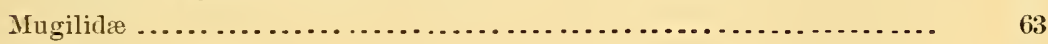

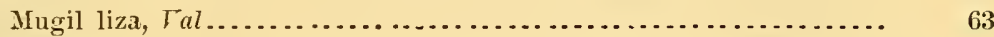

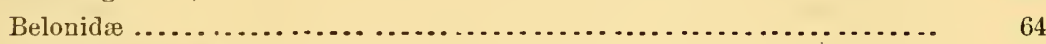

Scomberesocidi............................................ 64

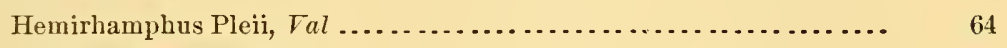

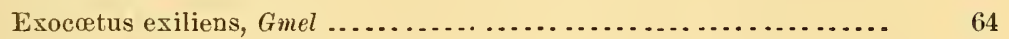

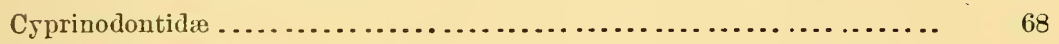

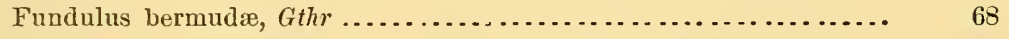

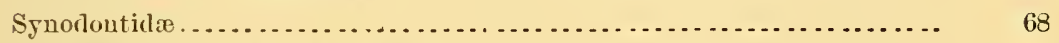

Synodus lacerta, ( $\Gamma_{\text {al. }}$ ) Goode .............................. 68

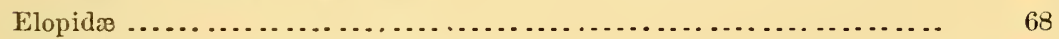

Megalops thrissoirles, (Bloch.) Glhr ......................... 68

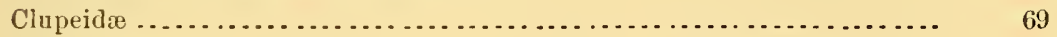

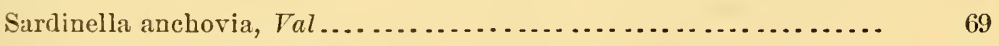

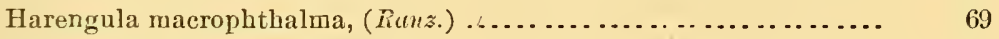

Opisthonema thrissa, (Linn.) Gill ........................... 69

Engraulididæ ........................................... $\tau_{0}$

Engranlis chœrostomus, Goode......................... 70

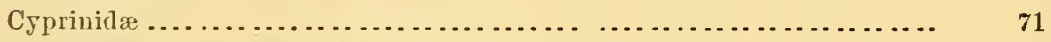

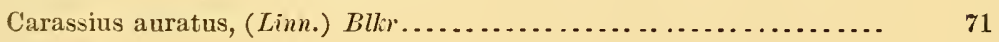

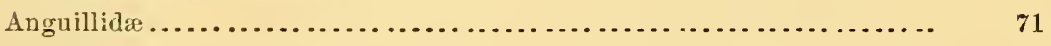

Anguilla bostoniensis (Les.) Ayres ......................... 71

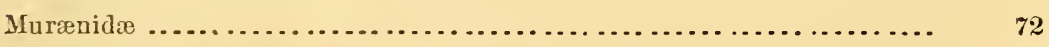

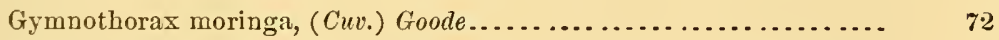

Echidna catenata, (Bloch) Blkr .......................... 73

Raiæ ................................................... 73

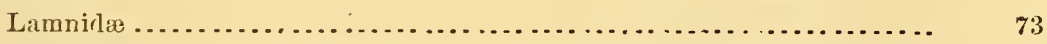

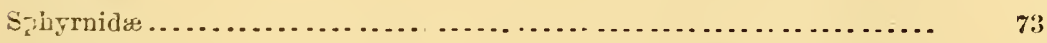

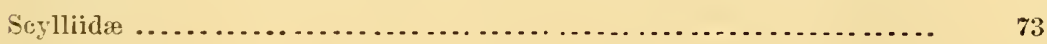

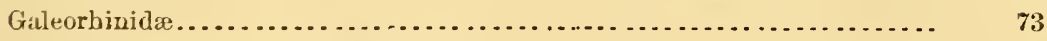

Mnstelus canis, (Mitch.) DeKaty .......................... 73

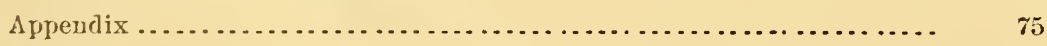

Adritional species observed by Mr. Jones....................... 75

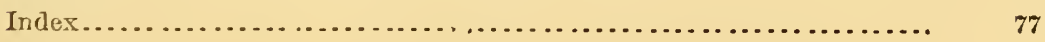





\section{INTRODUCT'ORY REMARKS.}

A visit to the Bermudas during the months of February and March, 1872 , afforded opportunities for collecting the notes and specimens upon which the present paper is based. The enumeration of species here attempted, although necessarily far from exhaustive, is believed to indicate, with some degree of accuracy, the character of the ichthyological fauna of the group ; and it is hoped that this list, with its annotations, may not be without interest as a contribution to geographical zoology. Surprisingly little has been done by naturalists in the investigation of the marine life of this region, interesting as it is likely to prove on account of its isolated, mid-atlantic position, the peculiarities of its climate, and its proximity to the Gulf Stream, rendering so easy observations upon the influence of ocean-currents in the distribution of living forms. The ichthyologist finds here the best of opportunities for the study of pelagic and migratory species. A broad field lies before some resident naturalist who will do for the ichthyology of the Bermudas what Poey and Bleeker have done and are doing for that of the East and West Indies. Comparatively little could be done in two months, least of all in winter and early spring, when stormy weather rendered explorations of the reefs impracticable, and often prevented the fishermen from leaving their moorings in the harbors. At the time of my risit, only seven species of fishes had been recorded from this locality; and the only authentic information regarding the fish-fauna was contained in one chapter, which was unfortunately very short, of Mr. Jones's admirable little work,* the author at that time not having turned his attention to the study of this class. The list given by Godet $\dagger$ should

\footnotetext{
* The Naturalist in Bermuda ; a sketch of the geology, zoology, and botany of that remarkable group of islands; together with meteorological observations. By John Matthew Jones, esq.. (of the Middle Temple), assisted by Maj. J. W. Wedderburn (late 42nd Roy. Highlanders) and J. L.Hurdis, esq.-With a map and illustrations.-_Every kingdom, every province, should have its own monographer."-Gilbert White. London : Reeve \& Turner, 238, Straud.-1859. 12mo, pp. xii, 200.
}

$\uparrow$ Bermuda, its History, Geology, Climate, Products, Agriculture, Commerce, and Govcrument. By T. L. Godet. London, $1860.12 \mathrm{mo}$. 
be ignored, as it is taken almost bodily from Gosse's "Naturalist in Jamaica."

In the present list, I enumerate seventy-five species, most of which were personally observed; for convenience of reference, all species known to occur in this locality hare been included. In working up my notes, I have endeavored to supplement previous descriptions by (1) descriptions of the colors of the fishes while living, (2) notes on size and proportions, (3) observations on habits, (4) hints in reference to the origin and meaning of their popular names, (5) notes upon modes of capture and economic value. The meaning of the specific names employed has been defined by partial synonymies, to which critical notes are occasionally appended. To make the list a more complete contribution to chorological knowledge, a brief note has been given upon the geographical distribution of each species.

The scheme of classification proposed by Professor Gill * has been followed throughout. I am indebted to Professor Gill for valuable suggestions and the identification of two or three of the more doubtful species.

\section{TOPOGRAPATY OF THE ISLANDS.}

The general topography of the Bermudas is so well known that no detailed account will be necessary. It may not be out of place, how-

* Arrangement of the Families of Fishes or Classes Pisces, Marsipobranchii, and Leptocardii. Prepared for the Smithsonian Institution by Theodore Gill, M. D., Ph. D. Washington: published by the Smithsonian Institution, November, 1872. 8vo, pp. xlri, 50. (Smithsouian Miscellaneous Collections, 247.)

Catalogue of the Fishes of the East Coast of North America, by Theodore Gill. < Report ou the Condition of the Sea Fisheries of the South Coast of New Eugland in 1871 and 1872, by Spencer F. Baird, Commissioner, \&c. pp. 779-322.

Catalogue of the Fishes of the East Coast of North America, by Theodore Gill, M. D.

Ph. D. Washington. Published by the Smithsonian Institution, 1873. 8ro, pp. 50. (Smithsoniau Miscellaneous Collections, 283.-A reprint of the preceding).

On the Limits of the Class of Fishes. By Theodore Gill, M. D., Ph. D. < American Naturalist, vol.vii, pp. $71-\tau ;$, February, 18\%3. (Reprinted with repagination, 8vo, pp. 9 ; no title-page.)

The Number of Classes of Vertebrates and their Mutual Relations, By Prof. Thedore Gill. (Abstract of a Communication to the National Academy of Sciences, made October 29, 1873.) < American Journal of Science and Arts, vi, December, 1873, pp. 432-436. Reprinted with repagiration, \&ro, pp. 4; no title-page;) also reprinted Annals and Magazine of Katural History, (Loudon, xiii, pp. 71-73, Jan. 1874.

Article Fish aud descriptious of the various families, prepared by Professor Gill, as associate editor in the department of zoologg, \&c. < Johnson's New Universal Cjelopædia and Popular Treasury of Useful Knowledge. * * * A. J. Johnson \& Son, New York. 
erer, to refer to those features which bear more particularly upon the homes of the fishes. The sunken atoll, which is the foundation of the group, is shaped like an ellipse, its major axis twenty-five miles in length, its minor axis thirteen. The major axis runs in a northeast and sonthwest direction, the chain of main islands lying on the southeast edge of the ellipse, and forming a nearly continuous line twenty-six miles long, the lower or western end curving, nearly in the shape of a shepherd's crook or a fish-hook, to the southernmost focus of the supposed curve. The main islands, fire in number, are separated by narrow channels, fifteen or trenty feet in depth, and their shores are deeply indented by shallow bays and lagoons. The reef, which approaches within a few hundred yards of the shore of the main islands on the south, is distant on the north and north west from five to nine miles; the intervening space is crossed and recrossed by submerged reefs and ledges of coral limestone, and dotted in the neighborhood of the main islands by smaller islands and emerging ledges to the number of three hundred or more. The harbors are not particularly calm, but there are many broad bays whose surface the severest storms scarcely ripple. Within the encircling reef the depth of water rarely exceeds twelve and fourteen fathoms, while beyond this reef the bottom rapidly slopes to the level of the Atlantic bottom. Twenty miles to the southwest by west are two or three ledges, to which the fishermen resort for line-fishing in fine weather.

\section{FISHERIES AND FISH-MARKETS.}

The Bermudian fisheries have always been famous. A large number of the poorer islanders, particularly the negroes, are professional fishermen, and are bold and skillful sailors, thongh their ambition only suffces to keep them at work when purse and larder show signs of exhanstion. Every cottage has its little garden, where bananas and sweetpotatoes grow for the trouble of planting, so that the fishermen are not entirely dependent upon their occupation for support, and the supply of fish often falls far short of the demand, and this is especially the case in the winter, when the landing of a boat is the signal for a general rush to the shore. The people of Bermuda, over twelve thousand in number, are dependent chiefly upon the fisheries for their animal food. Large shipments of cattle and sheep are received from the United States, but these are monopolized by the wealthier classes and by the garrison, so that their flesh rarely finds its way to the tables of the negroes, who number orer seven thousand, or of the poorer white colonists, who constitute more than one-half of the remaining population. 
The fishing-boats are built in the English style, drawing five or six feet of water, deep-keeled, sloop or schooner rigged, and usually provided with a large well in the hold, in which the fish are brought in alive.

The only market is the water's edge. In the large towns, Hamilton and St. George's, the quay is lined nearly every morning at sunrise by a long row of fish-boats. The fish swim in the wells until customers are found for them; when one is selected, it is taken up in a landing-net or by a gaff-hook, and quickly killed by thrusting a sharp awl into the base of the brain; it is then bled, skinned (rarely scaled), eviscerated, and delicered into the hands of the purchaser, a loop of palmetto fiber always being attached for convenience in carrying. At an early hour the fares are disposed of, and the boats are under weigh for the fishinggronuds. At almost any time, however, row-boats filled with small seined fish may be found at the quay. Those who live in the countryparishes watch the return of their neighbors' boats at night-fall, and thus secure their supplies of fish.

Fish from such a market cannot fail to be fresh, and the excellence of the Bermuda food-fishes is due to this, and to the fact that they are never allowerl to die of suffocation in the air, but are killed quickly and bled. The Angel-fish (Holacanthus ciliaris) is perhaps the most highly esteemed; next in rank are the rarious species of Pristipomatidce, Serranida, and Sparida, with the Hog-fish (Lachnolcomus falcatus). All others are regarded inferior in quality. The price of fish is fixed by law at fourpence a pound, an adrance of one penny having been made within a few years.

Most of the line-fishing is done among the outer reefs or on the outer banks, trenty miles distant. The farorite baits are the flesh of the "Bermuda lobster" (Palinurus americanus) and the "Spanish lobster" (Scyllarus cquinoxialis), and that of some of the larger fishes, such as the "Mackerel" (Orcynus alliteratus), and the Morays (Murcenidce). The Pilchard (Harengula macrophthalma), Shad (Eucinostomus gula and $E$. Lefroyi), and the Robin (Dccapterus punctatus), are used as "full-baits," as are also the various kinds of "fry" (Atherina and Engraulis sp.). The "Scuttle," a large Octopus, very common on the reefs, is also frequently used, its toughuess making it a rery lasting bait. Many of the choicest and largest species, such as the Pristipomatide, Scrranide, and Scombrida, are taken exclusirely with lines.

The Sparider, Labrida, Scaride, the smaller Serranida, and many others, with great quantities of the large crustaceans so wach in demand for bait, are captured in basket-work fish-pots constructed of split cane. 
These are built on the same principle with the lobster-pots in use on the New England coast, but are very peculiar in shape. A fair idea of one of them may be gained by imagining two crockery-crates placed together, with the ends at an angle so as to form a very thick capital letter $\mathbf{V}$, with arms about four feet square, the entrance being through a funnelshaped aperture placed in the inner angle. Smaller and more portable pots, made after the same model in annealed wire, are also in use. Such pots are baited with fish or lobsters, and anchored in two or three fathoms of water.

Shallow seines, a hundred yards or so in length, are plied in the bays, and with them are taken rast numbers of the smaller school-fishes, such as Sargus variegatus, Pimelepterus Boscii, Mugil liza, Eucinostomus gula, Eucinostomus Lefroyi, Hemirhamphus Pleii, Decapterus punctatus, \&c. These seines are usually tanned with the bark of the mangrove-tree, (Rhizophora mangle.)

Circular casting-nets, ten feet in diameter, are used with much dexterity in capturing small fish for bait.

The "grains," a heavy, two-pronged instrument, resembling an ordinary fish-spear or gig, is carried in every boat, and used in striking large fish. The skillful grainsman seldom misses his mark, and in these waters, clear as crystal, this instrument is effectire at the depth of ten or twelre feet.

During the winter months, recourse is had to the fish-ponds, which are stocked with the surplus of the summer's catch. These are of simple construction, usually natural pools in the rocks, or protected coves, inclosed by loosely-laid stone walls. Hundreds, sometimes thousands, of large fishes are here stored up for seasons when the severity of the weather is such as to prevent the usual visits to the fishing-grounds. The largest of these, the "Devil's Hole," on Harrington Sound, is visited by almost all the strangers on the islands, a small fee being charged for the privilege of seeing the fishes feed. Several hundred large Groupers and Hamlets (Epinephelus striatus) are usually confined here; and, when bait is thrown into the pond, the visitor can see only a close array of widely-stretched hungry mouths, each six or eight inches in diameter.

THE RELATIONS OF THE BERMUDIAN FISH-FAUNA.

These islands, considered in reference to their marine fauna, lie on the extreme northern and eastern boundary of the West Indian "Pegion." All the more characteristic fishes of this "Region" are represented in Bermudian waters, and the invertebrate fauna, as far 
as investigated, appears to have very similar relations. The reefbuilding polyps find here their farthest northern remove from the equator. That the subtropical character of the marine fauna and flora is determined to a great extent by the influence of the Gulf Stream is rendered very evident by comparing the life on the land with that of the surrounding waters. The latter is much the more tropical and West Indian in character; while the former, although many West Indian species are represented in the flora, is a curious assemblage of forms brought together from various quarters by winds, ocean-currents, and the agency of man. Drift-wood and seeds from the Antilles are cast up in great quantities with the flotsam and jetsam of the shore, and many of the commonest plants of the Bermudas are supposed to have found their way thither in this manner. Thus the transporting power of the Gulf Stream appears to have been quite as important in the introduction of tropical forms of life to this group as has been its thermal effect in rendering it a suitable home for them. Since the Bermuda atoll is comparatirely recent in origin, it is not difficult to believe that it has thus been supplied with living forms. Many fishes of the West Indian fauna have been found in the waters of the Azores, Canaries, Madeira, the Cape Verde Islands, and other points in the Eastern Atlantic; it appears easy to account for their wanderings by an extension of the action of the same transporting agent.

The occurrence of several strictly European species is also to be noted. All of these appear to be powerful, rapid swimmers, with the exception, perhaps, of Synodus lacerta.

The subjoined tables are intended to exhibit the geographical relations of the fishes obserred in Bermudian waters. Several of the species mentioned in the paper are not included, since confusion in their synonymy has rendered their limits of distribution doubtful.

The total number of species enumerated is 75 . Of these, 18 are so widely distributed as to be of little importance in a comparison of this nature. Of the 57 remaining, 50 , or 86 per cent. (68, or 89 per cent. of the whole number, 75), are common to the Bermudas and the West Indies; 18 species, or 32 per cent. of the whole, or 37 per cent. of those common to the tro faunas compared abore, occur on the coast of Bra. zil, only 2, howerer, south of Bahia; $\$$ species, or 14 per cent., are found on the eastern coast of the United States north of Georgia; 4 of these are undoubtedly accidental there, while 2, Decapterus punctatus and $P a$ ratractus pisquetus, have a range along the coast from Rio de Janeiro to Cape Cod, and the serenth, Anguilla bostoniensis, is not sufficiently 
established in its specific relations to warrant generalizations; 13 species, or 23 per cent., occur in the Eastern Atlantic; 3 of these have not been recorded west of the Bermudas, and I prefer for the present to consider them as wanderers from the Mediterranean fauna. The relations, fauvally, of others, such as Balistes capriscus and Pimelepterus Boscii, are somewhat problematical.

Four species of marine fishes and one inhabiting brackish water aro known to be peculiar to the group.

Species common to the Bermudas and West Indies.

Ostracium triquetrum.

Pseudoscarus superbus.

Pseudoscarus cœruleus.

Chœrojulis radiatus.

Lachnolæmus falcatus.

Eucinostomus Lefroyi.

Acanthurus cœruleus.

Sarothrodus bimaculatus.

Calamus megacephalus.

Calamus orbitarius.

Lutjanus caxis.

Mesoprion aya.

Trisotropis guttatus.
Epinephelus striatus.

Epinephelus guttatus.

Hypoplectrus puella.

Mugil liza.

Auostoma coloratum.

Hemirhamphus Pleii.

Exocœtus exiliens.

Megalops thrissoides.

Sardinella anchovia.

Harengula macrophthalma.

Echidna catenata.

Zonichthys fasciatus (South Carolina).

Common to the Bermudas, West Indies, and Eastern Atlantic.

Chilomjeterus reticulatus (Saint Helena).

Chilichthys Spengleri (Madeira, Cape Verdes, and Western Africa). Ostracium quadricorne (Saint Helena, Western Africa, Cape of Good Hope).

Sphrræna picuda (river Niger).

Common to the Bermudas, Brazil, Cape Verdes, and Ascension Island.

Salarias textilis.

Common to the Bermudas, West Indies, and Northern Brazil.

Malthe vespertilio.

Scarus radians.

Eucinostomus gula.

Hypeneus maculatus (Rio de Janeiro).
Pareques punctatus. Hæmylum capeuna. Hæmylum chrysopterum.

Trisotropis undulosus.

Hemirhamphus Pleii.

Holocentrum sogo. 
Common to the Bermudas, West Indies, Brazil, and the Eastern Atlantic.

Labrosomus nuchipinnis (Gorea).

Harpe rufus (Saint Helena, Rio de Janeiro).

Glyphidodon saxatilis (Cape Verde Islands; accidental in Now Eng. land).

Enneacentrus punctatus (Cape Verde Islands).

Gymnothorax moringa (Saint Helena).

Common to the Bermudas, West Indies, Brazil, and the east coast of the United States.

Acanthurus nigricans (South Carolina).

Decapterus punctatus.

Paratractus pisquetus.

Common to the Western Atlantic and Western Pacific??

Anguilla bostoniensis.

Common to the Bermudas, Mediterranean, and Eastern Atlantic.

Sargus variegatus (Madeira). Synodus lacerta (Madeira).

Sphyræna spet (Canaries).

Common to the Bermudas, West Indies, Madeira, and the Mediterranean. Pimelepterus Boscii (accidental at New York).

Common to the Bermudas, West Indies, east coast of United States, Ma. deira, Mediterranean, and the Pacific.

Balistes capriscus.

Pelagic: Atlantic.

Hippocampus, sp.

Exocœtus, sp.

Dactylopterus rolitans (Mediterra- Mustelus canis. nean).

Isuropsis punctata.

Pelagic : both hemispheres.

Paradiodon hystrix.

Alutera scripta.

Antenuarius marmoratus.

Trachurops crumenophthalmus.

Oreynus alliteratus.

* Naucrates ductor.
Corsphæna hippurus.

* Leptecheneis naucrates.

* Ptheirichthys lineatus.

Regalecus gladius.

* Sphyrna zygæna.

* Reniceps tiburo. 
Peculiar to the Bermudas.

Bynguathus Jonesii.

Lefroyia bermudensis.
Engraulis chœrostomus.

Fundulus bermudæ.

\section{Acclimated.}

\section{Carassius auratus.}

\section{POPULAR NAMES.}

The names in use among the fishermen afford some curious studies. Where practicable, hints in regard to their origin have been given.

I observe that of the thirty-three names given by Catesby* as in use in the Bahamas at the time of his visit to those islands, one hundred and fifty years ago (1724-25), twenty-six are applied to common species in the Bermudas. Nearly all of these are applied to fishes of the same family or genus, and most of them to the same species. This may perhaps be explained by the common origin of the colonists of the two regions. It is an interesting instance of the persistency of common names. Many of these names are in use at the present time in the southern Atlantic States, though usually applied to different species.

Subjoined is a list of names in use among the fishermen, to the application of which I can give no clew:-

Glare-eye Squirrel.

Black Jack.

Deer Grouper.

Spanish Hog-fish.

Black Hog-fish.

Clucker.

Sand-eel.

Runner.

Blue-bone Porgy.

White-bone Porgy.
Shad Porgy.

Scotch Porgy.

Red-tail.

Bone-fish.

Grubble.

Yellow Tang.

White Belly.

Blue Belly.

Permit.

Sand Shark.
- Sunburnt Shark.

Rainbow.

Thumper.

Mermaid.

Skip-jack.

Slippery Dick.

Prickly Hind.

Sardine.

Sand Mullet.

* The Natural History of Carolina, Florida and the Bahama Islands ; containing The Figures of Birds, Beasts, Fishes, Serpents, Insects and Plants: Particularly the ForestTrees, Shrubs and other Plants not hitherto described or very incorrectly figured by Authors. Together with their Descriptions in'English and French. To which are added, Observations on the Air, Soil and Waters: With Remarks upon Agriculture, Grain, Pulse, Roots, \&c. To the Whole is Prefixed a new and correct Map of the Countries Treated of. By Mark Catesby, F. R. S. London * * * MDCCCXXXIXLIII. 2 vols. folio. 
The English names given to the species in this paper are those which are commonly applied to them by the islanders, and no others are emplosed.

The following identifications of Catesby's species are suggested in connection with the plates of fishes given in the second volume. These conclusions were reached after a careful examination of the synonymy of the names here proposed as adopted by later writers, especially Linné, who appears to have founded several species upon these figures and descriptions. In many cases, comparative measurements have been made with these plates and the fishes they are supposed to represent, so as to make the identification as accurate as might be. A casual comparison will show the reader how closely the local names correspond to those in use in the Bermudas :-

T. 1. Umbla minor, marina, \&c. (BARRACUDA) is Sphyrona picuda.

Vulpis Bahamensis is Albula conorhynchus.

T. 2. Perca marina gibbosa, \&c. (The Margate Fish) is (₹) Homylum chrysopterum. Szurus ex cinereo nigricans (The SEa Sparrow Hawk) is Synodus fotens.

T. 3. Perca mariua, pinua dorsi divisa (THE CRoKer) is Micropogon undulatus.

Perca marina rubra (The SquirReL) is Holcocentrum sogo.

T. 4. Perca marina rhomboidalis (The PORK FISH) does not agree with Lagodon rhomboides, to which it has been referred. The figure is too indefinite for determination and does not agree with the author's description.

Perca marina piuuis branchialibus careus (Tine Schoolmaster) is equally indefinite; the pectoral fins were evidently an afterthought of the artist.

T. 5. Pcrca marina veneuosa, \&c. (THE Rock FISH) is Trisotropis gutiatus, or some allied species.

T. 6. Perca marina capite striato (The GRUNT) is some species of Hamylum, perhaps H. arcuatum.

Albula bahamensis (THE MULLET) is Mugil sp.

T. 7. Perca marina puucticulata (The Negro FISI) is Enneacentrus ouatalibi.

Perca cauda nigra (THe BlaCK-TAIL) is very like Ocyurus chrysurus.

T. 8. Hirundo (Tme Flying Fish) is unidentitiable, but is probably the common Barbados species, perhaps Exococtus Roberti, M. \& T.

Perca marina sectatrix (THe RUnder Fisir) cannot be recognized, but is probably one of the Stromateido.

Perca fluviatilis gibbosa ventre luteo (The Fresh-water Pearch) is Ponotis vulgaris.

T. 9. Turdus piunis branchialibus carens (The MAxGrove SNaPper) is quite uurecognizable, the grotesque figure without pectoral fins being evidently imaginary.

T. 10. Turdus rhomboidalis (THE TANG) is Acantharus nigricans.

Turdus canda convexa (THE YeLLow FrSH) is probably Enneacentrus ouatcibi. Compare T. 7, supra. 
T. 11. Turdus flavus (The HoG FisH) is perhaps Harpe rufus; is certainly a Labroid. Turdus cinereus peltatus (THE SIIAD) is a Eucinostomus, aud closely resembles the new Bermuda species E. Lefroyi.

T. 12. Turdus oculo radiato (The Pudding-Wife) is a young specimen of Chornjulis radiatus.

Alburnus americanus (The Carolina Whiting) is clearly Menticirrus alburnus, with which its shape and the barbels on the chin would place it, in spite of the manifest omission of the second dorsal fin.

T. 13. Mornnyrus ex cinereo nigricaus (The Bone-FISH) I am unable to identify, though the name is in use at the present day in the Bahamas.

T. 14. Cugupuguacu Brazil (The Hivd) is Epinephelus guttatus.

Saltatrix (SKIPJACK) is Pomatomus saltutrix.

T. 15. Suillus (The Great Hog-Fisi) is Lachnolamus falcatus.

T. 16. Aurata Bahamensis (The PORGY) is probably Chrysophrys auratus or C. orbitarius.

T. 17. Salpa purpurescens variegata (The LANE SNAPPER) I canuot place.

Petimbuabo Brazil (The Tobaccopipe-Fish) is Fistulari tabaccaria.

T. 18. Novacula cerulea (The Blue-FISH) is Pseudoscarus corulens.

T. 19. Uuicornis, Piscis Bahamensis (The Bahana Unicors-FIsH) is Alutera scripta.

T. 20. Muræna maculatus, nigra et viriclis (The Muray) closely resembles Gymmothorax rostratus.

T. 21. Muræna maculata nigra (The Black MURaY) is not clearly identified.

T. 22. Turdus oculo radiato (THE OLD WIFE) is Balistes vetula.

T. 23. Bagre, \&c. (The CAT-FISH) somewhat resembles Noturus flavus.

'T. 24. Harengus minor Bahamensis (The Pilchard) is some small Clupeoid.

T. 25. Anthea quartus, Rondeletii (The MUtTon-FISII) is a Lutjanus, perhaps L. aya or some allied form.

T. 26. Remora (The Suckivg Fish) belongs of course to Echeneidide, though lack of detail will not allow even generic identification.

T. 27. Solea luuata et punctata (The Sole) I do not know.

T. 23. Orbis lævis variegatus (THe GLOBE FISI) is Chilichthys turgidus.

T. 29. Psittacus piscis viridis, Bahamensis (The Parrot Fisin) is Pseudoscarus Catesbyi.

T. 30. Acus maximus squanmosa viridis (THE Greex Gar-FISR) is Lepidostens ossens.

T. 31. Acaranna major pinnis coruutis (THE ANGEL Fish) is Holacanthus ciliaris. 



\section{FISHES OF THE BERMUDA ISLANDS.}

\section{LIST OF SPECIES.}

\section{MALTHEID AE.}

MALTHE VESPERTILIO, (Linn.) Cuv., subspecies VESPERTILIO.

\section{DEVIL-FISH.}

Lophius fronte unicorni, Lixxé, Mus. Ad. Fried. 1, 1754, 55.-Antwd; Syn. Pisc. 1788, 88. Guaperea, Browx, Hist. Jamaica, 1756, 457, pl. 48, f. 3.

Rana piscatrix americana, SEBA, Locup. Rer. Nat. Thes. Desc. 1, 1758, 118, tab. 1xxiv, f. 2. Lopkius respertilio, Lrivè, Syst. Nat. ed. 10, 1, 1758, 236; ed. 12, 1, 1766, 402.-GMelis,

Linn. Sðst. Nat. 1, 1788, 480 (partim).-Bloci, Ichth. iv, 1787, 8, taf. cx. (on a drawing bj Plumier).-Schxemer, Bloch, S5st. Ichth. 1801, 140.-LacḱPìne, Hist. Nat. Poiss. 1, 1798, 302-315.

Malthe vespertilio, Cuvinr, Règue Anim. 1817.-MüLler \& Troscmel in Schomburgk, Hist. Barbados, 1848, 678.-Güstner, Cat. Fish. Brit. Mus. iii, 1861, 200 (partim).-Poer, Mem. ii, 1861, 382 ; Rep. Fis.-Nat. Cuba, ii, 1868, 406.-Cope, Trans. Am. Phil. Soc. 18\%0, 480.-GiLl in Baird's Rep. Sea Fisheries of New England, 1873, 792.

Malthea respertilio, Cuv. \& VAL., Hist. Nat. Poiss. xii, 1837, 440.-Storer, Syn. Fish. N. Amer. 1846, 131.-GruL, Cat. Fish. E. Coast N. Amer. 1861, 47.-LÜtKen, Nat. Foren. Vid. Med. 1865, 5.

Malthaca respertilio, DeKay, New York Fauna, Fish, 1842, 45\%.

A single specimen of this species was noticed in the collection of $\mathrm{Mr}$. Juhn T. Bartram, of Stocks Point, Saint George's Island. It is recorded from rarious points in the West Indies. Dr. Güuther has united all described species, except Malthe cubifrons, Richardson, under the name Malthe vespertilio. The species thus limited is very variable in respect to the length of snout, which in some individnals equals one-sixth of the entire length of the fish, in others reduced to one-twentieth or one trrenty-fifth. Professor Liitken recognizes three species within these limits; Malthe vespertilio, represented by the synonymy given above; 
Malthe longirostris, Cuv. \& Val., the Guacucuja of Marcgrave;* and Malthe notata, Cuv. \& Val. These speojes seem to correspond with certain limits of variation, and are probably entitled to subspecific rank, particularly since these limits of variation are correlated with their geographical distribution. The form designated as vespertilio corresponds to section $(\delta)$ of Giinther, having the snont one-ninth or one-tenth of the total length, and is recorded from Cuba, Jamaica, Santo Domingo, Porto Rico, and Martinique.

$M$. longirostris corresponds to section $(\alpha)$ of Günther, having the snont one-sixth of the total length, and is recorded from Bahia and Para.

M. notata was described from Surinam, and, according to Dr. Günther, from joung specimens. Dr. Günther identifies it with a Demerara specimen, and refers it to section ( $\varepsilon$ ), having the snout one-thirteenth of the total length.

$M$. angusta, corresponding to section $(\eta)$ of Ginther, with the snout one-twentieth to one twenty-fifth of the total length, represents the minimum development of snout, and is known from Brazil.

Malthe cubifrons, Richardson, is uudonbtedly entitled to full specific rank.

\section{ANTENNARIIDAE.}

\section{PTEROPHRYNE PICTA, (Tal.) Goode.}

\section{Devil-FISH; MARBLED ANGLER.}

Lophius histrio, var. $b$, pictus, SchNeIder, Bloch, Syst. Ichth. 1801, 124.

Chironectes pictus, Cuv. \& V.1L., Hist. Nat. Poiss. xii, 293, pl. 361.

Antemnarius marmoratus, var. a, picta, Grun., Cat. Fish. Brit. Mus. iii, 1861, 186.

A single specimen was given me by C. C. Keane, esq., of Hamilton, and I saw sereral others. The fish is pelagic, occurring only in the warmer parts of the Atlantic. Its home is among the floating masses of Gulf-Ireed (Sargassum bacciferum). It is often brought ashore in the beds of this alga, which is thrown up among the rocks in great heaps after the rrinter storms. I have seen its curious nest, consisting of a bunch of eggs adhering in glutinous masses to the Sargassum, the whole cluster large enough to fill a quart measure. One of these was thrown ashore in February, and is now in the collection of J. Yatthew Jones, esq., of Halifax, Nora Scotia. 


\section{DIODONTID AE.}

\section{PARADIODON HYSTRIX, (Limué) Bleeker.}

\section{Sea Hedgehog; Sea Poncupine.}

Guamajacu Guara, Marcgrave, Hist. \&c. Brazil. 1648, 158.

Diodon Hystrix, LINNe, Syst. Nat. ed. 10, 1, 1758, 335; ed. 12, 1, 1766, 413 (not Gmelin)

Linné, S5st. Nat. 1, 1788, 449, according to Barneville, Revue zoologique 1816, 141).-Poex, Mem. ii, 1861, 361.-GǗtuer, Cat. Fish. Brit. Mus., viii, 18\%0, 306.-Cope, Trans. Am. Phil. Soc. 18\%0, 480.

Paradiodon hystrix, Bleerer, Atl. Ichth. $\nabla$, 1865, tab. cevii, f. 2.-Poex, Rep. Fis. Nat. Cuba, ii, 186s, 430.

Erizo, Parra, Dese. Dif. Piez. Hist. Nat. Cuba, 1787, 60, lam. xxix, f. 1-2.

Diodon atinga, Bloch, Ichth. iv, 1787, 75, taf. exxv, (not Linné).-Gmemin, Linné, Syst. Nat. 1, 1788, 1449.-Schneider, Bloch, Syst. Ichth. 1801, 511.-LaCéṖ̀de, Hist. Nat. Poiss. ii, 1801, 1-3.-SIIAw, Gen. Zool. v, 1804, 434.-MÜLr. \& Trosch. in Sehomburgk, Hist. Barbados, 1848, fi77.-KAUP, Wiegmann's Arch. Naturg. xxi, 1855, 22\%.-JuUAN, Anim. Nouv. Caledonie, Mem. Soc. Imp. Sci. Nat. Cherbourg, 1861-'63, 18.-Bleeker, Enum. Pisc. Ar'ch. Ind. $1859,203$.

Diodon attinga, Ruppell. Verzeichn. Senckenb. Mus. Fisch. 18², 35.

Divdon Plumieri, LACÉPÈDE, op. cit. ii, 1, 1801, 1-10, pl. iii, f. 3.

Diodon Brachiatus, Schnerder, op. cit. 213 (founded on Parra's figure No. 1, cited above.)

Diodon punctatus, Cutrer, Mem. Mus. Hist. Nat. iv, 1818, 132, and Règne Animal, 181\%, p.-.-BLeeker, Verhaudl. Bat. Geu. xxiv, Blootk. Visseh. 1852, 19.

This species, common in the West Indies, recorded also from the Pacific and the Indian Archipelago, is occasionally found here, and, on account of its bristly skin, is greatly prized by curiosity-hunters. It is never eaten. I saw four specimens, each about eighteeu inches long.

CHILOMYCTERUS RETICULATUS, (Linn.) Bibron.

Orbis muricatus et reticulatus, Wrllughis, Ichthyographia, 1685 , 155, tab. J, No. vii.-

Seb., Locup. Rer. Nat. Thes. Desc. iii, 1758, 58, tab. xxiii, f. 3.

Ostracion subrotundus, aculeis undique brevibus triquetris varis, ArTed, Gen. Pisc. 1738, 52, No. 16.

Diodon reticulatus, Lixwe, S5st. Nat. 1, 1758, 334.-GMelLi, Linué, Syst. Nat. 1, 1788, 1449 .

Chilomycterus reticulatus, Bibrox apud Barnevilr., Revue Zoolngiqne, 1846, 141.-

Bleeker, Atl. Ichth. v, 1865, 54.-GüNther, Cat. Fish. Brit. Mus. viii, 1870, 313.

Dioc'on atringa $\beta$, Lișé, op. cit. ed. 12, 1, 1766, 413.

? Diodon atinga, Poer, Mem. ii, 1861, 361 ; Rep. Fis. Nat. Cuba, ii, 1868, 429.-Cope, Trans. Am. Phil. Soc. 1870, 480. 
Dr. Giinther records a single specimen from the Bermudas. Another, in the University Musenm at Middletown, Connecticut, is said to have come from the same locality.

Additional data are necessary in order to determine the true relations of Linné's Diodon atringa (atinga). Barneville and Bleeker consider it identical with Diodon orbicularis of Bloch. Günther does not commit himself decidedls, altbough Le cites, under Chilomycterus geometricus, Maregrave's Guamajacu atinga, upon which the splecies of Linné is presumably founded. The relations of the species $D$. atinga are important as throwing light upon the relations of the genus Diodon, of which it must be considered the type; there can be little doubt, however, that Bleeker is right is retaining in this genus those forms which have three rather than two roots to their spines.

\section{TETRODONTIDAE.}

\section{CHILIOHTHYS SPExGLERI, (Bloch) Goode.}

\section{STALLOW; PUfF.FISH.}

Tetrodon Spengleri, BLoci, Ichth. iv, 1787, 134, taf. exliv.-SchNeIDER, Bloch, Syst. Ichth. 1801, 504.-LaCfPł̀de, Hist. Nat. Poiss. i, 1798, 476-501.-Shaw, Gen. Zool. v, 1804, 445.-Güxtıer, Cat. Fish. Brit. Mus. viii, 18\%0, 284.-Cope, Trans. Am. Phil. Soc. $18 \% 0,479$.

Tetrodon Plumieri, LAclètde, op. cit. 476-504, pl. xx, f. 3.(on a draming by Plumier). Tetrodon marmoratus, Raxz.sx. Nov. Comm. Acad. Bonon, ir, 1840, 72, pl.x, f. 1.-Lowe, Trans. Zool. Soc. ii, 1241, 193.-ThLexciexnes in Webb and Berthelot, Hist. Nat. Canaries, Poiss. 1836, pl. xx, f. 2.

A single specimen of two inches was found on the beach at Bayley's Bay. The species ranges from Madeira and Northwestern Afirica to the Caribbean, and no doubt frequently occurs about the Bermudas. Bloch, in his description, figures the species with the imperforate nasal tentacles of the genus Arothron, giring the East Indies as its habitat. Making due allowances for the notorious carelessness of early ichthrologists in fixing the localities of specimens, and for the lack of detail in their dramings, we beliere that the present name should be retained, since the fish figured by Bloch is unmistakably the one before us. Should time render it necessary to adopt another name, that of Ranzani, who described the species accuratel 5 , mas be substituted.*

Color.-Abore, light chestnut; beneath, clear white; a lateral band

* Tetrodon marmoratus, R.xzaxi, Novi Commentarii Acad. Sci. Inst. Bonon iv, 1840, p. 72 , pl. $x$, fig. 1 . 
of tamny white, from chin to base of caudal rays, where it is confluent with a ring of the same color around the extremity of the caudal peduncle; beneath this lateral band a row of brown spots, of irregular size and fifteen in number, three being on the caudal peduncle; abore a similar row, often very obscure. Caudal brown, with broad, median transverse band of sellow; other fins immacnlate.

W'hen inflated with air, the diameter of the belly is considerably greater than half the entire length of the fish.

Its habits are donbtless very similar to those of Chilichithys iurgidus (Mitch.) Gill, common on the east coast of North America from Cape Cod to the Antilles, which it much resembles, and which is very likely to occur in the Bermuda waters.

\section{OSTRACIIDE. \\ OSTRACIOM TRIQUETRUM, Linu.}

\section{CUCKOLD.}

Ostracion triangulus, tuberculis, exiguis zumeris aculeis carens, ArTEDI, Gen. Pise. 1738, 57 ; Syn. Pisc. 1738, 85.

Ostracion polyodon incrmis triqneter, Lrxxí, Mus. Ad. Fried. 1, 1754, 60.

Ostracion triqueter, Lixwe, Syst. Nat. ed. 10, 1, 1758, 330 ; ed. 12, 1, 1766, 40\%-BLoch, Ichth. iv, 1787, 106, taf. exxx.-Gnienr, Linn6, Syst. Nat. 1, 1788, 1441.--SCHNEIDER, Bloch, Syst. Ichth. 1801, 498.-LaCÉPł̀de, Hist. Nat. Poiss. 1, 444.-SHaw, Gen. Zool. , 1804, 420.-MüLl. \& Trosch. in Schomburgk, Fist. Barbados, 18128, 677.-Hollard, Ann. Sei. Nat. 1857, 154.-Günther, Cat. Fish. Brit. Mus. viii, $1870,256$.

Ostracion triquetrum, Pory, Mem. ii, 1861, 361; Rep. Fis.-Nat. Cuba, ii, 1868, 442. Ostracium triquetrum, Cope, Trans. Am. Phil. Soc. 1870, 475.

Rhinesomus triqueter, Swansox, Nat. Hist. Fish. \& Rept. ii, 1839, 324.

Common, as it also is throughont the West Indies and the Gulf of Mexico. Its length seldom exceeds eight inches. Its habits are sluggish, and it hugs very closely the bottum, where it is frequently taken in fish-pots.

The locomotion of the trunk-fishes is very peculiar, and I found an excellent opportunity for observing the movements of a Cuckold confined in my aqnarium. The propelling force is exerted by the dorsal and anal fins, which have a half-rotary, sculling motion resembling that of a screw-propeller; the caudal fin acts as a rudder, save when it is needed for unusually rapid swimming, when it is used as by other fishes. The chief function of the broad pectorals appears to be that of fanning a 
current of water through the gills, thus aiding respiration, which would otherwise be difficult on acconnt of the narrowness and inflexibility of the branchial apertures.

When taken from the water, one of these fishes will live for two or three hours, all the time solemnly fanning its gills, and when restored to its native element seems none the worse for its experiences, except that, on account of the air absorbed, it cannot at once sink to the bottom. The Cuckold is not valued for food, though I am unable to learn that its use is ever followed by fatal results such as attend it in some of the West Indies.*

The local name is not applicable, and has probably been transferred from some other fish, as, for instance, the following species, which is known in Jamaica as "the cuckold."

Color.-Dark brown, thickly studded with circular spots of yellowishwhite, each about two lines in diameter. The epiciermis is often abraded, learing the shell uniform tawny-white.

\section{OSTRACIUM QUADRICORNE, Limné.}

COW.FISH.

Piscis triangularis cornutus Clusii, Wrllcgribr, Hist. Pisc. 1686, xir, tab. J.

Ostrucion triangularis 2 aculeis \&e., Artedr, Syu. Pise. 1738, 85, Xo. 9.

Ostracion quadricomis, Lrxwé, Syst. Nat. eả. 10, 1, 1758,331; ed. 12, 1, 1766, 408.-BLoch, Ichth ir, 1787, 113, taf. exxxir.-Guselis, Linue, Syst. Nat. 1, 1788, 1442.Schyeider, Bloch, Syst. Ichth. 1801, 499.-L.icérède, Hist. Nat. Poiss. 1, 1798, 442, 468.-Sinw, Gen. Zool. v, 1804, 424.-Kaup, Wiegmann's Areb. Naturg..xxi, 1555, :16.-Hollard, Ann. Sci. Nat. 1857, 143.-Blecker, Poiss. Guinea, 1863, 20.-Gưxtrer, Cat. Fish. Brit. Mus, viii, $18^{\circ} 0,258$.

Ostracion quadricorne, PoEx, Mem. ii, 1861, 362; Rep. Fis.-Nat. Cuba, ii, 1868, 439.

Ostracion (Acanthostrucion) quadricornis, BLEEKEr, Atl. Ichth. 1865, 32.

Ostracium quadricorne, Cope, Trans. Am. Phil. Soc. 1870, 474.

Latonhrys quadricomis, Swarsox, Hist. Nat. Fish. \& Rept. ii, 1839, 324.

Chopin, Panri, Desc. Dif. Piez. Hist. Nat. Cuba, 178 , 31, lam. xvii.

Ostracion Lister, LAcêpł̀de, op. cit. 468, pl. xxiii, f. 2.

Ostracion sexcormutns, MrtchlnL, Amer. Month. Mag. ii, 1818, 328.

Lactophrys sexcormutus, STorer, Syn. Fish. N. Am. 1846, 246.

Ostracion cornutus, MÜLL. \& Trosch. in Schomburgk, Hist. Barbados, 1843,677 (not Linné or Bloch).

Ostracion maculatns, Hollard, op. cit. 149.

Common; its habits much like those of Ostracium triquetrum. Its range is much mider, including Saint Helena, Guinea, the Cape of

\footnotetext{
* Schomburgk, History of Barbados, p. 6r7.
} 
Grood Hope, and Charleston, S. C. Its occurrence in the Indian Archipelago is extremely doubtful, as Bleeker himself almits. This species is extremely rariable, in length, breadth, and height of body, length of tail, and length of caudal, and these rariations seem to be individual as well as related to age. Hollard's Ostracion maculatus * and the rarious species dubia of Poey $\dagger$ will probably prove to be forms of this species.

The presence of plates upon the caudal peduncle is apparently accidental. Ther mas possibly have some relation to sex, but certainly none to age. Out of fourteen specimens examined, five had plates above and below, one had two above, and six had none. In none of the specimens can I distinguish traces of the spine in the middle of the dorsal ridge mentioned by Dr. Giinther. The color of joung specimens is well described by Giinther; the bands on the cheek are, however, of a bright blue. Adult specimens are colored in a rich bright blue, which quickly vanishes after death. In some individuals, the color is worn from the ridges of the carapace, learing patches of light brown. The largest specimens are trenty-one inches long.

The Corr-fish is, I was told, much esteemed for food, and is frequently baked whole in its shell. The popular name, like the Cuban "toro" and the Jamaican "cuckold," refers to the two horn-like supra-orbital spines.

\section{BALISTID AE.}

\section{BALISTES CAPRISCUS, Gmelin.}

\section{TurBot.}

Balistes capriscus, Gumern, Linne, Syst. Nat. 1, 1788, 1471.-Schnemder, Bloch, Syst Iehth. 1801, 476.-LACÉp̀̀de, Hist. Nat. Poiss. 1798, 1, 372, pl. xiii, f.3.Silaw, Gen. Zool. v, 1804, 411-Risso, Iehth. Nice, 1810, 51.-Yarrell, Brit Fish. ii, 1841, 472.-Hollard, Ann. Sei. Nat. 1854, 309.-Güntmle, Cat. Fish. Brit. Mus. viii, 1870, 217.-GILL, in Baird's Rep. on Sea Fisheries of Southern New England, 1873, 793.

Lalistes fuliginosus, DeKay, New York Fauna, Fishes, 1842, 339, pl. 1vii, f. 188.-STORER Syn. Fish• N. Am. 1846, 243.

Capriscus fuliginosus, Gil, Cat. Fish. E. Coast N. Am. 1861, 56.

Common. Very erratic in its distribution, having been observed in the Pacific at Panama, at Madeira, in the Mediterranean, and on the coast of Great Britain. DeKay figures a specimen taken in New York Harbor; the 
Tnited States National Museum has specimens from Wood's Hole, MIass., Charleston, S. C., and the Tortugas; it is not recorded from the West Indies. The Turbot attains a reight of fire or six pounds; its tlesh is not unpalatable, and its tough, shagreen-like skin is used for polishing purposes. It has a habit of swimming on its side, just at the surface, like the Sunfish (Hola rotunda), and, from this habit as $\pi$ ell as perhaps a fancied similarity of its form to that of the European Turbot (Rhombus maximus), its name appears to hare bcen derired. It no doubt breeds in these raters; I hare seen ronng individuals not exceeding three inches in length. The species shonld be compared with Balistes sobaco, Poey. No other species of this subfamily were observed.

I suppose the "Oid-wife," "Ocenn-turbot," and "Black-turbot" of the fishermen to correspond respectively to Balistes retula, Linné, Canthidermis maculatus, (Gmelin) Bleeker, and Mclichthys buniva (Lacépède), all of which, as well as Balistes vingens, Linué, are quite certain to occur in these waters.

\section{ALUTERA SCRIPTA, (Osbeck) Bleeker.}

Unicornis Piscis Eahamonsis, Catesws, Nat. Hist. Carol. Floridit, and the Bahama Islauds, ii, $17: 3,19$, tab. 19.

Balistes scriptus, Osbeck, Iter. Sin. 1765, 144.-Guelis, Linn6, Syst. Nat. 1, 17ES, 1463.

Aluteres seriptus, Bleeken, Ned. Tyds. Dierk. iii, 1865, 28; Ichth. 1865, 141, tab. cсххтii, 4.

Monacanthus scriptus, Gïxtmer, Cat. Fish. Drit. Mus. riii, 18r0, 252.

Lija Trompa, P.nm, Desc. Dif. Piez. Hist. Nat. Cnba, 1; 7 , 46, lam. xxii, f. 1.

Ialistes Laris, Bloch, Ichth. xii, 1797, 63, tab. ccccxir.-Sinw, Gen. Zocl. v. 1804, 405.

Aluterius laris, Curier, Rigne Animal, 181\%.-C.ñtor, Cat. Malajan Fish. 355.Bleerer, Verhandl. Butar. Gen. xxir (Balistidæ), 21.-Hollard, Anu. Sci. Nat. 1555, 15.-D.1 , Fish. Jalabar, 1805, 355.

Alutera Toris, Swalssox, Nat. Hist. Fish. \& Rept. ii, 1839, 327.

Aleuteres levis, Richardsox, Vor. H. M. S. Sulpher, 1845, 131, pl. lxi, f. 3.

Balistes Monoceros, var. Laris, ScmNeIder, Bloch, Ssst. Ichth. 1801, 463.

Balistes ornatus, Procé, Bull. Philom. 1822, 131.

Aluteres parera, Lessox, Toy. Coquille, ii, 1830, 106.

Aluterus renosus, Hollard, op. cit. 14, pl. 1, f. 3.

Alutera picturata, Poer, Proc. Acad. Nat. Sci. Phila. 1863, 1£3; Rep. Fis.-Nat. Cuba, ii, 438 .

Aleuteres picturatus, Core, Trans. Am. Phil. Soc., 1870, 476.

A specimen trent5-one inches long was taken off the islands in April, 1572. The occurrence of the species is so unusual that it has no common name. It appears to be strictly pelagic, and is recorded from China, the Indian Archipelago, Tahiti, New Ireland, Coromandel, the Canaries, the West Indies, Brazil, and South Carolina. 


\section{HIPPOCANPIDAE.}

\section{HIPPOCAMPUS, sp.}

\section{SEA.HORSE.}

Tro specimens, apparently of different species, were secured; but, oring to the unsatisfactors nature of the published descriptions, it is impossible at present to identify them. One agrees tolerably with $\mathbb{H}$. antiquor?m, Leach.

\section{SYNGNATHIDAE.}

STNGNATHUS JONESII, Günther.

Syngnathus Jonesii, Güntmer, Ann. \& Mag. of Nat. Hist. 1874.

This species was deserredly dedicated to J. Matthew Jones, esq., F. I. S., who is doing so much toward elucidating the natural history of these islands. Pipe-fishes are not uncommon. S. pelagicus, Osbeck, is likely also to occur.

\section{AULOSTOMID AE.}

\section{AULOSTOMA MACULATUM, Valenciennes.}

\section{TRUMPET-FISH.}

Trompetero colorado, Parra, Descr. Dif. Piez. Hist. Nat. Cuba, 1787, 63, lam. xxx, f. 2. Aulostoma naculatuus, Valexcienses in Cnvier, Règne Animal, 1817; ill. ed. Poiss. 1829, pl. xcii, f. 2.

Autostona cotoratum, MüLl. \& Trosch. in Schomburgk's Hist. Barbados, 1848, 173.Gẗxther, Cat. Fish Brit. Mus. iii, 1861, 536.-Powy, Rep. Fis.-Nat. Cuba, ii, 1868, 386.-Cope, Trans. Am. Phil. Soc. Phila. 1870, 480.

A dried head of this species was shown me by C. C. Keane, esq., of Hamilton. The fishermen speak of two Trumpet-fishes found here, one of them designated the Black Trumpet-fish. One of these is probably Fistularia tabaccaria, Liuné. Mr. J. Matthew Jones informs me of the capture, in 1874, of a specimen of Fistularia serrata, Cuv., hitherto known only from the Indian and Pacific Oceans.

\section{FIERASFERIDA.}

\section{LEFROYIABERMUDENSIS, Jones.}

Lefroyia Bermudensis, Joves; Zoologist, Jan., 1874, 3838.

A single specimen four and one-half inches long was taken by Gov. ermor Lefroy in the summer of 1873.

"Total length rather more than $4 \frac{1}{2}$ inches. Greatest depth at twe rer- 
tical of the pectorals, three lines and one-half. The length of the head is slightly more than one-seventh of the total length. The greatest width of the head is rather less than one-third of its length. Body naked, attenuate, compressed. Facial outline rugose. Eje moderate; borizontal diameter of the eye-cup, one and three-quarter lines; vertical diameter, one and one-quarter lines. Gape of mouth wide. Lower jaw shorter, and receired within the upper. Cardiform teeth of irregnlar size in both jaws, romer, and palatines; those of the latter largest. Branchiostegals seven, inflated, united below. Vent thoracic. Pectorals originating at the upper angle of the operculum, three lines in extent, of delicate soft rays. Dorsal indistinct, commeneing in a groore at about the rertical of the twentieth anal raf, continuous to caudal extreme; when in conjunction with the anal, it forms a small filamentous tip. Anal prominent, commencing immediatels behind the vent, in adrance of the vertical to the upper angles of the operculum, and extending to the caudal extreme. About its centre, it is equal in depth to that of the body at the same position. Owing to the delicate texture of the fins, it is impossible to determine the number of rays, but those of the anal exceed one hundred and forty. Color when dried, ont of spirit, golden-yeliow. The body transparent, showing the rertebra within, a condition, according to General Lefroy, equalls obserrable in life."Jones.

The genus proposed by Mr. Jones has not ret been defined, and the name Lefroyia ean be adopted only prorisionally.

\section{BLENNIIDA.}

LABrosomus NUCHIPINxis, (quoy d Guimard) Poey.

-Molly Miller.

Climus muchipinnis, Qror of Gammad, Voy. Uravie et Physsicienue, Zool. 1824, 255.Güxtmer, Cat. Fish. Brit. Mus. iii, 1-61, 262.

Labrosomus nuchipinnis, Pokr, Rep. Fis.-Nat. Cuba, ii, $1 \searrow 69,30 \S$.

Clime pectinifer, Cur.et Val., Hist. Nat. Poiss. xi, 1836,374(female).-MÜLl. \& Trosch.

in Schomburgk's Hist. Barbados, 1848, 6r1.-Cistelxad, Anim. Nouv. \&c.

Aniérique du Sud, 1855, Poiss. 26.

Labrisomus pectinifer, Swansox, Nat. Hist. Fishes f c. 1839, 2ат.-Cope, Trans. Am.

Phil. Soc. $18 \% 0,473$.

Labrosomus pectinifer, Gil.L, Proc. Acad. Nat. Sci. Phila. 1\$60, 105.--Poer, Mem. Hist.

Nat. Cuba. ii, $1=61,381$.

Climus capillatus, Cev. \& VAL, op. cit. 37 (male),-MÜlL. \& Trosch., l. c.

Labrisomus capillatus, Stinssox, 1. c. 
Labrosomus capillatus, GiLL, op. cit. 107.-Poey, l. c.

Lepisoma cirrhosum, DeKsx, New York Fauna, Fishes, 1842, 41, pl. xxx, f. 94.-STorer. Syn. Fish. N. Am. 49.

Ver5 common under stones in tide-pools and in crevices; their habits closely resembling those of the "Rock-eel" (Murcenoides mucronatus), so familiar to naturalists on the New England coast. Some individuals are brilliantly colored with red beneath, while others are gray. These differences are most probably sexual. My largest specimens are four inches long. The species is recorded from the Antilles, Bahia, Gorea, and the National M useum has specimens from Florida.

\section{SALARIAS TEXTILIS, $Q \cdot \& G$.}

Salarias textilis, Quoy \& Gamird, MS.-Cuvier \& Valenciennes, Hist. Nat. Poiss. $\mathrm{xi}, 307$.

2. Salarias vomerinus, CUV. \& VAL., op. cit. 349.

Salarias vomerinus (Cuv. \& VAL. ?) Jenyns, Zool. Voy. H. M. S. Beagle, Fishes, 1842, 88, pl. 17, f. 3.

This species, found in tide-pools in compaus with the preceding, appears to be identical with that brought by Quoy and Gaimard from the Isle of Ascension. The measurements do not agree precisely with those giren bs Valenciennes (which are expressed in very general terms); its colors, however, are precisel $y$ the same. It agrees in many points with the specimens collected by Darwin at Porto Praya, and provisionally referred by Jenyns to Salarias vomerinus, C. \& V.

The Bermuda specimens have the vomerine teeth and the four ventral rays, the omission of which in the description of Salarias textilis was Jenyn's chief reason for not referring the Cape Verde specimens to that species. The affinities of S. textilis and S. vomerinus, almays considered close, have some light thrown upon them by the discovery of vomerine teeth in the former. The question of their identity, however probable it may seem, must be rlecided by the comparison of a larger series of specimens. Such study will probably result in the establishment of a new genus for the reception of the species at present referred to Salarias, which possess vomerine teeth.

A detailed description of the Bermuda specimens is given for convenience in future comparisons. The greatest height of the body, at the beginning of the dorsal, is slightly less than one-sixth $(0.16)$ of the extreme length, and is four-fifths of the length of the head; the height of the lowest part of the candal peduncle equals one-half the greatest height of the bods (0.08). The head measures one-fifth $(0.20)$ of total 
length. The eye is slightly elliptical, and its longitudinal diameter equals the length of the snout, or one trrenty-fifth (0.04) of the total length. The interorbital space equals half the diameter of the orbit, and is concave. The profile is very obtuse, and the eye is situated just within the angle formed by profile and crown. There are two broadly-palmated superciliary filaments, not so long as the diameter of the orbit; two similar but smaller ones at the nostrils; aiso two short filaments, one on either side of the nape. The lips are crenated at the sides of the mouth, though not anteriorly. In addition to the row of numerous small movable teeth common to all the species of the genus, there is a long recurred canine tooth ou each side of the lower jaw, behind the series of small teeth; also, a transcerse row of minute teeth on the anterior portion of the romer.

The dorsal fin originates just behind the nuchal filaments, at a distance from the snout (0.22) slightly greater than the length of the liead; its spinous portion nearly equals its soft portion, the former measuring 0.30 , the latter 0.31. A deep notch almost separates the two parts.

The anal fin originates at a distance from the snout equal to one-half the lengtl of the body exclusive of the caudal (0.42). Its first ray measures $0.0 \%$, its penultimate ray 0.12 , its ultimate ray 0.05 . The caudal is four twenty-fifths. $(0.16)$ of the total length, and is slightly rounded at the extremity. The pectorals equal the head in length $(0.20)$, and barely reach to the veut. The distance from the suont to the upper axilla of the pectorals equals the distance to the origin of the rentrals, and also the length of the ventrals $(0.11)$.

The lateral line is faintly indicated by a delicate line, arching above the pectorals, then rumning straight aloug the middle.

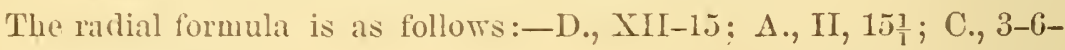
5-3; P., 14; V., I-t.

The color is greenish above, becoming white beneath. Twelre or fourteen brownish-violet cross-bands, arranged in pairs, and in part interrupted bs three series of whitish dots, so as to form a row of quadrate blotehes just abore the lateral line. The third row of white dots is more prononnced, the dots beconing short lines, and is situated on the lateral line; a fourth series, less pronounced, may be seen near the lower elge of the body.

A $Y$-shaped figure of brown upon the ehin, the arms extending forwarl, and three other fine brown lines on each side of the throat, exteuding trausversely upward and backward, continued upon the cheek and opercle by lines of fine brown dots. A row of similar dots may be seen 
a little below the base of the anterior part of the dorsal. The fascia nyon the sides extend on the dorsil, where they take an oblique direction backward. They are most prononnced at the base of the dorsal, forming a series of squares at the peint of its junction with the body. The caudal has five or six irregular vertical lines. The anal is pale at its base, the tips of the rays dark brown, pectorals and rentrals dusky.

\section{Measurements.}

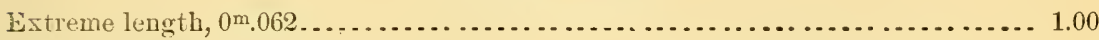

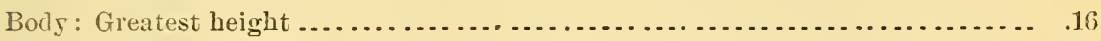

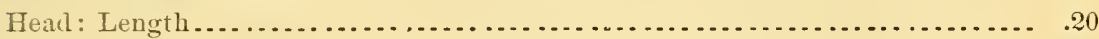

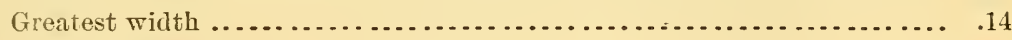

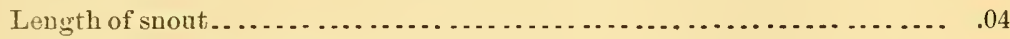

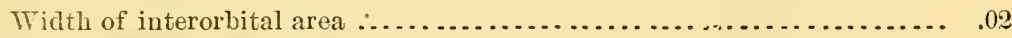

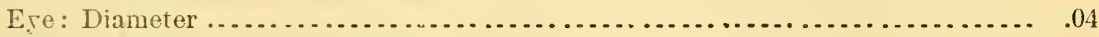

Dorsal (spinous) : Distance from snout............................ . .22

Length of base.................................. .31

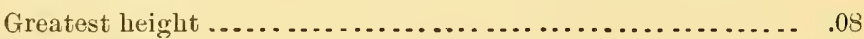

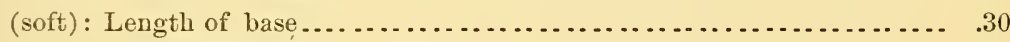

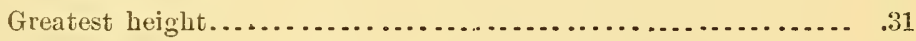

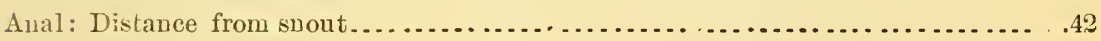

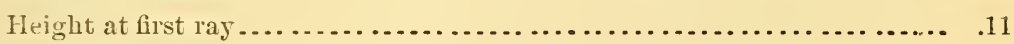

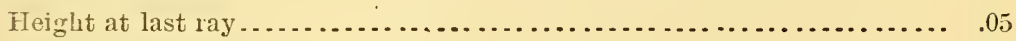

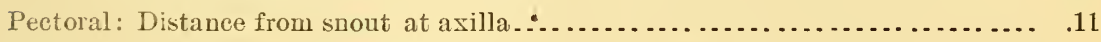

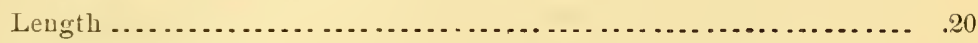

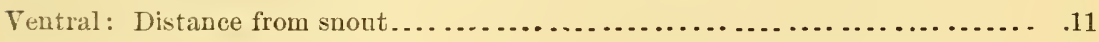

Length .....................................................

\section{TRIGLID E.}

\section{DACTYLOPTERUS VOLITANS, (Linné) Cuv.}

Pirapebe or Niivipira, MarcGrave, Hist. \&e. Brasil, 1648, 162.

Trigla rolitans, Lixwe, Syst. Nat. ed. 10, 1, 1758, 302; ed. 12, 1, 1766, 498.-Guelre, Linué, Syst. Nat. 1, 1788, 1346.-Bloch, Ichth. x, 1797, 93, tat. cecli.-SchneIDEr, Bloch, Syst. Ichth. 1801, 12.-Sнаw, Gen. Zool. iv, 622, pl. xei.

Dactylopterus volitans, Cuv. \& VAL., Hist. Nat. Poiss. iv, 1829, 117.-DeKaY, New York Fauna, Fish. 1842, 49, pl. xvii, f. 46.-Müluer \& Troschel, Schomburgk, Hist. Barbados, 1848, 667.-Guichenot, Explor. Scient. Algérie, Rept. \& Poiss. 1850, 41.-Castelnau, Auim. Nonv. \&c. Amérique du Sud, Poiss. 1855, 26.-Povy, Mem. ii, 1861, 367; Rep. Fis.-Nat. Cuba, ii, 1868, 304.-GilL, Cat. Fish. E. Coast N. Am. 1861, 43; Baird's Rep. on Sea Fisheries of Southern New England, 1873, 799.-Güvтruer, Cat. Fish. Brit. Mus. ii, 1861, 222.B.ırd, Rep. on Sea Fisheries of Southern New England, 1873, 824.

Morcielago, Parra, Descr. Uif. Piez. Hist. Nat. Cuba, 1787, 25, lam. xiv. 
Polynemus sexradiatus, Mrchicl, Amer. Month. Mag. 1818, 323 (figured as "The Sixrayed Polyneme," Traus. Lit. \& Phil. Soc. N. Y. 1815, pl. iv. f. 10).

Dactylopterus communis, Owex, Descr. Cat. Ost. Series, Roy. Soc. Surg. 1, 1853, 56. Gonocephalus macroccphalus, Groxow, Cat. Fish. (1780), ed. Gray, 1854, 106.

Rare and without a common name. The Colonial Museum at Hamilton and Mr. Bartram's collection at Saint George's each contain a dried specimen. Mr. Jones secured one in Hamilton Harbor in October, $18 \tilde{1} 1$.

The species ranges, from Newfoundland to Rio de Janeiro, throughout the West Indies, and to the Cape Verde Islauds, and the Mediterranean, where it is comparatively common.

\section{SCARIDAS.}

\section{SCARUS RADIANS, Talenciennes.}

\section{Spanisil PoRgr.}

Scarus radians, Cuv. \& Val., Hist. Nat. Poiss. xiv, 1839, 207.-Storer, Syn. Fish. N. Am. 1\&46, 147.-Gưrnis, Cat. Fish. Brit. Mns. iv, 1\&62, 207.-Guncmexot; Men. Soc. Inp. Sci. Nat. Cherbourg, $186 j, 10 .-$ Cope, Trans. Am. Phil. Soc. 1870,462 .

Labrus radians, C.stexxiu, Anim. Nouv. Ec. Amérique du Sud, 1E55, 29.

Common, occurring in large schools. The greatest length obserred was eight inches. Though seined in quantity, the Spanish Porgies are not eaten, their flesh, like that of the other members of this family, being dry and flarorless. .

The species is recorded from Balia, Mexico, and Saint Martin's. Specimens from Barbados and Jamaica are in the National Museum. Bermuda appears to be tle northern limit of its range.

Color.-Abore, olive, tinged with reddish-brown; beneath, rose-color; lead, upper part of body, and dorsal marbled with brown; caudai irregularly handed with black, the extremits and spots on the membrane white; anal immaculate (in sis specimens); base of pectorals black; chin white.

\section{PSEUdOSCARUS TETUL.1. (Schneider) Gill.}

\section{MUD FISH.}

Tieja, PArra, Descr. Dif. Picz. Hist. Nat. Cuba, 17=7, 5\%, lam. 28. fig. 1.

Scarus vetula, Blocit-Scinemer, Syst. Ichth. 1, 1801, 289 (description founded on Parra's figures).-Cer. \& Val., Hist. Nat. Poiss. xir, 1839, 193.-STomer, S n. Fish. X. Amer. 14j.-MÜller \& Troschel in Schomiungli's History of Barbados, 184:, 674.-Cope, Trans. Am. Phil. Soc. 18i0, 461. 
Pseudoscarus vetula, Gri, MS.

Scarus superbus, PoEx, Mem. Hist. Kat. Cuba, ii, 1860, 218.

Pseudoscarus superbus, GüNther, Cat. Fish Brit. Mus. iv, 1862, 218.-Poey, Rep. Fis.-Nat. Cuba, ii, 1858, 346.

Pseudoscarus psittacus, GüNTHER, op. cit. 225 .

The Iud-fish is very common, its gorgeous colors making it very conspicuous as it swims. The young may be seen by the hundred in the shallow rock-pools, while in the deeper waters the larger fish are sailing about with the precision and regularity of a squadron of cavalry under drill. Though its flesh is not unpalatable, this fish is not often brought to market; the enormous scales are much used in fancy work. The species is recorded from several Antilles.

The young fish differ much from the adult in coloration, their markings closely approximating those of Pseudoscarus sancte-crucis (Schn.) Gthr. Since no specimens of the latter species measuring more than eight or nine inches are on record, and none of $P$. vetula, in adult coloring, less than eighteen inches in length have fallen under my observation, it seems possible that the two species may be the same in different stages of growth, particularly since both are usually recorded from the same locality. The question of their identity may be easily decided by the Berwuclian naturalists.

As is indicated in the synonjmy, vetula is the specific name properly belonging to this species. Parra (l. c.) gives an excellent figure of the fish under the name Vieja, and on this figure Schneider founded his Scarus vetula, the specific name being a translation of Parra's Vieja. Of this fact, Valenciennes was arrare, and by it he was guided in adopting the name of Schneider. Professor Poey renamed the species with the remark: "C'est à tort que .I. Valenciennes rapport la figure de Parra au Sc. vetula," seemingly forgetful that Schneider's name was founded not upon specimens, but upon Parra's figure solely. Dr. Giinther, adopting the vierss of Prof. Poey, cites Scarus vetula as a synonym of Pseudo. scarus psittucus, (Linn.) Gthr.

\section{PSEUdOSCARUS CERULEUS, (Bloch) Gïnther.}

"Clamacore" OR "Kulmagóre."

Novacul. cerntea, Catessy, Nat. Hist. Carolina, Florida and the Bahama Islands, ii, 1743, 18, pl. 18.

Coryphona corulea, Bloc r, Ichth. v, 120.-Guelis, Linné, Syst. Nat. 1, 1788, 1791. Scarus caruleus, Schìnder, Bloch, Syst. Ichth. 1, 1801, 288. 
Pseudoscarus coruleus, Güstren, Cat. Fish. Brit. Mus. iv, 1862, 227-Guichexot. Proc. Soc. Imp. Sci. Nat. Cherbourg, 1865, 24.-PoEr, Rep. Fis. Nat. Cuba, ii, 1861, 348.

Trompa, Parra, Descr. Dif. Piez. Hist. Nat. Cuba, 1787, 57, lam. xxvii, f. 2.

Loro, PARRA, l. c. f. 1.

Scarus loro, SCHNEIDER, op. cit. 288.

Scarus trilobatus, Lacépìde, Hist. Nat. Poiss. ir, 1803, 21.

Sparus holocyanosus, LACÉPÈDE, op. cit. 45.

The "Clamacore" or "Kilmagore" is vers unusual in Bermudian waters; a single specimen of thirty-six inches was taken ontside the reefs in April, 1872, and was an object of much curiosity. The color in life was brilliant turquoise-blue, fading to olive-green in alcohol. The species is recorded from Cuba and some of the adjoining islauds.

Dr. Giinther suggests that this species is probably only the adult stage of one of the other species, such as Pseudoscarus chloris,

* The study of the synonymy of this species has brought to light an error, which may be referred to here. It appears that Parra's Firja, No. 3, and Schneider's scarus chloris, founded upon the figure of Parra, belong, not to Pscudoscarus, as is intimated by Dr. Güuther, but to Scarus; such is the judgment of Professor Poey after consulting the type of Parra's description, preserved is the Museum in Madrid. M. Guichenot, after an examination of the types in the Musée d'Histoire Naturelle, Paris, ret:ins in this genus Scarns virens, Valene. There now remains o' 15 Scarus quadrispinosus, Tal., as a synonjm of Ginther's Pscudorcarus chloris, and, of these names, that of Talenciennes has undoubted priority. The reversed synongmy should stand then somewhat as follows:-

\section{SCARUS CHLORIS, schn.}

Tieja, Parra, Deser. Dif. Piez. Hist. Jat. Cuba, 17\%7, 59, lam. 28, f. 3.

Scarus chloris, Scuxemen, Bloch, Syst. Ichth. 1201, 289 (on Parra's figure).-Cor', Trans. Am. Phil. Soc. 1870,461 .

Psoudoscarus chloris, Gïxther, Cat. Fish. Brit. Mus. iv, 1£62, 227.

Scarus virens, Cuv. \& Y.ı., Hist. Nat. Poiss. xiv, 1839, 203.-Storen, Syn. Fish. N. Am. 1846, 146.Míller \& Troschel in Schomburgh's Hist. Barbados, 1E48, 674.

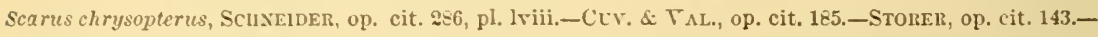
COrE, op. cit. $46: 2$.

Searus lateralis, Poer, Mem. Hist. Nat. Cuba, 1860, ii, 219; Rep. Fis. Nat. 1, 1867, 337, 375.

Habitat.-Cuba, Santa Cruz, Saint Christopher's, Saint Thomas, Martinique, Porto Rico, Barbados.

\section{Pseudoscarts quadrispinosts, (Talenc.) Guichenot.}

Scarus quadrispinosus, Cuv. \& VAL., Hist. Nat. Poiss. xir, 1839, 197.-Stoler, Syn. Fish. X. Am. 1846, $14 t$.

Pscudoscarus quadrispinosus. Gt"1chexot, Proc. Soc. Inıp. Sci.-Nat. Cherbourg. 1865, 27.

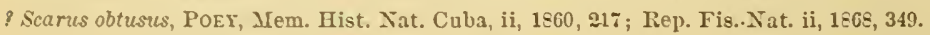

Pscudoscarus chlorie (not Bloch), Gëxther, Cat. Fish. Brit. Mus. iv, 1862, 227.-Core, Trans. Am. Phil. Soc. $1870,461$.

HaBitat.-Saint Thomas, Cuba, Jamaica, Bahamas. 
amination of specimens has convinced me that this is not the case. In the National Insenm are two well-characterized specimens of Pseudoscarus ccruleus, measuring vine and fifteen inches respectively, both of which have the hump upon the profile well developed, though not so prominent as in the adult specimen of thirty-six inches. Parra's two figures (lamina xxviii) named "Lorv" and "Trompa" represent different ages of this species, the prolonged caudal lobes as well as the additional size of the caudal lobe being characters of age.

\section{LABRIDA.}

\section{CHOEROJULIS RADIATUS, (Linné) Goode.}

\section{BLUE-FISH.}

Turdus Oculo radiato (Pudding-wife), CatesBr, Nat. Hist. Carol. \& s. 1743, ii, 12, tab. xii, fig. 1.

Sparus radiatus, Lrxxé, Syst. Nat. ed. 12, 1, 1776, 472.-Gmelrs, Linné, Syst. Nat. 1, $1788,1278$.

Doncella, Parra, Desc. Dif. Piez. Hist. Nat. Cuba, 1787, 95, lam. xxxvii, fig. 1.

Julis eyanostigma, Cuv. \& Val.., Hist. Nat. Poiss. xii, 1839, 391 (type 6 inches long).-

MÜLL. \& Troscr. in Schomburgk's Hist. Barbados, 1848, 673.-STorer, Ş̨n.

Fish. N. Am. 1846, 139.

Platyglossus cyanostigna, Günther, Cat. Fish. Brit. Mus. iv, 1862, 161.-CoPe, Trans.

Am. Phil. Soc. 1870, 464.

Charojulis cyanostigma, PoEY, Rep. Fis. Nat. Cuba, ii, 1868, 334.

Julis Principis, Cur. \& VAL., op. cit. 402, (type 11 inches long).-STorer, op. cit. 140, Platyglossus principis, Güxther, op. cit. 164.

Julis patatus (partim), Cuv. \& VAL. op. cit. 398 (types 13 to 15 inches long).-SToreR op. eit. 140.

The Blue-fish is frequently taken in the pots, though not valued as food. My largest specimen measures sixteen inches. The common name refers to the color of the adult fish. The species is recorded from several of the West India islands.

Color.-In the adult, a brilliant azure-blue, each scale edged with bright pearly-green. A longitudinal band on anal and the margin of the dorsal light blue. In the young, the prevailing hue is brownish, a large light-blue spot on the base of each scale. Head with spots and longitudinal stripes of light blue. Dorsal with broad margin, and fun lines of spots and blotches, longitudinally arranged, of the same colo: Caudal with broad white margin, outer rass blue to the extremitr, the base of the fin thickly spotted with the same. Anal with border and two longitudinal lines of blue, the fin being thus divided into th:ee 
nearly equal parts, a large circular spot of the same color at the base of each ray except the first. Pectoral with the first five rays and a narrow transverse line across the base from the fourth ray blue.

Iy notes on the colors of young and adult specimens of this species have led me to believe that the different ages have been described under several different specific names, as the synonymy given above wonid indicate. Julis cyanostigma was the name given by Curier and Valenciennes to specimens six inches in length, Julis principis to those of eleren inches, while those ranging from thirteen to fifteen inches are iucluded under Julis patatus. The specimens of larger size ("lindividus " plus de quinzes pouces"), included under the latter name, probably belong to another species. The 'Mudian fishermen recognize the difference in color to be caused by age.* I hare seen specimens with the colors of immaturity, which had attained the length of ten inches. It will probably be found that the change of color is not restricted to any fixed period in the growtl of the fish. Should farther in restigations sustain the opinion of Dr. Giinther that Linnés Sparus radiatus is a different slrecies from that figured by Catesby; the specific name cyanostigma should be retained.

\section{LACHXOLAIUS FALCATUS, (Limné) Fal.}

HOG.FISII.

Suillus (Great Hog-fish), Curessr, Hist. Carol. Florida and the Babama Islands, ii, 1743,135, tab. $x \mathrm{r}$.

Labus falcatus, Lixwe, syst. Nat. ed. 10, 1, 1758, 284; ed. 12, 1, 1766, 475.-Gmens,

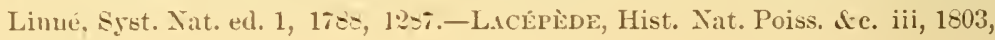
$4: 5,463$.

Lacholaimus falcutus, Cuv. \& V.aL, Hist. Nat. Poiss. xiii, 276.-Gëxther, Cat. Fish. Brit. Mns, iv, 1e6: \&7.-Poes, Rep. Fis.-Nat. Cuba, ii, 1E68, 330.-Cope, Trans Am. Phil. Soc. 1870, $4(44$.

Latholaimus aiguia, Cev. of V.aL., op. cit. 2⿰氵7, tab. 358 (type 11 incbes long).-STORER, Syz. Fish. N. Am., 136.

Lachnolaimus dux, Cur. \& V.ı., op. cit. 255 (trpe 8 inches long).-STorer, 1. c.

Lachuolaimus suillus, Cev. \& V.L., op. cit. 286 (type 24 inches long).-STORER, l. c.

Lachuolaimus caninus, CLT. A TAL., op. cit. $28 E$ (trpe 10 inches long).-STORER, l.c. Lachuolaimus psittacus, Crr. \& VAL., op. eit. 291.-STORER, 1. c.

Terr common here, as it is throughout the West Indies. Hog-fish

- Since the abore was written, I find that very similar conclusions bare beeu reached. by Professor Poey, who gires under Charojulis cyanostigma a s5noyyms uuch like the wiove.

TCat. Fish. Brit. Mus. ir, p. 164, note. 
Ledge, at the entrance to Hamilton Harbor, is marked by a pyramid of stone, called the "Hog fish Beacou," which is surmounted by a huge iron image of a Hog-fish.

The long streamer-like appendages or continuations of the vertical fins give to the Hog-fish as it swims a singularly graceful appearance. The beauty of those exposed in the market is frequently marred, how. ever, by having had these ornaments bitten off by the craw-fish and lobsters confined with them in the wells of the boats.

The Hog-fish attains the weight of twenty pounds, and is among the choicest of table-tish; its hard, white, exquisitely-flavored flesh has never been found injurious here, though in some parts of the West Indies it is regarded with suspicion. The common name refers to the swine-like profile and dentition.

\section{HARPE RUFUS, (Linné) Gill.}

\section{Spanish LADY-FISH.}

Pudiano vermellio, Marcgrave, Hist. \&c., Brasil, iv, 1648, 145.

Turdus flarus (Hog-fish), Catesny, Nat. Hist. Carol. Florida and the Bahama Islands, ii, 1743,11 , tab. xi, f. 1 .

Labrus rufus, Lixvé, Syst. Nat. ed. 10, 1, 1758, 284 ; ed. 12, 1, 1766, 475.-Gueliv, Linné, Syst. Nat. 1, 1788, 1287.-SchNeider, Bloch, Syst. Ichth. 1801, 244.-LACÉPède, Hist. Nat. Poiss. ii i, 1803, 427.

Cossyphns rufus, Gǜther, Cat. Fish. Brit. Mus. iv, 1862, 108.-Cope, Trans. Am. Phil. Soc. Phila. 1870, 463.

Harpe rufus, Gils, Proc. Acad. Nat. Sci. Phil. 1863, p. 222.

Bodianus rufns, Poey, Rep. Fis.-Nat. Cuba, ii, 1863, 331.

Perro colorado, Parra, Descr. Dif. Piez. Hist. Nat. Cuba, 1787, 3, lam. iii, fig. 1.

Bodianus bodianus, BLoch, Ichth. vii, 1797, 24, tab. cexxiii.

Cossyphlus bodianus, Cuv. \& VAL., Hist. Nat. Poiss. xiii, 1839, 103.

Lutjanus verres, BLoch, op. cit. tab. celv.

Sparus verres, Silaw, Gen. Zool. iv, 1803, 414.

Cossyphus verres, Castelnav, Anim. Nouv. ou Rares, Amérique du Sud, Ichth. $1855,27$.

Sparns falcatus, BLoch, op. cit. tab. cclviii.

Bodianns Blochii, Lacépède, Hist. Nat. Poiss. iv, 1803, 279, 290.

Horpe coruleo-aureus, LaCÉPìde, op. cit. 426, 427, tab. viii. fig. 2.

Labrns semiruber, LaḉṖ̀DE, op. cit. iii, 428.

Not common. The species is also recorded from various of the West India Islands, the Gulf of Mexico, Bahia, Rio de Janeiro, and Saint Helena. Closely-related species are known in the Spanish aud French Antilles under the names "Doncella" and "Demoiselle," and the Bermu- 
dian name mar perhaps be iucerpreted to mean "the fish which the Spanish call Lady-fish." The name is not inappropriate, for the species is remarkable for the grace of its form and the beanty and elegance of its colors. My specimens measure eight inches.

Color.-Head and upper half of body to the third ray of the soft dorsal rich chestnut-brown; the remainder, including the lower half of the operculum, bright golden-yellow.

The lips have couspicuous folds. The pre-operculum is very perceptibly denticulated. The two anterior ventral rassand the soft dorsal and anal and the caudal lobes are much produced, the dorsal and anal prolongations extending to the middle of the median caudal rays; the outer caudal rays are twice as long as the median.

\section{POMACENTRIDAE.}

\section{GLYPHIDODON SAXATILIS, (Limné) Cuvier.}

\section{CoW-PILOT; SERGEANT-MIAJOR.}

Jaguaeaquare, Mancrisure, Hist. Sc. Brasil. iv, 1648, 156.

Sparns fasciis quinque transtersis fuseis, Lrxws, Amœn. Acad. i, 1749, 312.

Chatodon fasciis quinqme albis, cauda bifurca, Lrxwe, Mus. Ad. Fried. i, 1754, 54.

Chatodon saxatilis, Lixié, Sy'st. Nat. ed. 10, 1, 1758, 27\% ; ed. 12, 1, 1766, 466.-Guelin, Linné, Ș̣st. Nat. 1, 1788, 1:253.-BLoch, Ichth. vi, 1787, 71, tab. cevi, f. 2 .

Glyphisodon saxatilis, Cev. \& V.al., Hist. Nat. Poiss. v, 1830, 446.-Müller \& Troschel

Schomburgli's Hist. Barbados, 1848, 674.-Castelxau, Anim. Nouv. ou Rares, Amérique du Sud, 1855, 11.

Glyphidodou saxatilis, Güxtmer, Cat. Fish. Brit. Mus. iv, 1e62, 36.-Ponr, Rep. Fis.-Nat. Cuba, ii, 1e68, 329.-Cope, Trans. Au. Phil. Soc. 1ะ70, 461. .

Chatodon Marginatus, Bloci, op. cit. tab. cerii.-LAcépède, Hist. Nat. Poiss.iv, 1803, $451,463$.

Chatodou Manitii, Bloch, op. cit. tab. cexiii, f. 1.-Schiserner, Bloch, Syst. Ichth. 1801,234 . LACÉṖ̀DE, on cit. $452,470$.

Chatodou sargoides, LaCÉrÈDE, op. cit. 453, 4i 1, 472.

Tery common in sheltered waters. The largest, six to eight inches in length, frequent the shallow sbaded cores in company with Pyeudoscarus retulu, Holacanthus citiaris, and Sarothrodus bimaculatus. The young may be seen basking in every shallow tide-pool. The origin of the cornmon name is not apparent, unless it refers to some supposed relation between this species and the Cow-fish (Acant'iostracium quadricorne), such as Nancrates ductor is supposed by sailors to bold with the Sharks. The tish is sometimes called the "Sergeaut-major," in allusion to the cherronlike bands of jellow on the sides. The species is rery common through. 
out the Test Indies, and has been observed as far south as Bahia and east to the Cape Verde Islands. Its accidental occurrence at Newport, R. I., has been recorded.

Color-Adults golden-green, young golden-yellow, with five black cross-bands, which are not as broad as the interspaces between them, the first from a point in front of the origin of the dorsal to the base of the pectoral; the second below the third and fifth dorsal spines; the third from the eighth and tenth dorsal spines toward the vent; the fourth from the twelfth and thirteenth dorsal spines to the middle of the anal; the fifth below the end of the soft dorsal and continued on the posterior rays of the dorsal and anal.

The rentrals, soft dorsal, and anal are produced; the fourth and fifth raș of soft dorsal and the fifth and sixth of anal longest. Dorsal and anal prolongations in young reaching to a point half-way between the posterior angle of dorsal and the base of candal rays; in adults reaching quite beyond the base of caudal rays. External caudal rays twice the length of median.

\section{GERRID E.}

EUCiNOSTOMUS GULA, (Cuv. \& Val.) Goode.

SHaD.

Gerres gu7a, Cuv. \& VaL., Hist. Nat. Poiss. vi, 1830, 464.-Jenyns, Zool. Voy. H. M. S.

Beagle, 1842, 58.-GüNther, Cat. Fish. Brit. Mus. iv, 1862, 255.-MÜLler \& Troscnel, Sushomburgk, Hist. Barbados, 1848.-PoEx, Mem. Hist. Nat. Cuba, ii, $1861,368$.

Diapterus gula, Poey, Rep. Fis.-Nat. Cuba, ii, 1868, 323.

Common and secured in quantity in the shallow bays, with Decapterus punctatus, Eucinostomus Lefroyi, and Trachurops crumenophthalmus. The largest specimens seen, which were apparently adult, measure six inches in length; intermediate sizes down to one inch were observed.

The species has also been seen about Martinique, Santo Domingo, Cuba, Jamaica, and Bahia. The "Turdus cinereus peltatus" of Catesby," for which he gives the common name of "Shad," seems to be identical with this species or the closely-allied Eucinostomus aprion, if not with the following species.

\section{EUCINOSTOMUS LEFROYI, Goode.}

\section{LONG-BONED SHAD.}

Diapterus Lefroyi, Goodw, Amer. Journ. Sci. \& Arts, viii, 1874, (Aug.) 123.

This species is distinguished from all other members of the family and genus by its relatively greatly-elongated form. The body is fusiform,

\footnotetext{
* Natural History of Carolina, Florida, and the Bahamas, ii, p. 11, tab. xi, fig. 1.
} 
compressed; its greatest height, at the thoracic region, being a little less than one-fourth (0.23) of the total length, and a little more than onefourth (0.27) of the length without caudal (0.89). In Eucinostomus aprion, the most elongated of the species hitherto described, the greatest heiglit is but one-third of the length.

The height of the body is uniform under the spinous portion of the dorsal, sloping gently, and at a nearly uniform angle above and below, to the middle of the caudal peduncle. The height of the body behind the dorsal $(0.10)$ is less than one-half, that of the least height of the tail $(0.06)$ is one-fourth of the greatest height of the body.

The scales are large, measuring 0.03 and 0.04 in height, and 0.02 and 0.03 in length; they form about forty'five oblique transverse rows between the head and the candal, four and a half longitudinal rows between the back and the lateral line, and ten longitudinal between rows the lateral line and the belly.

The length of the head (0.22) cquals the greatest height of the bods, and is double the greatest width of the head $(0.11)$; the height at the pupil $(0.14)$ is double the width of the interorbital space $(0.07)$. The leingth of the snout $(0.06)$ equals the length of the operculum $(0.06)$; when the mouth is protruded, the length of the snout is doubled (0.12), and when retracted, the posterior extremity of the intermaxillary proecss cxtends to the vertical through the center of the pupil. The nasals are very prominent, and the nostrils are nearer to the orbit than to the extremity of the jaw. The orbit is circular, its diameter $(0.08)$ one-third the length of the head.

The origin of the dorsal is slightly behind that of the rentral; its distance from the suout $(0.31)$ trrice the length of its base $(0.16)$. The dorsal spines are graduated nearls in the proportion $(\mathrm{I}=0.02 ; \mathrm{II}=0.12$; III $=0.11 ; \mathrm{IV}=0.10 ; \mathrm{V}=0.09 ; \mathrm{VI}=0.085 ; \mathrm{VII}=0.725 ; \mathrm{VIII}=0.05 ; \mathrm{IX}$ $=0.01)$. The notch betreen the spinous and soft portions is rery dcep, and the connecting membrane barely perceptible. In the soft iorsal, the fifth ray is the longest (0.09), and equals the fifth spinc; the succeding rays diminishing regularly to the last, which equals the ultimate spine (0.04); the length of its base $(0.20)$ is greater than that of the spinous dorsals. The anal begins behind the center of the body $(0.50)$; the first spine is very short $(0.01)$, one-fifth the length ( $(0.05)$ of the second, which is slender; the first ray is the longest $(0.08)$; the succeeding rays regularly diminishing in length to the last $(0.03)$. The lobes of the caulal are equal; the outer rass in length (0.21) fire times the inner ones $(0.04)$. The cxtremity of the pectoral reaches the rertical from the last dorsal spine; its distance 
from the snout at the axilla (0.25) is nearly equal to the length of the body. The rentral spine resembles the fifth dorsal. spine in shape and size. The length of the longest ray (0.11) slightly exceeds one-third of the distance from the snout to the ventral axilla $(0.30)$; the axillary appendage consists of four lanceolate scales, the first and the longest as long as the last rentral ras.

Color.-Silvery, with a bluish tint above; axils of the pectorals and extremity of snout brownish. Radial formula: D. IX, 10; A. II, 8, P. 12 ; V. I, 5 ; C. $3,9,9,3$.

The unit of measurement used above is the one-bundredth of the total length, which in an average specimen is 7.29 inches $\left(0^{\mathrm{m}} .185\right)$. The species is common in the protected inlets about the islands, in company with the preceding species, the "Shad." The "Long-boned Shad" are in much demand for bait, and are easily seined in large quantities.

The species is dedicated to his excellency Maj. Gen. J. H. Lefrof, F. R. S., goveruor of the Bermudas, a gentleman of well-known scientific attainments and reputation, who, while doing so much for the social and political welfare of the islands, is also taking an active part in the derelopment of their natural history.

Since the publication of the preliminary description of this fish, I have had the opportunity of comparing specimens from the Bermudas with others sent from Harana to the National Musenm by Professor Poey, by whom the species had been recognized as new, and described in IIS. under the name of Eucinostomus productus. The specimens are precisely the same, and coincide in having only two anal spines; a character in which they differ from the remainder of the genus, and which may prove to be, as suggested by Professor Poey, an indication of generic distinction.

\section{TEUTHIDID AE.}

ACANTHURUS NIGRICANS, (Linné) Gill.

\section{DOCTOR-FISII.}

Turdus rhomboidalis, CATESBY, Nat. Hist. Carolina, Flor. and the Bahama Islauds, ii, 1743, 10, tab. $x$, fig. 1 .

Chcetodon nigriscens cauda albescente aqali utrinque aculeata, Artedr, Dese. Spec. Pisc. 90. Chatodon nigricans, Lrvwe, Syst. Nat. ed. 10,1,1758, 274 ; ed. 12, 1, 1766, 462.-Gminus, Linné, Syst. Nat. 1, 1788, 1245.

Acanthurus nigricans, GILL in Baird's Report Sea Fisheries of Southern New England, 1873,801 . 
Acanthurus corulens, Schneider, Bloch, Syst. Ichth. 1801, 214.-Cuv. \& VAL., Hist. Nat. Poise. x, 1835, 179.-Guichexoт, Poiss. in Sagra, Hist. Nat. Cuba, 1845, 121.-Storer, Syn. Fish. N. Amer. 1846, 112.-Castelyau, Anim. Nouv. ou Rares, Amérique du Sud, 1855, 25, pl. 12, f. 2.-Güsther, Cat. Fish. Brit. Mus. iii, 1861, 335-Poex, Rep. Fis.-Nat. Cuba, ii, 1858, 355.-Cope, Trans. Am. Phil. Soc. $18 \% 0,474$.

Not uncommon. The species extends through the West Indies, and has also been observed on the coasts of Florida and South Carolina. Its quick nervous morements, as it plays about the recesses in the reet, are very characteristic. The local name has reference to the lancet-like processes on the sides of the caudal peduncle. The "Barbero" and "Barbeiro" of Cuba and Brazil, and the "Chirurgien-bleu," "Porte Lancette," and "Saigneur" of the French Antilles, are names of similar origin.

Color.-Bluish-bromn; dorsal and anal with numerous obliquely longitudinal lines of light blue. Caudal spine amber-colored, glassf, posteriorly half as long as anteriorly. A prominence in front of orbit; profile of suout slightly concave. Operculum, pre-operculum, and scapular bones with deep strie. Upler jaw with seven, lower with eight five to eight lobed incisors.

\section{ACANTHURUS CHIRURGUS, (Bloch) Schneitler.}

\section{DOCTOR-FISH.}

Chatodon nigricans, Blocir, Ichth. vi, 17єð, 60, tab. ceiii (not Linné).

Acauthurus nigricans, Schxeider, Bloch, Syst. Ichth. 1=01, 211.

Chatorlon chirnrgus, Blocir, op. cit. tab. ceviii.-Gırers, Limne, Syst. Nat. 1788, 1259. Acanthurus chirmrgus, Schxemen, op. cit. 214.-Cov. \& VAL., Hist. Nat. Poiss. $\mathbf{x}$, 1835, 168.-Сuсnехот, Poiss, in Sagra, Hist. Nat. Cuba, 1845, 120.-Storer, Syn. Fish N. Am. 1E46, 113.-Castelyau, Anim. Nouv, ou Rares, Amérique du Sud, 1855,"21-Güxtrer, Cat. Fish. Brit. Mus. iii, 1861, 329.-Poey, Rep. Fis. Nat. Cuba, ii, 186;, 355.-Cope, Trans. Am. Phil. Soc. Phila. 1670, 474.GILL in Baird's Rep. Fisheries of Southeru New England, 18i3, 801.

Acronums fuscus, Groxow, Cat. Fish. (1780), ed. Gray, 1854, 191.

This species undoubtedly occurs, associated as it always is with the preceding. The name "Tang;" found in the list of local names, is prob. ably applied to one or both, if we can judge from the remarkable correspondence of the local names in the Bermuda and Bahama groups. 


\section{CHATODONTIDEE.}

\section{SAROTHRODUS BIMACULATUS, (Bloch) Poey.}

\section{Four-EYed FisH.}

Chatodon bimaenlatus, Blocr, Ichth. vii, 1797, tab. cexix, f. 1.-Scnnemer, Bloch, Syst. Ichth. 1801, 225.-Cuv. \& VAL., Hist. Nat. Poiss. vii, 1831, 67.-Storer, Syn. Fish. N. Am. 1846, 86.-GüNther, Cat. Fish. Brit. Mus. ii, 1861, 9.-Poey, Mem. Hist. Nat. Cuba, ii, 1861, 37 ].

Sarothrodus bimaculatus, Poer, Rep. Fis. Nat. Cuba, ii, 1868, 353.-Cope, Trans. Am. Phil. Soc. $1870,474$.

The "Four-eyed Fish" is usually seen in sheltered coves, lazily swimming a fer feet below the surface, under the shadow of some high rock. Its local name has reference to the eye-like spots near the tail, which the fishermen believe to be a true pair of eyes. The species is also recorded from the northern West Indies.

Color.-Pearly-gray ; snout, posterior edge of opercnlum, base of pectoral, the anal, caudal, and dorsal bright yellow, blending into the gray of the borly. A band, black, edged with sellow, extends from a point in front of and below the first dorsal spine across the eye to the margin of interoperculum; soft dorsal with a large round indistinct black spot at its base between the fifth and twelfth rays, and a small spot of deep black at its angle; soft dorsal with narrow marginal line of black; soft anal with narrow, submarginal band of light blue, anteriorly edged with black; caudal with terminal band of bluish-white, with brightseliow center; base of rentrals blotched with yellow.

\section{HOLACANTHUS CILIARIS, (Linné) Lacépède.}

\section{ANGEL-FISH.}

Acarauna major pinnis cornutis, Catessy, Nat. Hist. Carolina, Florida, and the Bahama Islands, ii, 31, tab. $x x x i, 1743$.

Chatodon griseus fasciis quatuor fuscis, Liswe, Mus. Ad. Fried. 1, 1754, 62, tab. xxxiii, f. 1. Chotodon ciliaris, Lixvé, Syst. Nat. ed. 10, 1, 1758, 276; ed. 12, 1, 1766, 465.-Gmein, Linné, Syst. Nat. 1, 1788, 1252.-BLoch, Ichth. vi, 1788, 83, taf. ecxiv.SCHNEIDEI, Bloch, Syst., Ichtl. ell. 1801, 218.

Holacanthus ciliaris, Lacírède, Hist. Nat. Poiss. iv, 1803, 527-534.-Cuv. \& Val. Hist. Nat. Poiss. vii, 1831, 154.-Güxrner, Cat. Fish. Irit. Mus. ii, 1861, 46.Poey, Mem. Hist. Nat. Cuba, ii, 1861, 371; Rep. Fis.-Nat. Cuba, ii, 1868, 351.Girt, Baird, Rep. on Sea Fisheries of Southern New Eugland, 1873, 802.

Gabelita, Parsa, Desc. Dif. Piezas Hist. Nat. Cuba, ii, 1787, 11, tab. vii, f. 1.

Clactodon Parro, Schneider, op. cit. 235 (ou Parra's figure). 
Chatodon squamulosus, Sнaw, Nat. Misc. ——, 275.

Chatodon Catesbeii, SHaw, Gen. Zool. iv, 1, 1803, 325.

Chatodon cornutus, Desmarest, Déc. Ichthyol.

Chatodon aculeatus, Gronow, Cat. Fishes (1780), ed. Gray, 1854, 72.

Common. The species is found, also, in the West Indies, at Bahia, and on the coasts of Mexico. The Angel-fish is partial to sheltered parts of the reef, where it may be seen lazily and gracefully swimming or floating a few feet below the surface. Its motions are very slow; and it frequently swims upon its side, or, sinking to the bottom, swims perpendicularly to the surface, where its bright colors flash for a moment as it floats broadside upward. I have frequently seen them grazing upon the alga-corered rocks. The Angel-fish attains the weight of four pounds, and as far surpasses all the other fishes of the region in its delicious flaror as in its lọrely hues. The largest $I$ have seen measured fifteen inches from suout to extremity of soft dorsal.

Color.-Brown with a sharle of olive-green, each scale edged with a lighter tint; on the dorsal and anal fins, the brown has reddish tinge. Chin, nape, base of pectoral, borders, and spines of operculum and preoperculum, bright cobalt-blue. Extremity of pectorals, bright jellow. Borders of dorsal and anal bright blue, passing through a virid green to bright yellow on the slender streamers formed by the prolongations of the soft dorsal and anal fins. Caudal bright yellow, with narrow border of greenish blue. Base of rentrals blue, passing through green into sellow at the extremities. Young and half-gromn individuals are ornamented with three or four broad transrerse bands of blue and jellow.

My specimens, some twelre in number, differ from all descriptions in the absence of the spot of brown, encircled with blue, on the nape. I hare ex:mined numerous West Indian specimens and find it universally present. Should this character prove constant, the Bermuda Angel-fish may be considered a geographical rariets, Holacanthus cilieris, rar. Bermudensis.

\section{HOLACANTHUS TRICOLOR, (Bloch) Lacépède.}

\section{BLACK ANGEL-FISH.}

Acarauna, Enwands, pl. 583, f. 4.

- La Teure C'oquette, Dem.nel, Trait. Gén. Pesch. 1782, pt. 2, pl. 13, f. 1.

Catalineta, Pırra, Deser. Dif. Piez. Hist. Nat. Cuba, 1787, 12, lam. rii, f. 2.

Chatodon tricolor, BLoch, Ichth. xii, 1797, tab. 425.-SchNember, Bloch, S5st. Ichth. $1=01,219$. 
Holacanthus tricolor, L.AcÉṖ̀de, Hist. Nat. Poiss. iv, 1803, 525-530.-Cuv. \& VaI., Hist. Nat. Poiss, vii, 1831, 162.-Castelnau, Anim. Nouv. ou Rares, Anér. du Sud, 1855, 19.-Güsther, Cat. Fisb. Brit. Mus. ii, 1861, 49.-Poer, Mem. Hist. Nat. Cuba, ii, 1861, 371; Rep. Fis.-Nat. Cuba, ii, 1868, 352.

Occasional. Mr. Jones captured a specimell in 1871, and the name occurs on the local list. The species occurs throughout the West Indies, an $d$ is also recorded from Bahia and Trinidad.

Chcetodon arcuatus, (Linu.) Cuvier, is also likely to occur in these waters.

\section{XIPHIIDA.}

The name of "Sword-nish" oceurs on the local list. The common Srord-fish (Xiphias gladius, Linn.) must oceur in Bermuda waters, and probably also 'Tetrapturus albidus, Poey, and Histiophorus americanus, Cur. \& Val.

The following reference to the Sword-fish occurs in "Newes from the Bermudas," a pamphlet dated Burmuda, July, 1609, and reprinted in "Force's Historical Tracts," vol. ii.

Whate, Sicord-fish \& Threasher.- "The sword fish swimmes under the whale, \& pricketh him upward: The Threasher keepeth above him, \& with a mighty great thing like unto a flaile, hee so bangeth the whale, that hee will roare as though it thundered, \& doth give him such blowes, with his weapon, that you would thinke it to be a crake of great shot."(Page 22.)

\section{SCOMBRIDA.}

\section{OROYNUS ALLITERATUS, (Rafinesque) Gill.}

\section{MACKEREL.}

Scomber alliteratus, RdFrnesque, Caratteri \&c. Anim. Sicilia, 1810, 46.

Oreymus alliteratus, Gill, Baird, Rep. Sea Fisheries of Southern New England, 1873, 802.-Barrd, Rep. Sea Fisheries of Sonthern New England, 1873, 825.

Maquereau à Quatre Points, Geofrr. St. Hilarie, Desc. Egypí. Hist. Nat. 1813, pl. xxiv, f. 3.

Thynnus Leaciianus, Risso, Hist. Nat. Eur. Merid. iii, 1827, 414.

Thynnus thunnina, Cuv. \& Val. Hist. Nat. Poiss. viii, 1831, 104.-Bleeker, Verhandl. Batav. Genootsch. xxiv, 1851, 36. - Tem.. \& Schleg., Fauna Japonica Poiss. 1850, 95, pl. 48.-Guichenot, Rept. et Poiss. Exp. Scient. Algérie, 1850, Poiss. 57.-GüNTher, Cat. Fish. Brit. Mus. ii, 1861, 364.

Orcynus thunnina, Poey, Rep. Fis.-Nat. Cuba, 1, 1867, 321; ii, 1868, 362.

Thynnus Brasiliensis, Cuv. \& VAL., op. cit. 110.-Powy, Mem. Hist. Nat Cuba, ii, 1861, 373.

Thynnus vagans, Lessox, Voy. Coquille, Zool. ii, 1830, 162, pl. cxxxii. 
Large schools were obserred in March. This large and powerful pelagic fish has been observed in the Mediterranean, on the east of Norway, in the East Indies, on the coasts of Brazil and Cuba, and was found in 1871 by Professor Baird in large numbers at Wood's Hole, Mass, and several hare since been takeu on the shores of Southern New England. It is highly valued for bait, but is the only large fish which is not thought good to eat; thongh rather oily, I think it superior to many of the Bermuda food-fishes. It attains the length of two feet and a half.

\section{CARANGIDE.}

\section{DECAPTERUS PUNCTATUS, (Agassi ) Gill.}

\section{Round RoBin.}

Scomber hippos, Mitcnill, Amer. Month. Mag. 1818, 246 (not Linné), (figured as "The Hippos Mackerel," Trans. Lit. \& Phil. Suc. N. Y. 1815, pl. 5, f. 5).

Caranx punctatus, AGassiz, Selecta Gen. et Spec. Pise. Brasil, coll. Spix, 1829, 108, pl. Ivi $a$, f. 2.-Cur. \& V.l., Hist. Nat. Poiss. ix, 1833-38.-DeKay, New York Fanna, Fish, 1842, 122, pl. 73, f. 123 (cupied from Mitchill).-Stoner, S5n. Fish. X. An. 1846, 101.-GÜxtner, Cat. Fish. Brit. Mus. ii, 1861, 446.

Decapterus punctatus, Gill, Proc. Acad. Nat. Sci Phila. 1E62, 432; and in Baird, Rep. on Sea Fisheries of Southern New England, 1-73, 803.-Porr, Rep. Fis.-Nat. Cuba, ii, 1868, 368 (see, also, Mem. ii, 374).-Bımi, Rep. on Sea Fisheries of Southern New Eugland, 1873, 825.

Vers common. This species ranges aloug the coast from Brazil to Cape Cod, and has been seen at Cuba and Martinique. The Round Robin is seined in great numbers in Hamilton Marbor, in company with the various species of Clupeide and Gervider, and is sold from row-boats along the quat at the legal rate of four-pence a pound. The largest measure six iuches. "Jigging robius" is a farorite amusement of the little negroes. A fer bread-crumbs are thrown orer the dock, and the little fish collect in such numbers that a line with a bare fish-hook jerked rapidy through the group seldom fails to impale one or more. The local name seems to be fanciful in origin; at Barbados, it is giren to the allied species Decapterus macavellus, which perbaps also occurs at the Bermudas.

Color.-Above, olive-brown; beneath, white, with pearly reflections. A golden stripe along the lateral line, studded with small black spots, mhich cease at the commencement of the lateral plates. Eye sellow, mith black iris. 
TRACHUPOPS CRUMENOPHTHALMUS, (Bloch) Gill.

GoGGLER; GOGGLE-EYE.

Scomber crumenophthalmus, BLOCH, Ichth. x, 1797, 65, taf. cccxliii.

Caranx crumenophthalmus, Liḉpł̀de, Hist. Nat. Poiss. iv, 1803, 107.-Cuv. \& Val,

Hist. Nat. Poiss. ix, 1833, 62.-GüxтHen, Cat. Fish. Brit. Mus. ii, 1861, 429.

Trachurops crumenophthalmus, Gill, Proc. Ac. Nat. Sci. Plila. 1862, 432; and in Baird,

Reps. on Sea Fisheries of Southern New England, 1873, 803.-Powx. Rep. Fis.

Nat. Cuba, ii, 1868, 357.-Barnd, Rep. on Sea Fisheries of Southern New Eng-

land, 187:3, 825.

Scomber balantiophthalmus, SchNeider, Bloch, Syst. Ichth. 1801, 29.

Scomber plumieri, Blocn, op. cit. tab. ccclxiv.-Schnemder. np. cit. 30.

Caranx plumieri, CUr. \& VAL., op. cit. 65.-Müll. \& Trosch., Schomburgk, Hist. Barba-

dos, 1848, 669.-Guichexot, Poiss. in Sagra, Hist. Nat. Cuba, ii, 1845, 110.

Caranx Daubentonii, LAḉpł̀de, op. cit. iii, 59, 71.

Caranx macrophthalmus, RüPPELL, Atlas, Reise Nord-Africa, Fische, 1828, 97, tab. xxv,

f. 4 (not Agassiz).

Caranx macrophthalmus, AGassiz, in Spix, Select. Gen. \& Spec. Pisc. Brasil, 1829, 107, pl. lvi $a$, f. 2 (not Rïppell).

Caranx mauritianus, Qroy \& Gamard, Voy. Uranie \& Physicienne, Zool. 1824, 359.

Common; the species, like the preceding, is found in the West Indies and on the coast of the United States to Southern Massachusetts; it is found also at Mauritius, in the Pacific and Indian Oceans, the Red Sea, and on the coast of Guinea. The Goggler reaches the reight of a pound, is found with the preceding, and is used for food. The local names refer to its great, staring eyes.

Oolor.-Abore, lluish; beneath, silvery white.

PARATRACTLS PISQUETUS, (Cuv. \& Val.) Gill.

\section{JACK; BUFFALO JACK.}

Caranx pisquetus, Cuv. \& Val., Hist. Nat. Poiss. ix, 1833, 97.-Poey, Mem. Hist. Nat. Cuba, ii, 1861, 373.

Paratractus pisquetus, GiLl, Proc. Ac. Nat. Sci. Phila. 1862, 432; Baird's Rep. Sea Fisheries of Southern New England 1873, 803.-Poìr, Rep. Fis. Nat. Cuba, ii, 1868, 365.-Burrd, Rep. Sca Fisheries of Southern New England, 1873, 825.

Caranx chrysos, DeKay, Fishes, New York Fauna, 1842, 121, pl. xxvii, f. 85 (not Scomber chrysos, Mitchill).-B.irnd, Fishes New Jersey Coast, 1855, 22.

Carangus chrysos, Grrard, Ichth. U. S. \& Mex. Bound. Surr. 1859, 23.

Caranx hippos, Holbivor, Ichth. South Carolina, 1856, 88, pl. xii, fig. 2 (not Scomber hippos, Linné).

Carangus hippos, Gill, Cat. Fish. E. Coast N. Am. 1861, 36.

Trachurus squamosus, Groxow, Cat. Fish. (1780), ed. Gray, 1854, 1:5.

The Jack, or Buffalo Jack, is common, occurring also in the Wcst 
Indies and on the coast of Brazil, and the United States as far north as Cape Cod. Its habits closely resemble those of the preceding species. My largest specimen is nine inches long; the fishermen claim that the species attains the weight of five or six pounds, but they probably confound this with some other species of the same family.

Color--Above, light slate; beneath, pearly white; snout and line over the orbit blue. Second dorsal margined with black. Base of lateral plates and tip of caudal light brown.

\section{NACCRATES DUCTOR, (Linné).}

\section{PILOT-FISH.}

Gasterosteus ductor, Lixif, Syst. Nat. ed. 10, 1, p. 295.

Naucrates ductor, Cuv. \& VAL., Hist. Nat. Poiss. viii, p. 312, pl. 332.

This universally-distributed species occasionally finds its way into the hands of the Bermudian fishermen.

ZONICHTHYS FASCIATUS, (Bloch.) Swainson.

BONITO.

Scomber fasciatus, Blocu, Ichth. x, 61, taf. cecxli, 17 ; Syst. Ichth. ed. Schxeider, 29. Seriola fasciata, Cuv. \& V.ı., Hist. Nat. Poiss. is, 211, 1833.-Güxtier, Cat. Fish. Brit. Mus. ii, 464.

Zonichthys fasciatus, Swanson, Nat. Hist. Fish. \& Rept.-Gill, Cat. Fish. E. Coast N. Am. 1861, v, 36, and in Rep. U. S. Com. Fish. 18\%1, 803.

Mulatractus fasciatus, PoEr, Rep. Fis. Nat. Cuba, ii, 373, 1868.

Tot uncommon; recorded also from Cuba and South Carolina. A specimen was taken near New York in October, 1875, and is now in the National Irusemm. The Bonito is an excellent tabie-fish, and reaches the length of two feet or more.

The "Amber-fish," the "Guelly," or "Carally" (Caballa ?), the "Slippery Dick," and the "Skip-jack" of the fishermen probably beloug to this family ; but, as I secured no specimens, they cannot be identified. The "Slip-jack" is perhaps an Oligoplites, and the "Amber fish" is doubtless a Seriola.

\section{CORTPHANID E.}

CORYPHAENA HIPPURUS, Linn.

\section{DOLPIII.}

Coryphana hippurus, Lrxé, Srst. Nat. ed. 12, i, 446.

I obserred a Dolphin, measuring five or six feet, playing about our steamer in the Gulf Stream, about two hundred miles northwest of the Bermudas. The Dolphin is well known to the fistermen. 


\section{MULLIDA. \\ HYPENEUS MACULATUS, (Bloch) Ouv.}

\section{GOAT-FISH.}

Pira metara, Mancgrave, Hist. \&c. Brasil, 1648, 156, 181.

Inllus maculatus, Bloch, Ichth. x, 1797, 79, tab.348.-Schnemer, Bloch, Syst. Ichth. $1801,78$.

Cpeneus maculatus, Cuv. \& VAl., Hist. Nat. Poiss. iii, 1829, 478.-Storer, Syn. Fish. N. Am. 1846, 48.-Poey, Mem. Hist. Nat. Cuba, i, 1853, 223 ; ii, 1861, 367.-CastreNAU, Anim. Nouv. \&e. Amérique du Sud, Pois. 1855, 6.-Günther, Cat. Fish. Brit. Mus. i, 1861, 408.-Cope, Trans. Am. Phil. Soc. 1870, 471.

Mulliypeneus macnlatus, Poes, Rep. Fis.-Nat. Cuba, ii, 1868, 307.

I did not secure a specimen, but was told that a fish of this description is common among the reefs. Godet, in his "History of Bermuda," gives a description of color which is apparently taken from specimens by him, which renders the identification sufficiently certain. The species is also recorded from Cuba, Jamaica, Martinique, and Rio de Janeiro.

\section{BERYCID E.}

\section{HOLOCENTRUM SOGO, Bloch.}

\section{SQUIRREL.}

Jaquaraca, Marcgrave, Hist. \&e. Brasil, 1648, 147.

Perca marina rubra, Catbsir, Nat. Hist. Carolina, Florida, and the Bahama Islands, ii, 1743, 2., tab. ii, f. 2.

Bodianus pentacanthus, BıocH, Ichth. vii, 1797, 29, tab. cexxxv (a badly-distorted copy of Marcgrave's figure).

Holocentrus sago, BLOCH, op. cit. 46, tab. cexxxii.

Holocentmum sogho, Gill, Cat.'Fish. E. Coast N. Am. 41, 186; and in Baird's Rep. on Sea Fisheries of South. New England, 1873, 804.

Holocentrus rubellus laminis branchiostegis serratis etc., Brows, Hist. \&c. Jamaica, 1799, 447.

Sogo holocentrus, SHaw, Gen. Zool. v. 1803, 555.

Zoulianns jaguar, LACÉPł̀DE, Hist. Nat. Poiss. \&c. iv, 1803, 236.

Scicena rubra, SchNeIDER, Bloch, Syst. Ichth. 1801, 82 (not'Forskâl).

Eolocentrum longipinne, Cuv. \& VaL., Hist. Nat. Poiss. iii, 1829, 181.-STorer, Syn.

Fish. N. Am. 1846, 46.-GüNther, Cat. Fish. Brit. Mus. i, 1861, 28.-Cope, Trans. Am. Phil. Soc. 18\%0, 465.

Common; its bright color and nervous darting motions rendering it one of the most conspicuous denizens of the rock-pools. It is found $4 \mathrm{~F}$ 
throughout the West Indies and south to Brazil. Their voracity is very great, and the tyro in angling usually finds his first prize to be a "squirrel." They are not often eaten. They breed plentifully about the islands, and reach a length of fifteen inches; the lobes of the vertical fins beconing proportionally more and more produced with age. The local name is the same as that giren by Catesby, and refers to a grunting noise uttered by them, which resembles the bark of a squirrel.

The Cuban form seems to be nearly the same; but Professor Poey hesitatingly places it in a distinet species.

\section{SCI ENID A.}

Genus Pareques, Gill, MS.*

PAREQUES ACUMINATUS, (Schneider) Gill.

\section{Carrub.}

Grammistes acuminatus, ScIneIder, Bloch. Sjst. Ichth. 1801, 184.

Eques acuminatus, C.sstrexat, Anim. Nonr. \&e. Amérique du Sud, Poiss. 1855, 11.Güxтner, Cat. Fish. Brit. Mus. ii, 1861, 280.-Poky, Mem. Hist. Nat. Cuba, ii, 1Е61, 370; Rep. Fis.-Nat. Cubal, ii, 1868, 325.-Cope, Trans. Am. Phil. Soc. 1870, $4 i 1$.

Eques lineatus, Cur. \& VגL., Hist. Nat. Poiss. v, 1830, 169.

Common here, though of rare occurrence elsewhere, having been obserred only at Cubat, Santa Cruz, and Bahia ; not valued for food. My specimens measure eleven inches. The name "Carrub" is inexplicable, unless it be a corruption of "Carp."

Color.-Tamy:sellow; extremities of fins and base of pectorals and rentrals blackish.brown; head blotched with the same. Two specimeus have seren straight, longitudinal lines upon the side; the third is without any traces of such markings. Whether this difference is sexual, I have no means of determining. The first dorsal is one-fourth the beight of the body, measured immediately below it.

* The genus Pareques is distinguished, according to Professor Gill, by the derelopment of the spines of the first dorsal fin in normal number, (ten or eleven,) as well as other osteological characters. 


\section{SPARIDAE.}

\section{CALAMUS MEGACEPHALUS, (Swainson) Poey.}

\section{GOAT'S HEAD PORGY.}

Pagellus calamus, Cuv. \&. VAL., Hist. Nat. Poiss. vi, 1830, 206, pl. 152.-Poer, Mem. Hist. Nat. Cuba, ii, 1861, 367.

Sparus calamus, PoEr, Rep. Fis.-Nat. Cuba, ii, 1868, 308.

Calamus megacephalus, Swainsox, Nat. Hist. Fish, ii, 1839, p. 222.-Guichenot, Mem. Soc. Imp. Sci. Nat. Cherbourg, xix, 1868, 112.-Poer, Ann. Lyc. Nat. Hist. x, 1874,178 .

Common; found also in the West Indies, reaching south to Bahia. My specimens measure from six to eighteen inches.

\section{CALAMUS ORBitariUs, Poey.}

\section{Sheep's-hend Porgy.}

Pagellus orbitarius, Poey, Mem. Cuba, ii, 1860, 201; 1861, 367.

Sparus orbitarius, Poey, Rep. Fis.-Nat. Cuba, ii, 1868, 308.

Calamus orbitarius, Poex, Ann. Lyc. Nat. Hist., N. Y., x, 1874, 79.

Common; recorded also from Cuba. This species very closely resembles the preceding in form and babits, but is easily distinguished by the shortness of the snont, which gives it a very abrupt profile. In S. calamus, the diameter of the orbit is contained twice in the distance from the extremity of the snout to the perpendicular from the anterior border of the orbit; in S. orbitarius, once and one-half. The height of the two specimens before me is the same; and, in S.calcmus, the height is contained in the length twice and three-quarters; in S. orbitarius, twice and one-half. The specimens measure sixteen and fifteen inches, respectirely.

Color.-Both species, greenish-olive, with golden longitudinal stripes. The names Goat's-head and Sheep's-head no doubt refer to the enormous pre-orbital bones which impart an ovine physiognomy to the fish. The Porgies are taken with the hook in large quantity, and rank among the most salable kinds. They live in deep water; and, when bronght to the surface, their bellies are greatly expanded from the removal of pres. sure, giring them a very comical appearance. 


\section{SARGUS VARIEGATUS, (Lacépède, Goode.}

\section{Cinub.}

Sparus Surgus, Lixwé, Syst. Nat. ed. 10, 1, 1758, 278; ed. 12, 1, 1766, 469.-Guelin, Linné, Syst. Nat. 1, 1788, 1270.-BLoch, Ichth. viii, 1797, 31, tab. cclxıv.Schneider, Bloch, Ş̧st. Ichth. 1801, 270.-LacéPìde, Hist. Nat. Poiss. iv, 1803, 27, 77.-Risso, Ichth. Nice, 1810, 236.

Sargus variegahus, LACÉPł̀de, op. cit. iv, 1803, 207 (from Haür, Encyclopédie Methodique.)

Sargus raucus, Geoffror St. Hilaine, Descr. de l’Eggpte, Poiss. 1813, pl. xviii, f. 1. Sargus Rondeletii, Cuv. \& Val., Hist. Nat. Poiss. vi, 1830, 14, pl. cxli.-Valenciexnes. Webb \& Berthelot, Hist. Nat. Cauaries, Poiss. 1836, 28.-Guichenot, Expl. Scient. Algérie, Poiss. 1850, 46.-Güxthen, Cat. Fish. Brit. Mus. 1ع61, 44.

Very abundant; occurring in large schools in company with Pimelepterus Boscii, which it closely resembles in form and habits. It is strictly European, and is especially common in the Mediterranean, but has not been found west of Madeira and the Canaries. I have carefully compared Bermudian specimens with Mediterranean specimens in the Boniparte collection labeled Sargus Rondeletii. The Chub is seined in vast quantities in Hamilton Harbor and other secluded bays. My specimens measure from ten to twelve inches.

\section{PIMELEPTERID E.}

PJMELEPTERUS BOSCH, Lacépède.

Breay.

Chatodon eyprinaceus, Bnocssoxet, MS.-GMelix, Linné, Syst. Nat. 1, 1788, 1269, note Pimelepterus Boscii, Lacĺpène, Hist. Nitt. Poiss. iv, 1z03, 429,-Cuv. \& Val., Hist. Nat. Poiss. vii, 1831,25:- - Valexciexwes, in Webb of Berthelot, Hist. Nat. Cauaries, 1836, pl. xix.-DEK.1Y, Zool. N. Y. Fishes, 1042, 100, pl. xx, fig. 56.-SToner, Syn. Fish. X. A. 1846, 89.-Güxtier, Cat. Fish. Brit. Mrus. i, 1E61, 49\%.-Gili, Cat. Fish. E. Coast N. Am. 1e61, 31.-Powr, Rep. Fis.-Nat. Cuba, ii, 1868, 323.Grul, in l3aird's Rep. on Sea Fisheries of S. New Eugland, 1873, 805.-Banid, Rep. Sea Fisheries of S. New England, 1073, 824.

Pimelepterus incisor, V.ALE⿰亻exiss, op. cit. $=05$.

Common. The Bream is always found in compans rith the preceding species, to which it is rery like in size, shape, and habits, and is taken with it in large mmbers and bronght to the marliet. It is easily distinguished from the Chub, as far as it can be seen under rater, by the large black spot just behind the dorsal. It is also recorled from Madeira, 
the Canaries, Jamaica, and Cuba. A single specimen was taken in the spring of 1873, at Staten Island, New York Harbor, by Mr. C. L. Copley, and sent by him to the Smithsonian Institution.

Color--Golden-brown, with a longitudinal stripe of gold along the center of each row of scales, a silvery streak along the preorbital.

\section{PRISTIPOMATIDE.}

\section{HEMYLUM CAPEUNA, (Lichtenstein) Goode.}

\section{White Grunt.}

Capeuna Brasiliensibus, Makcgrave, Hist. \&c. Brasil, i, 1648, 155, f. 163.

Grammistes trivittata, SchNeIder, Bloch, Syst. Ichth. 1801, 188 (on Marcgrave's figure) Serranus eapeuna, Lichtexstein, Abbandl. Berl. Akad. 1820-1, 288 (on Marcgrave's figure).

Hamulon quadritineatum, Cuv. \& VAL., Hist. Nat. Poiss. v, 1830, 288, pl. cxx.-STorer, Syn. Fish. N. Am. 1846, 75.-Günther, Cat. Fish. Brit. Mus. i, 1861, 316.Poex, Rep. Fis.-Nat. Cuba, ii, 1868, 319.-Gill, in Baird's Rep. Sea Fisheries of S. New Eugland, 1s73, 806.

Hremulum quadrilineatum, Cope, Trans. Am. Phil. Soc. 1870, 471.

Hamulon quinquelineatum, PoEy, Mem. Hist. Nat. Cuba, ii, 1861, 419; Rep. Fis.-Nat.

Cuba, i, 1867, 310; ii, 1868, 162.

Common, occurring in schools. My specimens measure four inches. Cuvier's description of the color is excellent ; but Günther, in quoting it, fails to mention, either in generic or specific diagnoses, the brilliant red of the lips and mouth, which Curier thought of sufficient importance to found upon it his generic name Hremulon. I have made use of the specific name capeuna, because it seems to have priority over that usually accepted. The name trivittata can scarcely stand, since it is not only inapplicable, but sure to inislead, as is erident from the two other names which have been given to the species, viz, quadrilineatum and quinquelineatum.

The species is recorded from Brazil, San Domingo, and Cuba.

\section{HEMYLUM CHRYSOPTERUM, (Linné) Cuvier.}

\section{MARgATE-FisH.}

Perea marina gibbosa cinerea (Margate-fish), CATEsby, Hist. Carolina, Florida, and Bahamas, ii, 1743, 2, pl. ii, f. 1 .

Perea ehrysoptera, Linne, Syst. Nat. ed. 12, 1766, 485.-Guelin, Linné, Syst. Nat. 1, $1788,1314$.

Lufjanus chrysopterus, LACÉPł̀de, Hist. Nat. Poiss. iv, 1803, 186, 226. 
Hamulon chrysopteron, Cuv. \& VAL, Hist. Nat. Poiss. v, 1830, 240-DEKAY, New York Fauna, Fishes, 1842, 85, pl. rii, f. 22.-STorer, Sjn. Fish. N. Am. 1846, 75.Hollrook, Ichth. South Carolina, 1855, 120, pl. svii, f. 1.-Güxther, Cat. Fish. Brit. Mus. i, 1861, 313.-GILL, in Baird's Rep. Sea Fisheries of S. New England, 1873, 806.

The Margate-fish of the fishermen is probably this species. It is common in summer, but was not to be found in the markets at the time of $\mathrm{mr}$ visit. The species is recorded from the West Indies and Brazil. The fishermen recognize sereral others, as the Yellow, Streaked, Spotted, and Black Grunts, all of which probably belong to this family, if not to this genus.

\section{LUTJANUS CAXIS, (Schneider) Pocy.}

\section{Grat SNapper.}

Caxis, Parra, Descr. Dif. Pie. Hist. Nat. Cuba, 1787, 1ł, lam. viii, f. 2. Sparus Caxis, ScmNeIDER, Bloch, Syst. Ichth. 1801, 284.

Lutjanus Caxis, Puex, Rep. Fis.-Nat. Cuba, i, 186\%, 269; ii, 1868, 293.-Gru, in Baird's

Report on Sea Fisheries of S. Nen England, 1873, 806.

Bodianus Tilanet, LAç.pède, Hist. Nat. Poiss. ir, 1803, pl. iv, f. 3 (on a figure by Pluuier).

Sparus tetracanthus, Buoch, Ichth. viii, 1797, 279, 930 (ou a figure of Plumier).

Cichla tetracantha, Scmxemen, op. cit. 338 .

? Bodiunus striatus (Fasciatus), ScHNEIDFr, op. cit. 335, ta\}. 1xv.

Lutjanus acutirastris, Desmanest, Déc. lebth. pl. ii, f. 1 (fide Cuvier).

Meroprion griseus, Cev. \& Val, His, Nat. Poiss, ii, 1£29, 4i1.-SToren, S5n. Fish. N. Am. 1-4ti, 34.-Gïnthek, Cat. Fish. Brit. Mas. i, 1Е61, 195.

Very common; distributed also thronghout the Caribbean Sea and the Gulf of Mexico, aud, according to Ginther, who considers it identical with Mesoprion goreensis Cur. \& Tal, extending east to the African coast. It breeds abundantly, and hundreds of indiriduals from four feet to four inches in length mar be seen in alwost any sheltered nook. It is one of the most delicious of food-fish, its flaror not unlike that of the Blue-fish (Pomatomus saltatrix). Its extreme cunning renders it vers difficult to capture with either hook, pot, or grains, and has gained it the soubriquet of "Sea Lawyer". The market-name is "Gray Snapper".

Color-DDark gras, changing but slightly in spirits.

The synonomy of this and the allied forms is much eusuarled, and a careful study of a full series of specimens is desirable. 


\section{LUTJANUS AYA, (Bloch) Gill.}

Yelting; GLass-eyed SNAPPER.

Acara aya, Marcgrave, Hist. \&e. Brasil, 1648, 167.

Eodianus aya, Bloch Ichth. 1797, 33, tab. eexxvii (on a figure by Prince Maurice).LACÉPìde, Hist. Nat. Poiss. ir, 1803, 286.

Mesoprion aya, Cuv. \& Val., Hist. Nat. Poiss. ii, 1829, 457.-? Gurchexot, Sagra's Hist. Nat. Cuba, Poiss. 1845, 24.-GÜxrmer, Cat. Fish. Brit. Mus. i, 1861, 198.

Lutjanus aya, GILL, MS.

Bodianus ruber, Schnemen, Bloch, Syst. Nat. ed. 1801, 330.

Common. It probably breeds, as individuals of all ages occur; the largest weigh ten pounds or more, and are much esteemed as food. Its abrupt profile and large eses give it a very sparoid appearance; to the Jatter feature it no doubt owes one of its popular names, a similar epithet being applied to the large-eyed Stizostedium amsicanum, the Walleyed or Glass-eyed Pike of the great lakes and the Mississippi Valles. The name "Yeltiug" is very puzzling.

Color.-Brilliant rose-red, fading in spirits to grayish-olive, with black blotch along the base of the soft dorsal; base of pectoral dęep black.*

The species is peculiarly West Indian. Large specimens are sometimes brought in winter to the Washington market, in lots from Florida.

The Schoolmaster Snapper and Silk Snapper of the fishermen probably belong to this genus. The Spot Snapper and the Yellow-tail correspond doubtless to Mesoprion uninotatus (Cuv. \& Val.) Gill, and to Ocyurus chrysurus (Bl.) Gill. Lutjanus cynodon (Cuv.) Gill probably also occurs. All these species are peculiarly West Indian.

\section{SERRANIDAE. \\ TRISOTROPIS UNDULOSUS, (Cuvier) Gill.}

ROCK-FISH.

Perca marina venenosa punctata (Roek-fish), Catessy, Nat. Hist. Carolina, Florida, and Bahamas, ii, 1743, 15, tab. xv.-Cuv. \& Val., Hist. Nat. Poiss. ii, 1829, 386. Serranüs undulosus, Cev. \& VAL., op. eit. 295.-GüNtmen, Cat. Fish. Brit. Mus. i, 1861, 143.

Trisotropis undulosus, GiLl, Proc. Aead. Nat. Sci. Phila. 1865, 105.

Serranus brunneus, Poey, Mem. Hist. Nat. Cuba ii, 1860, 1314.

*Dr. Günther, in the "Synopsis of the Species", whieh serves as a key to the genus places this and the preceding species under the head "aa. Ground-color olive, vith a yellow, green, or brown shade." This is eertainly very apt to mislead, and illustrates the diffieulty of drawing correct ideas from the study of distorted and diseolored museumspecimens. 


\section{6}

Trisotropis brunnews, Gill, 1. c.-PoEY, Rep. Fis.-Nat. Cuba, ii, 1868, 156, §34; Annals Lyc. Nat. Hist. N. Y. ix, 18\%0, 305.

Serranus arara, Poey (not Cuv. \& VAL.), Mem. ii, 1860, 132.

Serranus decimalis, PoEY, Mem. ii, 1860, 138.

Serranus cyclopomatus, Porr, Mem. ii, 1861, 353 ; Rep. ii, 1868, 284.

Serranus latepictus, PoEr, Mcm. ii, 1861, 353.

Very common; recorded also from the West Indies and the coast of Brazil. The Rock-fish attains the length of four or five feet, and is ore of the choicest of table-fishes, though Catesby declares that his "Rockfish", which seems most probably the same, "has the worst character for its poisonous quality of any other among the Bahama Islands".

Color-Brown, thickly mottled with large, irlegularly quadrilateral spots of brownish-riolet. The sides of the head are marked with wary, irregular lines of deep violet. Dorsal broadly margined with black; caudal, anal, and rentral tipped with deep black, which gradually shades into the color of the bods; pectorals tipped with orange.

It may be regarled as somerhat doubiful whether the species of Cuvier is identical with that whose diannosis is giren by Dr. Giunther molder the same name, since the former makes no allusion to the yellow tips of the pectorals. Protessor Poey, after an examination of one of Cuvier's types, pronouncesit distinct from his Serranus brunneus bỵ reason of a slighty-romeded caudal. The Serranus undulosus defined by Giinther coincides with Poeg's Serranus brunneus in its truncated caudal and in other respects. I have provisionally accepted Giinther's identificaltion of Cuvier's species. C'atesby's tigure disagrees in its slightly-forked caudal, but in other respects corresponds with the specinen before we; and, since no conjecture has been oftered as to its relations, I have, after maling allowances for the carelessness which the artist manitests in many of the other plates, rentured to refer it to the same species.

\section{TRISOTROPIS GCTTATUS, (Schneider) Gill.}

\section{RED RiOCK-FISH.}

Bunacé cardenal, P.une, Descr. Dif. Pitz. His. Nat. Cuba, 17E7, 29, lam. xri, f. 1. Johnius guttatus, Scrixennel, Bloch, Ș̣st. Ichth. 1801, i (on Parra's ligure). Trisotropis quttatus, Gill, Proc. Acad. Nat. Sci. Phila. 1865, 105. Scrranus cardinalis, Ccr. of V.lL., His. Nat. Poiss. ii, 1-29,378 (on Parra's fignur(").Storıı, Sym. Fish., N. Am., 1810, 2T.-Güxrıfı, Cat. Fish. Brit. Mus. i, 1=61, 57, note 19.-Por:, Rep. Fis.-Nat. Cuba, i, 1є6i, 200.

Trisotropis cardinalis, PoÉ, op. cit. ii, 2-2; Annals Lyc. Nat. Hist. .. Y. ix, 1870, 303. Serranus rupestris, CUY. \& TAL., op. cit. ix, 1833, 437.-STORER, op. cit. 29.-GÜxTHEẊ, op. cit. $14 \bar{i}$. 
Witb some doubt I refer to this species the Red Rock-fish of the Bermuda market. In habits, form, and dimension, it much resembles the preceding. It is recorded from Saint Bartholomews, Cuba, and San Domingo, and at the latter place is called by the same name as in Bermuda.

\section{EPINEPHELUS STRIATUS, (Bloch) Gill.}

\section{HAMLET; Grouper.}

Cherna, PArra, Desc. Dif. Piez. Hist. Nat. Cuba, 1787, 50, lam. xxiv. Anthias striatus, BLoch, Ichth. ix, 1797, 109, tab. 324 (on a figure by Plumier). Lutjanus striatus, Licḱpk̀DE, Hist. Nat. Poiss. iv, 1803, 324.

Serranus striatus, Cuv \& VaL., Hist. Nat. Poiss. ii, 1829, 288.-Storen, Syn. Fish. N. Am. 1846, 27.-Guichenot, Sagra's Hist. Nat. Cuba, Poiss. 1850, 12.-GÜnther, Cat. Fish. Brit. Mus. i, 1861, 110.

Epinephelus striatus, GrLt, Proc. Acad. Nat. Sci. Phila. 1865, 105.-Poer, Rep. Fis. Nat. Cuba, ii, 1868, 285.-Cope, Trans. Am. Phil. Soc. 1870, 466. Anthias cherna, SchNeider, Bloch, Syst. Ichth. ed. 1801, 310 (on Parra's figure). Sparus chrysomelanurus, LACÉPÈDE, op. cit. 160. (on a bad copy of Plumier's figure).

Vers common; found also throughout the Caribbean Sea and the Gulf of Mexico. The Grouper attains an enormous size; and, on account of its abundance and the ease of capturing, it is used as food more than any other species. Its flesh is rather inferior in flavor and coarse in texture, especially that of large individuals. Great numbers are caught off the islands, and are brought in the wells of the smacks to the artificial ponds along the shore, where they are kept for the market, and are fed on fish and lobsters.

The "Devil's Hole" is a large natural pool near the center of the main island, and about one hundred feet from the south shore of Harrington Sound. Here a large number of Groupers may usually be found confined, and the place is much visited by strangers. At feeding-time, when one looks into the clear waters of the pool, nothing can be seen but an array of great open mouths. When the food is thrown in, a scene of indescribable commotion and splashing ensues. They are very fierce, and rush savagely at anything which looks eatable. I have seen two large ones, each four feet in length, seize the opposite ends of a cuttlefish arm tugging for several minutes at the tough morsel before the question of ornership could be decided.

The young fish are called Hamlets; but, after reaching a length of eighteen or twenty inches, are known as Groupers; the latter name is a corruption of the Portuguese Garoupa, which is applied to a similar fish found at Madeira. 
Color-Adult fishes range from a light-slate color to a deep chestnut-brown. In some individuals a narrow baud of black extends from the tip of the snont to a point between the eyes, where it divides; the branches extending, one to the origin of the dorsal and the other to the angle of the operculum, and upward to unite with the first at the origin of the dorsal. The lips and throat are bright vermilion.

A great variation is apparent in the color of different individuals, which has not yet been satisfactorily explained, though it is no doubt due to the depth of water or color of the bottom in the place where they are taken, as is suggested below under Enneasentrus punctatus. The fishermen claim that the color of individuals confined in the ponds changes from one extreme to the other within the period of a few weeks. I have mrself seen rery considerable rariation in color in the course of a week in fishes confined in shallow fish-ponds. The joung fish are always slate-color and are also marked with six or seren broad, transrerse bands of light brown and a large quadrangnlar black blotch across the back of the tail behind the dorsal.

EPINEPHELUS GUTTATUS, (Gmelin) Goode.

Hixd.

? Cugupuguacu, MarcGrave, Hist. Se. Brasil, 1648, 169.-Sloase, Voyage aux Iles de Madire, des Barbades, de St. Christophe, et de la Jamaique, 1727, tab. cexlvii.Cugupuguacu Brazil, Catesis;, Nat. Hist. Carolina, Florida, and Bahamas, ii, 1743, 14, tilb. xiv (the Hind).

I'erca guttata, Gundr, Linué, syst. Nat. 1, 17Es, 1315) (on a figure by Catesby).-Cuv. of VAL., Hist. Nat. Poiss. ii, 1828, 372.

Bodianus apua, BLoci, Ichth. vii, 1797, 37, tab. cexxix (on a firure by Prince Maurice).-Lacerène, Hist. Nat. Poiss. iv, 1e03, 296.

2 simanus apua, Cuv. of Val., op. cit. 257 (citing as a sjnongm Pirationia, MarcGRATE, op. cit. 15s).

Servunus ариа, Güмтіке, Cat. Fish. Brit. Mus. i, 1861, 140.

Dodiunus maryinatus, Schxemer, Bloch, syst. Ichth. 1Eu1, 331.

Very common; recorded also from Jamaica, and probably from Brazil. The Hind is readily sold in the market, where specimens two feet in lellgth are sometimes seen.

The name Hind perbaps refers to the spotted marlings as similar to those of the deer. The name is fonnd in nearly an the English West Indian islands, applied to the spotted species of this family.

Color--Brownish, red, or rosy-mhite, with numerous small circular spots of deep rose-color, fading to brown in spirits. Vertical fins broadly margined with black. 
The Hind is subject to great variations of color, specmens from the "white water", where there is a bottom of white sand, being nearly white, while others have the ground-eolor a dusky reddish-brown.

The descriptions of Gmelin and Bloch were both founded upon drawings, and their relations are somewhat doubtful. The former has been preferred, since the figure of Catesby agrees precisely with the Bermuda "Hind", except in the smaller number of dorsal spines, a matter of detail not likels to have been noticed by Catesby, judging from his other figules. The Bermudian form is much more likely to be identical with that from the Bahamas and Jamaica than that from Brazil, if, indeed, they are not all identical. Günther records from Jamaica his Serranus apuo, which is, beyond a doubt, the Bermuda species, thus furnishing another argument for its identity with that figured by Sloane.

\section{ENNeacentrus PUNC'Tatus, (Linné) Poey.}

\section{BUTTER-FISI or CONEY (yellow variety); NIGGER-FISH (red variety).}

Carauna, Marcgrave, Hist. \&.e. Brasil, 1648, 147.-Lichtenstein, Abhandl. Akad. Berl. 18:0-1, 278.

Perca marina puncticulata (Negro-fish), Catesby, Nat. Hist. Carolina, Florida, and Bahamas, ii, 1743, 7, pl. vii.

Perca punctata, Lrvxé, Syst. Nat. ed. 10, i, 1758, 291; ed. 12, 1766, 485 (on Catesby's figure).

Enneacentrus punctatus, PoEY, Rep. Fis.-Nat. Cuba, ii, 1868, 288.

Guativere, Parra, Deser. Dif. Piez. Hist. Nat. Cuba, 1787, 7, lam. v, f. 1, 2.

Holocentrus aurafus, BLoch, Ichth. vii, 1792, 57, tab. cexxxvi.-SCHNEIDer, Bloch, Syst. Ichth. 1801, 314.

Gymnocephalus ruber, SCHNEIDER, op. cit. 346, tab. lxvii (on a figure by Prince Maurice). Serranus ouatalibi, Cuv. \& Val., Hist. Nat. Poiss. ii, 1829, 381.-Storer, Syn. Fish. N. Am. 1846, 56.-Guichexot, Sagra's Hist. Nat. Cuba, Poiss. 1845, 15.-Müll. \& Trosch., Schomburgh's Hist. Barbados, 1848, 665.-Günther, Cat. Fish. Brit. Mus. i, 1861, 120.-Puer, op. cit. 202.-Cope, Trans. Am. Phil. Soc. Phila. 1870, 446.

Epinephelus ouatalibi, Gru, Proc. Acad. Nat. Sci. Phila. 1865, 105.

Bodianus guativere, SchNender, S5st. Ichth. Bloch, 1801, 336 (on Parra's figures).

Serranus guativere, Cuv. \& VaL., op. cit. 383 (limited to Parra's f. 2).-STorer, l. c.MǗl. \& Trosch., l. c.-Cope, l. c.

Semanns carauno, Cuv. \& VAL., op: cit. 384 (on a drawing by Prince Maximilian).Casteliau, Anim. Nouv, ou Rares, Amérique du Sud, Poiss. 1, pl. 1, fig. 1.

Common; recorded also from the West Indies, Brazil, and the Cape Verde Islands. Its small size and the softness of its flesh render it of little economic value. In this species, as in the preceding, the range of color is very great; some individuals are orange-yellow, with blue 
spots confined to the head and anterior part of the body; others are red, slightly dingy above, and thickly studded throughout with black dots, each of which has a blue center. The specimens examined were not very fresh; and, from the rapidity with which the colors change, I can readily believe that in life they were as brilliant as is indicated in the description of Cuvier.* The yellow form corresponds to the typical Perca punctata or Serranus guativere, and is known as the Butter-fish or Yellow Coney; the red form corresponds to serranus ouatalibi, and is known as the Nigger-fish.

Professor Poey suggests that the former inhabits shallow aud the latter deep waters, and thus explains the variations of color. These would seem, howerer, to depend more upon the color of the bottom than upon the depth. On the coast of Maaine, the bright-red variety of the Cod (Gadus morrlua, Linné) is found only on bottoms covered with lied Algæ, such as Ptilota serrata, Delesseria sinuosa, and Rhodymenia palmata.

The names Butter-fish aud Nigger-fish are in use also at Barbados, Saint Thomas, and the Bahamas, as applied to this and an allied species. The first refers to the color and soft, oily feeling of the yellow variety; the latter probably also to color.

The Black Hind, Prickly IInd, and Black Coney are probably allied species, but not laving seen them I can only surmise their character.

A "Soap-fish" also oceurs, probably either Rhypticus saponaceus (Bloch) Curier, or Promicropterus maculatus (Holbrook) Gill.

$$
\text { IIYOPLECTRUS PUELLA, (Curier) Gill. }
$$

\section{Cataphebe.}

Plectropoma puella, Cuv. \& V.l., Hist. Nat. Poiss. ii, 1829, 405, pl. xxxrii.Gurchexoт, Sagra's Hist. Nat. Cuba, Poiss, 1845, 15--SToner, Syn. Fish. N. Am. 1846, 31.-Ponr, Mem. Hist. Nat. Cuba, i, 1=52, 62, lam. ix, f. 2.-Güxtrien, Cat. Fish. Brit. Mus. i, 1861, 165.

Hypoplectrus puella, Grli, Proe. Acad. Nat. Sci. Phila. 1862, 236.-Poer, Rep. Fis.-Nat. Cuba, ii, 1868,290 .

Plectropoma ritulinum, Poex, Mem. Hist. Nat. Cuba, i, 1552, 68.

Common in the rock-pools; recorded also from Martinique and Jamaica. My specimen measures three inches. The name seems to be peculiar to Bermuda, and its origin is not apparent.

Color:-Olire, with six riolet-black cross-bands; the third fery uroad and conspicuous and below the fourth and tenth dorsal spines. A tine

* Cuvier aud Valencienues, Histoire Naturelle des Poissons, ii, 3๖'1 
around the orbit, another from posterior nostril across anterior edge of orbit to lower limb of preoperculum, then broken, then continued to base of rentral; and two others across the operculum; the anterior extending orer the base of pectoral to belly, blue. Several blue spots between the orbit and snout. Fins jellowish.

\section{ECHENEIDIDÆ.}

Fishes of this family are freqently taken, clinging to sharks or to the shells of turtles.* The sharks thos encumbered are frequently much emaciated. Leptecheneis naucrates (Linn.) Gill, L. naucrateoides (Zuiew) Gill, and Ptheirichthys lineatus (Menz.) Gill are probably the most common species of "Suck-fish" found here.

\section{SPHYRANIDA.}

\section{SPHYRANA SPET, (Haiiy) Goode.}

\section{Barractida.}

Esox dorso dipterygio Lrvxé, Mus. Ad. Fried. ii. 1754, 100.

Esox sphyrana, Livé, Syst. Nat. ed. 10. i, 1758,313, ed.12; i, 1766, 115; Gmelis, Linné, Syst. Nat. i, 1788, 1389.-Blocir, Ichth. xi, 1797.

Sphyrna sphyrcena, BLoch, Ichth. 1797, taf. ceclxxxix.-Scineider, Bloc', Syst. Ichth. 1801, 107.-Risso, Ichtb. Nice, 1810, 332.

Esox spet, HıƯr, Lncyclopédie Méthodique, iii, Poissons, 7187.

Sphyrcena spet L.cépède, Hist. Nat. Poiss. v, 1803, 326-8.-? ZonaParte, Iconografia della Fauna Italica, iii, Pesci, plate with part 152.

Spleyrcena becuna, L.1CÉPł̀DE, op. cit. 327-9, pl. ix, f. 1.-CUv. \& VAL., Hist Nat. Pois. iii, 1829, 340 (part) ; and vii, 1831, 507.

Splyyrona vulgaris, Cuv. \& VAL., op. cit. iii, 1829, 327.-GüntHer, Cat. Fish. Brit. Mus. ii, 1861, 334.

Sphyrona viridensis, Cuv. \& VAL., sc., op. cit. 339.

Common; frequently found in the markets, and eaten with impunity, as far as I could learn. My specimens measured nearly two feet, and it is said to attain a much greater size. This is not the Barracuda of the West Indies, but the common species of the Mediterranean known by the Spanish as Espeto and by the Italians as Sfïrena and Luzzo. Its occurrence so far west has, I believe, never before been observed. Günther

* All four species of the pelagic turtles of the Atlantic are common, and were observed l,y me, viz:-Sphargis coriacea, Chelone mydas, Eretmochelys imbricata, and Thalassochelys caouana. These, with a small saurian, Eumeces longirostris, Cope, make up the reptilian fauna of the Bermudas. 
considers the Sphyrana borealis of DeKay,* described from specimens eight inches long taken in New York Harbor, to be the same. This might be inferred from the somewhat loose language of the description; but the figure shows it to be closely allied to, if not identical with, Sphyrcena picuda. The origin of the first dorsal is shown by the artist to be situated almost directly above the extremity of the pectorals and far in firont of the middle of the fish. The locality, New York, giren by Dr. Giinther for his specimen "purchased of Mr. Brandt" must, I fear, be placed in the same category with that of Lake Champlain given for specimens of Chilomycterus geometricus and Tetrodon turgidus, $\dagger$ and with some of the cases of reptiles described as North American by Duméril and Bibron from collections professedly North American.

\section{SPHYRENA PICUIA, Schneider.}

\section{SENNET.}

Barracuda, Sloñ́e, Voyage aux iles de Madère et de la Jamaique, ii, 1727, 185, pl. cexlvii, f. 3.

Umbla minor marina maxillis longioribus (Barracuda), CAtesby, Hist. Carolina, Florida, and the Bahamas, ii, 1743,1 , tab. 1.

Picuda, PAliki, Deser. Dif. Piez. Hist. Nat. Cuba, 17s7, 90, lam. xxxv, f. 2.

Sphyrana sphyrena, var. picnda, Scinender, Bloch, Syst. Ichth. ed. 1801, 110, tab. xxix,

f. 1.-MÜller \& Troschel, Schomburgh's Hist. Barbados, 1848, 667.-GÜN-tren, Cat. Fish. Brit. Mns. ii, 1861, 336.

Esox barracuda, Siraw, Geu. Zool. v, 1804, 105.

sphyrena barracuda, Cuv. of V.1L., Hist. Nat. Poiss. iii, 1829, 343, pl. lxvi.-STonel, Syn.

Fish. N. A. 1846, 47.-MÜller of Troschel, 1. c.-Cope, T:ans. Am. Phil. Soc. Phila. 1870, 47:.

Common; breeding plentifully. The young may be seen basking in the sun in the shallows, where they are seined in large numbers. My largest specimens measured orer two feet in length. Both this and the preceding species are eaten with impunits, though the former is regarded with suspicion on the Mediterranean and the latter has to answer for sereral rell-attested cases of ciguatera, though in some of the West India Islands it is eaten freely.

The popular name is also in nse at Barbarlos, where it is applied to the same or an allied species. Schomburgk spells it Simnet.

The species of this genus are not yet rery accurately defined. Professor Copeț takes exceptiou to the supposed inlentity of S. picuda and

*Zoologr of New York, Fishes, 39, „l. 1x, t. 193.

† Cat. Fish. Brit. Mns. viii, 255.

†Proc. Aner. Phil. Soc. Phila. 1870, tis. 
S. barracuda. The latter mas be easily distinguished from the preceding by observing the situation of the first dorsal. In S. spet, this begins in the midlle of the body and far behind the extremity of the pectorals; in $S$ : picuda, on the anterior half of the body and above the extremity of the pectorals. The first is much the slenderer, and has nearly double the number of scales in the lateral line.

\section{TRACHYPTERID EE.}

REGALECUS GLADIUS, (Walbaum) Cuv. \& Val.

Spada marina, IMPenATI, $58 \%$.

Cepola gladius, Walbaum, Artedi Gen. Pisc. iii, 1792, 617.

Regalecus gladius, Cuv. \& Val., Hist. Nat. Poiss. x, 1835, 352, pl. cexeviii-Gü.NTher, Cat Fish. Brit. Mus. iii, 1861, 308.-Hutton, Fishes of New Zealand, 35.

Gymnetrus longeradiatus, Risso, Hist. Nat. Eur. Merid. iii, 1827, 296.

(Fymnetrus capensis, Cuv. \& VAL., op. cit. 376.

Regalccus Jonesii, Newman, Zoologist, 1860, 7019.

This is the great "Sea-serpent" which came ashore at Hungary Bay in the winter of 1860 , the capture of which has been recorded by Mr. J. Mathew Jones.*

Portions of this specimen, which measured 16 feet and 7 inches in length, are preserved in the British Museum.

This specimen is thought by Giinther to "probably belong" to the sprecies given above. The well-identified specimens of the species are all from the Mediterranean, the largest $9 \frac{1}{2}$ feet long, while the relations of the specimens from New Zealand and the Cape of Good Hope are conjectural. The data are not sufficient to warrant the adoption of Newman's species, founded on the Bermuda specimen as a good one.

\section{MUGILID 炁.}

\section{MUGIL LIZA, Valenciennes.}

\section{MULLET.}

Mrugil liza, Cúv. \& VaL., Hist. Nat. Poiss. xi, 1836, 86.-JFnyns, Zool. Voyage H. M. S. Beagle, Fish, 80.-Gǜtier, Cat. Fish. Brit. Mus. iii, 1861, 423.Poty, Rep. Fis.-Nat. Cuba, ii, 1868, 388

Very common, especially in Hamilton Harbor and other shallow bays; breeding. They are seined, and bronght to market in large numbers.

* Bermuda Rojal Gazeite, Jan. 24 and Jan. 31, 1860.-Proc.Zool. Soc. London, 1860, 185. 
I have some hesitation in referring the Bermuda Mullet to this species, though it appears to be identical with that taken at Bahia Blance and Monte Video by Darwin and described by Jenyns." Poey considers his Mugil lebranchust separated from this species by characters of coubtful value.

\section{BELONIDA.}

The Hound-fish of the fishermen is a Belone; but as I could get no specimens for careful examination, it is not possible to sar to which of the nineteen West India species it belongs, or whether two or three species are not confounded under the same name.

\section{SCOMBERESOCIDA.}

HEMIRHAMPHUS PLEII, Talenciennes.

GAR.FISH.

Hemirhamphus Pleii, Cuv. \& Yal., Hist. Nat. Poiss, xix, 21, 1846.-Gưxther, Cat. Fisl. Brit. Mus. vi, 268.-Cope, Trans. Am. Phil. Soc. Phila. 18i0, 481.

Common; recorded also from various points in the West Indies and from Bahia. The Gar-fish oceurs in enormons schools, and is seined in quantity for the market. I observed two sizes, the smallest areraging eight inches, the larger twenty inches. The fish of different sizes swam in separate schools.

The name Gur, applied so indiscriminatels to fishes with long slender beaks, is probably the old Saxon word gar, which means a weapon, a lance. The name Half-beak usually given to fishes of this family is much more appropriate.

EXOCETCS EXILIENS, Gmelin.

Exocotus exiliens, Guelix, Linné, Syst. Nat. 1, 1788, 1400.-Cuv. \& Val., Hist. Nat. Poiss. xix, 1E46, 114.-Ricinadsox, Fauva Boreali-Americana, iii, 129.-GüxTils, Cat. Fish. Brit. Mus. ri, 1=61, 291.-Gill, in Baird's Rep. on Sea Fisheries of Southern New England, 809.

Erocotns fasciatus, Lesceur, Journ. Acad. Nat. Sci. Pbila. ii, 1821, 8, pl. iv, f. 2.

A single specimen was brought me March 1 by some negro fishermen "ho had caught it in Hamilton Harbor by holding a tin pail ("kettle") unler it when it leaped from the water. I liept it alice for some hours,

* Zool. Vosagre H. M. S. Beagle, Fisb, 1042, s0.

† Memorias sobre la Mistoria Natural de la Isla de Cuba * * * ii, 1861, 260, tab. 13, f. 3 ; Rel. Fis.-Nat. Caba, ii, $1863,353$. 
and had an opportunity to observe its motions. Its favorite position was on the bottom of the dish, where it would remain with its pectorals and ventrals widely expanded, looking very like a large butterfly sunning itself on a flower. Wheu disturbed, it would fold its fius close to the sides of its body, and swim about with great velocity by rapid, long, s reeping strokes of the tail and posterior half of the body. The extent to which it flexed its body was quite remarkable, almost reminding one of the motions of a Shark. When much excited, it would rise into the air with a sudden spring, its pectorals and ventrals expanded, seeming to hare no difficulty in leaving the water in a space less than a foot in diameter: I am inclined to believe that the impetus from the action of the caudal is all that is used in leaving the water, and that the motion of the pectorals in flying-fishes is not begun until the fish is fairly in the air. It seemed rery timid and watchful, and any quick motion of the hand withiu its sight would start it into rapid, nervous action.

The figures given by Lesueur and Edwards* are very accurate; but all publisbed descriptions fail to mention the most striking character, viz, the deep notch in the membrane between the second and third pectoral rass, which seems the more apparent from the fact that the second ray is longer than the third, and projects in a spine-like process; the membrane between the third and fourth rays is slightly emarginate. The fourth ray is much the longest and the rays posterior to that regularly decrease in length.

The Bermuda fishermen recognize two kinds of flying-fish, the pelagic rariety and this, which they believe to live among the sea-weed and seldom leare the water. The specimens of this species on record are all quite small: Gmelin describes his as "at vix digito longior"; Lesueur's was three inches long; Valencienne's was "petite"; and Edwards's figure indicates that his was diminutive. They may prove to be the young of some other species; but this is not probable, since no other form has pectorals of such peculiar form. The absence of barbels, if this be a character of immature Exoccetidce, is also noteworthy.

A detailed description is given below :-

Radial formula: D. 12 ; A. 12 ; P. 18 ; V. 6 ; L. lat. 48.

The body is slender, its height being less than one-eighth $(0.12)$ of the total leugth. Viewed from above, its outline is that of a narrow wedge, with its base at the nape and its apex at the extremity of the lower caudal lobe. The greatest width of the body is at the nape, where it is

* Gleanings in Natural History, pl. cex. 
equal to the greatest height, which occurs at the same point. The length of the head is one-sixth (0.17) of total length, and its greatest width equals that of the body. The orbit is circular, and its diameter equals the interorbital space, which is half the length of the head. The snout is very short, equaling one-sixth the length of the head; the lower projects far beyond the upper jaw. The interorbital space is deeply concave. The dorsal and aual fins begin at a point slightly behind the middle of the body, and are nearly alike in shape and in the length of the base and of the longest rays. The pectorals measure three-fifths $(0.58)$ of the total length, extending nearly to the base of the caudal fin. 'The first ray is half' as long as the second, which projects far beyond the margin of the membrane in a spine-like process; the third ray equals the second, while the fourth is much longer. The membrane between the second and third rays is deeply, between the third and fourth slightly, emarginated. The rays sneceeding the fourth gradually decrease in lengtl. The reutrals begin slightly in adrance of the middle of the body, in length equaling a third (0.31) of total length. The five posterior rays are bifid nearly to the base. The tips of rentral aud pectoral fins are equidistant from the snont. The npper lobe of the caudal measures two-thirds the length of the lower lobe.

Color.-Back bluish, shading into the silvery white of the belly; fire broad lateral transrerse bauds. The snout transparent white. Two yellow spots upon the nape. Pectorals and rentrals black at base and at margin, and with broad, irregular bauds and blotehes of black and dark blue; where unspotted, clear, colorless, and transparent. Caudal lobes each with a terminal spot of black; the lower with spot of same color on its onter margin half-way from the body to its extremity.

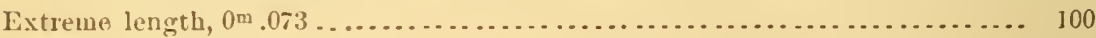
Body:

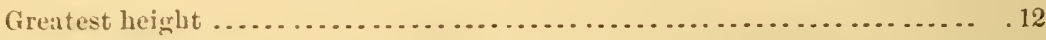

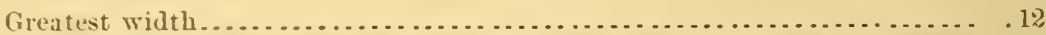

Height at ventrals .......................................... 10

Height of tail behind dorsal fin ............................... .06 Heal :

Length ............................................... . 17

I) istance from snout to nape................................ . 15

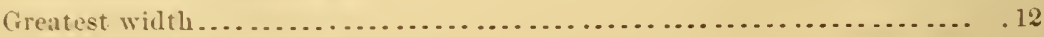

11 idtlt of interorbital area................................... 10

Length of snont .......................................... .03 lige:

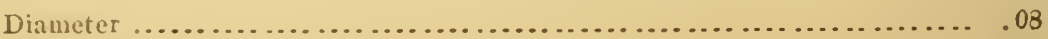


Dorsal :

Distance from snout....................................... .56

Length of base............................................ . 13

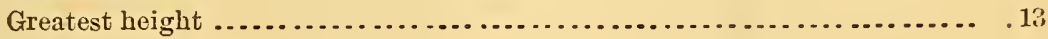
Anal:

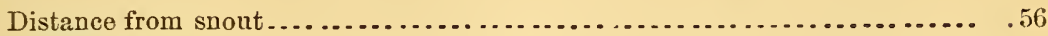

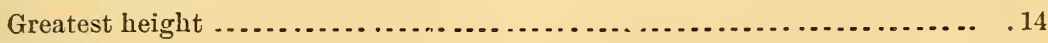
Caudal :

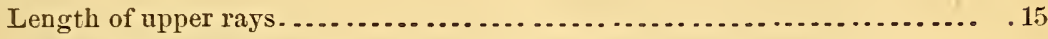

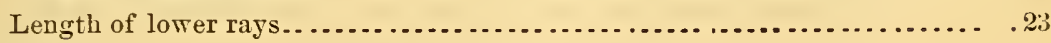

Pectoral :

Distance from snout at upper axilla ............................. . 16

Length ....................................................... .58

Distance of tip from snout..................................... . 80 Ventral:

Distance of base from snout. ................................... .45

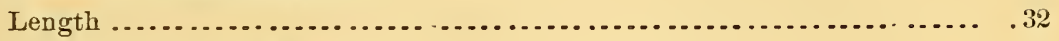

Distance of tip from snout...................................... . 78

The Exocotus exiliens of Bloch is totally different.

I observed numerous specimens of the pelagic species in the vicinity of the islands, both on going and return. I take from my note-book some observations on their flight.

"February 10, 1871. - Several flying-fishes were observed on approaching the islands; usually they were single, but often a school of half a dozen or more started out from nnder the side of the brig. The distance of flight varied from six to one hundred yards. When they leare the water, the pectorals assume a rapid vibration, reminding one of the flight of a grouse, the tail also rapidly vibrating. The fins soon assume a rigid position, and the fish rises over the crests and falls in the trough of the waves, following their motion; sometimes it dashes through the crest, and on re-appearing the fins are again in motion. They seem unable to fly except in a straight liue (I afterwards saw them reering considerably from a straight line, taking a direction nearly at right angles with their first course), but are not dependent on the direction of the wind. The motion is very bird-like; but the illusion is dispelled by the decidedly piscine splash with which the fish plunges into the water. It was a truly beautiful sight as the fishes emerged from the waves, their silvery fins quivering and glistening in the light."

I am convinced that at the moment the fish leaves the water the mode of propulsion changes from a true swimming motion to a true flying motion. The leap with which it leaves the water is due to the former, and is analogous to the spring from the ground or from a perch, made by some birds in the act of taking wing. 


\section{CYPRINODONTIDE.}

\section{FUNDULUS BERIUDA, Günther.}

Fundulus Bermudo, GüNther, Ann. \& Mag. Nat. Hist., 1874.

Very common in the brackish water of the swamps and in ditches. Attaips the length of four inches.

\section{SYNODONTID正.}

\section{SYNODUS LACERTA, (Valenciennes) Goode. \\ SNAKEE-FISH.}

Salmo Saurus, Livwe, Syst. Nat. 2 ed. 11,511, 1766; Gmelin, Syst. Nat. 1, 1376.

Saurus lacerta, Cuv \& VAL., Hist. Nat. Poiss. xxii, 463, 1849 (not Risso).

Saurus griseus, Lowe, Trans. Zool. Soc. ii, 188, 1841.-Güntuen, Cat. Fish. Brit. Mus. $\mathrm{v}, 395$.

A specimen, serenteen inches long, was taken off the "ducking-stool" in March, by a line fisherman. Its occurrence in this part of the Atlautic is vers novel, but it agrees closely with a specimen of Saurus griseus sent to the United States National Museum by Dr. Guinther. Its color was dusky-gray above, yellow below. Its formulæ are as follows:-

Branchiostegals, 16-17 (on opposite sides). D. 12; A. 12. Lateral line, 60. Transrerse line, $\frac{3 \frac{1}{2}}{6}$.

\section{ELOPIDE.}

MIEGALOPS THRISSOIDES, (Bloch) Giinther.

TARPUA.

Camaripucuagu, M.ncGratr, Hist. Sc. Brasil, 1648, 179.

Clupea cyprinoides, Blocr, Ichth., xii, 1797, 24, tab. cecciii.

Clupea thrissoides, ScINEInEr, Bhoch, Srst. Ichth. 1801, 424.

Megalops thrissoides, Güstuen, Cat. Fish. Brit. Mus. vii, 1868, 472.-GILL, in Baird's Rep. on Sea Fisheries of Southeru New England, 1873, 810.

Clupea apalike, HaỦx, Encyclopédie Méthodique-LacíPÈde, Hist. Nat. Poiss. v, 1803, $4: 5,461$.

Clupea gigantea, Smaw, Geu. Zool. r, 1803, 173.

Mcgalops atlanticus, Cuv. \& V.ı., Hist. Nat. Poiss. xix, 1846, 393.-Mür.Ler \& Troscin:L, Schomburgk's Hist. Barbados, 1\&42, 6;6.-PoEr, Rep. Fis.-Nat. Cuba, ii, $1=68,4: 3$.

Extremely rare; a single skin about six feet long was shown me in the collection of John T. Bartram, of Saint George's. The species 
is recorded from the Gulf of Mexico, Demerara, Trinidad, Guadaloupe, Santo Domingo, Porto Rico, Martinique, and Cuba.

The species is very abundant on the eastern coast of Florida and in the Saint John's Rirer, where it is known as the Jew-fish. Several specimens were taken on the southern coast of New England and New York in $\mathbf{1 8 7 4 .}$

The name is inexplicable, but may have some connection with the name "Caffum", which is given to the same fish in Barbados.

\section{CLUPEID E.}

\section{SARDINELLA ANCHOVIA, Valenciennes.}

\section{ANCHOVY.}

Sardinella anchoria, Cuv. \& VAL., Hist. Nat. Pois. xx, 1847, 269.

Clupea anchovia, Güxtmen, Cat. Fish. Brit. Mus. vii, 1868, 421.

I refer with some doubt to this species a small fish which occurred in great schools during the month of March, and were seined together with Decapterus punctatus, and sold in quantities along the quay. Their arerage length was about five inches.

\section{HARENGULA MACROPHTHALMA (Ranzani).}

\section{Pilchard.}

Clupea macrophthalma, Ranzani, Novi Commentarii Acad. Scient. Inst. Bononiensis, v, 1842, 320, tab. xxiii.-Günther, Cat. Fish. Brit. Mus. vii, 1868, 421.-Cope, Trans. Am. Phil. Soc. Phila. 1870, 483.

Harengula sardina, Poey, Mem. Hist. Nat. Cuba, ii, 1863, 310 : Rep. Fis.-Nat. ii, Cuba. $1868,418$.

Common; also recorded from various islands in the West Indies. Great quantities were seined during the month of March, and sold from row-boats at the water's edge. Their average length was nine inches. Poey's Harengula sardina appears to be the same. The name is derived from England, where an allied species, Clupea pilchardus, Walbaum, is commonly known as "the Pilchard".

\section{OPISTHONEMA THRISSA, (Linnć) Gill.}

\section{HERring.}

Clupea minor, radio ultimo pinnce dorsalis longissimo, Brown, Civ. and Nat. Hist. Jamaica, $1756,443$.

? Clupea corpore ovało, Lixwt, Amœn. Acad. v, 251. 
Clupea thrissa, Linse, Syst. Nat. ed. 10, 1, 1758, 318; ed. 12, 1, 1750, 524; Gmeliv, Linné, Srst. Nat. 1, 1788, 1405 (part).-Broussonet, Ichth. 1, tab. x.--? BLoch, Ichth. xii, 1797, 27, taf. cceciv (from a drawing by Plumier).Schreider, Bloch, Syst. Ichth. ed. 1801, 424.-Gǘther, Cat. Fish. Brit. Mus. vii, $1868,432$.

Meletta thrissa, Cuv. \& VaL., Hist. Nat. Poiss. xx, 1847, 380.

Opisthonema thrissa, Gill, Proc. Acad. Nat. Sci. Phila. 1861, 37 ; Cat. Fish. E. Coast N. Am. 1861, 54; and in Baird's Rep. on Sea Fisheries of S. New England, 187:, 811.

Opisthonemus thrissa, Poer, Rep. Fis. Nat. Cuba, ii, 1886, 419.

Clupanodon thrissoides, SpIx, MÜLl., \&. TroscH., Schomburgk's Hist. Barbados, 1848, $6 \pi 6$.

Megalops thrissoides, AGassiz, in Spix's Selecta Gen. et Spee. Pisc. Brazil, 1829, 45, pl. xxii.

Megalops oglina, Lesueur, Journ. Acad. Nat. Sei. Phila. 1, 1817, 359.

Chatoessus oglina, Griffiti, Cuvier's Animal Kingdom, $x$, 1835, 439.-DEKay, Now York Fauna, Fishes, 1842, 265.-Storer, Syn. Fish. N. Am. 1846, 209.

Chatoessus signifer, DeKar, op. cit. 264, pl. xli, f. 132.-Storen, op. cit. 210.-Barrd, Fishes of New Jersey Coast, 1855, 35._Joxes, Naturalist in Bermuda, 103.

Chatocssus eumorphus, Gosse, Naturalist's Sojourn in Jamaica, 1851, 290 (notes).

This species was taken in great numbers during the month of March. They occurred in schools in two distinct sizes; the smaller, perhaps the young of the previous year, measured four inches on an average; the adults, ten. The species is common in the West Indies, and has been talien as far north as Newfoundlaud.

\section{ENGRAULIDIDE.}

\section{EYGRAULIS CHGROSTOMUS, Goode.}

Hog-MIOUTH FrY.

Engraulis chorrostomus, Goode, Amer. Journ. Science and Arts, viii, 1874 (Aug.), 125.

Common in the bays in large schools; used extensirely for bait. Its enormous mouth has giren it the name of "log-mouth fry."

This species closely resembles Engraulis surinamensis (Blkr.) Günther, differing from it, howerer, in sereral respects. The height of the body (0.16) is a little greater than two-thirds of the length of the head, and is contained six times in the total leugth, and slightly more than four times in the length to the end of middle caudal rays $(0.90)$; the height at the ventrals is less (0.13). The scales are large, in thirt5-eight oblique rows between the head and the caudal. The length of the learl $(0.22)$ is less than one-fourth of the total, and is double its height at the pupil $(0.11)$; its greatest ridth $(0.0 S)$ is about one-third of its 
length. The orbit is nearly circular, and its diameter (0.05) equals the length of the suout $(0.05)$ and the width of the interorbital area $(0.05)$. The snout projects far beyond the lower jaw, the extremity of which just passes the vertical from the anterior margin of the orbit. The maxillary is dilated above the mandibular joint, rather tapering behind, and extends to the gill-opening. The gill-rakers are fine, setiform, not longer than the eye (0.05); abont twenty-five on the lower branch of the outer branchial arch.

The origin of the dorsal fin is in front of the middle of the body ( 0.45 from thesuout), and directly above the extremities of the ventrals. The length of the first ray $(0.06)$ is half that of the second $(0.12)$, which nearly equals the length of the base (0.11). The origin of the anal is at the middle of the body ( 0.51 from the snout), and below the posterior dorsal rays; its greatest height (0.11) nearly equals that of the dorsal. The length of the middle caudal rays $(0.08)$ is two-fifths of that of the outer rass $(0.20)$. The length of the pectorals $(0.11)$ equals the length of the base of the dorsals (0.11), the extremities reaching to the origin of the rentrals. Length of ventrais, 0.09 ; and their distance from snout, 0.35 .

Color:-Back and sides brownish; belly white; a broad, clearly-defined lateral band of silver as wide as the diameter of the orbit (0.05).

Radial formula:-D. 13-14, A. $23-24$. Length, 2.68 inches $\left(0^{\mathrm{m}} .63\right)$.

\section{CYPRINIDA.}

\section{CARASSIUS AURATUS, (Linné) Bleeker.}

GOLD-FISH.

Cyprinus auratus, Lnvé, Syst. Nat. ed. 10, i, 1758, 323.-Jones, Naturalist in Bermuda. $1803,103$.

Carassius auratus, Bleeker, Cyprin. 255.-Günther, Cat. Fish. Brit. Mus. vii, 1868, 32,

Common in the brackish water of the ditches. Mr. Jones states that it was introduced from Demerara many years ago.

\section{ANGUILLID A.}

\section{ANGUILLA BOSTONIENSIS, (Lesueur) Ayres.}

EEL.

Murcena bostoniensis, Lesuevr, Journ. Acad. Nat. Sci. Phila. i, 1817, 81.

Anguilta bostoniensis, AYres, Boston Journ. Nat. Hist. iv, 1842, 279.-Güxther, Cat. Fish. Brit. Mus. viii. 1870, 31.-GrLl, in Baird's Rep. Sea Fisheries Southern New England, 1873, 811.-Burro, Rep. Sea Fisheries Southern New Eugland, 1871, 826. 
Common in the ditches and dikes of the salt-marshes. Mr. Jones states* that it attains the weight of two or three pounds, and is very destructive to young ducklings. It is not eaten.

I obtained a specimen measuring five inches, which I refer with some hesitation to the above species, as measurements made from specimens contracted by strong alcohol are not satisfactory. The length of the head is contained once and a half in the distance between the gillopening and the dorsal, twice in the distance betiveen the gill-opening and the vent. The distance between the origins of the dorsal and anal is contained once and a half in the length of the head.

\section{MURANID E. \\ GYMNOTHORAX MORINGA, (Cuivier) Goode.}

\section{SPECKLEd MaRay.}

Murana macutata nigra (Black Murey), Catessr, Nat. Hist. Carolina, Florida, and Bahaulas, ii, 17.43, 21, tab. $21,174$.

Mnrana moringa, Cuvisr, Rogue Auiual, 1817.-Stoner, Syn.Fish N. Am. 1846, 235 Murena moringua, Rich.sidsox, Voy. H. M. S. S. Erebus \& Terror, Ichth. 1846, 89.Kinup, Cat. Apod. Fish. Brit. Mus. 1856, 89.

Gymnothorax rostratus, AG.sssiz, in Spix's Selecta Gren. et Spec. Brasil, 1829, 91, tab. 1, a.-MÜLL et 'Troscir, Schomburgli's Hist. Barbados, 1848, 676.-Pokx, Rep. ii, $1 \leq 60-1,259,4: 27$. -Cope, Trans. Am. Phil. Soc. Phila. 1870, 483.

Murenophis rostratus, Castblaxad, Anim. Nouv, ou Rares, Amérique du Sud, 1855, 80, pl.xlii, f. 1.

Murenophis curvilincata, Cıstelxid, op. cit. 81, jI. xlii, f. 2.

Occasional: the species occurs throughout the West Indies, at Bahia and at Saint Helena. My specimen measures three feet, and has the vertical fins elged with white. These fishes are said to attain a length of fire or six feet, and are considered excellent food by the lower classes: I am told, howerer, that serious cases of poisoning have been occasioned by their use. The Speckled Maray is not rare, but by no means as common as the Green Maray. I saw a single specimen of the latter, but as I could not obtain it for study I was unable to determine its specific relations. It resembles closely the "Muray" of Catesbs, twhich I have reason to beliere is not identical with his "Black Mnray", as is generally supposed.

\footnotetext{
* Naturalist iu Bermula, p. 103.
}

†Nat. Ilist. Carolina, Florida, and Babamas, 20, pl. sx-Murana moculata nigra and viridis. 
ECHIDNA CATENATA, (Bloch) Blecker.

Gymnothorax catenatus, BLoch, Iehtl. xii, 1797, 69, taf. ceecxv.

Murcena catenata, Rrchardson, Voyage H. M. S. S. Erebus \& Terror, Ichth. 1846, 95.Güxtmer, Cat. Fish. Brit. Mus. viii, 1870, 131.

Pocilophis catenatus, Kıup, Cat. Apod. Fish. Brit. Mus. 1856, 100.

Echidna catenata, BLEeKer, Ned. Tyds. Dierk. ii, 242.

Dr. Kaup ( $l$. c. sup.) gives Bermuda as a locality for this species; it also occurs at many of the West India Islands, at Trinidad, and on the coast of Dutch Guiana at Surinam.

\section{RAIA.}

The names Sting Ray and White Ray would indicate the occurrence of one or more species of this order. Atobatis narinari (Euphrasen) Miiill. \& Henle is likely to occur here.

\section{IAMNID AE.}

IIr. Jones records a specimen nearly eight feet long taken in March, 18j0, which he belieres to be the Lamna punctata figured by DeKay.**

\section{SPHYRNIDA.}

The Hammer-head Shark known to the fishermen is probably the Sphyrna zygrena (Linné) Müiller \& Henle.

\section{SCYLIIID E.}

The large Shark confined in the Devil's Hole is probably Ginglymo. stoma cirratum (Gmelin) Müll. \& Henle.

\section{GALEORHINID E. \\ MUSTELUS CANIS, (Mitch.) DeKay. \\ Nurse SHARK.}

Squalus canis, Mrtchile, Trans. Lit. and Phil. Soc. N. Y., 1, 486, pl. lxiv, f. 209.

Mrustelus canis, DeKay, Zool. N. Y. Fish, 1842, 355, pl. lxiv, f. 209.-Storer, Syn. Fish. N. Am. 253.-Band, Fishes New Jersey Coast, 39, 1854; Rep. U. S. Com. Fish, 18r1, 827.-Gill, Cat. Fishes E. Coast N Am. 59 ; and in Baird's Rep. U. S. Com. Fish, 1871, 813.-Poey, Rep. Fis.-Nat. Cuba, ii, 453.

Common. My specimen measured three feet, and onc of the oviducts container a joung one eight inches long. It agrees exactly with specimens of Mustelus canis from Wood's Hole, Mass.

The Nurse is considcred excellent food; after it has been boiled until tender, and then fried in its own fat. The sharks are rarely eaten, however, except by the negroes. 



\section{A P PENDIX.}

ADDITIONAL SPECIES OBSERVED BY MR. J. MATTHEW JONES.

After the preceding pages were in type, I received from Mr. Jones a list of the species collected by him in the Bermudas. In order to represent as fully as possible the present state of knowledge in reference to the fish fauna of these islands, I venture to give below the names of those species cited by Mr. Jones which have not fallen under my personal observation. Many species are of course included both in his collection and my own. The specific names below are given on the authority of Mr. Jones, who employs the nomenclature of Dr. Günther's "Catalogue of the Fishes in the British Museum".

\section{I S T.}

Diodon maculatus.

Tetrodon rostratus.

Ostracion trigonus.

Balistes maculatus.

Monacanthus aurantiacus.

Ș̣ngnathas Jonesii.

Centriscus, sp.

Fistularia serrata.

Rhomboidichthys lunatus.

Hemirhombus aramaea.

Lefroyia bermudensis.

Brotula barbata.

Centronotus, sp.

Blennius crinitus.

Gobius soporator.

Scorpæena Plumieri.

Scarus Catesbyi.

Pseudoscarus psittacas.

Pseudoscarus sanctæ-crucis.*
Platyglossus bivittatus. Glyphidodon cælestinus. Acanthurus chirurgus. Chætodon capistratus. Holacanthus tricolor. Caranx dentex. Caranx carangus. Caranx chrysos. Thyrsites prometheus. Auxis Rochei. Seriola Dumerilii. Seriola zonata. Trachynotus ovatus. Coryphæna pelagica. Corsphæna hippurus. Mullus barbatus. Sargus argenteus. Mesoprion chrysurus. Hæmulon macrostoma.

* [Prolbably the joung of Pseudoscarus retula; see discussion on page 32, supra.] 
Hæmulon xanthopterum.

Serranus coronatus.

Rhypticns saponaceus.

Apogon imberbis.

Priacanthus macrophthalmus.

Regalecus gladius.

Belone hians.

Exocœetus lineatus.

Saurus fœetens.
Saurus myops.

Albula conorhynchus.

Ophichthys acuminatus.

Muræna miliaris.

Nuræna maculipinnis.

Muræna sanctæ-helenæ.

Acipenser sturio.*

Carcharias obscurus.

Etobatis narinari. 


\section{INDEX.}

Page.

Acanthurus chirurgus ..........13, 42,75

Bleeker, Dr................. 7, $2:$

Acanthurus nigricaus ............ 14, 41

Blenniidæ................... 28

Acipeuser sturio ................ $\quad 76$

Etobatis narinari .............. 73,76

Albula conorhyuchus............ $\quad \boldsymbol{7 6}$

Alutera scripta ................ 14, 26

Amber-fish ................... 48

Anchovy ......................

Angel-fish

$.10,17,43$

Angel-fish, Black .

Anguillidx

Anguilla bostoniensis

Autennariidæ

Apogou imberbis.

Appendix

Arothron

Atheriua, $\mathrm{sp}$

Aulostoma maculatum

Anlostomidx

Auxis Rochei

Bialumian names

Baits

10,11

Balistes caprisens

$.13,14,25$

Balistes maculatus 26,75

Balistes ringens..................

Balistes sobace ..................

Balistes vetula

Balistidie.

Banks, outer

Barbeiro

9,10

Barbero

Barracuda, 16,61

Bartram, John T 19,32

Belone hians.

Belonidx

Bervcidæ

Black-tail

\section{5}

Bloch ........................ 22

Blue Belly................... 15

Blue-fish ...................... 17, 35

Bone-fish ................... 15, 17

Bonito ..................... 48

Bream ....................... 52

Brotula barbata ................ 75

Buffalo Jack.................. 47

Butter-fish ................... 59

Caballa ...................... 48

Caffum......................

Calamus megacephalus........... 51

Calamus orbitarius.............. 51

Canthidermis maculatus. .......... $\quad 26$

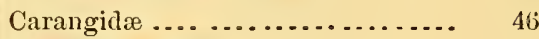

Caranx carangus............... 75

Caranx chrysos ................ 75

Caranx dentex................ $\quad$ i5

Carassius auratus............... 71

Carcharias obscurus............. 76

Carelessness of early ichthyologists. $\quad 22$

Carolina Whiting .............. 17

Carrub ...................... 50

Casting-nets.................. 11

Cataphebe.................... 60

Catesby, Mark ................. 13

Catesby's species.............. 16,39

Cat-fish ..................... 17

Cavally ..................... 48

Centriscus, $\mathrm{sp}$................ 75

Centronotus, sp............... 75

Chœrojuiis radiatus............. 13,35

Chætodon arcuatus............. 45

Chætodon capistratus........... 75

Chætodontidæ................. 43 
Chilichthys Spengleri

Page.

13,22

Chilichthys turgidus

Engraulis

Page.

Chilomycterus geometricus

Engraulis chœrostomus

Chilomyeterus reticulatus

Enveacentrus puuctatus.

13,21

Chirurgien-bleu

Enumeration of species

Epinephelus guttatus.

Chub

Clamacore

Clucker

Epinephelus striatus

Clupeidæ

Colonial museum

Coney

Coney, Black

Coufusion in synonymy

Coryphrena hippurus $.14,48,75$

Coryphæna pelagica

Coryphenidx

Cow-fish

Cow-pilot

Croker

Crustaceaus

Cnckold

Cyprinidæe

Cyprinodoutidx .................

Dactylopterus volitaus........... 14,31

Decapterus macirellus ............

Decapterus puuctatus ... . 10, 11, 12, 14, 39,

Deer Grouper ...................

Demoiselle .....................

Depth of waters ................

Devil-fish

Devil's Hole 19,20

Doctor-fish 11,57

Dolphin

Doucella

Diapterus Lefroyi

Diodon atinga ..................

Diodou maculatus ...............

Dionlon orbicularis...............

Diodontidi... . . . . ..............

Eeheueidilie....................

Echicha cateuata ................

Eel...........................

Elopidie .......................

Eugraulididee...................

Eucinostomus aprion 11,57

Eucinostomns gula...........10,11, 13, 39

Eucinostomus Lefroyi........ 10, 11, 13, 39

Eucinostomus productus ......... 41

European species ................ 12

Exocœtus exiliens................ 64

Exocœtus lineatus .............. $\quad 76$

Fauna of the Bermudas.......... 11, 12

Fierasferida.................. 27

Fish markets .................. 10

Fish ponds .................... 11

Fish pots ................... 10

Fisheries ..................... 9

Fishing boats.................. 10

Fistularia serrata.............. 27,75

Fistularia tabacearia............ $\quad 27$

Flora of the Bermudas ............ 12

Flying-fish $\ldots \ldots \ldots \ldots \ldots \ldots \ldots \ldots . . \ldots 10,64$

Four-ejed fish ................. 43

Fry ......................... 10

Fry, Hogr-mouth ................ $\quad 70$

Full-baits .................... 10

Fundulus Bermudæ ............. 68

Graleorhinida .................. 73

Gar-fish ..................... 17, 64

Garoupa.................... 57

Gerrill ...................... $\quad 39$

Gill, Prof. Theodore ............. 8,50

Glare-eye Squirrel .............. 15

Glass-ejed Suapper ............ 55

Globe-tish ................... 17

Gold-fish ..................... $\quad \boldsymbol{z}_{1}$

Glyphidodon cælestinus.......... 75

Glyphidodon saxatilis........... 14,38

Goat-tish ...................... . 49

Gobius soporator............... 75

Godet, T. L .................. 7

Goggle-cye .................. $4 \pi$

Goggler ...................... 48 
Gosse's, naturalist in Jamaica.....

Grains.

Gray Snapper.

Grouper

Grouper, Deer

Grubble

Grunt

Grunt, Black

Grunt, Spotted

Gruut, White

Grunt, Yellow

Guacuenja

Gnamajacn atinga

Guichenot, M

Guelly

Gulf Stream

Gulf-weed

Giinther, Dr

Ginglymostoma cirratnm.........

Gymnothorax moringa

Hiemulon

Haemnlon macrostoma.

Hæualon quadrilineatnm

Hæunlon santhopternm

Hremylum capenna ..............

Hæmylnm chrysopterum .........

Half-beak

Hamlet

Harbors

Harengnla macrophthalma

Harpe rufus

Harrington Sound

Hemirbamphus Pleii

Hemirhombus aramaca

Herring ......................

Hind

Hind, Black

Hind, Prickly

Hippocampirtæ ...............

Hiprocampus antiquorum........

Hippocampus, sp ................

Histiophorus americanns . .........

Hog-fish $\mathbf{1 0}, \mathbf{1 7}, 36$

Hogr-fish, Black

Hog-fisin, Spapish
Page.
Hog-fish Beacon

Holacanthus ciìiaris...... . . . . . 10, 38, 43

Holacauthus tricolor ............ 44, 75

Holocentrum sogo .............. 13, 49

Hound-fish ..................... 64

Hypeneus macnlatus............ 13, 49

Hypoplectrus pHella ............ 60

Introdnctory remarks ........... 7

Jack ........................ 47

Jew-fish $\ldots \ldots \ldots \ldots$

Jigging . . . . . . . . . . . . . . . . . . . . . 46

Jones, J. Matthew . ...7, 20, 27, 32, 45, 62, 75

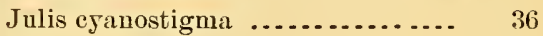

Julis principis ................ $\quad 36$

Julis patatus . ............... 36

Keane, C. C.................. 20,27

Killing fish ................... $\quad 10$

Kilmagore .................... 33

Labridæ. . . . . . . . . . . . . . . . . . . . 10,35

Lachnolæmns falcatus . . . . . . . . 10, 13, 36

Labrosomns nuchipinnis ......... 14, 28

Lady-fish, Spanish . ............. 37.

Lane Snapper . . . . . . . . . . . . . . . 17

Lamnidæ .................... $7: 3$

Lamna punctata.............. 73

Lefroyia................... 28

Lefroy, General J. H. . ........... 28, 41

Lefroyia bermurlensis ......... 15, 27, 75

Leptecheneis nancrates........... 61

Leptecheneis naucrateoides........ 61

Line fishing . . . . . . . . . . . . . . . . . 10

List of species............... 19,75

Lobster, Bermuda . . . . . . . . . . . 10, 37

Lobster, Spanish ............... 10,37

Loro ....................... 35

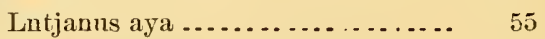

Lntjanus caxis.................. 54

Lutjanus cyuodon ............... 55

Lïtken, Professor ................... 19

Mackerel ........................ 10,45

Malthe augusta............... 20

Mal the cabifrons............... 19, 20

Maltheidæ.................... 19

Malthe longirostris............. $\quad 20$

Malthe notata ................ 20 
Malthe vespertilio

Mangrove Suapper.............

Maray, Black.................

Marbled Angler................

Margate-fish

Megalops thrissoides

Melichthys buniva

Mermaid

Mesoprion chrysurus

Mesoprion goreensis

Mesoprion uninotatus

Mirldletown University .

Molly Miller

Monacanthus aurantiacus

Moray.

Mioray, Speckled

Ind fish

Mugilidie

Mugil lebranchus

Mugil liza.....................

Mullet ..................... 16,63

Mrullet, Sand.

Mullidie

Mullus barbatus

Mrrena maculipiunis

Muriena miliaris.

Mur:ena sauctx-helenx

Mrurenide .........

Murenoides mucronatus ..........

Muray. (See Moray.)

Mutrou-fish . ..................

Mustelus canis..................

Names used in Uuited States ......

Naucrates ductor.

Negro-fish

Negroes, Bermuda

Newes from the Bermudas.

Nigger-fish ...................

Nurse Shark...................

Ocean Turbot..................

Octopus

Oerurus chrysurus..............

Old names retained ..............

Old-wife 17,26

Oligoplites
Page.

13,19

16

17

20

16,53

68

26

15

75

54

55

22

28

75

10,17

72

32

63

64

J1, 63

15

49

75

76

76

76

10

29

17

73

15

14,48

16

9

45

59

73

26

10

55

15

20

$4 \triangleleft$
Page

Ophichthys acnminatus ........... $\quad 76$

Opisthonema thrissa......... .69

Orcynus alliteratus ............10,14, 45

Origin of Bermuda colonists....... $\quad 15$

Ostraciidæ .................. 23

Ostracion trigonus ............. 75

Ostracinm quadricorne ........... 13, 24

Ostracium triquetrun .......... .13, 23, 24

Palinurus americanus ........... 10

Paradiodon hystrix ............. 14, 21

Paratractus pisquetus..........12, 14, 47

Pareques .................... 50

Pareques acuminatus .......... 13,50

Parrot-fish................... 17

Pearch ..................... 16

Permit ....................... 15

Persistency of common names...... $\quad 15$

Pilchard ...................10,17, 19

Pilot-fish ..................... 48

Pimelepterus Boscii............ $\quad 52$

Pipe-fishes.................... 27

Platyglossus bivittatus.......... $\quad 75$

Poes, Prof. Felipe............33, 34, 36, 41

Poisonous fishes ........24,37,56, 62, 72

Ponacentridie ................ 38

Popular names................ 15

Porgy ..................... 17,51

Porgy, Blue-bone ............... 15

Porgy, Goat's-head ............... 51

Porgy, Scotch................... 15

Porgy, Sheep's-head............ 51

Porgy, Spanish................ $\quad 32$

Porgs, White-bone.............. 15

Porte-lancette .................. 42

Pork-fish ...................... 16

Pots ......................... 10

Priacanthus macrophthalmus...... $\quad 76$

Price of fish .................. 10

Prickly Hind ................... 15

Pristipomatidæ ............... 10, 53

Promicropterus maculatus........ 60

Pseudoscarus cæruleus ............ 13, 33

Pseudoscarus chloris ............ $\quad 34$

Pseudoscarus psittacus........... 33, 75

Pseudoscarus qnadrispinosus ...... 34 
Pseudoscarus sanetæ-crucis....... . 33, 75

Pseufloscarus vetula .......... 13, 32, 38

Puff-fish ..................... 23

Pudding-wife................

Ptheirichthys lineatus.

Pterophrsne picta

Raice

Rainbow

Red Rock-fish ...................

Red-tail

Reef-building polyps

Reefs

Regalecus gladius .

63,76

Reptilian fauna of the Bermudas ..

Rhomboidichthys lunatus

Rhypticus saponacens

Robin

Rock-fish

Rock-fish, Red

Round Robin

Rudder-fish

Runner

Saigneur

Salarias textilis

Salarias romerinus.

Sand-eel

Sand-mullet

Sand-shark

Sardiné

Sardinella anchovia

Sargassum

Sargus argenteus

Sargus Rondeletii

Sargus variegatus

Sarothrodas bimacalatus.

$13,38,43$

Saurus fœtens

Saurus griseus

Saurus myops.

Scaridæ

Scaras Catesbyi

Scarus chloris

Scarus radians

Scarus virens.

School-fishes

Schoolmaster
Schoolmaster Snapper ........... $\quad 55$

Sciænidre................... 50

Scomberesncidæ................ 64

Scombridæ ................... 45

Scorprena Plumieri.............. $\quad 75$

Scuttle ....................... 10

Scyllarus æquinoxialis .......... 10

Scylliidæ.................... 73

Sea-hedgehog................. 21

Sea-horse .................. 27

Sea-porcupine ................ 21

Sea Lawyer. ... . . . . . . . . . . . . . 54

Sea-serpent..................... 63

Sea Sparrow Hawlk ............. 16

75 Seines ........................ 11

60,76 Sennet $\ldots \ldots \ldots \ldots \ldots \ldots \ldots \ldots \ldots \ldots$

10 Sergeant Major ................. 38

16,55 Seriola ....................... 48

56 Seriola dumerilii............... $\quad 75$

46 Seriola zonata ................ $\quad 75$

16 Serranidæ ................... 10,55

15 Serranus apua ................ 59

42 Serranus brunneus ............. 56

13, 29 Serranus coronatus............. 76

29 Shad . . . . . . . . . . . . . . 10, 15, 17, 39

15 Shad, Long-boned............... $\quad 39$

15 Shark, Sand .................... 15

15 Shark, Sunburnt ............... 15

15 Sheep's-head Porgy .............. 51

69 Silk Suapper................... 55

20 Skip Jack ................... 15, 17, 48

75 Slippery Dick.................... 15, 48

52 Snake-fish ................... 68

Snapper, Lane ................. 17

Snapper, Mangrove ............. 16

Snapper, Schoolmaster ........... 55

68 Snapper, Silk .................. 55

76 Srapper, Spot ...................... 55

10,32 Soap-fish .......................... 60

75 Givile ...................... 17

34 Sparidær.................... 10,51

13, 32 Sparus radiatus............... 36

34 Speckled Moray .................. $\quad 72$

11 Sphyræna borealis ............. 62

16 Sphyræna picuda ............... 62 
Sphyræna Page.

Sphyrænidæ.

Sphyrnidæ

Sphyrna zygæna.

Spot Snapper

Spotted Grunt

Squirrel

Sting-ray

Streaked Grunt

Suck-fish

Sucking-fish

Sunburnt Shark

Swallow

Sword-fish

Syngnathidæ

Syngnathus Jonesii

Syngnathus pelagicus

Synodontidæ

Synodus lacerta

Tarpum

Table of contents

Tang

Tetrapturus albidus

Tetrodon marmoratus

Tetrodou rostratus.

Tetrodon turgidus

Tetrodontidæ.

Teuthididæ

Thumper

Thyrsites prometheus

Tobaccopipe-fish

Topography of the islauds. . . . . . . .
16,49

73

54

61

17

15

23

45

$15,17,25$

27

12,68
Trachurops crumenophthalmus .. 14, 39, 47

Trachynotus ovatus.............. $\quad 75$

Trachypteridæ................. 63

Transporting power of Gulf Stream. $\quad 12$

Triglidæ....................... 31

Trisotropis guttatus ............. 56

Trisotropis undulosus ........... $\quad 55$

Trompa ....................... 35

Trumpet-fish................... 27

Trumpet-fish, Black.............. $\quad 27$

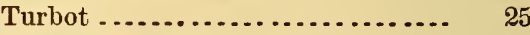

Turbot, Black .................. $\quad 26$

Turdus cinereus peltatus .......... $\quad 39$

Unicorn-fish ..................... 17

Valenciennes .................... . 33

Vieja......................... 33

West Indian region ............. 11

White-Ray..................... 73

White Belly .................... $\quad 15$

White-bone Porgy .............. $\quad 15$

White Grunt................... 53

Whiting ...................... 17

Whiting, Carolina ............. $\quad 17$

Xiphias gladius ................. 45

Xiphiidæ ..................... 45

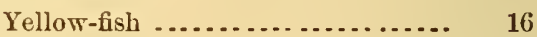

Yellow Grunt ..... ............... 54

Yellow-tail .................... 55

Yellow Tang................... 15

Yelting...................... 55

Zonichthys fasciatus ............ 13,48 


\section{Department of the Interior:}

U. S. NATIONAL MUSEUM.

\section{BULLETIN}

O) THE

\section{UNITED STATIS NATIONAL MUSEUM.}

N0. 5.-CATALOGUE OF THE FisheS OF THE BERMUdAS.

BY

G. BROWN GOODE.

WASHINGTON:

GOVERNMENT PRINTING OFHICE. 





\title{
THE SHORT POMPANO (Trachynotus ovatus). AND THE AMBER FISH (Seriola $s p$ ).
}

\author{
U. S. Fish CGMmission, Fish and Fisheries, | \\ SMITHSONIAN INSTITUTION. \\ Washington, D. C., Feb. 7ith, 18\%6. ।
}

EDitor Forest and Streas:-

The pompanoes from Pensacola, Fla., referred to in your lastissue, one of which was sent by Mr. Blackford to the National Musenm, belong to a species not nearly so common on our coast as tile Trachynotus Carolinus. The short pompano (Trachynotus ovatus) is easily distinguished by the greater height of its body, which is nearly or quite equal to the half of its length, and by the prolongations of the anterior rays of the dorsal and anal fins; the lobes of the caudal, dorsal, and anal are blackish, while the geveral hue of the body is more golden than in the. ordinary species. The short pompano is cosmopolitan; it has been observed in Anstralia; in the seas of China and India; in the Moluccas and about Ceylon; in the Maylayan Peninsula and the Red Sea. It occurs on the coast of south America and in the West Indies. It is probably the "pompynose" of New Orleans, though the other species probably also occnrs in those waters. While at Wood's Hole last Summer, the seining party of the United States Fish Commission took three specimens of this spccies at the head of Vineyard Haven (Hoime's Hole) Harbor; these were very yonng, not exceeding one inch in length, and were preserved in the aquaria for come days.

Mr. Blackford has recently sent to the museum another interesting fish belonging to the genus Seriola, one of the Cararigide, and not very remotely related to the banded rudder-fish (Jalatractus zonatus), which is frequently seen in our waters. It is very closely related to the fish known as the "amber fish" in the Bermudas, and as the "yellow tail" abont St. Helena. This fish, which came from Key West, was fortyseven inches in length and weighed thirty-two pounds. Its specific relations are not yet determined. G. Brown Goodr.

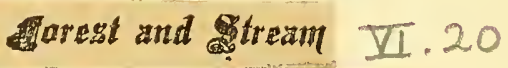

FEBRUARY 17, 1876. 






\section{Natural History of Florida.}

The zoology of Florida is in many respects peculiar and is very different from that of any other portion of the United States. An effort is being made to secure for the new Zoological Garden in Philadelphia, as large a series as possible, of living animals from this State. Mr. G. Brown Goode, of the Smithsonian Institute, Washington, is making collections during a short visit to Florida. This garden has been made upon a portion of Government Park, Philadelphia, which has been granted by the commissioners of the park, for that purpose. The success of the undertaking-the first of the kind in the United States-has been extraordinary, even in com. parison with the Zoological Gardens of Europe. Since the opening in July 1, 1874, up to the present time, over 200,000 persons have risited the collection. Should the society liave continued success, the collection will form a rery important and attractive feature in the Centennial Exposition of 1876 , besides being at all times a useful means for encoul aging the taste for and increasing the knowledge of Natural History. It is particularly desirable to obtain a large series of Florida reptiles, snakes and turtles, cranes, herons, ibises, pelecans and show birds generally, and fox.squirrels, wild hogs and manatees. Persons having opportunities to collect or having animals to dispose of, should communicate with G. Brown Goode, Arlington Bluffs, near this city. 


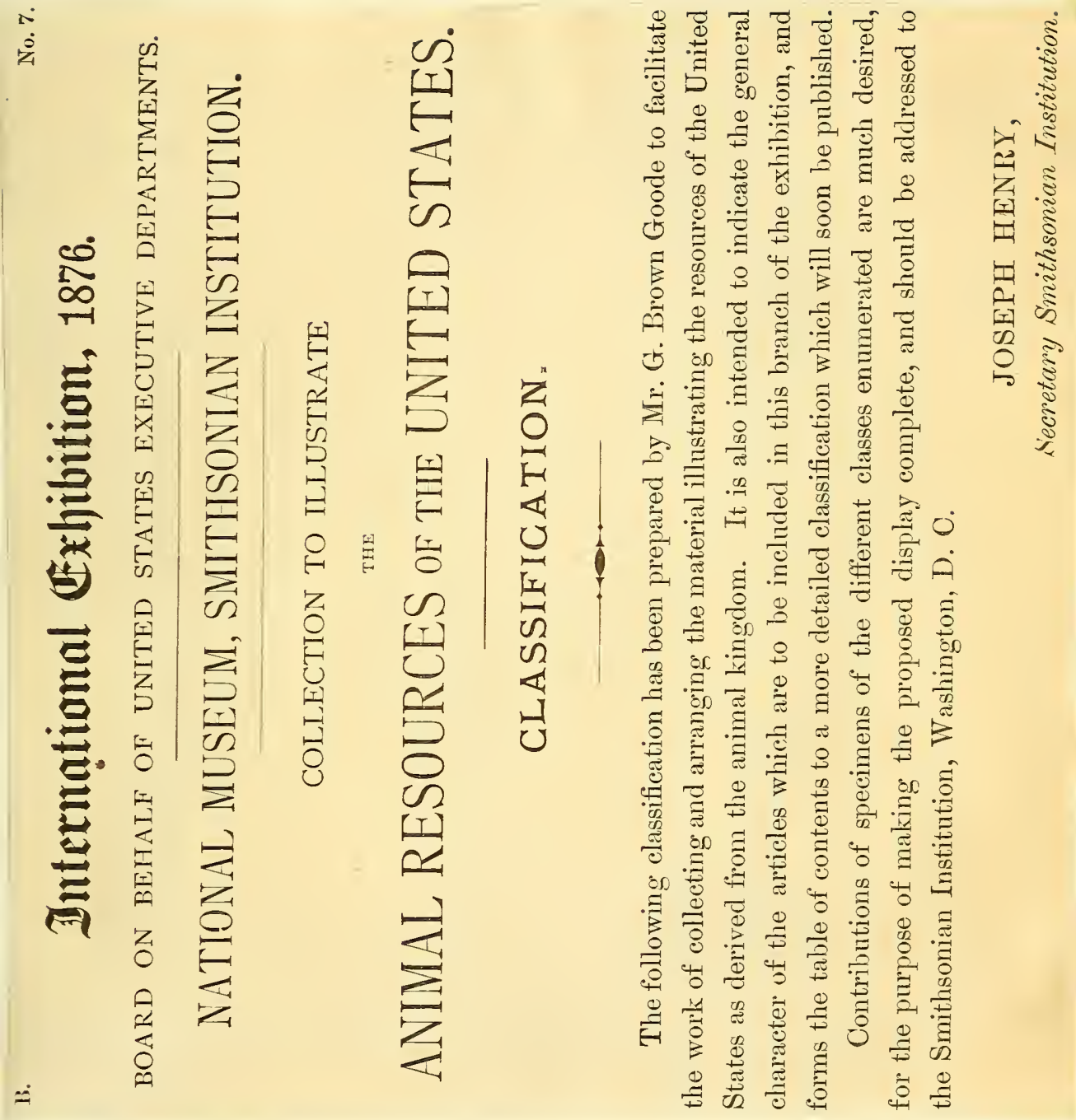




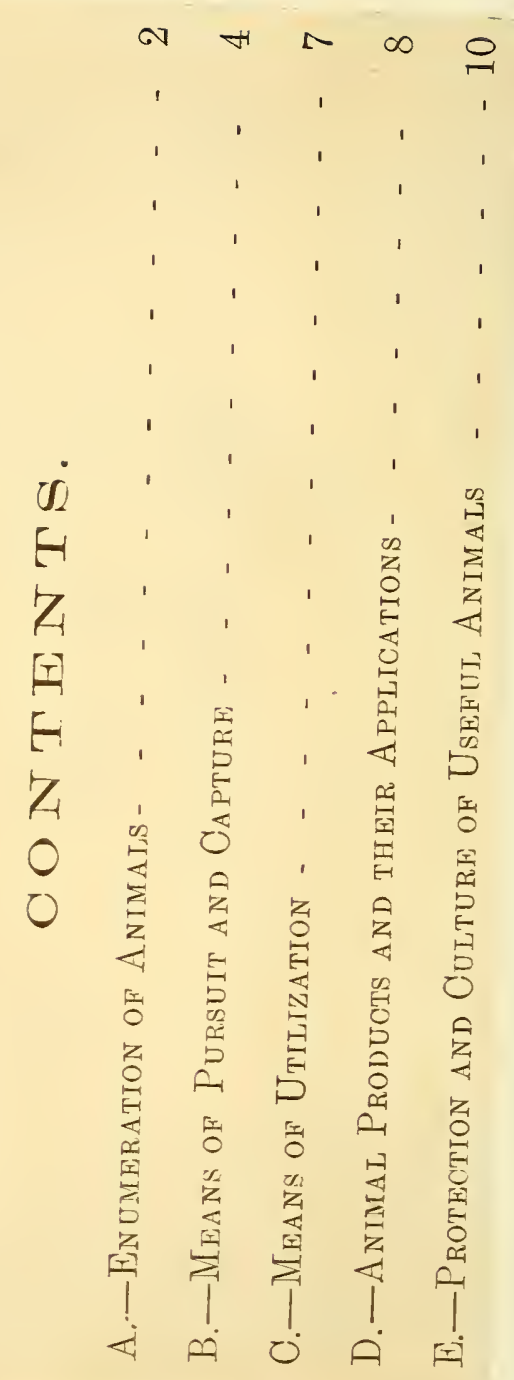




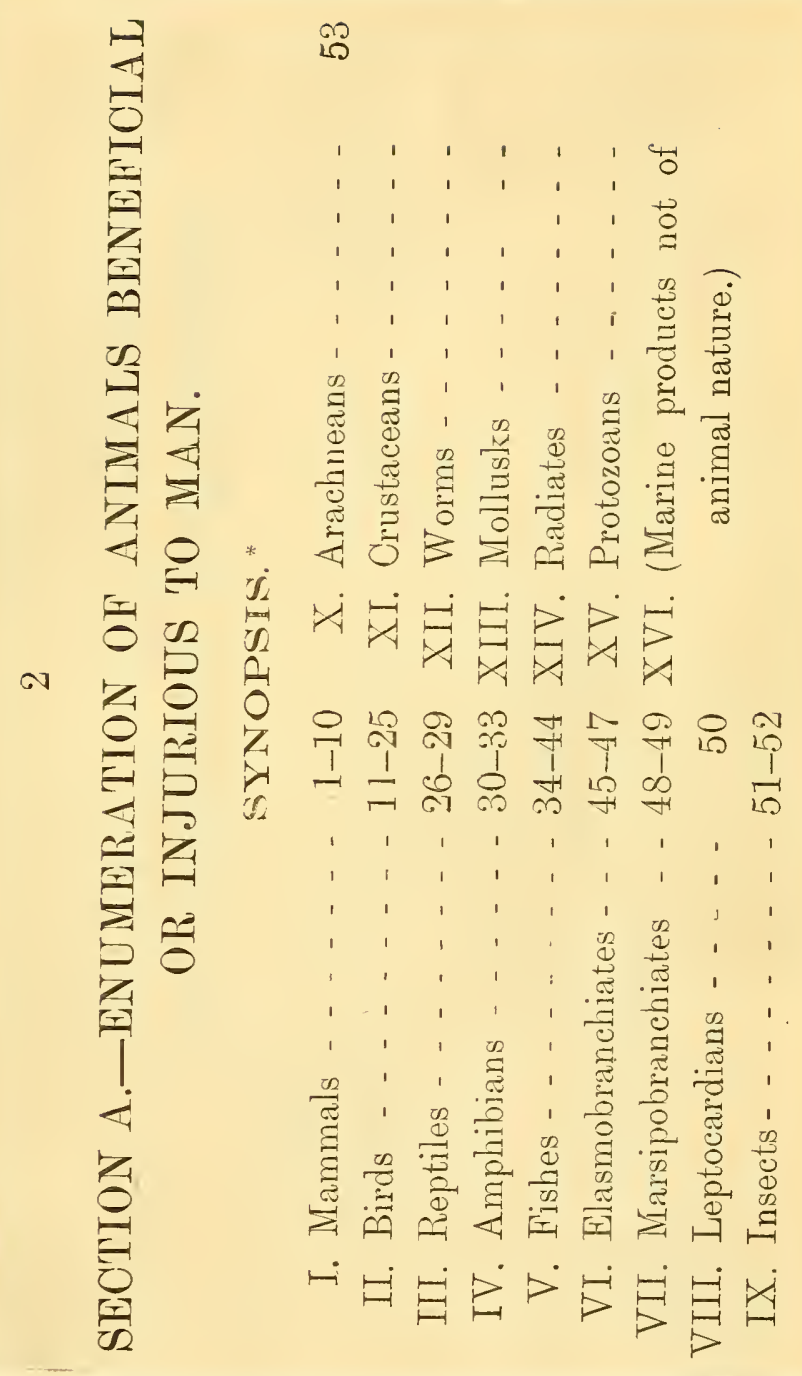




$$
\begin{aligned}
& \stackrel{\text { 量 }}{\frac{2}{9}}
\end{aligned}
$$

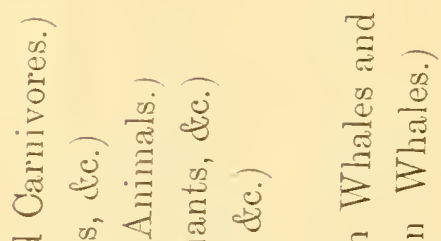

$$
\begin{aligned}
& \text { ब. }
\end{aligned}
$$

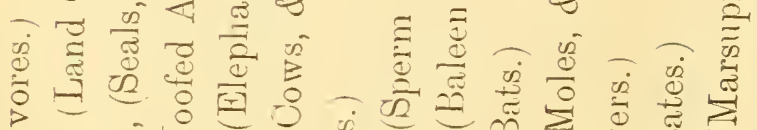

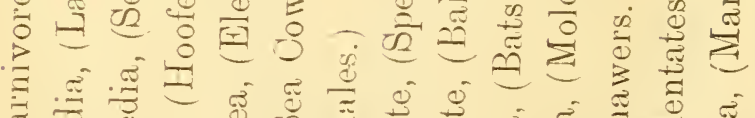

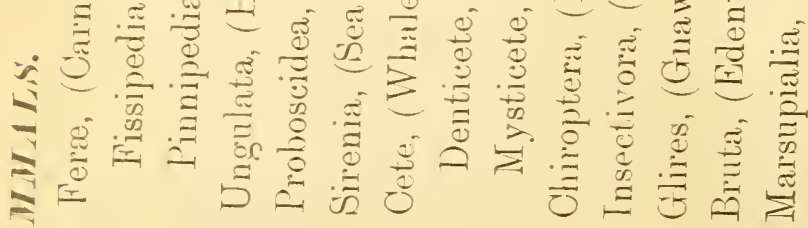

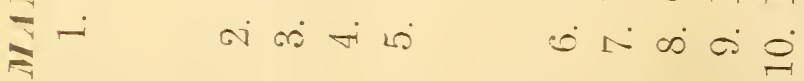




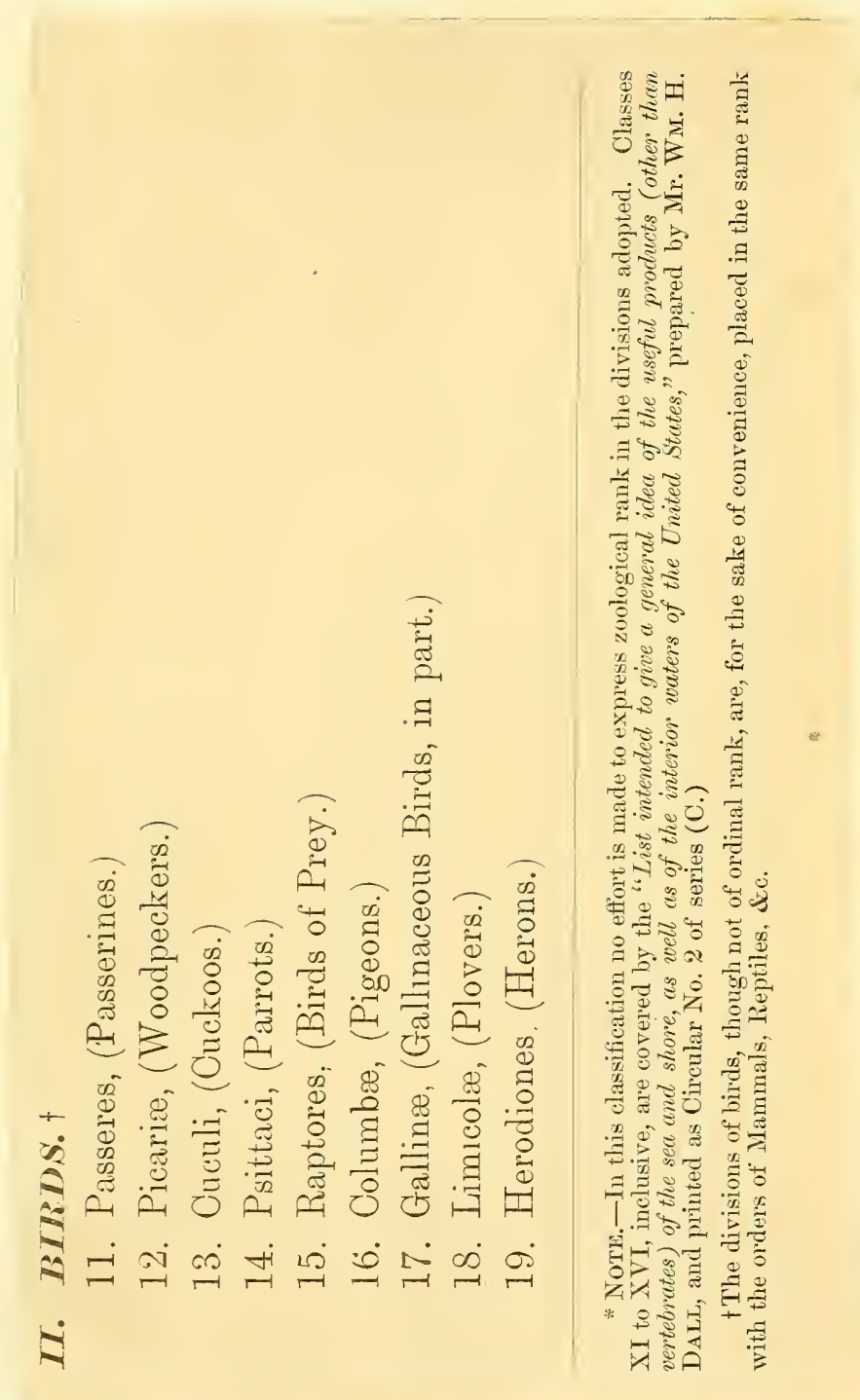




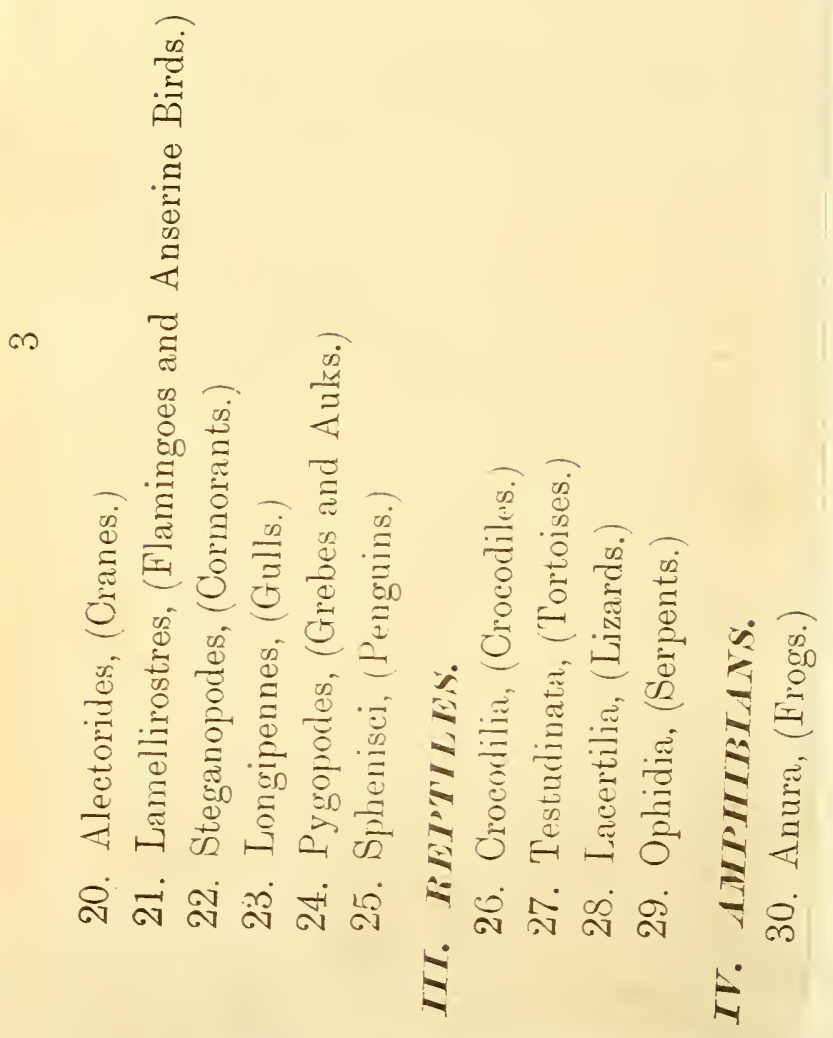




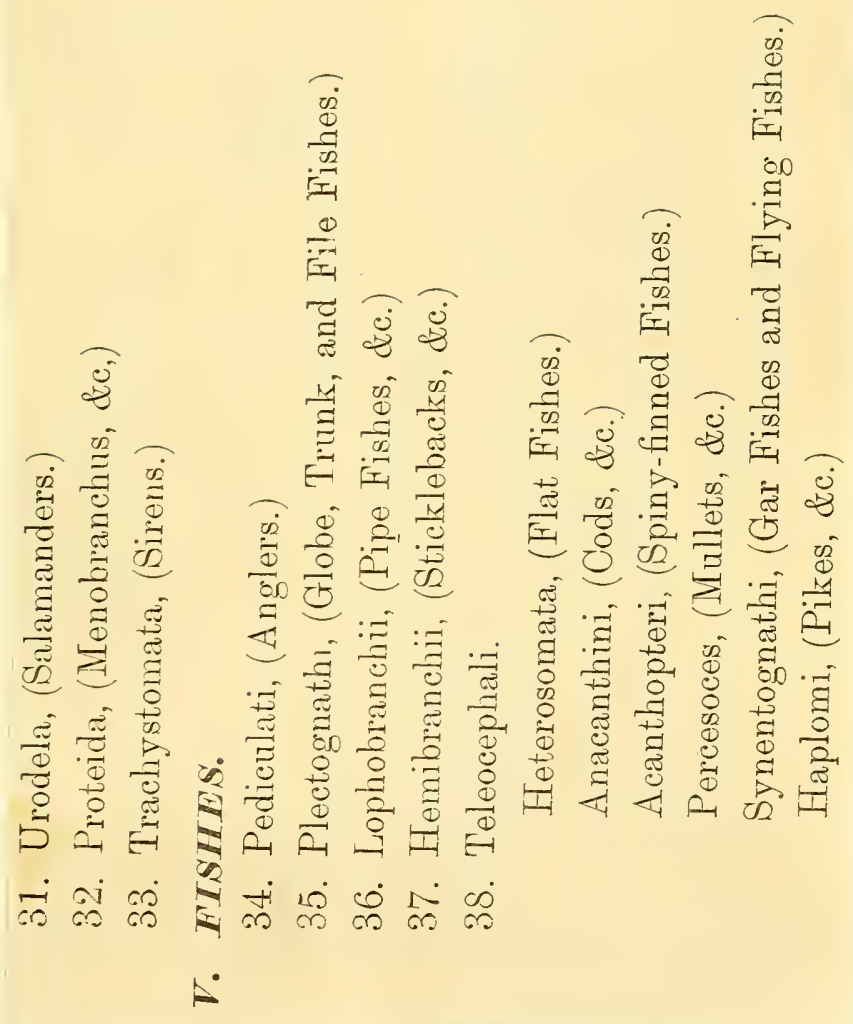


S

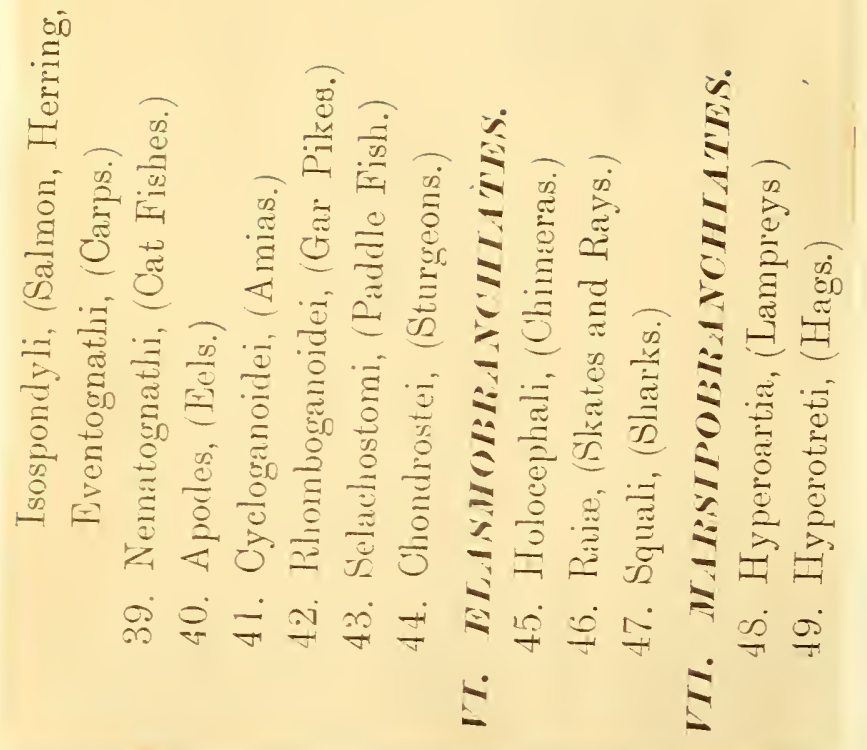




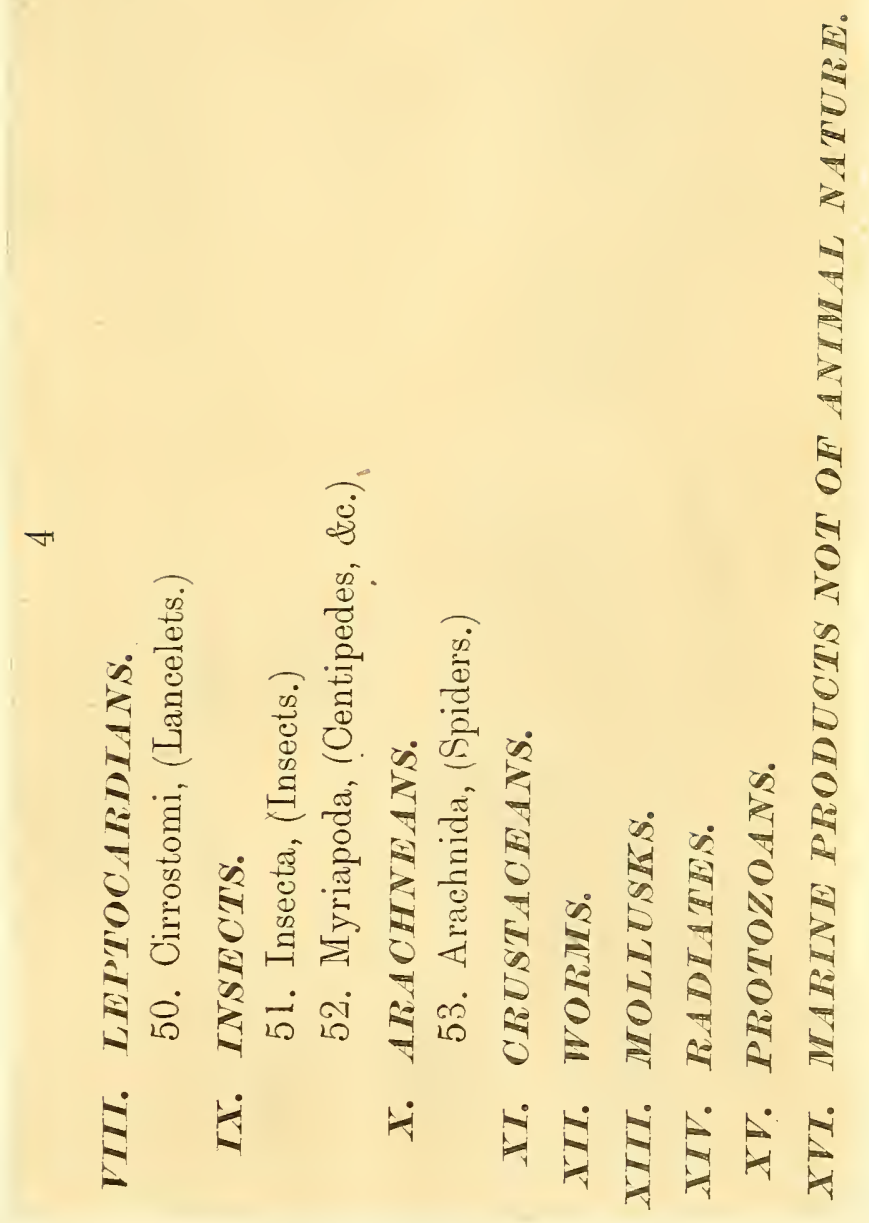




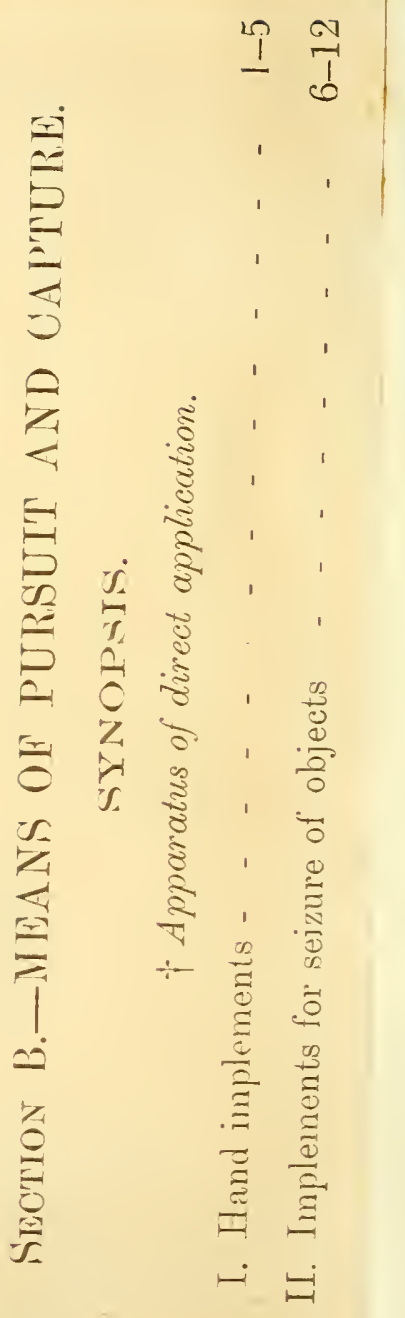




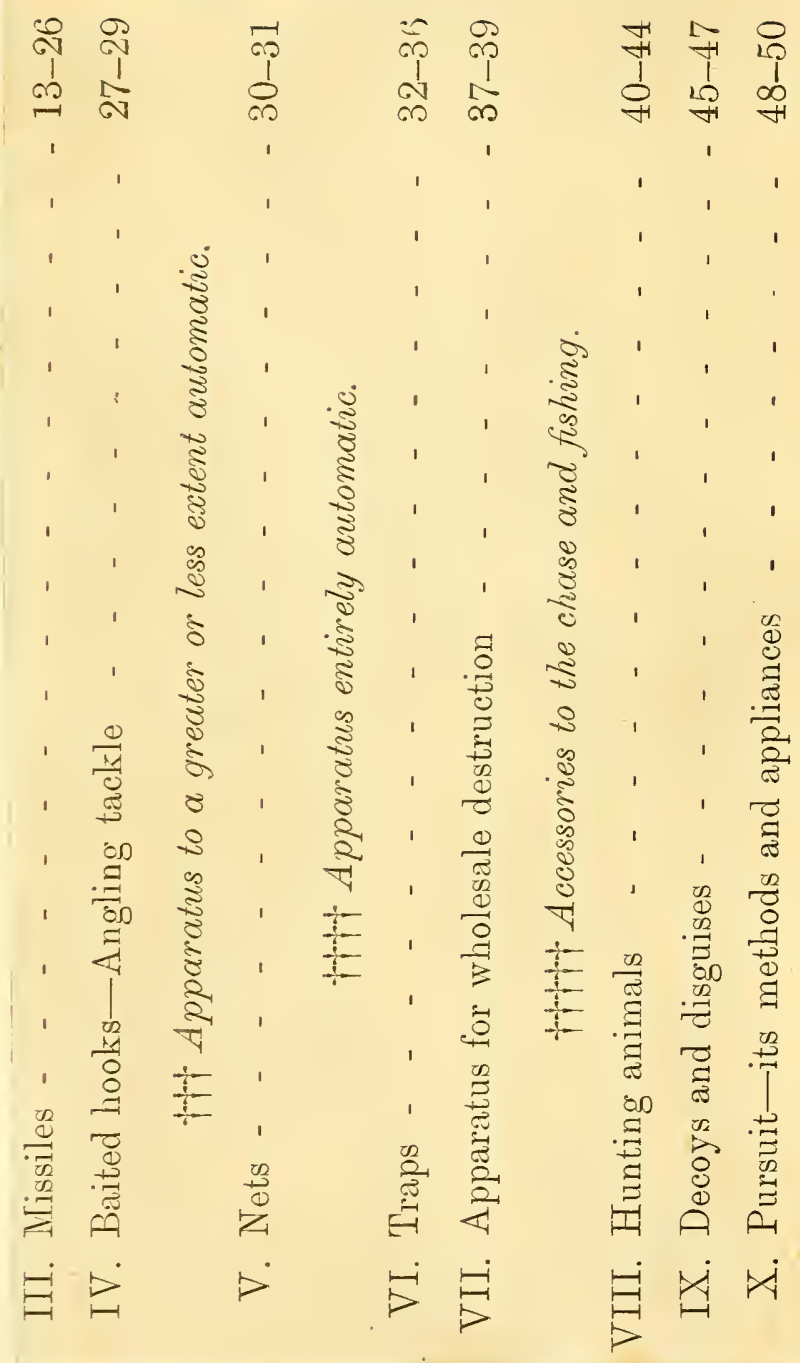




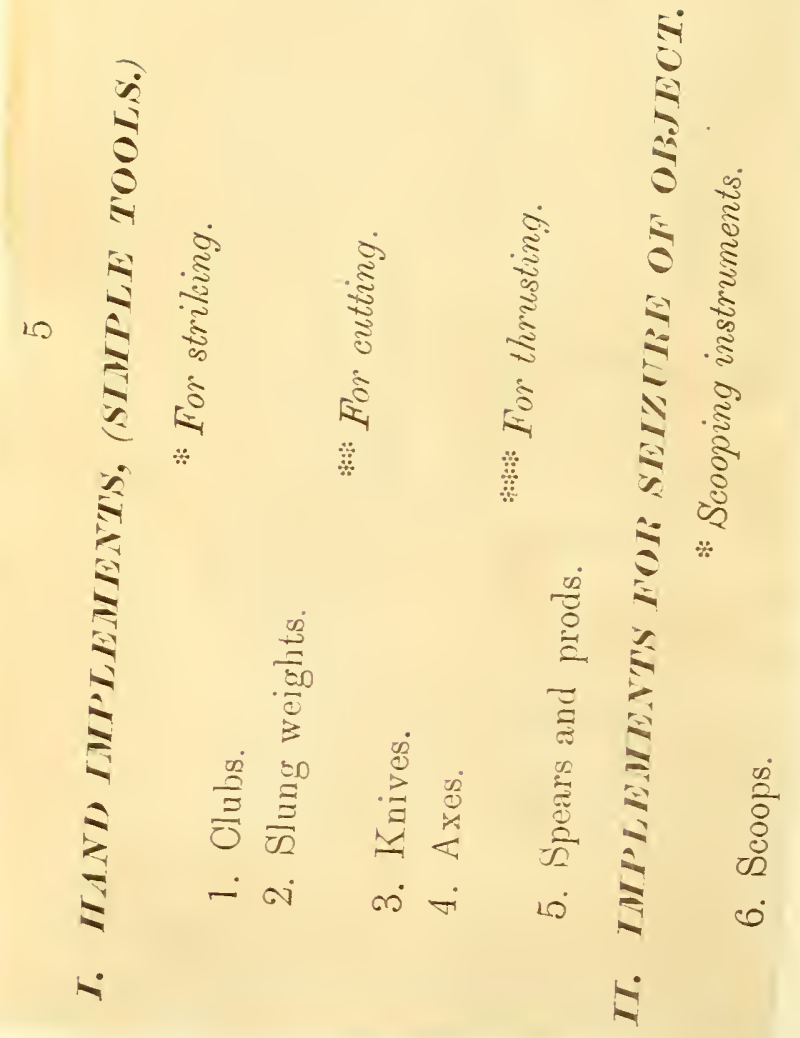




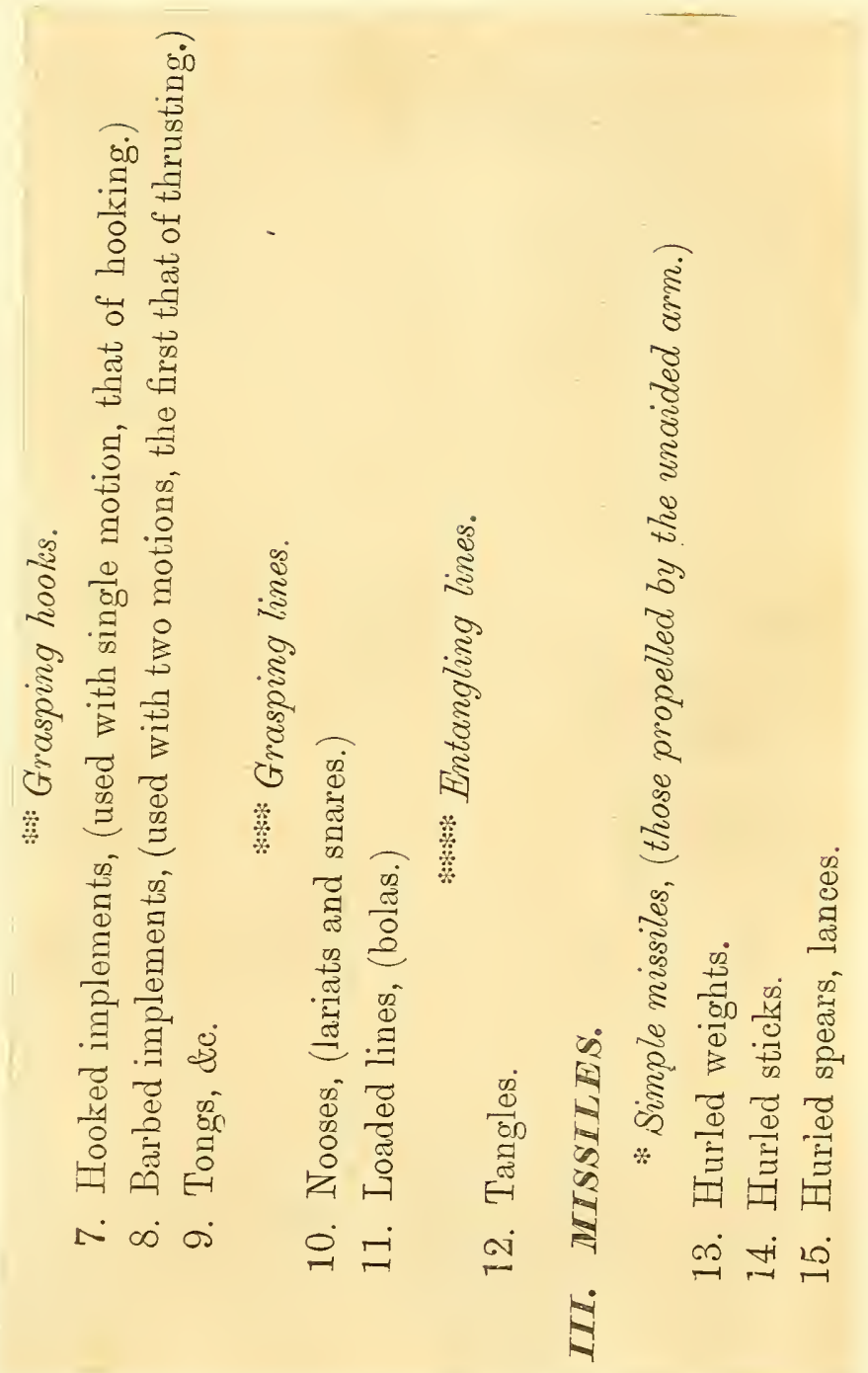




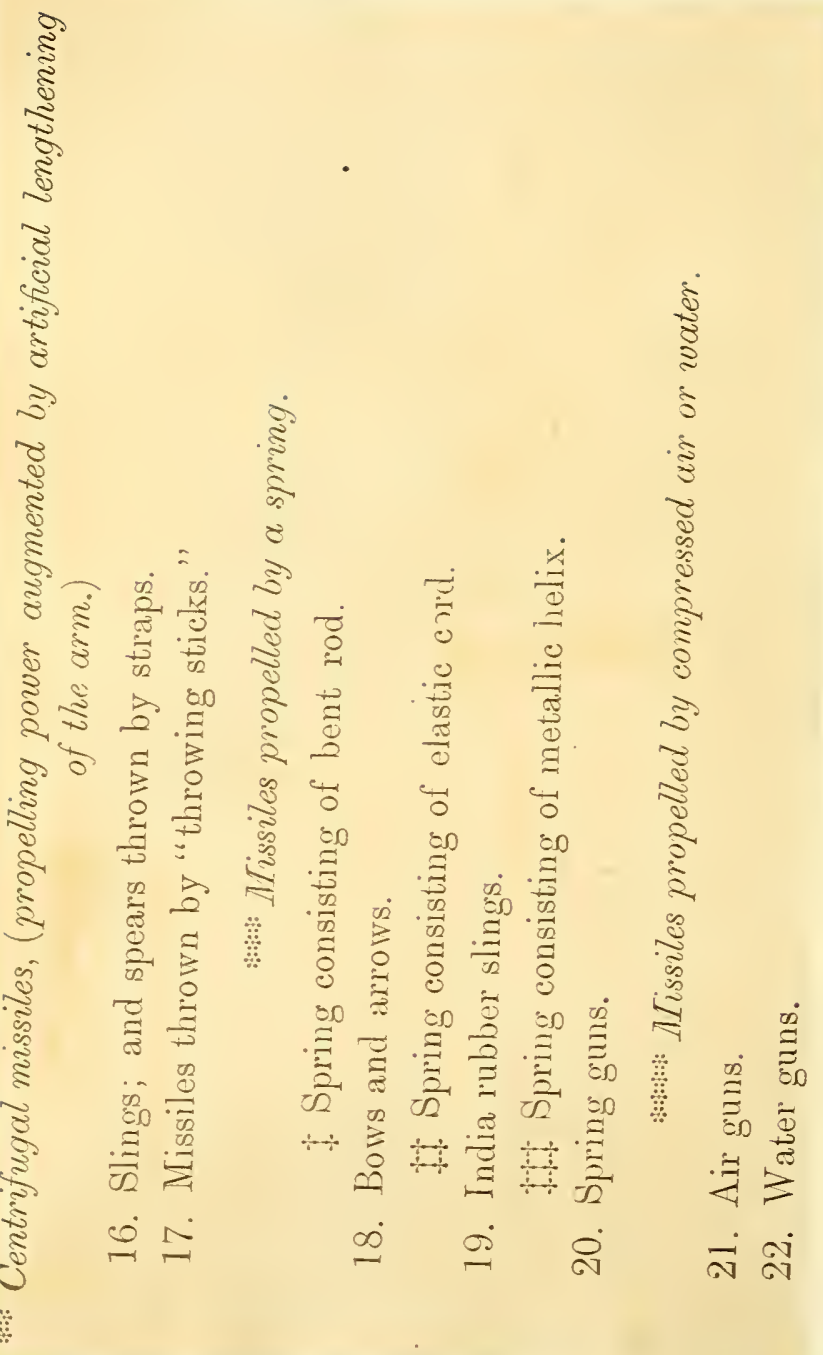




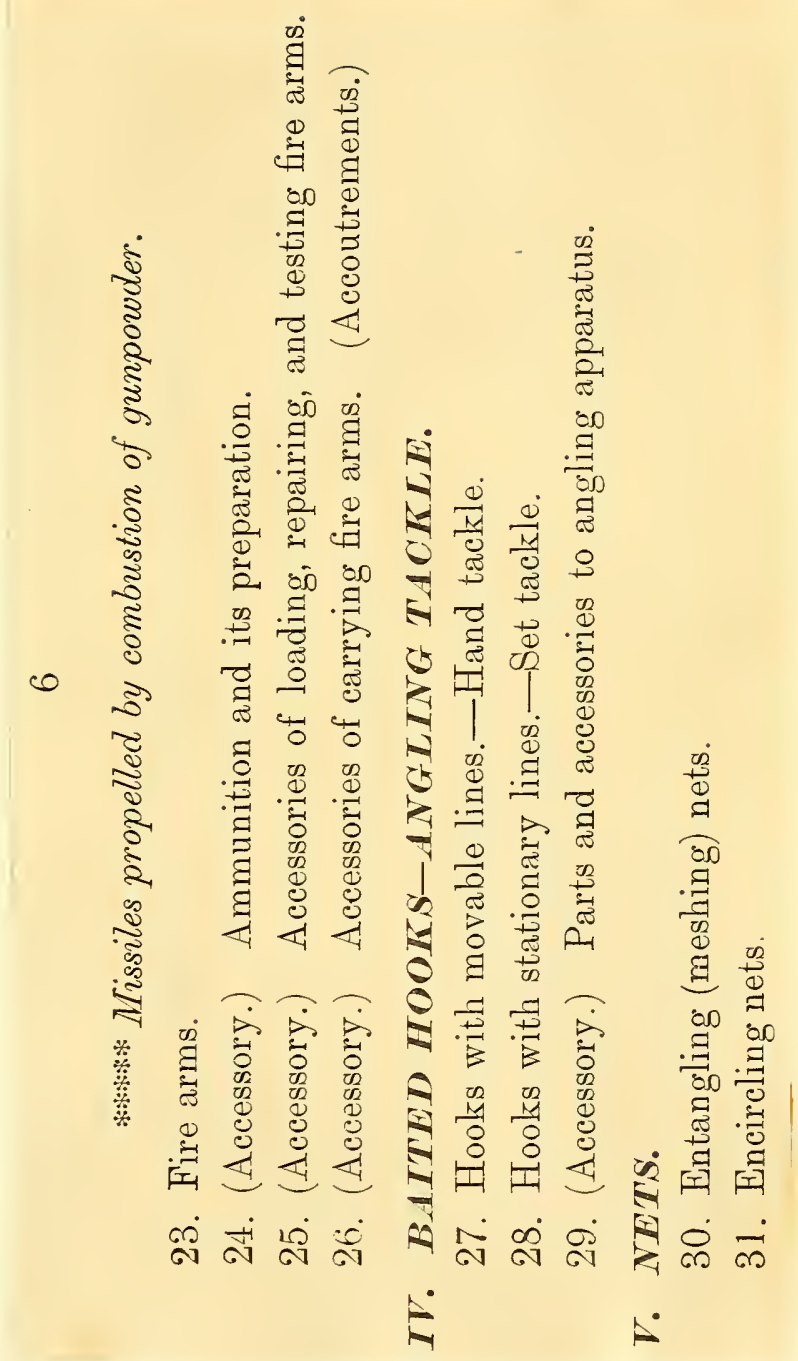




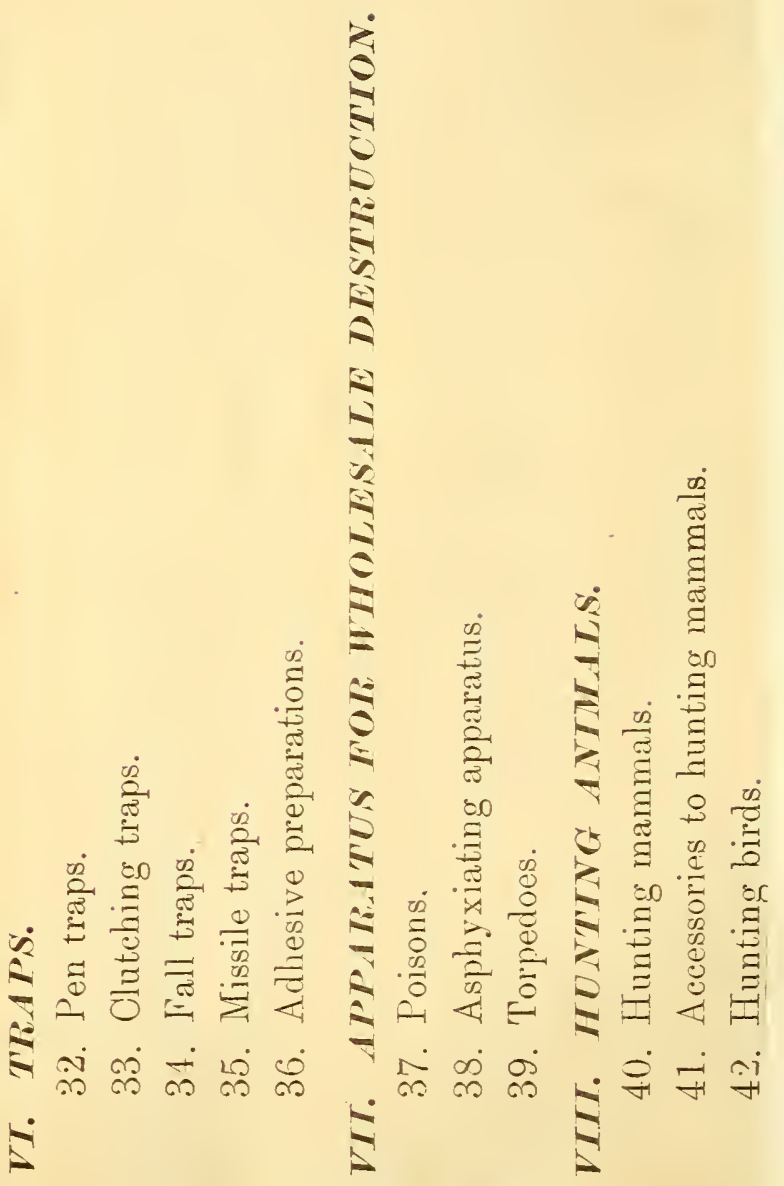




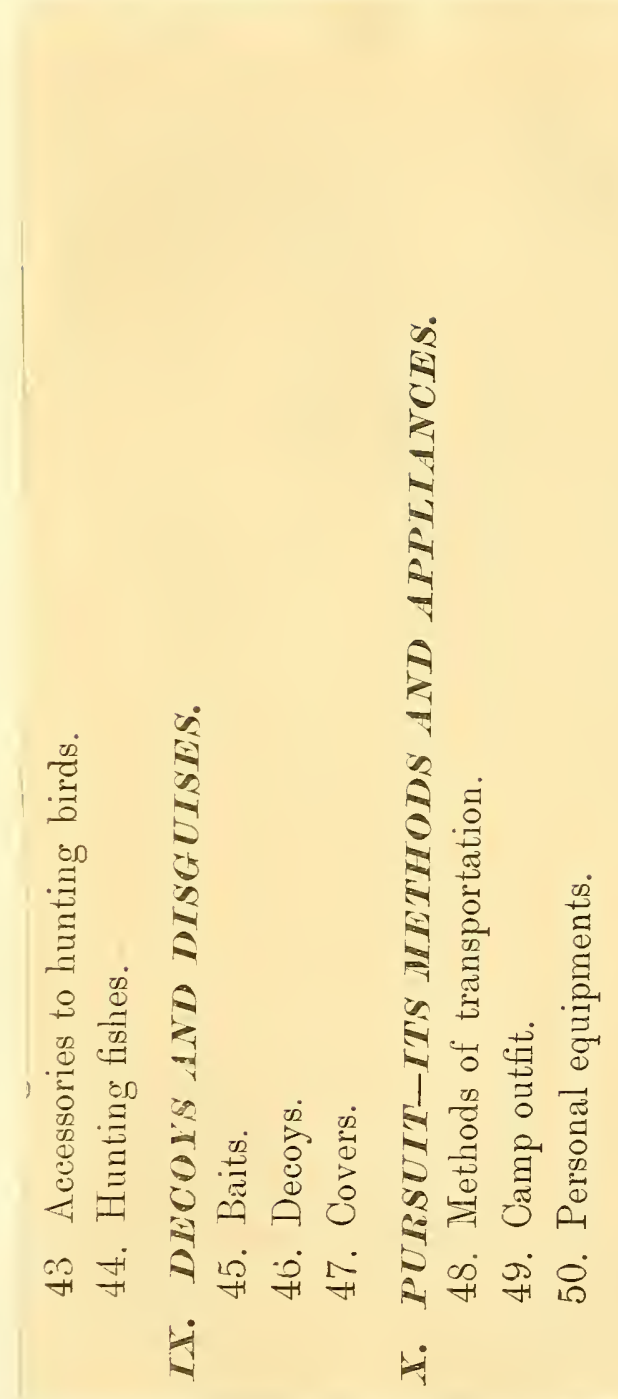




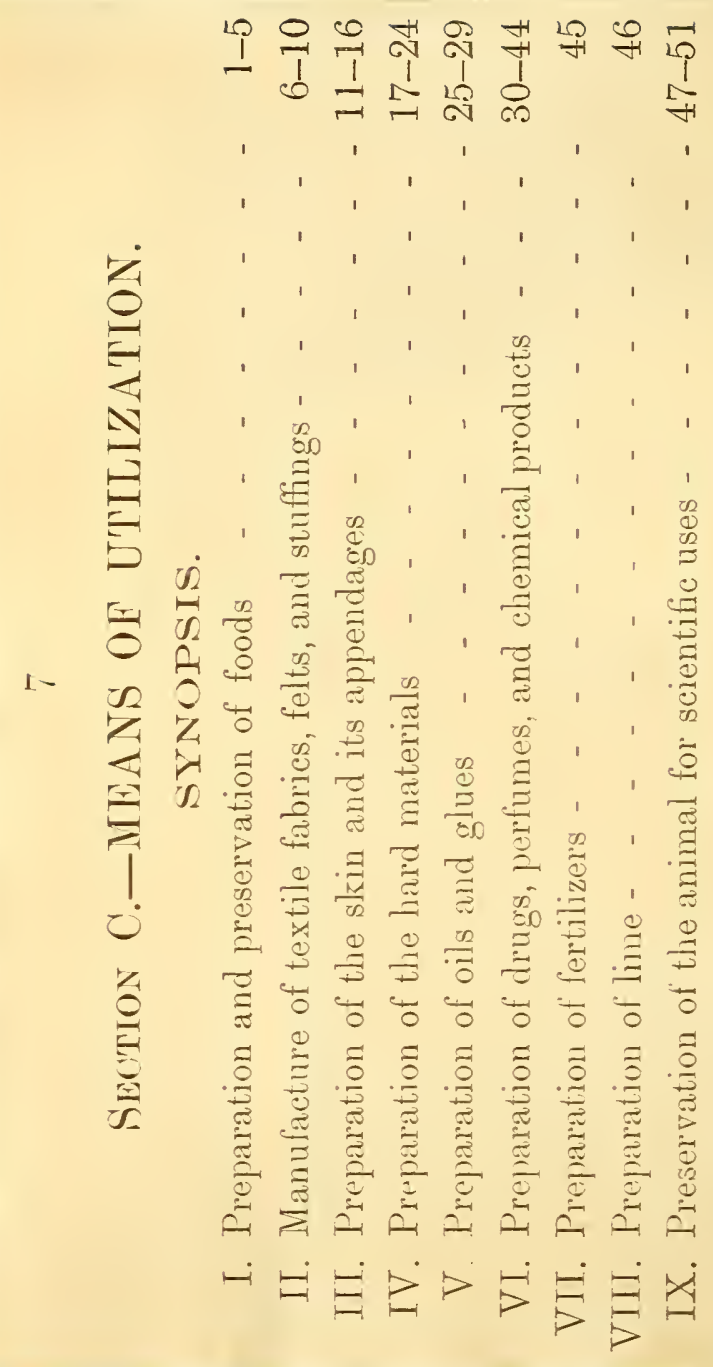




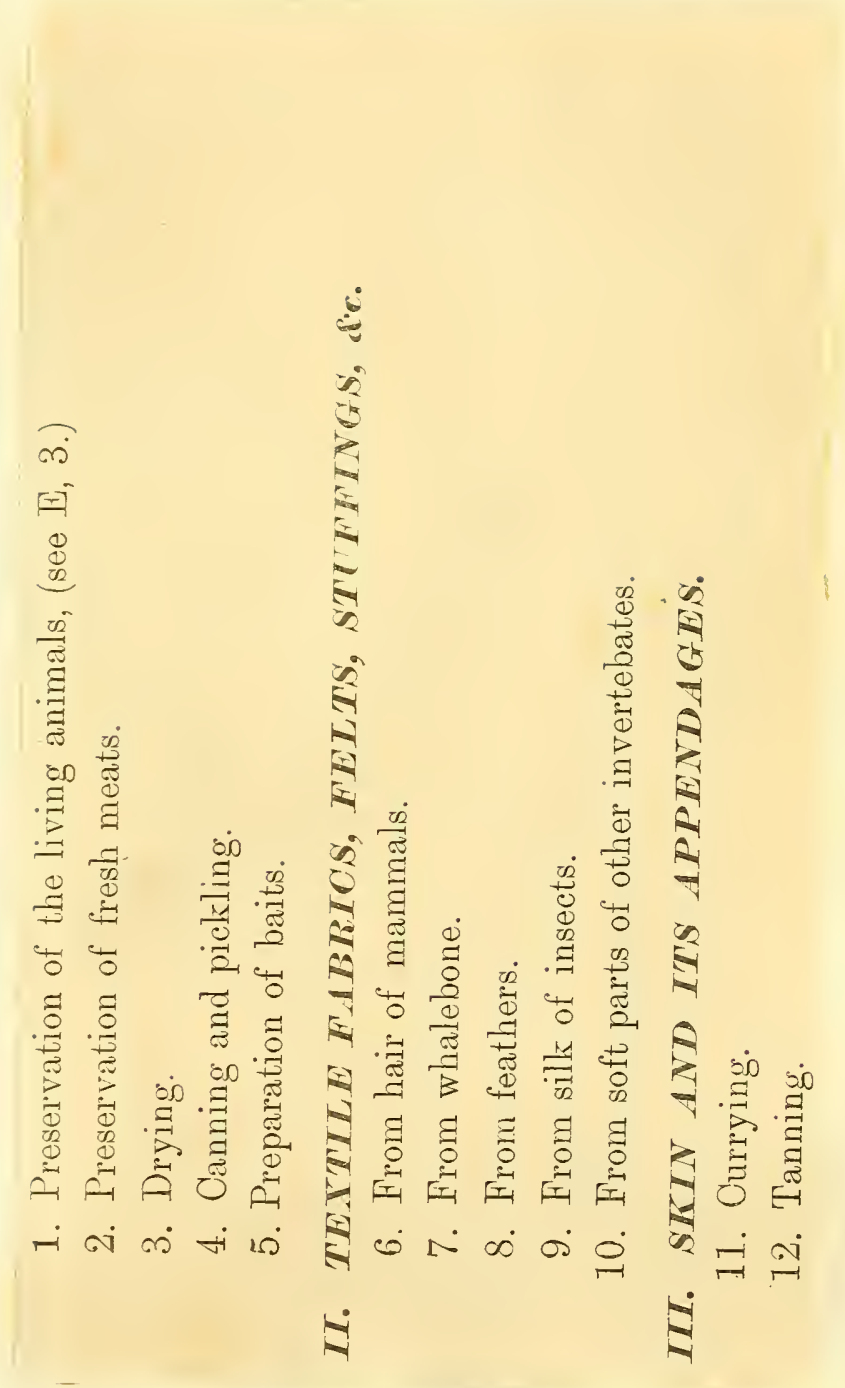




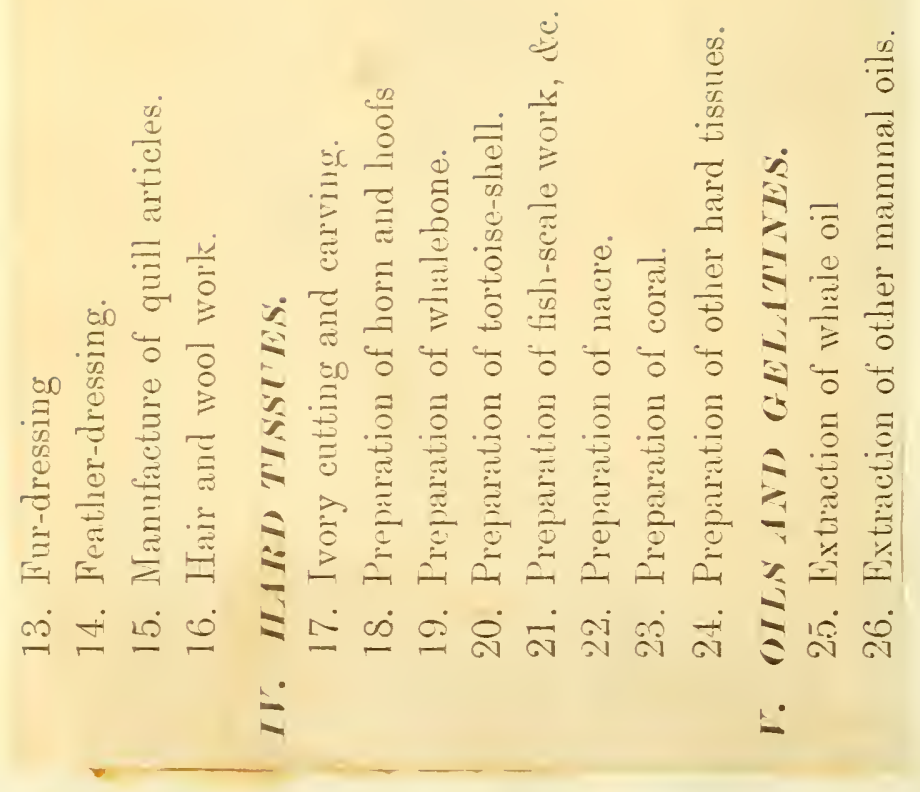




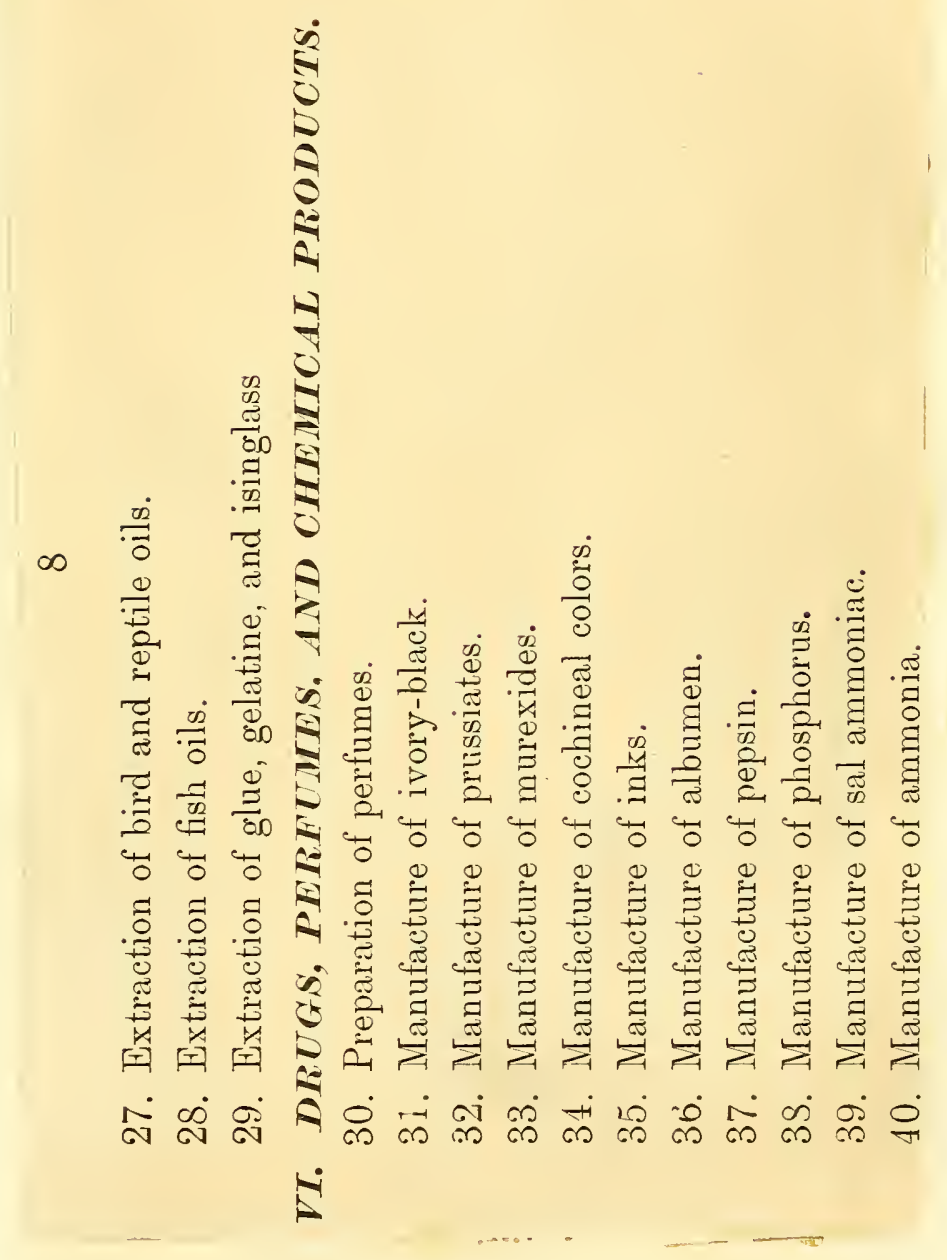




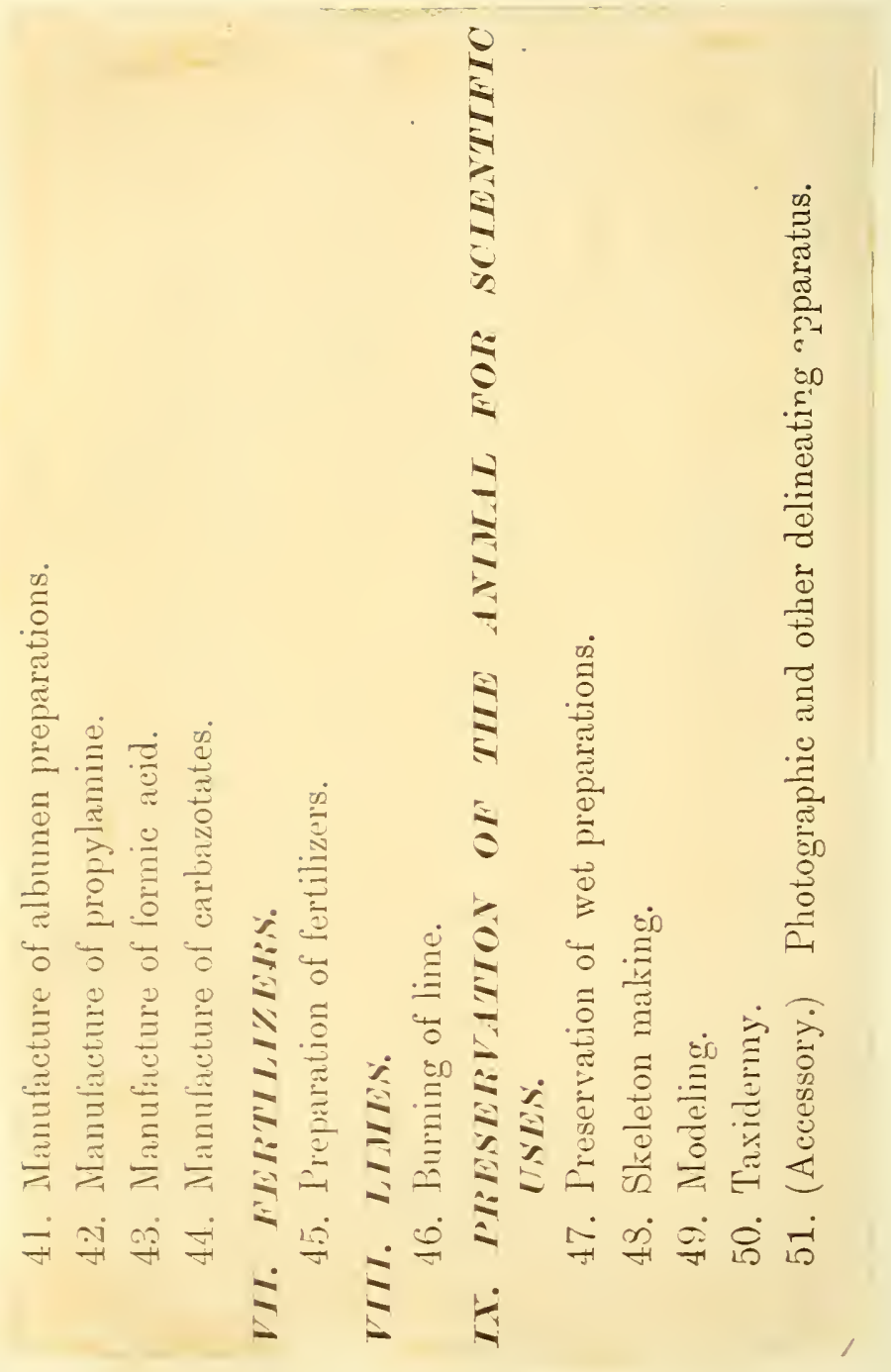




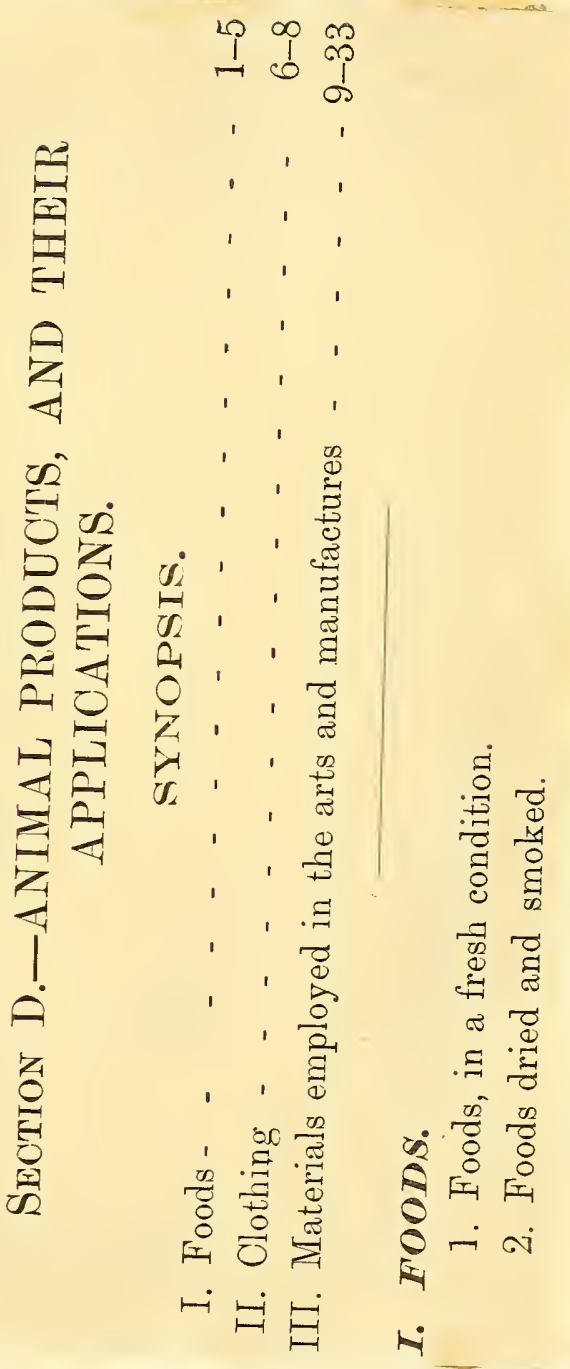




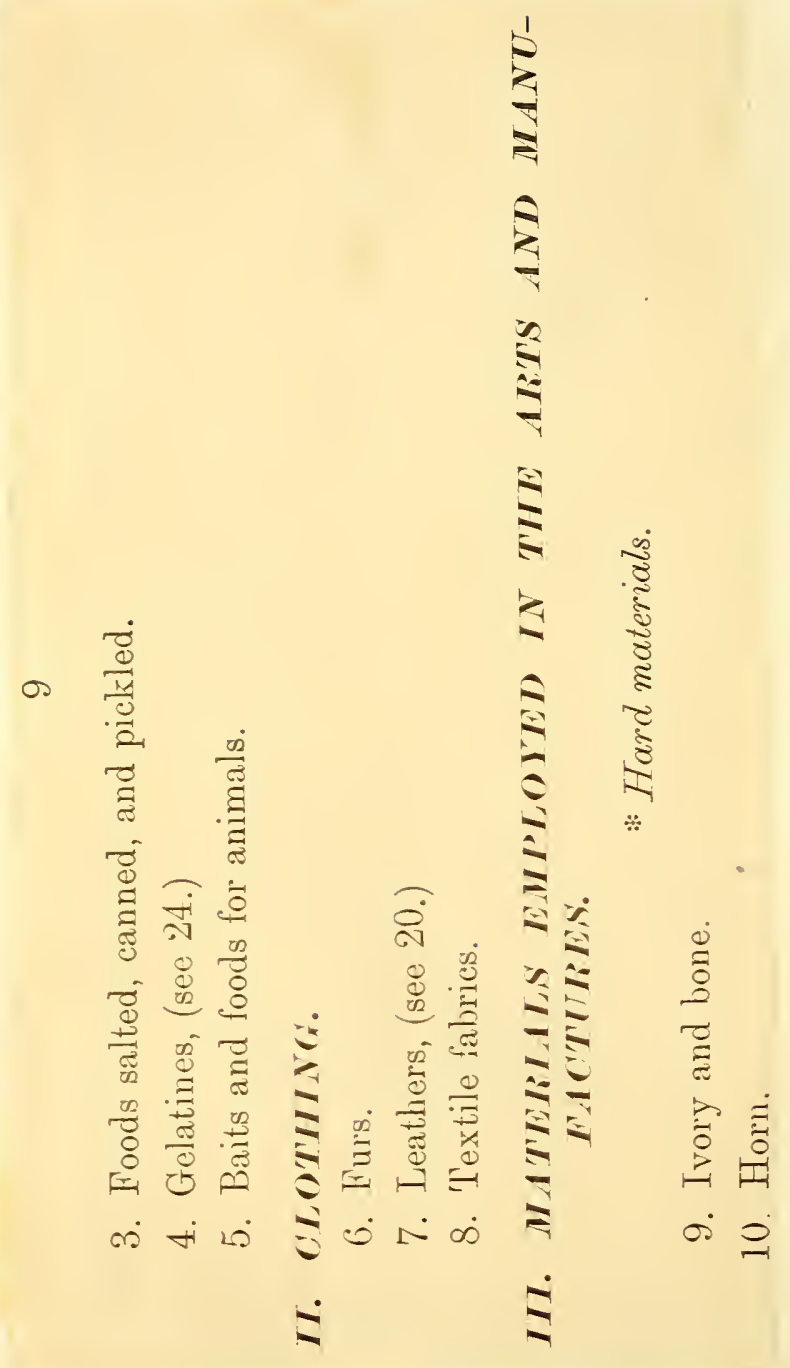




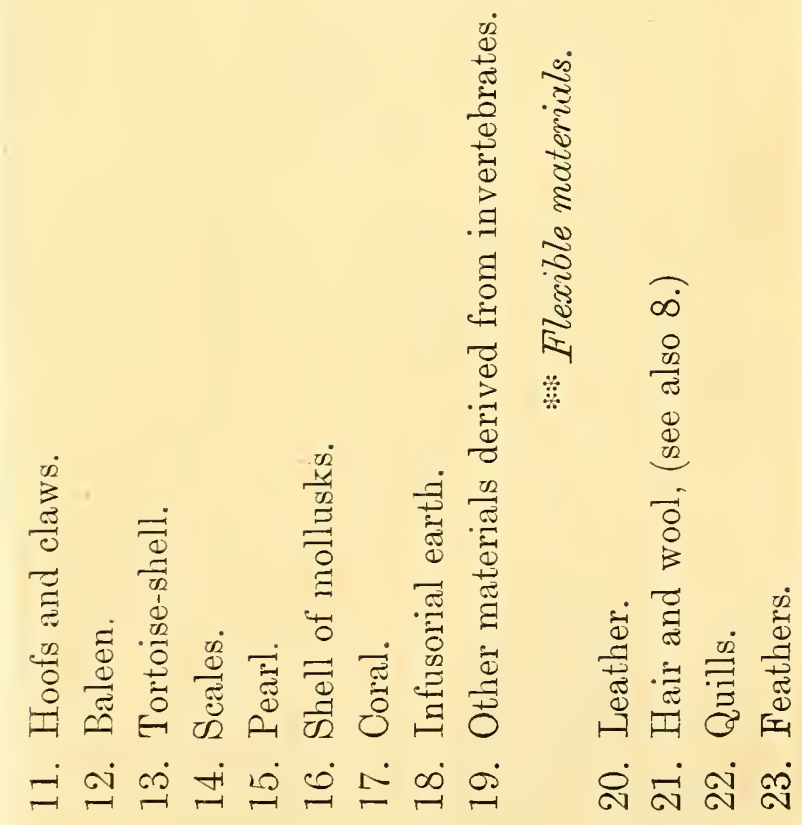




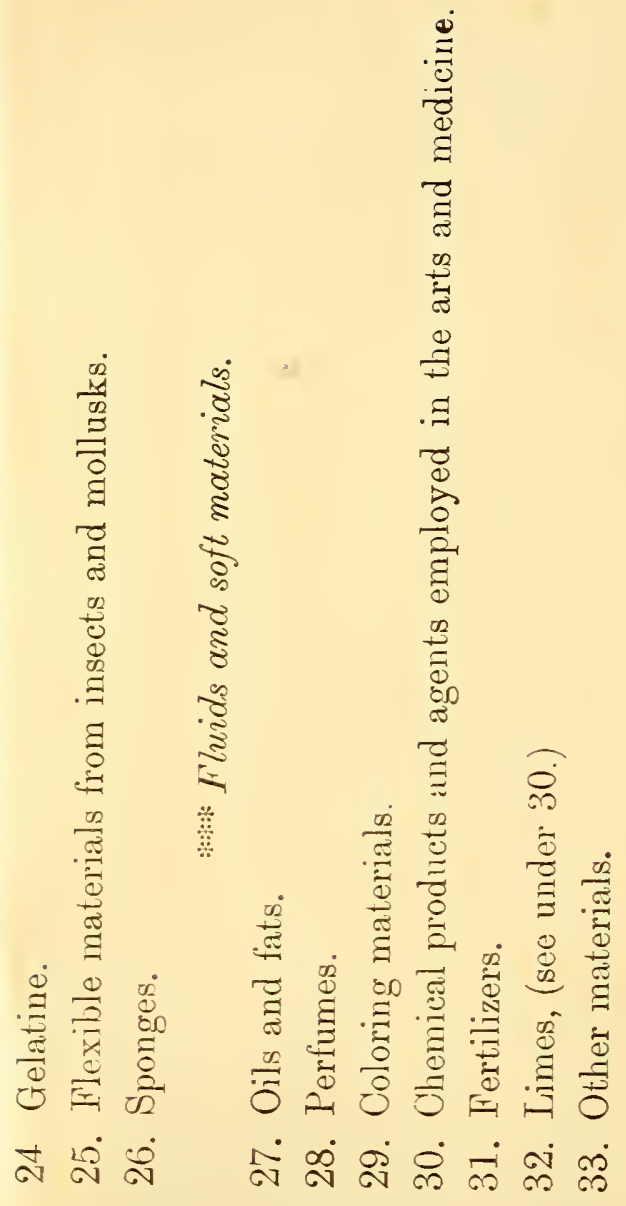




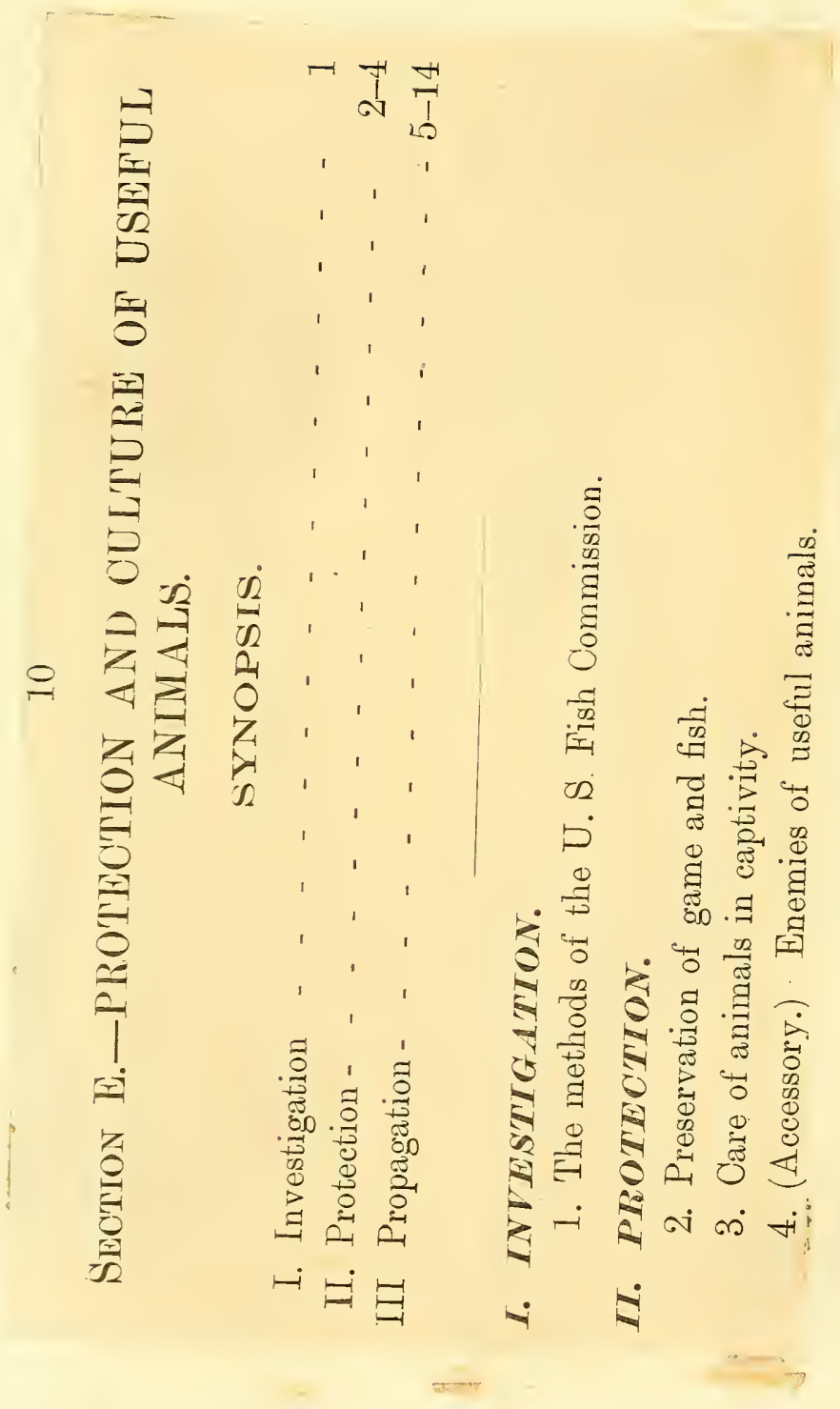




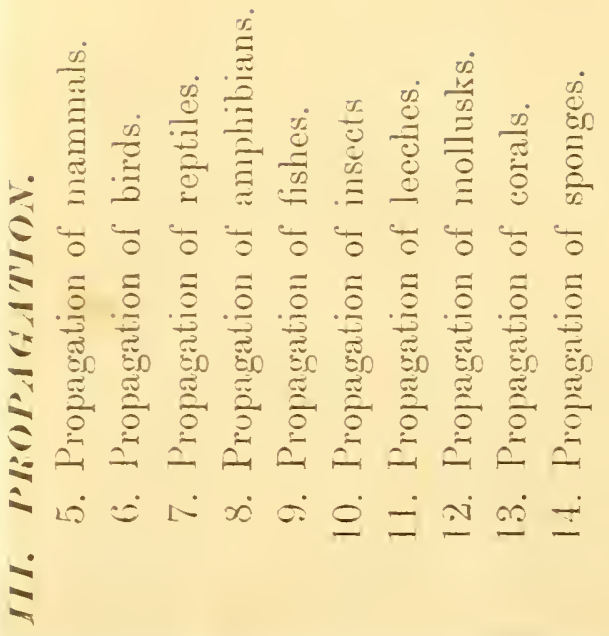




Department of the Interior:

U. S. NATIONAL MUSEUII.

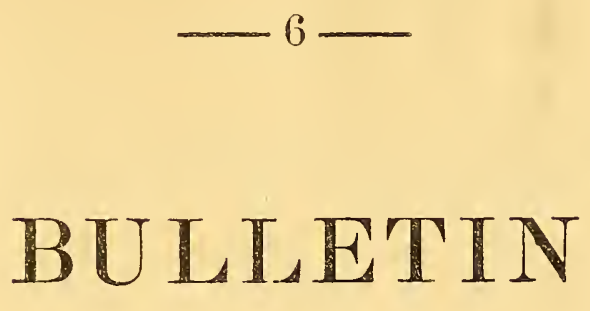

OF THE

\section{UNITED STATES NATTONAL MUSEUM.}

\section{No. 6.}

PUBLISHEI) U.NDER THE DHLETION (F THE SHITHSONIAN INSTITUTION.

WA SH IN GTON:

GOVERNMEN'T PRINIING OFICE.

1876. 

INTERNATIONAL EXHIBITION, 1876.

BOARD ON BEHALE OF UNITEI STATHS EXECUTHE UEPARTMENTS.

\title{
CLASSIFICATION
}

OF THE

\author{
COLLECTION TO ILLUSTRATE
}

THE

\section{ANIIAL RESOURCES of the UNITED STATES.}

A LIST OF SUBSTANCES DERIVED FROM THE ANIMAL KINGDOI, WTTH SFAOPSIS OF THE USEFUL AND INJURIOUS ANIMALS AND A CLASSIFICATION OF THE METHODS • OF CAPTURE AND UTILIZATION.

By G. BROWN GOODE, M. A., assigtaNt CURATOR L. S. NATIONAL MCSEUM.

WASIINGTON:

GOVERNAENT PRINTING OWIUE.

1876 . 


\section{A DVERTISEMENT.}

This work is the sixth of a series of papers inteuded to illustrate the collections of Natural History and Ethnology belonging to the United States and constituting the National Museum, of which the Smithsonian Institution was placed in charge by the act of Cougress of August 10, 1846.

It has been prepared at the request of the Institution, and printed by authority of the honorable Secretary of the Interior.

\section{JOSEPH HENRY,}

Secretary Smithsonian Institution.

Simtitisonian Institution,

Washington, February, $18 \pi 6$. 


\section{PREFA C E。}

The following classification has been prepared by Mr. Goode to facilitate the rork of collecting and arranging the material gathered by the National Museum to illustrate the resources of the United States as derived from the animal kingdom, in the International Exhibition of 1876. It is also intended to indicate the general character of the articles which are to be included in this branch of the exhibition.

Contributions of specimens of the different classes enumerated are much desired, for the purpose of making the proposed display complete, and shonld be addressed to the Smithsonian Institution, Washington, D. C.

\section{JOSEPH HENRY,} Secretary Smithsonian Institution. 



\section{TABLE OF CONTENTS.}

INTRODUCTORY REMARKS

\section{SECTION A.-ENUMERATION OF ANIMALS BENEFICIAL OR INJURIOUS TO MAN.}

I. Mamias

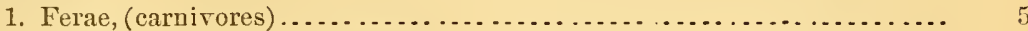

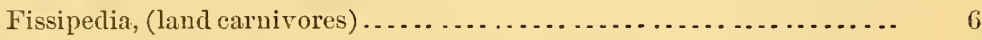

Pinnipedia, (seals, \&c.) ................................

2. Ungulata, (hoofed animals) ............................... 6

3. Proboscidea, (elephants, \&c.) ............................ 7

4. Sirenia, (sea-cows, \&c.) ................................. 7

5. Cete, (whales) ....................................... 7

Denticete, (sperm whales and dolphins) .................... 7

Mrsticete, (baleen whales) .............................. 7

6. Chiroptera, (bats) .....................................

7. Insectivora, (moles, \&c.) ................................ 8

૪. Glires, (gnawers) ........................................ 8

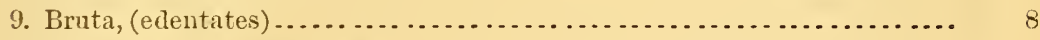

10. Marsupialia, (marsupiates) .................................. 8

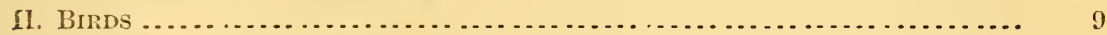

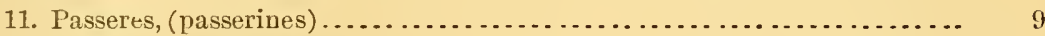

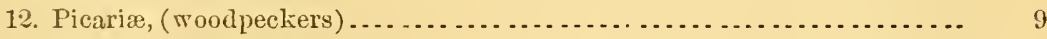

13. Cnculi, (cuckoos) ...................................

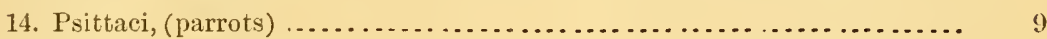

15. Raptores, (birds of preg) ................................ 9

16. Columbx, (pigeous) .................................. 10

17. Gallinæ, (gallınaceons birds, in part) ....................... 10

18. Limicolæe, (plovers) .................................... 10

19. Herodiones, (herons) ................................... 10

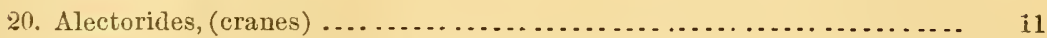

21. Lamellirostres, (flamingoes and anserine birds) . . . . . . . . . . . . . . 11

22. Steganopodes, (cormorants) $\ldots . \ldots \ldots \ldots \ldots \ldots \ldots \ldots \ldots \ldots \ldots \ldots \ldots \ldots . \ldots \ldots 11$

23. Longipennes, (gulls) ..... . ............................... 11

21. Pygropodes, (grebes and auks) ............................ 11

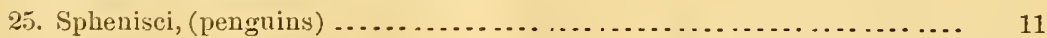

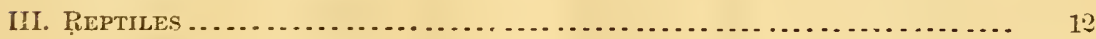

26. Crocodilia, (crocodiles) ............................... 12 
III. Reptiles-Continued.

27. Testudinata, (tortoises) $\ldots \ldots \ldots \ldots \ldots \ldots \ldots \ldots \ldots \ldots \ldots \ldots \ldots \ldots \ldots . \ldots \ldots \ldots$

28. Lacertilia, (lizards) ...................................... 12

29. Ophidia, (serpents) .................................... 12

IV. Aмrphibians ................................................. 12

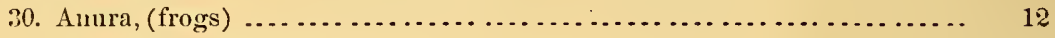

31. Urodela, (salanıvders) ................................. 18

32. Proteida, (menobranchus, \&c.) ............................. 12

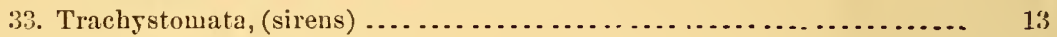

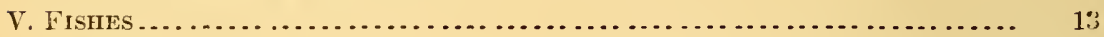

34. Pediculati, (auglers) ........................................ 13

35. Plectognathi, (globe, trunk, and file fishes).................. 13

36. Lophobranchii, (pipe-fishes, \&c.) ............................. 13

37. Hemibranchii, (sticklebacks, \&c.) .......................... 13

33. Teleocepbali ........................................... 13

Heterosomata, (1lat fishes) .............................. 13

Anacanthivi, (cods, \&c.) .................................. 14

Acauthopteri, (sping-fiuned fishes) .......................... 14

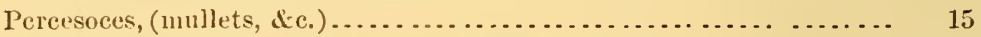

Synentognathi, (gar-fishes and fy.ing-fistes) .................. 15

Haplomi, (pikes, \&c.) ................................ 15

Isospondyli, (s:lnon, herring, \&e.)......................... 15

Eventognathi, (carps) ................................... 15

39. Nematonnathi, (eat-fishes) ............................... 16

40. Aporles, (eels) .......................................... 16

41. Cycloganoidli, (imias) ..................................... 16

43. Rhomboganoilei, (gar-pikes) .............................. 16

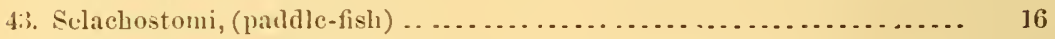

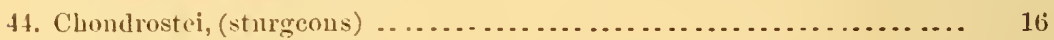

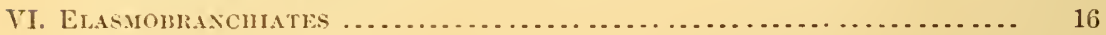

45. Holocephadi, (chimeras) .................................... 16

46. Raix, (skates and rays) .................................. 16

47. Squali, (sbarks) ........................................... 16

VII. Marsmobraxchintes..................................... 17

43. Iyperoiatia, (lampress) ................................. 17

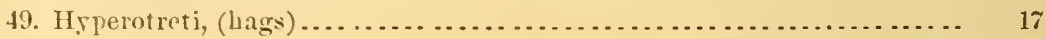

VIII. Leptocandixs ....................................... 17

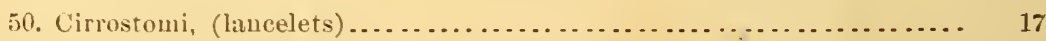

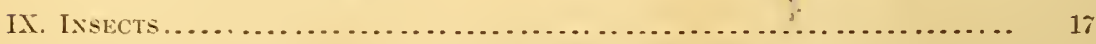

51. Insecta, (insects)............................................ 17

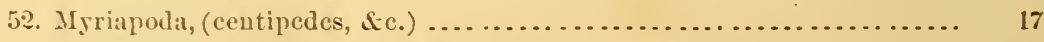

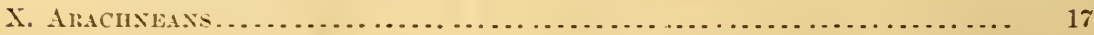

53. Arachnida, (spiders) .................................... 1

II. Arthropons ............................................. 18

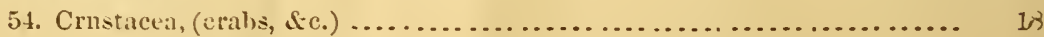


XII. Worus

55. Annelida, (annelids).

56. Scolecida, (spoon-wornıs, \&c.) ............................. 18

XIII. Mollesks...................................................... 19

5\%. Cephalopoda, (cephalopods) ................................ 19

58. Gastropoda, (sea and land snails) ............................. 19

59. Conchifera, (ordinary bivalve mollusks) ...................... 19

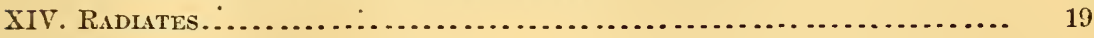

60. Echinodernata, (echinoderms).............................. 19

61. Cœlenterata, (acalephs and polsps) ......................... 20

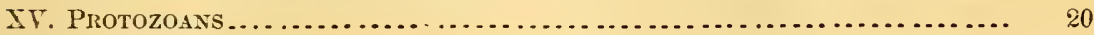

62. Rhizopoda, (sponges and foraminifera) ....................... 20

\section{SECTION B.-MEANS OF PURSUIT AND CAPTURE.}

$\dagger$ Apparatus of direct application.

I. HAND-IMPLEMENTS, (SMPLE TOOLS)

* For striking.

1. Clubs

2. Slung weights

3. Kuives

* For cutting.

4. Axes

5. Spears and prods

*** For thrusting.

II. IMPLEMENTS FOR SEIZURE OF OBJECT

* Scooping-instruments.

6. Scoops

** Grasping-hools.

7. Hooked implements, (used with single motion, that of hooking)....... 23

8. Barbed implements, (used with two motions, the first that of thrusting). . 24

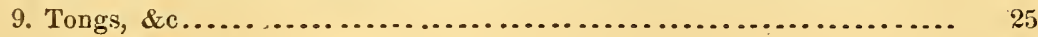

\section{*** Grasping-lines.}

10. Nooses, (lariats aud suares) .............................. 25

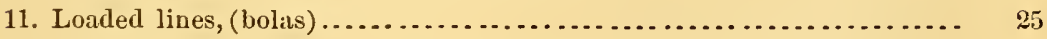

12. Tangles

**** Éntaugling-lines.

+†Aparatus of indirect application.

III. Mrssiles

* Simple missiles, (those propelled by the unaided arm.)

13. Hnrled weights

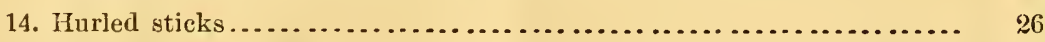

15. Hurled spears, lances .................................... 26 
* Centrifugal missiles, (propelling power augmented by artificial lengthening of the arm.)

III. MIssums-Continned.

Page.

16. Slings, and spears thrown by straps ......................... 26

17. Missiles thrown by "throwing-sticks"........................ 26

*** Missiles propelled by a spring.

$\ddagger$ Spring consisting of bent rod.

18. Bows and arrows

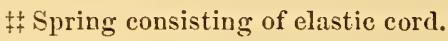

19. India-rubber slings

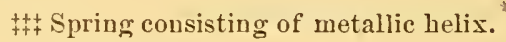

20. Spring guns

**** Missiles propelled by compressed air or water.

21. Air-gnus................................................

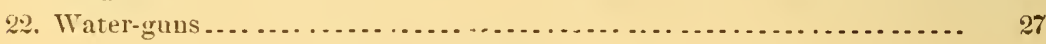

***** Missiles propelled by combustion of gunpouder.

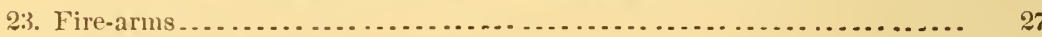

24. (Accessmy.) Ammunition and its preparation................... 23

25. (Aicessory.) Accessories of loadiug, repairing, and testing fire-arms.... 29

26. (Accessory.) Accessories of carrying fire-arms. (Accoutrements)...... 80

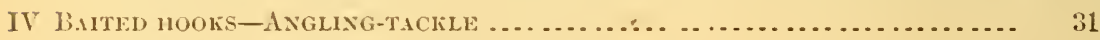

:27. Hooks with morablo lines. Hand-tackle...................... 31

2.). Hooks with stationary lines.-Set-tackle....................... 31

29. (Accessory.) Parts and aceessories to angling-apparatus............. 3 ?

$\dagger+\uparrow$ Apparatus to a greater or less esfent antomatic.

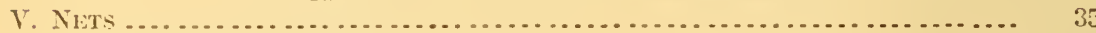

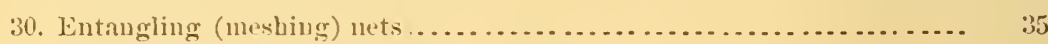

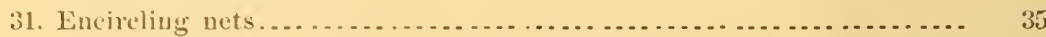

t+t+-Appuraitns entircly automatie.

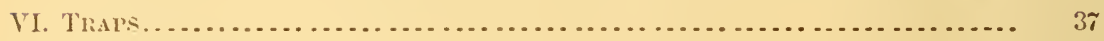

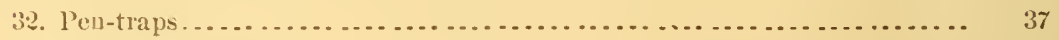

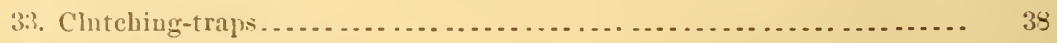

34. Fall-traps.................................................... 39

35. Missile-traps................................................ 39

36. Alhesive preparations......................................... 39

VII. APPARATLS FOR WHOLESALE DESTRCTTON ..................... 3 ?

37. Poisons .................................................. 39

38. Asphysiating apparatus.....................................

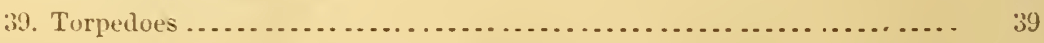

tt+tt.Aecessorics to the chase and fishing.

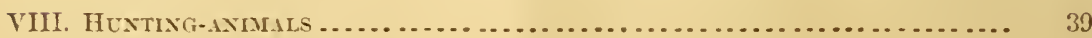

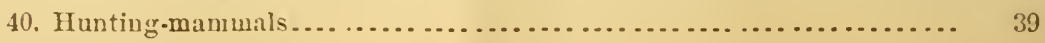


ViII. Hunting-Anmals-Continued.

Page.

41. Accessories to hunting-mammals .............................. 41

42. Hunting-birds .......................................... 41

43. Accessories to hunting-birds ............................... 41

44. Hunting-fishes......................................... 41

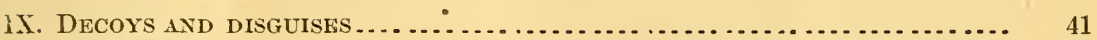

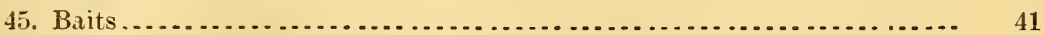

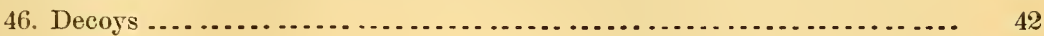

47. Covers .................................................... 42

X. Punsuit-its Methods and Appldances .............................. 42

4. Methods of transportation ................................... 42

49. Camp-outfit............................................ 44

50. Personal equipments........................................... 45

\section{SECTION C.-METHODS OF PREPARATION.}

I. Preparation and presertation of foons........................... 47

1. Preservation of the living animals, (see $\mathrm{E}, 3$ ) ................... 47

2. Preservation of fresh meats................................ 47

3. Drying .......................................................... 47

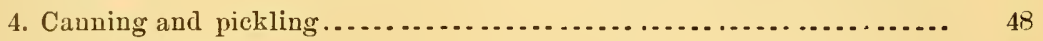

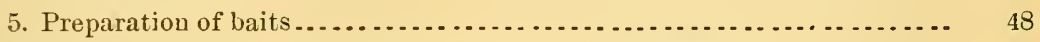

II. ManufaCture of Textile fabrics, felts, AND Stuffings............ 48

6. From hair of mammals................................... 48

๘. From whalebone............................................ 49

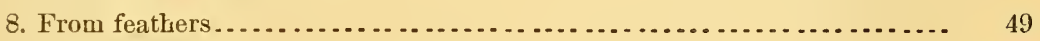

9. From silk of insects...................................... 49

10. From soft parts of other invertebrates........................ 49

III. Preparation of the skin and its appendages.................. 49

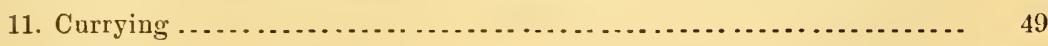

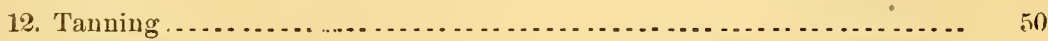

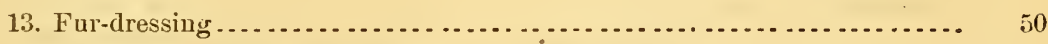

14. Feather-dressing................................................ 50

15. Mannfacture of quill articles................................ 51

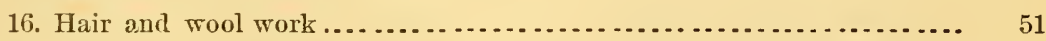

IV. Preparation of the hard tissues............................... 51

17. Ivory cutting and carving ................................... 51

18. Preparation of horn and hoofs............................... 51

19. Preparation of whaleboue................................. 51

20. Preparation of tortoise-shell................................. 51

21. Preparation of fish-scale work, $\&$ c.............................. 52

22. Preparation of nacre..................................... 52

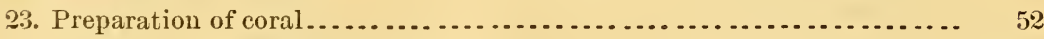

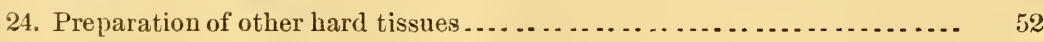

V. Preparation of orls and gelatines ............................ 52

25. Extraction of whale-oils ................................. 52

26. Extraction of other mammal oils............................. 52 
V. Preparation of oils and Gelatixes-Continued.

Page.

27. Extraction of bird and reptile oils.............................

28. Extraction of fish-oils ..................................... 52

29. Extraction of glue, gelatine, and isinglass ................... 52

VI. Preparation of drugs, perfunies, and chemichl, prodects.......... 53

30. Preparation of perfumes.................................. 5.3

31. Manufacture of ivory-black.................................

32. Manufacture of prussiates .................................. $5: 3$

33. Manufacture of murexides.................................... 53

34. Manufacture of cochiueal colors ............................. 53

35. Manufacture of iuks ........................................ 53

35. Manufacture of albumen ..................................... 53

37. Manufacture of pepsin ....................................... 53

38. Manufacture of phosphorus ................................ 5 ;

39. Manufacture of sal ammoniac.............................. $5 ;$

40. Manufacture of ammonia................................ 58,

41. Manufacture of albumen preparatious......................... 53

4. Mauufactire of propslauine.............................. 53

43. Mannfacture of formic acid............................... 5 ;i

44. Manuficture of carbazotates................................ 53

ViI. Preparation of mertilizers.............................. $5: 3$

45. Preparation of fertilizers.............................. 5.3

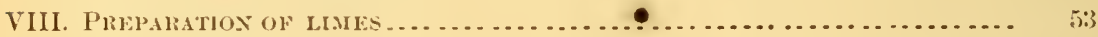

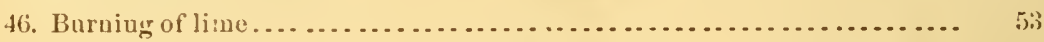

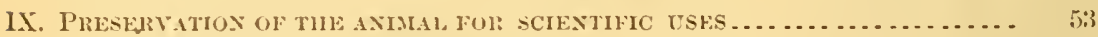

47. Preservation of wet preparatious.......................... $5 ;$

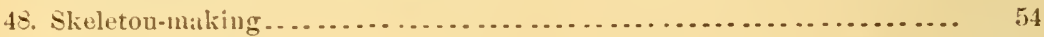

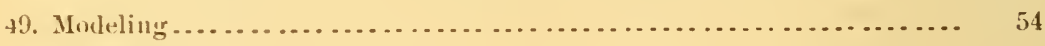

50. Taxileruy.................................................. 55

51. (Accessory.) Photographic aud other lelineating apparatus.......... 55

SECTION D.-ANLML PRODUCTS AND THEIR APPLICATIONS.

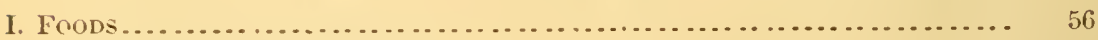

1. Foods in a fresh condition............................... 56

2. Foods dried aud smoked .................................. 65

3. Foods salted, canned, and pickled........................... 66

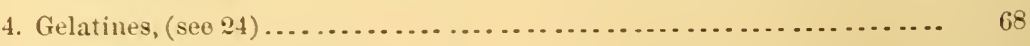

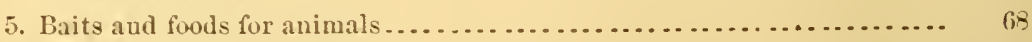

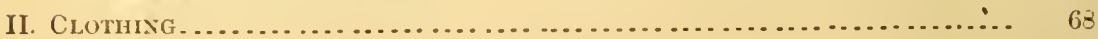

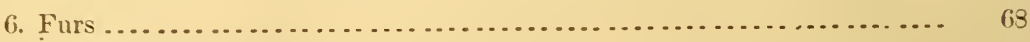

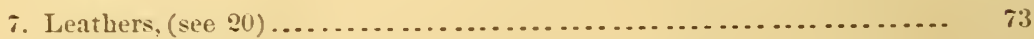

8. Textile fabrics......................................... 73

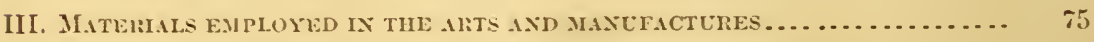

*Harl materials.

9. Irors and boue ........................................ $t 5$

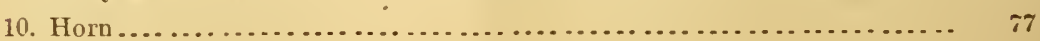


III. Materils EMPloyed IV the ARTS ANd manufaCtures-Continued.

Pinge.

11. Hoots and claws............................................ 78

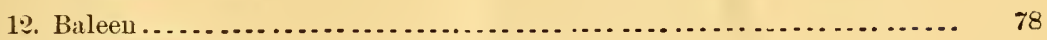

13. Tortoise-shell...............................................

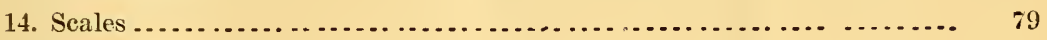

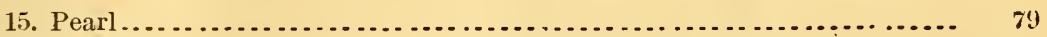

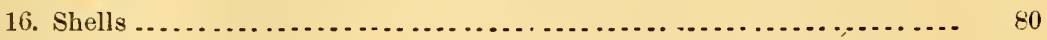

17. Coral ...................................................... 81

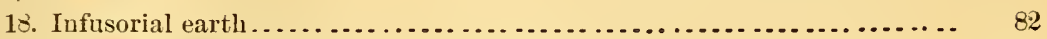

19. Other materials derived from invertebrates................... 82

**Flexible materials.

20. Leather

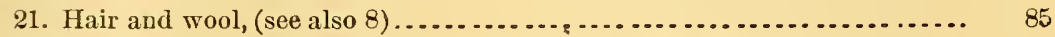

22. Quills ....................................................... 86

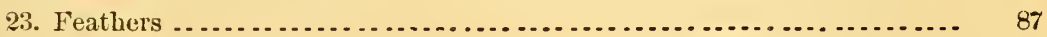

24. Gelatine and isinglass ...................................... 88

25. Flexible materials from insects and mollusks.................... 89

26. Sponges ...................................................... 89

***Fluids and soft materials.

27. Oils and fats.............................................. 90

28. Perfumes ............................................... 92

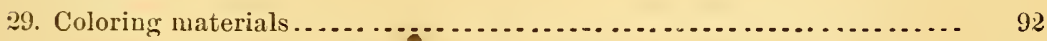

30. Chemical products and ageuts employed in the arts and medicine...... 93

31. Fertilizers ........................................... 96

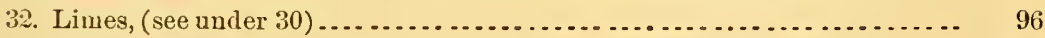

33. Other materials ................................................ 96

SECTION E.-PROTECTION AND CULITURE OF USEFUL ANIMALS.

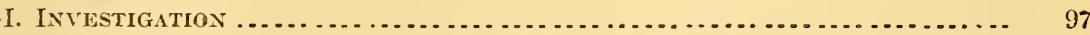

1. The methods of the United States Fish Commission................ 97

II. Protection ..................................................... 97

2. Preservation of game and fish ............................... 97

3. Care of animals in captivity .................................. 93

4. (Accessory.) Enemies of usefnl animals ....................... 98

III. Propagation ................................................. 98

5. Propagation of mammals................................... 98

6. Propagation of birds........................................ 99

7. Propagation of reptiles ....................................... 99

8. Propagation of amphibians.................................. 99

9. Propagation of fishes ........................................ 99

10. Propagation of insects....................................... 101

11. Propagation of leeches..................................... 101

12. Propagation of mollusks ...................................... 101

13. Propagation of corals........................................ 101

14. Proparation of sponges...................................... 101

ALPHABETICAL INDEX .................................. 103 



\section{INTRODUCTION.}

The system proposed in the following lists has been hurriedly prepared, and is necessarily very incomplete; it is intended merely as a prorisional classification, to be used in collecting the materials for the exhibition, and in their preliminary arrangement.

The first group, Section A, is an index to the whole series; it will include all North American animals which are directly beneficial or injurious to man. Although every species, down to the very least, exercises some influence upon human well-being, it seems scarcely practicable to attempt the exhibition of those which affect it only indirectly. Those species are considered useful which supply food, clothing, shelter, implements, materials, and amusement; those injurious which endanger the life or personal comfort of man, or destroy those animals and plants which are of direct benefit to him. In the enumeration of animals, the names of the orders are given, followed in parenthesis by the bestknown names of the more important species included, and a brief note on their principal uses. This enumeration, being simply of convenience, makes no claim to zoological precision.

SECTION B embraces all instruments and methods employed by the hunters, trappers, and fishermen of North America, aboriginal and civilized. Not only those which are directly employed in destruction or capture are included, but the means made use of in pursuing or attracting the animals and fishes, and the personal equipment of the pursuer. The collection will be a monograph of all matters relating to the chase and the fisheries of the country. In preparing the classification here submitted, the principles of zoological classification have been followed as closely as possible; each distinct form has been considered a species; and the specific forms have been grouped into genera, families, and orders according to the general balance of their affinities. Form and manner of use have not been without weight, but superficial resemblance has been set aside, and the idea given the first importance. Thus, barbed spears and harpoons have been placed with the "hooked instruments," while plain spears and lances are grouped with the knives and clubs. In studying the place of the fire-arms and bows and arrows, the missile itself has been regarded as more important than the 
machine which propels it, and the latter is placed in a subordinate relation.

In one group, that of nets, conrenience in arrangement of the specimens seems to demand that material, a character of small importance, shall be made prominent. Two widely direrging groups of apparatus are associated under the head of nets, viz, encircling-nets, the true relations of which are with grasping and scooping instruments, and entang. ling nets which belong with the traps, where a third group of nets, the pound aud weir nets are actually classed. Where the exigencies of administration of the specimens demand that thes should be arranged otherwise than in their exact systematic position, full cross-references are giren.

The simplest implemerits have always been placed first, the series advancing in the order of complication of structure. Thus we bare in the beginning the apparatus of direct application, or tools, including, first, those implements which are used in the hand, and which increase its porver in a simple way, such as clubs and slung-shot, which merels add to the reight of the fist, followed by the kuires, axes, and spears, which in their simplest and primitive form were sharpened stones and pointed sticks. Second, are the grasping-implements, or those by which the power of the fingers is extended. In this series the same principle of progress from simple to complex is followed; in the scoop we have the idea of the hollow palm of the haud developed in rarious forms, while the grasping-hooks and grasping-lines are the artificial extensions of the human finger. Uuder hooked instruments, the simple hooks, or those which are attached to the object by a single motion, a pulling one, are placed first, followed by the barbed implements, in which the attachment is made by a thrusting, succeeded by a pulling motion, and then by the tougs aud forceps, which are essentially double hooks. The succeediug division is that coutaiuing the lasso and bolas, which are worked at long distances and require great skll, succeeded by the tangles, which are, in principle, assemblages of lassos, entangling objects among their fiber nooses.

In the thirl dirision, that of missiles, the same priuciple of succession is adhered to. First are placed those missiles which are propelied by the unaided arm; then those in using which the arm is artific ally lengthened, as with the sling, string, or darting stick; then those in which the propelling power is derived from the elasticity of rods and cords, the strength of the arm haring become subsidiary; closing with those in 
the use of which the strength of the arm is of no essential value, and the propelling power originates in chemical combustion.

Accessory to these are groups containing those articles used in the mannfacture, testing, loading, and transportation of these missiles, and the machines which drive them through the air.

In a fourth division is the apparatus of angling, which is separated from hooked implements with which the form of the articles would naturally place them, since they are not implements of grasping, but partake of the nature of traps, being in part automatic.

The group of nets is a heterogeneous one, as has been stated above, consisting of two divisions, the first that of entangling-nets, belong. ing properly with traps, while encircling-nets are in idea instruments for grasping.

In arranging traps a logical succession has been preserved as far as possible. Those traps are considered the most simple in which the animal is penned by its own act, without any change in the arrangement of the trap. The pit-falls or "tipes" are first, followed by the mazes or labyrinths of greater or less complexity. Then coine the traps in which the entrance is closed, either by the falling of a door or by the falling of a box-like trap, as a whole, so as to surround the animal. Under clutching-traps are placed those which seize the animal, as in the fingers, while crushing-traps are those which seize or impale it bodily. Adhesive preparations, such as bird-lime, close the series.

The accessory divisions, including hunting-animals, decoys, and disguises, and the methods and appliances of pursuit, do not admit any thorough classification, and are arranged with reference to convenience of exhibition.

Section C includes all methods of utilizing animals products. It might be more satisfactorily arranged with the following section, were it not for the inconvenience of exhibiting models and tools in the same cases with the manufactured products; the arrangement of the two sections is nearly the same.

In SECTION D are grouped all useful substances derived from the animal kinglom. In order to avoid the omission of any products which are or may be obtained from North American animals, this enumeration has been made general, those not American being included in parentheses. This enumeration is far from complete, and is intended simply as an aid to future study in the same direction.

SECTION E includes all articles illustrating the culture and protection of useful animals. 



\section{SECTION A.}

\section{E N U M E R A T ION}

OF

\section{ANIMLALS BENEFICIAL OR INJURIOUS TO MAN,}

(WITH A SINOPSIS OF THEIR USEFUL APPLICATIONS.)

\section{M A M II A LS.}

1. FERAE :

Fissipedia. (Cats, pumas, jaguars, ocelots, lynxes, wolves and dogs, foxes, fishers, martens, minks, weasels, wolrerenes, badgers, skunks, otters, sea-otters, bears, raccoons, and the domesticated cat, dog, and ferret.)

Useful products :

Food, (bears, raccoon, \&c.) D. 1.

Fur, (all the group.) D. 6.

Leather, (dog, cat.) D. 20.

Textile fabrics, felt, (raccoou.) D. 8 .

Irory, teeth, (bear, fox, \&c.) D. 9.

Claws used by Indians, (bears, puma.) D. 11.

Hair, for brushes, (badger, dog, weasel, skunk, bear.) D. 21. Oil, (bears.) D. 27.

Perfumes, (civet, \&c.) D. 28.

Medicinal products, (skunk.) D. 30.

Chemical agent, album grcecum, (dog.) D. 30 .

Useful traits:

Susceptible of domestication, (wolves (Indian dog,) foxes, otters, bears, raccoon, dog, cat, ferret.)

Emplosed in hunting, (dog, cat, ferret.) B. 40.

Employed in fishing, (otter.) B. 40 . 


\section{FERAE-Continued.}

Fissipedia-Continued.

Injurious traits :

Enemies of man, (cats, wolves, bears.)

Enemies of domestic animals.

Maranders on crops, (bears, raccoon.)

Stench nuisances, (skunks.)

Modes of capture. B. I, II, III, VI, X.

Prnnipedia. (Fur-seals, sea-lions, hair-seals, hood-seals, sea-ele

Useful products :

$$
\text { phants, walruses.) }
$$

Food of aborigines. D. 1.

Fur, (fur-seals, \&c.) D. 6.

Leather, \&c., parchment from riscera, (sea-lions, hair-seals. walruses.) D. 20.

Oil, (hair-seal, hood-seal, sea-elephant, \&c.) D. $2 \pi$.

Ivory, (walrus.) D. 9.

Injurious traits: Destroy fish.

Modes of capture. B. I, III, T, X.

2. UNGULATA. (Bison, musk-ox, moutain-goat, mountain-sheep, antelope, moose, caribou, elk, deer, peccary, and the domesticated ox, goat, sheep, hog, horse, ass, and camel.)

Useful products:

Food, fresh, smoked, aud picklerl, (all the group.) D. $1, \stackrel{2}{-}, 3$.

Fur, (bison, musk-ox, goat, sheep, moose, \&c.) D. 6 .

Leather, (all the group.) D. 20.

Textile fabrics and feìt, (ox, goat, sheep, camel, musk-ox.) D. 8 .

Ivory and bone. D. 9.

Horn, (bison, ox, goat, sheep, deer, elk, \&c.) D. 10.

Hoof, (bison, musk-ox, goat, sheep, deer, horse, \&c.) D. 11. Hair, bristles, and wool, (bison, ox, goat, sheep, deer, hog, camel.) D. 21.

Gelatine and glue. D. 4, 24 .

Oil and fat. D. 27 .

Perfumes, (musk-ox, musk-leer.) D. 28.

Coloring materials from blood and bile. D. 29. 
2. UTGULATA-Continued.

Useful products :

Chemical products. D. 30 .

Fertilizers. D. 31.

Useful traits: Susceptible of domestication.

Modes of capture. B. I, II, III, VI, IX.

3. PROBOSCIDEA. (Elephants.*)

Useful products: Ivory. D. 9.

4. SIRENIA. (Manatee, or sea-cow.)

Useful products :

Food. D. 1.

Leather. D. 7, 20.

Oil. D. 27.

5. CETE. (Whales.)

Denticete. (Beluga, narwhal, porpoise, black-fish, killer, grampus, sperm.whale.)

Useful products :

Food, Indian, (sperm-whale, porpoise.) D. 1 .

Oils, (all the group.) D. 27.

Spermaceti, (sperm-whale.)

Leather, (porpoise, beluga.) D. 7, 20.

Bone and ivory, (narwhal, sperm-whale.) D. 9:

Perfume, ambergris, (sperm-wbale.)

Injurious traits: Destroy fish and seals.

Iodes of capture. B. I, II, III, X.

Mrsticete. (Right, or whale-bone whales.)

Useful products :

Food, (right-whale.) D. 1.

Baleen. D. 12.

Oil, (right-whale, \&c.) $\quad$ D. 27.

6. CHIROPTERA. (Bats.)

Useful products :

Food, Indians. D. 1.

Felting material. D. 8 .

Guano. D. 31 .

Useful traits : Destroy troublesome insects.

Injurious traits: Disseminate troublesome insects. 
7. INSECTIVORA. (Moles and shrews.)

Useful products :

Fur, (moles.) D. 6.

Felting material, (moles.) D. S.

Useful traits :

Destroy burrowing insects, \&c.

Injurious traits : Burrowers.

Modes of capture. B. VI.

8. (TLIRES. (Squirrels, prairie-dogs, showtl, marmots, musquash, beaver, rats, mice, lemmings, porcupines, rabbits, and the domesticated rabbit, and Guinea-pig.)

Useful products :

Food. D. 1.

Fur, (squirrels, showtl, marmots, musquash, beaver, lem. mings, rabbit, \&c.) D. 6.

Textile fabric, felt, (musquash, beaver, rabbit.) D. 8 .

Irory, (beaver.) D. 9.

Leather, (rat, beaver.) D. 7, 20.

Hair and down, (rabbits.) D. 21.

Quills, (poreupiue.) D. 21.

Perfume, castoreum, (bearer.) D. $2 S$.

Useful traits: Susceptible of domestication, (squirrels, rabbits, $\left.\& c^{\circ}\right)$

Injurious traits: Marauders.

Modes of capture. I3. I, II, III, VI, VII, VIII, IX.

9. BRUTA. (Armadillo, Se.)

Useful products: Shell used by Indians in rarious manufactures. D. 14.

Injurious traits :

Burrower.

Marander.

10. IfARSUPIALIA. (Opossum.)

Useful products :

Food. D. 1.

Hair used in felting. D. 8.

Injurious traits: Mrarauder.

Lodes of capture. B. I, II, III, VI, VIII 


\section{BIRDS.}

11. PASSERES. (Thrushes, stone-chats and blue-birds, dippers, kinglets, titmice, nuthatches, creepers, wrens, larks, wagtails, warblers, tanagers, swallows, waxwings, greenlets, shrikes, finches, starlings, black-birds and orioles, crows and jays, fly-catchers, and domesticated sparrow, canary, \&c.)

Useful products :

Foods, (thrushes, rice-birds, \&c.) D. 1.

Ornamental feathers. D. 23.

Useful traits :

Destroy insects.

Song-birds, (generally susceptible of domestication.)

12-13. PICARIE AND CUCULI. (Night-hawks, whippoorwills, swifts, humming-birds, trogons, saw-bills, kingfishers, cuckoos, woodpeckers.)

Useful products: Ornamental feathers, (humming-birds, trogons.) D. 23.

Useful traits :

Destroy noxious insects, (night-hawks, swifts.)

Destroy tree-borers, (woodpeckers.)

Injurious traits :

Destroy fish, (kingfishers.)

Destroy birds'-eggs, (cuckoos.)

Destroy fruit, (woodpeckers.)

Destroy trees, (sap-sucker.)

14. PSITTACI. (Parroquet and domesticated parrots.)

Useful products: Ornamental feathers. D. 23.

Useful traits: Susceptible of domestication.

15. RAPTORES. (Owls, hawks, eagles, vultures, buzzards.)

Useful products :

Ornamental feathers. D. 23.

Quills. D. 22.

Useful traits :

Susceptible of domestication and use in hunting. ${ }^{1}$

${ }^{1}$ Nine species of falcons, hawks, and owls have been employed in the chase by Europeans. 


\section{RAPTORES-Continued.}

\section{Useful traits :}

Scavengers, (vultures, buzzar ds.)

Destroy vermin, (owls, hawks.)

Injurious traits: Destroy domestic animals, eggs, \&c.

16. COLUMBA. (Pigeons and dores.)

Useful products:

Food.

Ornamental feathers. D. 23.

Useful traits :

Game-birds.

Susceptible of domestication.

Used as targets, (wild pigeon.) B. 25.

Used as carriers, (carrier-pigeon.)

17. GALLINA. (Turkey, grouse, partriclge, sage-cock, ptarmigan quail, and the domesticated peacock, guinea-fowl, and forl.)

Useful products :

Foods, flesh. D. 1.

Oruamental feathers. D. -3.

Quills. D. 22.

Albumen. D. 30.

Useful traits :

Game-birds.

Susceptible of domestication.

1S. LMICOLA. (Plorer, ring-neck, surf-bird, oyster-catcher, turnstone a roset, stilt, phalarope, woodcock, suipe, sandpiper dunlin, godwit, sauderling, willet, tattler, yellow shanks, green-shanks, curlew.)

Useful products :

Food: Flesh. D. 1.

$$
\text { Eggs. D. } 1 .
$$

Feathers. D. 23.

Useful traits: Game-birds.

19. HERODIONES. (Ibises, spoonbills, herons, egrets, bitterns.)

Useful products: Oruamental feathers. D. 23.

Useful traits: Destroy vermin. 
20. ALECTORIJES. (Cranes, rails, crakes, gallinules, coots.)

Useful products :

Food, (rails, crakes.) D. 1.

Feathers. D. 23.

Useful traits: Susceptible of domestication, (cranes.)

21. LAMELLIROSTRES. (Flamingoes, swans, geese, dncks.)

Useful products :

Food: Flesh, (geese, ducks.) D. 1. Eggs, (geese, ducks.)

Ornamental feathers, (flamingo, geęse, \&c.) D. 23.

Down, (geese, ducks.) D. 23.

Useful traits :

Susceptible of domestication, (geese, ducks.)

Used as decoys for other swimmers, (brants, ducks.)

22. STEGANOPODES. (Gannets, pelicans, cormorants, darters or water-turkeys, frigate birds, tropic birds.)

Useful products :

Ornamental feathers, (darters, tropic birds.) D. 23.

Leather, (of feet.) D. 20.

Useful traits: Susceptible of domestication. ${ }^{1}$

23. LONGIPENNES. (Gulls, terns, skimmers, petrels, albatrosses ' shearwater's.)

Useful products :

Food, eggs. D. 1.

Ornamental feathers, (gulls, terns, \&c.) D. 23.

Oil, (petrels, \&c., used by Eskimos.) D. 27.

24. PYGOPODES. (Loons, grebes, auks, puffins, guillemot, murres.)

Useful products :

Eoods, (eggs.) D. 1.

Ornamental feathers, (grebes.) D. 23.

Feathers used as furs, (grebes, auks, \&c.) D. 8.

25. SPHENISCI. (Penguins.)

Useful products:

Feathers used as fur. D. 6 .

Oil. D. 27.

${ }^{1}$ Graculus carbo used in Europe for fishing and a similar species in China. 


\section{REPTILES.}

26. CROCODILIA. (Alligator, crocodile.)

Useful products :

Food. D. 1.

Ivory. D. 8.

Leather. D. 20.

Oil. D. 27.

Musk. D. 28.

Injurious traits :

Enemies of man and domestic animals.

27. TESTUDINATA. (Tortoises, terrapin, leatber-back, green, loggerUseful products : head, and hawks·bill turtles.)

Food: Flesh, (green turtle, terrapin, gopher tortoise.) D. 1. Eggs, (green turtle, terrapin, gopher tortoise.)

Oil from eggs, (green turtle.) D. 27.

Shell, (turtles.) D. 13.

Perfume. D. 28 .

Methods of capture and transportation. E. 3.

2S. LACERTILIA. (Lizards, skinks, horned-toads, chameleons, sco1pions, joint-suakes, \&c.)

Useful products: Food of Indians. D. 1.

Medicinal product: (Skink.) D. 30.

Useful traits : Destroy noxious insects.

29. OPHIDIA. (Suakes.)

Useful products :

Leather, (rattlesnakes, bull suakes.) . 27.

Medicinal products, (rattlesualies, copperheads.) D. 30.

Oil, (rattlesnakes.) D. 27.

Useful traits: Destros rermin.

Injurious traits: Enemies of man, (rattlesnakes, copperheads, and moccasins.)

\section{AMPHIBIANS.}

30. ANURA. (Frogs, toads, hyla, \&c.)

Usefinl products :

Food, (frogs.) D. 1.

Material for physiological instruction, (frogs.) 
30. ANURA-Continued.

Useful products :

Weather indicators, (hyla.)

Useful traits: Destroy noxious insects, (toads.)

31. URODELA. (Salamanders, axolotis, and menopomes.)

Useful products: Foods, aboriginal, (axolotls.)

Useful traits : Aquarium use.

Injurious traits : Enemies of young fish.

32. PROTEIDA. (River-rogs, hell-benders.)

Injurious traits: Enemies of young fish.

33. TRACHYSTOMATA. (Sirens.)

\section{FISHES.}

34. PEDICULATI. (Sea-bats or devilfish, goose-fish or angler, mouse-fish, \&c.)

Useful products: Baits, (goose-fish.) D 1.

Injurious traits: Enemies of aquatic birds, (goose-fish.)

35. PLECTOGNATHI. (Sun-fish, rabbit-fish, porcupine-fish, swell-fish, box-fish, trunk-fish, cow-fish, file-fish, triggerfish.)

Useful products :

Food, (file-fish, trunk-fish.) D. 11.

Clothing, (helmets made from porcupine-fish.) D. 20.

Oils, used in medicine, (sun-fish.) D. 27.

Shagreen, (file-fish, trigger-fish.) D. 30.

36. LOPHOBRANCHII. (Sea.horse, pipe-fish.)

Useful traits: Aquarium use.

37. HEMIBRANCHII. (Snipe-fish, trumpet-fish, stıckleback.)

Useful traits: Aquarium use, (sticklebacks.)

Injurious traits: Destroy eggs of other fishes.

38. TELEOCEPHALI :

Heterosomata, (soles, flounders, flatfish, turbot, halibut.'

Useful products :

Foods: Fresh. D. 1.

Smoked, (halibut.) D. 2.

Pickled, (halibut.) D. 3.

Baits, D. 5. 
38. TELEOCEPHALI-Continued.

ANACANTHINI, (cod, pollock, haddock, hake, ling, cusk, burbot, rockling, lance.)

Useful products :

Food: Fresh. D. 1.

Salted, wet, (cod,) (cods' sounds, tongues.) D. 3.

Salted, dry, (cod, haddock, hake.) D. 2.

Bait, (lance.) D. 5.

Isinglass, (cod, haddock, hake.) D. 24.

Leather, (N. W. coast Indians, cod.) D. 27.

Oil, (cod, haddock, hake, livers.) D. 30.

ACANTHOPteri, (Wolf-fish, blenuy, oyster-fish, toad-fish, lumpfish, sea-suail, goby, sea-robin, gurnard, sculpin, sea-raven, Norway haddock or hemdurgan, red-fish, rock cod (west coast), black-fish, or tautog, cumer or chogset, parrot-fish, vurparous-fish (west coast), surgeon-fish, angelfish, chetodons, sword-fish, bayonet-fish, scabbard-fish, mackerel, cero, tunny, bouito, crerallé, pompano, pilot-fish, dolphin, butterfish, weak-fish, drum, croaker, king-fish, whiting, bass, sheepshead, scup or porgy, grunts or pig-fish, black bass, sunfish, straw berry bass, rock bass, perch, groupers, striped bass or rock-fish, blue-fish, tailor, cobia, remora, barracuda.)

Useful products :

Food: Fresh. D. 1.

Salted, wet, (sword-fish, mackerel, tunuies, pompanoes, blue-fish.) D. 2.

Baits. D. 5 .

lsinglass, (weak-fish, drum, sc.) D. 24.

Ornament, scales, (parrot-tish, drum.) D. 14.

Injurious traits :

Poisonous, (barracuda, dolphin, \&c.)

Enemies of ressels, (sword-fish, bayonet-fish.)

Parasitic on useful fishes, (remora, toad-fish, and sea-snail, (on oysters and pectens,) \&c.)

Bait-thieres, (sculpins.) 
3S. TELECOPHALI-Continned.

Percesoces. (Atherines, mullet.)

Useful products :

Food: Fresh. D. 1.

Salted, smoked, (mullet, mullet-spawn.) D. 2.

Salted, wet, (mullet.) D. 3.

Bait, (atherines.) D. 5.

Scales, (mullet.) D. 14.

SINENTOGNATHI. (Gar-fish, flying-fish.)

Useful products:

Food: Fresh. D. 1.

Salted, smoked, (gar-fish, flying-fish.) 1.

Haplom. (Blind-fish, pike, pickerel, minnows.)

Useful products:

Food, (pike, pickerel.) D. 1.

Bait, (minnows.) D. 5.

Injurious traits :

Enemies of other fishes and of aquatic birds, (pikes, pickerels.)

Isospoxdyl. (Capelin, oulachan, smelt, white-fish, salmon, trout, tarpum, herring, meuhaden, shad, alewife or gaspereau, anchovy, \&c.)

Useful products:

Food: Fresh. D. 1

Salted, (shad, salmon, white-fish, herring, \&c.) D. 2.

Smoked, (herring, salmon, \&c.) D. 1.

Canned, (salmon, menhaden, sardines, \&c.) D. 1.

Eggs. D. 1.

Sauce, (anchovy.) D. 3.

Oil,(salmon, oulachan, white-fish, menhaden, herring.) D.27.

Bait, (capelin.) D. 5.

Ornamental scales, (tarpum.) D. 14.

Guano, (menhaden, herring, \&c.) D. 31.

Modes of culture. W. 9.

Eventognathi. (Suckers, dace, buffalo-fish, carp, tench, \&c.)

Useful products :

Food. D. 1.

Bait. D. 5.

Artificial pearls. D. 29.

Modes of culture, (including domesticated species.) E. 9. 
39. NEMATOGNATHI. (Cat-fish, "bull-heads," \&c.)

Useful products :

Food. D. 1.

Guano, (cat-fish.) D. 31.

10. APODES. (Eels, congers.)

Useful products :

Food. D. 1.

Bait, eel-skins. D. 5.

Leather, (eels.) D. 20.

41. CYCLOGANOIDEI. (Mud-fish, or amia.)

42. RHOMBOGANOIDEI. (Gar-pikes.)

Useful products: Scales, used for arrow-tips. D. 14.

Injurious traits: Enemies of other fish.

43. SELACHOSTOMI. (Paddle-fish, or spoon-bill)

44. CHONDROSTEI. (Sturgeons.)

Useful products :

Foods: Fresh. D. 1.

Smoked. D. 1.

Eggs, pickled, (caviare.) D. 3.

Chorda-dorsalis; dried, (veziga.) D. 2.

Isiuglass, (sturgeon.) D. 24.

Oil. D. 27, T.

Scales. D. 14.

Useful traits: Scarengers.

Injurions traits: Said to destroy eggs of white-fish.

\section{ELASHOBRANCHIATES.}

45. HOLOCEPHALI. (Chimæra, or king of the herrings.)

46. RAIA. (Skates, rays, " deril-fish.")

47. SQUALI. (Sharks.)

Useful products :

Food, (sharks, skates.) D. 1.

Bone, (sharks.) D. 9.

Oil, livers, (sharks, rays, \&c.) D. 27 .

Shagreen, (sharks.) D. 20.

Injurious traits: Enemies of man and fishes. 


\section{MARSIPOBRANCHIATES.}

45. HIPLROARTIA. (Lamprey-eels, or nine ejes.)

49. HYPEROTRETI. (Suckers, or hags.)

Useful products: Food, (lamprey-eels.) D. 1.

Useful traits: Scarengers, (hags.)

\section{LEPTOCARDIANS.}

50. Cirrostomi. (Amphioxus.)

Modes of capture. D. 6.

\section{INSECTS.}

51. HEXAPODA. (Bees, butterflies and moths, flies, beetles, bugs and lice, grasshoppers and crickets, dragon-flies and caddice flies.)

Useful products :

Food of aborigines.

Honey, (bees, \&c.) D. 1.

Wax, (bees, \&e.) D. 30.

Baits, (flies, bees, dragon flies, beetles and their larvæ, grasshoppers, \&c.) D. 5, B. 45.

Silk, (moths.) D. 8.

('oloring material, (cochineal insect, \&c.) D. 29.

Blistering preparations, (Spanish-flies, \&c.) D. 30.

Wings used in the arts, (beetles.) D. 19.

Useful traits :

Puncture trees, producing galls, manna, lac, \&c.

Injurious traits :

Injurious to vegetation, (numerous species.)

Internal and external parasites, (flies.)

52. IIYRIAPODA. (Centipedes, millipedes.)

Useful products: Food of aborigines, (eggs.) D. 1.

Injurious traits: Venomous, (centipedes, millipedes.)

\section{ARACHNEANS.}

53. ARACHNIDA. (Spiders, scorpions, mites, \&c.)

Useful products:

Fine threads used by opticians, (spiders.)

Silk, (spiders.) 
53. ARACHNIDA-Continued.

Useful traits: Destroy noxious insects, (spiders.)

Injurious traits :

Venomous, (scorpions.)

Parasites, (mites.)

\section{ARTHROPODS.}

54. CRUSTACEA. (Crabs, lobsters, shrimps, prawns, crawfish, limnoria, fish-lice, lernæans, sand and water fleas, barnacles, horseshoe crabs, \&c.)

Useful products :

Foods, (fresh and canned crabs, lobsters, shrimps, prawns, crawfish, lobsters.)

Baits, (crabs, lobsters, shrimps, prawns, \&c.)

Nanures, (horseshoe crabs.)

Useftul traits: Skeleton cleaners, (beach fleas, \&c.)

Injurious traits :

Parasites on fishes and marine mammals, (barnacles, fishlice, sc.)

Destroy earthworks, dams, \&c., (crawfish.)

Destroy submerged timbers, (limnoria, Se.)

Modes of protection against injurious species. E. 4 .

Methods of capture. D. $7,31,32$.

\section{WORMS.}

55. ANALLIDA. (Sipniculoids, leeches, earth-Torms, serpalæ, sea. worms, \&e.)

Useful products:

Food of aborigines, (earth-morms.) D. 1,2.

Baits, (earth-worms, sea-worms.) D. 5.

Usefinl traits :

Used in surgery, (leeches.)

Used as barometers, (leeches.)

Injurious traits: External parasites of animals, (leeches.)

Methods of culture, (leeches.) E. 11.

56. SCGLECIDA. (Tape-worms and flukes, planarians, nemerteans, trichinæ, thread-worms, rotifers, \&c.)

Injurious traits: Internal parasites, (uumerous species.) 


\section{MOLLUSKS.}

57. CEPHALOPODA. (Octopus, nautilus, argonauts, calamaries or

Useful products : squids.)

Food, (squids and their eggs.) D. 1.

Bait, fresh and salted, (octopus, squids.) D. 1, 5.

Ink, sepia, (sepias.) D. 29.

"Bone," used as food for animals. D. 5 .

"Bone," used in arts and manufactures. D. 19.

5s. GASTROPODA. (Land-snails, sea-snails, whelks, limpets, \&c.)

Useful products :

Food, (numerous species.) D. 1, 2.

Bait, (limpets, \&c.) D. 5.

Nacre, (top-shells, ear-shells, \&c.) D. 15.

Shell used in arts and manufactures. D. 16.

Useful traits :

Carrion-feeders, (strombus and other siphonated genera.)

Food of useful animals.

Injurious traits :

Predatory on other mollusks, (murex, buccinum, natica, \&c.)

Injurious to vegetation.

59. CONCHIFERA. (Ordinary bivalve shells. ${ }^{1}$ )

Useful products :

Food, fresh, dried, and pickled, (numerous species.) D. $1,2,3$.

Baits, (clams, mussels, \&c.) D. 5.

Pearls and nacre, (river-mussels, pearl-ovsters, \&c.) D. 15.

Shell used in arts and manufactures. D. 16.

Injurious traits: Borers in wood and stone, (ship-worms, pholas, gastrochæua, date, shells, saxicava, ungulina, \&c.)

\section{RADIATES.}

60. ECHINODERMATA. (Sea-cucumber, sea-urchins, star-fishes, ophi-

Useful products : urans.)

Food, fresh, (sea-urchins and their eggs.) D. 1.

Food, dried, (bêches le mer.)

1 Tunicata, brachiopoda, and bryzoa are omitted, on account of their very remote usefulness. 
60. ECHINODERMATA-Continued.

Injurious traits :

Burrowers, (various echinoids.)

Destroyers of useful mollusks.

61. COELENTERATA. (Acalephs, polyps, \&c.)

Useful prodnets: Coral, varions species of polyps.) D. 17.

Injurious traits: Clog seines, weirs, and fishing-lines, (acalephs.)

\section{PROTOZOANS.}

62. RHIZOPODA. (Sponges aud foraminifera.)

Useful products :

Food, "mountain meal," (foraminifera.) D. 1

Infusorial earths, (foraminifera.) D. 18.

Sponges, used in arts and manufactures. D. 26. 


\section{SECTION B.}

(THE CHASE AND THE FISHERIES.)

\section{MEANS OF PURSUIT AND CAPTURE. \\ I. HAND IMLLEMENTS OR TOOLS.}

1. CLUBS:

* For striking.

a. Unarmed clubs:

Salmon.clubs, used by the Indians of the Northwest coast.

Other fishing.clubs.

Hunting-clubs.

b. Armed clubs:

Stone-headed clubs.

Clubs, armed with teeth or bone points.

Clubs, armed with metal points.

2. SLUNG-WEIGHTS :

a. Slung-stones.

b. Slung shot.

c. ("Norning stars.")

d. ("Flails.")

3. KYIVES :

$$
\text { ** For cutting. }
$$

a. Straight knives:

Hunting-dirks and daggers.

Hunting-knires, scalp-knives, \&re.

Blubber-knives, aboriginal and recent.

Boarding-knives used by whalemen.

Whaleman's boat-knives.

Bowie-knires.

Flaying-knives, aboriginal and recent.

Splitting-kuives.

Heading-knives.

Sailors' and fishermen's sheath-kuives.

Hunters' sheath-knives.

Slivering-kuives, used by fishermen.

Oyster-kuives. 


\section{KNIVES-Continued.}

a. Straight knires:

Mackerel rimmers or fatting knives.

(Swords, including the various forms incidentally used in hunting; sabers, cutlasses, machétes, creases, \&c.)

Stone and bone knires, used by Indians and Eskimos.

Skin scrapers and parers, used in preparing leather.

b. Clasp-knices:

Sailors' clasp-knires.

Hunters' clasp·kuires.

Clasp-dirks.

Jockey kuives,

4. AXES :

a. Axes, proper:

Tomahawks.

Hatchets.

Whaleman's boat-hatchets.

Cleavers.

Axes, used by fishermen and hunters.

Head-axes for whalemen.

b. Cutting-spades:

Whale-spades:

Cutting-spades.

Throat-spades, flat and round shank.

Wide spades.

Half-round spades.

Head-spades.

Blubber-mincing knires.

Chopping-knives.

$$
\text { **** For thrusting. }
$$

5. THRUSTING SPEARS AND PRODS:

a. Fishing-lances.

Whale-lances.

Whaleman's boat-spades, thick and thin.

Seal-lances.

Fish-lances.

b. Hunting-spears.

c. Bayonets.

d. Prodding-awls, used in piercing the base of the brain in killing fish for the table. 


\title{
II. IMPLEMENTS FOR SEIZURE OF OBJECT.
}

* Scooping-instruments.

6. SCOOPS.

\author{
$\dagger$ For hand-use.
}

a. Shovels:

Clam-shorels.

Trowels used in taking burrowing shore animals.

Haud-scoops.

Ђ. Hand-dredges, used in collecting mollusks.

c. Pile-scrapers.

t+ For use with sounding-lines.

d. Armed learls:

Common "deep-sea lead."

Deep-sea-sounding apparatus.

e. Cup-leads.

$f$. Scoop sounding-machines.

** Grasping-hooks.

7. HOOKED INSTRUMENTS. (Those used with a single motion, that of hooking:)

a. Single-pointed hooks:

Gaff-hooks.

Boat-hooks.

Jigs.

Rabbit and squirrel hooks, used by the Ute Indians.

Snake-hooks.

Clam-hooks.

Hoes and picks used in gathering shell-fish.

Forks used in handling salted and dried fish.

Whalemen's hooks :

Blubber-hooks.

Blubber-forks.

Junk hooks.

Lance-hooks.

Can-hooks. 


\section{HOOKED INSTRUMENTS-Continued.}

b. Many-pointed hooks :

Grappling-irons.

Lip hooks or grapnels, used by whalers.

Toggles, used by whalers.

Oyster-rakes.

Clam-rakes.

Oulachan rakes or spears.

Squid-jigs.

c. Twisting-rods, used in drawing small mammals from their burrows.

8. BARBED IMPLEMENTS. (Those nsed with two motions, the first that of thrusting:)

a. Spears with fixed heads:

Harpoons.

Ove-flued harpoons.

Tro-fined harpoons.

Toggle-harpoons.

Harpoon-bullets. (See nuder 23.)

Gun-harpoons.

Other whaleman's "craft."

Barbed spears, (with single point.)

Grains, (with two prongs.)

Gigs.

Bird-spears.

Otter-spears.

Sea-otter spears.

Seal-spears.

Walrus-spears.

Eel-spears.

Flounder-spears.

Sturgeon-spears, (west coust.)

Octopus-spears.

Crab-spears, used in Rhode Island.

b. Spears with detachable heads:

Lily-irons.

Dolphin-irons.

Indian harpoons of shell and irou.

Estimo harpoons of stone, bone, and iron. 
S. BARBED INSTRUMENTS-Coutinued.

b. Spears witl detachable heads:

Indian fish-harpoous.

Other fish-harpoons.

(For accessory apparatus, see under 29.)

9. TONGS, \&c.

\section{$\dagger$ For hand use.}

a. Tongs (with two haudles:)

Oyster-tongs.

Osster-rakes.

b. "Nippers," (with cord and handle.)

Suake-tongs.

Sponge-tongs.

Coral-tongs.

t† For use with sounding lines.

c. "Clamms" for deep-sea soundings, (forceps closed by a weight.) (Ross's "Deep sea clamms.") (Bull-dog sounding-machine.)

10. NOOSES.

**** Grasping-lines.

a. Jerk-snares :

† Stationary nooses.

Bird-suares.

Fish suares, of wire, gut, hair, \&c.

t† Thrown nooses.

b. Lariats and lassos:

Lariats with rope noose, made from hair, hemp, and rawbide. Lariats with metal noose.

(Chilian bird-lariat.)

11. LOADED LINES. (Bolas.)

a. Bird-slings, used by Eskimos.

b. Bolas, with oue or several weights.)

12. TANGLES.

****** Entangling lines.

a. Tangles:

Swab-tangles.

(Dredge-tangles, used by English collectors.)

Harrow-tangles.

Wheel-tangles. 


\section{MISSSILES.}

* Simple missiles, (those propelled by the unaided arm.)

13. IIU RLED WEIGHTS.

a. Stones and dises thrown by the hand.

b. Weights dropped from an elevation, (dead-falls, not antomatic.)

14. IIURLED STICKS.

a. Straight sticks :

Clubs used as missiles.

b. Curred sticks:

Throw-sticks, used by the Moqui Indians of New Mexico in hunting rabbits.

(Boomerangs.)

15. HURLED SPEARS.

a. Dirts and lances.

** Cenirifugal missiles. (Propelling poucer augmented by an artificial in. crease of the length of the arm.)

16. SLINGS AND SPEARS THROWN BI STRAPS.

a. Slings.

b. Spear's, with straps used in throwing them.

17. MISSILES PROPELLED BY "THROWING-STICKS."

a. Spear's with throwing-sticks, used by Eskimos:

Series of throwing or darting sticks.

*** .Missiles propelled by a spring.-千 Spring consisting of bent rod.

1S. BOWS AYD ARROWS.

a. Bows :

Simple bows.

(Cross-bows.)

(Ballistas.)

6. Arrows :

Lance-arrows.

Harpoon-arrows, used in fishing.

Blunt or club arrows, used in killing birds.

c. Accessories of bows and arrows:

Holders.

Quivers.

Arrow-head pouches. 
18. BOWS AND ARROWS-Continued.

d. Implements of manufacture:

Flint-chipping apparatus.

Arrow-head sharpeners.

Shaft-gauges.

Cord-twisting apparatus.

Shaft-polishers.

Glue-sticks, used in fastening head of arrow.

䩔 Spring consisting of elastic cord.

19. INDIA-RUBBER SLINGS.

a. Pea-shooters, used in killing birds.

trit Spring consisting of metallic helix.

20. SPIING-GUNS.

a. Spring-guns.

***** Missiles propelled by the compression of air or water.

21. AIR-GUNS.

a. Blow-guns, (missile propelled by the breath :)

Blow-guns carrying arrows.

Blow-guns carrying balls.

b. Piston air-guns.

c. Reservoir air-guns:

Air-guns.

Air-gun canes.

22. WATER-GUNS.

a. Syringe-guns :

Humming-bird guns.

23. GUNS AND PISTOLS.

\section{******ar Firearms.}

a. Mnzzle-loading arms :

With smooth bores:

Muskets.

Fowling-pieces.

Cane-guns.

Pistols:

Single-barreled pistols.

Rerolvers.

With grooved bores: Rifles.

Ritle-muskets.

Rifle-carbiues.

Pistols. 
23. GUNS AND PISTOLS-Continued.

b. Breech-loading arms :

With smooth bores:

Fowling-pieces.

Pistols.

With rifled bores:

Muskets.

Hunting riftes.

Carbines :

Single-barreled carbines.

Revolving carbines.

Pistols :

Pistols.

Revolvers.

c. Whaling-guns:

Bomb lance and gun.

Harpoon ball and gun.

Harpoon-gun.

Harpoon homb-lance gun.

24. (ICCESSORY.) AMMUNITION AYD ITS PREPARATION.

a. Explosives:

Gumpowder.

Gunccottou.

Percussion powder:

Caps.

Needle percussion.

Primers.

Wood powder.

Dynamite or giaut-porder.

Nitroglycerine.

Dualine.

Lithofracteur.

Colonia porter.

Othèr explosices.

b. Missiles:

Bullets.

(Accessors) bullet-molds.

Shot.

(Accessory) methods of manufacturing shot. 
24. (ACCESSORY.) AMMUNITION, \&c.-Continued.

b. Missiles :

Explosive bullets, shells, \&c.:

Bomb-lance.

Meigs's shells.

c. Wadding:

Bulk wadding.

Prepared wads.

(Accessory) wad-cutters.

a. Ammunition-measures:

Measures.

$\left.\begin{array}{l}\text { Shot-measures. } \\ \text { Powder-measures. }\end{array}\right\}$ Attached to pouches and separate.

Weighing-scales.

e. Prepared ammunition :

Cartridges :

Ball-cartridges.

Shot-cartridges.

Wire-cartridges.

(Accessory) paper-shells.

(Accessory) metallic shells.

f. Methods of preparing cartridges:

Loaders.

Crimpers.

Cappers.

25. ACCESSORIES OF LOADING, CLEANING AND REPAIRING, SIGHTING, AND TESTING FIRE-ARMS.

a. Instruments for cleaning, loading, \&c.:

Rammers.

Swabs.

Charge drawer's, "worms."

b. Sights, \&c. :

Muzzle-sights:

Plain sights.

Slit-sights.

Globe-sights.

Peep-sights.

Breech-sights :

Plain sights.

Graduating sights. 
25. ACCESSORIES OF LOADING, \&c.-Continued.

b. Sights, \&c.:

Telescope-sights.

Lerels, attached to guns

Wind-gauges.

c. Targets :

Practice-targets.

"Gyro-trap" targets.

Pigeon-traps and accessories of pigeon-shooting.

1. Recoil-checks.

26. FOR CARRYING ARMS AND AMMUNITION.

a. Ammunition-holders:

Powder-holders :

Horus.

jlasks.

Canisters.

Shot-holders :

Pouches.

Belts.

Cartridge-holders :

Pouches.

Boxes.

Belts.

Tests.

Cap-holders:

Pouches.

Boxes.

Cap-straps, used by Indians.

b. Weapon-holders:

Slings for arms :

Shoulder-sliugs.

Saddle-slings.

Holsters.

Beits :

Pistol-belts.

Racks and cases:

Gun-racks.

Gun-cases. 


\section{BAITED H0OKS. ANGLING-TACK!E.}

27. HOOKS WITH MOVABLE LINES.

a. Tackle for surface-fishing:

Fly-fishing tackle.

Salmon-tackle.

Trout-tackle.

Black-bass tackle.

Shad-tackle.

Trolling-tackle:

Trolling-tackle.

Whiffing-tackle.

Drailing-tackle.

Gangs of hooks for minnow-bait.

Surf-tackle for throwing and hauling:

Striped-bass tackle.

Redfish or bass tackle.

Bluefish tackle.

Tide.drailing tackle:

Pasque and cuttyhunk bass-tackle.

b. Tackle for fishing below the surface:

Short hand-gear :

Mackerel-gear.

Deep-sea gear:

Cod-gear.

Halibut-gear.

- Flounder-gear.

Shark-gear.

Tautog-gear.

Other bottom-gear.

Bobs:

Eel-bobs.

28. HOOKS, WITH STATIONARY LINES.-SET TACKLE.

a. Surface lines :

Spilliards, or floating-trawl lines.

b. Bottom-set lines:

Trawl-lines, or bull-tows. 
29. (ACCESSORY.) PARTS AND ACCESSORIES OF ANGLING. APPARATUS AND OF HARPOON AND SEINE LINES.

a. Hools, including a full series of unmounted hooks, of recent and aboriginal manufacture.

Plain hooks :

Fly-hooks.

Trout-hooks.

Salmon-hooks.

Cod and halibut hooks.

Hooks for general use.

Bass-hooks.

Jigs and drails :

Mackerel-jigs.

Blue-fish drails of bone and metal of the rarious patterns, Newport, Noank, Proridence, Provincetorn, \&c.

Block Island drails.

Pearl-squids of rarious patterns.

Bone-squids.

Metal-squids.

Petticoat-squids of tlannel, se.

Spoon-baits, plain and fluted:

Bass-spoons.

Pickerel-spoons.

Trout-spoons.

Blue-fish spoons.

Other trolling-spoons.

Artificial tlies on hooks :

Salmon-flies for each month.

Tront-flies for each month.

(Accessory.) Flr-boots.

乙. Lines, (twisted and plaited:)

Silk-lines.

Grass-lines.

Lineu-lines.

Cotton-lines.

Cotton-hemp lines.

Bark-lines.

Manila-lines.

Hide-lines. 
29. (ACCESSORY.) ANGLING-APPARATUS, \&C.--Continued.

b. Lines, (twisted and plated:)

Gut-lines.

Lines made from sea-weed, (Nereocystis Lütkeana,) and used by natives of Alaska.

(Lines of sea-weed, (Chorda filum,) used similarly in Scotland.)

(Accessory.) Apparatus for twisting lines.

c. Snoods, leaders, and traces:

"Cat-gut," (sheep,) snoods, and leaders.

Silk-worm-gut snoods.

Salmon-gut snoods.

Flax-snoods.

Gimp-snoods.

Wire-suoods.

"Sid-straps."

d. Whalers' chains and lines:

Head chains and ropes.

Fin-chains.

Fluke chains and rings and ropes.

Head pike and ring.

(Accessory.) Blocks, pendants, cutting-blocks, \&c.

e. Sinkers:

Boat-shaped sinkers, plain and shearing.

Pipe-lead sinkers.

Bullet-sinkers.

Plummet-sinkers, sugar-loaf, pear-shaped, and double-taper.

Banker-sinkers.

Seine-sinkers, of chain, lead balls, lead rings, stone, \&c.

(Accessory.) Molds for sinkers.

Jig-molds.

Other sinker-molds.

f. Spreaders :

Chopsticks.

One-armed chopsticks, or "revolving booms."

g. Floats :

Line-floats of wood, cork, and quill.

Harpoon-floats of bladder, inflated skin, and wood.

Seine-floats of cork, wood, glass, and rubber-tubing.

Keg and other floats for lobster-pots, gill-nets, \&c.

Whale-line drag. 
29. (ACCESSORY.) ANGLING-APPARATUS, \&c.-Continued.

$h$. Reels :

Simple reels for fly-fishing, with and without check.

Multiplying reels for bass-fishing, with and without check.

Other multiplying reels.

Gunwale-winches.

Dredge-line rollers.

Trawl-line rollers.

Seine-windlasses.

i. Line-holders :

Winders.

Spools.

Whaleman's line-tub.

Tuls for traml-lines.

Seine-reels.

k. Rods :

Straight rods, of cane, wood, whalebone, \&c.:

Salmon-rods.

Tront-rods.

Bass-rods.

Pickerel-rods.

Other rods.

Folding-rods.

Tips of rubber, whalebone, \&c.

Tell-tales, used in trolling.

Tell-tales for fishing under the ice.

(Accessory) cases for rods and rod-tops.

l. Swirels:

Box-swirels.

Hook·swirels.

Pot-gauge swivel.

Cod-line swivels.

Traml bnoy-rope swivels.

$m$. Clearing-rings.

$n$. Disgorgers. 


\section{NETS.}

30. ENTANGLING-NETS.

a. Meshing-nets, (entangling in meshes:)

$\ddagger$ BARRIER-NETS.

Rabbit-nets, used by Indians of the Southwest.

Bird mesh-pets.

Gill-nets, used in great lakes. -

$\ddagger$ DRifT-Nets.

$\dagger$ Those drifting across the tide.

Shad gill-nets, used in southern rivers.

Bass gill-nets.

Salmon gill-nets.

Mullet gill-nets.

if Those drifting along the tide.

Mackerel gill-nets.

Herring gill-nets.

b. Pocket-nets, (entangling in pockets:)

Trammel-nets.

31. ENCIRCLING-NETS.

a. Seines:

Seal-seines.

Manatee-seines.

Shad-seines.

Mullet-seines.

Menhaden-seines.

Bass-seines.

Blue-fish seines.

Capelin-seines.

Herring-seines:

Cod-seines.

Lance-bunts.

Baird collecting-seines.

Bait-seines.

"Fly-tail" seines of North Carolina.

b. Hoop-nets :

Handle, or dip-nets :

Bull.nets, (worked with ropes and blocks.) 


\section{ENCIRCLING-NETS-Continued.}

b. Hoop-nets :

Handle or dip-nets :

Scoop-nets, (herring-nets, pound-scoops, car-scoops, \&c.)

Landing-nets.

Eskimo auk-nets.

Baited hoop-nets :

Crab-nets.

c. Trailing-nets :

Trawls :

Beam-trawl.

(Otter-trawl.)

\section{Dredges :}

Flange, or ordinary dredge.

Rake-īredge.

Osster-scraper.

(Coral-dredge.)

Towing-nets :

Surface tow-nets.

d. Folding or jerk nets :

Purse-nets :

Mackerel purse-seines, (pursed by weight.)

Menhaten purse-seines, (pursed by hand-ropes.)

Cast-nets :

Mullet cast-nets.

Pompano cast-nets.

Bait cast-nets.

Clap-nets for birds.

Rabbit-spring nets.

Spring-weirs, (St. Lawrence.)

Sieve-traps, (for birds.)

e. (Accessory.) Parts of nets and apparatus for manufacture:

Raw material of nets.

Babiche. (See under D. 20.)

Netting-fibre.

Netting-twine.

Netting-needles.

Mesh-needles.

Hanging.needles.

Eskimo netting-needles. 


\section{TRAPS.}

32. PEN-TRAPS.

a. Pocket-traps :

Pitfalls :

Pits, covered.

Barrel-traps.

Jar mole-traps.

"Rabbit-tipe," used in England.

Salnon-baskets, (Columbia River.)

Salmon-weirs, (Upper Columbia River.)

Rirer-weirs, with pockets :

Eel-traps.

Fish-slides :

Shad-slides, used in the rivers of North Carolina.

b. Labyrinth-traps:

Corrals.

Turkey-traps.

Weirs, or pounds :

Heart-pound.

Salmon-weir.

Virginia Indian weir, (figured by DeBry.)

Salmon hook-gill-net of the Saint Lawrence.

Funnel-traps :

Fish-pots.

Lobster-pots.

Eel-weirs, (with leaders.)

Eel-pots, (without leaders.)

Barrel-pots, for eels.

West India wicker fish-pots.

Set-nets.

Fykes, (set-nets with leaders.)

Bass-traps.

c. Door-traps :

tClosed by the falling of a door.

Box-traps.

Rabbit-traps, (figure 4.)

Brick traps, (figure 4.) 


\section{PEN-TRAPS-Continued.}

c. Door-traps :

Box-traps :

Musquash traps, with hanging doors.

Rabbit-traps, for mouth of burrows.

Self-setting box-traps.

Double box-traps.

Spring-door traps.

it Closed by falling of whole trap.

Bowl-traps.

Cob-house bird-traps.

Pigeon-nets.

tt Closed by falling of tide.

Bar-weirs.

d. Sheaf-traps:

Sheaf-traps, (New York Harbor.)

33. CLUTCHING-TRAPS.

a. Noose-traps :

Snares :

Footpati-snares.

Barrier-suares.

Springes.

"Round mouse-traps."

b. Jawed traps:

"Steel traps:"

Nerrhouse traps:

No. 0. Rat-trap.

No. 1. Muskrat trap.

No. $1 \frac{1}{2}$. Mink-trap.

No. 2. Fox-trap.

No. 3. Otter-trap.

Yo. 4. Bearer-trap.

No. $4 \frac{1}{2}$. Deer-trap.

No. 5. Small bear-trap.

No. 6. Great bear-trap.

Spring bird.nets.

(French bird-trap.) 
34. FALL-TRAPS.

a. Crushing-traps:

Deadfalls.

Figure-four traps.

b. Piercing-traps :

Spear-falls.

Mole-traps.

Harpoon-traps.

c. Spring-hooks :

Pickerel-hooks.

35. MISSILE-TRAPS.

a. Cross-bow traps.

b. Spring-guns.

36. ADHESIVE PREPARATIONS.

a. Bird-lime, \&c.

b. Hoods, boots, \&c.

\section{APPARATUS FOR WHOLESALE DESTRUCTION.}

37. POISONS.

a. Food poisons:

Phosphorus poisons.

Strychnine.

Arsenic.

Corrosive sublimate.

Cyanide of potassium.

Opium poisons.

b. Blood poison: Woorara

38. ASPHYXIATORS.

a. Apparatus for smoking·out.

b. (Apparatus for suffocating with fumes of sulphur.)

c. Apparatus for drowning-out.

39. TORPEDOES.

391. STOMACH-SPRINGS.

a. Eskimo whalebone springs, used in killing bears.

\section{HUNTING-ANIMALS.}

40. HUNTING-MAMMALS.

a. Dogs.

b. Hunting-leopard. (Cynailurus jubatus.) 
40. HUNTING-MAMMALS-Continued.

c. Weasels and ferrets.

d. Otters.

41. ACCESSORIES TO HUNTING-DOGS.

a. Dog-whips.

b. Dog-whistles.

c. Dog-collars.

d. Dog-food.

e. Dog.carts.

$f$. Dog-inuzzles.

42. HUNTING-BIRDS.

a. Falcons.

b. Owls.

c. Cormorants, (Carbo sinensis, used in fishing in China.)

43. ACCESSORY TO HUNTING-BIRDS.

a. Hoods.

b. Perclies.

c. Cormorant-collars.

44. HUNTING-FISHES.

a. Remor!, used in West Indies and Australia.

\section{DECOYS AND DISGUISES.}

45. BAITS.

a. Nitural baits:

Flies and other insects. (This should include a collection of those insects which, as the farorite food of fishes, are imitated in making artificial flies.)

Worms.

Mollusks.

Salted baits, (prepared.)

Mentuaden.

Herring.

Squids.

Clims, long.

Clams, hen.

Peil-roe of cod, (used in French sardine-fisberies, and largely exported.)

Grasshomper paste, used as a substitute for pea-roe.

Tolling baits, "stosh," \&c. 
45. BAITS-Continued.

a. Natural baits:

(Accessory) methods of preparing baits :

Bait-cutters.

Bait-mills.

Bait-ladles.

Wheelbarrows for bait-clams, (Nantucket.)

Bait boxes and cans.

Bait-needles.

b. Artificial baits :

Trolling-spoons.

Spinners.

Squids and jigs.

"Bobs," nsed in sonthern waters.

Artificial flies.

c. Accessory to $b$ :

a. Fly-books.

b. Raw materials for making artificial flies.

c. Tools for making artificial tlies.

d. Pastes.

46. DECOYS.

a. Scent-decoys.

b. Sound-decoys:

Animal calls, whistles, \&c.

Bird-calls.

c. Sight-decoys :

Living decoy animals and birds.

Decoy-dogs, used in hunting ducks.

Stool-pigeons.

Tame decoy-ducks.

Tame decos-brants.

Imitations of animals and birds :

Decoy swimming-birds.

Decoy-waders.

Imitations of fishes :

Lure-fish used in taking Mackinaw tront.

Blanket-decoys, (for antelopes.)

Lanterns and other apparatus for fire-hunting and fishing,

Lanterns for still-hunting. 
46. DECOYS-Continued.

c. Sight-decoys:

Lanterns for weequashing, or fire-fishing, for eels.

Jack-lanterns for tishing.

47. COVERS.

a. Movable covers :

Masks :

Deer heads and antelope heads.

Morable copses.

Covers for hunter.

Covers for boats.

b. Stationary covers:

Hunting-lodges.

\section{PURSUIT, ITS METHODS AND APPLIANCES.}

45. METHODS OF TRANSPORTATION.

a. Personal aids:

Snow-shoes.

Skites.

Alpenstocks and stares.

Portable bridges.

b. Animal equipments:

Harness :

Horse-trappiugs.

Dog-barness.

Girtlıs, sinches.

Bits, cabrestos, spurs.

Saddles :

Riding-saddles.

Pack-saddles.

Aparejos.

Riding-pads, (for buffalo-hunting.)

Fur-pack saddle, (Hudson's Bay Territory.)

Vehicles:

Deer-sledges.

Dog.sledges.

Wagons.

Dog-carts.

Fish-carts, used in Nantucket. 


\section{METHODS OF TRANSPORTATION-Continued.}

c. Boats :

Hunting-boats, fishing-boats :

Birch canoes.

Canoes used by Indians of the northwest coast in whaling.

Kraks or bidarkas.

Umiaks or bidarras.

Indian raft-boats.

Launches.

Dug-outs.

Portable (paper and canvas) boats.

Duck-boats.

Scows.

Oyster-boats.

Whale-boats.

Seine-boats, (sea use.)

Seine-boats of the lakes.

Potomac seine-boats.

Dorys, sharpies, and dingies.

Pound-boats of the lakes.

Italian fishing-boats, (California.)

Pinkies, (Martha's Vineyard.)

Adirondack boats.

Alexandria Bay boats.

Surf-boats.

Whitehall boats.

Oyster-canoes.

Ducking-boats.

Cat-rigged fishing-boats.

Mackerel-smacks.

Oyster-smacks.

Menhaden-smacks.

Menbaden-carryaways.

Bank cod-smacks.

Smacks with wells, used near the coast.

Smacks employed in fish-trade.

Whale-ships.

sealers. 


\section{METHODS OF TRANSPORTATION-Continued.}

c. Boats :

Herring-boats.

Mackinaw boats. ?

Huron boats.

Norwegian boats. Used in the Great Lake fisheries.

Pound-boats. $\}$

Oyster-pungies, (canoe and square-sterned,) emplosed on the Chesapeake.

Oyster police-boats.

\section{Steamers :}

Mackerel-steamers.

Menhaden steam-mills.

Lake gill-net steamer.

Whale-steamers.

Sealing-steamers, \&c.

Accessory to fishing-ressels :

Riggiug, masts, sails, cordage, pulleys, sockets.

Anchors, killicks, chains.

Sail-needles, palms, fids, marline-spikes.

Oar-locks, chocks, oar-rests.

Stepping-irons for whale-boats.

Crotches and oar-rests.

Paddles and oars.

Rudder-heads, wheels, tillers, Sc.

Fog.horns, trumpets, drums, \&c.

Cabin, blubber room, cooks' and binnacle lamps and jacket-lamps, sigual, binuacle, and common lanterns.

C'ompasses, barometers, fic.

Astronomical instruments, sextants, quadrants, chronometers, hour and log glasses.

19. CAMP-OUTFIT.

a. Shelter:

Lodges.

Tents.

Hunting.camps.

Hunters' houses.

Fishing-houses. 
49. CAMP.OUTFIT-Continued.

b. Furniture:

Hammocks.

Beds, couches, stretchers, and lounges.

Blaukets, rubber and Mackinaw, and fur robes.

Fuel.

Apparatus for kindling fire.

Lamps and lanterns.

Tools.

c. Commissary supplies:

Cooking-apparatus, kettles, and stores.

Table-furniture.

Preserved meats, \&c.

50. PERSONAL EQUIPMENTS.

a. Clothing:

Hunting-suits.

Cloth-suits.

Skin-skins.

Water-proof suits.

Oil-skin suits.

Boots, moccasins, leggings.

Water-proof boots.

Wading boots and stockings.

Riding-boots.

Moccasins.

Leggings.

Hats and caps.

Protection from insects:

Nets for beds and for face.

Ointments, (such as tar and sweet-oil.)

Smudges, (such as pyrethrum powder.)

Shields, breastplates, and defensive armor.

b. Trappings :

Belts.

Cross-belts.

Game-bags.

Game and fish baskets and slings.

Wallets for lines and other tackle. 
50. PERSONAL EQUIPMENTS-Continued.

c. Optical instruments, \&c. :

Snow-goggles.

Telescopes.

Field-glasses, \&c.

Water-telescopes.

d. Medical outfit:

Medicine-chests.

Hunters' and fishermen's flasks.

e. Artificial lights :

Lanterns for camp and ship use.

Torches. 


\section{SECTION C. METHODS OF PREPARATION. \\ I. PREPARATION AND PRESERVATION OF FOOD}

1. PRESERVATION DURING LIFE, (see under $\mathrm{E}, 3$. )

2. PRESERVATION OF FRESH MEATS.

a. Refrigerators :

Ice-boxes and refrigerators.

Refrigerator-cars.

(Accessory.) The ice-trade:

lce cutting and handling apparatus.

Methods of manufacturing artificial ice.

Ice-houses.

$b$. Other accessories of preservation:

Meat-hooks.

Skewers, \&c.

Carving-tools.

3. PRESERVATION BY DRYING.

a. Sun-drying apparatus:

Beach dryers.

Flake-drying :

Newfoundland flakes.

Massachusetts flakes.

Covers for fish-drying.

b. Smoke-drying apparatus:

Herring smoke-houses.

Halibut smoke-houses.

Salmon smoke-houses.

Sturgeon smoke-houses.

Aboriginal drying-houses.

Methods of drying haliotis, used by the Indians of California. 
4. PRESERVATION BY CANNING AND PICKLING.

a. Salting fish :

Knives, (see under B, 2.)

Scaling-apparatus.

Tables, tubs, \&c.

Barrels.

(Accessorr.) Salt:

Specimens of the salts used in preserving fish.

Model of salt-mills used on Cape Cod in former days.

b. Cauning meats :

Model of salmon-canning establishment.

Model of sardine-factory.

(Accessory.) Cotton-oil, and its manufacture.

Mordel of lobster-canning factory.

Model of oyster-canning factory.

5. PREPARATION OF BAITS.

a. Bait-mills, knires, choppers, \&c., (see under B, 2 and 3.)

b. Bait tubs, vats, \&c.

\section{HANUFACTURE OF TEXTILE FABRICS, FELTS, AND STUFFINGS.}

6. PIEPARATION OF WOOL AND HAIR OF MAMMALS.

a. Preparation of wool cloths:

IVashing.

Shearing.

Stapling or assorting.

Scouring.

Combing, carding, and plucking.

Spiuning and reeling.

Nearing.

Fulling and teazling.

Cropping.

Pressing.

b. Weaving worsted cloths.

c. Felting and the hat manufacture:

Bowing.

Pressing.

Stopping. 
6. PREPARATION OF WOOL, \&c.-Continued.

c. Felting and the hat manufacture :

Rolling-off.

Shaping.

d. Preparation of curled hair for stuffings.

7. PREPARATION OF WHALEBONE.

a. Preparation of stuftings.

S. PREPARATION OF FEATHERS.

a. Preparation of down for stuffings.

b. Preparation of feather fabrics.

c. Preparation of "brillantine."

d. Preparation of or flocking for wall-paper, from refuse quills.

e. Preparation of fibres for manufacture of plush carpets.

9. PREPARATION OF SILK OF INSECTS. ·

a. Preparation of silk of silk-worms :

Boiling the cocoons.

Reeling.

Spiuning.

Dyeing.

Weaving.

10. PREPARATION OF SOFT PARTS OF OTHER INVERTEBRATES.

a. Preparation of silk from byssus of Pinna.

b. Preparation of sponge stuffing.

\section{PREPARATION OF THE SKIN AND ITS AP- PENDAGES.}

11. CURRYING OF LEATHER.

a. Processes of currying :

Dipping.

Graining.

Scraping.

Dressing.

b. Implements employed by curriers:

"Head-knives."

"Pommels."

"Stretching-irons."

"Round-knives."

"Cleaners." 
11. CURRYING OF LEATHER-Continued.

b. Implements employed by curriers:

"Maces."

"Horses," or trestles.

"Dressers."

"Treading-hurdles."

c. Eslimo and Indian currying methods and implements.

d. Methods of dressing gut and sinew.

12. LEATHER-DRESSING.

a. Processes of tanning leather:

Soaking.

Liming.

- Tanning.

b. Processes of taring or oil.dressing leather:

Soaking.

Liming.

Oiling.

c. Apparatus of leather-ilressing, recent and aboriginal.

13. FUR-DRESSING.

a. Processes of fur dressing:

Cinrying. (See under 12.)

Scouring.

Tanning.

Lustering.

Plucking and dyeing.

14. FEATHER-DRESSING.

a. Method of preparing ornamental feathers:

sconring.

Bleaching.

Washing.

Azuring.

Sulphuriug.

Scraping.

1) seing.

b. (Art of plumagery.)

15. MANUFACTURE OF QLILL ARTICLES.

a. Manufacture of quills for pens:

Sand-bath drying and steaming.

Polishing. 
15. MANUFACTURE OF QUILL ARTICLES-Continned.

a. Manufacture of quills for pens:

Dreing.

Sthaping.

b. Manufacture of tooth-picks.

c. Manufacture of floats and other articles.

d. Manufacture of quill brush-bristles.

16. HAIR AND WOOL WORK.

\section{PREPARATION OF HARD TISSUES.}

1i. IVORI CUTTING AND CARVING.

a. Manufacture of handles, trinkets, billiard-balls, \&re.:

Turning aud sawing.

Polishing.

Bleaching.

b. Manufacture of organ and piano keys :

Sawing.

Strip-sawing.

Polishing.

Bleaching, \&e.

c. Other processes.

18. PREPARATIUN OF HORN AND HOOF.

a. Steaming.

b. Pressing.

19. PREPARATION OF WHALEBONE.

a. Cutting and other processes.

b. Manufacture of whip-makers' stock and whips.

c. Manufacture of umbrella-maker's bone.

d. Manufacture of ribbon-weaver's bone.

e. Nanufacture of hat and bonnet maker's bone.

$f$. Manufacture of suspender-maker's boue.

g. Manufacture of stock-maker's bone.

h. Manufacture of dress and stay maker's bone.

$i$. Manufacture of billiard-table cushions.

l. Manufacture of surgical instruments.

l. Manufacture of whalebone-brushes.

$m$. Manufacture of rosettes, woven-work, and trinkets.

$n$. Other whalebone manufactures.

2). PREPARATION OF TORTUISE-SHELL. 
21. PREPARATION OF FISH-SCALE WORK.

22. PREPARATION OF NACRE.

23. PREPARATION OF CORAL.

24. PREPARATION OF OTHER HARD TISSUES

\section{OILS AND GELATINES.}

25. EXTRACTION OF WHALE OIL, (WITH MODELS OF TRYWORKS, CLARIFYING-VATS, \&C.)

a. Preparation of body-oil:

Cutting in and stowing.

Leaning and mincing.

Trying.

Bailing.

Cooling.

Barreling.

Refining.

b. Preparation of head-oil.

c. Preparation of spermaceti.

d. Instruments and appliances of rendering whale oil :

Boarding knives.

Leaning-knires.

Mincing-horse and mincing-knires.

Mincing.tub.

Mincing-machine.

Blubber-fork.

Try-pots.

Fire-pilie.

Stirring-pole.

Scrap-hopper.

Skimmer.

Bailer.

Cooler.

Deck-pot.

Casks.

26. EXTRACTION OF OTHER IAMMAL OILS.

27. EATRACTION OF BIRD AND REPTILE OILS.

28. EXTRACTION OF FISH-OILS, (WITH MODELS OF BOILERS, PRESSES, CLARIFTIXG.YATS, \&C.)

29. FXTRACTION OF GLUE, GELATINE, AND ISIXGLASS. 


\section{DRUGS, PERFUHES, AND CHEMICAL PRODUCTS.}

30. MANUFACTURE OF PEREUMES.

31. MANUFACTURE OF IVORY-BJACK.

32. MANUFACTURE OF PRUSSIATES.

33. MANUFACTURE OF MUREXIDES.

34. PREPARATION OF COCHINEAL COLORS.

35. MANUFACTURE OF INKS FROM ANIMAL SUBSTANCES.

36. PREPARATION OF ALBUMEN.

37. MANUFACTURE OF PEPSIN.

38. MANUFACTURE OF PHOSPHORUS.

39. MANUFACTURE OF SAL AMMONIAC.

40. MANUFACTURE OF AMMONIA.

41. MAYUFACTURE OF ALBUMEN PREPARATIONS.

42. MAYUFACTURE OF PROPYLAMINE.

43. MANUFACTURE OF FORMIC ACID.

44. MANUFACTURE UF CARBAZOTATES.

\section{MANUPACTURE OF FERTILIZERS.}

45. PREPARATION OF GUANO.

a. Model of fish-guano rorks:

Grinders aud pulverizers.

Mixers.

Guano in its various stages, with its ingredients, South Carolina phosphates, Navassa phosphates, scrap), (crude, and dried,) sulphurie acid, kainite, screened and unscreened guano, and sea-weed used in preparation.

\section{LIMES.}

46. BURNING OF LIME.

a. Models of kilns for burning shells.

\section{PRESERVATION OF THE ANINAL FOR SCIEN- TIFIC USES.}

47. APPARATUS FOR MAKLNG AND PRESERVING ALC(). HOLIC SPECIMENS.

a. Tanks and jars :

Agassiz collecting-tank. 
47. APPARATUS FOR MAKING AND PRESERVING ALCO HOLIC SPECIMENS-Continued.

a. Tanks and jars:

Army collecting-tank.

Museum storage-tank, Agassiz model.

Anatomical jars.

Self-sealing jars, used in collecting.

Phials.

Tube-phials.

b. Syringes for iujecting.

c. Inflatable bags.

d. Preservative mixtures:

Alcohol.

Glycerine.

Carbolic acist.

Chloral hydrate.

Picric acid.

Osmic acid.

e. Labels:

Metallic labels.

Parchment labels.

Indelible inks, pencils, sc.

49. APPARATUS FOR PRESERVING AND MAKING STELE TONS.

a. Preparation of the bones:

Macerating-vats.

Boiling-rats.

Cleansing and bleaching preparation.

b. Mountiug of the bones:

Scraping-tools.

Articulating-tools.

49. APPARATUS FUR MAKIYG CASTS. MODELING.

a. Materials :

Clays.

Plasters.

Glues.

Papier-maché and carton pierre.

Gelatine.

Paraffine.

Collodion. 
49. APPARATUS FOR MAKING CASTS, \&C.-Continued.

乙. Frames and modeling tools.

c. Molds :

Of plaster.

Of gelatine.

Of paper.

Of paraffine.

50. APPARATUS AND METHODS OF MAKING AND MOUNT ING SKINS. TAXIDERMY.

(1. Tools :

Flaying-tools.

Scraping-tools.

Taxidermists' tools for stuffiug :

Forceps.

Pliers.

6. Preservatives and insect-powders:

Arsenic and arsenical soap.

Corrosive sublimate.

Salt, alum, \&c.

Persian insect-powder.

Sjringes for application of insect-powder.

Tobacco, snuff, used as preservatives.

c. Frames, \&c. :

Wooden frames.

Wire frames.

Plaster model-bodies.

51. (ACCESSORY.) PHOTOGRAPHIC AND OTHER DELINEAT ING APPARATUS.

a. Photographic apparatus:

Lenses.

Cameras and fittings.

Camera tripods and stands, with model.

Fish Commission stands.

Plates, and their results :

Wet plates.

Dry plates.

Dark closets.

b. Camera obscuras.

c. Mechanical delineators.

d. Methods of heliotyping and engraving illustrations. 



\section{SECTION D.}

\section{ANIMAL PRODUCTS AND THEIR APPLI- CATIONS.}

\section{FOOUS.}

1. FOODS IN A FRESH CONITTION.

This section may include specimens of the marketable animals in a fresh condition in refrigerators.

For conrenience in making up and arranging this portion of the collection, a list is appended of the animals nsed as food in the United States. Many others are available, but for various reasons are not commonly eaten.

a. Mammals :

Grizzly bear, (Ursus horribilis.)

Black bear, (Ursus americanus.)

White bear, (Thalarctos maritimus.)

Raccoon, (Procyon lotor.)

Buffalo, (Bison americanus.)

Musk.ox, (Ovibos moschatus.)

Mountain goat, (Mazama montana.)

Mountain sheep, (Ovis montana.)

Antelope, (Antilocapra americana.)

Moose, (Alces malchis.)

Woodland caribou, (Tarandus rangifer, subsp. caribou.)

Barren-ground caribou, (Tarandus rangifer, subsp. græenlandicus.)

Elk or wapiti, (Cervus canadensis.)

Virginia deer, (Cariacus virginianus.)

Mule-deer, (Cariacus macrotis.)

Black-tailed deer, (Cariacus columbianus.)

Peccary, (Dicotyles torquatus.)

Manatee, (Trichechus manatus.)

Fox squirrel, (Sciurus cinereus.)

Gray squirrel, (Sciurus carolinensis.) 


\section{FOODS IN A FRESH CONDITION-Continued.}

a. Manmals :

California gray squirrel, (Sciurus fossor.)

Tuft-eared squirrel, (Sciurns Aberti.)

Red squirrel, (Sciurus hudsonins.)

Flying squirrel, (Sciuropterus volncclla.)

Woodchuck, (Arctomys monax.)

Marmots, (Arctomys caligatus and faviventer.)

Polar hare, (Lepus timidus, var. arcticus.)

Prairie hare, (Lepus campestris.)

Northern hare or white rabbit, (Lepus americanus, and $L$. americanus var. virginianus.)

Red hare, (Lepus americanus, var. Washingtoni.)

Baird's hair, (Lepus americanus, var. Bairdii.)

Gras hare or gras rabbit, (Lepus sylvaticus.)

Sage rabbit, (Lepus sylvaticus, var. Nuttalli.)

Audubon's hare, (Lepus syluaticus, var. Auduboni.)

Trowbrilge's hare, (Lepus Troubridgci.)

Jack rabbit or mule rabbit, (Lepus callotis.)

California hare, (Lepus californicus.)

Marsb bare, (Lepus palustris.)

Water hare, (Lepus aquaticus.)

Opossuci, (Didelphys virginiana.)

b. Birds :

Reed bird or rice bird, (Dolichonyx nryzirorns.)

Wild pigeon, (Ectopistes migratorius.)

Turkes, (Meleagris galloparo.)

Wild turkey, (Mclagris galloparo, var. americana.)

Spruce grouse, (Tetrao canadersis.)

Dusks grouse, (Tetrao obscurus.)

Singe cock, (Centrocercus mroplasianus.)

Sharp-tailed gronse, (Pcdiocetes phasianellus.)

Prairie gronse or prairie hen, (Cupidonia cupido.)

Ruffed grouse, (Bonasa umbcllus.)

Snow ptarmigan, (Lagopus albus.)

Rock ptarmigan, (Lagopus rupestris.)

White-tailed ptarmigan, (Lagopus lencurus.)

Bob-white or "quail," (Ortyx virginianus.)

Plumed partrilge, (Oreortyx pictus.) 


\section{FOODS IN A FRESH CONDITION-Continued.}

b. Birds :

California partringe, (Loplortys californicus.)

Gambel's partriage, (Lophortyx Gambeli.)

Scaled partriłge, (Callipepla squamata.)

Massena partridge, (Cyrtonyx massena.)

Black-billed plover, (Squatarola helvetica.)

Golden plover,(Charadrius fulvus var. virginicus.)

Kildeer plover, (Aegialitis vociferus.)

Wilson's plover, (Aegialitis wilsonius.)

Riugneck plover, (Aegialitis semipalmatus.)

Piping plover, (Aegialitis melodus.)

Stilt sandpiper,(Micropalama limantopus.)

Ruddy plover, (Calidris arenaria.)

Woodcock, (Philohela minor.)

American snipe, (Gallinago wilsoni.)

Red-breasted snipe, (Nacrorhamphus grisens.)

Willet, (Totanus semipalmatus.)

Tell-tale, (Totanus melanoleucus.)

Yellow-shanks, (Totanus flaripes.)

Upland piover, (Actiturus bartramius.)

Long-billed curlew, (Numenius longirostris.)

Hudsonian curlew, (Numcuius hudsonicus.)

Eskimo cullew, (Numenius borealis.)

Clapper rail, (Rallus longirostris.)

Marsh hen, (Rallus elegans.)

Virginia rail, (Rallus virginianus.)

Carolina rail, (Porzana carolina.)

Yellow rail,(Porzana noveboracensis.)

Trumpeter-swan, (Cygnus buccinator.)

Whistling swan, (Cygaus americanus.)

White-fronted goose, (Anser albifrous.)

Snow groose, (Anser hyperboreus.)

Brant, (Branta bernicla.)

Canada goose, (Branta canadensis.)

Mallard, (Anas boschas.)

Black duck, (Anas obscueru.)

Pintail duck, (Dafila acuta.)

Gras duck, (Chaulelasmus streperus.) 


\section{FOODS IN A FRESH CONDITION-Continued.}

b. Birds:

Widgeon or bald pate, (Mareca americana.)

Green-winged teal, (Querquedula carolincnsis.)

Blue.winged teal, (Querquedula discors.)

Red-breasted teal, (Querquedula cyanoptera.)

Shoveller, (Spatula clypeata.)

Wood duck, (Aix sponsa.)

Big black-head, (Fuligula marila.)

Little black-head, (Fuligula affinis.)

Ring-necked duck, (Fuligula collaris.)

Red-head, (Fuligula ferina, rar. americana.)

Canvas-back, (Fuligula vallisneria.)

Golden-eje, (Bucephala clangula.)

Barrow's golden-eye, (Bucephala islandica.)

Butter-ball, (Bucephala albeola.)

Long-tail duck, (Harelda glacialis.)

Harlequin-duck, (Histrionicus torquatus.)

Eider duck, (Somateria mollissima.)

King eider, (Somateria spectabilis.)

Scoter, (Gdemia americana.)

Velvet duck, (Edemia fusca, rar. velvctina.)

Surf duck, (OEdemia pcrspicillata.)

Long-billed scoter, (Edemia perspicillata rar. Trozbbridgci.)

Ruddy duck or bar duck, (Erismatura rubirla.)

Sheldiake, (Zlirgus merganser.)

Red-breasted merganser, (Mergus scrrator.)

Hooded merganser,( Mcrons cucullatus.)

c. Reptiles :

Gopher tortoise, (Testudo caroliua.)

Diamond-back terrapin, (Malacoclemmys palustris.)

Red-bellied terrapius, (Psendemys rugosa.)

Florida river-terrapin, (Psendemys concinna.)

Alligator turtle, (Macrochelys laccrtina.)

Suapping turtle, (Chclydra serpentina.)

Soft-shell, or leather-back turtle, (Aspidonectes fcrox, \&c.)

Green turtle, (Chelonia mydas.)

Pacific green turtle, (Chelonia virgata.)

Loggerhead turtle, (Thalassochclys caomana.) 


\section{FOODS IN A FRESH CONDITION-Continued.}

d. Amplibians:

Frogs, (Rana catesbiana, clamitans, \&c.)

e. Fishes, (eastern coast:)

File fish, (Balistes capriscus.)

American sole, (Achirus lineatus.)

Flat fish, (Pseudopleuronectes amcricanus.)

Smooth flounder, (Pleuronectes glaber.)

Sand flounder, (Lophopsetta maculata.)

Flounder, (Chanopsetta ocellaris.)

Southern flounder, (Chanopsetta dentata.)

Four-spotted flounder, (Chcenopsetta oblonga.)

Halibut, (Hippoglossus americanus.)

Newfoundland "Turbot," (Reinhardtius hippoglossoides.)

Pollack, (Pollachius carbonarius.)

Cod, (Gadus morrhua.)

Tom-cod, or frost fish, (Microgadus tomcodus.)

Haddock, (Melanogrammus aglefinus.)

Hake, (Plhycis chuss.)

Squirrel hake, (Plyycis teriuis.)

Cusk, (Brosmius americanus.)

Whiting, (Merlueins bilinearis.)

Norway harddock, (Sebastes norvegicus.)

Rose fish, (Sebastes viviparus.)

Tautog, or black-fish, (Tautoga onitis.)

Chogset, or cunner, (Tautogolabrus adspersus.)

Hog fish, (Lachnolcemus falcatus.)

Angel fish, (Holacanthus ciliaris.)

Sword fish, (Xiphias gladius.)

Spear fish, (Tetrapturus albidus.)

Sail fish, (Histiophorus americanus.)

Mackerel, (Scomber scombrus.)

Chub mackerel, (Scomber colias.)

Bonito, (Sarda pelamys.)

Horse mackerel, (Orcynus secundi-dorsalis.)

Spanish mackerel, (Cybium maculatum.)

Cero, (Cybium cabalia.)

Striped cero, (Cybium regale.)

Crevallé. (Carangus hippos and Parutractus pisquetus.) 


\section{FOODS IN A FRESH CONDITION-Continued.}

e. Fishes, (eastern coast:)

Pompano, (Trachynotus carolinus.)

Short poinpano, (Trachynotus ovalus.)

Butter-fish, (Poronotus triacanthus.)

Squeteague, (Cynoscion regalis.)

Spotted squeteague, (Cynoscion carolinensis.)

Drum, (Pogonias chromis.)

Spot, (Liostomus obliquus.)

Silver perch, or yellow-tail, (Bairdiella punctata.)

Red fish, or spotted bass, (Scianops ocellatus.)

King fish, (Menticimus nebulosus.)

Southern king fish, or Bermuda whiting, (Menticirrus albur nus.)

Croaker, (Micropogon mndulatus.)

Sailor's choice, (Lagodon rhomboides.)

Sheeps-hear, (Archosargus probatocephulus.)

Scuppang, or porgs, (Stenotomus argyrops.)

Grunts, (Homulon meuotum, \&e.)

Gray suapper, (Lutjanus caxis.)

Red suapper, (Luijunus aya.)

Grouper, (Epincphelus morio.)

Spotted grouper, (Epinepheius guttatus.)

Jew fish, (Promicrops gnasa.)

Sea bass, (Ccutropristis atrarius.)

Squirrel, (Diplectrum fasciculore.)

Striped bass or rock fish, (Roccus lincotus.)

White perch, (Morone americana.)

Ioon fish, (Parephipfus quadrutns aud $P$. fuber.)

- Triple-tail, (Lobotes surinamensis.)

Blue fish, (Pomatomus saltotrix.)

Striped mullet, (Mugil lineotus.)

Silver-sides, (Chirostoma notatum.)

Silver gar tish, (Bclone longirostris.)

Skipper, (Scombercsox scutellatus.) 。

Mummichogs, (Hydrargyra majalis, \&c.)

Capelin, (Mallotus villosus.)

Smelt, (Osmerus mordax.)

Salmon, (Salmo salor.) 


\section{FOODS IN A FRESH CONDITION-Continued.}

e. Fish, (eastern coast:)

Sea trout, (Salmo immaculatus.)

Tarpum, (Megalops thrissoides.)

Menhaden, (Brevoortia menhaden.)

Shad, (Alosa sapidissima.)

Alewife, or gaspereau, (Pomolobus pseudoharengus.)

Tailor herring, (Pomolobus mediouris.)

Herriug, (Clupea harengus )

Mud shad, (Dorosoma cepedianum.)

Anchory, (Engraulis vittatus, \&c.)

Sea eel or conger, (Conger oceanica.)

Eel, (Anguilla bostoniensis.)

Sturgeon, (Acipenser oxyrhynchus and A.brevirostris.)

Lamprey eel, (Petromyzon americanus.)

$f$. Fishes, (fresh waters:)

Burbot or lawyer, (Lota maculosa.)

Fresh-water drum, (Haploidonotus grunniens.)

Sinall-moutbed black-bass, (Micropterus salmoidcs.)

Large-mouthed black-bass, (Micropterus floridanus.)

Rock-bass, (Ambloplites rupestris.)

Sacramento "perch," (Archoplites interruptus.)

Sun-fish, (Pomotis aureus.)

Black-eared sunfish, (Pomotis auritus.)

"Bream" of Southern States, (Calliurus, Lcpomis, Enneacanthus, Chanobryttus, numerous species.)

Strawberry or grass bass, (Hyperistius hexacanthus, and Pomoxys storerius.)

Yellow perch, (Perca flavescens.)

Yellow pike-perch, (Stizostedium americanum.)

Gray pike-perch or sauger, (Stizostedium griseum.)

Canada pike-perch, (Stizostedium canadense.)

White bass, (Roceus chrysops.)

Short-striped bass, (Morone interrupta.)

Lake pike, (Esox lucius.)

Pickerel, (Esox reticulatus, E. fasciatus, E. cypho, \&e., Sc.)

Hasquallonge, (Esox nobilior.)

Brook trout, (of eastern slope,) (Salmo fontinalis.)

Brook trout, (of western slope,) (Salmo iridea.) 


\section{FOODS IN A FRESH CONDITION-Continued.}

$f$. Fish, (fresh waters:)

Utah trout, (Salmo virginalis.)

Oquassa trout, (Salmo oqnassa.)

Lake trout, (Salmo confinis.)

Salmon trout or Hackinaw trout, (Salmo namaycush.)

Siscowet, (Saluo siscowet.)

Sebago salmon, (Salmo sebago.)

Missouri trout, (Salmo Lexcisi.)

White fish, (Coregonns albus.)

Otsego whito fish, (Coregomus otsego.)

Lake herring, (Argyrosonns harengns and A. clnpeiformis.)

Black fin of Lake Michigan, (Argyrosomus nigripinnis.)

Michigan grayling, (Thymallns tricolor.)

Mountain grayling, (Thymollus montanus.)

Suckers of eastern slope, (Catostomus teres, \&c., Ptychostomus aureolus, \&e.)

Sucker's of western slope, (Catostomus occidentalis, \&c.)

Fall fish, (Semotilus rhotheus.)

Chubs of eastern slope, (Semotilus corporalis, \&c.)

Chubs of western slope, (Lavinia exilicauda, Algansea, sp., \&c.)

"Pike" or "salmon trout" of California, (Ptychocheilus graudis, \&c., Pogonichthys inceqnilobus, \&c.)

Dace, (Ceratichthys biguttatns, \&c.)

Buffalo fish, (Bubalichthys bubalus.)

Shiner, (Stilbe americona.)

Carp, (Corpiodes cypriuns, \&c.)

Cattishes, (Amiurns catus, A. nigricans, Sc., Ictalmus carulescens, \&c., and many other silurųid fishes.)

Sturgeon of the lakes, (Acipenser rubicundus.)

Shorel-nose sturgeon, (Scaphirhynchops plotyrhyuchus.)

g. Fishes, (western coast:)

Flounders, (Platichthys stellatus, Lepidopsetta mbrosa, \&c.)

"Soles," (Parophrys vetnlus, Psettichthys melanostictns, \&c.)

Halibut, (Uropsetta califormiana, Hippoglossus, sp., \&c.)

Tomeod. (Microgadus proximus.)

Cod of Alaska, (Gadus macrocephatus.)

Rock fish or "rock cod," (Sebastomus rosaceus and species of Sebastosomns, Sebastichthys, \&c.) 
1. FUODS IN A FRESH CONDITION-Continued.

g. Fishes, (western coast :)

Rock trout, (Chirus constellatus.)

"Cod" of San Francisco, (Ophiodon elongatus.)

Black fish or "sheeps-head," (Pimelometopon pulcher.)

"Perch," (numerous species of Embiotoca, Holconotus, \&c.)

"Bass," (Atractoscion, nobilis.)

Cognard or little bass, (Genyonemus lincatus.)

San Francisco "smelt," (Atherinopsis californiensis.)

Pacific smelt, (Osmerus elongatus.)

Salmon, (Salmo quinnat, \&c.)

Oulachan, (Thaleichthys pacificus.)

Sardine or pilchard, (Pomolobus cceruleus.)

Herring, (Clupea mirabilis.)

Sturgeon, (Acipenscr acutirostris, \&c.)

Columbia River sturgeon, (Acipenser transmontanus.)

h. Crustaceans. ${ }^{1}$

i. Mollusks. ${ }^{1}$

\section{FOODS: DRIED AND SMOKED.}

a. Mammal preparations:

Jerked bear-meat.

Jerked seal and walrus meat, (Indian.)

Jerked and smoked buffalo-meat.

Dried and smoked beef.

Dried and smoked venison.

Hams of various kinds.

Jerked porpoise-meat, (Indian.)

Jerked squirrels and other small mammals.

Pemmican.

Ieat-biscuit, desiccated meat, meat extract, (extractum carnis, ) desiccated milk, \&c.

Sausages.

Cheese.

b. Bird preparations:

Jerked birds, (Iudian.)

1 The varions applications of these groups are enumerated in the "List intended to give a general idea of the useful, products (other than vertebrates) of the sea and shore, as well as of the interior waters of the United States," prepared by Mr. Wr. H. DALI, and printed as Circular No. 2. of series (C, ) National Museum series. 


\section{FOODS: DRIED AND SMOKED-Continued.}

c. Reptile preparations:

Dried lizards, (Indian.)

d. Fish preparations :

Smoked halibut.

Dried cod, haddock, hake, sc.

Dried and smoked mullet and rues.

Dried and smoked garfish, flying-fish, \&c.

Smoked herring, alewires, \&c., and their roes.

Smoked salmon, oulachan, white-fish, smelt, \&c., and their roes.

Smoked sturgeon.

Teziga, prepared from the notochord of sturgeous.

e. Insects :

Dried grasshoppers, (Indian.)

f. Worms :

Dried worms, (Indian.)

g. Mollusk preparations :

Dried abalones, (Kaliotis, prepared by the California Chinese.

Dried siphons of Schizotharus prepared by the Indians of the morthwest coast.

Dried slugs, (Lima.r, \&c.,) used by Inclians.

h. Radiate preparations:

(Dried lıolothurians, "bêches de nrer," used by Chinese.)

i. Protozoans :

(" Iomntain meal," a lind of infusorial eartl, mixed with ftom, and used as food in Lapland and China.)

3. FUODS: SALTED, CANNED, AND PICRLED.

a. Mammal preparations :

Salted buffalo-meat.

Salted beef.

Salted ileer, reindeer, elk.

Salted tongues of beef, buffalo, deer, hor'se.

Salted pork.

Canned milk of the rarious brands.

b. Bird preparations:

Canned turker.

Canned chicken.

Cinned goose. 
3. FOODS: SALTED, CANNED, AND PICKLED-Continued.

b. Bird preparations:

(Canned ortolans, (Emberiza horiularia,) esteemed a delicacy in Cyprus.)

c. Reptile preparations:

Salted and canned turtles and turtle soup.

Canned frogs.

d. Fish preparations :

Salted halibut, halibuts' fins, \&c.

Salted cod, cods' tongues, sounds, and roe.

Salted mackerel.

Salted Spanish mackerel.

Salted bluefish.

Salted pompano.

Salted sword-fish.

Salted mullets.

Salted salmon.

Salted white-fish.

Salted trout.

Salted shad.

Salted herring.

Salted gaspereau.

Salted menharen.

Salted anchovies.

(Spiced lampreys) used in Europe.

Anchory-sauce and "essence of anchovies."

Canned menhaden, in oil, "American sardines."

Canned menhaden, in oil, "American club-fish."

Spiced menhaden, " ocean trout."

Canned herring, in oil, "Russian sardines."

Caviare, prepared from roe of the various sturgeons.

(Caviare, prepared from roe carps, used by Jews.)

("Boutargue" or "botargo" prepared on the Mediterranean from the roes of Labrax and Mugil.)

e. Crustacean preparations :

Cauned lobsters.

Canned crabs.

Canned prawns and shrimps.

f. Mollusk preparations:

Canned oysters. 
3. FOODS: SALTED, CANNED, AND PICKLED_Continued.

$f$. Mollusk preparations :

Canned clams.

Canned little-neck clams.

Canned scollops.

(Cockles, (Cardium edule,) used in Europe as pickles and catsup.)

\section{GELATINES.}

a Mammal gelatines, (see also under 24 :)

Gelatines made from tanners refuse and from sinews.

Gelatines made from feet and hoofs.

Gelatines made from bone and ivory sharings.

b. Bird gelatines :

(Nests of esculent srallows, (Calocalia esculenta, C. fuciphaga,

C. indifica, \&c.,) exported from Indian Archipelago to China.)

c. Fish gelatines or isiuglass, (see also under 24.)

d. Insect gelatine :

Gelatine from cocoons of silk- worms.

5. BAITS AND FOODS FOR ANIMALS.

a. Prepared baits, (see under $\mathrm{B}, 45$. .)

b. Food for domesticated animals :

Oil-factory scraps.

Fish-scraps.

Cuttle-fish bone; (see under 18.)

\section{CLOTHING.}

6. FCRS, (embracing the furs in their rough state, (peltries,) and in the rarious stages of preparation; also the inanufuctured arti. cles, such as robes, rugs, cloalis, sacks, tippets, cuffs, muffs, hats, caps, glores, trimmings and linings. $)^{1}$

a. Mammal furs :

(Diana monker, (Cercopithecus diana,) of West Africa.)

(Black monkes, (Colobuspolycomus, and other species,) of West Africa-trimmings, \&c.)

(Abyssinian monkes, (Colobus guereza.))

1 Totc-For convenience in arranging the general collections of the museum, this list has been made uuusually full, and includes all furs known to be found in American and European markets. 
6. FURS-Continued.

a. Mammal furs:

(American howling-monkey, (Hycetes, several species)-muffs.) (Lion, (Felis leo, of Africa and Asia-rugs.)

(Tiger, (Felis tigris)_rugs, \&c.)

(Leopard, (Felis pardus)_rugs and saddle-cloths.)

Puma, (Felis concolor)—carriage-robes, rugs, \&c.

Ocelot, (Felis pardalis)_rugs.

Jaguar, (Felis onca)-rugs.

Cat, (Felis domestica)-robes and philosophical apparatus.

Black cat.

White cat.

Maltese cat.

Tortoise-shell.

(Wild-cat, (Feliscatus,) of Europe and Asia-robes and linings.) (Snow leopard, (Felis irbis,) of Asia.)

Eyra, (Felis eyra.)

Yaguarundi, (Fetis yaguarundi.)

(Cheetah, (Cynailurus jubatus,) of India and Southern Asia.) Bay lgnx, (Lynx rufus)-rugs, and, when dyed, muffs and boas.

Canada lynx, (Lynx canadensis)_rugs and trimmings, and dyed muffis, boas, \&c.

Dog, (Canis familiaris.)

Eskimo dog.

Wolf, (Canis lupus)-linings, rugs, and robes.

White wolf.

Black wolf.

Gray wolf.

"Blue wolf."

Red wolf.

Coyote, or prairie wolf, (Canis latrans)-rugs and robes. (Jackal, (Canis aureus,) of Old World.)

Red fox, ( Vulpes ulopex, var. fulvus)-robes, (mostly imported to Turkey.)

Cross fox, (Vulpes alopex, var. decussatus)_robes, trimmings. Black and silver fox, (Vulpes alopex, var. argentatus)-muffs, cloaks, trimmings; also, fox-skins dyed to imitate lynx; also, various imitations of silver-fox, made from skins of more common varieties. 


\section{FURS-Continued.}

\section{a. Mammal furs:}

Arctic fox, ( Vulpes lagopus.)

White fox.

Blue fox.

Kit fox, ( $\nabla$ ulpes velox)-robes, muffs, trimmings.

(Cossac fox, (Vulpes corsac,) of Asia.)

(Mountain fox, (Vulpes montanus,) of India.)

Gray fox, (Urocyon virginianus)-rugs, robes, and linings.

(Spotted hyena, (Hycena crocuta,) of West and South Africa.) (Striped hyena, (Hycena striata,) of West Africa and India.) Fisher or pekau, (Mustela Pennanti)-linings, tails used for trimmings.

American or Hudsou's Bay sable, (Mustela americana)-cloaks, muffs, cuffs, boas, linings, \&c. :

Silver variety.

Orauge variety.

Brown or common variety.

(Russian sable, (Mustela zibellina,) of North Europe and Asia -cloaks, mutts, boas, liniugs, Sc.)

(Tartar sable, or holinsky, (Mnstela sibirica)-cloaks, muffis, and (yed to imitate Russian sable.)

(Pine marten, (Mustela abietum,) of North Europe and Asia.) (Stowe marteu, or Freuch sable, (Mustela saxorum,) of Lurope-dyed to imitate sable.)

(Beech marten, (Mustela foina,) of Europe and Asia-dyed to imitate sable.)

(Polecat, titch, or ferret, (Putorius vulgaris,) of Europe and Asia.)

Ermiue, or weasel, (Putorius erminea,) of Northern Henispliere-cloaks, linings, fc. :

Royal ermine, trimmed rith astrakhan fur, (minirer.)

Siberian ermine.

Loug-tailed weasel, (Putorius longicauda:)

Summer dress.

Tinter dress.

Miuk, (Putorius rison,)-cloaks, muffs.

Wolverine, (Gulo luscus.)-muffs, robes, linings.

American badger, (Taxidea americana)-muff's and rugs. 
6. FURS-Continued.

a. Mammal furs:

(European badger, (Meles vulgaris)—muffs and rugs.)

Skunk, Alaska sable, (Mephitis mephitica)-muffs, boas, \&c.

White-backed skunk. (Conepatus mapurito.)

Striped skunk, (Spilogale putorius.)

Otter, (Lutra canadensis,) with specimens of the plucked and dyed fur-muffs, trimmings, \&c.

Sea otter, (Enliydra marina)-muffs, gloves, collars, cuffis, trimmings.

Black bear, (Ursus americanus)-caps, rugs, muffs, robes, \&c. $a^{\prime}$. Cinuamon variety.

b. Silvery variety.

(Brown bear, (Ursus aretos,) of Europe and Asia.)

Grizzly bear, (Ursus horribilis)_rugs, robes, trimmings.

White bear, (Thalarctos maritimus)-rugs, robes, and used extensively by the Eskimos.

Raccoon, (Procyon lotor)-hats, linings.

Fur-seal, (Callorlinus ursinus)-cloaks, hats, gloves, muffs, linings, trimmings, \&c.

Cub fur.

(Antaretic fur-seal, (Arctocephalus ancklandicus, \&c.)

Hair seal. (Pheca vitulina and Phoca Richardsii)—coats, caps, linings for shoes.

Harp seal, (Pagophilus groenlandicus, ) with specimens of the white fur of the unborn cub, and the blue fur of the young. Hood seal, or bladder-nose, (Cystophora cristata.)

Square flipper, or bearded seal, (Erignathus barbatus,) with specimens of fur dyed to imitate leopard.

Banded seal, (Histriophoca equestris) -used by Eskimos as fur. Gray seal, (Pusa gryphus.)

Ringed seal, (Pagomys foetidus.)

Bison, or buffalo, (Bison americanus)-rugs and robes.

$a^{\prime}$. Mountain bison.

b. Common bison.

Musk.ox, (Ovibos moschatus)-robes, rugs, and trimmings. (Yak, (Poёplagus grumniens,) of Asia-robes and trimmings.) Mountain goat, (Aplocerus montanus)-robes, \&c. 


\section{FURS-Continued.}

a. Mammal furs :

(Llama, guanaco, paco, and vicugna, (Auchenia, sp.)-trimmings, \&c.)

Goat, (Capra, sp.)-rugs, trimmings.

$a^{\prime}$. Angora goat.

b. Cashmere goat.

c. Other varieties.

Sheep, (Ovis aries)—rugs, trimmings, \&c.

a. Astrakhan sheep.

b. Caracoul sheep.

c. Other varieties. Lamb-skins and dyed furs.

Antelope, (Antilocapra americana)-rugs.

Moose, (Alccs malchis)—rugs and robes.

Elk, (Corius canadcrisis)_rugs and robes.

Reindeer, (Tarandus rangifer)-robes, coats, gloves, \&c.

Caribon, (Tarandus rangifer var.)-robes, coats, glores.

Nule deer, (Cariacns macrotis)-trinmings, robes.

Virginia deer (Cariacns virginianus)—trimmings, robes.

Mole, (Scalops and Condylura, sp.)-robes, garments.

(European mole, (Talpa europara)-robes, garments.)

Woodchusk, or siffleur, (Arctomys monax)-robes, exported

to Europe as "white and gras weeuusk."

Marmot, (Arctomys caligatus)-robes, trimmings.

Parre's marmot, (Spermophilus Parryi)-robes, trimmings.

Gray squirrel, (Sciurns corolinensis, \&c.)-trimming; tails used for boas.

(Squirrel, or "calabar," (Sciurus vulgaris,) Northerı Europe and Asia.)

$a^{\prime}$. Siberian squirrel. Trimmings, muffs, capes, \&c.; tails used for boas, dsed to imitate sable.

b. "Teisenfels liuings" of the white fur of the belly.

Showt'l, (Haplodontia leporina)—used by Indiaus.

(Chinchilla, (Chinchilla lanigcr,) of South America-muffs, mantles, boas, cloak-linings, and trimmings.)

Musquash, (Fiber zibethicus)-muffs, capes, caps, and linings, and imitations of beaver-fur.

(Neutria, or Cospu, (Myopotamus coypus)-linings and muffs, and imitations of bearer.) 
6. FURS-Continued.

a. Mammal furs:

(Beaver, (Castor fiber,) of Northern Europe and Asia.)

Beaver, (Castor canadensis)-linings and inufis.

White beaver.

Spotted beaver.

Rats and mice, (Mus., sp. var.)

Lemming, (Myodes torquatus and obensis)-robes.

Rabbit, or cony, (Lepus cuniculus)-children's furs, and initations of seal, beaver, \&c, exported largely to China.

White variety.

Blue variety.

Brown variety.

American native rabbit furs, such as Lepus glacialis, used for muffs, boas, and feltings.

Possum, (Didelphys virginiana.)

(Kangaroo, (Macropus giganteus,) of Australia.)

(Ornithorhynchus, (Ornithorhynchus anatinus,) of Australia.)

b. Skins of birds used as furs:

Turkes furs, (Melagris gallopavo, \&c.)

Gull furs, (Larus argentatus, \&c.)

Grebe furs, (Podiccps aristatus, \&c.)

Loon furs, (Colymbus torquatus, Se.)

Swan furs and swan's down trimmings, (Cygnus americanus, \&c.)

Pelican furs, (Pelecanus fuscus, \&c.)

Adjutant crane, (Ciconia argala)-feathers used as fur.

Puffin furs, (Fratercula arctica, \&c.)

Penguin furs, (Aptenodytes, Pennantii, \&c.)

Feathers of common forl used in trimmings.

7. LEATHERS. (See under 20.)

8. TEXTILE FABRICS.

a. Prepared from hair of mammals :

Human bair used in manufacture of watch-chains.

- Hair of bats used in felting and in plaiting ropes in Central America and tassels in New Caledonia.

Hair of raccoon used in felting, (largely exported to Germany for the use of hatters.)

Hair of weasels and sables used in felting. 


\section{TEXTILE FABRICS-Continued.}

a. Preparations of hair of mammals :

Hair of fur seal woven with silk in the manufacture of shawls. Moose hair and its fabrics.

Ox and calf hair used in the manufacture of imitation woolen goods.

Sheep's wool, with specimens of fleeces and stapled wools, from various breeds and localities, short-wool fabrics, broadcloths, merinoes, flannels, mouselins de laine, serges, tweeds, blankets, carpets, and tartans, worsted fabric's, stuffs, bombazines, camlets, slawls, plushes and relrets, hosiery, and yarns, felts, felt-cloths, and felt-hats.

Goats' wool with specimens of mohairs, cashmeres, plushes, velveteens, camlets, and shawls. (For manufactured wigs and perukes, see under 21.)

(Yak (Poëphagus grunniens) wool with specimens of yak-lace and other fabrics.)

(Camels' hair with specimens of fabrics, plushes, felts, shawls, \&e.)

( Пair of llama, paco, guanaco, and ricugna, with sq)ecimens of alpaca, guanaco, and other fabrics, and umbrellas and other articles manufactnred.)

Hair of horses used in wearing furniture-covers, crinolineskirts, and bags for pressing oil.

Hair of buff̈alo used in plaiting ropes, lariats, \&e.

Fur of mole used in felting.

Bearer (eastor) fur with specimens of the felt cloths, hats, \&c. (Nentria-fur used in felting aud in the manufacture of lats.) Musquası fur used in felting.

Possum hair with fabrics of Indian and other manufacture. Fur of rabbit and hare used in felting, with specimens of hats and cluths.

Whalebone fiber used in wearing cloth corers for telescopes, \&e.

b. Prepared from feathers of birds:

Cloths woreu from feathers, (China.)

c. Prepared from silk of insects: (This collection shoulı inclurie specimens of the cocoons, the raw silk, the spmu silk, and of the rarious fabrics, plain and figured silks, sitins and sittinettes, shawls, damisks, brocades, crapes, aud ribbons.) 
S. TEXTILE FABRICS-Continued.

c. Prepared from silk of insects:

Silk of common silk-worm, (Bombyx mori.)

- Silk of Samia cecropia, Samia polyphemus, and other native American moths.

(Silk of exotic moths other than Bombyx mori, such as the tussain, (Bombyx pernyi and Bombyx mylitta,) the moonga, (Saturnia assamensis,) the joree, (Bombyx religiosa,) the ena or arinds, (Bombyx cynthia.))

Fabrics woren by the insects themselres, as Tinea padilla.

Silk of spiders.

d. Prepared from byssus of molluslis.

(Fabrics woren from byssus of the wing-shell (Pinna nobilis) and other mollusks.)

\section{HATERIALS EMPLOYED IN THE ARTS AND MAN- UFACTURES. \\ * Hard materials.}

9. ITORY AND BONE. (This collection should inclurle specimens of the various ivories and bones in their rough state, and manufactured into buttons, trinkets, cutlery-handles, canes, pen and pencil handles, brush-handles, billiard and bagatelle balls, dice, piano-keys, harnessrings, combs, false-teeth, philosophical instruments, and as used by portrait painters and photographers.)

a. Ivory of mammals :

Tusks of walrus used for trinkets, handles, jewelry, buttons, paper-knives, counters, \&c.

Teeth of bears, dogs, wolves, foxes, peccaries, and other large mammals, used as implements, arrow-tips, and ornaments, by Indians.

Elk-ivory used by Indians in ornamentation.

Tusks of mammoth elephant (Elephas primigenius) from northern America and Asia, with Eskimo carvings and specimens of "Siberian ivory." 


\section{IVORY AND BONE-Continued.}

a. Ivory of mammals :

(Tusks of African elephant with specimens of sawed aud scroll ivory and of the manufactured balls, combs, pianokeys, handles, rings, canes, buttons, trinkets, bangles, and miniature tablets.)

(Tusks of the Asiatic elephant and their applications.)

(Teeth of hippopotamus as used for handles for surgical instruments, index-fingers, and formerly for fialse-teeth, (trade-name, "sea-horse.")

Teeth of wild-hog used in manufacture of jewelry, vinaigrettes, \&c.

Teeth of peccary.

Ivory of narwhal used for canes.

Teeth of sperm-whale and their application to the manufacture of balls, buttons, and trinkets.

Incisors of bearer used by Indians for chisels, knires, and ornaments.

b. Irory of reptiles:

Teeth of alligator used for jewelry, whistles, cane-handles, buttons, \&c.

c. Irory of fishes:

Sharks' teeth used in arming weapons.

Teeth of sharks and other fish used as trinkets.

Jaws of the sleeper-shark (Somniosus brevipinna) used for head-dresses by Indians.

d. Bone of mammals :

Parts of splanchno-skeleton of ferae, used as charms.

Bones of bear and other large nammals, used by Indians for implements, and as tablets for paintings.

Bones of butialo and of the domestic ruminants, used as substitute for irory in the manufacture of buttous, handles, combs, \&c.

Sperm-whale jartbone, used for harness-rings, martingales, \&c.

Hortu-cores of ruminants, used in manufacture of assayers' cupels.

$e$. Bone of birds:

Bones of birds, used by Indians and Eskimos in making awls, needles, flutes, bird-calls, and dress-trimmings. 
9. IVORI AND BONE-Continued.

$f$. Bone of fishes:

Fish-bones, used by Indians and Eskimo in making implements.

Shark's vertebræ, used for canes.

Bones of sharks and skates, used (in Japan) in making imitation tortoise-shell.

g. Waste bone and ivory:

Use in manufacture of bone-black, ivory-black, and banknote ink, (see under 29.)

Use in manufacture of sizes and glues, (see ander 24.)

Use in manufacture or gelatine for food, (see under 4.)

Use in manufacture of phosphorus, carbonate of ammonia, (hartshorn,) and sal ammoniac, (see under 30.)

Use in manufacture of bone-charcoal for filters, (see under 30.)

Use in manufacture of paper.

Use of shavings in case-hardening gun-barrels and other fine steel.

10. HORN. (Embracing the varieties of horn known to commerce, the split and pressed horns, and the various manufactured articles, such as jewelry, combs, and handles.

a. Horn, employed as a material :

Horn of rhinoceros, used for handles and trinkets, cups, boxes, whips, and canes.

Horns of ox, sheep, and goat, used for handles, buttons, combs, powder-flasks, cups, boxes, stirrups, spoons, and imitations of tortoise-shell, also "sensitive Chinese leaves," and formerly for transparent plates in lanterns and horn. hooks, for trumpets, and for finger-nails in slay figures.

Horn of buffalo, used like that of ox.

(Horn of Asiatic buffalo, (Bos bubalus.))

Horn of mountain-sheep and mountain-goat, used by Aleutians, in making spoons, bowls, and numerous other implements.

b. Antlers:

Antlers of deer, elk, and moose, (stag-horn,) used in the manufacture of handles for iustruments, trinkets, and buttons. 


\section{HORN-Continued.}

b. Antlers:

Antlers of deer, elk, moose, and nearl 5 all species of ruminants, employed for ornamental purposes.

c. Chemical and other applications :

Burnt horn, (cornu ustum,) used in dentifrices.

Carbonate of ammonia, (hartshorn,) manufactured from deerhorns, (see under 30.)

11. IIUOFS AND CLAWS, \&c. (Embracing the commercial hoof, and the rarious stages of manufacture represented by specimens.)

a. Hoofs :

Hoofs of ox and bison, used in making buttous, combs, and liandles.

Hoofs of horse, nsed like those of ox and bison.

Hoofs of musk-ox, deer, and antelope, used by Indians in oruamentation.

Feet of deer, used for knife-haudles, stool-feet, sc.

b. Claws:

Claws of bear, puma, wolf, sc., used by Indians in ornamentation.

(Claws of lion and tiger, used by jewelers for trinkets.)

Human nails, used by Indiuns for oruamental trimmings.

c. Chemical applications of honfs and claws:

Use in manufacture of prussiate of potash, (sce under 30.)

Use in manufacture of glue, (see under 24.)

12. BALEEN. (Embracing the commercial baleen in its varions grades, Greenland, Northuest Coast, South Sea, finbaek, and hump.back, with the split, twisted, and diged boue.) .

a. Whalebone, as used by manufacturers of ribbons, liats, umbrellas, whips, canes, boots, fishing-rods, billiard-tables, buttous, handles, brushes, surgical instruments, stars, corsets, crinolines, harness-rosettes, corers, stuffugs, light woven hats aud bounets, Sc.; also, iwitation whalebone, (wallosiu.) made from rattan.

13. TORTOISE-SHELL. (Embracing the carapace entire, and the commercial shell, blade.s, fcet, noses, aud hcad.) 
13. TORTOISE-SHELL-Continued.

a. Shell of tortoise (Eretmochelys imbricata, E. squamata) used in manufacture of combs, handles, jewelry, inlaying, and buttons, together with imitations of tortoise-shell in horn, shark's bone, and celluloid.

b. Shells of land tortoises, used by Indians for pots, scoops, and rattles.

14. SCALES.

a. Shell of mammals:

Shell of armadillo, used by Texans and Mexicans.

$b$. Scales of fishes used in ornamental work, with specimens of flowers and other articles manufactured:

Scales of paviot issues, (Scaridce and Labridce.)

Scales of mullets, (Mugilider.)

Scales of sheepshead, \&c., (Sparidce.)

Scales of drum and bass, (Sciaenidce.)

Scales of Serrauidæ and perches, (Percidae and Labracida.)

Scales of Lobotide.

Scales of tarpum, (Elopidce.)

Scales of herrings, (Clupeida.)

Scales of Cyprinidæ.

Scales of eels, used in the north of Europe to give a pearly luster in ornamental bouse-painting.

Scales of gar-pikes, used by Indians for arrow-tips.

(Pearl white, or essence d'Orient, prepared from scales of $\mathrm{Al}$.

burnus lucidus and other Cyprinidæ and Clupeidæ, used in making artificial pearls.) (See under 27.)

Shagreen of trigger-fish, (Balistes, ) used in polishing wood. Shagreen of sharks, used as leather, (see under II, B. 5,) and for polishing purposes, particularly in the manufacture of quill pens.

Scales of sturgeons, used by Indians for implements.

For gelatine as a material and the arts and papier glacé, see 24 .

15. PEARL.

a. Pearls and nacre, (embracing the pearl-yielding shells, with the pearls and the mother-o'-pearl in the rough state, with the manufactured buttons, handles, and jewelry, pearl-powder, inlaid work, and papier maché, ornamented with mothero'-pearl:) 


\section{PEARL-Continued.}

a. Pearls and macre:

Top-shells, (Turbinida,) and their application to manufacture of shell-flowers.

Tower-sheils, (Trochica.)

Ear-shells, (Haliotide, ) used in manufacture of buttons, handles, inlaid work, and pearl-powder.

Other gastropods supplying nacre.

Pearl-oysters, (Aviculide, ) with pearls and nacre.

River-mussels, (Unionide,) with pearls and nacre.

IIussels, ofsters, and other conchifers supplying pearls and nacre.

Shells of nautilus and argonant, prepared to exhibit their nacre.

Ornamental pearl-work, imitating sprays of florers, \&c.

Imitation pearls.

16. SHELL.

a. Cameo shell :

Shell of conch, (Sirombus gigas,) and carrings.

Shell of helmet, (Cassis rufa, C. tuberosa, and C. madagascariensis,) with carvings.

b. Shells used for implements, \&c. :

Shells of Strombus, Triton, Dolium, Fusus, Murex, and Buccinum, used for fog-horns, lamps, vases, and ornamental borders in flower-gardens.

Shells of Busycon, Sycotypus, Mactra, Sc., used by Indians in manufacture of implements, with specimens of implements.

Shells of Mactra, used for ladles, scoops, and spoons by fishermell.

Shells of Tridacna, used for rases, fountains, and in the manufacture of handles and carvings.

Shells of Pecten, Haliotis, Dentalium, Mercenaria, \&c., used bs Indians for trimmings aud ornaments.

(Scallop, or palmer's shell, (Pecten jacobans, ) used as a decoration of houor.)

(Chank sheil, (Turbinella pyrmm,) used in the manufacture of Hindoo bangles, and in polishing cloth.)

Shells of Pecten, used in naking pin-cushions and purses. 
16. SHELL-Contintied.

b. Shells used for implements, \&c.:

(Painters' mussel, (Unio pictorum,) used to hold colors.)

(Shells of Placuna placenta, used in China as a substitute for windor.glass.)

Shells of Mercenaria violacea, Purpura lapillus, and Buccinum undatum, used by Indians of eastern coast in manufacture of mones, with specimens of wampum, (with the modern wampum or shell-beads manufactured for the Indian trade, ) and of the hyqua or Dentalium shells, employed in a similar manner by the Indians of the Pacific coast.

Specimens of the cowry, (Cypraea moneta.) "Live cowry" and dead cowry, used in African trade and for trimmings.

Shells of Cypraea, Rotella, Oliva, Turritella, Phasianella, (Venetian shells,) \&c., mounted as buttons and jewelry.

Composition shell-work for box-corers and frames, made by glueing shells in mosaics.

Calcined shells, used by dentifrice and porcelain makers. (See, also, under 32.)

Cuttle-fish bone from Sepia officinalis, used as a pounce, as a dentifrice, as polishing-powders, for taking fine impressions in counterfeiting, and as food for birds. (See, also, under D. 5.)

Concretions from the stomach of Astacus, known as "crab's. eyes" and "crab-stones," and used as antacids.

Shell of king-crab, (Limulus polyphemus,) used as a boat. bailer.

Opercula of mollusks, used as "eye-stones."

17. CORAL.

a. Coral as a material :

Red coral, (Corallium nobilis,) with specimens of the five commercial grades (1, froth of blood; 2, flower of blood; $3,4,5$, blood of first, second, and third qualities) of the white variety, and of the round beads, negligée beads, bracelets, pins, coronets, armlets, and earrings, \&c.

White coral, Oculina, sp., used by jewelers.

Madrepores and other showy corals, used for ormamental purposes.

Horny axis of black flexible coral, (Plexaura crassa,) used for canes and whips in the Bermudas. 


\section{CORAL-Continued.}

a. Coral as a material:

Axis of fan coral, (Rhipidogorgia,) used for skimmers and strainers in the Bermudas.

Coral, used for building purposes.

Coral rock of recent formation, (Coquina,) used in Florida in manufacture of ornamental rases and carvings.

Calcined coral, used for dentifrices, as an antacic, \&c.

Initations of red coral in celluloid, rubber, and other substances.

\section{INEUSORIAL EARTHS.}

a. Polishing powders, (used for polishing metals, cabiuet-ware, and stone:)

Specimens of polishing-slate, tripoli, and other foreign polishing-powder.

Specimens of American infusorial deposits.

b. Infusorial earths, emplosed in manufactures :

Infusorial earth, used in making window and plate glass.

Infusorial earth, used in making soluble glass.

Infusorial earth, used in making mortar.

Iufusorial earth, used in making molds for metal casting.

Infusorial earth, used in making filters.

Infusorial eartl, used in maxing dynamite.

Infusorial earth, used in making fire-proof packing.

Infusorial earth, as an absorbent for oils and liquids.

19. OTHER MATERIALS FROM INTERTEBRATES.

a. From insects :

Brazilian diamond-beetles, used in jewelry.

Wings of beetles, used iu embroiderș.

b. From echinoderms :

Spines of echinoids, used for slate-crajons.

** Flexible materials.

20. LEATHERS. (Embracing the hides in a rough state, in the various stages of dressing, and manufactured into shoeleather, parchment, vellum, binder's leather, thongs, \&ce)

a. Prepared from mammal skins:

Cit-leather.

Dog and wolf leather, used for drum-heads, \&c. 
20. LEATHERS-Continued.

a. Prepared from mammal skins:

Bear-leather.

Raceoon-leather, used for gloves and upper-leathers of shoes. Seal-leather, used for fine shoes and in the manufacture of "patent leather," and by Eskimos for numerous purposes. Sea-lion leather, used by Eskimos to cover bidarkas and for garments and beds.

Walrus-leather, used by Eskimos for harness, tables, thougs, seal-nets and for covering polishing wheels.

Bison-leather (and buffalo-leather, buff-leather.)

Ox-leather, with specimens of sole-leather, split-leather, grain-leather, rawhide thongs, whips, leather-belts and saddles, and of calf-skins, prepared for binders' and bootmakers' use, as Russia leather and rellum, and tawed, as parchment.

Sheep-leather, with specimens of binder's leather, imitation chamois leather, wash-leather, buff-leather, roan, imitation moroceo and parchment, with vellum made from skins of dead-born lambs, and manufactured gloves, \&c.

Goat-leather, with specimens of shagreen-leather, moroccoleather, as used for linings, upholstery, bindings, and pocket-books, parchment, drum-heads, \&c., with kidleather, used in mannfacture of shoes and gloves, underclothing, and vellum made from skin of young kids, also skin-bottles used in Asia.

Horse and ass leather, used in manufacture of shagreen, sole-leather, harness-leather, saddles, trunks, water-hose, pump-valves, military accontrements, ladies' shoe-uppers.

(Chamois leather, (Capella rupicapra,) used for polishing purposes and for straining mercury.)

(Leather of gazelle, (Gazella dorcas,) used in packing comlmercial aloes, and of African antelopes, used in packing elephants' tusks.)

Deer-leather, dressed as buff-leather, chamois-imitation leather, Indian dressed (buckskin, and for the finer moroccos, also manufactured into gloves, gaiters, undergarments, polishers, \&c.

Moose-leather in ordinary and buckskin finish. 


\section{LEATHERS-Continued.}

a. Prepared from mammal skins:

Caribou-leather in ordinary and buckskin finish. (Reindeer-leather.)

Elk-leather in ordinary and buckskin finish.

Antelope-leather in plain, buckskin, and oil-finish, used in maunfacture of castor-glores.

Peccary-leather as used in the mannfacture of gioves.

Hog-leather used by sadalers, shoemakers, and book-binders. Hippopotamus-leather used for buffing or polishing wheels. Rhinoceros-hide user for shields, targets, whips, \&c.

Beluga leather dressed as kid, sole, harness, relvet, plush, boot, mail-bags, belts, and patent (varnished) leather.

Porpoise-leather.

Beaver-leather used in manufacture of saddles, shoes, glores, and trunks.

(Nutria-leather (Myopotamus coypus) of South America.)

Rat-leather used for thumbs of kid glores.

(Kangaroo-leather.)

Leather trimmings used as stufting for balls, \&c.

b. Prepared from intestines of mammals:

Parchment from viscera of seals, used by Eskimo for clothing, bags, and blankets.

Leather from pharynx of seal and walrus used bs Eskimo for boot-soles.

Parchment from riscera of bears used in Kamtchatka for masks and windor-panes.

Tiscera of ox used in manufacture of gold-beaters' skin.

Bladders of animals used for pouches, parchment, bottle and jar covers, and by Eskimo for oil-bottles.

Tiscera of sheep used in manufacture of "cat-gut," with specimens of whip-cord, hatters' cord, for bowstrings, clock-makers' cord, filandre, guitar, violin, and harp strings, angling-lines, \&c.

Viscera of hog used as eurelopes for minced meat, sausages, Sc.

Sinews of sheep, dear, goat, buttialo, seal, walrus, and other animals used in manufactures of threads, lines, nets, and snow-shoes, in strengthening bors, \&c., the Babiche of the Eskimos of the northwest coast. 
20. LEATHERS-Continued.

c. Prepared from bird-skins: (Eskiuos.)

Eider-leather.

Auk-leather.

(Ostrich-leather used by A rabians.)

d. Prepared from reptile skins:

Alligator-leather.

Rattlesuake-leather.

Other snake-leatier.

e. Prepared from fish-skins:

Leather prepared from scaled fish by Indians.

Eel-leather, (pigtails, quenes, flail-thongs.)

Shark-leather, (shagreen used for coverings and by the

Alaska Indians for boot-soles.)

Sturgeon-leather.

(Skins of Diodon used in making helmets.)

Stomach membranes of halibnt used in Greenland for window-trausparencies.

$f$. Lcather waste:

Paper manufactured from waste.

Glve manufactured from waste, (see under 24.)

Prussian blue made from leather waste, (see under 30.) 21. HAIl AND WOOL.

a. Hair used in weaving and felting, (see under 8.)

b. Hair used for wigs and ornament:

Human hair as an article of commerce, with specimens of switches and wigs, and also of the trade imitations of hail in jute, horse-hair, \&c.

Goats' wool as employed in manufucture of wigs and perukes.

Horse-hair employed for military accoutrements and for standards, (Turkey.)

Huwan sealp-locks as Indian troplies.

Scalps of animals as trophies.

c. Hair and bristles used for brushes, (embracing the commercial hair and bristles, assorted and unassorted, and specimens of the manufactured articles:)

Hair of skunk used for fine brushes.

Hair of bear used for varnishing brushes. 


\section{HAIR AND WOOL-Continued.}

c. Hair and bristles used for brushes:

Hair of American badger used for fine sharing, grainiug, gilding, and dust brushes.

(Hair of European badger used for coarse brushes.)

Hair of dog used for coarse pencil-brushes.

Hair of squirrel, marten, sable, kolinsky, and weasel, especially the tails, used in making fine artists' pencils.

(Hair of camel used for peucils.)

Bristles of hog and peccary used in making coarse brushes for rarnishing, scrubbing, \&c.

Tails of horses, buffaloes, \&c., used for fly-brushes.

(Tails of yak used for fly-bruslies.)

(Tails of elephants used for brushes and staudards.)

Sheep's rool (on skin) used for black-board rubbers.

Hair of deer and antelope (on skin) used by Indians for hairbruslies.

Os-hair from the inside of cows' ears used for striping and lettering brushes.

d. Hair used in other manufictures:

Bristles used in shoemakers' waxed ends.

Bristles used in anatomical instruments.

Hair and bristles used in artificial thies. (See under B, 45.)

Hair of cattle used in strengthening mortar and plaster.

e. Hair used for stuffing:

Horse-hair, straight and curled, used for mattresses and cushious.

Refuse hair of bearer and musquash, cut from felting-hair, used for cuslions.

(Down of rabbits used for cushions.)

$f$. Wool used as a mediun for pigments :

Wool flocking used in the manufacture of wall-paper, colored felts, and rubber-cloth.

g. Chemical produets :

Refuse human and other hair used in manufacture of prussiate of potash, with specimens of manufactured product.

22. QUILLS.

a. Quills of mammals :

Quills of American bedge-hog used by Indians in embroidering. 
22. QUILLS-Continued.

a. Quills of mammals :

(Quills of porcupine used for pen-holders, floats for fishing, eyelet-punches, \&c.)

(Quills of European hedge-hog, on skin, used as a muzzle for weafing calves.)

6. Quills of birds :

Quills of swan and turkey for engrossing-pens.

Quills of goose and eagle for writing-pens.

Quills of crow and duck for fine pens.

Quills used in making toothpicks, fishing-floats, color-bottles, pencil-handles, needle-holders, \&c.

23. FEATHERS.

a. Feathers used for clothing. (See under Furs, D 6.)

b. Feathers used for implements, (including manufactured articles:)

Feathers of hawks used as fans and screens.

Feather's of fowl, turkey, grouse, and peacock used for brushes, fans, aud screens.

Feathers of ibis, spoonbill, egret, and bittern used for fans and screens.

Feathers of flamingoes, swans, geese, and ducks used for fans and screeus.

c. Feathers used for plumes and ornament, (including plumes, head-dresses, cockades, hat and dress trimming, \&c.:)

Feathers and wings of small perchers used in millinery and

- in manufacture of feather flowers.

Feathers of trogons and birds of paradise used as plumes and for feather flowers.

Feathers of humming-birds, scalps, and throats used in ormamental work.

Feathers of kingfishers used in plumagery.

(Feathers of parrots used in making feather flowers.)

Eagle and hawk feathers used for plumes.

Feathers of pigeons used for ornamental work.

Feathers and wings of cock used as plumes, trimmings, \& $\mathrm{c}_{z}$ natural and dyed.

Breast feathers of grouse, pheasants, and turkeys used as roll-plumes in hats. 


\section{FEATHERS-Continued.}

c. Feathers used for plumes, \&c.:

Feathers of ibises, spoonbills, flamingoes, herons, egrets, and bitterns used for plumes and ornamental work.

(Feathers of adjutant, (Lepoptilus aryala,) and marabou, (Lepoptilus marabou,) used for plumes ainl trimmings.)

Feathers of flamingoes, swans, geese, and ducks used in ornamental work for roll-plumes, and swans' down for trimmings. (See under 6.)

Breast-feathers of gulls, terns, and tropic birds used as rollplumes.

(Feathers of African ostrich used for plumes and trimmings, with specimens of undressed, scoured, bleached, scraped, and dyed grades.)

Feathers of American ostrich.

Specimens of composite feather flowers.

Specimens of plumagery work on metal.

Specimens of birds mounted for use in millinery.

d. Featleers used in otler manufactures:

Featliered arrow-shafts. (See under B, 18.)

Feathers ased in making artificial flies. (See under B, 45.)

Feathers used in manufacture of textile fabrics. (See under D, II, C.)

e. Down of birds :

Down of eider-duck nsed in bed-stuffing, with specimens of the balls in which it is pacied for transportation.

Down of other ducks.

Down of geese and swaus used as stuffing for beds, and as electrical non-conductor in manufacture of philosophical instruments.

24. GELATINE AND ISINGLASS.

a. Gelatine :

Gelatine marle from leather-shavings, bones, hoofs, and horns of bison, cattle, sheep, and other domestic animals, used in manufacture of glue, size, court-plaster, papier glacé for tracing, imitation glass, artificial flowers, and ornamental work, wrappings for confectious, table-jelly; (sce under D. 1,) \&c.

Size and gelatine from tine irory chips. 
21. GELATINE AND ISINGLASS-Continued.

a. Gelatine:

Bone-glue, (Osteocolia.)

(Glne made in India from skin of the ass, (Hippocolla.))

b. Isinglass :

Isinglass, (Ichthyocolla,) made from air-bladders and skins of fishes and nsed in the manufacture of fine glues and sizes, adhesire and court plasters, diamond cement, imitation glass, and table-jelly and coufectionery, (see under D. $1, \mathrm{D}$, ) in refining wines and liquors, in adulterating milk, in fixing the luster of artificial pearls, and in lustering silk ribbons, (embracing the dried bladders and the manufactured products,) in their grades of "lyre," "heart-shaped," "leaf," and "book" isinglass.

Isinglass from sounds of cod and hake.

Isinglass from the squeteague family, (Scicnidae,) principally used by confectioners.

Isinglass from cat fish family, (Siluridae.)

Isinglass from carp family, (Cyprinidae.)

Isinglass from sturgeons in all its grades and commercial forms.

Isinglass prepared from fish-skins.

25. FLEXIBLE MATERIALS DERIVED FLOM INVERTEBRATES. a. Insect productions :

Silk-worm "gut" used in making leaders for fish-lines.

(Nest of Carenue-ant, (Formica bispinosa, ) used as a mechanical stsptic.)

Spiders' web used as a mechanical styptic and for the crosslines in optical instruments, (see, also, under D, 8.)

Papier-maché of hornets' nests used for gun-wadding.

b. Mollusk prodnctions:

Byssus of mollusks, (see under D, 8.)

26. SPONGES.

a. Specimens of American commercial sponges, with the different grades, and bleached sponges:

(Specimens of Mediterrauean sponges.)

Surgical apparatus, probangs, aurilaves, "sponge-tents," and " other instruments manufactured.

Spongeo-piline used as a substitute for poultices.

Sponges used in stuffing mattresses and cushions. 


\section{OILS AND FATS.}

a. Mammal oils :

Bear-oil and bear-fat used as a cosmetic and in the manufacture of pomatums.

Dog-oil used in the manufacture of kid-gloves.

Seal-oil, in its various grades, used for lubricating.

Sea-elephant oil.

Sea-lion oil.

Manatee-oil.

Dugong-oil.

Oil and fat from domestic animals, tallow, suet, lard, lardoil used in lamps, for lubricating, and neats-foot oil used in dressing leather, also manufactured into varions substances, (see D, 30,) and tallow candles and night-lights.

Oil from body of whales, grampuses, and porpoises used in the arts, for lubricating, painting, \&c.

Black-fish and porpoise-jaw oil used in lubricating fine machinery, watches, clocks, and guns, with specimens of blubber.

Grampus-oil used for lubricating fine machinery.

Sperm-oil used in lamps, forlubricating, as an emollient in medicine, for lip-salves, and in the mannfacture of spermaceti.

Manufactured glycerines, used as a preservative and antiseptic, as a cosmetic, as an emollient, as a substitute for cod-liver oil, in the manufacture of perfumes and hairdressings, in photography, in the manufacture of nitro. glycerine, dynamite, dualine, lithofracteur, coloniamite, and other explosives, soap, \&c.

Manufactured stearines, with candles and othe: manufactured articles.

Soaps manufactured from manmal-oil, soda-soaps, (Lard, toilet, and resin soaps, potash-soaps, (washing, shaving, and soft soaps, diachyylon plaster, \&c.

Spermaceti, with specimens of candles.

Butter made from milk of cows, goats, and horses.

Oleomargarines, with specimens of imitation butter.

Brains of butialo used in tanning by Indians.

b. Bird-oils :

(Oils of petrels and otber sea-birds used by Eskimos and in the Azores for lamp-oil.) 


\section{OILS AND FATS-Continued.}

b. Bird-oils :

Goose-oil used by watch-makers, and as an emollient.

(Oil of guacharo, (Steatornis caripensis,) used in South Amer. ica as food.)

(Ostrich used for food, and by the Arabs in medicine, and emu-oil userl in Australia in medicine.)

(Oil of penguin, (Diomedea chilensis,) of Falklaud Islands, sold in Loudon for currying leather.)

(Peacock's fat and oil.)

(Oil of mutton-bird, (Procellaria obscura,) of Bass's Straits, used for lamp-oil illuminating.)

(Oil of frigate-bird, (Tachypetes aquila,) sometimes userl in medicine.)

Oil of pigeon, (Ectopistes migratorius,) used as food by Iudians and frontiersmen.

(Fulmar-oil from island of Saint Kilda.)

c. Reptile oils :

Alligator-oil manufactured in Florida.

(Alligator-oil used by Sonth American Indians, mixed with chica pigment for painting their bodies.)

Turtle-oil made from turtle-eggs, used in dressing leather and in manufacture of soap.

Rattlesnake and other snake oils.

d. Fish-oils :

Sun-fish oil used by fishermen for cure of rheumatism.

Cod-oil, also cod-liver oil used in medicine, as a food and emollient, and in lubricating.

Hake and haddock liver oil used in adulterating cod-liver oil. (Pollock-oil used by Shetlanders for illumination.)

Menhaden-oil used in eurrying leather, in rope making, for lubricating, for adulterating linseed-oil, as a paint-oil, and exported to Europe for use in the manufacture of soap and for smearing sheep.

Herring-oil. ${ }^{1}$

White-fish oil. ${ }^{1}$

Sturgeon-oil. ${ }^{1}$

( NoTE. - These oils, with other oils made from fishes, and a large part of the seal aud "black" whale oil, are known indiscriminately as fish-oil and used chiefly for the purposes enumerated under the head of menhadeu-oil.) 


\section{OILS AND FATS-Continued.}

d. Fish-oils :

Oulachan oil used by Indians of Northwest coast for food and illumination.

Shark' and skate liver oil, including the "Rouen oil," made on the coast of Normandy from the livers of Raia aquila, $R$. pastinaca, and $R$. batis, used like cod-liver oil.

Cramp-fish oil used by fishermen for cure of rheumatism.

Soaps made from fish-oil.

\section{PERFUMES.}

a. Mammal perfumes:

(Civet of the civet-cat (Viverra ciretta) of Africa.)

(Civet of the rasse (Viverra rasse) of Java.)

(Zibeth ciret of the Zibeth .( Tiverra zibetha) of Indian Archipelago.)

(Musk from musk-deer, (Tragulus, sp). var.,) in its varions grades, of Tonquin or Thibet. and Kabardin, Russian, or Siberian musk.)

Musk of musk-ox.

Misk of the musquash.

Castorenm of the benver, including the varions commereial grades, the Canadian, Hudson's Bay, and Russian castoreum, and specimens of castorine.

(Hyraceum of the daman, (Hyrax capensis.))

Ambergris of sperm-whale, with specimens of ambreine.

b. Reptile perfumes:

Musk of alligator.

Oil of hawksbill and loggerhead turtles, used in perfumery. 29. COLORING MATERLALS.

a. Derived from mammals :

Bone-black.

lvory-black, (noire d'iroire, ) used in fine painting, and in the manufacture of bank-note ink.

Prussiates, jrussian-blue, f'errocyanide of potassium, made from hoofs and refuse human and other hair.

Gall of animals used in dyeing.

Dung of animals used in calico-printing.

Hæwatin made from blood, and used in turker-red.dyeworks, and for the red liquor of priuters.

Wool-tlocking." (See under D, 21.) 
29. COLORING MATERIALS-Continued.

b. Derived from birds :

Shell of eggs, used for white pigment.

Series of murexides, or purpurate of ammonia dyes, made from guano.

c. Derived from fishes:

(Essence d'Oricht, or fish-scale pearl, used as a pigment.)

(Gall of carp, used in Turkey as a green paint and in staining paper.)

d. Derived from insects:

(Cochineal dye, from Coccus cacti of Mexico, used in manufacture of ronge, of carmine, and lake pigments, and in coloring tinctures.)

Canadian cochineal.

(Termes and other cochineals of commerce, Coccus ilicis.)

(Lac dye and lac lake, from Coceus lacea, C. polonicus, C. uva ursi, and Ophis fabce.)

Dye prepared from bed-bug, (Cimex lectularius.)

(Dye prepared from Trombidium, in Guinea and Surinam.)

Tut-galls produced by insects, and used in tanning, for black dyes, for woolen cloth, silk, and calico, and in manufacture of ink and gallic and pyrogallic acid, employed in photography.

e. Derived from mollusks:

(Sepia from Sepia officinalis.)

Purple dyes from gastropods, Murex, Purpura, \&c.

Purple dyes from nudibranch mollusks.

30. CHEMICAL PRODUCTS AND AGENTS EMPLOYED IN ARTS AND MEDICINE.

a. Dericed from mammals :

Secretion of skunk.

Album gracum of dogs, used as a depilatory in tanning hides. Albumen of blood, employed in sugar-refineries, in certain cements and pigments, and as antidote and emollient.

Dung, used in calico-printing.

Gall of animals, used in mixing colors, in fixing the lines of crayon and pencil drawings, in preparing the surface of irory for painting, in removing grease, and in medicine.

Pepsine and pancreatine, prepared from stomachs of hogs and calres. 
30. CHEMICAL PRODUCTS, \&c.-Continued.

a. Derived from mammals:

(Koumiss, a fermented liquor, prepared from mare's and cow's milk, and employed in medicine.)

Phosphorus, prepared from bones, with specimens of matches, rermin poisons, and other products.

Vaccine lymph, derived from cows.

Ammonia, prepared from bones and horn.

Sal ammoniac, prepared from bones and dung.

Prussiates, prepared from hoof, horn, and leather waste, dried blood, hair, and wool, with specimens of blue cyanide of potassium.

Lime from bones and bone phosphates. See also under 32.

Punk and tinder, made from droppings of camel and bison.

Animal charcoal, used as a decolorizer.

7. Derived from birds:

Albumen of eggs, used in photography, in clarifying liquors, by physicians as emollients and antidotes, and by apothecaries in suspending oils and other liquids in water.

Egg.shells, emplọed as an antacid.

c. Derived from reptiles:

Crotalin of rattlesnake and copperhead.

(Scincus officinalis of Egypt, used by European practitioners as sudorific and stimulant.)

d. Derived from fishes:

Propylamine, made from fish-brine.

(Intestines of grayling, used by Laplanders as a substitute for remnet.)

Shins of eels, used by negroes for rheumatism.

\section{e. Derived from iusects:}

Vesicatory preparations from American beetles, Cantharis cinerea and $C$. vittata.

(Vesicutory preparations derived from foreign beetles, cantharides or Spanish flies, (Cantharis vesicatoria,) and other species, and substitutes. Iylabris cichorii, Cercoma Schoefferi, Meloe, sp. rar., \&c.)

Vesicatory preparations from American spiders, such as Tegenaria medicinalis.

Gall-nuts, used in menicine. (See under 29.) 
30. CHEMICAL PRODUCTS, \&c.-Continued.

e. Derived from insects:

Coccinella, used as a remedy for toothache.

(Trehala, made from nests of beetles, (Larinas nidificans,) of East Indies, and used as a substitute for tapioca.)

Formic acid.

Carbazotic acid and its derivatives, made from sewing silk scraps, and used as a substitute for quinine.

Beeswax, used in manufacture of candles, cerates, plasters, and artificial flowers, in modeling and casting, and in medicine.

Honey, used as a preservative, a food, and in medicine as an aperient aud demulcent.

(Wax, used in Chivese pharmacy, secreted by the Coccus pehlah.)

(Nanna, produced by punctures of Coccus manniparus.

$a^{\prime}$. Manna from the Tamarix mannifera, used as food, and in medicine as a purgative.

b. Cedar manna of Mount Lebanon, from Pinus cedrus.

c. Arabian manna, from Hedysarum alliagi.)

(Eye-powder, made by Chinese from the Telini fly, (Mylabris cichorii,) of India.)

$f$. Derived from crustacea:

Salve-bug of fishermen of Banks, (Caligus curtus, ) parasite on cod-fish.

Crabs' eyes, or concretious from stomach of astacus, used as an antacid.

g. Derived from worms:

American leech, (Macrobdella decora,) used in surgery.

(European leech, (Hirudo medicinalis,) introduced into America.)

(African leech, (Hirudo trochina,) introduced.)

Leeches used as baroweters.

h. Derived from mollusks:

(Cuttle-fish bone of Sepia officinalis.) (See under D, III, H.)

Calcined shells, used for building-lime, and in manufacture of dentifrices and enamel. (See under III, H.)

i. Derived from radiates:

a. Limes, derived from calcining coral and coral rock. 
30. CHEMICAL PRODUCTS, \&e - Continued.

k. Derived from protozoans :

Burnt sponge, formerly used in medicine.

Infusorial earth, and its applications. (See above, under K.)

31. FERTILIZERS.

a. Natural guanos:

Bat guano from caves.

Bird guano from oceanic islauds.

b. Artificial guanos:

Meuhaden guano.

Herring guano.

White-fish guano.

Other fish guano.

c. Artificial fertilizers:

Bone-dust ground for use.

Bone phosphates.

Dried meat from refuse of slaughter-houses.

Poudrettes.

Other auimal fertilizers.

32. LIMES. (See under 30.)

33. OTHER MATERIALS NOT MENTIONED. 


\section{SECTION E. \\ PROTEOTION AND CULTURE. I. INVESTIGÁTION.}

1. METHODS OF THE UNITED STATES FISH COMMISSION.

a. Methods of work:

Apparatus for collecting specimens, (see under B.)

Apparatus for physical research.

Appliances for working up results.

(This should include a model of coast laboratory with all its fittings.)

b. Results of work:

Publications of the commission.

Collections, (see under $A, V$ to VIII.)

Photographs, \&c.

\section{PROTECTION}

2. PRESERVATION OF GAME, FISH, \&C.:

a. Game laws.

* From man.

** From artificial obstruetions.

b. Fish-ways $:^{1}$

Gap fish-ways.

Trench, ditch, or "Cape Cod" fish-ways.

Oblique grove fish-ways:

Single groove.

Brewer's.

Mather's.

Step fish-ways :

Box or pool fish-ways:

Overflowing, (old style.)

With passage-way cut down to the floor, (Smith's.)

With passage-rvay submerged, (Cail's.)

With contracting galleries, (Pike's.)

With transverse-sloping floors, (Steck's.) 
2. PREserVATION OF GAME, FISH, \&c.-Continued.

b. Fish-ways:

Steps contrived by arrangement of rocks and bowlders.

Inclined plane without steps :

Plain, (Pennsylvania.)

With partitions at right angles :

"Rectangular compartment."

Brackett's.

With oblique partitions :

Foster's.

Swazey's.

*** From natural enemies.

c. Apparatus for destroying injurious species:

Oyster-bed tangles, (see under B, 12.)

3. CARE OF ANIMALS IN CAPTIVITY.

$a$. Tethers and hopples.

b. Cages and pens:

Kennels for dogs, \&c.

Cages for animals.

Cages for birls.

Cages for iusects.

(West India fire-fly trap.)

c. Fish-cars and other floating-cages tor aquatic animals.

d. Aquaria :

Globes.

Aquaria.

e. Hives and other cages for insects.

f. Live-boxes, troughs, \&c., for microscopists' use.

g. Fish-ponds, fish-farms, (models.)

4. ENEMIES OF USEFUL ANIMALS.

a. Intestinal worms and other internal parasites.

b. Fish-lice, barnacles, and other external parasites.

c. Predatory animals not elsewhere exhibited.

\section{PROPAGATION.}

\section{PROPAGATION OF MAMMALS.}

a. Methods of mink culture.

b. Methods of culture of domesticated animals. 
6. PROPAGATION OF BIRDS.

(r. Methods of ostrich culture.

b. Methods of culture of domesticated birds, fowls, \&c.

7. PROPAGA'IION OF REPTILES.

a. Methods of terrapin culture.

8. PROPAGATION OF AMPHIBIANS.

a. Methods of frog culture.

9. PROPAGATION AND CULTURE OF FISHES. ${ }^{1}$

a. Accessories of obtaining and impreguating ova :

Pans, pails, \&e.

Strait-jackets used in spawning salmon.

Sparning-race, (Ainsworth.)

Roller-spawning screen, (Collins.)

Sparning-rat, (Bond.)

b. Hatcling-apparatus:

Troughs:

Plain.

Grarel-bottomed.

With siere-bottom trays:

Brackett's.

TVilliamson's.

Clark's.

Vats or cases:

Holton's.

Roth's.

Glass-grilled boxes, (Coste's.)

Jars and tin-ressels :

Bell and Mather's.

II. A. Green's.

Ferguson's.

Chase's.

Hatching-boxes, (floating:)

Seth Green's shad-box.

Brackett's shad-box.

Brackett's shad-box, (No. 2.)

Bryant's shad-box.

Stilwell \& Atkins's shad-box.

Banuister's shad-box. 


\section{PROPAGATION AND CULTURE OF FISHES-Continued.}

\section{b. Hatching-apparatus:}

Hatehing-boxes, (floatiug:)

Adhesive eggs apparatus:

-Vertical wire-cloth trays.

Hatching-basket.

Brook shanty, (Furmau's.)

(Bay or core barriers, Professor Rasch's.)

Accessories :

Tanks.

Nests.

Trays.

Grilles.

Gravel-filters.

Flaunel sereens.

Shallow troughs or tables (for picking eggs.)

Egg-nippers.

Cribbles.

Pipettes.

Skimmer-nets.

Feathering quills aud brushes.

Rose-nozzles, (for washing eggs.)

Syringes, bulb, \&c.

Shallow paus.

Aerating-pipe.

c. Transporting alparatus:

Apparatus for trausporting eggs:

Cans.

Case of cups, (Wilmot's.)

Case of cups, (Clark's.)

Case of trays, (Clark's.)

Moss-crates, (Stone's.)

Apparatus for transporting fish :

Barrels.

Cans, platiu.

Cans with aerating accessories:

Slack's.

Clark's.

Creveling.

II. A. Greeu's. 
9. PROPAGATION AND CULTURE OF FISHES-Continned.

c. Transporting apparatus :

Apparatus for transporting fish :

Tanks with aerating accessories:

Tanks, with attachment of band-wheel to car-axle, (Stone's.)

(Tauks, with Freiburg aerating apparatus.)

Aquarium-car, (Stone's.)

Live-box, (Atkins's.)

Accessories :

Air force-pumps.

Siphons.

- Siphon-tubes.

Bellows.

Roses, aerating.

10. PROPAGATION OF INSECTS.

a. Propagation of silk-worm :

Specimens of plants ased for food.

Model of house and its appliances.

$b$. Propagation of cochineal insect.

c. Propagation of bees:

For hives, (see under E. 3.)

11. PROPAGATION OF WORMS.

a. Propagation of leeches.

12. PROPAGATION OF MOLLUSKS.

a. Methods of ofster culture:

Stools for receiving spat, natural and artificial.

Other apparatus.

13. PROPAGATION OF CORALS.

14. PROPAGATION OF SPONGES. 



\section{$\frac{\text { Govork. }}{\text { april 4.76. }}$}

Department of the Interior:

U. S. NATIONAL MUSEUM.

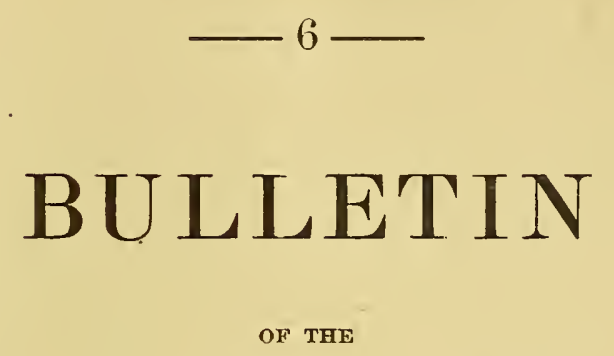

UNITED S'TATES NATIONAL MUSEUM.

N0. 6.-CLASSIFICATION OF THE COLLECTION TO ILLUSTRATE THE ANIMAL RESOURCES OF THE UNITED STATES,

A LIST OF SUBSTANCES DERIVED FROM THE ANIMAL KINGDOM, WITH SYNOPSIS OF THE USEFUL AND INJURIOUS ANIMALS AND A CLASSIFICATION OF THE METHODS OF CAPTURE AND UTILIZATION.

BY

G. BROWN GOO DE.

PUBLISHED UNDER THE DIRECTION OF THE SMITHSONIAN INSTITUTION.

WA S H IN G TON:

GOVERNMET PRINTING OFFICE. 1876. 





\title{
CLASSIF I C A T ION
}

OF TIE

\author{
COLLECTION TO ILLUSTRATE
}

THE

\section{ANIIIAL RESOURCES OF THE UNITED STATES.}

\author{
A LIST OF SUBSTANCES DERIFED FROM THE ANLMA KINGDOM, WITH \\ SYNOPSIS OF THE USEFUL AND INJURIOUS ANIMALS \\ AND A CLASSIFICATION OF THE METHODS \\ OF CAPTURE AND UTILIZATION.
}

\section{By G. BROWN GOODE, M. A}




\section{ADVERTISEMENT.}

This work is the sixth of a series of paper's intemled to iliustrate the wollections of Natural History and Ethnology belonging to the United States and constituting the National Museum, of which the Smithsonian Institution was placed in charge by the act of Congress of August 10, 1 sisti.

It has been prepared at the request of the Institution; and printed by authority of the honorable Secretary of the Interior.

\section{JOSEPH HENRY,}

Secretery S'mithsonian Institution.

SumTHSONIAN INSTITTTION,

Washington, February, 1876. 


\section{PR E F A C E.}

The following classification has been prepared by Mr. Goode to facilitate the work of collecting and arranging the material gathered by the National Museum to illustrate the resources of the United States as derived from the animal kinglom, in the International Exhibition of 1576. It is also intended to indicate the general character of the articles which are to be included in this branch of the exhibition.

Contributions of specimens of the different classes enumerated are mucli desired, for the purpose of malking the proposed display complete, and should be addressed to the Smithsonian Institntion, Washington, D. C.

JOSEPH HENRY,

Secretary Shithsonian Institution. 



\section{TABLE OF CONTENTS.}

\section{INTRODUCTORY REMARKS \\ Section A.-ENUMERATION OF ANIMALS BENEFICIAL OR INJURIOUS TO MAN.}

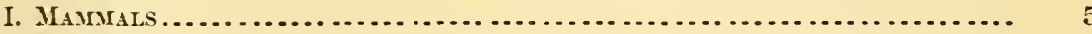

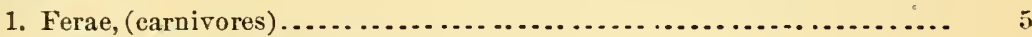

Fissipedia, (land carnivores) ................................ 6

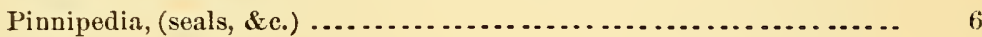

2. Ungulata, (hoofed animals) ................................ 6

3. Proboscidea, (elephants, \&c.) ............................ 7

4. Sirenia, (sea-cows, \&c.) ................................... 7

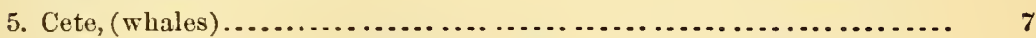

Denticete, (sperm whales and dolphins) ......................

Mysticete, (baleen whales) ...............................

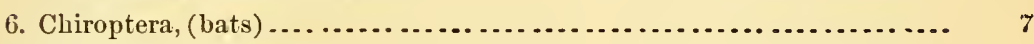

7. Insectivora, (moles, \&c.) .................................. 8

8. Glires, (guawers) ....................................... 8

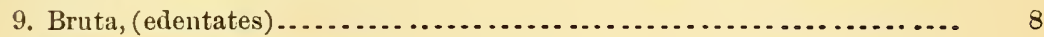

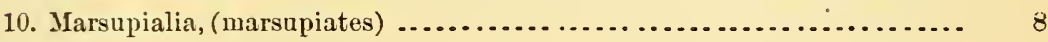

II. BrRds .................................................. 9

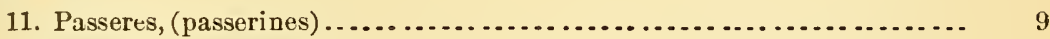

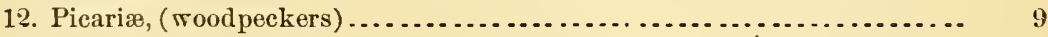

13. Cuculi, (cuckoos) ........................................ 9

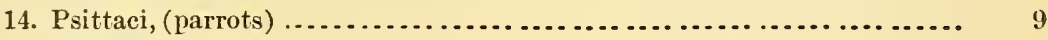

15. Raptores, (birds of pres)................................... 9

16. Columbæ, (pigeons) ....................................... 10

17. Gallinæ, (gallinaceous birds, in part) ......................... 10

18. Limicolæ, (plovers) ....................................... 10

19. Herodiones, (herons) ......................................... 10

20. Alectorides, (eranes) ........................................ is

21. Lamellirostres, (flamingoes and auserine birds) ................... 11

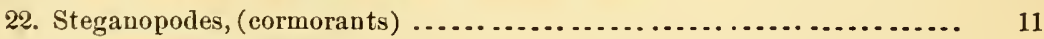

23. Longipennes, (gulls) ..................................... 11

44. Pygopodes, (grebes and auks) ............................... 11

5. Sphenisci, (penguins) .................................. 11

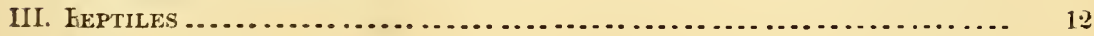

26. Crocodilı, (crocodiles) ................................... 12 
III. Reptiles-Continued.

Page.

27. Testudinata, (tortoises) .................................. 1?

28. Lacertilia, (lizards) ........................................ 12

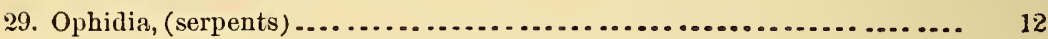

IV. AnpHibinis ................................................... 12

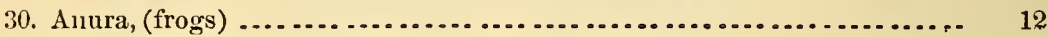

31. Urodela, (salamianders) ...................................... 13

32. Proteida, (menobranchus, \&c.)................................ 12

33. Trachystomata, (sirens) ..................................... 13

V. FisHes ....................................................... 13

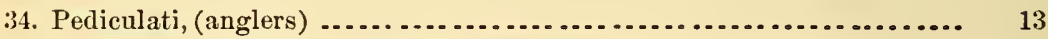

35. Plectognathi, (globe, trunk, and file fishes).................... 13

36. Lophobranchii, (pipe-fishes, \&c.) .............................. 13

37. Hemibranchii, (sticklebacks, \&c.)............................. 13

38. Teleocephali .............................................. 13

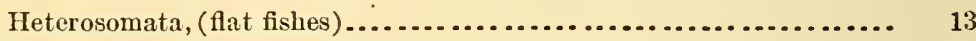

Anacanthini, (cods, \&c.).................................... 14

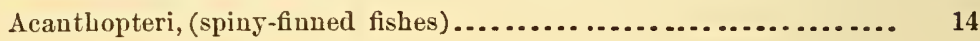

Percesoces, (mullets, \&c.)................................... 15

Synentognathi, (gar-fishes and flying-fishes).................. 15

Haplomi, (pikes, \&c.) ........................................ 15

Isospondyli, (salmon, herring, \&c.)......................... 15

Eventognathi, (carps) ........................................ 15

39. Nematognathi, (cat-fishes) ................................. 16

40. Apodes, (eels) .......................................... 16

41. Cycloganoidei, (amias) ................................... 16

42. Rhumboganoidei, (gar-pikes) .............................. 16

43. Solachostomi, (paddle-fish) ................................ 16

44. Chondrostei, (sturgeons) ................................. 16

VI. Elasmobraxchintes ........................................ 16

45. Holocephali, (chimeras).................................... 16

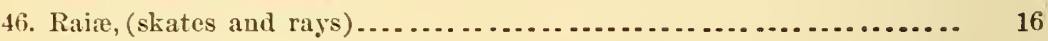

47. Squali, (sharks)............................................... 16

VII. Marsipobranchiates........................................

48. Hyperoartia, (lampreys) ...................................

49. Hsperotreti, (hags) ...................................... [z

VIII. Leptocardias ............................................. 17

50. Cirrostomi, (lancelets) .................................. 17

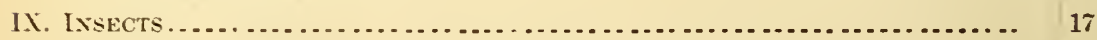

51. Insecta, (insects).............................................. 17

5.2. Myriapoda, (centipedes, \&c.) ............................... 17

X. Andchxeaxs.................................................. 17

53. Arachnida, (spiders) ....................................... 17

XI. Artinopods .................................................. 18

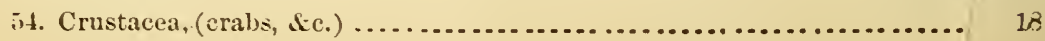


Page.

XII. Worms $\ldots \ldots \ldots \ldots \ldots \ldots \ldots \ldots \ldots \ldots \ldots \ldots \ldots \ldots \ldots \ldots \ldots \ldots \ldots \ldots \ldots \ldots \ldots \ldots \ldots \ldots \ldots . . . \ldots \ldots$

5i). Annelida, (annelids) .................................... 18

ј6. Scolecida, (spoon-worms, \&c.) ............................... 18

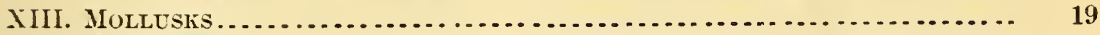

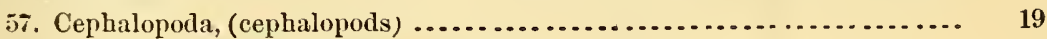

58. Gastropoda, (sea and land snails) ... . . . . . . . . . . . . . . . . . . . 19

59. Conchifera, (ordinary bivalve mollusks) . . . . . . . . . . . . . . . . . . . 19

XIV. Radites . . . . . . . . . . . . . . . . . . . . . . . . . . . . . . . . . . . . . . 19

60. Echinodermata, (echinoderms) .................................. 19

61. Colenterata, (acalephs and polyps) .......................... 20

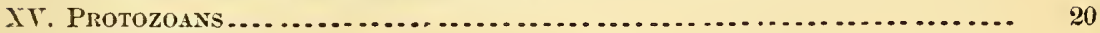

62. Rhizopoda, (sponges and foraminifera) $\ldots . \ldots \ldots \ldots \ldots \ldots \ldots \ldots \ldots \ldots \ldots \ldots . . \ldots \ldots$

\section{SECTION B.-MEANS OF PURSUIT AND CAPTURE.}

\section{tApparatus of divect application.}

I. HAND-IMPLEMENTS, (SIMPLE TOOLS)

* Eor striking.

1. Clubs ................................................. 21

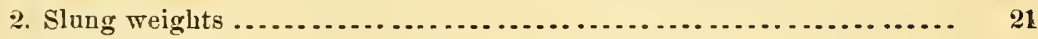

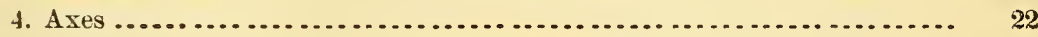

*** For thrusting.

* Scooping-instruments.

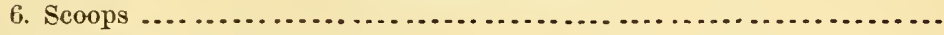

* Grasping-hooks.

¡. Hooked implements, (used with single motion, that of hooking)....... 2:3

ช. Barbed implements, (used with two motions, the first that of thrusting).

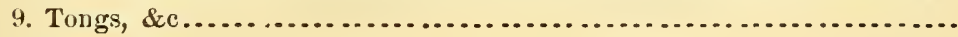

\section{*** Grasping-lines.}

10. Nooses, (lariats and suares) ............................... 25

11. Loaded lines, (bolas) ..................................... 25

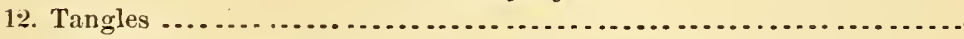

t+Apparatus of indirect applicafion.

III. MISSILES

* Simple missiles, (those propelled by the uuaided arm.)

13. Hurled weights

14. Hurled sticks........................................... 26

15. Hurled spears, lances ................................... 26 
** Centrifugal missiles, (propelling power augmented by artificial lengthening of the arm.)

IiI. Misswes-Continued.

Page

16. Slings, and spears thrown by straps......................... 26

17. Missiles thrown by "throwing-sticks" ........................ 26

*** Missiles propelled by a spring.

$\ddagger$ Spring consisting of bent rod.

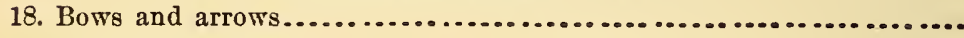

¥ Spring consisting of elastic cord.

19. India-rubber slings.

$\sharp \ddagger$ Spring consisting of metallic helix.

20. Spring guns

**** Missiles propelled by compressed air or water.

21. Air-guns..................................................

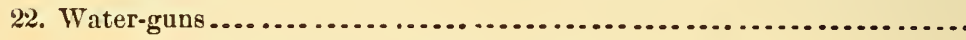

***** Missiles propelled by combustion of gunpowder.

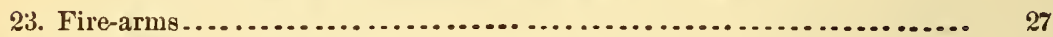

24. (Accessory.) Ammunition and its preparation.................... 28

25. (Accessor5.) Accessories of loading, repairing, and testing fire-arms.... 29

26. (Accessory.) Accessories of carrying fire-arms. (Accoutrenents)...... 30

IV Baited Hooks-ANgling-TaCkLE ............................ 31

27. Hooks with movable lines.-Hand-tackle...................... 31

28. Hooks with stationary lines. - Set-tackle....................... 31

29. (Accessory.) Parts and accessories to angling-apparatus............. 32

H+Apparatus to a greater or less extent automatic.

V. Nets .................................................... 35

30. Entangling (meshing) nets................................ 35

31. Encircling nets......................................... 35

$+1+\dagger$ Apparatus entirely automatic.

VI. Traps.................................................... 37

32. Pen-traps............................................. 37

33. Clutching-traps.......................................... 38

34. Fall-traps.............................................. 39

35. Missile-traps................................................ 39

36. Adhesive preparations ..................................... 39

VII. Apparatus for wholksale destruction ........................ 39

37. Poisons .................................................. 39

38. Asphyxiating apparatus................................... 39

39. Torpedoes .............................................. 39

$\mathrm{tt+t+Accessories} \mathrm{to} \mathrm{the} \mathrm{chase} \mathrm{and} \mathrm{fishing.}$

VIII. Huxtring-aximals ...................................... 39

40. Hunting-mammals ..................................... 39 
ViII. Huxtixg-iximils-Continned.

Page.

41. Accessories to hunting-mammals ............................ 41

42. Hunting-birds ............................................ 41

43. Accessories to hnnting-birds ................................ 41

44. Hunting-fishes........................................... 41

1X. Decors ANd DisGUises ..................................... 41

45. Baits ..................................................... 41

46. Decoys ............................................... 42

47. Covers ................................................. 42

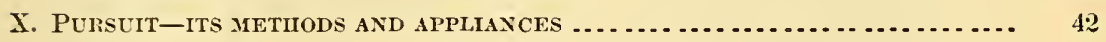

48. Methods of transportation ................................... 42

49. Camp-outfit........................................... 44

50. Personal equipments ...................................... 45

\section{Section C.-METHODS OF PREPARATION.}

I. Preparation and preservation of foods....................... 47

1. Preservation of the living animals, (see E, 3) ................... 47

2. Preservation of fresh meats............................... 47

3. Drying ................................................. 47

4. Canning and pickling..................................... 48

5. Preparation of baits............................................ 48

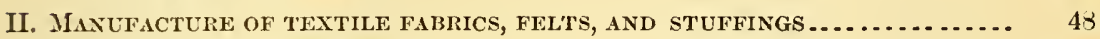

6. From hair of mammals .................................... 48

7. From whalebone........................................ 49

8. From feathers........................................... 49

9. From silk of insects....................................... 49

10. From soft parts of other invertebrates....................... 49

III. Preparation of the skin and its appendages .................. 49

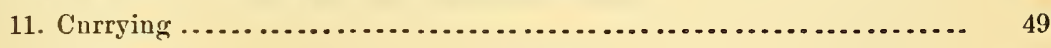

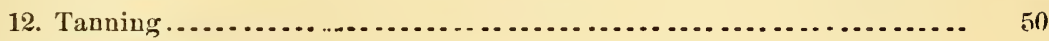

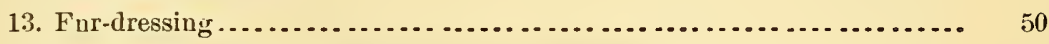

14. Feather-dressing......................................... 50

15. Manufacture of qnill articles.............................. 51

16. Hair and wool work ........................................ 51

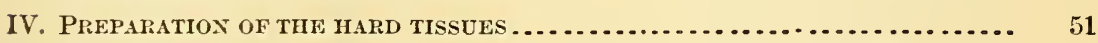

17. Ivory cntting and carving................................. 51

18. Preparation of horn and hoofs.............................. 51

19. Preparation of whalebone................................ . 51

20. Preparation of tortoise-shell............................... 51

21. Preparation of fish-scale work, \&c......................... 52

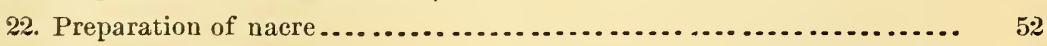

23. Preparation of coral ...................................... $5 \%$

24. Preparation of other hard tissn es............................ 52

V. Prepalition of OILS AND Gelatines......................... 52

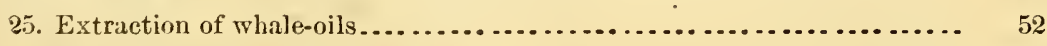

26. Extraction of other mammal oils............................ 52 
V. Preparatiox of olls and gelatines-Continued.

27. Extraction of bird and reptile oils ........................... 52

28. Extraction of fish-oils ........................................ 52

29. Extraction of glue, gelatiue, and isinglass .................... 5*.

VI. Preparation of drugs, perfches, and ciemical, prodects........... 5:3

30. Preparation of perfumes................................. 5 ;

:31. Mannfactnre of ivory-black ................................... $5:$

32. Manufacture of prussiates................................. 53

33. Maunfacture of murexides...................................

34. Manufacture of cochineal colors ............................... 53

35. Manufacture of inks....................................... $5:$;

35. Manufacture of albumen ................................... $5: 3$

37. Manufacture of pepsin ..................................... 53

38. Manufacture of phosphorus ..................................... .5

39. Manufacture of sal ammoniac............................... 5.3

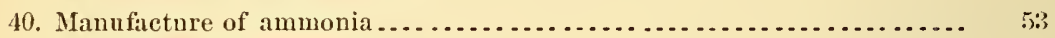

41. Manufacture of albumen preparations .........................

42. Manufacture of propslanine.............................. 53

43. Mauufacture of formic acid . . . . . . . . . . . . . . . . . . . . .

44. Manufacture of carbazotates ................................ 53

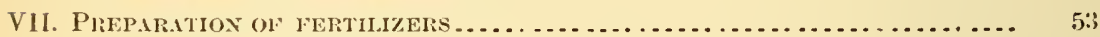

45. Preparation of fertilizers................................. 53

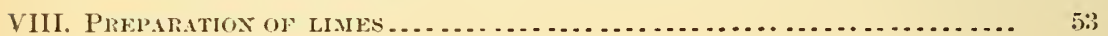

46. Burning of lime ..............................................

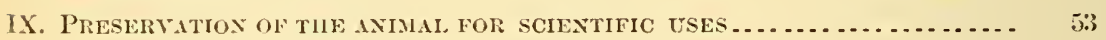

4\%. Preservation of wet preparations .............................

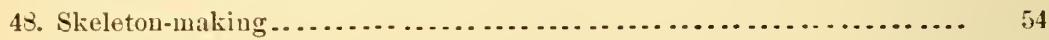

49. Modeling .................................................. 54

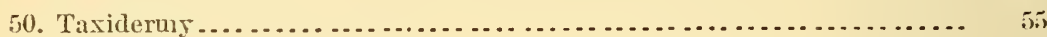

51. (Accessorr.) Photographic and other delineating apparatus......... 5i

SECTION D.-AXIMAL PRODUCTS AND THEIR APPLICATIONS.

I. Foods.............................................................

1. Foods in a fresh coudition ................................ 56

2. Foods dried and smoked ................................. (i)

3. Foods salted, canned, and pickled............................. 66

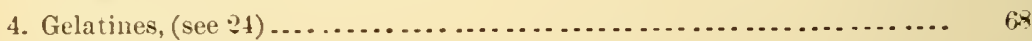

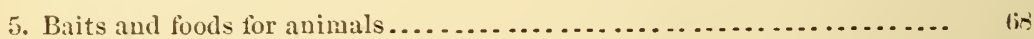

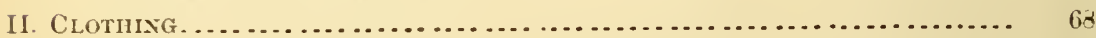

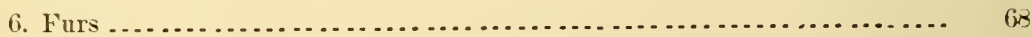

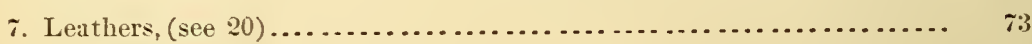

8. Textile fubrics.......................................... $\tau_{3}$

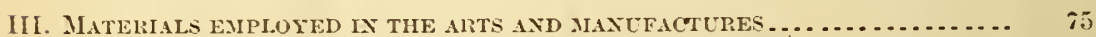

* Hard materials.

9. Ivory and bone......................................... 75,

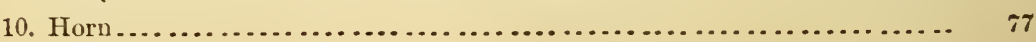


III. Materials EMPLOYED IN THE ARTS AND MLANUFACtures-Continued.

Puge.

11. Hoots and claws........................................ in

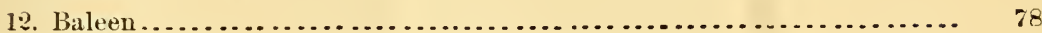

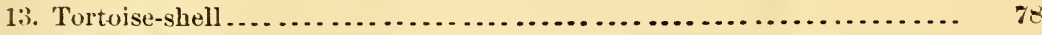

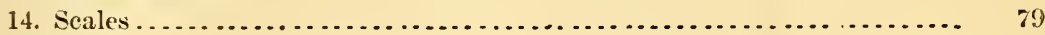

15. Pearl..................................................... 79

16. Shells .................................................... 80

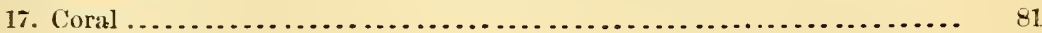

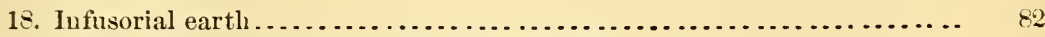

19. Other materials lerived from invertebrates................... $४ 2$

** Flexible materials.

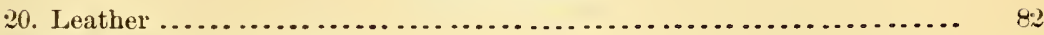

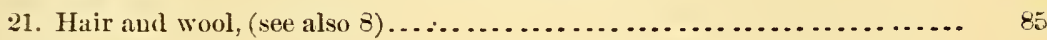

Q2. Quills ............................................ 86

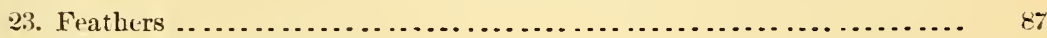

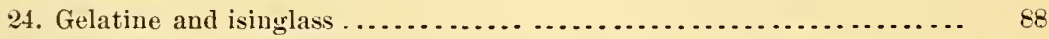

25. Flexible materials from insects and mollusks.................... 89

26. Sponges ................................................ 89

*** Fluids and soft materials.

27. Oils and fats............................................. 90

28. Perfumes .............................................. 92

29. Coloring materials.............................................. 92

30. Chemical products and agents employed in the arts and nedicine...... 98

31. Fertilizers .......................................... $96 ;$

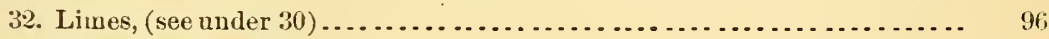

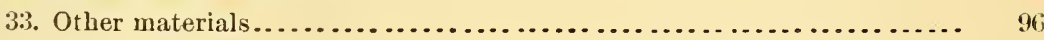

Section E.-PROTECTION AND CULTURE OF USEFUL ANIMALS.

I. INTESTIGATION

1. The methods of the United States Fish Commission ................ 97

II. Protection................................................. 97

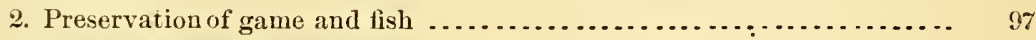

3. Care of animals in eaptivity ................................ 98

4. (Accessory.) Euemies of useful animals ...................... g8

III. Piropagatina

5. Propagation of mammals ................................. 98

6. Propagation of birds ..................................... 99

7. Propagation of reptiles ..................................... 99

४. Propagation of amphibians ............................... 99

9. Propagation of fishes................................... 99

10. Propagation of insects.................................. 101

11. Propagation of leeches ....................................... 101

12. Propagation of mollusks.................................. 101

13. Proparation of corals....................................... 101

14. Pronagration of sponges..................................... 101

ALI'HALETICAL INDEX ................................ 103 



\section{INTRODUCTION.}

The system proposed in the following lists has been hurriedly prepared, and is necessarily very incomplete; it is intended merely as a prorisional classification, to be used in collecting the materials for the exhibition, and in their preliminary arrangement.

The first group, Section $A$, is an index to the whole series; it will include all North American animals which are directly beneficial or injurious to man. Although every species, down to the very least, exercises some influence upon human well-being, it seems scarcely practicable to attempt the exhibition of those which affect it only indirectly. Those species are considered useful which supply food, clothing, shelter, implements, materials, and amusement; those injurious which endanger the life or personal comfort of man, or destroy those animals and plants which are of direct benefit to him. In the enumeration of animals, the names of the orders are giren, followed in parenthesis by the bestknown names of the more important species included, and a brief note on their principal uses. This enumeration, being simply of convenience, makes no claim to zoological precision.

SECTION B embraces all instruments and methods employed by the hunters, trappers, and fishermen of North America, aboriginal and civilized. Not only those which are directly employed in destruction or capture are included, but the means made use of in pursuing or attracting the animals and fishes, and the personal equipment of the pursuer. The collection will be a monograph of all matters relating to the chase and the fisheries of the country. In preparing the classification here submitted, the principles of zoological classification have been followed as closely as possible; each distinct form bas been considered a species; and the specific forms have been grouped into genera, families, and orders according to the general balance of their affinities. Form and manner of use have not been without weight, but superficial resemblance has been set aside, and the idea giren the first importance. Thus, barbed spears and harpoons have been placed with the "hooked instruments," while plain spears and lances are grouped with the knives and clubs. In studying the place of the fire-arms and bows and arrows, the missile itself has been regarded as more important than the 
machine which propels it, and the latter is placed in a subordinate relation.

In one group, that of nets, convenience in arrangement of the specimens seems to demand that material, a character of small importance, shall be made prominent. Two widely diverging groups of apparatus are associated nuder the head of nets, viz, encircling-nets, the true relations of which are with grasping and scooping instruments, and entangling nets which belong with the traps, where a third group of nets, the pound aud weir nets are actually classed. Where the exigencies of administration of the specimens demand that they should be arranged otherwise than in their exact systematic position, full cross-references are given.

The simplest implemelts have always been placed first, the series advancing in the order of complication of structure. Thus we have in the begiuning the apparatus of direct application, or tools, including, first, those implements which are used in the hand, and which increase its power in a simple way, such as clubs aud slung-shot, which merely add to the weight of the fist, followed by the knires, axes, and spears, which in their simplest and primitive form were sharpened stones and pointed sticks. Secoud, are the graspiug-implements, or those by which the power of the fingers is extended. In this series the same priuciple of progress from simple to complex is followed; in the scoop we hare the idea of the hollow palm of the hand dereloped in rarious forms, while the grasping-hooks and grasping-lines are the artificial extensions of the human finger. Under hooked iustruments, the simple hooks, or those which are attached to the object by a single motion, a pulling one, are placed first, followed by the barbed implements, in which the attachment is made by a thrusting, succeeded by a pulling motiou, and then by the tongs and forceps, which are essentially donble hooks. The succeeding division is that contaiuing the lasso and bolas, which are worked at long distauces and require great skill, succeeded by the tangles, which are, in principle, assemblages of lassos, entangling objects amoug their fiber nooses.

In the third dirision, that of missiles, the same principle of snecession is adhered to. First are placed those missiles which are propelied by the unaided arm; then those in using which the arm is artifically leugthened, as with the sling, string, or darting stick; then those iu which the propelling porrer is derived from the elasticity of rods and cords, the strength of the arm haring become subsidiary; closing with those in 
the use of which the strength of the arm is of no essential value, and the propelling porver originates in chemical combustion.

Accessory to these are groups containing those articles used in the mannfacture, testing, loading, and transportation of these missiles, and the machines which drive them through the air.

In a fourth division is the apparatus of angling, which is separated from hooked implements with which the form of the articles would naturall place them, since they are not implements of grasping, but partake of the nature of traps, being in part automatic.

The group of nets is a heterogeneons one, as has been stated above, consisting of two dirisions, the first that of entangling-nets, belonging properly with traps, while encircling-nets are in idea instruments for grasping.

Ir arranging traps a logical succession has been preserved as far as possible. Those traps are considered the most simple in which the animal is penned by its own act, without any change in the arrangement of the trap. The pit-falls or "tipes" are first, followed by the mazes or labyrinths of greater or less complexity. Then come the traps in which the entrance is closed, either by the falling of a door or by the falling of a box-like trap, as a whole, so as to surround the animal. Encler clutching.traps are placed those which seize the animal, as in the fingers, while crushing-traps are those which seize or impale it bodily. Adhesive preparations, such as bird-lime, close the series.

The accessory divisions, including hunting-animals, decoys, and disguises, and the methods and appliances of pursuit, do not admit any thorough classification, and are arranged with reference to convenience of exhibition.

SECTION C includes all methods of utilizing animals' products. It might be more satisfactorily arranged with the following section, were it not for the inconvenience of exhibiting models and tools in the same cases with the manufactured products; the arrangement of the two sections is nearly the same.

In Section D are grouped all useful substances derived from the animal kingdom. In order to avoid the omission of any products which are or may be obtained from North American animals, this enumeration has been made general, those not American being included in parentheses. This enumeration is far from complete, and is intended simply as an aid to future study in the same direction.

SECTION E includes all cirticles illustrating the culture and protection of useful animals. 



\section{SHCTION A.}

\section{E N U M E R A I I N}

OF

\section{ANIMALS BENEFICIAL OR INJURIOUS TO MAN,}

(WITH A SYNOPSIS OF THEIR USEFUL APPLICATIONS.)

\section{II A III A LS.}

L. FERAE:

Fissipedia. (Cats, pumas, jagaars, ocelots, lynxes, wolves and dogs, foxes, fishers, martens, minks, weasels, wolverenes, badgers, skunks, otters, sea-otters, bears, raccoons, and the domesticated cat, dog. and ferret.)

Useful products :

Food, (bears, raccoon, \&c.) D. 1.

Fur, (all the group.) D. 6.

Leather, (dog, cat.) D. 20.

Textile fabrics, felt, (raccoon.) D. 8.

Ivory, teeth, (bear, føx, \&c.) D. 9.

Claws used by Indians, (bears, puma.) D. 11.

Hair, for brushes, (badger, dog, weasel, skunk, bear.) D. 21.

Oil, (bears.) D. 27.

Perfumes, (civet, \&c.) D. 28.

Medicinal products, (skunk.) D. 30.

Chemical agent, album grecum, (dog.) D. 30.

Useful traits :

Susceptible of domestication, (wolres (Indian dog,) foxes, otters, bears, raccoon, rlog, cat, ferret.)

Employed in hunting, (dog, cat, ferret.) B. 40.

Employed in fishing, (otter.) B. 40. 


\section{FERAE-Contiuned.}

Fissipedia-Continued.

Injurious traits:

Enemies of man, (cats, wolves, bears.)

Enemies of domestic animals.

Marauders on crops, (bears, raccoon.)

Stench nuisances, (skunks.)

Modes of capture. ' B. I, II, III, VI, X.

Pinnipedia. (Fur-seals, sea-lions, hair-seals, hood-seals, sea-ele phants, walruses.)

Useful products :

Food of aborigines. D. 1.

Fur, (fur-seals, \&c.) D. 6.

Leather, \&c., parchment from viscera, (sea-lions, hair-seals. walruses.) D. 20.

Oil, (hair-seal, hood-seal, sea-elephant, \&c.) D. 27.

Irory, (walrus.) D. 9.

Injurious traits: Destroy fish.

Modes of capture. B. I, III, V, X.

2. UNGULATA. (Bison, musk-ox, mountain-goat, mountain-sheep, antelope, moose, caribon, elk, deer, peccary, and the domesticated ox, goat, sheep, hog, horse, ass, and camel.)

Useful products:

Food, fresh, smoked, and pickled, (all the group.) D. $1,2,3$.

Fur, (bison, musk-ox, goat, sheep, moose, \&c.) D. 6.

Leather, (all the group.) D. 20.

Textile fabrics and feit, (ox, goat, sheep, camel, musk-ox.) D. 8 .

Irory and bone. D. 9.

Horn, (bison, ox, goat, sheep, deer, elk, \&c.) D. 10.

Hoof, (bison, musk-ox, goat, sheep, deer, horse, \&c.) D. 11. Hair, bristles, and wool, (bison, ox, goat, sheep, deer, hog, camel.) D. 21.

Gelatine and glue. D. 4, 24.

Oil and fat. D. $2 \pi$.

Perfiumes, (musk-ox, musk-deer.) D. 28.

Coloring materials from blood and bile. D. 29. 
2. UNGULATA-Continued.

Useful products :

Chemical products. D. 30 .

Fertilizers. D. 31.

Useful traits: Susceptible of domestication.

Modes of capture. B. I, II, III, VI, IX.

3. PROBOSCIDEA. (Elephants.*)

Useful products: Irory. D. 9.

4. SIRENIA. (Manatee, or sea-cow.)

Useful products :

Food. D. 1.

Leather. D. 7, 20.

Oil. D. 27 .

5. CETE. (Whales.)

Dentricete. (Beluga, narwhal, porpoise, b'ack-fish, killer, grampus, sperm·whale.)

Useful products :

Food, Indian, (sperm-whale, porpoise.) D. 1.

Oils, (all the group.) D. 27.

Spermaceti, (sperm-whale,

Leather, (porpoise, beluga.) D. 7, 20.

Bone and ivory, (narwhal, sperm-whale.) D. 9.

Perfume, ambergris, (sperm-whale.)

Injurious traits: Destroy fish and seals.

Modes of capture. B. I, II, III, X.

IIrsticeTe. (Right, or whale-bone whales.)

Useful products :

Food, (right-whale.) D. 1.

Baleen. D. 12.

Oil, (right-whale, \&c.) D. 27.

6. CHIROPTERA. (Bats.)

Useful products :

Food, Indians. D. 1.

Felting material. D. 8 .

Guano. D. 31.

Useful traits: Destroy troublesome insects.

Injurious traits: Disseminate troublesome insects. 
7. INSECTIVORA. (Moles and shrews.)

Useful products :

Fur, (moles.) D. 6.

Felting material, (moles.) D. S.

Useful traits :

Destroy burrowing insects, \&c.

Injurious traits : Burrowers.

Modes of capture. B. VI.

8. GLIRES. (Squirrels, prairie-dogs, showtl, marmots, musquash, beaver, rats, mice, lemmings, porcupines, rabbits, and the domesticated rabbit, and Guinea-pig.)

Useful products :

Food. D. 1.

Fur, (squirrels, showtl, marmots, musquash, beaver, lemmings, rabbit, \&c.) D. 6 .

Textile fabric, felt, (musquash, beaver, rabbit.) D. 8 .

Irory, (beaver.) D. 9.

Leather, (rat, beaver.) D. 7, 20./

Hair and down, (rabbits.) D. 21.

Quills, (porcupiue.) D. 21.

Perfume, castoreum, (beaver.) D. 28.

Useful traits: Susceptible of domestication, (squirrels, rabbits, \&e.)

Injurious traits: Marauders.

Hodes of capture. B. I, II, III, VI, VII, VIII, IX.

9. BRUTA. (Armadillo, \&c.)

Useful products: Shell used by Indians in varions manufac-

tures. D. 14.

Injurious traits :

Burrower.

Marauder.

10. IARSUPIALTA. (Opossum.)

Useful products :

Food. D. 1.

Hair used in felting. D. 8 .

Injurious traits: Marauder.

Hocles of capture. B. I, II, III, VI, VIII 


\section{BIRDS.}

11. PASSERES. (Thrushes, stone-chats and blue-birds, dippers, kinglets, titmice, nuthatches, creepers, wrens, larks, wagtails, warblers, tanagers, swallows, waxwings, greenlets, shrikes, finches, starlings, black-birds and orioles, crows and jays, fly-catcbers, and domesticated sparrow, canary, \&c.)

Useful products :

Foods, (thrushes, rice-birds, \&c.) D. 1.

Ornamental feathers. D. 23.

Useful traits :

Destroy insects.

Song-birds, (generally susceptible of domestication.)

12-13. PICARI E AND CUCULI. (Night-hawks, whippoorwills, swifts, humming-birds, trogons, saw-bills, kingfishers, cuckoos, woodpeckers.)

Useful products: Ornamental feathers, (humming-birds, trogous.) D. 23.

Useful traits :

Destroy noxious insects, (night-hawks, swifts.)

Destroy tree-borers, (wootpeckers.)

Injurious traits:

Destroy fish, (kingfishers.)

Destroy birds'-eggs, (cuckoos.)

Destroy fruit, (woodpeckers.)

Destroy trees, (sap-sucker.)

14. PSITTACI. (Parroquet and domesticated parrots.)

Useful products: Ornamental feathers. D. 23.

Useful traits: Susceptible of domestication.

15. RAPTORES. (Owls, hawks, eagles, vultures, buzźards.)

Useful products:

Ornamental feathers. D. 23.

Quills. D. 22.

Useful traits :

Susceptible of domestication and use in hunting. ${ }^{1}$

\footnotetext{
${ }^{1}$ Nine species of falcons, hawks, and owls have been employed in the chasc by Europeans.
} 


\section{RAPTORES-Continued.}

Useful traits :

Scavengers, (vultures, buzzar ds.)

Destroy vermin, (owls, hawks.)

Injurious traits: Destroy domestic animals, eggs, \&c.

16. COLUMBસE. (Pigeons and dores.)

Useful products :

Food.

Ornamental feathers. D. 23.

Useful traits :

Game-birds.

Susceptible of domestication.

Used as targets, (wild pigeon.) B. 25.

Used as carriers, (carrier-pigeon.)

17. GALLINA. (Turkey, grouse, partridge, sage-cock, ptarmigan quail, and the domesticated peacock, guinea-fowl, and fowl.)

Useful products :

Foods, flesh. D. 1.

Ornamental feathers. D. $\{3$.

Quills. D. 22.

Albumen. D. 30.

Useful traits :

Game-birds.

Susceptible of domestication.

1S. LIMICOLAE. (Plover, ring-neck, surf-bird, oyster-catcher, turnstone a voset, stilt, phalarope, woodcock, snipe, sandpiper dunlin, godwit, sanderling, willet, tattler, yellow shanks, green-shanks, curlew.)

Useful products :

Food: Flesh. D. 1.

Eggs. D. 1.

Feathers. D. 23.

Useful traits: Game-birds.

19. HERODIONES. (Ibises, spoonbills, herons, egrets, bitterns.)

Useful products: Ornamental feathers. D. 23.

Useful traits: Destroy vermin. 
20. ALECTORIDES. (Cranes, rails, crakes, gallinules, coots.)

Useful products :

Food, (rails, crakes.) D. 1.

Feathers. D. 23.

Useful traits: Susceptible of domestication, (cranes.)

21. LAMEldirostres. (Flamingoes, swans, geese, ducks.)

Useful products :

Food: Flesh, (geese, ducks.) D. 1.

Eggs, (geese, ducks.)

Ornamental feathers, (flamingo, geese, \&c.) D. 23.

Down, (geese, ducks.) D. 23.

Useful traits :

Susceptible of domestication, (geese, ducks.)

Used as decoys for other swimmers, (brants, ducks.)

22. STEGANOPODES. (Gannets, pelicans, cormorants, darters or water-turkeys, frigate birds, tropic birds.)

Useful products :

Ornamental feathers, (darters, tropic birds.) D. 23.

Leather, (of feet.) D. 20.

Useful traits: Susceptible of domestication. ${ }^{1}$

23. LONGIPENNES. (Gulls, terns, skimmers, petrels, albatrosses shearwaters.)

Useful products :

Food, eggs. D. 1.

Ornamental feathers, (gulls, terns, \&c.) D. 23.

Oil, (petrels, \&c., used by Eskimos.) D. 27.

24. PYGOPODES. (Loons, grebes, auks, puffins, guillemot, murres.)

Useful products :

Foods, (eggs.) D. 1.

Ornamental feathers, (grebes.) D. 23.

Feathers used as furs, (grebes, auks, \&c.) D. 8.

25. SPHENISCI. (Penguins.)

Useful products:

Feathers used as fur. D. 6.

Oil. 1). 27. 


\section{REPTILES.}

26. CROCODILIA. (Alligator, crocodile.)

Useful products :

Food. D. 1.

Ivory. D. 8 .

Leather. D. 20.

Oil. D. 27.

Musk. D. 28.

Injurious traits :

Enemies of man and domestic animals.

27. TESTUDINATA. (Tortoises, terrapin, leather-back, green, loggerUseful products: head, and hawks.bill turtles.)

Food: Flesh, (green turtle, terrapin, gopher tortoise.) D. 1. Eggs, (green turtle, terrapiu, gopher tortoise.)

Oil from eggs, (green turtle.) D. 27.

Shell, (turtles.) D. 13.

Perfume. D. 28 .

Methods of capture and transportation. E. 3.

23. LACERTILIA. (Lizards, skinks, horned-toads, chameleons, scorpious, joint-snakes, \&c.)

Useful products: Food of Indians. D. 1.

Medicinal product: (Skink.) D. 30.

Useful traits: Destroy noxious insects.

29. OPHIDIA. (Suakes.)

Useful products :

Leather, (rattlesnakes, bull snakes.) D. 27.

Medicinal products, (rattlesnakes, copperheads.) D. 30.

Oil, (rattlesmakes.) D. 27.

Useful traits: Destroy rermin.

Injurious traits: Enemies of man, (rattlesnakes, copperheads, and moccasius.)

\section{AMPHIBIANS.}

30. ANURA. (Frogs, toads, hร̌la, \&c.)

Useful products :

Food, (frogs.) D. 1.

Material for phrsiological instruction, (frogs.) 
30. AYURA-Continued.

Useful products :

Weather indicators, (hyla.)

Useful traits: Destroy noxious insects, (toads.)

31. URODELA. (Salamanders, axolotls, and menopomes.)

Useful products: Foods, aboriginal, (axolotls.)

Useful traits: Aquarium use.

Injurious traits: Enemies of young fish.

32. PROTEIDA. (Rirer-dogs, hell-benders.)

Injurious traits: Enemies of young fish.

33. TRACHYSTOMATA. (Sirens.)

\section{FISHES.}

34. PEDICULATI. (Sea-bats or devilfish, goose-fish or angler, monse-fish, \&c.)

Useful products: Baits, (goose-fish.) D 1.

Injurious traits: Enemies of aquatic birds, (goose-fish.)

35. PLECTOGNATHI. (Sun-fish, rabbit-fish, porcupine-fish, swell-fish, box-fish, trunk-fish, cow-fish, file-fish, triggerfish.)

Useful products :

Food, (file-fish, trunk-fish.) D. 11.

Clothing, (helmets made from porcupine-fish.) D. 20.

Oils, used in medicine, (sun-fish.) D. 27.

Shagreen, (file-fish, trigger-fish.) D. 30.

36. LOPHOBRANCHIJ. (Sea-horse, pipe-fish.)

Useful traits: Aquarium use.

37. HEMIBRANOHII. (Suipe-fish, trumpet-fish, stickleback.)

Useful traits: Aquarium use, (sticklebacks.)

Injurious traits: Destroy eggs of other fishes.

38. TELEOCEPHALI :

Heterosonata, (soles, flounders, flatfish, turbot, halibut.'

Useful products :

Foods: Fresh. D. 1.

Smoked, (halibut.) D. 2.

Pickled, (halibut.) D. 3.

Baits, D. 5. 
38. TELEOCEPHALI-Continued.

ANACANIHINI, (cođ, pollock, haddlock, hake, ling, cusk, burbot, rockling, lance.)

Useful products :

Food: Fresh. D. 1.

Salted, wet, (cod,) (cods' sounds, tongues.) D. 3.

Salted, dry, (cod, haddock, hake.) D. 2.

Bait, (lance.) D. 5.

Isinglass, (cod, haddock, hake.) D. 24.

Leather, (N. W. coast Indians, cod.) D. 27.

Oil, (cod, haddock, hake, livers.) $\quad$ D. 30.

ACanthopteri, (Wolf-fish, blenuy, oyster-fish, toad-fish, lumpfish, sea-snail, gobs, sea-robin, gurnard, sculpin, sea-raven, Norway haddock or hemdurgan, red-fish, rock cod (west coast), black-fish, or tautog, cunner or chogset, parrot-fish, rurparous-fish (west coast), surgeon-fish, angelfish, chætodons, sword-fish, bayonet-fish, scabbard-fish, mackerel, cero, tunny, bonito, crevallé, pompano, pilot-fish, dolphin, butterfish, reak-fish, drum, eroaker, king-fish, whiting, bass, sheepshead, scup or porgy, grunts or pig-fish, black bass, sunfish, straw. berry bass, rock bass, perch, groupers, striped bass or rock-fish, blue-fish, tailor, cobia, remora, barracuda.)

Useful products :

Food: Fresh. D. 1.

Salted, wet, (sword-fish, mackerel, tunnies, pompanoes, blue-fish.) D. 2.

Baits. D. 5 .

lsinglass, (weak-fish, drum, \&c.) D. 24.

Oruament, scales, (parrot-tish, drum.) D. 14.

Injurious traits :

Poisonous, (barracuda, dolphin, \&c.)

Enemies of vessels, (sword-fish, bayonet-fish.)

Parasitic on useful fishes, (remora, toad-fish, aud sea-snail,

(on oysters and pectens,) \&c.)

Bait-thieres, (sculpins.) 
38. TELECOPHALI-Continued.

Percesoces. (Atherines, mullet.)

Useful products :

Food: Fresh. D. 1.

Salted, smoked, (mullet, mullet-spawn.) D. 2.

Salted, wet, (mullet.) D. 3.

Bait, (atherines.) D. 5.

Scales, (mullet.) D. 14.

Stantognathi. .(Gar-fish, flying-fish.)

Useful products :

Food: Fresh. D. 1.

Salted, smoked, (gar-fish, flying-fish.) 1.

HAPLoni. (Blind-fish, pike, pickerel, minnows.)

Useful products :

Food, (pike, pickerel.) D. 1.

Bait, (minnows.) D. 5.

Injurious traits :

Enemies of other fishes and of aquatic birds, (pikes, pickerels.)

IsospoxdiLI. (Capeliu, oulachan, smelt, white-fish, salmon, trout, tarpum, herring, menharlen, shad, alewiie or gaspereau, anchovy, \&c.)

Useful products:

Food: Fresh. D. 1

Salted, (shad, salmon, white-fish, herring, \&c.) D. 2.

Smoked, (herring, salmon, \&c.) D. 1.

Canned, (salmon, menharlen, sardines, \&c.) D. 1.

Eggs. D. 1.

Sauce, (anchory.) D. 3.

Oil,(salmon, oulachan, white-fish, menhaden, herring.) D.27.

Bait, (capelin.) D. 5.

Ornamental scales, (tarpum.) D. 14.

Guano, (menhaden, herring, \&c.) D. 31.

Modes of culture. E. 9.

Eventognathi. (Suckers, dace, buffalo-fish, carp, tench, \&c.)

Useful products :

Food. D. 1.

Bait. D. 5.

Artificial pearls. D. 29.

Modes of culture, (including domesticated species.) E. 9. 
39. NEMATOGNATHI. (Cat-fish, "bull-heads," \&c.)

Useful products :

Food. D. 1.

Guano, (cat-fish.) D. 31.

40. APODES. (Eels, congers.)

Useful products :

Food. D. 1.

Bait, eel-skins. D. 5 .

Leather, (eels.) D. 20.

41. CYCLOG ANOIDEI. (IIud-fish, or amia.)

42. RHOMBOGANOIDEI. (Gar-pikes.)

Useful products: Scales, used for arrow-tips. D. 14.

Injurious traits: Enemies of other fish.

43. SELACHOSTOMI. (Paddle-fish, or spoon-bill)

44. CHONDROSTEI. (Sturgeons.)

Useful products :

Foods: Fresh. D. 1.

Smoked. D. 1.

Eggs, pickled, (caviare.) D. 3 .

Chorda-dorsalis, dried, (reziga.) D. 2.

Isinglass, (sturgeon.) D. 24.

Oil. D. $2 \pi, T$.

Seales. D. 14.

Useful traits : Scavengers.

Injurious traits: Said to destroy eggs of white-fish.

\section{ELASHOBRANCHIATES.}

45. HOLOCEPHALI. (Chimsera, or ling of the herrings.)

46. RAIE. (Skates, rays, "deril-fish.")

4i. SQUALI. (Sharks.)

Useful products:

Food, (sharks, skates.) D. 1.

Bone, (slarks.) D. 9.

Oil, livers, (sharks, rays, \&e.) D. 2i.

Shagreen, (starks.) D. 20.

Injurious traits: Enemies of man and fishes. 


\section{MARSIPOBRANCHIATES.}

48. IIYPEROARTIA. (Lamprey-eels, or nine ejes.)

49. HYPEROTRETI. (Suckers, or hags.)

Useful products: Food, (lamprey-eels.) D. 1.

Useftul traits: Scarengers, (hags.)

\section{LEPTOCARDIANS.}

50. CIRROSTOMI. (Amphioxus.)

Modes of capture. D. 6.

\section{INSECTS.}

51. HEXAPODA. (Bees, butterflies and moths, flies, beetles, bugs and lice, grasshoppers and crickets, dragon flies and caddice flies.)

Useful products:

Food of aborigines.

Honey, (bees, \&c.) D. 1.

Wax, (bees, \&c.) D. 30.

Baits, (tlies, bees, dragonfflies, beetles and their larræ, gl'asshoppers, \&c.) D. 5, B. 45.

Silk, (moths.) D. 8.

(coloring material, (cochineal insect, \&c.) D. 29.

Blistering preparations, (Spanish-flies, \&e.) D. 30.

Wings used in the arts, (beetles.) D. 19.

Useful traits:

Puncture trees, producing galls, manna, lac, \&c.

Injurious traits :

Injurious to vegetation, (numerous species.)

Internal and external parasites, (flies.)

52. MYRIAPODA. (Centipedes, millipedes.)

Useful products: Food of aborigines, (eggs.) D. 1.

Injurious traits : Venomous, (centipedes, millipedes.)

\section{ARACHNEANS.}

53. ARACHNIDA. (Spiders, scorpions, mites, \&c.)

Useful products :

Fine threads used by opticians, (spiders.)

Silk, (spiders.) 
53. ARACHNIDA-Continued.

Useful traits: Destroy noxious insects, (spiders.)

Injurious traits :

Venomous, (scorpions.)

Parasites, (mites.)

\section{ARTHROPODS.}

54. CRUSTACEA. (Crabs, lobsters, shrimps, prawns, crawfish, limnoria, fish-lice, lernæans, sand and water fleas, barnacles, horseshoe crabs, \&c.)

Useful products :

Foods, (fresh and canned crabs, lobsters, shrimps, prawns, crawfish, lobsters.)

Baits, (crabs, lobsters, shrimps, prawns, \&c.)

Manures, (horseshoe crabs.)

Useful traits: Skeletou cleaners, (beach fleas, \&c.)

Injurious traits:

Parasites on fishes and marine mammals, (barnacles, fishlice, \&c.)

Destroy earthworks, dams, \&c., (crawfish.)

Destroy submerged timbers, (limnoria, \&e.)

Modes of protection against injurious species. E. 4 .

Methods of capture. D. $7,31,32$.

\section{WORMS.}

55. ANNELIDA. (Sipunculoids, leeches, earth-worms, serpalæ, seaworms, \&c.)

Useful products:

Food of aborimines, (earth-worms.) D. 1,2.

Baits, (earth-worms, sea-Torms.) D. 5.

Useful traits :

Used in surgery, (leeches.)

Used as barometers, (leeches.)

Injurious traits: External parasites of animals, (leeches.)

Methods of culture, (leeches.) E. 11.

56. SCCLLCIDA. (Tape-worms and flukes, planarians, nemerteans, trichinæ, thread-worms, rotifers, \&c.)

Injurious traits: Iuternal parasites, (nunerous species.) 


\section{MOLLUSKS.}

57. CEPHALOPODA. (Octopus, nantilus, argonauts, calamaries or squids.)

Useful products:

Food, (squids and their eggrs.) D. 1.

Bait, fresh and salted, (octopus, squids.) D. 1, 5.

Ink, sepia, (sepias.) D. 29.

"Bone," used as food for animals. D. 5.

"Bone," used in arts and manufactures. D. 19.

58. GASTROPODA. (Land-snails, sea-snails, whelks, limpets, \&c.;

Useful products:

Food, (numerous species.) D. 1, 2.

Bait, (limpets, \&c.) - D. 5.

Nacre, (top-shells, ear-shells, \&c.) D. 15.

Shell used in arts and manufactures. " D. 16.

Useful traits :

Carrion-feeders, (strombus and other siphonated genera.)

Food of useful animals.

lujurious traits:

Predatory on other mollusks, (murex, buccinum, natica, \&c.)

Injurious to vegetation.

59. CONCHIFERA. (Ordinary bivalve shells. ${ }^{1}$ )

Useful products :

Food, fresh, dried, and pickled, (numerous species.) D. $1,2,3$.

Baits, (clams, mussels, \&c.) D. 5.

Pearls and nacre, (river-mussels, pearl-ovsters, \&c.) D. 15.

Shell used in arts and manufactures. D. 16.

Injurious traits : Borers in wood and stone, (ship-worms, pholas, gastrochæna, date, shells, saxicava, ungulina, \&e.)

\section{RADIATES.}

60. ECHINODERMATA. (Sea-cucumber, sea-urchins, star-fishes, ophi-

Useful products : urans.)

Food, fresh, (sea-urchins and their eggss.) D. 1.

Food, dried, (bêches le mer.)

${ }^{1}$ Tunicata, brachiopoda, and bryzon are omitted, on account of their very remote usefulness. 
60. ECHINODERMATA-Continued.

Injurious traits:

Burrowers, (various echinoids.)

Destroyers of useful mollusks.

61. CALENTERATA. (Acalephs, polyps, \&c.)

Useful products: Coral, various species of polsps.) D. 17.

Injurious traits: Clog seines, weirs, and fishing-lines, (acalephs.)

\section{PROTOZOANS.}

62. RHIZOPODA. (Sponges and foraminifera.)

Useful products :

Food, "mountain meal," (foraminifera.) D. 1

Infusorial earths, (foraminifera.) D. 18.

Sponges, used in arts and manufactures. D. 26. 


\section{SECTION $\mathrm{B}$.}

(THE CHASE AND THE FISHERIES.)

\section{MEANS OF PURSUIT AND CAPTURE. \\ I. HAND MIPLEMENTS OR TOOLS.}

1. CLUBS:

* For striking.

a. Unarmed clubs:

Salmon-clubs, used by the Indians of the North west coast.

Other fishing-clubs.

Hunting-clubs.

b. Armed clubs:

Stone-headed clubs.

Clubs, armed with teeth or bone points.

Clubs, armed with metal points.

2. SLUNG-IVEIGHTS :

a. Slung-stones.

b. Slung shot.

c. ("Morning stars.")

d. ("Flails.")

3. KNIVES:

** For cutting.

a. Straight kuives:

Hunting-dirks and daggers.

Hunting-knives, scalp-knices, \&c.

Blubber-knives, aboriginal and recent.

Boarding-knives used by whalemen.

Whaleman's boat-knives.

Bowie-knives.

Flaying-knives, aboriginal and recent.

Splitting-knives.

Heading-knives.

Sailors' and fishermen's sheath-knives.

Hunters' sheath-knives.

Slivering-knives, used by fiskermen.

Oyster-knires. 


\section{KNIVES-Continued.}

a. Straight knives :

Mackerel rimmers or fatting knives.

(Swords, includiug the various forms incidentally used in hunting, sabers, cutlasses, machétes, creases, \&c.)

Stone and bone knives, used by Indians and Eskimos.

Skin scrapers and parers, used in preparing leather.

b. Clasp-knives :

Sailors' clasp-knives.

Hunters' clasp-kuives.

Clasp-dirks.

Jockey kuives.

4. AXES :

a. Axes, proper:

Tomahawlis.

Hatchets.

Whaleman's boat-liatchets.

Cleavers.

Axes, used by fishermen and hunters.

Head-axes for whalemen.

b. Cutting-spades:

Whale-spades:

Cutting-spades.

Throat-spades, flat and round shank.

TVide spades.

Half-round spades.

Head-spades.

Blubber-mincing knires.

Chopping-kuires.

*** For thrusting.

5. THRUSTING SPEARS AXD PRODS:

a. Fishing-lauces.

TThale-lances.

Thaleman's boat-spades, thick and thin.

Seal-lances.

Fish-]ances.

7. Hunting-spears.

c. Bayonets.

त. Prodding-awls, used in piereing the base of the brain in killing fish for the table. 


\title{
II. IMPLEMENTS FOR SEIZURE OF OBJECT.
}

* Scooping-instruments.

6. SCOOPS.

\author{
$\dagger$ For hand-use.
}

a. Shovels:

Clam-shovels.

Trowels used in taking burrowing shore animals.

Haud-scoops.

b. Hand-dredges, used in coliecting mollusks.

c. Pile-scrapers.

tt For use with sounding-lines.

d. Armed leads:

Common " deep-sea lead."

Deep-sea-sounding apparatus.

e. Cup-leads.

$f$. Scoop sounding-machines.

** Grasping-hooks.

7. HOOKED INSTRUMENTS. (Those used with a single motion, that of hooking:)

a. Single-pointed hooks:

Gaff-hooks.

Boat-hooks.

Jigs.

Rabbit and squirrel hooks, used by the Ute Indians.

Snake-hooks.

Clam-hooks.

Hoes and picks used in gathering shell-fish,

Forks used in handling salted and dried fish.

Whalemen's hooks :

Blubber-hooks.

Blubber forks.

Junk hooks.

Lance-hooks.

Can-hoolss. 
7. HOOKED INSTRUMENTS-Continued.

b. Many-pointed hooks :

Grappling-irons.

Lip hooks or grapnels, used by whaler's.

Toggles, used by whalers.

Oyster-rakes.

Clam-rakes.

Oulachan rakes or spears.

Squid-jigs.

c. Twisting-rods, used in drawing small mammals from their burrows.

8. BARBED IMPLEMENTS. (Those used with two motions, the first that of thrusting :)

a. Spears with fixed heads:

Harpoons.

One-flued harpoons.

Tiro-flued barpoons.

Toggle-harpoons.

Harpoon-bullets. (See under 23.)

Gun-harpoons.

Other whaleman's "craft."

Barbed spears, (with single point.)

Grains, (with two prougs.)

Gigs.

Bird-spears.

Otter-spears.

Sea-otter spears.

Seal-spears.

Walrus-spears.

Eel-spears.

Flounder-spears.

Sturgeon-spears, (rest coast.)

Octopus-spears.

Crab-spears, used in Rhode Island.

b. Spears with detachable heads:

Lily-irous.

Dolphin-irons.

Indian harpoons of shell and iron.

Eshimo harpoous of stone, bone, and iron. 
8. BARBED INSTRUMENTS-Continued.

b. Spears with detachable heads:

Indian fish-harpoons.

Other fish-harpoons.

(For accessory apparatus, see under 29.)

9. TONGS, \&c.

† For hand use.

a. Tongs (with two handles:)

Oyster-tongs.

Osster-rakes.

b. "Nippers," (with cord and handle.)

Snake-tongs.

Sponge-tongs.

Coral-tongs.

it For use with sounding-lines.

c. "Clamms" for deep-sea soundings, (forceps closed by a weight.)

(Ross's "Deep sea clamms.")

(Bull-dog sounding-machine.)

10. NOOSES.

*****asping-lines.

a. Jerk-snares :

† Stationary nooses.

Bird-snares.

Fish snares, of wire, gut, hair, \&c.

†† Thrown nooses.

b. Lariats and lassos:

Lariats with rope noose, made from hair, hemp, and rạnide.

Lariats with metal noose.

(Chilian bird-lariat.)

11. LOADED LINES. (Bolas.)

a. Bird-slings, used by Eskimos.

b. Bolas, with one or several weights.)

12. TANGLES.

***** Entangling lines.

a. Tangles :

Swab-tangles.

(Dredge-tangles, used by English collectors.)

Harrow-tangles.

Wheel-taugles. 


\section{HIISSILES.}

* Simple missiles, (those propelled by the unaided arm.)

13. HURLED WEIGHTS.

a. Stones and dises thrown by the hand.

b. Weights dropped from an elevation, (dead·falls, not antomatic.)

14. IU URLED STICKS.

a. Straight sticks :

Ulubs used as missiles.

b. Curred sticks:

Throw-sticks, used by the Moqui Indians of New Mexico in lunting rabbits.

(Boomerangs.)

1j. HURLED SPEARS.

a. Darts and lances.

** Centrifugal missiles. (Propelling pouer augmented by an artificial increase of the length of the arm.)

16. SLINGS AND SPEARS THROWN BY STRAPS.

a. Slings.

b. Spears, with straps used in throwing them.

17. MISSILES PROPELLED BY "THROWING-STICKS."

a. Spears with throwing-sticks, used by Eskimos:

Series of throwing or darting sticks.

*** Missiles propelled by a spring.-† Spring consisting of bent rod.

15. BOWS AYD ARROWS.

a. Bows :

Simple bows.

(Cross-bows.)

(Ballistas.)

b. Arrows:

Linuce-arrows.

Haripoon-arrows, used in fishing.

Blunt or club arrows, used in killing birds.

c. Accessories of bows and arrows:

Holders.

Quivers.

Arrow-head pouches. 
15. BOW'S AND ARROWS-Continued.

d. Implements of manufacture:

Flint-chipping apparatus.

Arrow-head sharpeners.

Shaft-gauges.

Cord-twisting apparatus.

Shaft-polishers.

Glue-sticks, used in fastening head of arrow.

新 Spring consisting of elastic cord.

19. INDIA-RUBBER SLINGS.

a. Pea-shooters, used in killing birds. .

辣 Spring consisting of metallic helix.

20. SPIING-GUNS.

a. Spring.guns.

**** Missiles propelled by the compression of air or uater.

21. AIR-GUNS.

a. Blow-guns, (missile propelled by the breath :)

Blow-guns carrying arrows.

Blorr-guns carrying balls.

b. Piston air-guns.

c. Reserroir air-guns:

Air.guns.

Air-gun canes.

22. WATER-GUNS.

a. Syringe-guns:

Humming-bird guns.

*******ire Firms.

23. GUNS AND PISTOLS.

a. Muzzle-loading arms :

With smooth bores:

Muskets. -

Fowling.pieces.

Cane-guns.

Pistols:

Single-barreled pistols.

lierolrers.

With grooved bores: Rifles.

Ritle-muskets.

Rifle-carbines.

Pistols. 
23. GUNS AND PISTOLS-Continued.

b. Breech-loading arms:

With swooth bores:

Fowling-pieces.

Pistols.

With rifled bores:

Muskets.

Hunting rifles.

Carbines :

Single-barreled carbines.

Rexolving carbines.

Pistols :

Pistols.

Revolvers.

c. Whaling-guns:

Bomb lance and gun.

Harpoon ball and gun.

Harpoon-gun.

Harpoon bomb-lauce gun.

24. (ACCESSORY.) AMMUXITION AND ITS PREPARATION.

a. Explosives:

Gunpowder.

Gun-cotton.

Percussion powder :

Daps.

Needle percussion.

Primers.

Wood powder.

Dynamite or giant-powder.

Nitroglycerine.

Dualine.

Lithofractenr.

Colonia powder.

Other explosires.

b. Missiles:

Bullets.

(Accessory) bullet-molds.

Shot.

(Accessory) methods of manufacturing shot. 
24. (ACCESSORY.) AMmUNITION, \&C.-Continued.

b. Missiles:

Explosive bullets, shells, \&c.:

Bomb-lance.

Meigs's shells.

c. Wadding:

Bulk wadding.

Prepared wads.

(Accessory) wad.cutters.

d. Ammunition-measures:

Measures.

$\left.\begin{array}{l}\text { Shot-measures. } \\ \text { Powder-measures. }\end{array}\right\}$ Attached to pouches and separate.

Weighing-scales.

e. Prepared ammunition :

Cartridges:

Ball-cartridges.

Shot-cartridges.

Wire-cartridges.

(Accessory) paper-shells.

(Accessory) metallic shells.

$f$. Nethods of preparing cartridges:

Loaders.

Crimpers.

Cappers.

25. ACCESSORIES OF LOADING, CLEANING AND REPAIR. ING, SIGHTING, AND TESTING FIRE-ARMS.

a. Instruments for cleaning, loading, \&c.:

Rammers.

Swabs.

Charge-drawers, "worms."

i. Sights, \&c. :

Muzzle-sights :

Plain sights.

Slit-sights.

Globe-sights.

Peep-sights.

Breech-sights :

Plain sights.

Graduating sights. 
25. ACCESSURIES OF LOADLNG, \&c.-Continued.

b. Sights, \&c. :

Telescope-sights.

Lerels, attached to guns

Wind-ganges.

c. Targets :

Practice-targets.

"Gyro-trap" targets.

Pigeon-traps and accessories of pigeon-sbooting.

๙. Recoil-checks.

26. FOR CARRYING ARMS AND AMMUNITION.

a. Ammunition-holders:

Powder-holders:

Horns.

Flasks.

Canisters.

Shot-holders :

Pouches.

Belts.

Cartridge-holders :

Pouches.

Boxes.

Belts.

Vests.

Cap-holders :

Pouches.

Boxes.

Cap-straps, used by Indians.

b. Weapon-holders:

Slings for arms :

Shoulder-slings.

Saddle-slings.

Holsters.

Belts :

Pistol-belts.

Racks and cases:

Gun-racks.

Gun-cases. 


\section{BAITED H00KS. ANGLING-TACKLE.}

\section{HOOKS WITH MOVABLE LINES.}

a. Tackle for surface-fishing:

Fly-fishing tackle.

Salmon-tackle.

Trout-tackle.

Black-bass tackle.

Shad-tackle.

Trolling-tackle :

Trolling-tackle.

Whiffing-tackle.

Drailing tackle.

Gangs of hooks for minnow-bait.

Surf-tackle for throwing and hauling:

Striped-bass tackle.

Redfish or bass tackle.

Bluefish tackle.

Tide drailing tackle:

Pasque and cuttyhunk bass-tackle.

乙. Tackle for fishing below the surface:

Short hand-gear :

Nackerel-gear.

Deep-sea gear:

Cod-gear.

Halibut-gear.

Flounder-gear.

Shark-gear.

Tautog-gear.

Other bottom-gear.

Bobs:

Eel-bobs.

28. HOOKS, WITH STATIONARY LINES.-SET TACKLE.

a. Surface lines:

Spilliards, or floating-trawl lines.

乙. Bottom-set lines:

Trawl-lines, or bull-tows. 
29. (ACCESSORY.) PARTS AND ACCESSORIES OF ANGLING. APPARATUS AND OF HARPOON AND SEINE LINES.

a. Hooks, including a full series of unmounted hooks, of recent and aboriginal manufacture.

Plain hooks :

Fly-hooks.

Trout-hooks.

Salmon-hooks.

Cod and halibut hooks.

Hooks for general use.

Bass-hooks.

Jigs and ìrails :

Mackerel-jigs.

Blue-fish drails of bone and metal of the rarious patterns, Newport, Noank, Providence, Provincetorn, \&c.

Block Island drails.

Pearl-squids of various patterns.

Bone-squids.

Metal-squids.

Petticoat-squids of flannel, \&c.

Spoon-baits, plain and fluted:

Bass-spoons.

Pickerel-spoons.

Trout-spoons.

Blue-fish spoons.

Other trolling-spoons.

Artificial flies on hooks :

Salmon-flies for each month.

Trout-flies for each month.

(Accessory.) Fly-books.

. Lines, (twisted and plaited:)

Sill-lines.

Grass-lines.

Linen-lines.

Cotton-lines.

Cotton-hemp lines.

Bark-lines.

Manila-lines.

Hide-lines. 
29. (ACCESSORY.) ANGLING-APPARATUS, \&C.-Continued.

b. Lines, (twisted and plated:)

Gut-lines.

Lines made from sea-weed, (Nereocystis Lütkeana,) and used by natives of Alaska.

(Lines of sea-weed, (Chorda filum,) used similarly in Scotland.) (Accessory.) Apparatus for twisting lines.

c. Snoods, leaders, and traces:

"Cat-gut," (sheep,) snoods, and leaders.

Silk-worm-gut snoods.

Salmon-gut snoods.

Flax-snoods.

Gimp-snoods.

Wire-suoods.

"Sil-straps."

d. Whalers' chains and lines:

Head chains and ropes.

Fin-chains.

Fluke chains and rings and ropes.

Head pike and ring.

(Accessory.) Blocks, pendants, cutting-blocks, \&c.

e. Sinkers :

Boat-shaped sinkers, plain and shearing.

Pipe-lead sinkers.

Bullet-siukers.

Plummet-sinkers, sugar-loaf, pear-shaped, and double-taper.

Banker-sinkers.

Seine-sinkers, of chain, lead balls, lead rings, stone, \&e.

(Accessory.) Molds for sinkers.

Jig-molds.

Other sinker-molds.

f. Spreaders :

Chopsticks.

One-armed chopsticks, or "revolving booms."

g. Floats :

Line-floats of wood, cork, and quill.

Harpoou-floats of bladder, inflated skir, and wood.

Seine-floats of cork, wood, glass, and rubber-tubing.

Keg and other floats for lobster-pots, gill-nets, \&e.

Whale-line drag. 
29. (ACCESSORY.) ANGLING-APPARATUS, \&C.-Continued.

h. Reels :

Simple reels for fly-fishing, with and without check.

Multiplying reels for bass-fishing, with and without check.

Other multiplying reels.

Gunwale-winches.

Dredge-line rollers.

Trawl-line rollers.

Seine-windlasses.

$i$. Line-holders :

Winders.

Spools.

Whaleman's line-tub.

Tulus for trawl-lines.

Seine-reels.

k. Rods:

Straight rods, of cane, wood, whalebone, \&c.:

Salmon-rods.

Trout-rods.

Bass-rods.

Pickerel-rods.

Other rods.

Folding-rods.

Tips of rubber, whalebone, \&c.

Tell-tales, used in trolling.

Tell-tales for fishing under the ice.

(Accessory) cases for rods and rod-tops.

l. Smirels:

Box-strirels.

Hook-swirels.

Pot-gauge smirel.

Codline swirels.

Traml buos-rope smirels.

m. Clearing rings.

n. Disgorgers. 


\section{NET'S.}

30. ENTANGLING-NETS.

a. Meshing-nets, (entangling in meshes:)

† BARRIER-NETS.

Rabbit-nets, used by Indians of the Sonthwest.

Bird mesh-nets.

Gill-nets, used in great lakes.

†े DRIFT-NETS.

+ Those drifting across the tide.

Shad gill-nets, used in southern rivers.

Bass gill-nets.

Salmon gill-nets.

Inullet gill-nets.

tt Those drifting along the tide.

Mackerel gill-nets.

Herring gill-nets.

b. Pocket-nets, (entangling in pockets:)

Trammel-nets.

31. ENCIRCLING-NETS.

a. Seines:

Seal-seines.

Manatee seines.

Shad-seines.

Mullet-seines.

Menhaden-seines.

Bass-seines.

Blue-fish seines.

Capelin-seines.

Herring-seines

Cod-seines.

Lance-bunts.

Baird collecting-seines.

Bait-seines.

"Fly-tail" seines of North Carolina.

b. Hoop-nets :

Handle, or dip-nets :

Bull-nets, (worked with ropes and blocks.) 


\section{ENCIRCLING-NETS-Contiuued.}

\section{b. Hoop-nets :}

Handle or dip-nets :

Scoop-nets, (herring-nets, pound-scoops, car-scoops, \&c.)

Landing-nets.

- Eskimo auk-nets.

Baited hoop-nets :

Crab-uets.

c. Trailing-nets :

Trawls :

Beam-trawl.

(Otter-trawl.)

Dredges :

Flange, or ordinary dredge.

Rake-diredge.

Osster-scraper.

(Coral-dredge.)

Towing-nets :

Surfuce tow-nets.

d. Folding or jerk nets :

Purse-nets :

Mackerel purse-seines, (pursed by reight.)

MenLarleu purse-seines, (pursed by hand-ropes.)

Cast-nets :

Mullet cast-nets.

Pompano cast-uets.

Bait cast-nets.

Clap-nets for birds.

Rabbit-spring nets.

Spring-reirs, (St. Lawrence.)

Sieve-traps, (for birds.)

e. (Accessory.) Parts of nets and apparatus for manufacture:

Raw material of nets.

Babiehe. (See under D. 20.)

Netting-fibre.

Nettiug-twine.

Netting-ueedles.

Miesh-rieedles.

Hanging-needles.

Eskimo netting-needles. 


\section{TRAPS.}

32. PEN-TRAPS.

a. Pocket-traps :

Pitfalls :

Pits, covered.

Barrel-traps.

Jar mole-traps.

"Rabbit.tipe," used in England.

Salmon-baskets, (Columbia Ricer.)

Salmon-weirs, (Upper Columbia River.)

River-weirs, with pockets:

Eel-traps.

Fish-slides :

Shad-slides, used in the rivers of North Carolina.

b. Labyrinth-traps:

Corrals.

Turkey-traps.

Weirs, or pounds:

Heart-pound.

Salmon-weir.

Virginia Indian weir, (figured by DeBry.)

Salmon hook-gill-net of the Saint Lawrence.

Funnel-traps :

Fish-pots.

Lobster-pots.

Eel-weirs, (with leaders.)

Eel-pots, (withont leaders.)

Barrel-pots, for eels.

West India wicker fish-p $\mathrm{c}$ 。

Set-nets.

Fykes, (set-nets with leaders.;

Bass-traps.

c. Door-traps :

$\dagger$ Closed by the falling of a door.

Box-traps.

Rabbit-traps, (figure 4.)

Brick traps, (figure 4.) 
32. PEN-TRAPS-Continued.

c. Door-traps :

Box-traps :

Musquash traps, with hanging doors.

Rabbit-traps, for mouth of burrows.

Self-setting box-traps.

Double box-traps.

Spring-door traps.

t† Closed by falling of whole trap.

Bowl-traps.

Cob-house bird-traps.

Pigeou-nets.

it十 Closed by falling of tide.

Bar-weirs.

d. Sheaf-traps:

Sheaf-traps, (New York Harbor.)

33. CLUTCHING-TRAPS.

a. Noose-traps :

Suares :

Footpath-snares.

Barrier-suares.

Springes.

"Round mouse-traps."

b. Jawed traps:

"Steel traps:"

Newhouse traps:

No. 0. Rat-trap.

No. 1. Muskrat trap.

No. $1 \frac{1}{2}$. Mink-trap.

No. 2. Fox-trap.

No. 3. Otter-trap.

No. 4. Bearer-trap.

No. $4 \frac{1}{2}$. Deer-trap.

No. 5. Small bear-trap.

No. 6. Great bear-trap.

Spring bird-nets.

(French bird-trap.) 
34. FALL-TRAPS.

a. Crushing-traps :

Deadfalls.

Figure-four traps.

b. Piercing-traps :

Spear-falls.

Mole-traps.

Harpoon-traps.

c. Spring-hooks :

Pickerel-hooks.

35. MISSILE-TRAPS.

a. Cross-bow traps.

b. Spring-guns.

36. ADHESIVE PREPARATIONS.

a. Bird-lime, \&c.

b. Hoods, boots, \&c.

\section{APPARATUS FOR WHOLESALE DESTRUCTION.}

37. POISONS.

a. Food poisons :

Phosphorus poisons.

Strychnine.

Arsenic.

Corrosive sublimate.

Cyanide of potassium.

Opium poisons.

b. Blood poison: Woorara

38. ASPHYXIATORS.

a. Apparatus for smoking.out.

b. (Apparatus for suffocating with fumes of sulphur.)

c. Apparatus for drowning-out.

39. TORPEDOES.

391. STOMACH-SPRINGS.

a. Eskimo whalebone springs, used in killing bears.

\section{HUNTING-ANIMALS.}

40. HUNTING-MAMMALS.

a. Dogs.

b. Hunting-leopard. (Cynailurus jubatus.) 
40. HUNTING-MAMMALS-Contiuned.

c. Weasels and ferrets.

d. Otters.

41. ACCESSORILS TO HUNTING-DOGS.

a. Dog-whips.

b. Dog-whistles.

c. Dog-collars.

d. Dog-food.

e. Dog.carts.

f. Dog-inuzzles.

42. HUNTING-BIRDS.

a. Falcons.

b. Owls.

c. Cormorants, (Carbo sinensis, used in fishing in China.)

43. ACCESSORY TO HUNTING-BIRDS.

a. Hoods.

b. Perches.

c. Cormorant-collars.

44. HUN'TING-FISHES.

a. Remor: used in West Indies and Australia.

\section{DECOYS AND DISGUISES.}

45. BAITS.

a. Natural baits:

Flies and other insects. (This should include a collection of those insects which, as the farorite food of fishes, are imitated in making artificial flies.)

Worms.

Mollusks.

Salted baits, (prepared.)

Menbaden.

Herring.

Squids.

Clams, long.

Clams, hen.

Pea-roe of cod, (used in French sarline-fisheries, and largely exported.)

Grasshopper paste, used as a suhstitute f(r pea-roe.

Tolling baits, "stosb," Sc. 
45. BAITS-Continued.
a. Natural baits:

(Accessory; methods of preparing baits :

Bait-cutters.

Bait-mills.

Bait-ladles.

Wheelbarrows for bait-clams, (Nantucket.)

Bait boxes and cans.

Bait-needles.

b. Artificial baits:

Trolling-spoons.

Spinners.

Squids and jigs.

"Bobs," used in southern waters.

Artificial flies.

c. Accessory to $b$ :

a. Fly-books.

b. Raw materials for making artificial flies.

c. Tools for making artificial flies.

d. Pastes.

16. DECOYS.

a. Scent-decoys.

b. Sound-decợs:

Animal calls, whistles, \&c.

Bird-calls.

c. Sight-decoys:

Living decoy animals and birds.

Decoy-dogs, used in hunting ducks.

Stool-pigeons.

Tame decoy-ducks.

Tame decoy-brants.

Imitations of animals and birds :

Decoy swimming-birds.

Decoy-waders.

Imitations of fishes:

Lare-fish used in taking Mackinaw trout.

Blanket-decoys, (for antelopes.)

Lanterns and other apparatus for fire-hunting and fishing,

Lanterns for still-hunting. 
46. DECOYS-Continued.

c. Sight-decoys :

Lanterns for weequashing, or fire-fishing, for eels. Jack-lanterns for tishing.

47. COVERS.

a. Movable covers :

Masks :

Deer heads and antelope heads.

Movable copses.

Covers for hunter.

Covers for boats.

b. Stationary covers:

Hunting-lodges.

\section{PURSUIT, ITS HETHODS AND APPLIANCES.}

48. METHODS OF TRANSPORTATION.

a. Personal aids:

Snow-shoes.

Skates.

Alpenstocks and stares.

Portable bridges.

b. Animal equipments:

Harness :

Horse-trappings.

Dog-barness.

Girths, sinches.

Bits, cabrestos, spurs.

Saddles:

Riding-saddles.

Pack-saddles.

Aparejos.

Riding-pads, (for buffalo-hunting.)

Furpack-saddle, (Hudson's Bas Territory.)

Vehicles :

Deer-sledges.

Dog-sledges.

Wagons.

Dog-carts.

Fish-carts, used in Nantucket. 
48. METHODS OF TRANSPOR'TATION-Continued.

c. Boats :

Hunting-boats, fishing-boats :

Birch canoes.

Canoes used by Indians of the northwest coast in whaling.

Kraks or bidarkas.

Umiaks or bidarras.

Indian raft-boats.

Launches.

Dug-outs.

Portable (paper and canvas) boats.

Duck-boats.

Scows.

Oyster-boats.

Whale-boats.

Seine-boats, (sea use.)

Seine-boats of the lakes.

Potomac seine-boats.

Dorys, sharpies, and dingies.

Pound-boats of the lakes.

Italian fishing-boats, (California.)

Pinkies, (Martha's Vineyard.)

Adirondack boats.

Alexandria Bay boats.

Surf-boats.

Whitehall boats.

Osster-canoes.

Ducking-boats.

Cat-rigged fisbing-boats.

Mackerel-smacks.

Oyster-smacks.

Menhaden-smacks.

Menbaden-carryaways.

Bank cod-smacks.

Smacks with wells, used near the coast.

Smacks employerl in fish-trade.

Whale-ships.

sealers. 


\section{METHODS OF TRANSPORTATION-Continued.}

c. Boats :

Herring-boats.

Mackinaw boats.

Huron boats.

Norwegian boats.

Used in the Great Lake fisheries.

Pound-boats.

Oyster-pungies, (canoe and square-sterned,) employed on the Chesapeake.

Oyster police-boats.

\section{Steamers :}

Mackerel-steamers.

Menhaden steam-mills.

Lake gill-net steamer.

Whale-steamers.

Sealing-steamers, \&c.

Accessory to fishing-ressels :

Rigging, masts, sails, cordage, pullers, sockets.

Anchors, killicks, chains.

Sail-needles, palms, fids, marline-spikes.

Oar-locks, chocks, oar-rests.

Stepping-irons for whale-boats.

Crotchès and oar-rests.

Paddles and oars.

Rudder-heads, wheels, tillers, \&c.

Fog.horns, trumpets, drums, \&c.

Cabin, blubber-room, cooks' and binnacle lamps and jacket-lamps, signal, binnacle, and common lanterns.

Compasses, barometers, \&c.

Astronomical instruments, sextauts, quadrants, chro nometers, hour and log glasses.

49. CAMP.OUTFIT.

a. Shelter :

Lodges.

Tents.

Huntrug camps.

Hunters' houses.

Fishing-houses. 
49. CAMP-OUTFIT-Contmued.

b. Furniture:

Hammocks.

Beds, couches, stretchers, and lounges.

Blankets, rubber and Mackinaw, and fur robes.

Fuel.

Apparatus for kindling fire.

Lamps and lanterns.

Tools.

c. Commissary supplies:

Cooking-apparatus, ketules, and stores. .

Table-furniture.

Preserved meats, \&c.

50. PERSONAL EQUIPMENTS.

a. Clothing:

Hunting-suits.

Cloth-suits.

Skin-suits.

Water-proof suits.

Oil-skin suits.

Boots, moccasins, leggings.

Water-proof boots.

Wading boots and stockings.

Riding-boots.

Moccasins.

Leggings.

Eats and caps.

Protection from insects:

Nets for beds and for face.

Ointments, (such as tar and sweet-oil.)

Smudges, (such as pyrethrum powder.)

Shields, breastplates, and defensive armor.

b. Trappings :

Belts.

Cross-belts.

- Game-bags.

Game and fish baskets and siings.

Wallets for lines and other tackle. 
50. PERSONAL EQUIPMENTS-Continued.

c. Optical instruments, \&c. :

Snow-goggles.

Telescopes.

Field-glasses, \&c.

Water-telescopes.

d. Medical outfit :

Medicine-chests.

Hunters' and fishermen's flasks.

e. Artificial lights :

Lanterns for camp and ship use.

Torches. 


\section{SECTION C. METHODS OF PREPARATION. \\ I. PREPARATION AND PRESERVATION OF FOOD}

1. PRESERTATION DURING LIFE, (see under E, 3.)

2. PRESERVATION OF FRESH MEATS.

a. Refrigerators :

Ice.boxes and refrigerators.

Refrigerator-cars.

(Accessory.) The ice-trade:

lce cutting and handling apparatus.

Ilethods of manufacturing artificial ice.

Ice-houses.

b. Other accessories of preservation:

Meat-hooks.

Skewers, \&c.

Carring-tools.

3. PRESERVATION BY DRIING.

a. Sun-drying apparatus:

Beach dryers.

Flake-drying:

Newfoundland Hakes.

Massachusetts flakes.

Covers for fish-drying.

b. Smoke-drying apparatus:

Herring smoke-houses.

Halibut smoke-houses.

Salmon smoke-houses.

Sturgeon smoke-houses.

Aboriginal drying-houses.

Methods of drying haliotis, used by the Indians of California. 
4. PRESERVATION BY UANNING AND PICKLING.

a. Salting fish :

Knives, (see under B, 2.)

Scaling-apparatus.

Tables, tubs, \&c.

Barrels.

(Accessory.) Salt:

Specimens of the salts used in preserving ish.

Model of salt-mills used on Cape Cod in former days.

b. Canning meats:

Model of salmon-canning establishment.

Model of sardine-factory.

(Accessory.) Cotton-oil, and its manufacture.

Model of lobster-canning factory.

iIodel of oyster-canning factory.

5. PREPARATION OF BAITS.

a. Bait-mills, knires, choppers, \&c., (see under B, 2 and 3.)

b. Bait tubs, rats, se.

II. HANUFAOTURE OF TEXTILE FABRICS, FELTS, AND STUFFINGS.

6. PREPARATION OF WOOL AND HAIR OF MAMMALS.

a. Preparation of wool cloths:

Washing.

Shearing.

Stapling or assorting.

Scouring.

Combing, carding, and plucking.

Spinning and reeling.

Wearing.

Fulling and teazling.

Cropping.

Pressing.

b. Weaving worsted cloths.

c. Felting and the hat manufacture:

Buwing.

Pressing.

Stopping. 
6. PREPARATION OF IVOOL, \&c.-Continued:

c. Felting and the hat manufacture:

Rolling-off.

Shaping.

d. Preparation of curled hair for stuffings.

7. PREPARATION OF WHALEBONE.

a. Preparation of stuftings.

S. PREPARATION OF FEATHERS.

a. Preparation of down for stuffings.

b. Preparation of feather fabrics.

c. Preparation of "brillantine."

d. Preparation of or flocking for wall-paper, from refuse quills.

$e$. Preparation of fibres for manufacture of plush carpets.

9. PREPARATION OF SILK OF INSECTS.

a. Preparation of silk of silk-worms :

Boiling the cocoons.

Reeling.

Spinning.

Djeing.

Weaving.

10. PREPARATION OF SOFT PARTS OF OTHER INVERTE. BRATES.

a. Preparation of silk from byssus of Pinna.

b. Preparation of sponge stuffing.

\section{PREPARATION OF THE SKIN AND ITS AP- PENDAGES.}

11. CURRIING OF LEATHER.

a. Processes of currying:

Dipping.

Graining.

Scraping.

Dressing.

b. Implements employed by curriers:

"Head-knives."

"Pommels."

"Stretching-irons."

"Round-knives."

"Cleaners." 


\section{CURRYING OF LEATHER-Continued.}

b. Implements employed by curriers:

"Maces."

"Horses," or trestles.

"Dressers."

"Treading-hurdles."

c. Eskimo and Indian currying methods and implements.

d. Methods of dressing gut and sinew.

12. LEATHER-DRESSING.

a. Processes of tanning leather:

Soaking.

Liming.

Tamning.

b. Processes of taming or oil.dressing leather:

Soaking.

Liming.

Oiling.

c. Apparatus of leather-dressing, recent and aboriginal.

13. FUR-DRESSING.

a. Processes of fur dressing:

Currying. (See under 12.)

Scouring.

Tanning.

Lustering.

Plucking and dyeing.

14. FEATHER-DRESSING.

a. Method of preparing ornamental feathers:

Scouring.

Bleaching.

Washing.

Azuring.

Sulphuring.

Seraping.

Dyeing.

b. (Art of plumagery.)

15. MAYUFACTURE OF QUILL ARTICLES.

a. Manufacture of quills for pens :

Sand-bath drçing and steaming.

Polishing. 
15. MANUFACTURE OF QUILL ARTIULES-Continued.

a. Manufacture of quills for pens :

Dseing.

Shaping.

b. Manufacture of tooth-picks.

c. Manufacture of floats and other articles.

d. Manufacture of quill brush-bristles.

16. HAIR AND WOOL WORK.

\section{PREPARATION OF HARD TISSUES.}

1i. IVORY CUTTING AND CARVING.

a. Manufacture of haudles, triukets, billiard-balls, \&c.:

Turning and sawing.

Polishing.

Bleaching.

b. Manufacture of organ and piano keys:

. Sawing.

Strip-sawing.

Polishing.

Bleaching, \&c.

c. Other processes.

18. PREPARATION OF HORN AND HOOF.

a. Steaming.

b. Pressing.

19. PREPARATION OF WHALEBONE.

a. Cutting and other processes.

b. Manufacture of whip-makers' stock and whips.

c. Manufacture of umbrella-maker's bone.

d. Manufacture of ribbon-weaver's bone.

e. Manufacture of hat aud bonnet maker's bone.

$f$. Manufacture of suspender-maker's bone.

g. Manufacture of stock-maker's bone.

h. Manufacture of dress and stay maker's bone.

$i$. Manufacture of billiard-table cushions.

k. Manufacture of surgical instruments.

l. Manufacture of whalebone-brushes.

$m$. Manufacture of rosettes, woven-work, and trinkets.

n. Other whalebone manufactures.

26). PREPARATION OF TORTUISE-SHELL. 
21. PREPARATION OF FISH-SCALE WORK.

22. PREPARATION OF NACRE.

23. PREPARATION OF CORAL.

24. PREPARATION OF OTHER HARD TISSUES

\section{OILS ANI) GELATINES.}

25. EXTRACTION OF WHALEOIL, (WITH MODELS OF TRYWORKS, CLARIFYING.VATS, \&C.)

a. Preparation of body.oil:

Cutting in and stowing.

Leaning and mincing.

Trying.

Bailing.

Cooling.

Barreling.

Refining.

b. Preparation of head-oil.

c. Preparation of spermaceti.

d. Instruments and appliances of rendering whale oil :

Boarding-knives.

Leaning-kuives.

Mincing-horse and mincing-kuives.

Nincing.tub.

Mincing-machine.

Blubber-fork.

Try-pots.

Fire-pike.

Stirriug-pole.

Scrap-hopper.

Slimmer.

Bailer.

Cooler.

Deck-pot.

Casks.

26. EXTRACTION OF OTHER MAMIAL OILS.

27. EXTRACTION OF BIRD AND REPTILE OLLS.

28. EXTRACTION JF FISH.OILS, (WITH MODELS OF BOILERS, PRESSES, CLARIFIING.TATS, \&C.)

29. EXTRACTION OF GLUE, GELATINE, AND ISINGLASS. 


\section{DRUGS, PERFUHES, AND CHEMICAL PRODUCTS.}

30. MANUFACTURE OF PEREUMES.

31. MANUFACTURE OF IVORY.BIACK.

32. MANUFACTURE OF PRUSSIATES.

33. MANUFACTURE OF MUREXIDES.

34. PREPARATION OF COCHINEAL COLORS.

35. MANUFACTURE OF INKS FROM ANIMAL SUBSTANCES.

36. PREPARATION OF ALBUMEN.

37. MANUFACTURE OF PEPSIN.

38. MANUFACTURE OF PHOSPHORUS.

39. MANUFACTURE OF SAL AMMONIAC.

40. MANUFACTURE OF AMMONIA.

41. MANUFACTURE OF ALBUMEN PREPARATIONS.

42. MÃNUFACTÚRE OF PROPYLAMINE.

43. MANUFACTURE OF FORMIG ACID.

44. IINUFACTURE UF CARBAZOTATES.

\section{MANUPACTURE OF FERTLLIZERS.}

45. PREPARATION OF GUANO.

a. Model of fish-guano rorks:

Grinders and pulverizers.

Mixers.

Guano in its various stages, with its ingredients, South Carolina phosphates, Navassa phosphates, scrap, (crude, and dried,) sulphuric acid, kainite, screened and unscreened guano, and sea-weed used in preparation.

\section{VII.. LIMES.}

46. BURNING OF LIME.

a. Models of kilus for burning shells.

\section{PRESERVATION OF THE ANINAL FOR SCIEN- TIFIC USES.}

47. APPARATUS FOR MAKING AND PRESERVING ALC?HOLIC SPECIMENS.

a. Tanks and jars :

Agassiz collecting-tank. 
47. APPARATUS FOR MAKING AND PRESERVING ALCO HOLIC SPECIMENS-Continued.

a. Tanks and jars :

Army collecting-tauk.

Museum storage-tank, Agassiz model.

Anatomical jars.

Self-sealing jars, used in collecting.

Phials.

Tube-phials.

b. Syringes for injecting.

c. Iuflatable bags.

d. Preservative mixtures:

Alcohol.

Glycerine.

Carbolic acid.

Chloral hydrate.

Picric acid.

Osmic acid.

e. Labels :

Metallic labels.

Parchment labels.

Indelible inks, pencils, \&c.

48. APPARATUS FOR PRESERVING AND MAKING SKELE TONS.

a. Preparation of the bones:

Macerating-vats.

Boilingु-vats.

Cleansing and bleaching preparation.

b. Mounting of the bones:

Scrapiug-tools.

Articulating-tools.

49. APPARATUS FUR IIAKMG CASTS. MODELING.

a. Materials :

Clays.

Plasters.

Glues.

Pupier-maché and carton pierre.

Gelatine.

Paraffine.

Collodion. 
49. APPARATUS FOR MAKING CASTS, \&c.-Continued.

b. Frames and modeling tools.

c. Molds :

Of plaster.

Of gelatine.

of paper.

Of parafine.

50. APPARATUS AND METHODS OF MAKING AND MOUNT ING SKINS. TAXIDERMY.

a. Tools :

Flasing-tools.

Seraping-tools.

Taxidermists' tools for stuffing:

Forceps.

Pliers.

b. Preservatives and insect-powders:

Arsenic and arsenical soap.

Corrosive sublimate.

Salt, alum, \&c.

Persian insect-powder.

Syringes for application of insect-powder.

Tobacco, snuff, used as preservatives.

c. Frames, \&c. :

Wooden frames.

Wire frames.

Plaster model-bodies.

51. (ACCESSORY.) PHOTOGRAPHIC ANI) OTHER DELINEAT' ING APPARATUS.

a. Photographic apparatus:

Lenses.

Cameras and fittings.

Camera tripods and stands, with model.

Fish Commission stands.

Plates, and their results :

Wet plates.

Dry plates.

Dark closets.

b. Camera obscuras.

c. Mechanical delineators.

d. Methods of heliotyping and engraving illustrations. 



\section{SECTION D. \\ ANIMAL PRODUCTS AND THEIR APPLI- CATIONS. \\ I. Fools.}

\section{FOODS IN A FRESH CONDITION.}

This section may include specimens of the marketable animals in a fresh condition in refrigerators.

For convenience in making up and arranging this portion of the collection, a list is appended of the animals used as food in the United States. Many others are available, but for various reasons are not commonly eaten.

a. Mammals :

Grizzly bear, (Ursus horribilis.)

Black bear, (Ursus americanus.)

White bear, (Thalarctos maritimus.)

Raccoon, (Procyon lotor.)

Buffalo, (Bison americanus.)

Musk-ox, (Ovibos moschatus.)

Mountain goat, (Mazama montana.)

Mountain sheep, (Ovis montana.)

Antelope, (Antilocapra americana.)

Moose, (Alccs malchis.)

Woodland caribou, (Tarandus rangifer, subsp. caribou.)

Barren-ground caribou, (Tarandus rangifer, subsp. gronlandicus.)

Elk or wapiti, (Ccrvus canadcnsis.)

Virginia deer, (Cariacus virginianus.)

Mule-deer, (Cariacus macrotis.)

Black-tailed deer, (Cariacus columbianus.)

Peccary, (Dicotyles torquatus.)

Ianatee, (Trichechus manatus.)

Fox squirrel, (Sciurus cinercus.)

Gray squirrel, (Sciurus carolinensis.) 


\section{FOODS IN A FRESH CONDITION-Continued.}

a. Mammals :

California gray squirrel, (Sciurus fossor.)

Tuft-eared squirrel, (Sciurus Aberti.)

Red squirrel, (Sciurus hudsonius.)

Flying squirrel, (Sciuropterus volucella.)

Woodchuck, (Arctomys monax.)

Marmots, (Arctomys caligatus and faviventer.)

Polar hare, (Lepus timidus, var. arcticus.)

Prairie hare, (Lepus campestris.)

Northern hare or white rabbit, (Lepus americanus, and $L$. americanus var. virginianus.)

Red hare, (Lepus amcricanus, rar. W'ashingtoni.)

Baird's hair, (Lepus americanus, rar. Bairdii.)

Gray hare or gray rabbit, (Lepus syluaticus.)

Sage rabbit, (Lepus sylvaticus, var. Nuttalli.)

Audubon's hare, (Lepus sylvaticus, rar. Auduboni.)

Trowbridge's hare, (Lepus Troubridgei.)

Jack rabbit or mule rabbit, (Lepus callotis.)

Califoruia hare, (Lepus californicus.)

Marsh hare, (Lepus palustris.)

Water hare, (Lepus aquaticus.)

Opossum, (Didelphys virginiaua.)

b. Birds :

Reed bird or rice bird, (Dolichonyx nxyzirorus.)

Wild pigeon, (Ectopistes migratorius.)

Turkes, (Mcleagris galloparo.)

Wild turkey, (Mcleagris galloparo, var. americana.)

Spruce grouse, (Tctrao canaderisis.)

Dusky gronse, (Tctrao obscurus.)

Sige cock, (Centrocercus urophasianus.)

Sharp-tailed gronse, (Pcdiocetes phasianellus.)

Prairie gronse or prairie hen, (Cupidonia cupido.)

Ruffed grouse, (Bonasa umbcllus.)

Snow ptarmigan, (Lagopus albus.)

Tock ptarmigan, (Lagopus vupestris.)

White-tailed ptarmigan, (Lagopus lencurus.)

Bob-white or "quail," (Ortyx virginianus.)

Plumed partrilge, (Oreortyx pictus.) 


\section{FOODS IN A FRESH CONDITION-Continued.}

b. Birds :

California partrilge, (Lophortyx californicus.)

Gambel's partridge, (Lophortyx Gumbeli.)

Scaled partrilge, (Callipepla squamata.)

Massena partridge, (Cyrtonyx massena.)

Black-billed plorer, (Squatarola helvetica.)

Golden plover,(Charadrius fulvus var. virginions.)

Kildeer plover, (Aegialitis vociferus.)

Wilson's plover, (Aegialitis wilsonius.)

Ringneck plover, (Aegialitis semipalmatus.)

Piping plover, (Aegialitis melodus.)

Stilt sandpiper,(Micropalama himantopus.)

Ruddy plorer, (Calidris arenaria.)

Woodeock, (Philohela minor.)

American snipe, (Gallinago wilsoni.)

Red-breasted snipe, (Macrorhamphus griscus.)

Willet, (Totanus semipalmatus.)

Tell-tale, (Totanus melanoleucus.)

Yellow-shanks, (Totamus flavipcs.)

Upland piover, (Astiturus bartramius.)

Long-billed curlew, (Numenius longirostris.)

Hudsonian curlew, (Numenius hudsonicus.)

Eskimo curlew, (Numenius borealis.)

Clapper rail, (Rallus longirostris.)

Marsh hen, (Rallus elegans.)

Virginia rail, (Rallus virginienus.)

Carolina rail, (Porzana carolina.)

Jellow rail,(Porzana noveboracensis.)

Trumpeter-swan, (Cygnus buccinator.)

Whistling swan, (Cygnus americanus.)

White-fronted goose, (Anser albifrons.)

Snow goose, (Anser hyperboreus.)

Brant, (Branta bernicla.)

Canada goose, (Branta canadensis.)

Mallard, (Anas boschus.)

Black duck, (Anas obscuru.)

Pintail duck, (Dafila acuta.)

Gray duck, (Chaulelasmus streporus.) 


\section{FOODS IN A FRESH CONDITION-Continued.}

b. Birds:

Widgeon or bald pate, (Mareca americana.)

Green-winged teal, (Querquedula carolinensis.)

Blue-winged teal, (Querquedula discors.)

Red-breasted teal, (Querquedula cyanopter $a$.)

Shoreller, (Spatula clypeata.)

Wood duck,(Aix sponsa.)

Big black-head, (Fuligula marila.)

Little black-head, (Fuligula affinis.)

Ring-necked duck, (Fuligula collaris.)

Red-head, (Fuligula ferina, var. americana.)

Canras-back, (Fuligula vallisneria.)

Golden-eje, (Bucephala clangula.)

Barrow's golden-eje, (Bucephala islandica.)

Butter-ball, (Bucephala albeola.)

Long-tail duck, (Harelda glacialis.)

Harlequin-duck, (Histrionicus torquatus.)

Eider duck, (Somateria mollissima.)

King eider, (Somateria spectabilis.)

Scoter, (Edemia americana.)

Velret duck, (Edemia fisca, rar. velvetina.)

Surf duck, (Edemia perspicillata.)

Long-billed scoter, (UEdemia perspicillata rar. Troucbridlyci.)

Ruddy luck or bar duck, (Erismatura rubilla.)

Sheldralie, (Mergus merganser.)

Red-breasted merganser, (1Mergus serrator.)

Hooded merganser,(Mergus cucullatus.)

c. Rieptiles:

Gopher tortoise, (Testudo carolina.)

Diamond-back terrapiu, (Malacoclemmys pulustris.)

Red-bellied terrapins, (Pseudemys rugosa.)

Florida river terrapin, (Pseudemys concinna.)

Alligator turtle, (Macrochelys lacertina.)

Suapping turtle,(Chelydra serpentina.)

Soft-shell, or leather-back turtle, (Aspidonectes ferox, \&u.)

Greeu turtle, (Chelonia mydas.)

Pacific green turtle, (Chelonia virgata.)

Loggerhead turtle, (Thalassochclys caouana.) 


\section{FOODS IN A FRESH CONDITION-Continued.}

d. Amphibians :

Frogs, (Rana catesbiana, clamitans, \&c.)

e. Fishes, (eastern coast:)

File fish, (Batistes capriscus.)

American sole, (Achivus lineatus.)

Flat fish, (Pseudopleuronectes amcricanus.)

Smooth flounder, (Pleuronectes glaber.)

Sand flounder, (Lophopsctta maculata.)

Flounder, (Chanopsetta ocellaris.)

Southern flounder, (Chcenopsetta dentata.)

Four-spotted flounder, (Chcenopsetta oblonga.)

Halibut, (Hippoglossus americanus.)

Newfoundland "Turbot," (Reinhardtius hippoglossoides.)

Pollack, (Pollachius carbonarius.)

Cod, (Gadus morrhua.)

Tom-cor, or frost fish, (Microgadus tomcodus.)

Haddock, (Melanogrammus ceglefinus.)

Hake, (Phycis chuss.)

Squirrel hake, (Phycis tenuis.)

Cusk, (Brosmius americanus.)

Whiting, (Merlucius bilinearis.)

Norway haddock, (Sebastes norvegicus.)

Rose fish, (Sebastes viviparus.)

Tautog, or black-fish, (Tautoga onitis.)

Chogset, or cunner, (Tautogolabrus adspersus.)

Hog fish, (Lachnolcemus falcatus.)

Angel fish, (Holacanthus ciliaris.)

Sword fish, (Xiphias gladius.)

Spear fish, ( Tetrapturus albidus.)

Sail fish, (Histiophorus americanus.)

Mackerel, (Scomber scombrus.)

Chub mackerel, (Scomber colias.)

Bonito, (Sarda pelamys.)

Horse mackerel, (Orcynus secundi-dorsalis.)

Spanish mackerel, (Cybium maculatum.)

Cero, (Cybium cabalia.)

Striped cero, (Cybium regale.)

Crevallé. (Carangus hippos and Parutractus pisquetus.) 


\section{FOODS IN A FRESH CONDITION-Continued.}

e. Fishes, (eastern coast:)

Pompano, (Trachynotus carolinus.)

Short pompano, (Trachynotus ovalus:)

Butter-fish, (Poronotus triccanthus.)

Squeteague, (Cynoscion regalis.)

Spotted squeteague, (Cynoscion carolincnsis.)

Drum, (Pogonias chromis.)

Spot, (Liostomus obliquus.)

Silver perch, or yellow-tail, (Bairdiella punctata.)

Red fish, or spotted bass, (Scicnops ocellatus.)

King fish, (Menticirrns nebulosus.)

Solithern king fish, or Bermuda whiting, (Menticirrus albur nus.)

Croaker, (Micropogon undulatus.)

Sailor's choice, (Lagodon rhomboides.)

Sheeps-head, (Archosargus probatocephalus.)

Scuppang, or porgy, (Stenotomus argyrops.)

Grunts, (Hemulon nrcuetum, \&e.)

Gray suapper, (Lutjanus caxis.)

Red suapper, (Lutjanus aya.)

Gromper, (Epinephelus morio.)

Spotted grouper, (Epinephelus guttatus.)

Jew fish, (Promicrops ynasa.)

Sea bass, (Centropristis utrarins.)

Squirrel, (Diplectrum fusciculare.)

Striped bass or rock fish, (Roceus lineatus.)

White perch, (Mornue americana.)

Moon fish, (Parephippus quadrutus and P. faber.)

Triple-tail, (Lobotes surinamensis.)

Blue fish, (Pomatomins saltutrix:)

Striped mullet, (Mugil lineutus.)

Silver-sides, (Chirostoma notatum.)

Silver gar tisl,, (Belone longirostris.)

Skipper, (Scomberesox scutellatus.)

Mummichogs, (Hydrargyra majalis, \&c.)

Capelin, (Mallotus villosus.)

Smelt, (Osmerus mordax.)

Salmon, (Salmo salar.) 


\section{FOODS IN A FRESH CONDITION-Continued.}

e. Fish, (eastern coast:)

- Sea trout, (Salmo immaenlatus.)

Tarpum, (Megalops thrissoides.)

Menhaden, (Brevoortia menhaden.)

Suad, (Alosa sapidissima.)

Alewife, or gasperean, (Pomolobus pseudoharengus.)

Tailor herring, (Pomolobus mediocris.)

Herring, (Clupea harengus)

Mud shad, (Dorosoma cepedianum.)

Anchors, (Engraulis vittatus, \&c.)

Sea cel or conger, (Conger oceaniea.)

Eel, (Anguilla bostoniensis.)

Sturgeon, (Acipenser oxyrhynchus and A. brevirostris.)

Lamprey eel, (Petromyzon americanus.)

$f$. Fishes, (fresh waters:)

Burbot or lawser, (Lota maculosa.)

Fresh-water drum, (Haploidonotus grunniens.)

Small-mouthed black-bass, (Micropterus salmoides.)

Large-monthed black-bass, (Micropterus floridanus.)

Rock-bass, (Ambloplites rupestris.)

Sacramento "perch," (Archoplites interruptus.)

Sun-fish, (Pomotis aureus.)

Black-eared sunfish, (Pomotis auritus.)

"Bream" of Southeru States, (Calliurus, Lepomis, Enneacan. thus, Chcenobryttus, numerous species.)

Strawberry or grass biss, (Hyperistius hexacanthus, and Pomoxys storerius.)

Yellow perch, (Perca .favescens.)

Yellow pike-perch, (Stizostedium americanum.)

Gray pike-perch or sanger, (Stizostedizm griseum.)

Canada pilie-perch, (Stizostedium canadense.)

White bass, (Roccus chrysops.)

Short-striped bass, (Morone interrupta.)

Lake pike, (Esox lucius.)

Pickerel, (Esox reticulatus, E. fuscintus, E. cypho, \&e., \&c.)

Masquallonge, (Esox nobilior.)

Brook trout, (of eastern slope,) (Salmo fontzinalis.)

Brook trout, (of western slope,) (Salmo iridea.) 


\section{FOODS IN A FRESH CONDITION_Continued.}

$f$. Fish, (fresh waters:)

Utah trout, (Salmo virginalis.)

Oquassa trout, (Salmo oquassa.)

Lake trout, (Salmo confinis.)

Salmon trout or Mackinaw trout, (Salmo namaycush.)

Siscowet, (Salneo siscowet.)

Sebago salmon, (Salmo sebago.)

Missouri trout, (Salmo Lewisi.)

White fish, (Coiegonus albus.)

Otsego whito fish, (Coregonus otsego.)

Lake herring, (Argyrosomus harengus and A. clupeiformis.)

Black fin of Lake Michigan, (Argyrosomus nigripinnis.)

Michigan grayling, (Thymallus tricolor.)

Mountain grayling, ( Thymallus montanus.)

Suckers of eastern slope, (Catostomus teres, \&c., Ptychostomus aureolus, \&c.)

Suckers of western slope, (Catostomus occidentalis, \&c.)

Fall fish, (Semotilus thotheus.)

Chubs of eastern slope, (Semotilus corporalis, \&e.)

Chubs of western slope, (Lavinia exilicauda, Algansea, sp., \&c.)

"Pike" or "salmon trout" of California, (Ptychocheilus graudis, \&ce., Pongonichthys incoquilobus, \&c.)

Dace, (Ceratichthys biguttatus, \&c.)

Buffalo tish, (Bubalichthys bubalus.)

Shiner, (Stilbe americana.)

Carp, (Carpiodes cyprinus, \&c.)

Catfishes, (Amiurus catus, A. nigicans, \&c., Ictalurus carulescens, sc., and many other siluroid tishes.)

Sturgeon of the lakes, (Acipenser rubicundus.)

Shovel-nose sturgeon, (Scaphirhynchops platyrhynchus.)

9. Fishes, (western coast:)

Flounders, (Platichtinys stellatus, Lepidopsetta umbrosa, \&c.)

"Soles," (Parophrys retulus, Psettichthys melanostictus, \&c.)

Halibut, (Uropsetta californiana, Hippoglossus, sp., \&c.)

Tomend, (Microgadus proximus.)

Cod of Alaska, (Gadus macrocephalus.)

Rock fish or "rock cod," (Sebastomus rosaceus and species of Sebastosomus, Sebastichthys, \&c.) 


\section{FUODS IN A FRESH CONDITION-Continued.}

g. Hishes, (western coast:)

Rock trout, (Chirus constellatus.)

"Cod" of San Francisco, (Ophiodon elongatus.)

Black fish or "sheeps-head," (Pimelometopon pulcher.)

"Perch," (numerous species of Embiotoca, Holconotus, \&c.)

"Bass," (Atractoscion nobilis.)

Coguard or little bass, (Genyonemus lineatus.)

San Francisco "smelt," (Atherinopsis californiensis.)

Pacific smelt, (Osmerus elongatus.)

Salmon, (Salmo quinnat, \&e.)

Oulachan, (Thaleichthys pacificus.)

Sardine or pilchard, (Pomolobus cceruleus.)

Herring, (Clupea mirabilis.)

Sturgeon, (Acipenscr acutirostris, \&c.)

Columbia Rirer sturgeon, (Acipenser transmontanus.)

h. Crustaceans. ${ }^{1}$

$i$. Mollusks. ${ }^{1}$

\section{FOODS: DRIED AND SMOKED.}

a. MIammal preparations:

Jerked bear-meat.

Jerked seal and walrus meat, (Indian.)

Jerked and smoked buffalo-meat.

Dried and smoked beef.

Dried and smoked renison.

Hams of various kinds.

Jerked porpoise-meat, (Indian.)

Jerked squirrels and other small mammals.

Pemmican.

- Meat-biscuit, desiccated meat, meat extract, (extractum carnis, ) desiccated milk, \&c.

Sausages.

Cheese.

b. Bird preparations:

Jerked birds, (Indian.)

${ }^{1}$ The varions applications of these groups are enumerated in the "List intended to give a general idea of the useful products (other than vertebrates) of the sta and shore, as well as of the interior waters of the United States," prepared by Mr. WM. H. DALL, and printed as Circular No. 2 of series (C, ) National Museum series. 


\section{FOODS: DRIED AND SMOKED-Continued.}

c. Reptile preparations :

Dried lizards, (Indian.)

d. Fish preparations:

Smoked hailbut.

Dried cod, haddock, hake, sc.

Dried and smoked mullet and rues.

Dried and smoked garfish, flying-fish, \&c.

Smoked herring, alewires, Sc., and their roes.

Smoked salmon, oulachan, white-fish, smelt, \&c., and their roes.

Smoked sturgeon.

Veziga, prepared from the notochord of sturgeons.

e. Insects :

Dried grasshoppers, (Indian.)

f. Worms :

Dried worms, (Indian.)

g. Mollusk preparations:

Dried abalones, (Haliotis, ) prepared by the California Chinese.

Dried siphons of Schizothcorus prepared by the Indians of the northwest coast.

Dried slugs, (Limax, Sc.,) used by Indians.

h. Radiate preparations :

(Dried holothurians, "bêches de mer," used by Chinese.)

i. Protozoans :

("Mountain meal," a kind of infusorial earth, mixed with flour, and used as food in Lapland and China.)

3. FOODS: SALTED, CANAED, AND PICKLED.

a. Irammal preparations:

Salted buffalo-meat.

Salted beef.

Salted deer, reindeer, elk.

Salted tongues of beef, buffalo, deer, horse.

Salted pork.

Canned milk of the rarions brands.

b. Bird preparations:

Cauned turker.

Canned chicken.

Canned goose. 
3. FOODS: SALTED, CANNED, AND PICKLED-Continued.

b. Bird preparations:

(Canned ortolans, (Emberiza hortularia,) esteemed a delicacy in Csprus.)

c. Reptile preparations:

Salted and canned turtles and turtle soup.

Canned frogs.

d. Fish preparations:

Salted halibut, halibuts' fins, \&c.

Salted cod, cods' tongues, sounds, and roe.

Salted mackerel.

Salted Spanish mackerel.

Salted binefish.

Salted pompano.

Salted sword-fish.

Salted mullets.

Salted salmon.

Salted white-fish.

Salted trout.

Salted shad.

Salted herring.

Salted gaspereau.

Salted menharlen.

Salted anchovies.

(Spiced lampreys) used in Europe.

Anchorj-sauce and "essence of anchories."

Canued menhaden, in oil, "American sardines."

Canned menhaden, in oil, "American club-fish."

Spiced menhaden, "ocean trout."

Canned herring, in oil, "Russian sardines."

Caviare, prepared from roe of the various sturgeons.

(Caviare, prepared from roe carps, used by Jews.)

("Boutargue" or "botargo" prepared on the Mediterranean from the roes of Labrax and Mugil.)

e. Crustacean preparations :

Canned lobsters.

Canned crabs.

Canned prawns and shrimps.

$f$. Mollusk preparations:

Canned oysters. 
3. FOODS: SALTED, CANNED, AND PICKLED-Continued.

f. Mollusk preparations:

Canned clams.

Canned little-neck clams.

Canned scollops.

(Cockles, (Cardium edule,) used in Europe as pickles and catsup.)

4. GELATINES.

a Mammal gelatines, (see also under 24 :)

Gelatines made from tauners refuse and from sinews.

Gelatines made from feet and hoofs.

Gelatines made from bone and ivory sharings.

b. Bird gelatines:

(Nests of esculent swallows, (Calocalia esculenta, C. fuciphaga, C. indifica, \&c.,) exported from Indian Archipelago to China.)

c. Fish gelatines or isinglass, (see also under 24.)

d. Insect gelatine :

Gelatiue from cocoòus of silk.worms.

5. BAITS AND FOODS FOR ANIMIALS.

a. Prepared baits, (see under $\mathrm{B}, 45$.)

b. Food for domesticated animals:

Oil-factory scraps.

Fish-soraps.

Cuttle-fish bone, (see under 18.)

\section{CLOTHING.}

6. FURS, (embracing the furs in their rough state, (peltries,) and in the rarious stages of preparation; also the mannfactnred articles, such as robes, rugs, cloaks, sacks, tippets, cuffs, muffs, hats, caps, gloves, trimmings and linings.) $)^{1}$

a. Mammal furs :

(Diana monkes, (Cercopithecus diana,) of Trest Africa.)

(Black monkes, (Colobus polycomus, and other species,) of West Africa-trimmings, \&c.)

(Abyssinian monkey, (Colobus guereza.))

1 Tote-For convenience in arranging the general collections of the museum, this list has been made uuusually full, and includes all furs linown to be found in American and European markets. 


\section{FURS-Contiuned.}

a. Mammal furs:

(American bowling-monker, (Mycetes, several species)-muffs.) (Lion, (Felis leo,) of Africa and Asia-rugs.)

(Tiger, (Felis tigris)-rugs, \&c.)

(Leopard, (Felis pardus)—rugs and saddle-cloths.)

Puma, (Felis concolor)--carriage-robes, rugs, \&c.

Ocelot, (Felis pardalis)-rugs.

Jaguar, (Felis onca)-rugs.

Cat, (Felis domestica)-_robes and philosophical apparatus.

Black cat.

White cat.

Maltese cat.

Tortoise-shell.

(Wild-cat, (Felis catus, ) of Europe and Asia-robes andlinings.) (Snow leopard, (Felis irbis,) of Asia.)

Eyra, (Felis eyra.)

Taguarundi, (Felis yaguarundi.)

(Cheetah, (Cynailume jubatus;) of India and Southern Asia.) Bas lyux, (Lymx rufus)-rugs, and, when dyed, muffs and boas.

Canada lynx, (Lynx canadensis)_rugs and trimmings, and dyed muffis, boas, \&c.

Dog, (Canis familiaris.)

Eskimo dog.

Wolf, (Canis lupus)-linings, rugs, and robes.

White wolf.

Black wolf.

Gray wolf.

"Blue wolf."

Red wolf.

Coyote, or prairie wolf, (Canis latrans)-rugs and robes. (Jackal, (Canis aureus,) of Old World.)

Red fox, (Vulpes alopex, rar. fulvus)-robes, (mostly imported to Turkey.)

Cross fox, (Vulpesalopex, var. decussatus)-rohes, trimmings. Black and silver fox, (Vulpes alopex, var. argentatus)-muffs, cloaks, trimmings; also, fox-skins dyed to imitate lynx; also, various imitations of silver-fox, mate from skins of more common varieties. 


\section{FURS-Continued.}

a. Mammal furs:

Aretic fos, (Vulpes lagopus.)

- White fox.

Blue fox.

Kit fox, ( Vulpes velox)-robes, muffs, trimmings.

(Cossac fox, (Vulpes corsac,) of Asia.)

(Mountain fox, (Vulpes montanus,) of India.)

Gray fox, (Urocyon virginianus)-rugs, robes, and linings.

(Spotted hyena, (Hycena crocuta,) of West and South Africa.)

(Striped hyena, (Hycena striata,) of West Africa and India.)

Fisher or pekau, (Mustela Peunanti)-linings, tails used for trimmings.

American or Hudson's Bay sable, (Mustela americana)-cloaks, muffs, cuffs, boas, linings, \&e. :

Silver variety.

Orange variety.

Brown or commou variets.

(Russian sable, (Mustela zibellina,) of Torth Europe and Asia -cloaks, muff's, boas, linings, Stc.)

(Tartar sable, or kolinsky, (Mustela sibirica)-cloaks, muffs, and dyed to imitate Russian sable.)

(Pine marten, (Mustcla abietum,) of North Europe and Asia.) (Stone marteu, or French sable, (Mustela saxorum,) of Europe-dyed to imitate sable.)

(Beech marten, (Hustela foina,) of Europe and Asia-dyed to imitate sable.)

(Polecat, fitch, or ferret, (Putorius vulgaris.) of Europe and Asia.)

Ermine, or weasel. (Putorius erminea,) of Northern Hemisphere-cloaks, linings, \&c. :

Royal ermine, trimmed witl astrakhan fur, (miniver.)

Siberian ermine.

Long-tailed weasel, (Putorius longicanda:)

Summer dress.

Winter dress.

Mink, (Putorius risou,)-cloaks, mufts.

Wolverine, (Gulo luscus.)-muftis, robes, linings.

American badger, (Taxidea americana)-muffs and rugs. 
6. FURS-Continued.

a. Mammal furs :

(European badger, (Meles vulgaris)-mufl's and rugs.)

Skunk, Alaska sable, (Mephitis mephitica)-muffs, boas, \&c.

White-backed skunk, (Conepatus mapurito.)

Striped skunk, (Spilogale putorius.)

Otter, (Lutra canadensis, ) with specimens of the plucked and dyed fur-muffs, trimmings, \&c.

Sea otter, (Enhydra marina)-muffs, gloves, collars, cuffs, trimmings.

Black bear, (Ursus americanus)-caps, rugs, muff's, robes, \&c. $a^{\prime}$. Cinnamon rariety.

b. Silrery variety.

(Brown bear, (Ursus arctos, of Europe and Asia.)

Grizzly bear, (Ursus horribilis)—rugs, robes, trimmings.

White bear, (Thalarctos maritimus)-rugs, robes, and used extensively by the Eskimos.

Raccoon, (Procyon lotor)-hats, linings.

Fur-seal, (Callorhinus ursinus)-cloaks, hats, gloves, muffs, linings, trimmings, \&c.

Cub fur.

(Antaretic fur-seal, (Arctocephalus aucklandicus, \&c.)

Hair seal. (Pheca vitulina and Phoca Richardsii)-coats, caps, linings for shoes.

Harp seal, (Pagoptilus groenlandicus,) with specimens of the white fur of the unborn cub, and the blue fur of the young.

Hood seal, or bladder-nose, (Cystophora cristata.)

Square flipper, or bearded seal, (Erignathus barbatus,) with specimens of fur dyed to imitate leopard.

Banded seal, (Histriophoca equestris)—used by Eskimos as fur. Gray seal, (Pusa gryphus.)

Pinged seal, (Pagomys foetidus.)

Bison, or buffalo, (Bison americanus)-rugs and robes. $a^{\prime}$. Mountain bison.

b. Common bison.

Musk.ox; (Ovibns moschatus)-robes, rugs, and trimmings. (Yak, (Poёphagus grunnitns,) of Asia-robes and trimmings.) Mountain goat, (Aplocerus montanus)-robes, \&c. 


\section{FURS-Continued.}

a. Mammal furs :

(Llama, guanaco, paco, and vicugina, (Auchenia, sp.)-trim. mings, \&c.)

Goat, (Capra, sp.)—rugs, trimmings.

$a^{\prime}$. Angora goat.

b. Cashmere goat.

c. Other varieties.

Sheep, (Ovis aries)-rugs, trimmings, \&c.

a. Astrakhan sheep.

b. Caracoul sheep.

c. Other varieties. Lamb-skins and dsed furs.

Antelope, (Antilocapra americana)-rugs.

Moose, (Alccs malchis)_rugs and robes.

Elk, (Cervus canadensis)-rugs and robes.

Reindeer, (Tarandus rangifer)-robes, coats, gloves, \&c.

Caribou, (Tarandus rangifer var.)-robes, coats, gloves.

Mule deer, (Cariacus macrotis)-trimmings, robes.

Virginia deer (Cariacus virginianus)—trimmings, robes.

Mole, (Scalops and Condylura, sp.)-robes, garmeuts.

(European mole, (Talpa europara)-robes, garments.)

Woodchuck, or siffeur, (Avctomys monax)-robes, exported

to-Europe as "white and gray weenusk."

Marmot, (Arctomys caligatus)-robes, trimmings.

Parry's marmot, (Spermoplitus Parryi)-robes, trimmings.

Gray squirrel, (Sciumes ctrolinensis, \&c.)-trimıning; tails used for boas.

(Squirrel, or "calabar," (Sciurus vulguris,) Norther" Europe and Asia.)

$a^{\prime}$. Siberian squirrel. Trimmings, muffs, capes, src.; tails used for boas, dyed to imitate sable.

b. "Teisenfels linings" of the white fur of the belly.

Showt'l, (Iraplodontia leporina)-used by Indians.

(Chinchilla, (Chinchilla lanigor,) of South America-muffs, mantles, boas, cloak-linings, and trimmings.)

Iusquash, (Fiber zibethicus)-muffs, capes, caps, and linings, and imitations of bearer-fur.

(Nentria, or Cospu, (Myopotamus coypus)—linings and maffs, and imitations of beaver.) 
6. FURS-Continued.

a. Mammal furs:

(Bearer, (Castor fiber,) of Northern Europe and Asia.)

Beater, (Castor canadensis)-liniugs and muffs.

White beaver.

Spotted beaver.

Rats and mice, (Mus., sp. var.)

Lemming, (Myodes torquatus and obensis)-robes.

Rabbit, or cony, (Lepus cuniculus)-children's furs, and imitations of seal, beaver, \&c., exported largely to China.

White rariety.

Blue variety.

Brown variety.

American native rabbit furs, such as Lepus glacialis, used for muffs, boas, and feltings.

Possum, (Didclphys virginiana.)

(Kangaroo, (Macropus giganteus,) of Australia.)

(Ornithorhynchus, (Ornithorhynchus anatinus,) of ${ }^{\bullet}$ Australia.)

b. Skins of birds used as furs:

Turkę furs, (Melagris gallopavo, \&c.)

Gull furs, (Larus argentatus, \&c.)

Grebe furs, (Podiceps aristatus, \&c.).

Loon furs, (Colymbus torquatus, \&c.)

Swan furs and swan's down trimmings, (Cygnus americanus, \&c.)

Pelican furs, (Pelecanus fuscus, \&c.)

Adjutant crane, (Ciconia argala)-feathers used as fur.

Puffin furs, (Fratercula arctica, \&c.)

Penguin furs, (Aptenodytes, Pennantii, \&c.)

Feathers of common fowl used in trimmings.

7. LEATHERS. (See under 20.)

8. TEXTILE FABRICS.

a. Prepared from hair of mammals :

Human hair used in manufacture of wateh-chains.

Hair of bats used in felting and in plaiting ropes in Central America and tassels in New Caledonia.

Hair of raccoou used in felting, (largely exported to Germany for the use of hatters.)

Hair of weasels and sables used in felting. 


\section{TEXTILE FABRICS-Continued.}

a. Preparations of hair of mammals :

Hair of fur seal woven with silk in the manufacture of shawls. Moose hair and its fabrics.

Ox aud calf hair used in the manufacture of imitation woolen goods.

Sheep's wool, with specimens of fleeces and stapled wools, from various breeds and localities, short-wool fabrics, broadeloths, merinoes, flannels, mouselins de laine, serges, tweeds, blankets, carpets, and tartans, worsted fabrics, stuffs, bombazines, camlets, shawls, plushes and velrets, hosiery, and yarns, felts, felt-cloths, and felt-hats.

Goats' wool with specimens of mohairs, cashmeres, plushes, relveteens, camlets, and shawls. (For manufactured wigs and perukes, see under 21.)

(Yak (Pö̈phagus grunniens) wool with specimens of yak-lace and other fabrics.)

(Camels' hair with specimens of fabrics, plushes, felts, shawls, Sce)

(Hair of llama, paco, gnanaco, and ricugni, with specimens of alpaca, guanaco, and other fubrics, and umbrellas and other articles manufactured.)

Hair of horses used in wearing furniture-covers, crinolineskirts, and bags for pressing oil.

Hair of buffalo used in plaiting ropes, lariats, sc.

Fur of mole used in felting.

Beaver (castor) fur with specimens of the felt cloths, hats, \&c. (Nentria-fur used in feiting and in the manufacture of hats.) Musquas' fur used in felting.

Possum hair with fabrics of Indian and other manufacture. Fur of rabbit and hare used in felting, with specimens of hats and cloths.

Whalebone fiber used in weaving cloth corers for telescopes, ste.

b. Prepared from feathers of birds :

Cloths woren from feathers, (China.)

c. Prepared from silk of insects: (This collection should include specimens of the cocoons, the raw silk, the spun silk, and of the various fubrics, plain and figured silks, satins and satinettes, sharls, damisks, brocades, crapes, and ribbons.) 
S. TEXTILE FABRICS-Continned.

c. Prepared from silk of insects:

Silk of common silk-worm, (Bombyx mori.)

Silk of Samia cecropia, Samia polyphemus, and other native American moths.

(Silk of exotic moths other than Bombyx mori, such as the tussah, (Bombyx pernyi and Bombyx mylitta,) the moonga, (Saturnia assamensis,) the joree, (Bombyx religiosa,) the ena or arindy, (Bombyx cynthia.))

Fabrics woren by the insects themselves, as Tinea padilla.

Silk of spiders.

d. Prepared from byssus of mollusks.

(Fabrics woren from byssus of the wiug-shell (Pinna nobilis) and other mollusks.)

\section{MATERIALS EMPLOYED IN THE ARTS AND MAN- UFAC'TURES. \\ * Hard materials.}

9. IVORY AND BONE. (This collection should include specimens of the various irories and bones in their rough state, aud maunfactured into buttons, trinkets, cutlery-handles, caues, pen and pencil handles, brush-handles, bill ard and bagatelle balls, dice, piano-keys, haruess. rings, consbs, false-teeth, philosophical instruments, and as used by portrait printers and photographers.)

a. Irory of mammals :

Tusks of walrus used for trinkets, handles, jewelry, buttons, paper-knives, counters, \&c.

Teeth of bears, dogs, wolves, foxes, peccaries, and other large mammals, used as implements, arrow-tips, and ornaments, by Indians.

Elk-ivory used by Indians in ornamentation.

Tusks of mammoth elephant (Elephas primigenius) from northern America and Asia, with Eskimo carvings and specimeus of "Siberian ivory." 


\section{IVORY AND BONE-Continued.}

a. Irory of mammals :

(Tusks of African elephant with specimens of sarred and scroll ivory and of the manufactured balls, combs, piano. keys, handles, rings, canes, buttons, trinkets, bangles, and miniature tablets.)

(Tusks of the Asiatic elephant and their applications.)

(Teeth of hippopotamus as used for handles for surgical in. struments, index-fingers, and formerly for false-teeth, (trade-name, "sea-horse.")

Teeth of wild-hog used in manufacture of jerrelry, vinaigrettes, \&c.

Teeth of peccars.

Irory of narwhal used for canes.

Teeth of sperm-whale and their application to the manufacture of balls, buttons, and trinkets.

Incisors of bearer used by Indians for chisels, knires, and ornaments.

b. Irors of reptiles:

Teeth of alligator used for jewelry, whistles, cane-handles, buttons, sc.

c. Irory of tishes:

Sharks' teeth used in arming weapons.

Teeth of sharks and other fish userl as trinkets.

Jaws of the sleeper-shark (Somniosus breripinna) used for head-dresses by Indians.

d. Bone of mammals :

Parts of splanchno-skeleton of ferie, used as charms.

Bones of bear and other large mammals, used by Indiaus for implements, and as taluets for paintings.

Bones of buffalo and of the domestic rumiuants, used as substitute for irory in the mannfacture of buttous, han. dles, cornbs, sc.

Sperm-whale jaw-bone, used for laruess-rings, martingales, sc.

Horn-cores of ruminants, used in manufacture of assayers' cupels.

e. Bone of birls:

Bones of birds, used by Indians and Eskimos in making amls, needles, flutes, bird-calls, and dress-trimmings. 
9. IVORY AND BONE-Continued.

\section{$f$. Bone of fishes:}

Fish-bones, used bj Indians and Eskimo in making implements.

Shark's rertebræ, used for canes.

Bones of sharks and skates, used (in Japan) in making imitation tortoise-shell.

g. Waste bone and ivory:

Jse in manufacture of bone-black, ivory-black, and banknote ink, (see under 29.)

Use in manufacture of sizes and glues, (see under 24.) ,

Use in manufacture or gelatine for food, (see under 4.)

Use in manufacture of phosphorus, carbonate of anmonia, (hartshorn,) and sal ammoniac, (see under 30.)

Use in manufacture of bone-charcoal for tilters, (see under 30$.

Use in manufacture of paper.

Use of sharings in case-hardening gun-barrels and other fine steel.

10. HORN. (Embracing the varieties of horn known to commerce, the split and pressed horns, and the various manufactured articles, such as jewelry, combs, and handles

a. Horn, emplojed as a material:

Horn of rhinoceros, used for handles and trinkets, cups, bores, whips, and canes.

Horns of ox, sheep, and goat, used for handles, buttons, combs, powder-flasks, cups, boxes, stirrups, spoons, and imitations of tortoise-shell, also "sensitive Chinese leaves," and formerly for transparent plates in lanterns and hornhooks, for trumpets, and for finger-nails in lay figures.

Horn of buffalo, used like that of ox.

(Horn of Asiatic buffalo, (Bos bubalus.))

Horn of mountain-sheep and mountain-goat, used by Aleutians, in making spoons, bowls, and numerous other implements.

b. Antlers:

Antlers of deer, elk, and moose, (stag-horn,) used in the manufacture of handles for instruments, trinkets, and buttons. 


\section{HORN-Continued.}

b. Antlers :

Antlers of deer, elk, moose, and nearly all species of rumi. nants, emplosed for ornamental purposes.

c. Chemical and other applications:

Burnt horn, (cornu ustum,) used in dentifrices.

Carbonate of ammonia, (hartshorn,) manufactured from deer. horus, (see under 30.)

11. HOOFS AND CLAWS, \&c. (Embracing the commercial hoof, and the rarious stages of manufacture represented by specimens.)

a. Hoot's :

Hoofs of ox and bison, used in making buttons, combs, and handles.

Hoof's of horse, used like those of ox and bison.

Hoofs of musk-ox, deer, and antelope, used by Indians in orllamentation.

Feet of deer, used for knife-haudles, stool-feet, Sc.

b. Claws :

Claws of bear, puma, wolf', Se., used by Indians in oruainellation.

(Claws of lion and tiger, used by jewelel's for trinkets.)

Human nails, used by Indians for ornamental trimmings.

c. Chenical applications of hoofs and claws :

Use in manufacture of prussiate of potash, (ste under 30.)

Use in manufactme of glue, (see under 24.)

12. BALEEx. (Embracing the commercial baleen in its various grades, Greenlund, Northuest Coast, South Sea, finback, and hump.back, with the split, twisted, and dyed bone.)

a. Whalebone, as used by manufacturers of ribbons, hats, umbrellas, whips, canes, boots, fishing-rods, billiard-tables, buttous, baudles, brushes, surgical instruments, stays, corsets, crimolines, harness-rosettes, corers, stuffugs, light woreu hats aud bounets, \&c.; also, imitation whalebone, (wallosin.) made from rattan.

13. TORTOISE-SHELL. (Embracing the carapace entire, and the commercial shell, blades, feet, noses, and head.) 
13. TORTOISE-SBELL-Continued.

a. Shell of tortoise (Eretmochelys imbricata, E. squamata) used in manufacture of combs, handles, jervelry, iulaying, and buttons, together with imitations of tortoise-shell in horn, shark's bone, and celluloid.

b. Shells of land tortoises, used by Indians for pots, scoops, and rattles.

14. SCALES.

a. Shell of mammals:

Shell of armadillo, used by Texans and Mexicans.

$b$. Seales of fishes used in ornamental work, with specimens of flowers and other articles manufactured:

Scales of parrot fishes, (Scaride and Labride.)

Scales of mullets, (Mngilidae.)

Scales of sheepshead, \&c., (Sparidce.)

Seales of drum and bass, (Sciatridce.)

Scales of Serranidæ and perches, (Percidae and Labracidce.)

Scales of Lobotidre.

Scales of tarpum, (Elopidce.)

Scales of herrings, (Clupeidec.)

Scales of Crprinidr.

Scales of eels, used in the north of Europe to gire a pearly luster in ornamental house-painting.

Seales of gar-pikes, used by Indians for arrow-tips.

(Pearl white, or essence d'Orient, prepared from scales of Al-

-burnus lucidus and other Cyprinidæ and Clnpeidæ, used in making artificial pearls.) (See under 27.)

Shagreeu of trigger-fish, (Balistes,) used in polishing wood. Shagreen of sharks, used as leather, (see under II, B. 5, ) and for polishing purposes, particnlarly in the manufacture of quill peus.

Scales of sturgeons, used by Indians for implements.

For gelatine as a material and the arts and papier glacé, see 24 .

15. PEARL.

a. Pearls and nacre, (embracing the pearl-yielding shells, with the pearls and the mother-o'-pearl in the rough state, with the manufactured buttons, handles, and jewelry, pearl-powder, inlaid work, and papier maché, ornamented with mothero'-pearl :) 


\section{PEARL-Continued.}

a. Pearls and niacre:

Top-shells, (Turbinida, and their application to manufacture of shell-flowers.

Tower-sheils, (Trochidce.)

Ear-shells, (Haliotida, ) used in manufacture of' buttons, handles, inlaid work, and pearl-powder.

Other gastropods supplying wacre.

Pearl-oysters, (Aviculida, ) with pearls and nacre.

River-mussels, (Unionida,) with pearls and nacre.

Mussels, oysters, and other conchifers supplying pearls and nacre.

Shells of nautilus and argonaut, prepared to exhibit their nacre.

Ornamental pearl-work, imitating sprays of flowers, \&c. Imitation pearls.

16. SHELL.

a. Cameo shell:

Shell of conch, (Strombus gigas, and carrings.

Shell of helmet, (Cassis rufa, C. tuberosa, and C. madagascari. ensis,) with carrings.

b. Shells used for implements, \&c.:

Shells of Strombus, Triton, Dolium, Fusus, Murcx, and Buccinum, used for fog-horns, lamps, rases, and ornamental borders in flower-gardens.

Shells of Busycon, Sycotypus, Mactra, Sc., used by Indians in manufacture of implements, with specimens of implements.

Shells of Ifactra, used for ladles, scoops, and spoons by fishermen.

Shells of Tridacna, used for rases, fountaius, and in the manufacture of handles and carrings.

Shells of Pecten, Haliotis, Dentalium, Mcrconaria, \&c., used by Indians for triminings and oruaments.

(Scallop, or palmer's shell, (Pecten jacobcus,) used as a decoration of honor.)

(Chauk sheil, (Turbinella pyrum,) used in the manufacture of Hindoo bangles, and in polishing cloth.)

Shells of Pecten, used in making pin-cushions and purses. 
16. SHELL-Continued.

b. Shells used for implements, \&c.:

(Painters' mnssel, (Unio pictorum,) used to hold colors.)

(Shells of Placuna placenta, used in China as a substitute for windor-glass.)

Shells of Mercenarici violacea, Purpura lapillus, and Buccinum undatum, used by Indians of eastern coast in manufacture of mones, with specimens of wampum, iwith the modern wampun or shell beads manufactured for the Indian trade,) and of the hyqua or Dentalium shells, employed in a similar manner by the Indians of the Pacific coast.

Specimens of the cowry, (Cypraea moneta.) "Live cowry" and dead cowry, used in African trade and for trimmings.

Shells of Cypraea, Rotella, Oliva, Turritella, Phasianella, (Venetian shells,) \&c., mounted as buttons and jewelry.

Composition shell-work for box-covers and frames, made by glueing shells in mosaics.

Calcined shells, used by dentifrice and porcelain makers. (See, also, under 32.)

Cuttle-fisli bone from Sepia officinalis, used as a pounce, as a dentifrice, as polishing-powders, for taking fine impressions in comnterfeiting, and as food for bircls. (See, also, under D. 5.)

Concretions from the stomach of Astacus, known as " crab's. eyes" and "crab-stones," and used as antacids.

Shell of king-crab, (Limulus polyphemus,) used as a boatbailer.

Opercula of mollusks, used as "eye-stones."

17. CORAL.

a. Coral as a material :

Red coral, (Corallium nobilis,) with specimens of the five commercial grades (1, froth of blood; 2, flower of blood; $3,4,5$, blood of first, second, and third qualities) of the white rariety, and of the round beads, negligée beacss, bracelets, pins, roronets, armlets, and earrings, \&c.

White coral, Oculina, sp., used by jewelers.

Madrepores and other showy corals, used for ornamental purposes.

Horny axis of black flexible coral, (Plexaura crassa,) used for canes and whips in the Bermudas. 
17. CORAL-Continued.

a. Coral as a material:

Axis of fan coral, (Rhipidogorgia,) used for slimmers and strainers in the Bermudas.

Coral, used for building purposes.

Coral rock of recent formation, (Coquina,) used in Florida in manufacture of ornamental vases and carrings.

Calcined coral, used for dentifrices, as an antacid, \&c.

Imitations of red coral in celluloid, rubber, and other substances.

18. INFUSORIAL EARTHS.

a. Polishing powders, (used for polishing metals, cabinet-ware, and stone:)

Specimens of polishing-slate, tripoli, and other foreign polishing-powder.

Specimens of American infusorial deposits.

b. Infusorial earths, emplored in manufactures:

Infusorial eartb, used in making window and plate glass.

Infusorial earth, used in making soluble glass.

Infusorial earth, used in making mortar.

Infusorial earth, used in making molds for metal casting.

Infusorial earth, used in making filters.

Infusorial earth, used in maxing dynamite.

Infusorial earth, used in making fire-proof packing.

Infusorial earth, as an absorbent for oils and liquids.

19. OTHER MATERIALS FROM INVERTEBRATES.

a. From insects :

Brazilian diamond-beetles, used in jewelrs.

Wings of beetles, used in embroiders.

ఒ. From echinoderms:

Spines of echinoids, used for slate-crasons.

** Flexible materials.

20. LEATHERS. (Embracing the hides in a rough stute, in the various stages of dressing, and manufactured into shoeleather, parchment, rellum, binder's leather, thongs, sco)

a. Prepared from mammal skins:

Cat-leather.

Dog and wolf leather, used fur drum-heads, \&c. 
20. LEATHERS-Continued.

a. Prepared from mammal skins:

Bear-leather.

Raccon-leather, used for gloves and upper-leathers of shoes. Seal-leather, used for fine shoes and in the manufacture of "patent leather," and by Eskimos for numerous purposes. Sea-lion leather, used by Eskimos to cover bitarkas and for garments and beds.

Walrus-leather, used by Eskimos for harness, tables, thougs, seal-nets and for covering polishing wheels.

Bison-leather (and buffalo-leather, buff-leather.)

Оx-leather, with specimens of sole-leather, split-leather, grain-leather, rawhide thongs, whips, leather-belts and saddles, and of calf-skins, prepared for binder's' and bootmakers' use, as Russia leather and vellum, and tawed, as parchment.

Sheep-leather, with specimens of binder's leather, imitation chamois leather, wash-leather, buff-leather, roan, imitation moroceo and parchment, with vellum made from skins of deat-born lambs, and manufactured gloves, \&c.

Goat-leather, with specimens of shagreen-leather, moroceoleather, as used for linings, upholstery, bindings, and pocket-books, parchment, drum-heads, \&c., with kidleather, used in manufacture of shoes and glores, underclothing, and rellum made from skin of young kids, also skin-bottles used in Asia.

Horse and ass leather, used in manufacture of shagreen, sole-leather, liarness-leather, saddles, trunks, water-liose, pump-valves, military accoutrements, ladies' shoe-uppers.

(Chamois leather, (Capella rupicapra,) used for polishing purposes and for straining mercury.)

(Leather of gazelle, (Gazella dorcas,) used in packing comwercial aloes, and of African antelopes, used in packing elephants' tusks.)

Deer-leather, dressed as buff-leather, chamois-imitation leather, Indian dressed (buckskin,) and for the finer mo. roces, also manufactured into gloves, gaiters, undergar. ments, polishers, \&c.

Moose-leather in ordinary and buckskin finish. 


\section{LEATHERS-Continued.}

a. Prepared from mammal skins:

Caribou-leather in ordinary and buckskin finish. (Reindeer-leather.)

Elk-leather in ordinary and buckskin finish.

Antelope-leather in plain, buckskin, and oil-finish, used in manufacture of castor-gloves.

Peccary-leather as used in the manufacture of glores.

Hog-leather used by saddlers, shoemakers, and book-binders. Hippopotamus-leather used for buffing or polishing wheels. Rhinoceros-hide user for sbields, targets, whips, \&c.

Beluga leather dressed as kid, sole, harness, velvet, plush, boot, mail-bags, belts, aur patent (raruished) leather.

Porpoise-leather.

Bearer-leather used in manufacture of saddles, shoes, gloves, and trunks.

(Nutria-leather (Myopotamus coypus) of South America.)

Rat-leather used for thumbs of kid gloves.

(Kangaroo-leat ber.)

Leatber trimmings used as stufting for balls, \&c.

$b$. Prepared from intestines of mammals:

Parchment from viscera of seals, used by Eskimo for clothing, bags, and blankets.

Leather from pharyns of seal and ralrus used by Eskimo for boot-soles.

Parchment from riscera of bears used in Kantchatka for masks and wiudow-panes.

Viscera of ox used in manufacture of gold-beaters' skin.

Bladders of animals used for pouches, parchment, bottle and jar eorers, aud by Eskimo for oil-bottles.

Viscera of sheep used in manufacture of "cat-gut," with specimens of whip-cord, hatters' cord, for bowstrings, clock-makers' cord, filandre, guitar, riolin, and harp strings, ingling-lives, sre.

Viscera of hog used as enrelopes for minced meat, sausages, Ste.

Siners of sheep, deer, goat, buttialo, seal, walrus, and other animals used in manufactures of threats, lines, nets, and snow-shoes, in strengthening bows, \&c., the Babiche of the Eskimos of the northwest coast. 
20. LEATHERS-Continued.

c. Prepared from bird-skins : (Eskimos.)

Eiler-leather.

Auk-leather.

(Ostrich-leather used by Arabians.)

d. Prepared from reptile skins:

Alligator-leather.

Rattlesnake-leather.

Other snake-leatier.

e. Prepared from fisli-skins :

Leather prepared from scaled fish by Indians.

Eel-leather, (pigtails, queues, flail-thongs.)

Shark-leather, (shagreen used for coverings and by the Alaska Iudians for boot-soles.)

Sturgeon-leather.

(Skins of Diodon used in making helmets.)

Stomach membranes of halibut used in Greenland for window-transparencies.

$f$. Leather waste:

Paper manufactured from waste.

Glve manufactured from waste, (see under 24.)

Prussian blue made from leather waste, (see under 30.)

21. HAIR AND WOOL. .

a. Hair used in weaving and felting, (see under 8.)

b. Hair used for wigs and ornament:

Human hair as an article of commerce, with specimens of switches and wigs, and also of the trade imitations of hair in jute, horse-hair, \&c.

Guats' wool as employed in manufacture of wigs and perukes.

Horse-hair employed for nilitary accoutrements and for standards, (Turkey.)

Human scalp-locks as Indian trophies.

Scatps of animals as trophies.

c. Hair and bristles used for brushes, (embracing the commercial hair and bristles, assorted and unassorted, and specimens of the manufactured articles:)

Hair of skunk used for fine brushes.

Hair of bear used for varnishing-brushes. 


\section{HAIR AND WOOL-Continued.}

c. Hair aud bristles used for brushes:

Hitir of American badger used for fine shaving, graining, gilding, and dust brushes.

(Hair of European badger used for coarse brushes.)

Hair of dog used for coarse pencil-brushes.

Hair of squirrel, marten, sable, kolinsky, and weasel, especially the tails, used in making fine artists' pencils.

(Hair of camel used for pencils.)

Bristles of hog and peceary used in making coarse brushes for varnishing, scrubbing, \&c.

Tails of horses, buftaloes, \&c., used for fly-brushes.

(Tails of yak used for fly-bruslies.)

(Tails of elephants used for brushes and standards.)

Sheep's mool (on skin) used for lolack-board rubbers.

Hair of deer and antelope (on skin) used by Indians for hairbrushes.

Ox-hair from the inside of eors' ears used for striping and lettering brushes.

d. Hair used in other manufuetures:

Bristles used in shoemakers' waxed ends.

Bristles used in anatomieal instruments.

Hair aud bristles used in artificial flies. (See muder B, 45.)

Hair of cattle used in strengthening mortar and plaster.

e. Hair used for stuffing:

Horse-hair, straight and curled, used for mattresses and cushions.

Refuse hair of bearer and musquash, cut from felting-hair, used for cushions.

(Down of rabbits used for cuslions.)

f. Wool used as a medium for pigments :

Trool flocking used in the manufacture of wall-paper, colored felts, and rubber-cloth.

g. Chemieal produets :

Refuse hrman and other hair used in manufacture of prussiate of potash, with specimens of maufactured product. 22. QUILLS.

a. Quills of manmals:

Quils of Americun Ledge-hog used by Indians in embroidering. 
2.. QUILLS-Contiuued.

a. Quills of mammals :

(Quills of porcupine used for pen-holders, floats for fishing, eyelet-punches, \&c.)

(Quills of European hedge-hog, on skin, used as a muzzle for reaniug calves.)

b. Quills of birds :

Quills of swan and turkey for engrossiug-pens.

Quills of goose and eagle for writing-pens.

Quills of crow and duck for fine pens.

Quills used in making toothpicks, fishing floats, color-bottles, pencil-handles, needle-holders, \&c.

23. FEATHERS.

a. Feathers userl for clothing. (See nuder Furs, D 6.)

b. Feathers used for implements, (ivcluding mannfactured articles:)

Feathers of hawks used as fans and screens.

Feathers of fowl, turkey, grouse, and peacock used for brushes, fans, and screens.

Feathers of ibis, spoonbill, egret, and bittern used for fans and screens.

Feathers of flamingoes, swans, geese, and durks used for fans and screens.

c. Feathers used for plumes and ornament, (including plumes, head-dresses, cockades, hat and dress trimming, \&c.:)

Feathers and wings of small perchers used in milliners and in manufacture of feather flowers.

Feathers of trogons and birds of paradise used as plumes and for feather flowers.

Feathers of humming-birds, scalps, and throats used in ornamental work.

Feathers of kingfishers used in plumagery.

(Feathers of parrots used in making teather flowers.)

Eagle and hawk feathers used for plumes.

Feathers of pigeons used for ornamental work.

Feathers and wings of cock used as plumes, trimmings, \&c., natural and dyed.

Breast feathers of grouse, pheasants, and turkeys used as roll-plumes in hats. 


\section{FEATHERS-Continued.}

c. Feathers used for piumes, \&c. :

Feathers of ibises, spoonbills, flamingoes, Lerons, egrets, and bitterus used for plumes and ornamental work.

(Feathers of adjutant, (Lepoptilus argala,) and marabou, (Lepoptilus marabou,) used for plumes and trimmings.)

Feathers of flamingoes, swans, geese, aud ducks used in ornamental mork for roll-plumes, and swans'down for trimmings. (See under 6.)

Breast-feathers of gulls, terns, and tropic birds used as rollplumes.

(Feathers of African ostrich used for plumes and trimmings, with specimens of undressed, scoured, bleached, scraped, and dsed grades.)

Feathers of American ostrich.

Specimens of composite feather flowers.

Specimens of plumagery work on metal.

Specimens of birds mounted for use in millinery.

d. Feathers used in other manufactures:

Feathered arrow-shafts. (See under B, 18.)

Feathers used in making artificial flies. (See under B, 45.)

Feathers used in manufacture of textile fabries. (See nnder D, II, C.)

e. Down of birds :

Down of eider-duck used in bed-stufing, with suecimens of the balls in which it is packed for transportation.

Down of other ducks.

Doilu of geese and swaus used as stuffing for beds, and as electrical non-conductor in manufacture of philosophical instruments.

24. GELATINE AND ISINGLASS.

a. Gelatine:

Gelatine made from leather-sharings, bones, hoot's, and Lorns of bison, cattle, sheep, and other domestic animals, used in manufacture of glue, size, court-plaster, papier glacé for tracing, initation glass, artificial flower's, and ornamental work, rrappings for confections, table-jells, (see under D. 1,) \&c.

Size aud gelatine from tine irory chips. 
24. GELATINE AND ISINGLASS-Continued.

a. Gelatine:

Bone-glue, (Ostencolla.)

(Glue made in India from skin of the ass, (Hippocolla.))

b. Isinglass :

Isinglass, (Ichthyocolla,) made from air-blactders and skins of fishes and used in the manufacture of fine glues and sizes, adbesire and court plasters, diamond cement, imitation glass, and table-jelly and confectionery, (see under D. $1, \mathrm{D}$, ) in refining wines and liquors, in adulterating milk, in fixing the luster of artificial pearls, and in lustering silk ribbons, (embracing the dried bladders and the manufactured products,) in their grades of "lyre," "heart-shaped," "leaf," and "book" isinglass.

Isinglass from sounds of cod and hake.

Isinglass from the squeteague family, (Scicenidae,) principally used by confectioners.

Isinglass from eat-fish family, (Siluridae.)

Isinglass from carp family, (Cyprinidae.)

Isinglass from sturgeons in all its grades and commercial forms.

Isinglass prepared from fish-skins.

25. FLEXIBLE MATERIALS DERIVED FROM INVERTEBRATES. a. Insect productions:

Silk-rrorm "gut" used in making leaders for fish-lines.

(Nest of Carenne-ant, (Formica bispinosa, ) used as a mechanical styptic.)

Spiders' web used as a mechanical styptic and for the crosslines in optical instruments, (see, also, under D, 8.)

Papier-maché of hornets' nests used for gun-wadding..

b. Mollusk productions:

Byssus of mollusks, (see under D, 8.)

26. SPONGES.

a. Specimens of Americau commercial sponges, with the difterent grades, and bleached snonges:

(Specinens of Mediterranean sponges.)

Surgical apparatus, probangs, aurilares, "sponge-tents," and other instruments manufactured.

Spongeo-piliue nsed as a substitute for poultices. Sponges used in stuffiug mattresses and cushions. 


\section{OILS AND FATS.}

a. Mammal oils :

Bear-oil and bear-fat used as a cosmetic and in the manufacture of pomatums.

Dog-oil used in the manufacture of kid-glores.

Seal-oil, in its various grades, used for lubricating.

Sea-elephant oil.

Sea-lion oil.

Manatee-oil.

Dugong-oil.

Oil and fat from domestic animals, tallow, suet, lard, lardoil used in lamps, for lubricating, and neats foot oil used in dressing leather, also manufactured into various substances, (see D, 30,) and tallow candiles and night-lights.

Oil from body of whales, grampuses, and porpoises nsed in the arts, for Inbricating, painting, se.

Black-tish and porpoise.jaw oil used in lubricuting tine machinery, watches, clocks, aud guus, with specinens of blubber.

Grampus-oil used for lubricating fine machinery.

Sperm-oil used in lamps, for Inbricating, as an emollient 11 medicine, for lip-salves, and in the manufacture of spermaceti.

Manufactnred glycerines, used as a preservative alid "ntiseptic, as a cosmetic, as an emollient, as a substitute for cod-liser oil, in the manufacture of ierfumes and hairdressings, in photography, in the manufacture of nitroglscerine, dynamite, dualine, lithofiacteur, coloniamite, and other explosires, soap, \&e.

Manufactured stearines, with candles and othe: maunfactured articles.

Soaps manufactured from mammal-oil, sorlil-soaps, (hard, toilet, and resin soaps,) potash.soaps, (washiug, sharing, and soft soips, diachylon plaster, \&c.

Spermaceti, with specimeus of candles.

Butter made from milk of cors, goats, atd horses.

Oleomarganines, mith speciulens of imitation butter.

Braius of buttalo used in tamning by Indians.

6. Bircl-oils :

(Oils of petrels anci otber sea-birrls used by Eskimos and in the Azores for lawp-oil.) 
27. OILS AND FATS-Continued.

b. Bird-oils :

Goose-oil used by watch-makers, and as au emollient.

(Oil of guacharo, (Steatomis caripensis,) used in South America as food.)

(Ostrich nsed for food, and by the Arabs in medicine, and emn-oil nsed in Anstralia in medicine.)

(Oil of pengnin, (Diomedea chilensis,) of Falkland Islands, sold in London for currying leather.)

(Peacock's fat and oil.)

(Oil of mutton-bird, (Procellaria obscura,) of Bass's Straits, used for lamp-oil illuminating.)

(Oil of frigate-birl, (Tachypetes aquila,) sometimes used in medicine.)

Oil of pigeon, (Ectopistes migratorius,) used as food by Indians and frontiersmen.

(Fulmar-oil from island of Saint Kilda.)

c. Reptile oils :

Alligator-oil manufactured in Fiorids.

(Alligator-oil used by Sonth American Indians, mixed with chica pigment for painting their bodies.)

Turtle-oil made from turtle-eggs, used in dressing leather and in maunfacture of soap.

Rattlesnake and other snake oils.

d. Fish-oils :

Sun-fish oil used by fishermen for cure of theumatism.

Cod-oil, also cod-liver oil used in medicine, as a food and emollient, and in lubricating.

Hake and haddock liver oil used in adulterating cod-liver oil. (Pollock-oil used by Sheťlanders for illumiuation.)

Menhaden-oil used in currying leather, in rope making, for lubricating, for adulterating linseed-oil, as a paint-oil, and exported to Europe for use in the manufacture of soap and for smearing sheep.

Herring-oil. ${ }^{1}$

White-fish oil. ${ }^{1}$

Sturgeon-oil. ${ }^{1}$

('Note. -These oils, with other oils made from fishes, and a large part of the seal and "black" whale onl, are known indiscriminately as fish-oil and used chiefly for the purposes enumerated under the heid of menhaden-oil.) 
27. OILS AND FATS-Continued.

d. Fish-oils :

Oulachan oil used by Indians of Northwest coast for food and illumination.

Shark and skate liver oil, including the "Ronen oil," made on the coast of Normandy from the licers of Raia aquila, $R$. pastinaca, and $R$. batis, used like cod-liver oil.

Cramp-fish oil used by fishermen for cure of rheumatism.

Soaps made from fish-oil.

28. PERFUMLS.

a. Mammal perfumes:

(Ciret of the ciret-cat (Viverra civetta) of Africa.)

(Civet of the rasse (Viverra rasse) of Jaris.)

(Zibeth ciret of the Zibeth (Viverra zibetha) of Indian Archipelago.)

(Musk from musk-deer, (Tragulus, sp. val.,) in its rarious grades, of Tonquin or Thibet. and. Kabardin, Russian, or Siberian musk.)

Musk of musk-ox.

Musk of the musquash.

Castureum of the bearer, including the various commercial grades, the Canadian, Hudson's Bay, and Russian castoreum, and specimens of castorine.

(Hrraceum of the daman, (Hyrax cupensis.))

Ambergris of sperm-whale, with specimens of ambreine.

b. leptile perfumes:

Muskis of alligator.

Oil of hawksbill and loggerhead turtles, used in pertumery.

29. COLORIYG MaterLALS.

a. Derived from mammals:

Bone-black.

Irory-black, (noire divoire,) used in fine painting, and in the manufacture of bank-note ink.

Prussiates, prussian-blue, ferrocranide of potassium, made from hoofs and refuse buman and other hair.

Gall of animals used in dreing.

Dung of animals used in eulico-printing.

Hæmatin made from blood, and used in turkey-red dyerrorks, and for the red liquor of printers.

Wool.tlocking. (See nuder D. 2h.) 
29. COLORING MATERIALS-Continued.

b. Derired from birds :

Shell of eggs, used for white pigment.

Series of murexides, or purpurate of ammonia dyes, made from guano.

c. Derired from fishes:

(Essence d'Orient, or fish-scale pearl, nsed as a pigment.)

(Gall of carp, used in Turkey as a green paint aud in staining paper.)

d. Derived from insects:

(Cochineal dye, from Coccus cacti of Mexico, used in manufacture of rouge, of carmine, and lake pigments, and in coloring tinctures.)

Canadian cochineal.

(Kermes(and other cochineals of commerce, Coccus ilicis.)

(Lac dye and lac lake, from Coccus lacca, O. polonicus, C. uva ursi, and Ophis fabce.)

Dye prepared from bed-bug, (Cimcx lectularius.)

(Dje prepared from Trombidium, in Guinea and Surinam.)

Nut-galls produced by insects, and used in tanning, for black dyes, for woolen cloth, silk, and calico, and in manufacture of ink and gallic and psrogallic acid, employed in photography.

e. Dexived from mollusks:

(Sepia from Sepia officinalis.)

Purple dres from gastropods, Murex, Purpura, \&c.

Purple djes from nudibranch mollusks.

30. CHEIICAL PRODUCTS AND AGENTS EMPLOYED IN ARTS AND MEDICINE.

a. Derived from inammals :

Secretion of skunk.

Album grceum of dogs, used as a depilatory in tanning hides. Albumen of blood, employed in sugar-refineries, in certain cements and pigments, and as antidote and emollient.

Dung, used in calico-printing.

Gall of animals, used in mixing colors, in fixing the lines of crayon and pencil drawings, in preparing the surface of irory for painting, in removing grease, and in medicine.

Pepsine and pancreatine, prepared from stomachs of hogs and calve's. 


\section{CHEMICAL PRODUCTS, \&c.-Continned.}

a. Derived from mammals :

(Koumiss, a fermented liquor, prepared from mare's and cow's milk, and emplored in medicine.)

Phosphorus, prepared from bones, with specimens of matches, rermin poisons, and other products.

Vaccine lymph, derived from cows.

Ammonia, prepared from bones and horu.

Sal ammoniac, prepared from bones and dung.

Prussiates, prepared from hoof, holn, and leather waste, dried blood, hair, and wool, with speciunens of blue cranide of potassium.

Lime from bones aud bone phosphates. See also nuder 32.

Punk and tinder, made from droppings of camel and bison.

Animal charcoal, used as a ilecolorizer.

b. Derived from birds :

Albumen of eggs, used in photographr, in clarifsiug liquors, by physicians as emollients and antidotes, and by apothecaries in suspendiug oils and other liquids in water.

Egg-shells, employed as an autacid.

c. Delived from reptiles:

Crotalin of rattlesnake aud copperhead.

(Scincus officinalis of Egrpt, used hy European practitioners as sudorific and stimulant.)

d. Derised from fishes:

Propslanine, made from fish-brine.

(Intestimes of grayling, usel by Laplanders as a substitute for remnet.)

Skins of eels, used by negroes for rheumatisın.

e. Derived from insects :

Tesicatory preparations from American beetles, Cantharis cinerea and $C$. vittata.

(Vesicatory preparations derived from foreigu beetles, cantharides or Spanish flies, (Cantharis vesicatoria,) and other species, and substitutes Mylabris cichorii, Cercoma Schoefferi, Meloe, sp. rar., Sc.)

Vesicatory preparations from American spiders, such as Tegenaria medicinalis.

Gall-nuts, used in medicine. (See under 29.) 
30. CHEMICAL PRODUCTS, \&c.-Continued.

e. Dericed from insects:

Coccinella, used as a remedy for toothache.

(Trehala, made from nests of beetles, (Larinas nidificans, ) of East Indies, and used as a substitute for tapioca.)

Formic acid.

Carbazotic acid and its derivatives, made from sewing silk scraps, anid used as a substitute for quinine.

Beestax, used in manufacture of candles, cerates, plasters, and artificial flowers, in modeling and casting, and in medicine.

Honey, used as a preservative, a food, and in medicine as an aperient and demulcent.

(Wax, used in Chinese pharmacy, secreted by the Coccus pehlah.)

(Nanna, produced by punctures of Coccus manniparus.

$a^{\prime}$. Manna from the Tamarix mannifera, used as food, and in medicine as a purgative.

b. Cedar manna of Mount Lebanon, from Pinus cedrus.

c. Arabian manna, from Hedysarum alliagi.)

(Eye-powder, made by Chinese from the Telini fly, (Mylabris cichorii,) of India.)

$f$. Derived from crustacea :

Salve-bug of fishermen of Banks, (Caligus curtus,) parasite on cod-fish.

Crabs' eyes, or concretions from stomach of astacus, used as an antacid.

g. Derived from worms:

American leech, (Macrobdella decora,) used in surgery.

(European leech, (Hirudo medicinalis, introduced into America.)

(African leech, (Hirudo trochina,) introduced.)

Leeches used as baroweters.

h. Derived from mollusks:

(Cuttle-fish bone of Sepia officinalis.) (See under D, III, H.)

Calcined shells, used for building-lime, and in manufacture of dentifrices and enamel. (See under III, H.)

i. Derived from radiates:

a. Limes, derived from calcining coral and coral rock. 
30. CHEMICAI PRODUCTS, \&c-Continued.

7. Derived from protozoans:

Burnt sponge, formeily used in medicine.

Infusorial earth, and its applications. (See above, under $\mathbf{K}$.) 31. FERTILIZERS.

a. Natur:il guanos:

Bat guawo from cares.

Bird guano from oceanic islands.

b. Artificial guanos:

Menhaden guano.

Herring guano.

White-fish guano.

Other fish guano.

c. Artificial fertilizers:

Bone-dust ground for use.

Bone phosphates.

Dried meat from refuse of slaughter-houses. Pondrettes.

Other animal fertilizers.

32. LIMES. (See under 30.)

33. OTHER MATERIALS NOT MENTIONED. 


\section{SECTION W. \\ PROTECTION AND CULTURE. . \\ I. INVESTIGATION.}

1. METHODS OF THE UNITED STATES FISH COMMISSION.

a. Methods of work:

Apparatus for collecting specimens, (see under B.)

Apparatus for physical research.

Appliances for working up results.

(This should include a model of coast laboratory with all its fittings.)

b. Results of work :

Publications of the commission.

Collections, (see under $A, V$ to VIII.)

Photographs, \&c.

\section{PROTECTION}

2. PRESERVATION OF GAME, FISH, \&c.

a. Game laws.

$$
\text { * From man. }
$$

$$
\text { ** From artificial obstructions. }
$$

b. Fish-ways $:^{1}$

Gap fish-ways.

Trench, ditch, or "Cape Cod" fish-ways.

Ohlique grove fish-ways:

Single groove.

Brewer's.

Mather's.

Step fish-ways:

Box or pool fish-ways:

- Overflowing, (old style.)

With passage-way cut down to the floor, (Smith's.)

With passage-way submerged, (Cail's.)

With contracting galleries, (Pike's.)

With transverse-sloping floors, (Steck's.) 
2. PRESERVATION OF GAME, FISH, \&d.-Continued.

b. Fish-ways:

Steps contrived by arrangement of rocks and bowlders. Inclined plane without steps:

Plain, (Pennsylrania.)

With partitions at right angles:

- "Rectangular compartment."

Brackett's.

With oblique partitions :

Foster's.

Swazey's.

*** From natural enemies.

c. Apparatus for destroying injurious species:

Oyster-bed tangles, (see under B, 12.)

3. CARE OF ANIMALS IN CAPTIVITT.

a. Tethers and hopples.

b. Cages and pens:

Kennels for logs, se. .

Cages for animals.

Cages for birls.

Cages for insects.

(West Iudia tire-tly trap.)

e. Fish-cars and other fluating eages tor aquatic animals.

d. Aquaria :

Gilubes.

Ayuiriat.

e. Hires and other cages for insects.

f. Lire-boxes, tromghs, Sce, for microscopists' use.

g. Fish-pouds, fish-farms, (models.)

4. MALAIES OF USEFUL AYMALS.

a. Intestinal worms and other interual parasites.

b. Fish-lice, barnacles, and other exterual parasites.

c. Predatory animals not elsewhere exhibited.

\section{PROPAGATION.}

5. PROPAGATION OF MAIMALS.

a. Methods of minls culture.

u. Methods of culture of domesticated animals. 


\section{PROPAGATION OF BIRDS.}

6. Methods of ostrich culture.

b. Methods of culture of domesticated birds, fowls, \&c.

7. PROPAGA'IIION OF REPTILES.

a. Methods of terrapin culture.

8. PROPAGATION OF AMPHIBIANS.

a. Methods of frog culture.

9. PROPAGATION AND CULTURE OF FISHES. ${ }^{1}$

a. Accessories of obtaining and impreguating ova :

Pans, pails, \&c.

Strait-jackets used in spawning salmon.

Spawning-race, (Ainsirorth.)

Roller-spawning screen, (Collins.)

Spawning-vat, (Bond.)

b. Hatching-apparatus:

Troughs:

Plain.

Gravel-bottomed.

With sieve-bottom trays:

Brackett's.

Williamson's.

Clark's.

Vats or cases:

Holton's.

Roth's.

Glass-grilled boxes, (Coste's.)

Jars and tin-ressels :

Bell and. Mather's.

M. A. Green's.

Ferguson's.

Chase's.

Hatching-boxes, (floating:)

Seth Green's shad-box.

Brackett's shad-box.

Brackett's shad-box, (No. 2.)

Bryant's shad-box.

Stilwell \& Atkins's shad-box.

Bannister's shad-box. 
9. PROPAGATION AND CULTURE OF FISHES-Continued.

b. Hatching-apparatus :

Hatching-boxes, (floating:)

Adhesive eggs apparatus:

Vertical wire-cloth trays.

Hatching-basket.

Brook shanty, (Furman's.)

(Bay or cove barriers, Professor Rasch's.)

Accessories :

Tauks.

Nests.

Trays.

Giilles.

Gravel-filters.

Flannel sereens.

Shallow troughs or tables (for picking eggs.)

Egro-uippers.

Cribbles.

Pipettes.

Slimmer-nets.

Feathering quills and brusbes.

Rose-nozzles, (for washing eggs.)

Syringes, bulb, \&c.

Shallow paus.

Aerating-pipe.

e. Transporting aploratus:

Apparatus for trausportiug eggs:

Caus.

Cise of cups, (Wilmot's.)

Case of cups, (Clark's.)

Case of trașs, (Clarliss.)

Moss-crates, (Stone's.)

Apparaltus for transporting fish :

Barrels.

C:ins, plaiu.

Cizns with aerating accessories:

Slack's.

Clark's.

Creveling.

II. A. Green's. 
9. PROPAGATION AND CULTURE OF FISHES-Continued.

c. Transporting apparatus:

Apparatus for transporting fish:

Tanks with aerating accessories:

Tauks, with attachment of band-wheel to car-axle, (Stone's.)

(Tanks, with Freiburg aerating apparatus.)

Aquarium-car, (Stone's.)

Live-box, (Atkins's.)

Accessories :

Air force-pumps.

Siphons.

Siphon-tubes.

Bellows.

Roses, aerating.

10. PROPAGATION OF INSECTS.

a. Propagation of silk-worm :

Specimens of plants used for food.

Model of house and its appliances.

b. Propagation of cochineal insect.

c. Propagation of bees:

For hives, (see under E. 3.)

11. PROPAGATION OF WORMS.

a. Propagation of leeches.

12. PROPAGATION OF MOLLUSKS.

a. Methods of oyster culture:

Stools for receiving spat, natural and artificial.

Other apparatus.

13. PROPAGATION OF CORALS.

14. PROPAGATION OF SPONGES. 



\section{N D.FX.}

Page.

Acalephs

Acanthopteri

Accessory to fishing-vessels........

Adhesive preparations ............

Adirondack boat ................

Advertisement

terating-accessories

derating, roses .................

Agassiz collecting-tank...........

Agassiz storage-tank ............

Aids, personal ..................

Ainsworth spawning-race

Air force-pumps ................

Air-guns .....................

Albatrosses......................

Albumen of blood.

Albumen of eggs................

Albnmen, preparation of

Albumen preparations, manufacture of ..........................

tlbum gracum of dogs

Alcohol.

Alcobolic specimens

Alectorides

Alewife, or gaspereau

Alexandria Bay boats

Alligator .....................

Alpaca

Alpenstocks

Ambergris.

Ambreine

Amia

Ammonia

Ammonia, carbonate of.

Ammonia dyes, purpurate of ......

Ammonia, manufacture of.........

Ammunition .....................
14 Ammunition-holders .............

44 Ammunition-measures ...........

39 Amphibians ....................

43 Amphibians, propagation of .......

iv Amphibians used as food .........

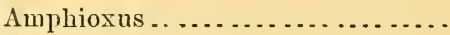

Anacanthiui........................

Anatomical jars............... 54

Anchors ..................... 44

Anchory ..................... 15

Angel-fish .................... 14

Angler ...................... 13

Angling-apparatus............. 33,34

Angling-tackle................ 31

Animal-cages ................. 98

Animal-calls.................. 41

Animal charcoal ............... 94

Animal equipments ............. 42

Animal, preservation of, for scientific 
Apparatus for destroying injurions

species

Apparatus for kindling fire.

Apparatus for leather-dressing, recent and aboriginal

Apparatus for transporting fish.... Apparatus for wholesale destruction

Appliances, instrunıents and, for rendering whalc-oil

Apodes

Aquaria

Aquarium-car (Stone's)

Aquatic animals, floating eages for. Arachneans....................

Arachnida . . . . . . . . . . . . . . . .

Argonauts .

Armadillo

Armor, defensive

Arms collectiug-tank

Arrows

Artbropods

Articulating-tools

Artiticial flies.

-

Artiticial flies, raw materials for making ..................

Artificial flies, tuols for making....

Artificial lights.

Alt of plumagers..............

Arts and manufactures, materials employed in .................

A, section

Asplęrxiators

Assorting ...................

Astacus ....................

Astronomical instrumeuts ........

Atheriues ...................

Atzius's live-box..............

Auks.

Aroset

Awls, prodding ...............

Axes ........................

Axolotls

Azuring 
INDEX.

Page.

Bees

Bees, propagation of

Beeswax

Beetles

Beetles, vesicatory

Bellows ........................

Belts.

Beluga .....................

Bidarkas

Bidarras

Binder's leather.

Binnacle-lamps.

Binnacle-lanterns

Birch eanoes...................

Bird and reptile oils, extraction of

Bird-eages.....................

Bird-lime.....................

Bird-nets

Bird-slings (used by Eskimos)....

Birds

Birds, decoy ...................

Birds, domesticated, methods of eulture of .....................

Birds, hunting.................

Birds, quills of.

Birds, skins of, used as furs........

Birds used as food ...............

Bison ........................

Bits..........................

Bitterns.....................

Black-bass....................

Black-birds

Black, bone ....................

Black-fish

Black-fish, or tautog ............

Black, ivory ...................

Blankets

Blankets, decoy (for antelopes) ....

Blenny......................

Blind fish

Blocks

Blood

Blood, hæmatin from

Blood-poison : woorara
17

101

95

17

94

101

30,45

7

43

43

82,83

44

44

43

52

98

39

30

25

9

41

40

87

73

58
Blow-anns

Blubber-fork.................. 52

Blubber-mineing-knives......... 22

Blubber-room ................ 44

Blue-birds...................... 9

Blue-fish ..................... 14

Blue, Prussian................ 85, 92

Boarding-knives.............. 52

Boat-hooks................. $\quad 23$

Boats ...................... 43, 44

Boat-spades ................. $\quad 22$

Bobs ...................... 31, 41

Boilers ...................... 52

Boiling-vats ................. 54

Bolas....................... 25

Bombazines .................. 74

Bomb-lance .................. 29

Bomb-lance and gun ............ 28

Bond spawning-vat............. 99

Bone ...................... 75, 76

Bone-black ................. 77,92

Bone charcoal for filters .......... $\pi 7$

Bone phosphates............... 93

Bonito ...................... 14

Boomerangs .................. 25

Boots ....................... 39, 45

Botargo ..................... 67

Bottom-gear................. $\quad 31$

Bottom-set lines ............... 31

Boutargue.................. $6 \pi$

Bowing ..................... 48

Bowlder fishways ............... 98

Bowl-traps ................... 38

Bows....................... 26

Boxes ......................... 30

Box-fish..................... 13

Box fish-mays................ 9

Box-swivels .................... 34

Box-traps ................... 37,38

Brackett's fish-way ............. 98

Brains of buffalo ................ 90

Brants, decoy ................ 41

Breastplates ................... 45

Brewer's fish-way .............. 97 
Brick traps (fig. 4) .............

Bridges, portable.

Brillantine

Bristles

Broadcloths

Brocades

Brook-shanty (Furinan's)

Brushes

Bruta

$\mathrm{B}$, section

Buckskin

Buckskin finish

Buffalo brains

Buffalo-fish

Buff leather

Bugs.

Bullet-molds

Bullets

Bull-hearls

Bull-uets

Bull-tows

Bunts

Burbot

Buruing of lime

Burnt horn

Burut spouge

Butter

Butter-fish

Butterflies.

Buzzards

liyssus of mollusks

Cabin

Cabrestos

Caddice flies.

Cages

Carges for auiluals

Cages for birds

Carres for iusects.

Cail's fish-ways.

Calamaries, or squids

Calcined coral

Calico priuting

Caligus curtus

Calls .

Capel.
Page.
Page. 80 55 74 46 44,45 
Cashmeres

Casks .......................

Cast-nets

Castoreum.

Castor-leather

Cats..

Cat, domesticated.

Cat-fish

Cat-gut

Cat-gut (sheep)

Cat-rigged fishing-boats

Caviare

Centipedes

Cephalopoda.

Cero

Cete

Chretodons

Chains 33,44

Chameleons

Chamois-leather

Charcoal, animal

Charcoal, bone.

Charge-drawers.

Cheese

Chemical products..............

Chemical products and agents ent-

plosed in arts and nedicine ..... Chimæra

\section{Chiroptera}

Chloral hydrate.

Chocks

Cbogset

Chondrostei

Choppers

Chopping-knives

Chopsticks

Chorda filum

Chronometers

Cinera vittata

Cirrostomi

C'ivet of eivet-cat

Civet of the Zibeth

"Clamms" for deep-sea soundings.. Clap-nets for birds
Clarifying-vats ...............

Page.

Claws ......................... 78

Cleaners..................... 49

Cleaning instruments ............ $\quad 29$

Clearing-rings ................. 34

Cleavers ..................... 22

Clothing ...................... 45

Cloth-suits .................... 45

Cloths woven from feathers....... 74

Clubs ........................ 21

Clubs used as missiles........... 26

Clutching-traps................ 38

Coast laboratory ................ 97

Cob-house bird-traps ............ 38

Cobia ......................... 14

4 Culture, protection and .......... 97

Coccinella ...................... 95

Coccus cacti ...................... 93

Coccus ilicis ..................... 93

2 Coccus lacca.................... 93

83 Coccus manniparus................ 95

44 Coccus pehlah .................. 95

77 Coccus polonicus ................ 93

29 Coccus uva-ursi................. 93

65 Cochineal colors, preparation of ... $\quad 53$

53 Cochineal ..................... 93

Cochineal insect, propagation of.... 101

93 Cockades...................... 87

16 Cod ............................ 14

7 Cod, rock..................... 14

54 Colenterata .................... 20

44 Collars ........................ 40

14 Collecting-tanks ................ 53

16 Collins's roller spawning-screen .... 99

48 Coloniamite .................... 28, 90

22 Colonia powder ............... 28,90

33 Coloring materials.............. 92

33 Columbæ..................... 10

44 Combing ..................... 48

94 Comnissary supplies............ 45

17 Compasses..................... 44

92 Conchifera ...................... 19

92 Congers ....................... 16

52 Contents, table of............... vii

36 Cooking-apparatus.............. 45 
Cooks' lamps

Cooler.

Cooling

Coots

Copperhead, crotalin of.

Copses

44

52

52

11

94

42

82

Coquina......................

Coral $.37,81,95$

Coral, preparation of .............

Coral, propagation of.

Coral rock

Cordage.

Cork floats

Cornorant-collars.

Cormorants.

Cormorants (Carbo sinensis, used in fishing in China)

Cosmeties

Cotton-oil and its manufacture ....

Couches

Covers

Covers for fish-drșing.

Covers for luuters

Cow-fish

Cowry.

Cows........................

Crab's-cyes ...................

Crab-stones..................

Crakes .....................

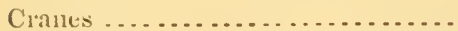

Crapes .......................

Crates, moss (Stone's) ............

Creases.....................

Creepers ....................

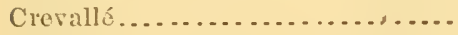

Cribules.....................

Crickets.....................

Crimpers....................

Crinoline skirts................

Croaker ......................

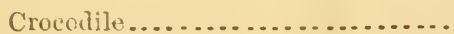

Crocortilia ....................

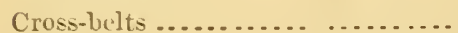

Cross-bowrs ...................

Cross-bow traps ..............

52

101

95

44

33

40

11

40

99

45
Page.

Crotalin

Page.

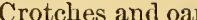

Crows....................... 9

Crushing-traps ................ $\quad 39$

Crustacea .................... 18

C, section .................. 47

Cuckoos..................... 9

Cंneuli ...................... 9

Cucumber, sea................ 19

Cunner, or chogset............. 14

Cup-leads ................... 23

Cups........................ 100

Curled hair.................. 49

Curlew...................... 10

Curriers' implements........... 49,50

Currying ................... 49,50

Cusk ....................... 14

Curlasses...................... 29

Cutting and carving ivory ........ 51

Cutting-spades ................ $2:$

Cnttle-fish bone.............6 $8,81,95$

Cycloganoirlei ................. 16

Cynailurns jubatus............... 39

Dace ........................ 15

Dagerers....................... 21

Damasks .................... 74

Darters, or water-tırkeys ........ 11

Darting-sticks............... 20

Darts ....................... $\quad 26$

it Deaclefalls, not antomatic - n......

100 Deck-pot .................... 52

22 Decoy animals, birds........... 41

9 Decos-bircts .................. 41

14 Decur-brants .................. 41

100 Decor-dogs.................. 41

17 Decoy-ducks.................. 41

29 Decoss .................... 40,41,42

if Decor-waders ................. 41

14 Deep-sta gear ................. 31

$1:$ Deer ......................... 6

12 Deer-beads .................... 42

t5 Deer, musk.................. 92

$\approx 6$ Deer-siedres.................. $4: 2$

39 Defensive armor .............. 45 
INDEX.

Page.

Delineating-apparatus

Denticete

Desiccated meat

Desiccated milk.

Destroying injurions species, apparatus for.

Destruction, apparatus for wholesale

Devil-fish

Dingies

Dip-nets

Dippers

Dirks

Disgorgers

Disgnises

Ditch fish-ways

Dog-carts

Dog-collars

Dog-food

Dog-harness

Dog-kennel

Dog-muzzles

Dog-sledges

Dog-whips

Dog-whistles

Dogs .

Dogs, decoy

Dogs, prairie

Dolpbin

Dolphin-irons.

Domesticated animals, methods of culture of

Domesticated birds, methods of culture of

Domesticated cat

Dumesticated fowls, methods of culture of ........................

Domesticated peacock............

Domesticated ralıit

Domesticated sparrow ............

Door-traps

Derss.

Double box-traps

Doves

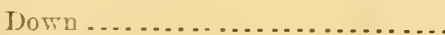

Down of birds
55

65

65

98

39

13,16

43 35,36
Down, preparation of........... 49

Dragon-flies ................... 17

Drags....................... 33

Drailing-tackle ................ $\quad 31$

Drails...................... $\quad 32$

Dredge-line rollers ............. 34

Dredges ...................... 36

Dressers...................... 50

Dressing feathers .............. 50

Dressing fur .................. 50

Dressing leather.............. 50

Dried foods .................. 65

Drift-nets .................. 35

Drugs...................... 53

Drum ...................... 14

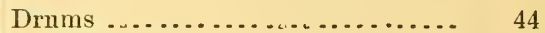

Drying-houses ............... 47

Drying, preservation by ......... 47

D, section ................... 57

Dualine .................... 28,90

Ducking-boats................ 43

Ducks..................... 11

Ducks, decoy ................. 41

Dug-outs..................... 43

Dung .................... 92, 93

Dunlin ..................... 10

Dyeing................. $49,50,51,92$

Dyes ....................... 93

D5nanite, or giant-powder ...... 28,90

Eagles ...................... 9

Earths, infusorial .............. 82,96

Earth-worms .................. 18

Echinodermata ............... $\quad 19$

Eel-pots (without covers) ........ $\quad 37$

Eels ......................... 16, 17

Eels, lanterns for fire-fishing for.... 42

Eel-traps..................... 37

Eel weirs (with leaders) ......... 37

Egrgs, albumen of ............... 94

Egg-nippers .................. 100

Egrets ...................... 10

Elasmobranchiates.............. 16

Elephants................... 6,7 


\section{INDEX.}

Encircling-nets

Page.

Enemies of useful animals

35,36

93

Engraring, heliotyping, and illustrations, methods of.

\section{Entangling-nets}

Enumeration of animals

Equipments

E, section

Essence d'Orient

55

Eventognathi.

49,93

Explosive bullets

Explosive shells

Explosires 28,90

External parasites

Extraction of birả-oils

Extraction of fish-oils

Extraction of gelatine ...........

Extraction of glue.

Extraction of isinglass

Extraction of mammal oils

Estraction of reptile-oils..........

Extraction of whale-oil...........

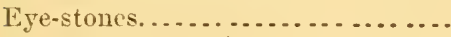

Face-net......................

Falcons

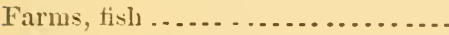

Fats

Fatting-linives .................

Feather-dressing

Featler fabrics, preparation of.....

Feather tlowers.................

Feathering brushes ..............

Featiering quills ...............

Feathers ......................

Feathers, preparation of ..........

Felt-cloths ....................

Felt-hat:

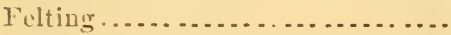

Felting and the hat-manufacture...

Felts

Ferre.

Ferret.

Ferrocranide of potassium

Fertilizers .....................

Fertilizers, manufacture of.........

Fids

Field-glasses................... 46

Figure-four traps . ............. 39

File-fish ...................... 13

Filters ...................... it

Fin-chains.................... 33

Fire-fishing

Fire-hshing.................... 41

Tire-fly trap ......................

Fish, apparatus for transporting....

Fish-baskets.................. 45

8 Fish-cars ..................... 98

Fish-carts (nsed in Nantucket) .... 42

52 Fish Commission, United States ... 97

52 Fisherman's flasks .............. 46

52 Fishers..................... 5

52 Fishes..................... 1:

52 Fishes, hunting ............... 40

5.2 Fishes, propagation and culture of.. $\quad 99$

52 Fishes, scales of ............... 49

81 Fishes used as food.............. 61

45 Fish-farms................... 98

t0 Fish-muano works, model of ........ 53

98 Fishing-boats................ 43

90 Fishing-houses................ 44

$2:$ Fishing-lanterns ............... 41

50 Fishing-ressel accessories......... 44

49 Fish-lice ................... 42

$\Rightarrow$ Fisl-oil, soaps from ............

100 Fish-oils, extraction of..........

100 Fish-pots................... 3 3;

$8 i$, os Fish-pounds .................. 93

49) Fisb, preservation of ........... 95

it Fish-scale work, preparation of....

74 Fish-slirles................... $3 \pi$

if Fish-slings .................. 4i)

$4=, 49$ Fish-transporting apparatus...... 100

48, it Fish-wars .................. 07,12

5 Fissipedia ................... 5

$\overline{5}, 40$ Flails ...................... 21

92 Flake-drying ................ . 47

96 Flamingoes.................. 11

53 Flanne]s .................... it 
Page.

Page.

Flanuel screens

100 Fowls, domesticated, methods of

Flasks

30,46 culture of

Flat-fish

13 Foxes ................................

Flaying-tools

F'lies

17,40

Frames, \&c ................. 55

Flics, artificial

40,4

Floating hatching-boxes

French sardine-fisheries .......... 40

Floating trawl-lines.

9

Floating cages for aquatic animals.

Floats ........................

Floats, manufacture of ............

Flocking from refuse quills, preparation of 49,87

Flocking, wool

Flounders

Flowers, feather

Fluke-chains .

Flukes

Fly-books

Fresh food

Frigate-birds

Frog-culture, methods of ..........

Frogs

45

Fulling ...................... 48

Funnel-traps .................. 37

, 87 Fur-dressiug ................... 50

86 Furman's brook-shanty .......... 100

13 Furviture ..................... 45

8r Furs pack-saddle (Hudsou's Bay

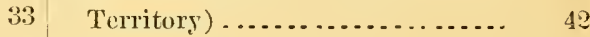

18 Fur robes ..................... 45

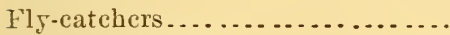

Fly-fishing tackle................

$\mathrm{Fly}$-hcoks

Flying-fish

Flг-tail seines of North Carolina...

Fog-horus ....................

Folủing or jerk nets .............

Food.............................

Food, dog

32,41

9 Fur-seals ......................

68

31 Tykes - 37

32 Gaff-hooks ................... 23

15. Gallinæ ...................... 10

35 Gallinules .................... 11

44 Gall-nuts....................... 94

30 Gall of animals ................ . 93

57,77 Gall of aninals used in dyeing..... 92

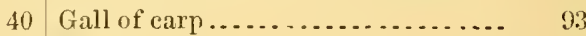

$5 \%$ Galls, nut.................... 9.3

47 Game-bags ................... 45

39 Game-laws .................... 97

Food, methods of preparation of...

Food-poisons ...................

Foods......................... 65, 66

Fuods, dried and smoked ..........

Footpatli-snares ................

Foraminifera

Forceps .....................

Force-punus, air ................

Fork, blnbber ..................

Forks nsed in handling salted and dried fish ..................... .

Iormic acid

Formic acid, manufacture of ......

Foster's fish-ways ................

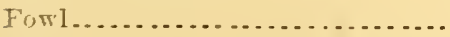

Fowling-pieces .. $2 \pi, 28$

(i5) Game, preservation of .......... 97

38 Game-slings .................. 45

20 Gangs of hooks for minnow-bait.... 31

55 Gannets ....................... 11

101 Gap fish-ways ................ 97

52 Gar-fish ..................... 15

Gar-pikes ................... 16

23 Gaspereau.................... 15

95 Gastropoda..................... 19

53 Gastropods, purple dyes from...... 93

98 Geese ........................ 11

10 Gelatine, extraction of ........... 52 
Page.

Gelatines

Giant-powder

Gigs

Gill-net floats

Gill-nets, used in great lakes

Girths

Glacé, papier

Glass floats.

Glires

Globes, fish

Glue, extraction of

Gun-racks

Gunwale-winches

Gun-worms ................... 29

Guruard ..................... 14

$\$ 2$ Gut-lines ....................... 33

79 Gut, method of dressing ......... 50

33 Gut, silk-worm ............... 89

8 Gut-snoods, silk-worm .......... $\quad 33$

98 Gjro-trap targets ............... 30

52 Haddock ..................... 14

Glues $.4 \%, 28,85$

Fræmatin.................... 92

Glycerine

Iass....................... 17

Goat

6) Hair 73,85

Goat, mountain

6 Hair and rrool rork 51

Goby

Godwit

Goose-fish

Graining

Grain-leather

Grains.

(irampus

Hair of mammals, preparation of .

10 Hair-seals .................... 6

13 Hake........................ 14

49 Malibnt .................... 13

ह. Hammocks ................... 45

91 IIans ....................... 6.5

† Hand-dredges .................. 23

(iraplling-irons................

Grasshoppers

?4 Hand-gear.................... 31

17 II:un-implements.............. 21

(iravel-filters ..................

(ivelues

$10(1)$ Handic or dip nets .............

11 Hangiug-needles.............. 36

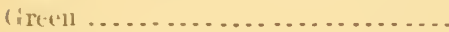

Circenlets

1? IIillomi ...................

9 Ilard tissues. preparation of...... 51

10 Harness ...................... 42

100 If arponon ball and grn .......... 23

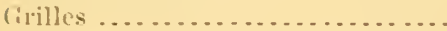

(irinders

-3 Ilappoon bomb-lance gun ........

if Hinponon-billets .............. 24

101 lin!poous.................. $\$ 4$

14 II:ripoon-traps................ 39

¡1 IIatsbor' ................ 7,78

yo IItchets ................... 22

$\because$ Hatching ipluaratus ........... 99, 100

11 Hatching-boxes (floating)........ 100

10 Hat-manufacture. ........... \& 4,49

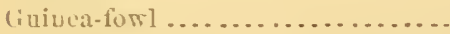

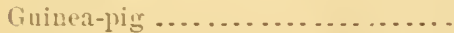

Gilllls.......................

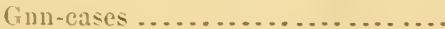

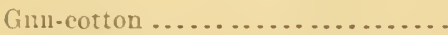

Gun-harpoons

Guzporder .

- IIits ..................... 4ii, it

11 Hanliug-taclile (sinf) ........... 31

• 30 Hawlis ..................... 9

¿ Mamks-bill turtles .............. 12

24 Head-ases for whalemen ........ 22

?S IIcarl-cliains ani ropes........... \$3 
Head-kuives.

Heat-oil, preparation of.

Head-pike and ring

Heart-pound..................

Hell-benders ..................

Hemdurgan

Hemibranchii

Herodiones

Herons.

Herring

Herring-boats

Iierring-nets..

Herrings, king of the.

Heterosomata

Hexapoda

Hippocolla

Hires for insects.

Hoes insed in gathering shell-fisb...

Hog

Holocephali

Holsters

Finey.

Hoods

Hood-seals

Hoof, preparation of

Hoofs

Hooked instruments

Hook-gill-net of the SaintLawrence. Hooks

Hooks, movable lines with .......

Hooks with stationary lines .......

IIook-swivels

Boop-nets

IIopper, scrap

Hopples

Horn...

Horn, preparation of

Horn, burnt

Horned-toads

Horns

Horse

Horse, minciug

Horse, sea...

Horse-trappings

Hosiery
Hour-glasses.................... . 44

Humming-birds.............. . 9

33 Hunters' flasks................. 49

37 Hunters' houses................ 44

13 Hunting-birds ................. . 40

14 Ilunting-boats ................. 43

13 Husting-camps ................. 44

10 Hunting-dogs.................. 40

10 Hunting-fishes................. 40

15 Hunting-lanterms .............. 41

44 Hunting-leopard.............. 39

36 Hunting-lodges .... . . . . . . . . . . . 42

16 Hunting-mawinals ............. 39, 49

13 Hunting-rifles ................ 28

17 Hunting-suits . . . . . . . . . . . . . . . 45

89 Hurled sticks ................. 26

98 Hurled weights ................ . 28

23 Huron boats.................. 44

6 Hyla ...................... 12

16 Hyperoartia .................. 17

30 Hsperotreti .................. 17

95 Hyracenm........................... 92

39, 40 Hyrax capensis................ 92

6 Ibises . . . . . . . . . . . . . . . . ... 10

51 Ice-boxes and refrigerators ....... 47

78 Ice-houses .................. 47

23,24 Ice-trade.................... 47

37 Ichthyocolla................. 89

32 Imitation pearls .............. 80

30 Imitations of animals and birds... 41

:1 Imitations of fishes.............. 41

34 Imitatious of red coral ........... 82

30,36 Imitation tor toise-sbell .........

52 Implements employed by cnrriers.. 49,50

98 Implements, hand ............. 21

77 Inıpreguating ova, acecssories of ob-

51 taining and ................. 99

\% Incline-plane fisb-ways.......... 98

12 Indelible inks................. 54

30 Indelible pencils ................ 54

6,50 Indian raft-boats.............. 43

52 Inflatable bags ................ 54

13 Infinsorial earth ............... 82,96

42 Injurious species, apparatus for de-

74 stroyiug................... 
Ink

Inks, manufacture of

it

53

98

98

Inseet-hives

Inseetivora

Insect-powders

Insects

Insects, propagation of

Iusects, protection from

Instruments and appliances of renGeriug whale-oil ..............

Instruwents for eleaving, loadiug, \&c................................

Internal parasites................

Introduction

Iuvertebrates, other waterials from . Isinglass

Isinglass, extraction of ............

Isospondyli . .

Italian fishivgr-boats (California)...

Ivory .......................

Irory-black....................

Irory-black, manufacture of ......

Irory cutting and earving .........

Jacket-lamps ...................

lack-lanterns, for tishing ..........

Jagruars .......................

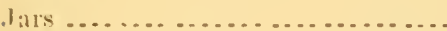

Jar mole-traps . . . . . . . . . . . . . .

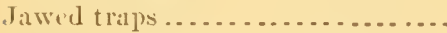

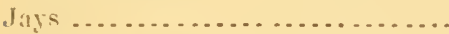

Jerkenl meat .....................

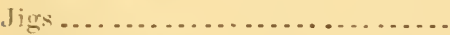

digs and drails..................

Jigr-molds ......................

Joint-snakes. . . . . . . . . . . . . . .

Kainite .......................

lier used for tlonts, de ...........

Kenuels ......................

Kermes .....................

liettles.......................

Kid-leather

Killer

Killicks

Kilns for lurning sbells
Page.

Kindling fire, apparatus for

Page.

King-fisl 45

8 Kingfishers.................... 9

98 Kinglets ..................... 9

8 King of the herrings ............. 16

55 Knives ..................21, 22,48

17 Kionmiss .................... 94

101 Kyalis...................... 43

45 Labels ...................... 54

Laboratory, coast............. 97

52 Labyrinth-traps .............. 27

Lae dye ...................... 93

29 Lace ......................... 74

98 Lacertilia .................... 12

1 Lae lake ...................... 93

8: Lake gill-net steanier............ 44

8:, 89 Lambs, rellum from ............. 8 83

52 Lamellirostres .................. 11

1.5 Lamprey-eels, or nine-ejes ....... 17

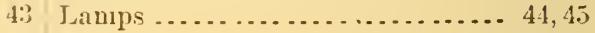

i5 Lanees .................... 14, 22,26

7,92 Landing-nets ................. $\quad 36$

53 Lamel-suails................... 19

51 Janterns ....................44, 45, 40

41 Lanterns for fire hunting and fishing 41

4. Lanterus for camp and ship nse.... 46

5) I anterns for wecquashing........ 4 .

5.3 Lariats......................

37 Larks $\ldots . . . .6$

3- Lassos ....................... 25

9 Lauvches...................... 4:

65 Lans, gane ................ 97

2:3 Lealers ...................... 33,89

;2 Leads . . . . . . . . . . . . . . . . . . $\$ 3$

33 Leauiug ................... 52

12 Leaniug-linives................ 52

53 Leather-back................. 12

3:3 Leather belts.................. 83

9o Leather, curryiug of .......... 49,50

93 Leather-dressing............... 50

45 Leathers ................... 73,82

¿3 Lecthes .................. 18,95

7 Leeches, propagation of .......... 101

41 Legrings .................... 45

53 Lewmings ................... 
Leptocardiass

Lice

Lice, fish

Lights

Lily-irons

Lime

Lime, bird

Limes

Limicolre

Lining

Limpets.

Line-holders

Lines, hooks with movable.

Lines (tristed and plaited) ........

Ling .

Lions, sea

Lip-hooks

Lithofracteur.

Live-box (Atkins's).

Live-boxes for microscopists

Lizards

roaded lines (bolas)

Loaders

Lobster-canniug factory

Lobster-pot floats

Lobster-pots

Lodges

Loggerhead

Log-glasses.

Longipennes

Loons

Lophobranchii

Lounges.

Lump-fish

Lure-fish

Lynxes.

Macerating-vats

Yaces

Machétes

Mackerel

Mackerel-jigs

Mackerel-smacks.

Mackerel-steamers

Mackinaw blankets
17

98

46

24

94

39

53,95

10

50

19

34

31

32

14

6

24 28,90

101

98

Mackinaw boats ................

Mammal furs.

Mammal oils, extraction of...... 5

Mammals .................... 5

Mammals, quills of............ of

Mammals, shell of ............... $\quad 79$

Mammals used as food .......... 57

Mammals, hair of, preparation of .. 43

Manatee, or sea-cow........... 7

Manna ..................... 95

Maunfacture of albumen preparations..................... 53

Manufacture of ammonia.........

Mannfacture of billierd-table cushions.................... 51

Manufacture of carbazotates......

Manufacture of dress and stay maker's bone .................. $\quad \vdots 1$

Manufacture of fertilizers . . . . . . $\quad 53$

Manufacture of fioats and other a:ticles......................

Manufacture of formic acid.......

Manufacture of handles, trinkets, billiard-balls, \&c.............

Manufacture of hat and boncet maker's boue .................. 51

Mannfacture of inks froru auinal substances.................. 53

Manufacture of ivory-black ...... 53

Manufacture of murexides........ 53

Manufacture of organ and piano kess ........................ 51

Manufacture of pepsin .......... 53

Mannfacture of perfumes..........

Manufacture of phosphorus....... 53

Manufacture of propylamine ..... 53

Manufacture of prussiates......... 53

Manufacture of quill articles ...... . 50,51

Manufacture of quill brush-bristles. $\quad 51$

Manufacture of quills for pens..... 51

Manufacture of ribbon - wearer's bone ....................... 51

Manufacture of rosettes.......... iL

Manufacture of sal aumouiac..... 53 
Manufacture of stockmaker's bone. Manufacture of surgical instruments

Manufacture of suspender-maker's bone

Manufacture of toothpicks

Manufacture of trinkets.

Manufacture of umbrella-maker's bone

Manufacture of whalebone brusles.

Manufacture of whipmaker's stock and whips

Manufacture of woren work

Manufactures, arts aud, materials emplosed in ..................

Marline-spikes .................

Marmots

Marsipobranchiates .............

Marsupialia

Martens ......................

Masks

Massachusetts flakes

Masts

Materials employed in the arts aul manufactures................

Mather's fish-ıajs...............

Meaus of pursuit and capture......

Measures.......................

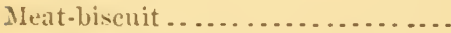

Meat, desiccated ................

Merat-extract . . . . . . . . . . . . . . . .

Meat-hoolis .....................

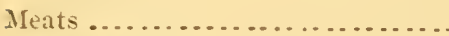

Meats, cauning..................

Meats, preserration of............

Mechanical delineators.............

Medical out fit ....................

Mcdicine, chcmical products aud agents emplored in arts and.....

Medicinc-chests .................

Menhaden ...............................

Menhaden-carryaways ..........

Menhadeu-smacks ..............

Mreuhaden steam-mills ............

Menopolnes
Page,

\section{Merinoes}

Meshing-nets (entangling in meshes)

Mesh-needles

Methods of culture of d mesticated animals

Methods of culture of domesticated fowls

Nethods of culture of domesticated birds...................... 99

Methods of dressing gut and sinew. $\quad 50$

Jiethods of frog-culture ......... 99

Methods of heliotyping and eugraving illustrations.............. एँ

Methods of mink-culture ......... 93

Methods of ostrich-culture ........ . 99

Methods of oyster-culture ......... 101

Methods of preparation of food... $4 \pi$

Methouls of terrapin-culture ...... 99

Methods of transportation . ....... $42,43,44$

Methods of Lnited Statcs Fish Commission.................... $9 i$

Nice ...................... 8

Microscopists'live-boxcs, troughs, fe. 93

Milk, desiccated................ 65

Millipedes................... 17

Minciug ...................... 52

Jincing-horse and mincing-knives. 5:

Mincing-kuives ............... 20.

Nincing-machine .............. 5

Jincing-tnl, .................. 5:

Jiuk-culture, wethods of .......... 9j

Minks...................... 5

Mimuow bait-hooks ............. 31

Minnows ..................... 15

Missiles ...................26, 28, 29

Missile-traps................ 39

Mites ..................... 1 1

Mixers ..................... 53

Voccalsins .................... 45

Modeling .................... 54

Model of fish-gnano works ....... 5 ;

Mohairs..................... it

Moles ........................ 8

Molc-traps .................. 39

Mollusks .................... 19 


\section{INDEX}

Page.

Míllusks, bjssus of.

Mollusks, propagation of

Moose.

Moming stars

Moss-crates (Stone's).

Mother-o'-pearl

Moths

Monntain-goat

Mountain meal

Mountain-sheep

Mouse-fish.

Mouselins de laine

Movable copses

Movable covers

Movable liues, hooks with

Mud-fish, or amia

Mallet

Murexides

Murexides, manufacture of.

Minres

Museum storage-tauk, Agassiz model .........................

Muskets

Musk from musk-deer ............

Musk-ox

Musquash

Musquash - traps, with hanging doors

Muzzles

Mrsiapoda

Mysticete

Nacre

Nacre, preparation of.

Narwhal

Natural baits

Tautilus.

Navassa phosphates

Needle-percussion

Needles

Nematoguathi

Nemerteans.

Nereocystis Litkeana

Nests .......................

Nets

Nets for bed and face.
75 Netting-needles.

101 Newfoundlaud flakes

6 Newhouse traps................

21 Night-hawks ..................

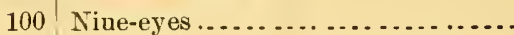

79 Nippers (with cord and handle)....
17

6

66

6

13

13

74

42

42

42

30

16

15

93

53

11

1 Ocelots

Octopus

54

27,28

92

6

8

38

40

17

7

49

52

7

40

19

53

28

35

\section{6}

18

33

100

35

45 Oil
Page. 36 47 38

Oil, cotton.................. 4s

Oil-dressing ................. 50

Oil, fish, soaps from ............ 92

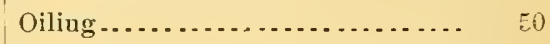

Oil-skin suits............... 45

Ointmeuts................. 45

Oleomargariues............... . 90

Ophidia ..................... 12

Ophis fabe................ 9;

Ophiurans.................... 19

Opossum ..................

Optical instruments............. 46

Orgau-keys, maunfucture of ...... $5 \mathrm{~L}$

Orioles ..................... 9

Osmic acid ..................... 54

Osteocolla .................... 89

Ostricb-culture, methois of....... 99

Otters...................... 5,40

Otter-trawl.................. 36

Oulachan .................... 15

0 Ova, accessories of obtaiuing and

5 impregnating................ 99

Overflowing fish-ways .......... 9 97 


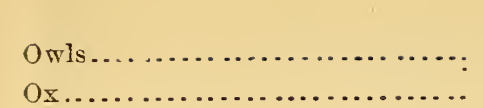

Ox, domesticated.

$\mathrm{Ox}$, musk

Osster-bed tangles.

Oyster-boats

Osster-canning factory ...........

Oyster-canoes.................

Oyster-catcher.

Oyster-eulture, methods of ........

Osster-fish

Oyster-police-boats

O5ster-pungies

Oyster-scraper

Oyster-smaeks

Pack-saddles

Paddle-fish, or spoon-bill

Paddles

Pads, riding.

Pails

P'alms

Pancreatine

Pans

Paper boats

Paprier glaeé

I'arasites.

Parchment ...

Parchuınt from viscera of seals...

l'arers

l'arroquet

I'irrot-fish

Parrots

partridge

Passcres.

I'astes

l'atent lcather.

Ieacock.

l'earl.

l'earl-powder.

l'earls

Pearl-white

Pea-roe of coll

P'ea-shooters

Peccary

Pediculati
Page.

9,40

Pelieans

Pemmiean...................... 65

6 Peneils........................ 54

6 Penguins........................ 11

95 Pens (for animals) .............. 98

43 Pens, mannfaeture of quills for .... 51

49 Pens, quill.................... si

43 Pen-traps .................... 37

10 Pepsins ........................ 99

101 Pepsin, manufacture of........... 53

14 Percesoces...................... 15

44 Perch ......................... 14

44 Perehes ..................... 40

36 Percussion-powder............. 28

48 Perfumes..................... 5.5, 92

42 Personal aids.................. 42

16 Personal equipments........... 45

44 Petrels ........................ 11

42 Phalarope .................... 10

99 Phiais....................... 54

4 P'hospliates.................... 53,96.

93 Phosphorus...................

99,100 Phos] horus, manufacture of....... 53

43 Phosphorus prepared from bones..

79,88 Photographic apparatus......... 55

98 Photographs................. 97

8., \&3 Piauo-keys, manufaeture of....... $\quad$.1

84 Picarie .................... 9

2. Pickerel....................... 15

9 Pickerel-books................. ;9

14 Pickled foods................... 66

9 Pickliug, preservation by ......... 48

10 Picks used in gatheriug sheil-fish.. 23

9 Picric acid..................... 54

$\$ 1$ Piereingatraps.................

E3 Pigeon-nels .................. 38

10 Pigeons ...................... 10

ig Pigeon-traps and accessories of lig-

c0! eon-shooting................ 30

i9 Pig-fish ...................... 14

79 Pike ...................... 15

40 Pike s fish-way................ 9 9

27 Pile-serapers.................. 23

6 Pilot-fish ..................... 14

13 Pinkies (Martha: Vinesard) ..... 43 
Pima, silk from byssus of, preparatiou of.

Pinnipedia

Pipe-fisb

Pipettes

Pistol-belts

Pistols

Pitfalls

Pits, eorered

Plaited lines

Planarians

Pleetoguathi

Pliers

Plover

Plucking .

Plumagers, art of.

Plumes.

Plushes

Poeket-nets.

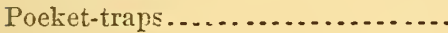

Poisons

Poliee-boats, ojster.

Polishing

Polishing-powders

Polloek

Polsps

Pomatums

Pommels .

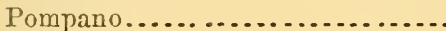

Ponds, fish

Pool fish-ways

Poreupine-fish

Poreupines

Porgy

Porpoise

Portable bridges.................

Portable boats

Potash, prussiate of

Potassium, ferrocyanide of.......

Pot-gauge swivel ...............

Potomac seine-boats

Pots, try

Ponelies

Poudrettes

Pound-boats.

Pound-boats of the lakes

Pounds

Powder-holders................ $\quad 30$

Powder-measures.............. 29

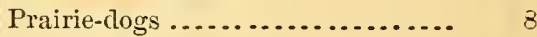

Predatory animals .............. 98

Prefaee...................... V V

Preparation of albumen.......... 53

Preparation of ammunition....... 28

Preparation of baits ............ 48

Preparation of brillantine........ 49

Preparation of eoehineal eolors .... 53

Preparation of eoral ............ $\quad 59$

Preparation of down ............ 49

Preparation of feather fabrics..... 49

0 Preparation of feathers............ 49

Preparation of fibers for unanufae-

4 ture of plush earpets........... 49

Preparation of fish-seale work...... 52

Preparation of food, methods of .... $4 \pi$

Preparation of guano............ 53

Preparation of hair of mammals... 48

Preparation of hard tissues........ 51

Preparation of head-oil............ 52

Preparation of horn aud hoof ...... 51

Preparation of naere .............. 52

Preparation of floekiug from refuse quills ....................... 49

Preparatiou of silk from byssus of Pinna ...................... 49

Preparation of silk of inseets ...... 49

Preparatiou of silk of silk-worms .. 49

Preparation of spermaeeti ........ 52

Preparation of sponge-stuffing.... 49

Preparation of stuffings.......... 49

Preparation of the slsin and its appendages.................... 49

Preparation of tortoise-shell....... 51

Preparation of whale-bone ........ 49,51

Preparation of wool............. 49

Preservation by eanning and piek-

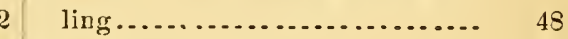

Preserration by drying........... 47

Preservation of fish ............. 47

Preservation of fresh meats....... 47 


\section{INDEX.}

Page.

Preservation of game

Preservation of animals for scientific uses.

Preservative mixtures

Preservatives

Preserved meats

Presses

Pressing

Primers

Printing, calico

Proboscidea

Proccsses of tanniug lcather.

Processes of tawing or oil-dressing leather.

Process of currying

Prodding-awls

Prods

Propagation and cnlture of fishes.

Propagation of amplibians........

Propagation of bees..............

Propagation of cochineal inscet....

Propragation of corals . ...........

Propragation of insects ...........

Propiagation of leeches...........

Proplagation of mollusks .........

Propragation of reptiles...........

l'roparation of silk-worm . .......

Propagation of spouges ...........

Proparation of worms ............

Propylamino....................

Propylamine, manufacture of......

Prolection and culture...........

Protection from insects...........

Proteida .......................

Protozoilus

lrusiau-blne .................

Prussiate of potash ..............

Prussiates .....................

Prussiates, manufacture of ........

Psittaci ........................

Ptarmitran...................

Publications of Lnited States Fish

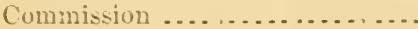

Pufius

Pullcys
Pulverizers

Puma

11 Refrigcrator-cars .....................

$\$ 4$ Refrigeratoi's .................

Page. 53 Quivers .................... $\quad 26$ 
Renora

Renderivg whale-oil

Rennet

Reptile-oils, extraction of

Reptiles

Reptiles, propagation of

Reptiles used as food

Rerolvers

Rerolving booms

Rhizopoda.

Rhomboganoidei

Ribbons.

Ribbou - rreaver's bone, manufacture of...

Riding-loots

Ridiug-pads

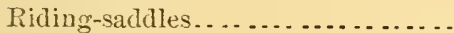

Rifle-musliets

Pifles

Rigging

Right whales

Rimmers

Ring-ñeck

Rings

Rirer-dogs

River-meirs, witl pockets

Roan

Robes

Rock-bass

Rock-cod (west coast)...

Rock-fish

Rockling

Rocks and bowlders as fish-Trays...

Rod-cases ....................

Rods

Rod-top cases ..................

Rollers

Roller-spawning screen (Collins)... Rolling off.

Ropes ......................

Rose-nozzles (for washing eggs) ....

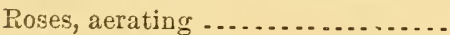

Rosettes, whalebone, manufacture of, Roticers

Round-knives

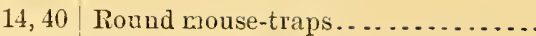
38

52 Rubber blankets.............. 45

94 Rubber tips ................... 34

52 Rubber-tubing floats ............ 33

12 Rudder-heads.................. 44

99 Russia leather .................. 8 . .

60 Sabers ..................... 22

$2 \gamma$ Saddles ............................ 42

33 Saddle-slings ................ 30

20 Sage-cock ...................... . . 10

16 Sail-peedles ...... . . . . . . . . . . . 44

74 Sails ........................ 44

Salamanders................... 13

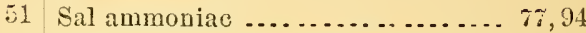

45 Sal ammoniac, manufizcture of.... 53

42 Salmon ............... . . . . . . . 15, 99

49 Salmon-flies ...................

27 Salmon-meir................ 37

27 Salt................................. 48

44 Salted foods ................... 66

7 Salt-nills .................... 48

22 Salve-bug ................... 95

10 Saud-bath .................. 50

33 Sanderling ................... 10

1.3 Sandpiper .................... 10

37 Sardine-factory............... 48

83 Sardine-fisheries, French ......... 40

45 Satinettes .................... 74

14 Sausages ........................ 65

14 Saw-bills ..................... 9

14 Scabbard-fish ................... 14

14 Scales . . . . . . . . . . . . . . . . . . . $\quad 79$

98 Scaling-apparatus............... 48

34 Scent-decoys .................. 41

34 Scolecida...................... 18

34 Scoop-nets .................. 36

34 Scoops ..................... 23

99 Scoop sounding-machines......... 23

49 Scorpions..................... 12, 17

33 Scouring ................... 48,50

100 Scows ....................... 43

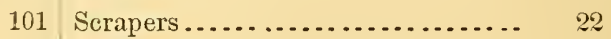

51 Scrap-hopper ....................... 52

18 Scraping ..................... 49

49 Seraping-tools .................. 54 
Sereens

Screen, roller spawning (Collins) ..

Seulpin

Scup, or porgy

Sea-bats

Sea-cow

Sea-cucumber

Sea-horse

Seal-elephants

Sealers

Sealing-steamers

Sea-lious

Seals

Seals, parchment from

Sea-otter's

Sea-1*atch

Sea-robin

Sea-snails

Sea-nrchins .................

Searreed.

Sea-mi'ms

Section 1

Section B

Section C

Section D

Sectiou 1:

Seine-boats

Seine-floats

Seine-reels

Seines.

Scine-windlasses ...............

Seizure of object

Selachostomi Self-sealing jars, nsed in collectiug. Seplia ......................

Sepra ofïcinalis.

serges

Serpulie

Set-nets

Set-tackle.

Sextauis

Sluad

Shat-slicles

Sharreen leather

Shagreen of trigger-fish
Page.

100 Shanty, brook (Furman's).

Page.

14 Sharpies ...................... 43

14 Shawls ....................... 41

13 Sheaf-traps ..................... 33

7. Shearing ...................... 48

19 Shearwaters ..................... 11

13 Sheep ......................... 6

6 'Sheepshead ..................... 14

4.3 Shell of mammals............... 79

44 Shells ......................... 29,80

6 shell, tortoise .................. is

6 Shell-work ................... 81

64. Shieldis..................... 45

5 Ship-lauterns................ 46

11 slot ......................... 28

14 Shot-cartrilges ................ 29

19 Shot-bolders.................. 30

19 Sbot-measurers................ 29

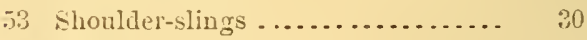

15 shovels ..................... 23

¿Showtl..................... $s$

21 Shrews.....................

4) Shrikes ..................... 9

7) Sicl-strajs.................

9\% Sieve-traps................. 36

13) Sight-lecoss .. .............. 41

33 Sights $\ldots . \ldots \ldots \ldots \ldots \ldots \ldots . . . .29,30$

34 Sigual-lanterns ............... 44

$3 j$ Silk; preparation of........... 49

34 Silks..................... 74

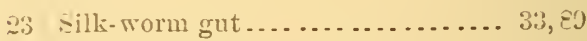

10 Silk-Trorm, propagation of ....... 101

-t Sinches ................... 4.

93 siuew, dressing ............. 50

81,05 sinews............................ 81

if Siuliers..................

18 Siphous........................ 101

3\% Siphon-tubes ................... 101

21 Sipunculoids ................ 19

41 Sirunia.................. 7

15 sireus... .................. 13

37 Size ................... $7 \%, 88$

83 Skates .................... 16, 42

†9 skeleton, making............. 54 
Page.

Page.

Skewurs

Skimmer-ncts

100 Specinens, apparatus for eollecting.

Skimmers

Skin and its appendages, preparation of.

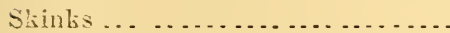

Skins of birds used as furs .......

Slin-serapers ................

Skin-suits . . . . . . . . . . . . . . .

shirts, crinoline

Spernaceti

97

Spermaceti, preparation of ....... 5

12 Speru-whale $\ldots . \ldots \ldots \ldots \ldots \ldots \ldots .7,9$

73 Sphenisei .................... 11

22 spiders......................... 17

45 Epilliards................... 31

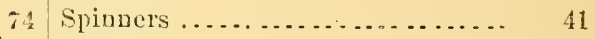

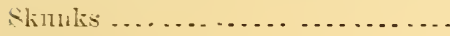

Eletges . . . . . . . . . . . . . . . . .

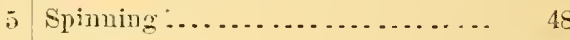

42 Split-leather................. 83

Slings.................26,87, 47

Spovge, burnt ................ 96

Slings for arms .................

so Spongeo-piline................

Slung-meights ................

21 Spourges..................... 20,89

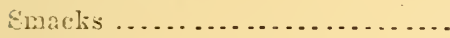

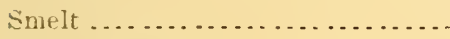

43 Sponges, propagation of......... 101

1.) Sponge-stuffing, preparation of ... 49

Smith's fish-may ...............

Smoked foods ..................

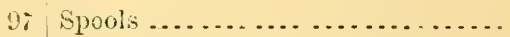

65 Spoon-baits, plain and fluted.....

Smoke-drying apparatus .........

Smoke-houses ..................

Snudges ...... . . . . . . . . . . . . .

Snails......................

Snail, sca...................

Snakes ....................

Suares ..........................

Snipe ......................

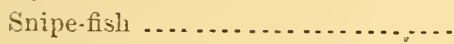

Snoods

Snow-gogrles.................

Snom-shoes.

Soaps ........................ 90,92

Sockets

Sole-leather

Soles

Sound-decoss

Sounding-maelines

Spoonbills

Spring bird-nets .............. 38

Spring-door traps.............. 38

Springes ...................... 38

Spring-gmus .................... . .

Spring-hooks . . . . . . . . . . . . . . . . 39

Spring-nets.................. 36

Spring-weirs (Saint Lawrence) .... $\quad 36$

Spurs ..................... 42

Squali ........................ 16

Squid-jigs .................. 24

Squids ................... 19, 32, 41

Squirrels ..................... 8

Star-fishes..................... 19

41 Starlings ....................

23 Stationary eovers ............ 42

.2. Stationary lines with hooks ...... 31

9 Staves .................. 49

Sparrow .......................

Spat stools.

99 Stearines..................... 90

Spawning screen, roller..........

Spawning-rat..................

Spear-falls ....................

99 Steck's fish-ways ................

99 Steel-traps.................... 38

39 Steganopodes.................. 11

Spears 
Stepping-irons for whale-boats.... Stickleback.

Sticks, hurled

Sticks, throw

Still-hunting, lanterns for.

Stilt

Stirring-pole

Stockings

Stomach-springs

Stoue-chats.

Stone's aquarinm-car.

13 Swell-fish

Swell-tish

Stone's moss-crates

Stool-pigeons

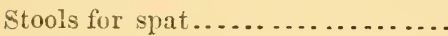

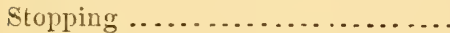

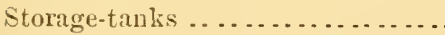

Stosh.

Stoves

Stowing

Strait-jackets.

Strawberry-bass

Stretchers

Stretebing-irons ................

Striped bass...................

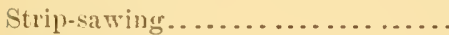

Stuflings .....................

stufiugs, preparation of ..........

Stulìng tools ....................

stutits.

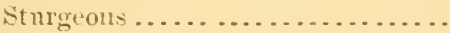

Suckers ......................

Suckers ......................

sulhuric acil .................

Sun-dryiner apparatus............

sun-tish .........................

Surface-lines ..................

surf-birt .....................

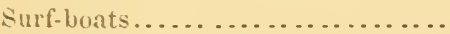

Surf-tackle ...................

Surgeon-fisls

Swals.

Swab tangles

Swallows.

Srans....

Swazey"s fish-may

9 Syringes for injecting . . . . . . . . . . 54

101 Table-furnitnre............... 45

100 Table of contents............ . vii

11 Tables ...................... 48

101 Tailor....................... 14

48 Tanagers...................... 9

54 Tangles ......................

10 Taugles, ofster-bed ............. 98

45 Tanks....................53, 100, 101

52 Tauning................... 50,90

99 Tape-worms ................. 18

14 Targets ...................... 30

45 Tar-ointment .................. 45

49 Тагрum ..................... 15

14 Tartans ...................... 74

51 Tattler ......................... 10

48 Tautog....................... 14

49 Tawing leather............... 50

55 Taxidermy .................... 55

74 Teleocephali................... 13

16 Telescopes..................... 46

15 Tell-tales .................... 34

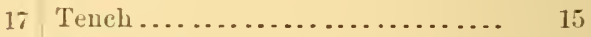

.33 Trench fish-wass.............. 97

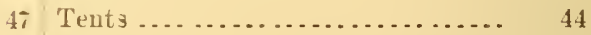

13 Terns ........................ 11

:1 Terrapin ................... 12

10 Terrapin-culínre, methouls of .....

43 Testudinata ................... 12

31 Tethers ..................... 98

14 Textile fabries................ 48, 73

99 Thongs.................... 83

25 Thread-rormis................ 18

9) Throwing-sticks ............... 26

11 Throwing-tackle (surf) .......... 31

$9=$ Throw-sticks ................ 
Thrushes

Thrusting-spears

Tide drailing-tackle.

Tillers

Tinder

Tissues, hard, preparation of......

Titmice

Toad-fish.

Toads

Toads, horved

Toggle-harpoons

Toggles, used by whalers

Tolling-baits .

Tomalawks

Tongs

Toothpicks, manufacture of.

Torches

Torpedoes

Tortoises

Tortoise-shell

Tortoise-shell, imitation

Tortoise-shell, preparation of......

Towing-nets..................

Trachystomata ...............

Trailing-nets

Trammel-nets .................

Transportation, methods of . . . ..42, 43, 44

Transporting fish, apparatus for ...

Trappings

Traps

Trawl-line rollers

Trawl-lines

Trawls

Trass

Treading-lurdles ...............

Trehala

Trestles

Trichina

Trigger-fish

Tripoli

Trogons.

Trolling-spoons

Trolling-tackle

Tropic birds

îroughs

2

9 Trout

Page.

31

44

94

51

9

14

12

12

24

24

41 Wagons......................... 42

31 Wagtails ..................... 9

11 Wallets for lines, \&c............ 45

90,98 Wallosin ................... 78

15 


\section{INDEX.}

IValrus.

Iage.

Warblers

6

Whiffing-tackle.

Page.

9

Wask-Ieather

Water-guns

Water-proof boots

83

Whippoorwills

Whips

Water-proof suits

Water-telescones

Watcr-turkess

Was

Waxwings ....................

Weak-fish

Weapon-bolders ...............

Weaseis

Wearing.................

Wearing worsted cloths

IVceruashing lanterns.............

Weighing-seales .................

Weights, hurled ................

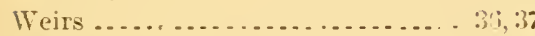

Whale-boats .....................

Whalebone ...................

Whalebone, preparation of'....... 49, 51

Whalebone springs.............

Whale-liue drng................

Whalcman's " craft ".............

Whalemau's line-tul ..............

Whale-oil ......................

Whale-oil, rendering.............

Whalers' chains and lines..........

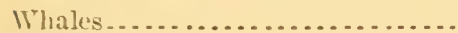

Whale-ships..................

Whale-spades .................

WTliale-steamers .................

Whaling-canocs ...............

Whaling-guvs ..................

Wheelbarrows ...................

Wheels.........................

Whelks ....................

14 Wilmot's cups .................. 100

30 Winebes ..................... 34

5,40 Winders ..................... 34

18 Windlasses................... 34

If Wirc-cartridges................ 29

42 Wolf-fish ..................... 14

29 Wolverenes...................

2(i) Wulics..................... 5

i, 37 Woodeock..................... 10

43 Wood floats .................... 33

is Woolpeckers .................. 9

IVood-powder..................

:39 Wool ...................... 84,85

33 Wool-floeking .................. 84,92

24 Wool, preparation of ............. 49

34 Wool work ................... 51

52 Woorara .................... 39

52 Worms...................... 18

33 Worms, intestinal ............... 98

; Worms, propagation of........... 101

43 Worsted cloths, wearing ......... 48

2. Worsted faurics .............. 74

44 IVrens ...................... 9

43 Yak lace............... .6 it

$2 \Xi$ Yarns...................... 74

41 Yellow-shanks................ 10

44 Zibeth ciret................. 9. 
INTERNATIONAL EXHIBITION, 1876. BOARD ON BEHALF OF UNITEI) STATES EXECUTIVE DEPARTHENTS.

\section{CLASSIF I C A T ION}

OF THE

COLLECTION TO ILLUSTRATE

THE

\section{ANIIIAL RESOURCES OF THE UNITED STATES.}

A LIST OF SUBSTANCES DERIVED HROM THE ANIMAL KINGDOM, WITH SXNOPSIS OF THE USEFUL AND INJURIOUS ANIMALS AND A CLASSIFICATION OF THE METHODS OF CAPTURE AND UTILIZATION.

By G. BROWN GOODE, M. A., ASSISTANT CURATOR U. 8 . NATIONAL MUSEUM.

WA SH I N GTON:

GOVERNMENT PRINTING OFFICE. 1876 . 








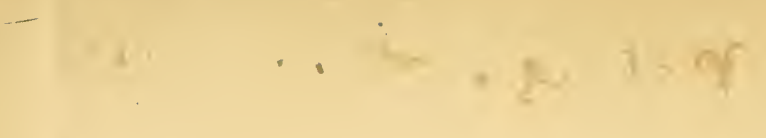




\title{
LIST OF BOOKS AND PAPERS
}

\author{
PUBLISHED BY \\ G. BROWN GOODE,
}

WASHINGTON, D. C.

$187 \mathrm{I}-\mathrm{I} 882$.

I87 I. The Billfish in Freshwater. American Naturalist, v, I87 I. p. 439.

I872. A Sea Bird Inland. American Naturalist, vi, 1872. p. 49.

1873. [Associate Editor] Alumni Record of Wesleyan University, Middletown, Conn ... Boston: Press of Rand, Avery, \& Company, 1873. $8^{\circ} \mathrm{pp}$. xxviii, I-293.

1873. Do Snakes Swallow their Young? American Agriculturist, xxxii, Feb., I873. p. 一.

1873. Mimicry in Snakes. American Naturalist, vii, 1873. p. 747 .

1874. Description of two new species of fishes. American Journal Science and Arts, vii. Aug., I874. pp. 123-1 25. Also separately, without title page. pp. 3 (I). Also in Annals and Magazine of Natural History, London, xiv, I 874. pp. 379-381.

I874. On the Question, "Do Snakes swallow their Young?" Proc. Amer. Assoc. Advan. Sci., I873. (1874) pp. 176-185. Portland Meeting. Also separately, repaged. $8^{n}$ pp. 12.

1874. The Shad and Shad Fishery of the St. Johns River, Florida. Report U. S. Commissioner of Fish \& Fisheries. Part II, (1872-3), I874. pp. xlviii-xlix.

1875. About Snakes' Eggs. American Agriculturist, xxxiv, 1875. p. 141.

1875. Albino Fishes. American Naturalist, ix, 1875. p. 517.

I875. Notes on the Salamander of Florida. (Geomystuza). Ponvell's Exploration of the Colorado Valley of the West, Washington, 1875 . pp. $281-285$. Also separately with Coues' "Abstract of a study of the genera Geomys and Thomomys."

1876. Catalngue of the Fishes of the Bermudas. Based chiefly upon the collections of the United States National Museum... Washington: Government Printing Office, I $876.8^{\circ} \mathrm{pp}$. (2) $\mathrm{I}-82$. Bulletin U. S. National Museum No. 5 .

1876. International Exhibition, 1876. Board on Behalf of United States Ex ecutive Departments, National Museum, Smithsonian Institution. Collection to Illustrate the Annual Resources of the United States. Classification. Folio p. Io. [Washington: Government Printing Office, 1876 .]

1876. International Exhibition, 1876. Board in Behalf of United States Executive Departments. Classification of the Collection to illustrate the Annual Resources of the United States. A list of substances derived from the animal kingdom, with synopsis of the useful and injurious animals and a classification of the methods of capture and utilization... Washington: Government Printing Office, 1876. $8^{\circ} \mathrm{pp}$. I26. A second edition with supplementary title as bulletin No. 6, U. S. National Museum. 

IS77. Provisional Catalogue of the Fishes of Bermuda... Hamilton, Bermudas. Privately Printed, May, I $877 . S^{\circ}$ pp. (2) I-S. (2). Also in yearly editions of Bermuda Almanac, IS78-8I. I88I. pp. II6-122.

I 877 . Fifth and Sixth Annual Reports of the Curators of the Museum of IVesleyan University. Including a History of the Museum from its Formation. First of Printed Series. Middletown, Conn. Pelton \& King, Printers and Book Binders, I877. $8^{\circ}$ pp. 30.

1877. Statistics of American Fisheries Halifax Commission, 1877. Appendix $O$, Statistics produced on behalf of the United States.

1877. Table showing Statistics of the Manufacture of Menhaden Oil and Guano in the United States in the years $1873,1874,1875,1876$. Halifax Commission, $\mathrm{I} 877$. Appendix 0 . Table xviii.

1877. A Preliminary Catalogue of the Reptiles, Fishes, and Leptocardians of the Bermudas, with descriptions of four species of fishes believed to be new. American Fournal of Science and Arts, xiv. Oct., 1877, pp. 289-298. Separately as follows:

1877. A Preliminary Catalogue of the Reptiles, Fishes, and Leptocardıans of the Bermudas, with descriptions of four species of fishes believed to be new... New Haven: Tuttle, Morehouse \& Taylor, Printers, I877. $S^{\circ}$ pp. I $2-(2)-289-298$.

1877. (with T. H. Bean) Descriptions of two new species of Fishes (Macrurus Bairdii and Lycodes Verrillii), recently discovered by the U. S. Fish Commission, with notes upon the occurrence of several unusual forms. American Fournal Science and Arts, xiv, Dec., 1877, pp. 470-478. [Noticed in Nature, London, xvii, p. 213.] Separate as follows:

1877. (with T. H. Bean) (From the American Fournal of Science and Arts, vol. xiv, Dec., 1877.) Descriptions of two new Species of Fishes (Macrurus Bairdii and Lycodes Verrillii) recently discovered by the U. S. Fish Commission, with notes upon the occurrence of several unusual forms... $8^{\circ}$ pp. $10[1+470-478]$.

1878. The bermuda Lizard. Nature, London, xvii, p. 425, March 28, and Science Neres, i, 1879, p. 96, Jan. 15.

1878. Migration of Fishes. Transactions Amer. Fish Cultural Association, I 878 , pp. $27-65,2$ pls. [Read before the American Fish Cultura] Association.]

1878. Statistics of American Fisheries for 1876. Transactions American Fish Cultural Association, i878, pp. 99-108.

1878. Notes on the American Species of the Genus Cybium by Felipe Poey. Proceedings U.S. National Musium, i, I878, pp. 3-5. June. [Translated from MSS. memoranda of Prof. Felipe Poey.]

I878. The Clupea tyrannus of Latrobe. Proceedings U.S. National Museum, i, I878, pp. 5-6. June.

1878. The Occurrence of Belone latimanus in Buzzards Bay, Massachusetts. Proceedings U. S. National MIuseum, i, I878, pp. 6-7. June.

1878. The Voices of Crustaceans. Proceedings U. S. National Museum, i, I 878, pp. 7-8. June.

1878. (with T. H. Bean) The Craig Flounder of Europe, Glyptaplialus cyno. glomus, on the coast of North America. Proceedings U.S. National Museum, i, 1878, pp. 19-. June.

1878. Seventh Annual Report of the Curators of the Museum of Wesleyan University, including a Visitor's Guide to the Museum. (Second of the Printed Series.) Middletown, Conn., I878. $8^{\circ}$ pp. 24 .

1878. (with T. H. Bean) The Oceanic Bonito on the coast of the United States. Proceedings U.S. National Museum, i, 1878, pp. 24-26. July I.

I878. A Revision of the American Species of the Genus Brevortia, with a description of a new species from the Gulf of Mexico. Proceedings U. S. National Museum, i, I878, pp. 30-42.

1878. (with T. H. Bean) Description of Caulolatilus microps, a new species of fish from the Gulf Coa-t of Florida. Proceidings $U$. S. National Museum, i, I878, pp. 42-45. July I. 

IS78. The occurrence of Hippocampus antiquarum, or an allied form, on Georges Banks. Proceedings U. S. National MItsentm, i, I878, pp. 45-46. July I.

1878. (with T. H. Bean) On a new Serranoid fish, Epinephelus DrummondHayi, from the Bermudas and Florida. Proceedings U. S. National Mucserm, i, I878, pp. I73-175. Oct. 2.

IS78. (with T. H. Bean) Descriptions of two new species of fishes, Lutjanus Blackfordii and Lutjanus Stzarnsii, from the Coast of Florida. Proceedings U. S. National Museum, i, 1878, pp. I76-ISI. Oct. 2, 4.

IS78. (with T. H. Bean) A note on the Black Grouper (Epinephelus nigritus (Holbrook), Gill), of the Southern Coast. Proceedings U. S. National IInseum, i, I878, pp. I82-I84. Oct. 4.

I878. A Study of the Popular Names of Menhaden. American Naturalist, Nov., I878, pp. 735-739. Also as separate, without title-page.

is78. The Earliest American Naturalist, Thomas Heriot. Science Neres, New York, i, IS 78 , pp. I2-I3. Nov. I.

1878. (with . T. H. Bean) Descriptions of two Gadoid Fishes, Phycis Chesteri and Haloporphyrus viola, from the degep sea fauna of the Northwestern Atlantic. Proceedings U. S. National Museum, i, i878, pp. 256-260. Dec. Io and 17 .

I878. (with T. H. Bean) Description of Argentina syrtensizm, a new deep sea fish from Sable Island Bank. Proceedings U. S. National Museum, i, I 878 , pp. 26I-263. Dec. I7.

I878. The occurrence of the Canada Porcupine in West Virginia. Proceedings U. S. National Museum, i, I878, Pp. 264-265. Dec. 17.

I879. (with T. H. Bean) A Catalogue of the Fishes of Essex County, Massachusetts, including the fauna of Massachusetts Bay and the contiguous deep waters. Bulletin Essex Institute, xi, I879. Separate as follows:

1879. (with T. H. Bean) A List of the Fishes of Essex County, including those of Massachusetts Bay, According to the latest results of the work of the U. S. Fish Commission... (From the Bulletin of the Essex Institute, vol. xi.) Salem: Printed at the Salem Press, I879. $8^{\circ} \mathrm{pp}$. (2) $3^{8}$.

I879. (with T. H. Bean) Discoveries of the United States Fish Commission. Notices of fifty species of east coast fishes, many of which are new to the fauna. American fournal Science and Arts, xvii, Jan., I879, pp. 39-48. Also issued as excerpt.

I879. American Ichthyology in I878. Science Nerws, i, 1879, pp. 97-100, Feb. I, IS79, as editorial.

I879. (with T. H. Bean) The identity of Rhinonemus caudacuta (Storer), Gill, with Gadus cimbrius, Linn. Proceedings U. S. National Museum, i, I879, pp. 348-349. Feb. I4.

I879. (with T. H. Bean) Note on Platessa ferruginea, D. H. Storer, and Platessa rostrata, H. R. Storer. Proceedings U. S. National Museum, i, I879, pp. 36I-362. Feb. I4.

I879. (with T. H. Bean) On the identity of Brosmizes amercanus, Gill, with Brosmius brosme (Müller), White. Proceedings U.S. National Museum, i, I879, pp. 362-3. Mar. Io.

1879. The National Museum Building. Science News, i, pp, I6I-I64, A pril I, as editorial.

1879. On two fishes from the Bermudas, mistakenly described as new by Dr. Günther. Proceedings U. S. National Mruseum, i, IS79, pp. 462463. April 22. Also in American foumal Science and Arts, xvii, A pril, I879, p. 340.

1879. International Exhibition, I876. Catalogue of the Collection to illustrate the Annual Resources and the Fisheries of the United States,exhibited at Philadelphia in 1876 by the Smithsonian Institution and the United States Fish Commission, and forming a part of the United States National Museum... Washington: Government Printing Office, I 879. $8^{\circ}$ pp. 35ı (ı). [Bulletin U. S. National Musseum, No. I4.] 

I879. Commercial Statistics of Annual Products in the United States: a Review of a portion of the Report of the Chief of the Bureau of Statistics for the Fiscal Year ending June 30, 1877. Bulletin U.S. National MTuseum, No. 14, 1879, pp. 272-300.

I879. (with T. H. Bean) Description of a species of Lycodes (L. paxillus) obtained by the United States Fish Commission. Proceedings $U . S$. National Museum, ii, 1879, pp. 44-46. May 23.

I879. (with T. H. Bean) Description of a new species of Liparis (L. ranula) obtained by the United States Fish Commission off Halifax, Nova Scotia. Proceedings U. S. National Museum, ii, 1879, pp. 46-48. May 23.

I 879. (with T. H. Bean) Description of a new species of Amber Fish (Seriola Stearnsii) obtained near Pensacola, Florida, by Mr. Silas Stearns. Proceedings U.S. National Miseum, ii, I879, pp. 48-51. July I.

I879. (with T. H. Bean) Description of Alepocephalus Bairdii, a new species of fish from the deep sea fauna of the Western Atlantic. Proceedings U.S. National Museum, ii, I879, pp. 55-57. July I.

1879. Executive proceedings of the United States Senate from which the injunction of secrecy has been removed. The North American Fisheries. Arrangements with Great Britain... Memoranda in relation to statistics of the fisheries of North America, prepared for Senator Edmunds in response to his request of December 31, 1878. Congressional Record, ix, No. \$9, IS79, pp. 2-4. July ro.

1879. Eighth Annual Report of the Curators of the Museum of Wesleyan University. Third of printed series. Middletown, Conn., 1879. $8^{\circ}$ pp. 17 (1).

I879. [7074] U. S. Fish Commission and Census of r88o. (44) Plan of Inquiry into the History and Present Condition of the Fisheries of the United States. Washington: Government Printing Office, 1879. $8^{\circ}$ pp. 54 (2). Also in Report U. S. Fish Com., Part VIII. I88I.

I879. A Preliminary Catalogue of the Fishes of the Saint John's River, Florida, with descriptions of a new genus and three new species. Proceedings U.S. National MVuseum, ii, I879, pp. 108-121. Sept. I9.

I879. (with T. H. Bean) Catalogue of a collection of fishes sent from Pensacola, Florida, and vicinity, by Mr. Silas Stearns, with descriptions of six new species. Proceedings $U$. S. National Museum, ii, 1879, pp. 121-156. Sept. 19, Nov. 5 .

1879. The Natural and Economical History of the American Menhaden. Report U. S. Commissioners of Fish and Fisheries, Part v, 1879 . A ppendix A, pp. I-529. Plates i-xxxi (xxx canceled). Pp. I94-267 by Prof. W. O. Atwater.

I879. (with T. H. Bean) Description of a new genus and species of fish, Lopholatilus chamaleonticeps, from the south coast of New England. Proceedings U.S. National Minseum, ii, 1879, pp. 205-209. Nov. 5.

1879. The Two Kinds of River Herring. Report Commissioner of Fisheries of Virginia, Richmond, I879, p. I4.

1879. (with T. H. Bean) On the occurrence of Lycodes Vahlii, Reinhardt, on La Havre and Grand Banks. Proceedings U. S. National Museum, ii, I 879, pp. 209-2ro.

1879. The Bait Problem. Gamgee's "On Artificial Refrigeration," in Report U.S. Fish Commission, Part v, 1879, pp. 960-961.

1879. Biography of the Menhaden. Proceedings Central Fish Cultural Society, Chicago, 1879, pp. 48-59.

1880. (with W. O. Atwater) American Fisheries, A History of the Menhaden ... with an account of the Agricultural Uses of Fish.... and an introduction, bringing the subject down to date. Thirty plates. New York: Orange Judd Company...8 $8^{\circ}$ pp. x (I), iii-xii, I-529(I). Reviewed in Nature, London, xxii, p. 335 .

1880. A Distinguished Immigrant-Prof. Baird's European Carp. American Agriculturist, Jan., I88o, pp. 13-14. 

I880. Address before the U. S. Menhaden Oil and Guano Association. Seventh Annual Report Menhaden Oil and Guano Association, I880, pp. 3-7. Also in Oil, Paint, and Drug Reporter, New York, xvii, I880, pp. 6i-62.

I880. A Study of the Trunk-Fishes (Ostraciontide), with notes upon the American Species of the Family. Proceedings U.S. National Museum, ii, ISSo, pp. 26I-283. Jan. 27-March 25.

r880. (with T. H. Bean) Catalogue of a collection of fishes obtained in the Gulf of Mexico, by Dr. J. W. Velie, with descriptions of seven new species. Proceedings $U$. S. National Museum, ii, I880, pp. 333-345. March 25 .

I880. International Fishery Exhibition, Berlin, I88o. Exhibit of the Fisheries and Fish Culture of the United States of America at the Internationale Fischerei Ausstellung, held at Berlin, April 20, I880, and forming a part of the collections of the National Museum, made by the United States Fish Commission... Washington: Government Printing Office, 1880. $S^{\circ}$ pp. 263 (I). Bulletin U.S. National Museum, No. I8.

I880. Internationale Fischerei-Ausstellung, Berlin, I88o. Amerikanische Abtheilung. Verzeichniss der Aussteller, nach dem, vor dem Deutschen Fischerei-Verein.

1880. The use of Agricultural Fertilizers by the American Indians and the early English Colonists. American Naturalist, xiv, I880, pp. 473-479. July.

I880. A Short Biography of the Menhaden. Proc. Amer. Assoc. Advan. Sci., IS79 (I880), pp. 425-437. Saratoga Meeting.

I880. A short biography of the Menhaden, an abstract of "A History of the Menhaden "... Read before the Saratoga Meeting of the American Association for the Advancement of Science, and the Chicago Meeting of the Central Fish Cultural Association, and in an extended form before the New York Meeting of the United States Menhaden Oil and Guano Association. Salem: Printed at the Salem Press, I880. $8^{\circ}$ pp. I 5 ( I).

I880. The First Decade of the United States Fish Commission, Its Plan of Work and Accomplished Results, scientific and economical. Proceed. Amer. Assoc. Advan. Sci., 1881, pp. 563-574. Boston Meeting. Also, Nature, London, xxii, I880, pp. 597-599. Oct. 21; Smithsonian Report, I880, and Report U S. Fish Conimission, Part VIII. I88I.

IS80. The Frigate Mackerel, Auxis Rochei, on the New England Coast. American Naturalist, xiv, 1880 , pp. So8-810. Proceedings U.S. National Museum, iii, p. 532 .

I880. Das erste Jahrzehnt der Wirksamkeit der Fisch-Kommission der Vereinigten Staaten, Ihre Geschichte, ihr System und ihre Arbeiten für die Wissenschaft und die öffentliche Wohlfahrt, Vollstandige Uebersicht über eine Menterverwaltung. Circular Deutschen Fischerei Verein, Berlin, 1880, pp. 190-197.

I880. Descriptions of Seven New Species of Fishes from Deep Soundings on the Southern New England Coast, with diagnoses of two undescribed genera of Flounders, and a genus related to Merlucius. Proceedings U. S. National Museum, II, I880, pp. 337-350. Nov. 23.

I88I. Fishes from the deep water on the south coast of New England, obtained by the United States Fish Comnission in the summer of I880. Proceedings U. S. National Museum, iii, I881, pp. 467-486. Feb. I6.

I881. Notacanthus phasganorus, a new species of Notacanthida from the Grand Banks of Newfoundland. Proceedings U.S. National MTuseum, iii, I881, pp. 535-537. April I8.

I879-I88r. Game Fishes of the United States, by S. A. Kilbourne, text by G. Brown Goode. New York: Published by Charles Scribner's Sons, I879. Folio pp. (46), 20 plates and map. Published in ten parts, each with two plates, lithographs in water color, and four pages folio of text. 

I88r. The Carangoid Fishes of the United States, Pompanoes, Crevalles, Amberfishes, etc. Bulletin U. S. Fish Commission, I, I88I, pp. 30-43.

I88I. The Eel Question. Trans-American Fish Cultural Association, I88I, Pp. $8 I-I 23$.

IS8I. Bibliography of the publications of Professor Spencer Fullerton Baird. Bulletin U. S. National Museum. No. XX, pp. 450 (in press).

I88I. [Letter to Society of American Taxidermists.] First Annual Report American Taxidermists, 1880-I88I, Rochester, I88I, p. I7.

188I. Epochs in the History of Fish Culture. Trans. Amer. Fish Cultural Association, I88I, pp. 34-57. Also in Report U.S. Fish Commission, Part VII.

188r. Preliminary Statistical Report on the Fisheries of California, Oregon, Washington, and Alaska. Census Bulletin, No. i76. Folio, letter size, pp. 6 (2). [Washington: Government Printing Office, June, I88I.]

I88I. Materials for a History of the Sword Fishes. Report U. S. Commis. sioner Fish and Fisheries, Part VIII, pp. Ioo, and thirty plates.

1882. (with T. H. Bean) Description of a New Species of Fish, (Apogon Pan. dionis,) from the deep waters off the mouth of Chesapeake Bay. Proceedings. U. S. National MTuseum, IV, pp. I60-I. June 22.

1882. (with J. H. Bean) Benthodesmus, a new genus of deep-sea fishes, allied to Sepidopus. Proceedings U. S. National MTuseum, IV, pp. 379-383. April 6.

1882. The Taxaianic Relations and Geographical Distribution of the Members of the Sword Fish Family, Xipluivide. Proceedings U. S. National Museum, IV, pp. 4I 5-433. April 24.

1882. Smithsonian Institution. U. S. National Museum. No. I. Plan of Organization and Regulations (for the Museum). Dated Oct. I, I88I. pp. $1-58$.

1882. Smithsonian Institution. U.S. National Museum. No. II. A Provisional Classification of the Food Collections $8^{\circ} \mathrm{pp}$. I-22.

1882. Smithsonian Institution. U. S. National Museum. No. 13. Outline of a Scheme of Museum Classification. $8^{\circ} \mathrm{pp}$. I-4.

1882. Notes on the True History of the Eel, chiefly derived from a study of recent European authorities. Bulletin U. S. Fish Commission, I, pp. 7 I-I 24 .

1882. (with J. W. Collins) The Winter Haddock Fishery of New. England. Bulletion U.S. Fish Commission, I, pp. 226-235.

1882. The Fisheries of the World. N. Y. Cyclopadia of Political Economy, etc. Chicago. II, pp. 2 I I-23I.

1882. (Editor) Proceedings of the Biological Society of Washington, etc. Vol. I, Nov. 19, I880, to May 26, I882. $8^{\circ}$ pp. I-1 Io.

1882. (with J. W. Collins, Attoward Clark, and R. E. Earll). Materials for a History of the American Mackerel Fishery. Report U.S. Fish Com., Part VIII, PP. I-400 (in press).

1882. (with T. H. Bean) A List of the (296) Species of Fishes recorded as occurring in the Gulf of Mexico. Proceedings U. S. National Museum, $\mathrm{V}, \mathrm{I} 882$, pp. 234-240. July 29.

1882. (with T. H. Bean) Descriptions of Twenty-four New Species of Fish from the Southern United States, and their new Genera, Letharas Ioglossus and Chriodorus. Proceedings U. S. National Museum, V, I882, pp. 412. Sept I2.

1882. (Editor) The Fishery Industries of the United States : a report prepared by the co-operation of the U.S. Commission of Fish and Fisheries, and the Superintendent of the Tenth Census. 4to, pp. 2000 (in press).

1882. (Editor, with J. Matthew Jones) The Natural History of the Bermuda Islands. Bulletin U. S. National Museum, No. 24 (in press). 



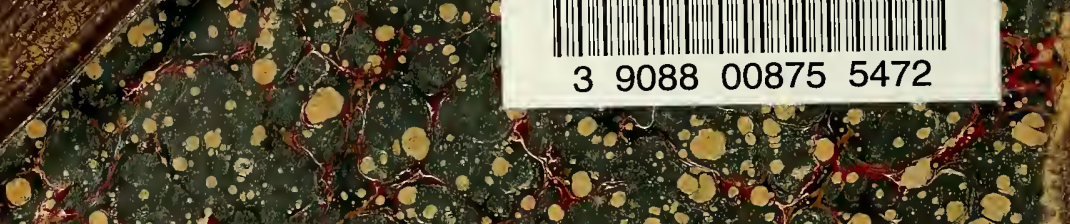

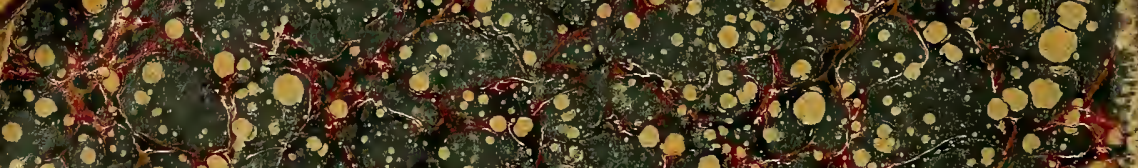

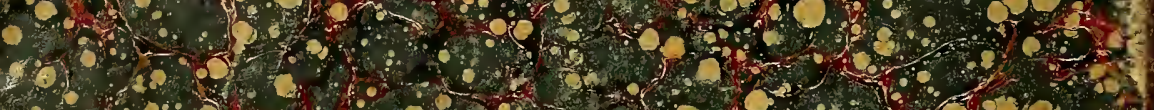

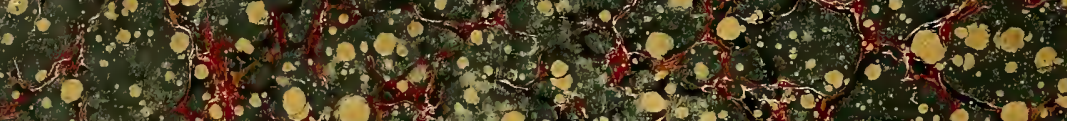
2.0.0.

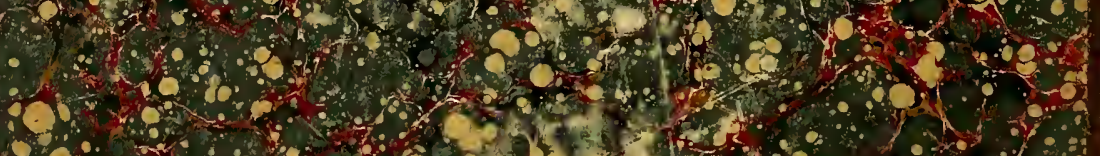

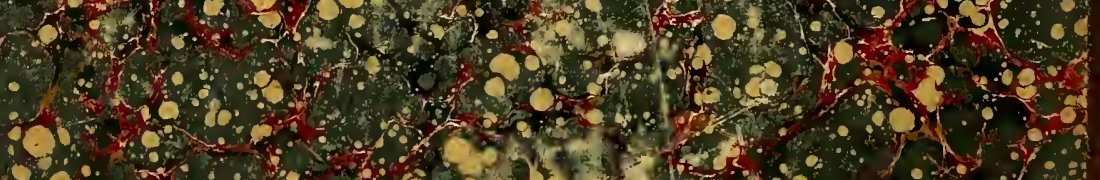

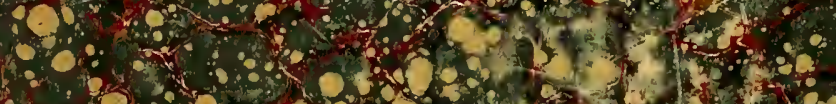

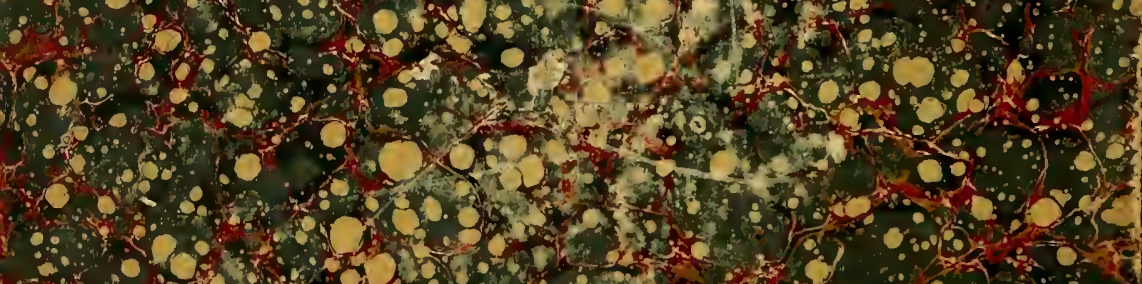

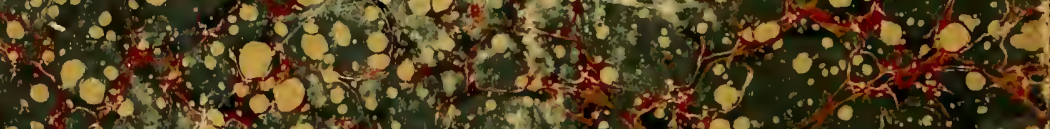

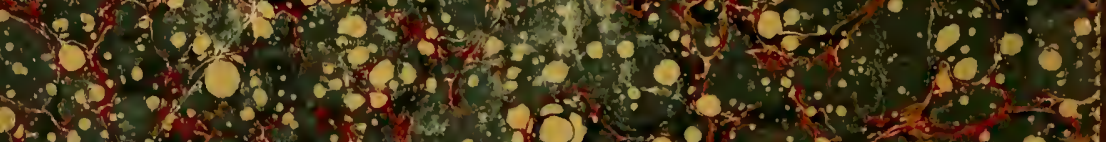

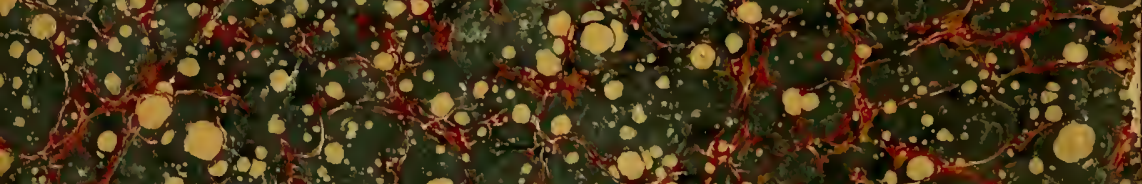

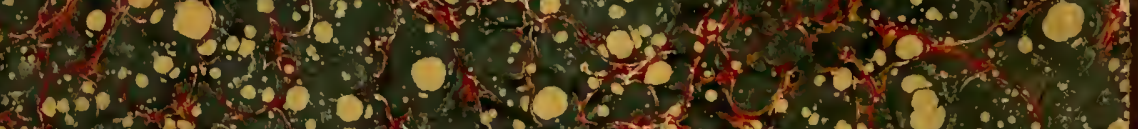

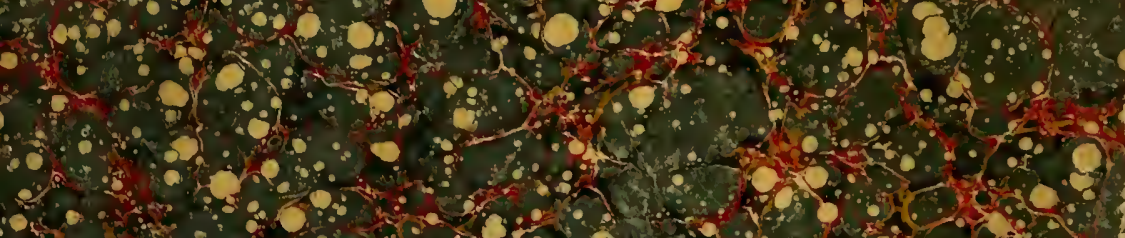

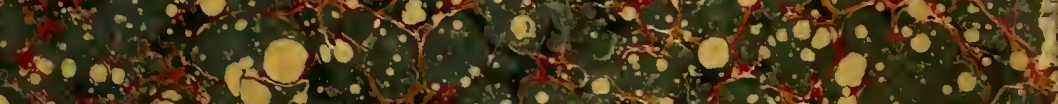

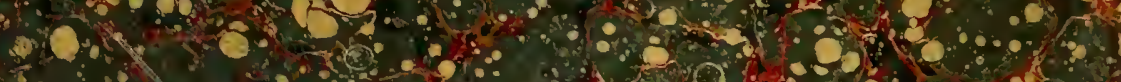

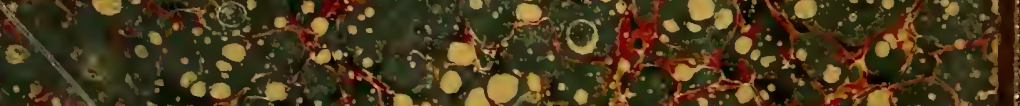

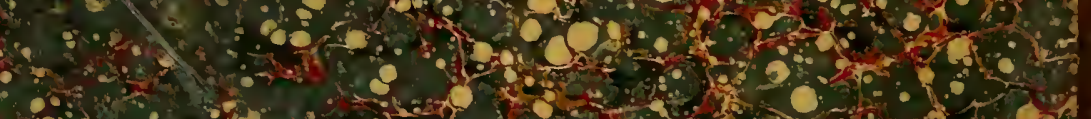

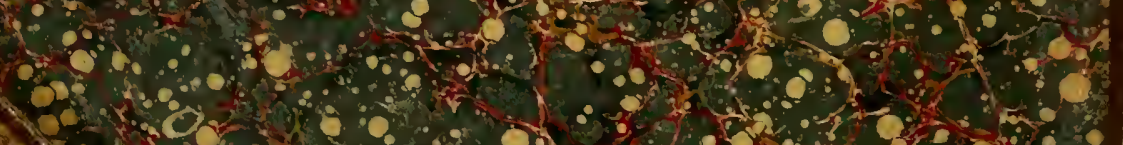

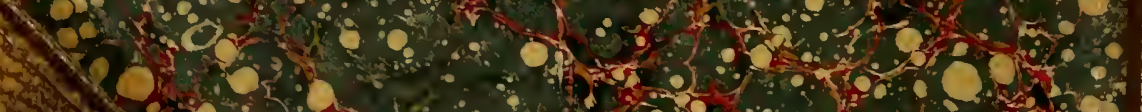

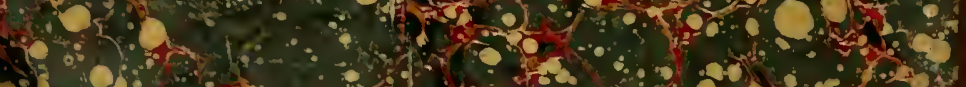

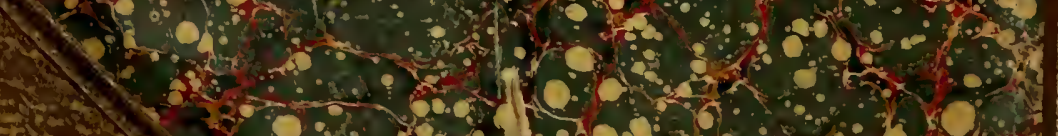

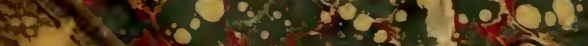

